$\frac{12}{4^{2}} / 10^{0} / 7^{8}$

DOE/ET-0013 (78)

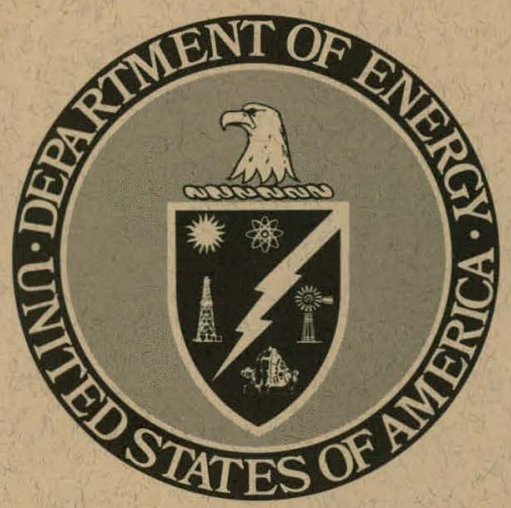

Fossil Energy Research and Development Program of the

U. S. Department of Energy

FY 1979

Assistant Secretary tor

Energy Technology 


\section{DISCLAIMER}

This report was prepared as an account of work sponsored by an agency of the United States Government. Neither the United States Government nor any agency Thereof, nor any of their employees, makes any warranty, express or implied, or assumes any legal liability or responsibility for the accuracy, completeness, or usefulness of any information, apparatus, product, or process disclosed, or represents that its use would not infringe privately owned rights. Reference herein to any specific commercial product, process, or service by trade name, trademark, manufacturer, or otherwise does not necessarily constitute or imply its endorsement, recommendation, or favoring by the United States Government or any agency thereof. The views and opinions of authors expressed herein do not necessarily state or reflect those of the United States Government or any agency thereof. 


\section{DISCLAIMER}

Portions of this document may be illegible in electronic image products. Images are produced from the best available original document. 


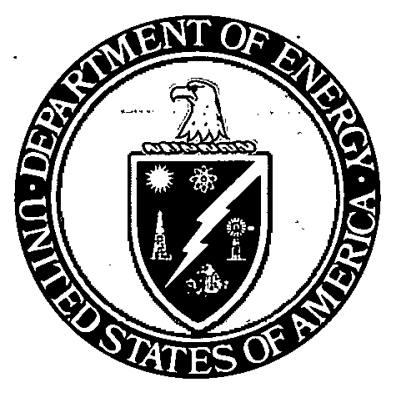

This report was prepared as an account of work sponsored by the United States Government. Neither the United States nor the United States Department of Eniergy, nor any of their employees, nor any of theit contractors, subcontractors, or their employees, makes

any warrenty express or implted, vi assumes any lagal

lib ility or responsibitity for the accuracy, completenes

or usefulnes of any information, apparatus, product or

proces disces or represents that its use would nor

infringe privately owned rights.

\author{
DOE/ET-0013(78) \\ DIst. Calegory \\ UC-12, D, 88, 89, \\ $90,91,92,93,95$
}

\title{
Fossil Energy Research and Development Program of the \\ U. S. Department of Energy
}

FV 1979

Assistanl Secretary Ior

Energy Technology

Washinglon, D. C. 20545 


$$
\begin{aligned}
& \text { THIS PAGE } \\
& \text { WAS INTENTIONALLY } \\
& \text { LEFT BLANK }
\end{aligned}
$$$$
\%
$$ 


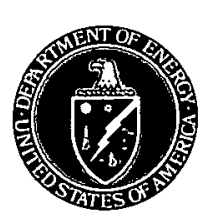

DEPARTMENT OF ENERGY

WASHINGTON, D.C. 20545

\section{PREFACE}

The U.S. Department of Energy (DOE), which came together on October 1, 1977, focuses energy Research and Development efforts under the Assistant Secretary of Energy.Technology (ASET). The thrust of this work is to find new and promising ways to provide for our future energy needs. This document focuses on DOE's and ASET's programs and projects, particularly the nation's fossil energy resources: coal, oil, natural gas and oil shale.

Fossil Energy programs have grown rapidly from about $\$ 58$ million in FY 1973 to the $\$ 802$ million requested for FY 1979 . As those programs have matured, there have been significant shifts in emphasis. For example, by FY 1979, gasification technologies will have matured sufficiently to enter the demonstration phase. Then we will have to make critical decisions, based on sound analysis, as to which candidate processes to pursue and to encourage industry's active participation as early as possible. We will present the rationale for those changes and others at the beginning of each section describing a particular grouping of similar projects, e.g., coal liquefaction. We will then discuss each project and present its current status along with past and future milestones.

Looking to the future, we see emphasis on projects with early payoff potential, particularly the direct utilization of coal. However, this nearterm emphasis will not overshadow the need for a strong technological base for development of longer-term promising technologies and the need for a strong environmental concern.

The Department of Energy Organization Act of 1977, PL 95-91, has drawn into the Fossil Energy Program, R\&D efforts related to the greater use and efficiency of coal. These activities include the Mines RD\&D Program from the Bureau of Mines, DOI and the Improved Conversion Efficiency Programs formerly under the Assistant Administrator for Conservation in ERDA. Additional executive reorganization also incorporates R\&D work in Advanced Environmental Control technology at EPA into the newly integrated Fossil Energy RD\&D Program. Activities in commercial applications have been transferred to the Assistant Secretary for Resource Applications to strengthen the commercialization efforts within the Department. These changes, when incorporated in to the new resource program structure, should provide a sound basis for strengthening our overall R\&D efforts in Fossil Energy.

Hopefully, we will be successful in trying to assure that a range of demonstrated fossil energy technologies is available to meet the nation's energy needs in a timely and environmentally sound way.

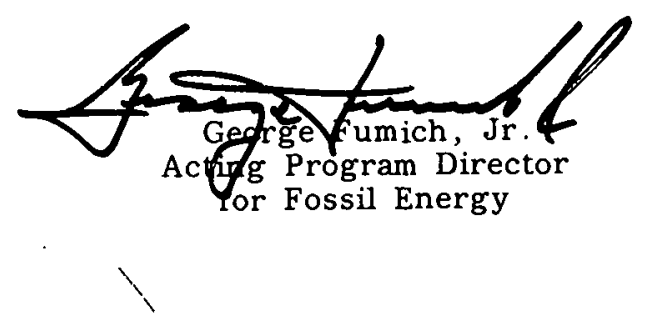




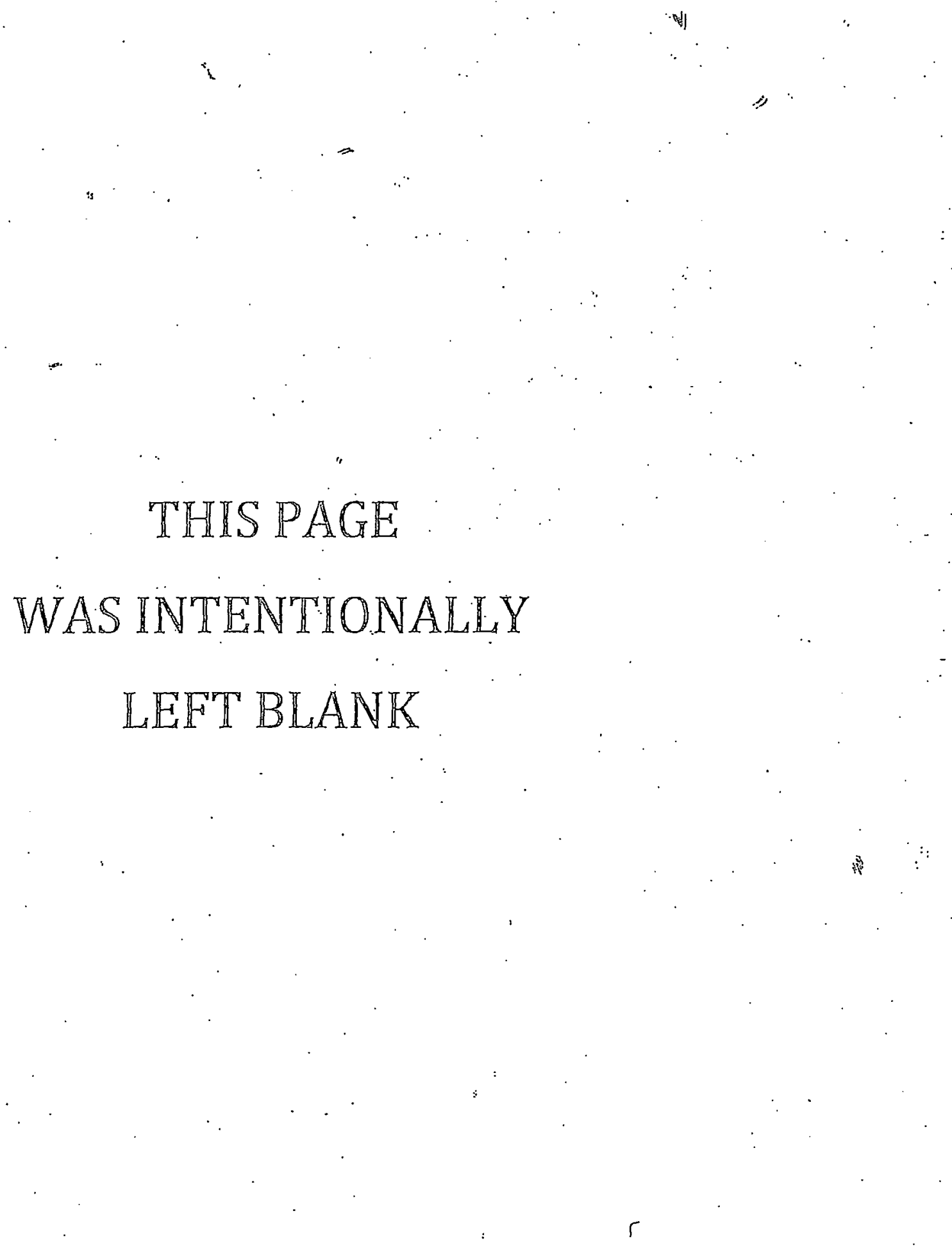


TABLE OF CONTENTS

Page

Number

PREFACE

iii

I. THE NATIONAL ENERGY PLAN AND FOSSIL ENERGY

TECHNOLOGY

II. FOSSIL ENERGY RESEARCH: FISCAL YEAR 1979 OVERVIEW

A. PROGRAM STRUCTURE AND FY 1979 PROGRAM BUDGET REQUEST

B. FOSSIL ENERGY RESOURCE STRATEGIES

1.0 Coal Resource Strategy

2.0 Petroleum Resource Strategy

3.0 Gas Resource Strategy

C. PROGRAM MANAGEMENT

III. COAL RESOURCE

A. COAL RESOURCE OVERVIEW

B. MINES RESEARCH, DEVELOPMENT AND DEMONSTRATION

1.0 Underground Coal Mining

1.1 Coal Mine Shaft Development (Mine Planning and Development)

1.2 In-Mine Development (Mine Planning and Development)

1.3 Methane Drainage

1.4 Room and Pillar (Production Mining)

1.5 Panel (Production Mining)

1.6 Novel Systems (Production Mining)

1.7 Transport and Other Support 47

2.0 Surface Coal Mining

2.1 Area Mining

2.2 Contour Mining

2.3 Reclamation and Supporting Studies $\quad 55$

3.0 Coal Preparation Research

3.1 Process Test Facility

57

3.2 Coal Preparation Technology

57

3.3 Waste Utilization and Control

57

3.4 Supporting Studies

58

58 
C. COAL LIQUEFACTION 60

1.0 Direct Hydrogenation Projects 62

1.1 Ebullated-Bed (H-Coal) Pilot Plant 62

1.2 Fixed-Bed Hydrogenation (Synthoil) PDU 65

$\begin{array}{lll}1.3 & \text { Zinc Chloride Catalyst PDU } & 67\end{array}$

1.4 Disposable Catalyst Hydrogenation 69

1.5 Multistage Liquefaction Process $\quad 71$

$\begin{array}{lll}2.0 & \text { Solvent Extraction Projects } & \mathbf{7 4}\end{array}$

2.1 Solvent Refined Coal (SRC)

Pilot Plant

75

2.2 Solvent Refined Coal Utilization $\quad 79$

$\begin{array}{lll}2.3 & \text { CO Eleam l'rucess } & 79\end{array}$

2.4. Donnr Snlvent Process 80

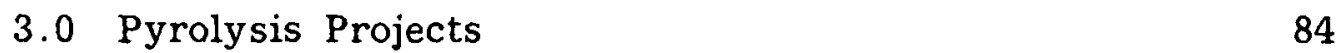

3.1 Entrained Pyrolysis Process . 85

$\begin{array}{lll}3.2 & \text { Flash Liquefaction Process } & 87\end{array}$

$\begin{array}{ll}3.3 \text { Fluid Coke Process } & 89\end{array}$

4.0 Support Studies and Engineering

$\begin{array}{ll}\text { Evaluations } & 91\end{array}$

4.1 Cresap Liquefaction Test Facility 92

4.2 Coal Liquids Refining 95

4.3 Environmental Studies and Supporting
Projects

5.0 Liquefaction Demonstration Projects 99

5.1 Solvent Refined Coal (SRC)
Demonstration Plant

5.2 Design and Technical Support . 102

6.0 Summary of Pilot Plants, PDUs, and
Major Hardware Fabrication

$\begin{array}{ll}\text { D. COAL GASIFICATION } & 105\end{array}$

$\begin{array}{lll}1.0 & \text { High-Btu Gasification } & 105\end{array}$

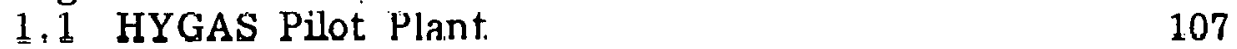

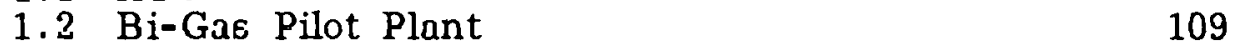

1.3 Synthane Pilot Plant $\quad \cdot \quad 111$

1.4 BLedil Irun Pllot Plant 114

$\begin{array}{ll}1.5 \text { Hydrogasification } & 116\end{array}$

1.6 Catalytic Gasification Pilol Plant il8

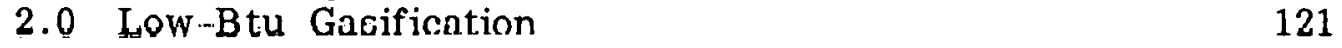

$\begin{array}{ll}2.1 & \text { Fixed-Bed Gasification, Stirred } \\ \text { Process } & 123\end{array}$

2.2 Fixed-Bed Gasifier, Slagging Process 125

$\begin{array}{ll}2.3 & \begin{array}{l}\text { Fluidized-Bed Gasification, Two-Stage } \\ \text { Pressurized }\end{array} \\ & 127\end{array}$ 
2.4 Fluidized-Bed Gasification, Tri-Gas Pressurized

2.5 Fast Fluid-Bed Process

2.6 Entrained-Bed Gasification, Atmospheric Process

2.7 Combined-Cycle Test Facility

2.8 Molten Salt Pressurized Process

2.9 Hydrogen-from-Coal Facility

2.10 Ash Agglomeration

141

2.11 Gasifiers in Industry

3.0 Special Projects and Support Studies

3.1 Hot-Gas Cleanup, Molten Salt Process

3.2 Hot-Gas Cleanup, Iron Oxide Process

3.3 Engineering Evaluations

151

3.4 Equipment, Materials, and Process

3.5 Environmental Studies

3.6 Other Support and Special Projects 156

4.0 In Situ Coal Gasification

4.1 Western Low-Btu Gas (Linked Vertical Wells)

161

4.2 Western Medium-Btu Gas (Packed-Bed) 164

4.3 Eastern Coal Technology (Longwall Generator)

4.4 Steeply Dipping Beds

4.5 Environmental Support

4.6 Advanced Concepts and Supporting Research

5.0 Gasification Demonstration Projects

5.1 High-Btu Pipeline Gas Demonstration Project

5.2 HYGAS Demonstration Plant

5.3 Fuel Gas, Industrial - A\&B

182

5.4 Fuel Gas, Utility Plant

186

b.b Fuel Gas, Small Industrial Planl 187

5.6 Design and Technical Support 190

6.0 Summary of Pilot Plants, PDUs, and Major Hardware Fabrication 191

E. HEAT ENGINES \& HEAT RECOVERY 194

1.0 Integrated Coal Conversion Utilization (Advanced Power) Systems 197

1.1 Open-Cycle Gas Turbine Systems 199

1.2 Closed Power Systems 202

1.3 Support \& Additional Programs . 206 
$\begin{array}{lll}2.0 & \text { Advanced Cogeneration Systems } & 208\end{array}$

2.1 Prototype Systems Assessment 209

2.2 Directly-Fired Heat Cycles 212

2.3 Externally-Fired Heat Cycles 218

3.0 Heat Recovery Component Technology 222

3.1 Low Grade Heat Recovery 223

3.2 High Grade Heat Recovery $\quad 226$

$\begin{array}{lll}3.3 & \text { Heat Exchanger Technology } & 229\end{array}$

F. COMBUSTION SYSTEMS 233

1.0 Atmospheric Fluidized-Beds (AFB) 236

1.1 AFB Builer. 30 MWe 2338

1.2 AFB Industrial Applications $\quad 240$

1.3 AFB Closed-Cycle Gas Turbine TTU 242

1.4 AFR Compnnent Tést \& Integration
Unit

1.5 AFB Anthracite Applications 246

$\begin{array}{lll}2.0 & \text { Pressurized Fluidized-Beds (PFB) } & 247\end{array}$

2.1 PFB Combined-Cycle Pilot Plant, 13 MWe

$\begin{array}{ll}2.2 & \text { PFB Component Test \& Integration } \\ \text { Unit } & 251\end{array}$

2.3 Hot-Gas Cleanup 253

2.4 International Energy Agency 254

3.0 Advanced Combustion Technology 254

3.1 Engine Combustion Technology 255

3.2 Improved Oil \& Gas Burners 258

$\begin{array}{ll}3.3 \text { Coal Combustion Support and } & \\ \text { Engineering Lvaluatione } & 258\end{array}$

4.0 Alternate Fuel Utilization 265

4.1 Coal-Oil Mixtures 265

4.2 Alternate Fuel Combustion 268

4.3 Coal Bed Methane Utilization 271

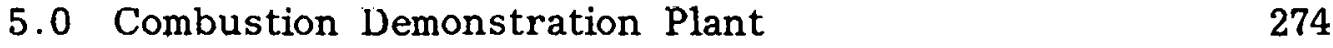

6.0 Summary of Pilot Plants, PDUs, and
Major Hardware Fabrication

$\begin{array}{ll}\text { G. FUEL CELLS } & 278\end{array}$

1.0 4.8 MW Electric Utility Power Plant Test and Development $\quad 281$

2.0 Phosphoric Acid Systems Development 283

3.0 Molten Carbonate Systems Development 288

$\begin{array}{ll}4.0 & \text { Applied Research } \\ 5.0 & 290\end{array}$

5.0 Summary of Pilot Plants, PDUs, and
Major Hardware Fabrication 
H. ADVANCED ENVIRONMENTAL CONTROL TECHNOLOGY 294

I. ADVANCED RESEARCH AND SUPPORTING TECHNOLOGY (AR\&ST)

$\begin{array}{lll}1.0 & \text { Materials and Components } & 299\end{array}$

1.1 Materials for Coal Conversion 300

$\begin{array}{ll}1.2 & \text { Equipment Subsystems for Coal } \\ \text { Conversion } & 304\end{array}$

2.0 Conversion Processes 308

2.1 Liquefaction $\quad 308$

2.2 Gasification $\quad 313$

2.3 Refining and Chemicals 317

$\begin{array}{lll}3.0 & \text { Direct Utilization Technology } & 321\end{array}$

3.1 Beneficiation 321

3.2 Combustion $\quad 325$

3.3 Power 326

3.4 Support Studies $\quad 326$

4.0 Program Development \& Integration 327

4.1 Environmental Coordination , 328

4.2 Planning and Budget 328

4.3 Review and Analysis $\quad 330$

4.4 Project and Policy Coordination 330

J. MAGNETOHYDRODYNAMICS 332

$\begin{array}{lll}1.0 & \text { Open-Cycle } & 333\end{array}$

1.1 CDIF Project 336

$\begin{array}{lll}2.0 & \text { Closed-Cycle } & 337\end{array}$

3.0 Summary of Pilot Plants, PDUs, and

K. SUMIMARY OF CAPITAL ACQUISITION 340

$\begin{array}{lll}1.0 & \text { Plant Construction } & 340\end{array}$

$\begin{array}{ll}\text { 2.0 Capital Equipment } & 342\end{array}$

IV. PETROLEUM RESOURCE 343

A. PETROLEUM RESOURCE OVERVIEW 343

B . ENHANCED OIL RECOVERY 348

1.0 Micellar - Polymer Flooding/Improved
Waterflooding

$2.0 \mathrm{CO}_{2}$ Flooding 355

3.0 Resources Recovery and Solvent (Thermal) 358

4.0 Environmental Studies and Supporting
Research 
C. OIL FROM OIL SHALE 365

1.0 Shale Oil Production 365

1.1 Laboratory and Field Tests 368

1.2 Environmental Aspects 377

1.3 Supporting Research 379

D. DRILLING AND OFFSHORE TECHNOLOGY 383

$\begin{array}{lll}1.0 & \text { Drilling } & 384\end{array}$

$\begin{array}{ll}2.0 & \text { Offshore Technology } \\ 387\end{array}$

3.0 Environmental and Supporting Research 387

E. PRODUCT .CHARACTERIZATION AND UTITIT.ATION 389

$\begin{array}{lll}1.0 & \text { Characterization } & 389\end{array}$

$\begin{array}{lll}2.0 & \text { Utilization } & 391\end{array}$

F. SUMMARY OF CAPITAL ACQUISITION .

1.0 Plant Construction 393

2.0 Capital Equipment 393

V. GAS RESOURCE 395

A. GAS RESOURCE OVERVIEW 395

B. ENHANCED GAS RECOVERY 398

1.0 Eastern Gas Ghales Piuject $\quad 399$

2.0 Western Gas Sands Project 404

3.0 Methane from Coal and Geopressured
Aquifers

4.0 Project Support Activities 406

Technolngy Dessriptinns 407

1.0 Advanced Hydraulic Fracturing Process 407

2.0 Chemical Explosive Fracturing Process 409

3.0 Deviated Wells and Earth Fracture Systems Process 411

4.0 Resource. Characterization $\quad 413$

5.0 Environmental and Supporting Research 413

C. GAS FROM OIL SHALE $\quad 414$

1.0 Shale Gas Production $\quad 414$ 
D. SUMMARY OF CAPITAL ACQUISITION 418

$\begin{array}{lll}1.0 & \text { Plant Construction } & 418\end{array}$

$\begin{array}{lll}2.0 & \text { Capital Equipment } & 418\end{array}$

VI. ENERGY RESEARCH CENTERS, MINING OPERATIONS CENTERS, AND NATIONAL LABORATORIES

A. ENERGY RESEARCH CENTERS (ERCS) 419

1.0 Bartlesville ERC (BERC) 419

2.0 Grand Forks ERC (GFERC) $\quad 420$

3.0 Laramie ERC (LERC) 420

4.0 Morgantown ERC (MERC) 421

5.0 Pittsburgh ERC (PERC) 422

B. MINING OPERATIONS CENTERS (MOCs) 423

1.0 Carbondale MOC 423

2.0 Pittsburgh MOC 423

C. NATIONAL LABORATORIES 426

1.0 Ames Laboratory (AL) 426

2:0 Argonne National Laboratory (ANL) 426

3.0 Brookhaven National Laboratory (BNL) 426

4.0 Idaho National Energy Laboratory (INEL) 426

5.0 Lawrence Berkeley Laboratory (LBL) 427

6.0 Lawrence Livermore Laboratory (LLL) 427

7.0 Los Alamos Scientific Laboratory (LASL)

8.0 Mound Laboratory (ML)

9.0 Oak Ridge National Laboratory (ORNL)

10.0 Pacific Northwest Laboratory (PNL) 427

11.0 Sandia Laboratory (SL) 428

VII. UNIVERSITY ACTIVITIES 435

A. Overview 435 .

B. Coal Laboratories (PL 95-87) 438

VIII. ENVIKONMENTAL AND SOCIOECONOMIC IMPLICATIONS 439

IX. INTERNATIONAL PROGRAMS 443

A. UNITED STATES - INTERNATIONAL ENERGY AGENCY (IEA)

1.0 Fluidized-Bed Combustion 446

2.0 Economic Assessment Service for Coal 447 
3.0 Technical Information Services 448

4.0 Mining Technology Clearing House 449

5.0 National Planning Coordination in the

449

6.0 Cooperation in Coal Technology 449

7.0 Combustion $\quad 450$

$\begin{array}{ll}\mathbf{8 . 0} \text { Heat Transfer } & 450\end{array}$

B. UNITED STATES - UNITED KINGDOM 451

1.0 Coal Utilization 451

2.0 Coal Mining 451

C. UNITED STATES - BERGBAI FOR.SCHUNG (FEDERAL
REPUBLIC OF GERMANY)

$\begin{array}{lll}1.0 & \text { Coal Mining } & 451\end{array}$

D. UNITED STATES - UNION OF SOVIET SOCIALIST

1.0 Magnetohydrodynamics. 452

2.0 Oil 453

3.0 Gas 453

4.0 Coal . 454

E. UNITED STATES - POLAND 454

1.0 Magnetohydrodynamics 454

2.0 Corl Tiıpurferetion 454

3.0 Combustion of Synthetic Fuels for Power.
Generation

4.0 Coal Mining and Preparation 455

X. DEFINITIONS $\quad 457$

A. RD\&D SCALEUP PHASES $\quad 457$

B. ABBREVIATIONS AND ACRONYMS 460

$\begin{array}{ll}\text { INDEX } & 467\end{array}$

$\begin{array}{lr}\text { LEGEND } & 477\end{array}$ 


\section{LIST OF FIGURES}

Page

Number

?igure

1. Fossil Energy FY 1979 Funding Percentages

2. Relation of Demonstration Plants to Energy Requirements

3. Typical Process Development Sequence 22

4. DOE Fossil Energy Organization 24

5. Program Structure for Materials and Components Subactivity and Related Details (AR\&ST)

6. Program Structure for Liquefaction, Detail of the Conversion Processes Subactivity (AR\&ST)

7. Program Structure for Gasification, Detail of the Conversion Processes Subactivity (AR\&ST)

8. Program Structure for Refining and Chemicals, Detail of the Conversion Processes Subactivity (AR\&ST)

9. Program Structure for Direct Utilization Subactivity and Related Details (AR\&ST)

10. Production, Reserves, and Residual Oil-In-Place -- Total United States, Including Offshore and Alaska (PNG)

11. Cost-Sharing Contractor Locations, Enhanced Oil Recovery

12. Location of DOE Fossil Energy Research Centers, Mining Operation Centers, and National

Laboratories 


\section{LIST OF TABLES}

Table

Page

$\underline{\text { Number }}$

6

Fossil Energy Development
FY 1973-FY 1976 Total Funding Levels

7

3. Fussil Energy Development

FY 1979 Budget Estimates

Summary Table of Plant and Capital Equipment

by Technologies

4. Fossil Energy Development

Summary of Total FY 1979 Budget Request

by Activity/Fund Source

16

5. Comparability Table FY 1979 Estimates

Budget to Congress/FE Program Summary Book

6. Fossil Energy Program Management

25

7. Energy Research Center and Mining Operation

Center Funding and Employment Levels

424

8. Fossil Energy Development

Energy Research Centers/Mining Operations

Centers/National Laboratories Support Activities 


\section{THE NATIONAL ENERGY PLAN AND FOSSIL ENERGY TECHNOLOGY}

Today the United States relies on scarce fossil fuels to supply a disproportionate share of this country's energy needs. Oil and gas account for only about 11 percent of known U.S. recoverable reserves while they meet about 75 percent of our energy demands. Coal, on the other hand, makes up about 77 percent of national recoverable reserves, while constituting less than 20 percent of the nationally consumed energy. The National Energy Plan (NEP) was born out of recognition of the necessity to shift our national energy consumption profile away from scarce resources and toward more plentiful fossil resources in the near-term and eventually to inexhaustible resources.

Three underlying energy objectives are identified in the Plan:

- To reduce dependence on foreign oil in the immediate future

- To keep U.S. imports in the mid-term sufficiently low, that the period when world oil production approaches its capacity be weathered

- To have renewable and essentially inexhaustible sources of energy for sustained economic growth in the long-term.

It is the Plan's intent that in achieving these goals disruptions of our economy and lifestyle must be minimized, and dislocations, if any, should be shared equally among all segments of society.

The Plan outlines three major strategies to accomplish these objectives:

- The U.S. should reduce the rate of growth of demand from the post war historical average of 3 percent to less than 2 percent

- Industries and utilities using oil and natural gas should convert to coal and other abundant fuels

- The U.S. should pursue an effective research and development program to provide renewable resources to meet our energy needs in the next century.

The government has two principal means through which it can exercise leadership in pursuit of the above:

- Establishing regulations or incentives to promote the development or implementation of technology and use (or disuse) of various forms of energy 
- Conducting or financially supporting research and development to provide new technologies capable of economically producing useful energy from hitherto unusable sources as well as extracting more usable and environmentally acceptable energy from existing sources.

The Fossil Energy Research, Development, and Demonstration (RD\&D) Program must be responsive to the needs for new and improved technology created by the former mechanism, it is itself an integral part of the latter. The NEP enunciates a variety of incentives designed to encourage industries and utilities to use less conventional gas and oil and more coal. Major research and development efforts are required if the role of coal in supplying energy in the U.S. is to be significantly expanded. Environmental, health and safety problems must he nvercnme, and coal technologies must be economically attractive when compared to available alternalives. A major objective of the Fossil Finergy Prngram is to meet these challenges, thereby facilitating a smooth transition to a more coalbased mid-term national energy profile. Major coal research programs are directed towards developing more efficient technologies, and making coal more economically competitive and environmentally acceptable (in accord with the premise that disruptions, dislocations, and total energy costs must be minimized).

In the near-term, the United States will continue to use large quantities of oil and gas. In accordance with the first NEP objective, the reduction of U.S. dependence on oil imports, and its corollary, the avoidance of substantial U.S. dependence on liquefied natural gas (LNG) imports, are major goals of the Fossil Energy Program through development of alternate sources of oil and natural gas.

The greatest need for research and development breakthroughs is in the area of liquid fuels, because domestic liquid fuel supplies are dwindling and large amounts are needed for transportation and industrial feedstocks. Alternatives to liquids in these applications are generally very expensive. The emphasis of the Fossil Energy liquids program is on increasing domestic production by recovering a higher fraction of oil from developed oil fields and by developing economically competitive shale oil extraction and coal liquefaction technologies.

A balance between gas supply and demand may be obtainable without requiring extreme prices, mandated curtailments or extraordinary technical breakthroughs. Conventional gas resources, while very uncertain, may contribute significantly to U.S. gas supplies through the year 2000 . In addition, there are a variety of technologies potentially available to obtain gas from unconventional geologic formations (e.g., Devonian Shale, coal seams, tight sands, geopressured acquifers) and from coal gasification. Fossil Energy gas research has focused on transforming these potential technologies into ones that are commercially viable. Together with conventional supplies, they should permit the U.S. to meet its demand for gas well into the next century without becoming dependent on LNG imports. 
Successful implementation of this program will:

- Transform plentiful fossil fuels from a form incompatible with present end-use devices to a compatible one (i.e., coal to liquids).

- Permit us to economically tap large reservoirs of formerly inaccessible or unusable fossil fuels that are already compatible with existing end-use devices (i.e., shale oil and gas from Devonian shale).

- Permit the economical and environmentally acceptable use of now accessible fossil fuel supplies which now fail to meet environmental requirements (i.e., direct coal combustion in atmospheric fluidized-bed). future.

The NEP recognizes the vital role RD\&D will play in our energy

"An effective Federal research, development and demonstration program is indispensible for the production of new energy sources. The Federal Government should support many research options in their early stages, but continue support into the later stages only for these that meet technical, economic, national security, health, safety, and environmental criteria. Research and development should be accompanied by preparation for commercialization so that successful projects can rapidly be put to practical use." (p. xxii)

In carrying out the Fossil Energy RD\&D Program a progression from stage to stage compatible with the one outlined above is anticipated. Process economics, the study of the total costs of a given technology and its expected and potential market penetration, is a useful tool in determining which technologies should be advanced to the next stage of development. Only those technologies which are likely to satisfy a significant end-use demand at econoin-ially, environmentally, and socially acceptable costs should be pushed to commercialization.

The Fossil Energy RD\&D Program assumes the initial responsibility for the development of a comprehensive technology transfer effort. Potential users are kept informed as the research and development effort progresses. Cost-sharing of pilot and demonstration plants helps assure that the private sector is interested in the technology and assists in the transfer of technical information. When technology transfer and commercialization becomes the principal focus, a technology is shifted from Energy Technology to Resource Applications. 


$$
\begin{gathered}
\text { THIS PAGE } \\
\text { WAS INTENTIONALLY } \\
\text { LEFT BLANK }
\end{gathered}
$$




\section{FOSSIL ENERGY RESEARCH: FISCAL YEAR 1979 OVERVIEW}

\section{A. PROGRAM STRUCTURE AND FY 1979 PROGRAM BUDGET REQUEST}

Fossil Energy activities are structured in three main resources: Coal, Petroleum, and Gas. A funding history for Fossil Energy RD\&D prior year programs is summarized in Table 1. This historical table displays the funding for Fossil Energy from FY 1973 to FY 1976. Total funding has increased from approximately $\$ 58$ million in FY 1973 to the $\$ 802$ million requested in FY 1979. The FY 1979 funding requested for the Coal Resource is about $\$ 696$ million, or about 87 percent of the total. The Petroleum Resource represents about 10 percent of the total ( $\$ 80$ million) and the Gas Resource represents 3 percent ( $\$ 26$ million). Figure 1 presents the requested FY 1979 funding levels by the percentage that each major element represents of the total budget.

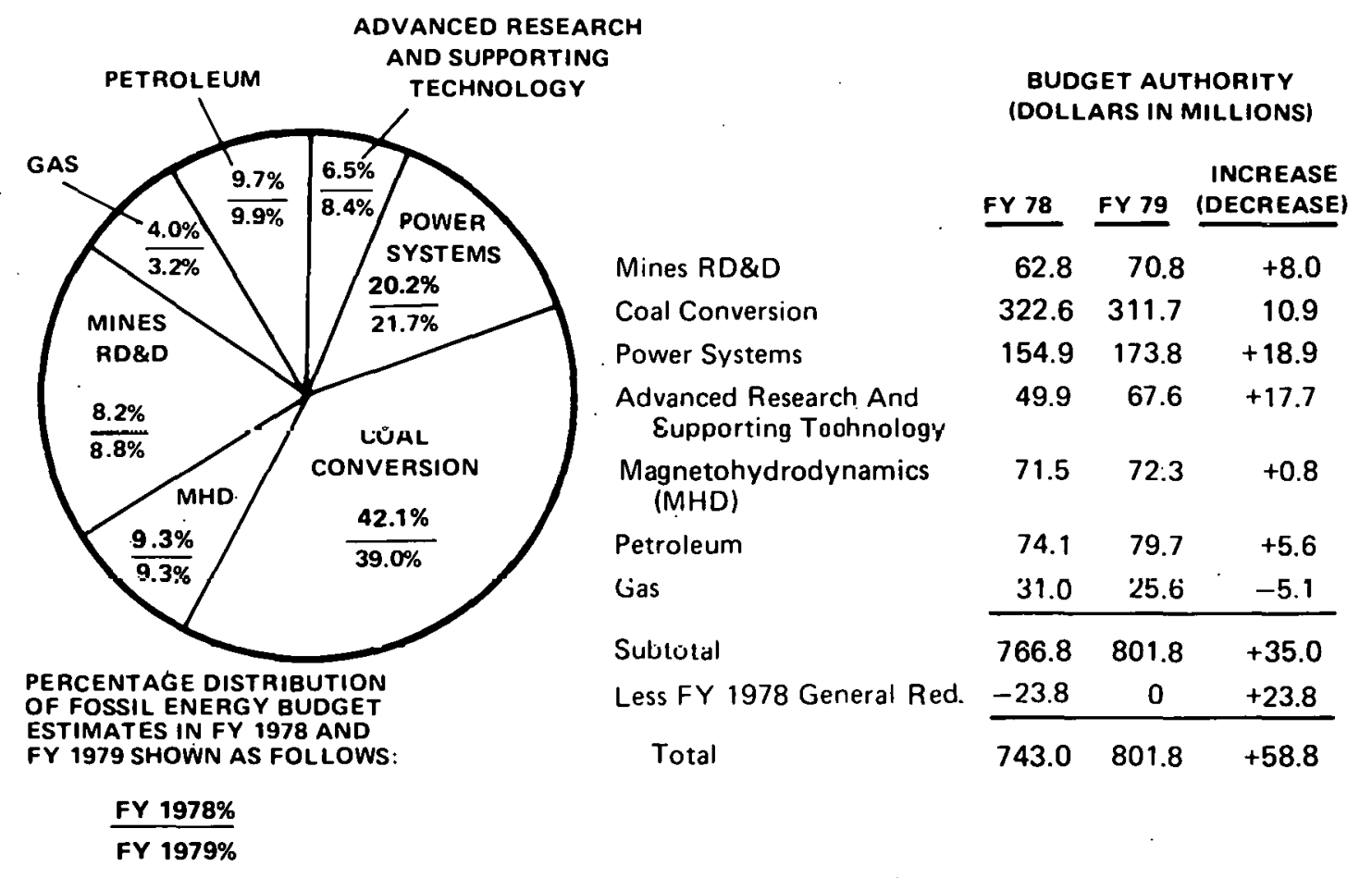

Figure 1 Fossil Energy FY 1979 Funding Percentages

A detailed display of FY 1977 to FY 1979 operating expenses for DOE's Fossil Energy programs is presented in Table 2. Table 3 summarizes FY 1977 to FY 1979 capital acquisition expenses. Table 4 summarizes only the FY 1979 request by fund source at the activity level. 
Table 1 Fossil Energy Development

FY 1973-FY 1976 Total Funding Levels ${ }^{3}$

Budget Authority

(Dollars in Millions)

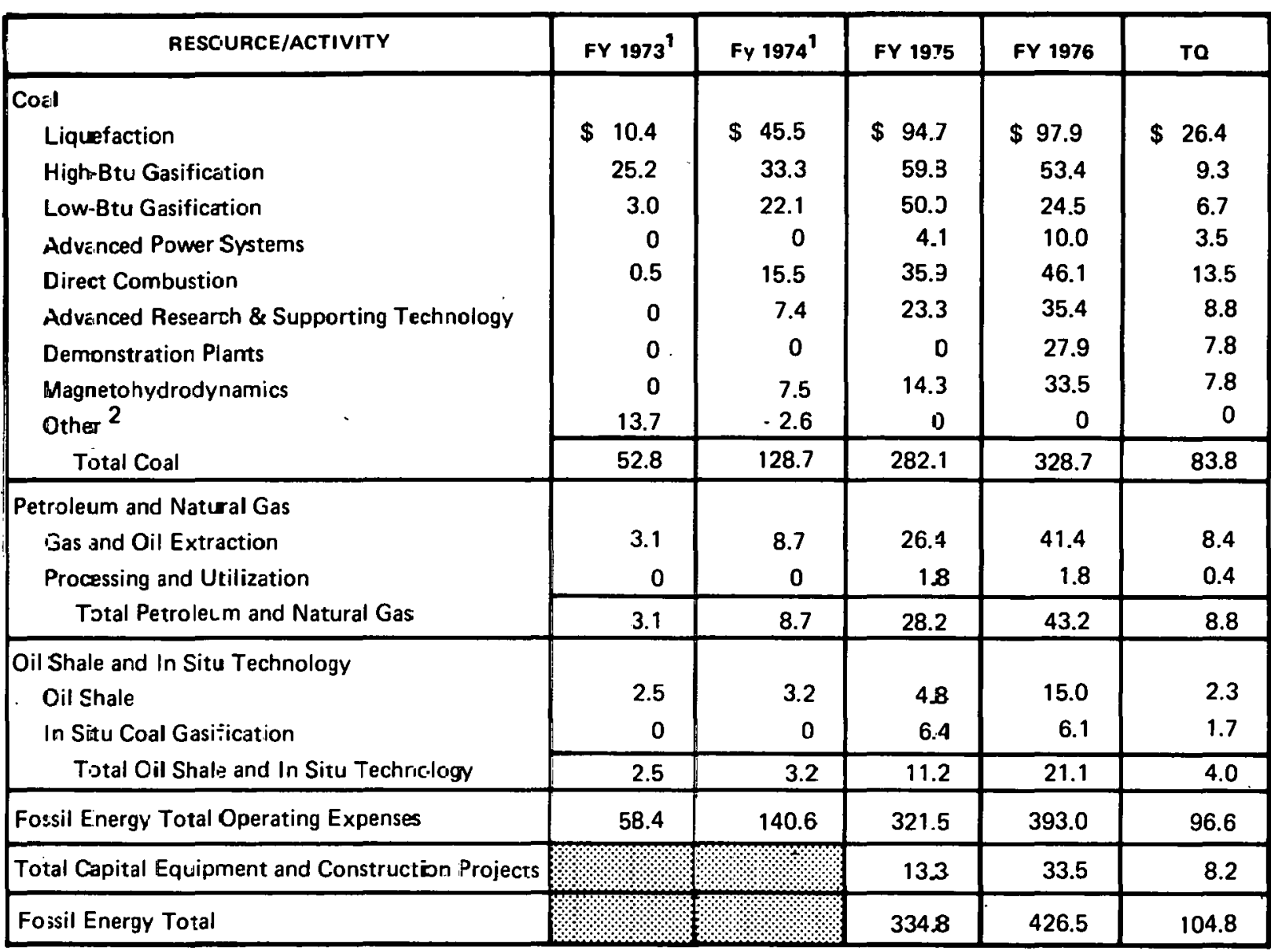

1 DQI data.

2 May be negative because of prior-year adjustment

${ }^{3}$ Based on FY 1976 existing budget structure.

FY 1977 - FY 1979 data is presented ir Table 2 in revised 1978

budget structure for comparability purposes. 
Table 2 Fossil Energy Development

FY 1979 Budget Estimates

Summary Table of Operating Expenses by Technologies

Budget Authority

(Dollars in Thousands)

\begin{tabular}{|c|c|c|c|}
\hline $\begin{array}{l}\text { COAL RESOURCE } \\
\text { OPERATING EXPENSES }\end{array}$ & $\begin{array}{l}\text { ACTUAL } \\
\text { FY } 1977\end{array}$ & $\begin{array}{l}\text { APPROPRIATION } \\
\text { FY } 1978\end{array}$ & $\begin{array}{l}\text { ESTIMATE } \\
\text { FY } 1979\end{array}$ \\
\hline \multicolumn{4}{|l|}{ MIN $\equiv S$ RESEARCH, DEVELOPMENT, \& DEMONSTRATION } \\
\hline \multirow{2}{*}{$\begin{array}{l}\text { a. Underground Coal Mining } \\
\text { b. Surface Coal Mining } \\
\text { c. Coal Preparation Research } \\
\text { Total, Mines Research, Development, \& Demonstration }\end{array}$} & $\begin{array}{r}\$ 39,735 \\
10,000 \\
2,120 \\
\end{array}$ & $\begin{array}{r}\$ 46,285 \\
11,475 \\
5,020 \\
\end{array}$ & $\begin{array}{r}\$ 52,860 \\
12,615 \\
5,071 \\
\end{array}$ \\
\hline & 51,855 & 62,780 & 70,546 \\
\hline \multicolumn{4}{|l|}{ LIQUEFACTION } \\
\hline \multicolumn{4}{|l|}{ a. Direct Hydrogenation } \\
\hline $\begin{array}{l}\text { 1. Ebullated-Bed (H-Ccal) Pilot Plant } \\
\text { 2. Fixed-Bed Hydrogenation (Synthoil) PDU }\end{array}$ & $\begin{array}{r}20,800 \\
7,900\end{array}$ & $\begin{array}{l}26,000 \\
11,000\end{array}$ & $\begin{array}{r}21,000 \\
4,889\end{array}$ \\
\hline $\begin{array}{l}\text { 3. Zinc Chloride Catalyst PDU } \\
\text { 4. Disposable Catalyst Hydrogenation }\end{array}$ & $\begin{array}{r}2,400 \\
601\end{array}$ & $\begin{array}{r}2,000 \\
500\end{array}$ & 2,100 \\
\hline 5. Multi-Stage Liquefaction Pilot Plant & 0 & . 1,000 & 0 \\
\hline Total Direct Hydrogenation &.$\overline{31,701}$ & 40,500 & 29,000 \\
\hline \multicolumn{4}{|l|}{ b. Solvent Extraction } \\
\hline $\begin{array}{l}\text { 1. Solvent Refined Coal (SRC) Pilot Plant } \\
\text { 2. Solvent Refined Co.al Utilization }\end{array}$ & $\begin{array}{r}19,635 \\
1,120\end{array}$ & $\begin{array}{r}15,000 \\
1,000\end{array}$ & $\begin{array}{r}13,500 \\
1000\end{array}$ \\
\hline 3. Solvent Extraction of Lignite & 1,000 & & \\
\hline 4. CO-Steam Process & 500 & 500 & 640 \\
\hline 5. Chemicals From Coal & 450 & 400 & \\
\hline 6. Donor Solvent Pilot Plant & 2,000 & 30,300 & 34,600 \\
\hline Total Solvent Extraction & 24,705 & 47,200 & 49,740 \\
\hline \multicolumn{4}{|l|}{ c. Pyrolysis } \\
\hline 1. Clean Metallurgical Coke/Liquids: & 2,400 & $\begin{array}{r}0 \\
500\end{array}$ & 0 \\
\hline $\begin{array}{l}\text { 2. Flash Liquefaction } 1 \\
\text { 3. Entrained-Bed Pyrolysis }\end{array}$ & $\begin{array}{l}900 \\
600\end{array}$ & $\begin{array}{l}500 \\
500\end{array}$ & 2,000 \\
\hline 4. Hydrocarbonization/Residue Carbonization & 900 & 0 & \\
\hline 5. Fluid Coke & 600 & 1,000 & 0 \\
\hline - Total Pyrolysis & 5,400 & 2,000 & 2,000 \\
\hline d. Indirect Liquefactior. & 1,100 & 0 & 0 \\
\hline
\end{tabular}


Table 2 (Continued)

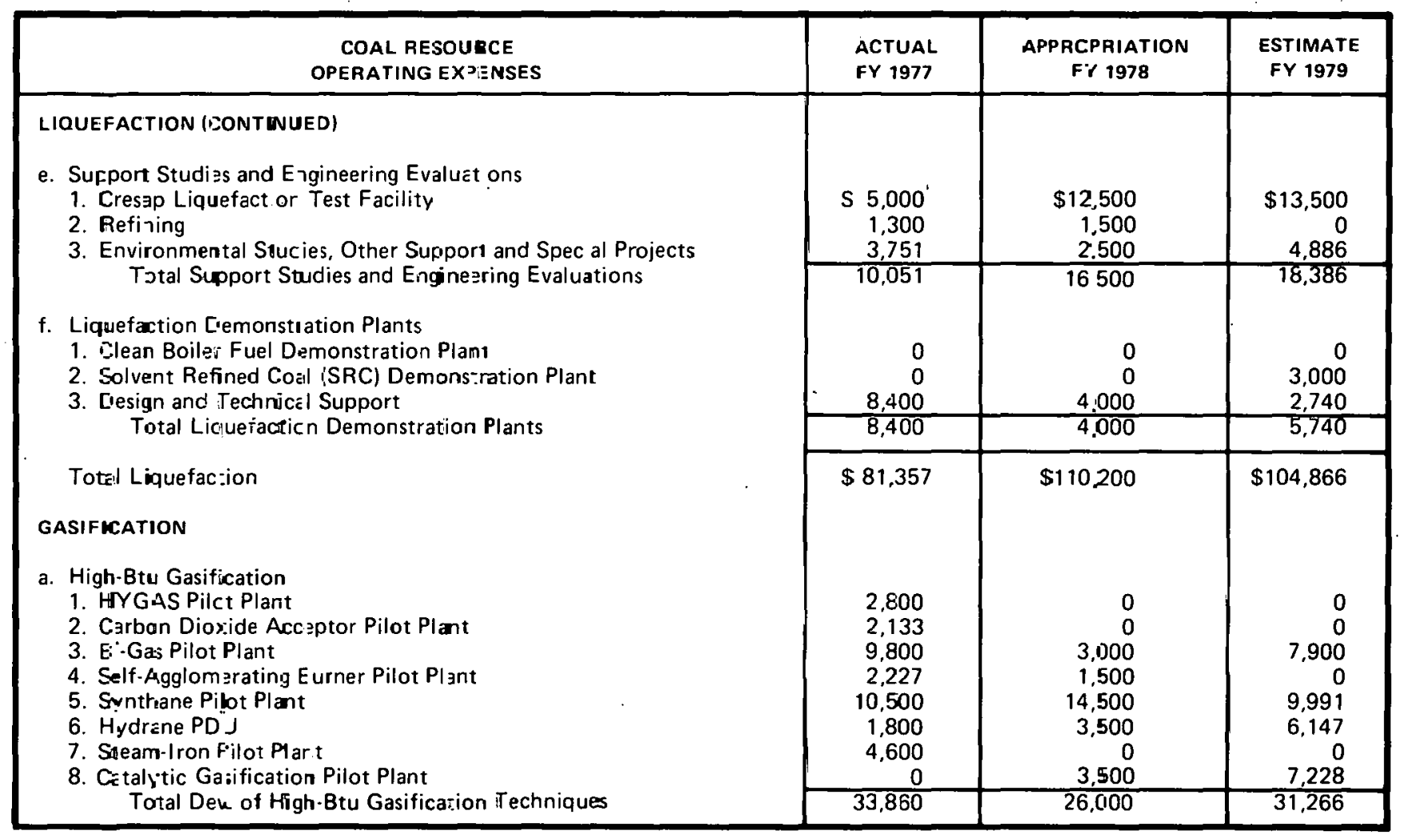


Table 2 (Continued)

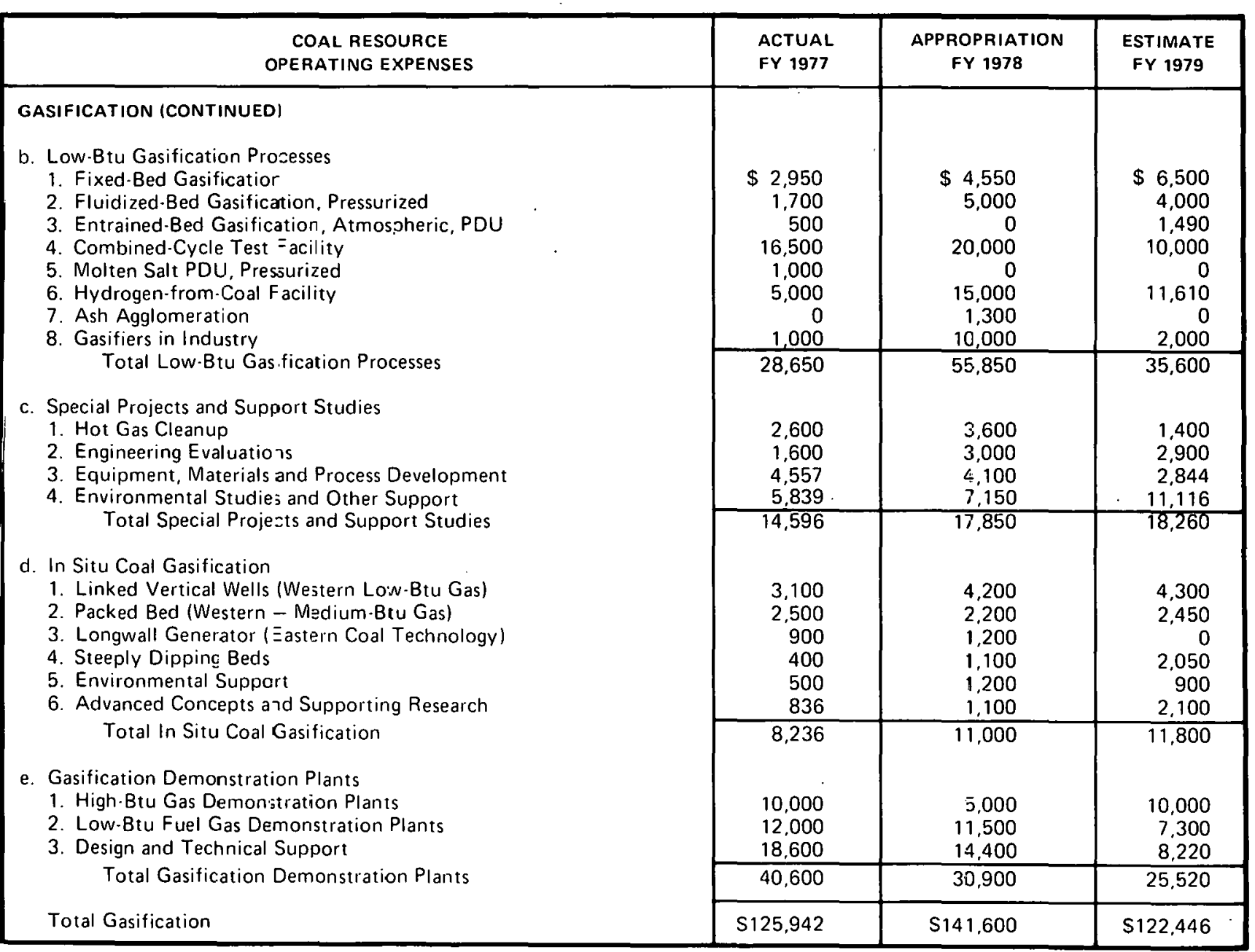


Table 2 (Continued)

\begin{tabular}{|c|c|c|c|}
\hline $\begin{array}{c}\text { COAL RESOURC } \\
\text { OPERATING EXPEVSES }\end{array}$ & $\begin{array}{l}\text { ACTUAL } \\
\text { FY } 1977\end{array}$ & $\begin{array}{l}\text { AFPROPRIATION } \\
\text { FY } 1978\end{array}$ & $\begin{array}{l}\text { ESTIMATE } \\
\text { FY } 1979\end{array}$ \\
\hline \multicolumn{4}{|l|}{ ADVANCED FOWER SYSTE MS } \\
\hline a. Open-Cyde Gas Turbine & 516,400 & $\$ 18,700$ & $\$ 24,350$ \\
\hline $\begin{array}{l}\text { b. Closed Power Systems } \\
\text { 1. Closed-Cycle Gas Turbine/Primary Heat E «changer } \\
\text { 2. Alkali Metal Vapor Systems } \\
\text { Total Closed Power Systems }\end{array}$ & $\begin{array}{l}1,500 \\
1,380 \\
2,880\end{array}$ & $\begin{array}{r}3,250 \\
250 \\
3,500\end{array}$ & $\begin{array}{l}0 \\
0 \\
0\end{array}$ \\
\hline \multirow{2}{*}{$\begin{array}{l}\text { c. Support and Additiona Programs } \\
\text { Total Advanced Power Systems }\end{array}$} & 3,220 & 3,300 & 2,350 \\
\hline & S22,500 & $\$ 25,500$ & $\$ 26,700$ \\
\hline \multicolumn{4}{|l|}{ DIRECT COMBUSTION } \\
\hline $\begin{array}{l}\text { a. Fluidized-Bed Boilers, Atmospheric } \\
\text { 1. Fluidized-Bed Boiler, } 30 \mathrm{MW} \text { e } \\
\text { 2. Industrial Apptications } \\
\text { 3. Component Test and lintegration Unit (AF 3-CTIU) } \\
\text { 4. AFB Closed-Cycle Gias Turbine TTU } \\
\text { 5. Plant Conversion } \\
\text { 6. Anthracite Applications }\end{array}$ & $\begin{array}{r}3,000 \\
10,000 \\
4,365 \\
1,700 \\
1,100 \\
1,000\end{array}$ & $\begin{array}{r}4,000 \\
10,000 \\
13,500 \\
2,000 \\
0 \\
0\end{array}$ & $\begin{array}{r}8,700 \\
2,000 \\
11,800 \\
714 \\
0 \\
2,186\end{array}$ \\
\hline Total Fluidized-Bed Boilers, Atmosp ar c & 21,165 & 29,500 & 25,400 \\
\hline $\begin{array}{l}\text { b. Fluidized-Bed Combustion, Pressurized Sy:tens } \\
\text { 1. Fluidized-Bed Combined-Cycle Pilot Plam } \\
\text { 2. Pressurized Fluidized-Bed Technology } \\
\text { 3. Co npo ent Test anc Imtegration Unit (PFE-CTIU) } \\
\text { 4. Granular Bed Filter/-tot Gas Cleanup } \\
\text { 5. Interna-ional Energy Administration }\end{array}$ & $\begin{array}{l}6,000 \\
1,600 \\
5,100 \\
1,500 \\
3,000 \\
\end{array}$ & $\begin{array}{r}7,000 \\
0 \\
4,729 \\
1,500 \\
2,000 \\
\end{array}$ & $\begin{array}{r}2,500 \\
0 \\
3,800 \\
2,876 \\
3,400 \\
\end{array}$ \\
\hline Total Pressurized Systems & 17,200 & 15,229 & 12,576 \\
\hline c. Mixtures & 4,300 & 3,000 & 5,450 \\
\hline
\end{tabular}


Table 2 (Continued)

\begin{tabular}{|c|c|c|c|}
\hline $\begin{array}{c}\text { COAL RESOURCE } \\
\text { JPERATING EXPENSES }\end{array}$ & $\begin{array}{l}\text { ACTUAL } \\
\text { FY } 1977\end{array}$ & $\begin{array}{l}\text { APPROPRIATION } \\
\text { FY } 1978\end{array}$ & $\begin{array}{l}\text { ESTIMATE } \\
\text { FY } 1979\end{array}$ \\
\hline \multicolumn{4}{|l|}{ DIRECT COMBUSTION (CONTINUED) } \\
\hline \multirow[t]{2}{*}{$\begin{array}{l}\text { d. Support Studies and Engineering Evaluations } \\
\text { 1. Engineering Studies } \\
\text { 2. Nonfluidized-Bed Combustion } \\
\text {. Regeneration } \\
\text { 4. Environmental Studiss, Other Support and Special Projects } \\
\text { Total Support Stidies and Engineering Evaluations }\end{array}$} & $\begin{array}{r}5,101 \\
1,500 \\
0 \\
2,635 \\
\end{array}$ & $\begin{array}{r}4,471 \\
4,000 \\
0 \\
2,000 \\
\end{array}$ & $\begin{array}{r}2,887 \\
545 \\
563 \\
3.455 \\
\end{array}$ \\
\hline & 9,236 & 10,471 & 7,450 \\
\hline \multirow{2}{*}{$\begin{array}{l}\text { e. Direct Combustion Demonstration Plants } \\
\text { 1. Atmospheric Fluidized-Bed Demonstration Plant } \\
\text { 2. Design and Technica Support } \\
\text { Total Direct Comsustion Demonstration Plants }\end{array}$} & $\begin{array}{r}0 \\
4,000\end{array}$ & $\begin{array}{l}6,000 \\
4,000\end{array}$ & $\begin{array}{l}1,600 \\
2,240\end{array}$ \\
\hline & 4,000 & 10,000 & 3,840 \\
\hline -otal Direct Combustion & $\$ 55,901$ & $\$ 68,200$ & $\$ 54,716$ \\
\hline
\end{tabular}


Table 2 (Continued)

\begin{tabular}{|c|c|c|c|}
\hline $\begin{array}{c}\text { COAL RESOURCE } \\
\text { OPERATING } \equiv \text { XPENSES }\end{array}$ & $\begin{array}{l}\text { ACTUAL } \\
\text { FY } 1977\end{array}$ & $\begin{array}{l}\text { ATP ZOPRIATION } \\
\text { FY } 1978\end{array}$ & $\begin{array}{l}\text { ESTIMATE } \\
\text { FY } 1979\end{array}$ \\
\hline \multicolumn{4}{|l|}{ ADVANEED RESEARCH AND SUPPORTING TECHNOLOGY } \\
\hline $\begin{array}{l}\text { a. Materials and Components } \\
\text { b. Procミsses } \\
\text { c. Direct Utilizaticn } \\
\text { d. Progam Develosment and Coordination }\end{array}$ & $\begin{array}{r}58.535 \\
15,2100 \\
5.535 \\
7.750 \\
\end{array}$ & $\begin{array}{r}59,264 \\
16,401 \\
5,972 \\
8,363 \\
\end{array}$ & $\begin{array}{r}\$ 11.090 \\
24,450 \\
9,450 \\
12.836 \\
\end{array}$ \\
\hline $\begin{array}{l}\text { d. Progam Develosment and Coordination } \\
\qquad \begin{array}{l}T=\text { tal Advanced Research and Sujporting Technoiogy }\end{array}\end{array}$ & 537.070 & 510.000 & S57,826 \\
\hline \multicolumn{4}{|l|}{ MAGNETOHYDRORYNAIWICS } \\
\hline $\begin{array}{l}\text { a. Open Cycle } \\
\text { 1. CJIF Project } \\
\text { 2. E-gineering Devalcpnent } \\
\text { 3. Engineering - est Facility } \\
\text { 4. Syster Engir.eering } \\
\text { 5. Suppcrting Fesearch }\end{array}$ & $\begin{array}{r}2.550 \\
18.794 \\
0 \\
4.700 \\
7.846 \\
\end{array}$ & $\begin{array}{r}17.305 \\
27,300 \\
2.941 \\
6.754 \\
9.300 \\
\end{array}$ & $\begin{array}{r}16.889 \\
27.096 \\
400 \\
9,886 \\
13,554 \\
\end{array}$ \\
\hline Total Open Cyc e & 33,890 & 63,600 & 67,825 \\
\hline \multirow{2}{*}{$\begin{array}{l}\text { b. Closed Crcle } \\
\text { Total Magnetahydrocynamics }\end{array}$} & 1.100 & 3,200 & 1,000 \\
\hline & $34.990^{\circ}$ & 66,800 & 68.825 \\
\hline
\end{tabular}


Table 2 (Continued)

\begin{tabular}{|c|c|c|c|}
\hline $\begin{array}{l}\text { COAL \& PETROLELM RESOURCES } \\
\text { OPERATING EXPENSES }\end{array}$ & $\begin{array}{l}\text { ACTUAL } \\
\text { FY } 1977\end{array}$ & $\begin{array}{l}\text { APPROPRIATION } \\
\text { FY } 1978\end{array}$ & $\begin{array}{l}\text { ESTIMATE } \\
\text { FY } 1979\end{array}$ \\
\hline \multirow{3}{*}{$\begin{array}{l}\text { ADVANCED ENVIRONMENTAL CONTROL TECHNOLOGY } \\
\text { IMPF.OVED CONVERSION EFFICIENCY } \\
\text { a. Heat Engines \& Heat Re:overy } \\
\text { b. Combustion Systems } \\
\text { c. Fuel Cells } \\
\text { Total Improved Conversion Efficiency } \\
\text { S.Jbtotal Coal Resource } \\
\text { Less Undistributed FY } 1978 \text { Approp-iation General Reduction } \\
\text { Total Coal Resource }\end{array}$} & 0 & . & 14,000 \\
\hline & $\begin{array}{r}3,300 \\
850 \\
19,000\end{array}$ & $\begin{array}{r}16,600 \\
6,480 \\
35,200\end{array}$ & $\begin{array}{l}29,600 \\
.11,900 \\
35,500\end{array}$ \\
\hline & $\begin{array}{r}23,150 \\
\$ 432,765\end{array}$ & $\begin{array}{r}58,280 \\
\$ 573,360 \\
.23,800 \\
\end{array}$ & $\begin{array}{r}77,000 \\
\$ 596,925 \\
\end{array}$ \\
\hline \multirow{2}{*}{$\begin{array}{l}\text { PETROLEUM } \\
\text { ENHANCED OIL RECOVERY } \\
\text { a. Micellar Polymer Flood ng } \\
\text { b. Carbon Dioxide Flooding } \\
\text { c. Improved Waterflooding } \\
\text { d. Thermal Recovery } \\
\text { e. Environmental Studies and Other Support } \\
\text { Total Enhanced Oil Riecovery }\end{array}$} & $\$ 432,765$ & $\$ 549,560$ & $\$ 596,925$ \\
\hline & $\begin{array}{l}7,500 \\
5,500 \\
1,000 \\
4,500 \\
5,282 \\
\end{array}$ & $\begin{array}{r}12,500 \\
6,600 \\
3,500 \\
12,000 \\
11,340 \\
\end{array}$ & $\begin{array}{r}5,860 \\
5,220 \\
4,690 \\
18,430 \\
11,800\end{array}$ \\
\hline $\begin{array}{l}\text { Total Enhanced Oil Riecovery } \\
\text { OIL SHALE }\end{array}$ & 23,782 & 45,940 & 46,000 \\
\hline $\begin{array}{l}\text { a. Shale Oil Production } \\
\text { DRILLING EXPLORATION AND OFFSHORE TECHNOLOGY }\end{array}$ & 18,678 & 24,032 & 29,350 \\
\hline $\begin{array}{l}\text { a. Drilling } \\
\text { b. Environment and Advariced Concept }\end{array}$ & $\begin{array}{r}1,800 \\
600\end{array}$ & $\begin{array}{r}1,000 \\
600\end{array}$ & $\begin{array}{l}777 \\
823\end{array}$ \\
\hline Total Drilling and Offshore Techrology & 2,400 & 1,600 & 1,600 \\
\hline
\end{tabular}


Table 2 (Continued)

\begin{tabular}{|c|c|c|c|}
\hline $\begin{array}{l}\text { PETROLEUM \& GAS RESOURCES } \\
\text { OPERATING EXPENSES }\end{array}$ & $\begin{array}{l}\text { ACTUAL } \\
\text { FY } 1977\end{array}$ & $\begin{array}{l}\text { AFPROPRIATION } \\
\text { FY } 1978\end{array}$ & $\begin{array}{l}\text { ESTIMATE } \\
\text { FY } 1979\end{array}$ \\
\hline \multirow[b]{2}{*}{ To:al Petroleum Resource } & 1,831 & 1.400 & 1,200 \\
\hline & $\$ 46,691$ & $\$ 72.972$ & $\$ 78,150$ \\
\hline $\begin{array}{l}\text { a. Eac-ern Gas Shales } \\
\text { b. Westerr Gas Sands } \\
\text { c. Methan Fror Coal } \\
\text { d. Gerpressured Aquifers } \\
\text { e. Enrirorment end Support }\end{array}$ & $\begin{array}{r}9,500 \\
4,474 \\
0 \\
0 \\
900\end{array}$ & $\begin{array}{r}14.000 \\
4.300 \\
2.000 \\
1.500 \\
4.985\end{array}$ & $\begin{array}{r}12,000 \\
5,500 \\
0 \\
0 \\
3,800\end{array}$ \\
\hline $\begin{array}{l}\text {-otal Enhanced Gas Recovery } \\
\text { GAS FROM OIL SHALE }\end{array}$ & 14,874 & 26.785 & 21,300 \\
\hline $\begin{array}{l}\text { a. Sha'e Gas Productio } 7 \\
\text { Total Gas fom Oil Shale }\end{array}$ & $\begin{array}{r}3,600 \\
3,600 \\
\end{array}$ & $\begin{array}{r}3,850 \\
3,850 \\
\end{array}$ & $\begin{array}{r}4,350 \\
4,350 \\
\end{array}$ \\
\hline Toral Gas & $\$ 18,474$ & $\$ 30.635$ & $\$ 25,650$ \\
\hline Total F.ossil Emergy Jevelopment Operat'ing Expenses & $\$ 497,930$ & $\$ 653,167$ & $\$ 700,725$ \\
\hline
\end{tabular}


Table 3 Fossil Energy Development

FY 1979 Budget Estimates

Summary Table of Plant and Capital Equipment by Technologies

Budget Authority

(Dollars in Thousands)

\begin{tabular}{|c|c|c|c|}
\hline RESOURCE/ACTIVITY & FY 1977 & $\begin{array}{l}\text { APPRO- } \\
\text { PRIATION } \\
\text { FY } 1978\end{array}$ & $\begin{array}{l}\text { ESTIMATE } \\
\text { FY } 1979\end{array}$ \\
\hline COAL & & & \\
\hline $\begin{array}{l}\text { Liquefaction } \\
\text { Clean Eoiler Fuels } \\
\text { Solvent Refined Coal Demon stration Plant }\end{array}$ & $\begin{array}{r}\$ 30,000 \\
0\end{array}$ & $\begin{array}{ll}\$ & 0 \\
& 0\end{array}$ & $\begin{array}{r}\$ 0 \\
20,000\end{array}$ \\
\hline $\begin{array}{l}\text { Gasificaticn } \\
\text { High-B1u synthetic pipeline gas demonstration plant } \\
\text { Low-Btu fuel gas industrial demonstratiori plant } \\
\text { Low-Btu fuel gas small industrial demonsiration plants (2) }\end{array}$ & $\begin{array}{r}10,000 \\
7,300 \\
0\end{array}$ & $\begin{array}{r}29,000 \\
36,000 \\
3,000\end{array}$ & $\begin{array}{r}40,000 \\
14,000 \\
9,000\end{array}$ \\
\hline $\begin{array}{l}\text { Direct Combustion } \\
\quad \text { Fluidized-Bed Direct Combustion Demonstration Plant }\end{array}$ & 0 & 2,000 & 0 \\
\hline $\begin{array}{l}\text { Magnetohvdrodynamics } \\
\text { Component Development and Integration Facility }\end{array}$ & 5,000 & 4,200 & 3,000 \\
\hline $\begin{array}{l}\text { Energy Research Centers } \\
\text { Modifications and Additions }\end{array}$ & 6,900 & 9,600 & 9,350 \\
\hline Other Capital Equipment & 750 & 4,500 & 3,920 \\
\hline PETROLEUM & & & \\
\hline Other Capital Equipment & 600 & 1,153 & 1,575 \\
\hline GAS & & & \\
\hline Other Capital Equipment & 170 & 347 & 225 \\
\hline Total Fossil Energy Capital Acquisition Expens:ss & $\$ 60,720$ & $\$ 89,800$ & $\$ 101,070$ \\
\hline
\end{tabular}




\section{Table 4 Fossil Energy Development Summary of Total FY 1979 Budget Request by Activity/Fund Source} (Dollars in Millions)

\begin{tabular}{|c|c|c|c|c|}
\hline \multirow[b]{2}{*}{ RESOURCE/ACTIVITY } & \multicolumn{4}{|c|}{ FUND SOURCE (BA) } \\
\hline & $\begin{array}{r}\text { OPERATING } \\
\text { EXPENSES }\end{array}$ & PLANT & $\begin{array}{l}\text { CAPITAL } \\
\text { EQUIPMENT }\end{array}$ & TOTAL \\
\hline $\begin{array}{l}\text { COAL } \\
\text { Mines RD\&D } \\
\text { Liquefaction } \\
\text { Gasification } \\
\text { Advanced Power System } \\
\text { Virect Combustion } \\
\text { Advanced Research and Supporting Technology } \\
\text { Magnetohydrodynamics } \\
\text { Improved Conversion Efficiency }{ }^{1} \\
\text { Advanced Environmental Control Tcchnology }\end{array}$ & $\begin{array}{r}70.6 \\
104.8 \\
122.5 \\
26.7 \\
54.1 \\
57.8 \\
68.8 \\
77.0 \\
14.0\end{array}$ & $\begin{array}{r}0 \\
20.0 \\
63.0 \\
0 \\
0 \\
9.4 \\
3.0 \\
0 \\
0\end{array}$ & $\begin{array}{r}0.2 \\
0.2 \\
1.2 \\
0.2 \\
U .2 \\
0.4 \\
0.5 \\
1.0 \\
0\end{array}$ & $\begin{array}{r}70.8 \\
125.0 \\
186.7 \\
26.9 \\
54.9 \\
67.6 \\
72.3 \\
78.0 \\
14.0\end{array}$ \\
\hline $\begin{array}{l}\text { Total Coal } \\
\text { PETROLEUM } \\
\text { Enhanced Oil Recovery } \\
\text { Oil from Oil Shale } \\
\text { Drilling and Offshore Recovery } \\
\text { Product Characterization and Utilization }\end{array}$ & $\begin{array}{r}46.0 \\
29.3 \\
1.6 \\
1.2\end{array}$ & $\begin{array}{l}0 \\
0 \\
0 \\
0\end{array}$ & $\begin{array}{r}0.7 \\
0.9 \\
0 \\
0\end{array}$ & $\begin{array}{r}696.2 \\
\\
46.7 \\
30.2 \\
1.6 \\
1.2\end{array}$ \\
\hline $\begin{array}{l}\text { Total Petroleum } \\
\text { GAS }\end{array}$ & 78.1 & 0 & 1.6 & 79.7 \\
\hline $\begin{array}{l}\text { Enhanced Gas Recovery } \\
\text { Gas from Oil Shale }\end{array}$ & $\begin{array}{r}21.3 \\
4.4\end{array}$ & $\begin{array}{l}0 \\
0\end{array}$ & $\begin{array}{r}0.2 \\
0\end{array}$ & $\begin{array}{r}21.5 \\
4.4\end{array}$ \\
\hline Total Gas & 25.7 & 0 & 0.2 & 25.0 \\
\hline Total Fossil Energy & 700.7 & 95.4 & 5.7 & 801.8 \\
\hline
\end{tabular}

${ }^{1}$ From Conservation Budget 
Within the total Fossil Energy programs, several important changes in emphasis have taken place. Initial emphasis in the programs (before FY 1974) was placed on the priority development of substitute natural gas (high-Btu gasification). As the high-Btu projects reached the pilot plant stage, the emphasis switched (about 1974) to the development of synthetic liquids from coal (liquefaction). Presently, the emphasis is focusing on demonstration of mature technologies such as coal gasification as well as enhanced recovery of petroleum and natural gas.

The FY 1979 Budget Request for the Coal Resource is $\$ 58.3$ million above the 1978 level. The majority of this increase is in the area of Heat Engines and Heat Recovery Technology (pertaining to Advanced Cogeneration Systems and Heat Recovery Components), Underground Coal Mining technology, and Advanced Research efforts into promising thirdgeneration conversion processes. These increases are offset by a slight reduction in Gasification as its technologies mature and approach the technology transfer phases.

The 1979 Budget Request for the Petroleum Resource is $\$ 5.6$ million above the 1978 level. The increase in this resource focuses on Shale Oil Production and the incremental cost for continuing four cost-shared projects to develop in situ technology aimed at utilizing each of four geologic types of oil shales.

The 1979 Budget Request for the Gas Resource is $\$ 5.1$ million below the FY 1978 level. The decrease in this resource is primarily related to deferral of work in two subactivities, Methane from Coal and Geopressured Aquifers, plus a slightly reduced funding requirement in environmental and support activities.

The program structure, as presented in this book, differs slightly from the actual FY 1979 Congressional Budget Submission Activity structure in order to address the technological relationship of the Improved Conversion Efficiency Activity to the Fossil Energy Advanced Power Systems and Direct Combusion Activities. A cross-reference budget table is presented in Table 5 , however, the Congressional Budget activities remain clearly visable in the technological discussion presented in this document.

The demonstration phase of the research and development (R\&D) process has been integrated into the appropriate technology activities in the new resource program structure. Figure 2 shows a conceptual demonstration plants overview and their interrelationships with the overall Fossil Energy R\&D program designed to ultimately transfer promising technologies into the commercial demonstration phase.

Taken as a whole, the Fossil Energy programs have been evolving over the past several years, and significant shifts in emphasis have taken place as projects have been completed and new ones initiated. However, only a few processes have been taken to large-scale development; therefore, the Fossil Energy programs can be expected to become even more focused in the future, since only a few technologies will be taken to the demonstration-scale of development, the final step before technologies transfer occurs, leading to commercial demonstration and implementation. 
Table 5 Comparability Table - FY 1979 Estimates Budget

to Corgress/FE Program Summary Book

(Operating Expenses)

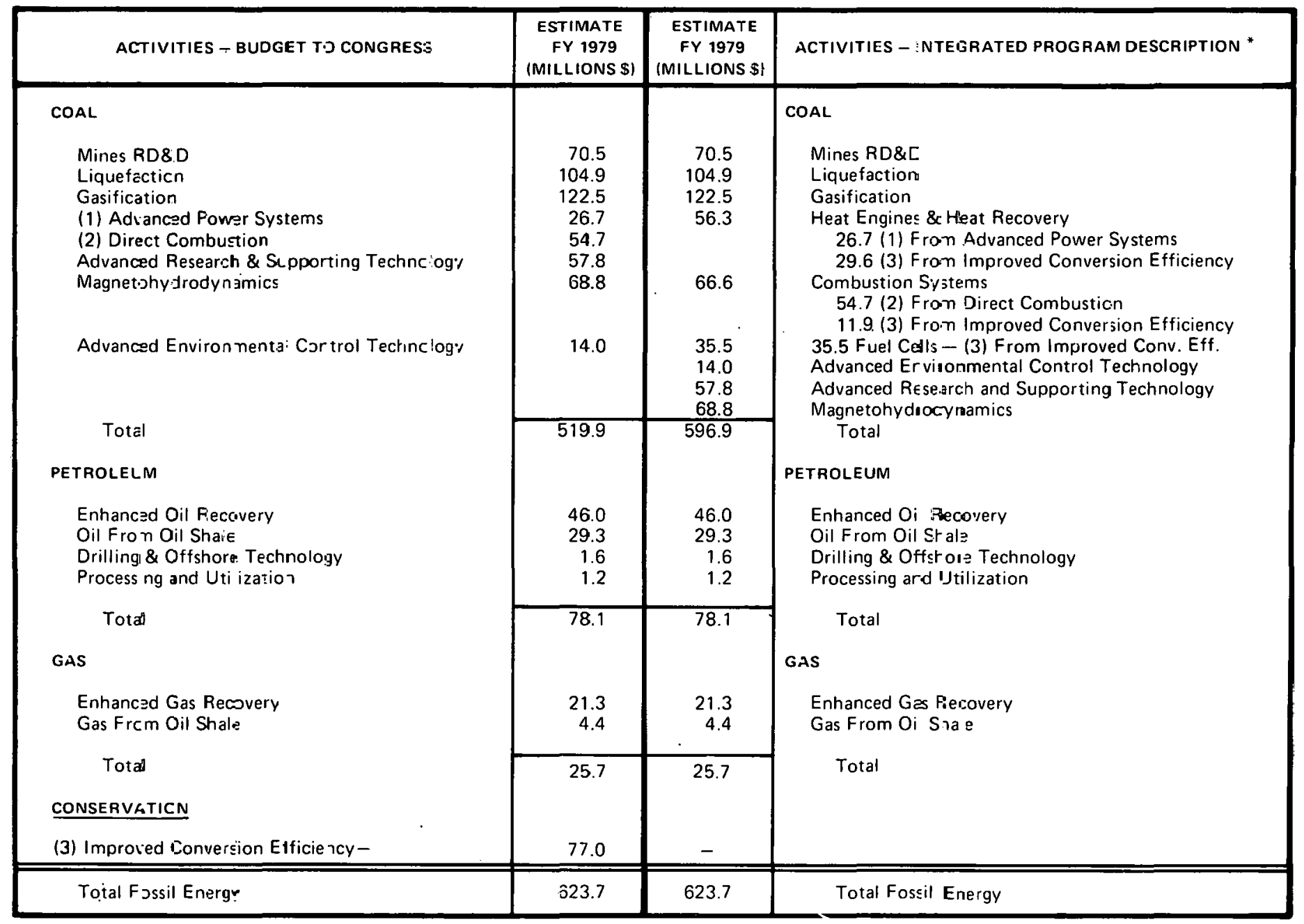

*Numbers in Farentheses indicat? program correlation 


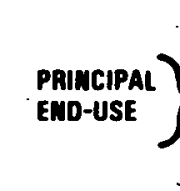

crcLi $\}$

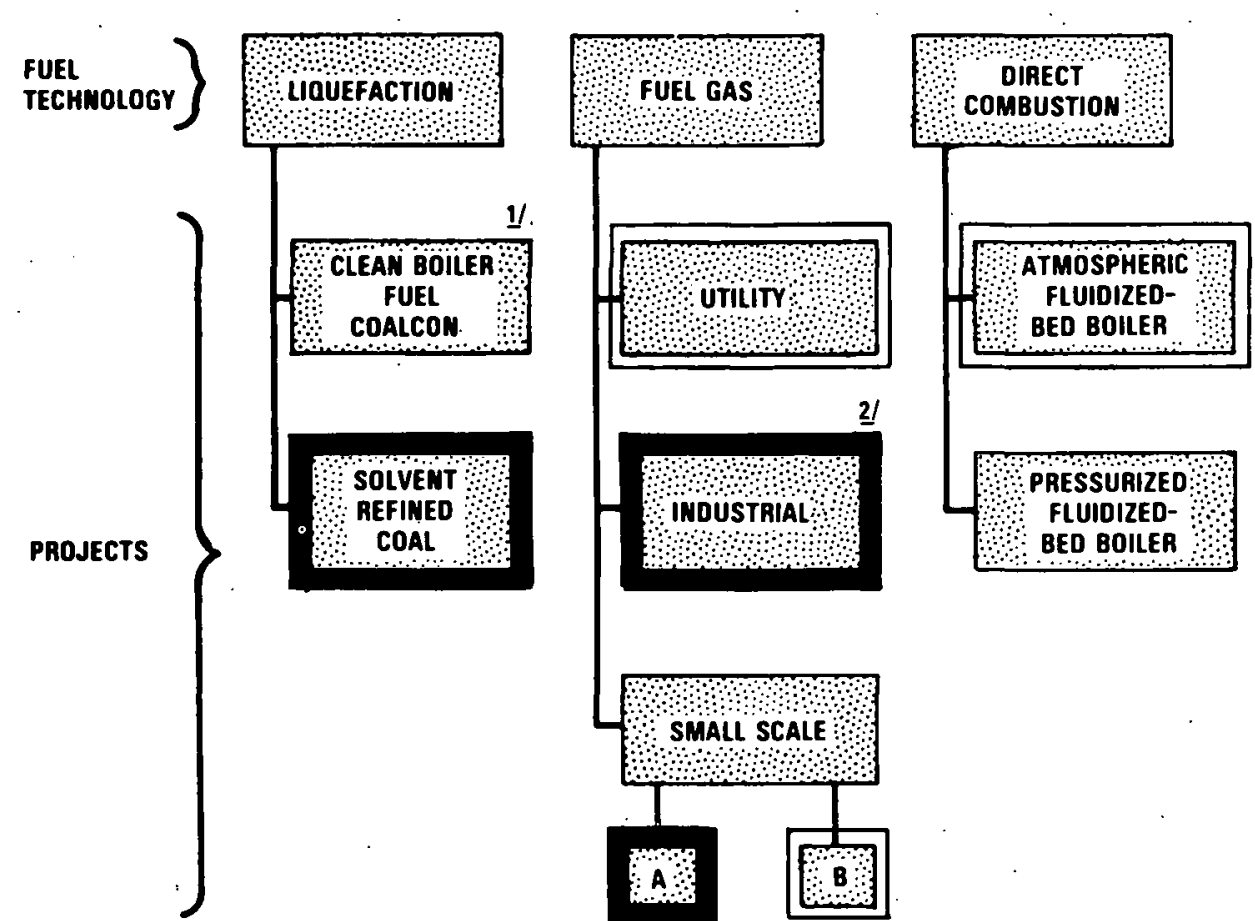

PRODUCTS $\left\{\begin{array}{l}\text { BOLER FUEL OIL } \\ \text { PPPELIEG GAS } \\ \text { LPG + SGG } \\ \text { UGHT OLI } \\ \text { AMMMOMIA }\end{array}\right.$

1/UNOERGOING REEVALUATION

2! TWO CONCEPTUAL DESIGNS BEING DEVELOPED

$\square=$ comtaimed IH CAPITAL ACQUI!SIIION PROGRAM FOR FY 1979

$\square$ = CONTAMED IN CURRENT OVERALL PROGRAM FOR FY 1979 (CONCEPTUAL DESIGM)

LOW-BTU GAS

$-$

AMMOMIA

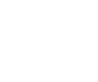

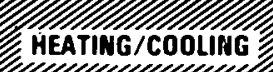

TRANPORATIOM FUELS

BRATON/RANKIME

nHo
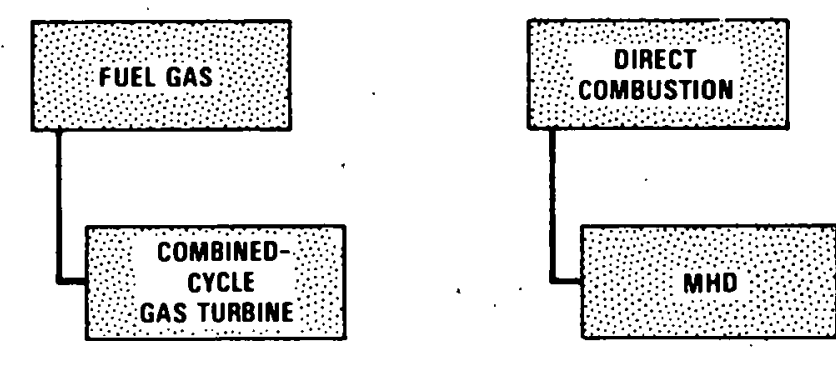

LOW-BTU GAS
AMMONIA

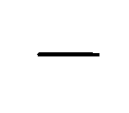

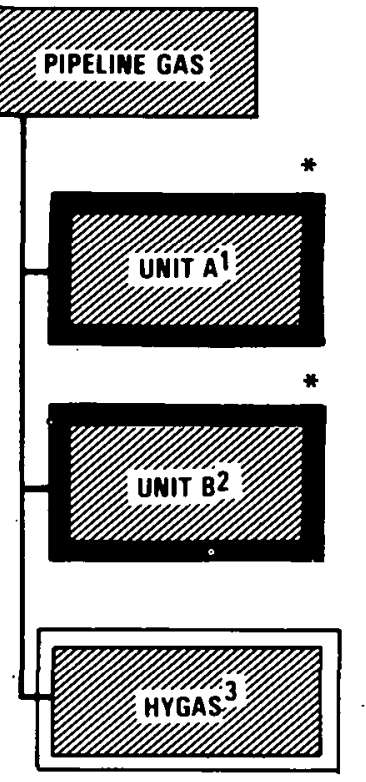
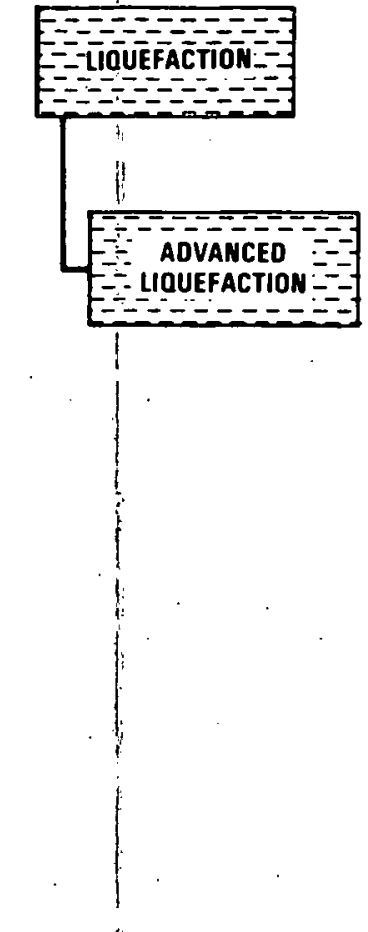

PIPELINE GAS
NAPHHA
PHENOLS
TAR
AMMONIA

AMMONIA

PIPELINE GAS ${ }^{2}$

PIPELINE G
SYNCRUOE

PHEMOLS

PIPELINE GAS

AMMONIA

* OMLY OME PLANT ( $\mathrm{O}$ OR $\mathrm{B}$ )

TO PROCEED THROUGH CONSTRUCTION
UIGHT BOILER FUEL DIESEL FUEL
PIPELINE GAS
GASOLINE
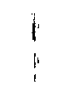

Figure 2

Relation of Demonstration Plants to Energy Requirements 


\section{B. FOSSIL ENERGY RESOURCE STRATEGIES}

The fundamental strategy of the Fossil Energy program is to develop technologies that will permit a smooth transition to the widespread use of plentiful fossil fuels in lieu of scarcer and more expensive resources. This strategy then focuses on technologies that will:

- Transform plentiful fossil fuels from a form incompatible with present end-use devices to one that is compatible. (For example, the transition will be smoother if coal is economically transformed into a liquid suitable for use with existing internal combustion engines.)

- Permit economical tapping of large reservoirs of formerly inaccessible or unusable fossil fuels that are compatible with existing end-use devices, thereby substantially postponing the consequences of shortages of the depleting resources. (For example, there is little or no negative societal impact if we economically obtain additional oil from known reservoirs.)

- Permit the economical and environmentally acceptable use of presently accessible fossil fuel supplies which currently fail to meet environmental requirements. (For example, greater quantities of and additional types of-coal.)

\subsection{COAL RESOURCE STRATEGY}

The coal resource objectives are to develop and demonstrate, in cooperation with industry, the technologies necessary to allow coal and coal derived fuels to substitute for oil and gas in ways and at rates that are economically, environmentally, and socially acceptable.

The coal strategy is to identify technologies having significant potential to substantially increase coal use within economic, social and environmental limits, to develop and demonstrate the technology, and to transfer the knowledge and technology to the private sector for implementation.

The transfer of knowledge and technology to the private sector is a key aspect of this strategy. It is accomplished by obtaining industry participation at all stages of the process. Industry is involved in the typical development sequence shown in Figure 3. 


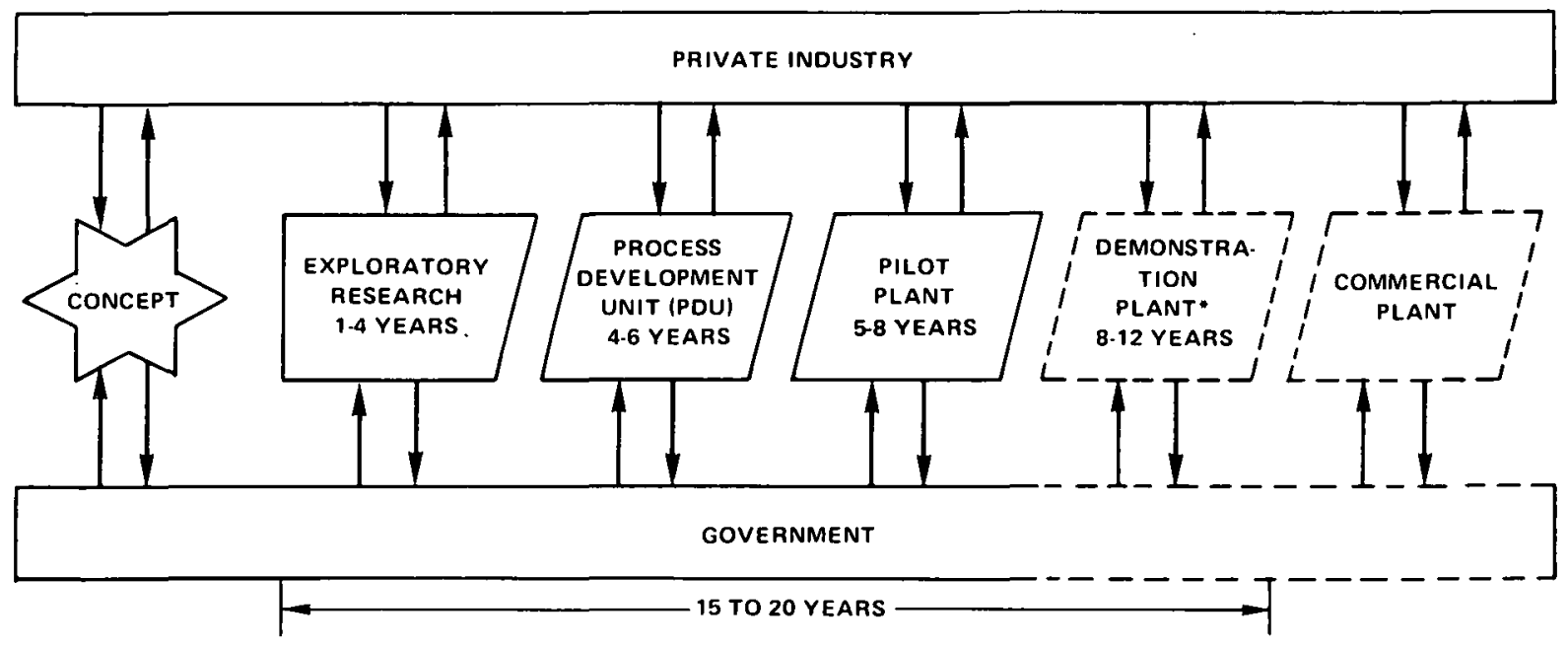

* DEMONSTRATION PLANT PHASE IS NQT NECESSARILY REQUIRED IN ALL R,D\&D PROGRAMS.

Figure 3 Typical Process Development Sequence

Each phase in the sequence involves scaling up to larger units, until the scale in demonstration plants is large enough to provide firm data for cost estimates and design of commercial-scale plants. Industry funding participation is concentrated in the pilot plant and demonstration plant phases, although cost-sharing also takes place earlier. The lengths of time of the phases of development depend upon the complexity of the process, project, scope, and resources applied. Approximate times spent in each are shown in the diagram above. (Definitions of these various RD\&D phases are provided in Chapter $X$.$) Because the phases usually$ overlap, the total development time is less than the sum of all phases. Total development time from laboratory to completion of demonstration plant operation is typically 15 to 20 years.

Technical feasibility and economic, social and environmental acceptability are evaluated in each phase. These evaluations are tentative in the early stages and improve through demonstration plant phase. Environmental impact statements are developed as required when large plants are constructed.

Some of the technologies are suited for use by small- and medium-size firms. For these, the strategy includes identifying specific potential markets and targeting technology development directly to these uses . This, in conjunction with industry cost-sharing increases the prospect of technology commercialization by the private sector.

\subsection{PETROLEUM RESOURCE STRATEGY}

The objective of the petroleum program is to increase the domestic production and reserves of oil from both onshore and offshore areas and from tar sands and oil shale. The strategy is to accelerate exploration and extraction by developing and encouraging the use of advanced technologies that are economically feasible, environmentally and socially acceptable, and 
operationally safe and dependable. Because the effectiveness of a technology depends largely upon the characteristics of a particular field or deposit, the strategy includes identifying those fields or deposits that have significant potential for substantial production and developing technologies for those situations. The strategy includes accelerating technology implementation by cost-sharing the development with the private sector.

Identification of oil fields in which enhanced oil recovery has the potential to make a significant contribution to total production involved a complete in-depth quantitative analysis. This led to a detailed five-year RD\&D program that has gained widespread acceptance with the private sector.

This RD\&D program is designed to stimulate private industry participation in an area in which economic and technical risk are currently inhibiting development.

\subsection{GAS RESOURCE STRATEGY}

The objective of the natural gas recovery program is to obtain significant production of natural gas from unconventional sources to reduce our dependence on foreign sources of gas or oil.

The strategy is to identify new sources of natural gas that have significant production potential and to develop technologies to extract this resource at acceptable costs and in an environmentally and socially acceptable manner.

This strategy involves:

- Determining characteristics and production potential of the different resources

- Developing reliable exploratory techniques for the significant resources

- Developing, demonstrating and transfering effective extraction technologies.

The strategy includes a cost-sharing project with the private sector to enhance timely transfer and commercialization of the technology. 


\section{PROGRAM MANAGEMENT}

The Organizational Structure of the Program Director for Fossil Energy has been changed in accordance with the Department of Energy Organization Act of 1977, PL 95-91, dated August 4, 1977. The Program Director for Fossil Energy reports to the Assistant Secretary for Energy Technology, Department of Energy.

This new organization, shown in Figure 4 below, describes the program flow and management and control of major fossil energy research, development and demonstration projects.

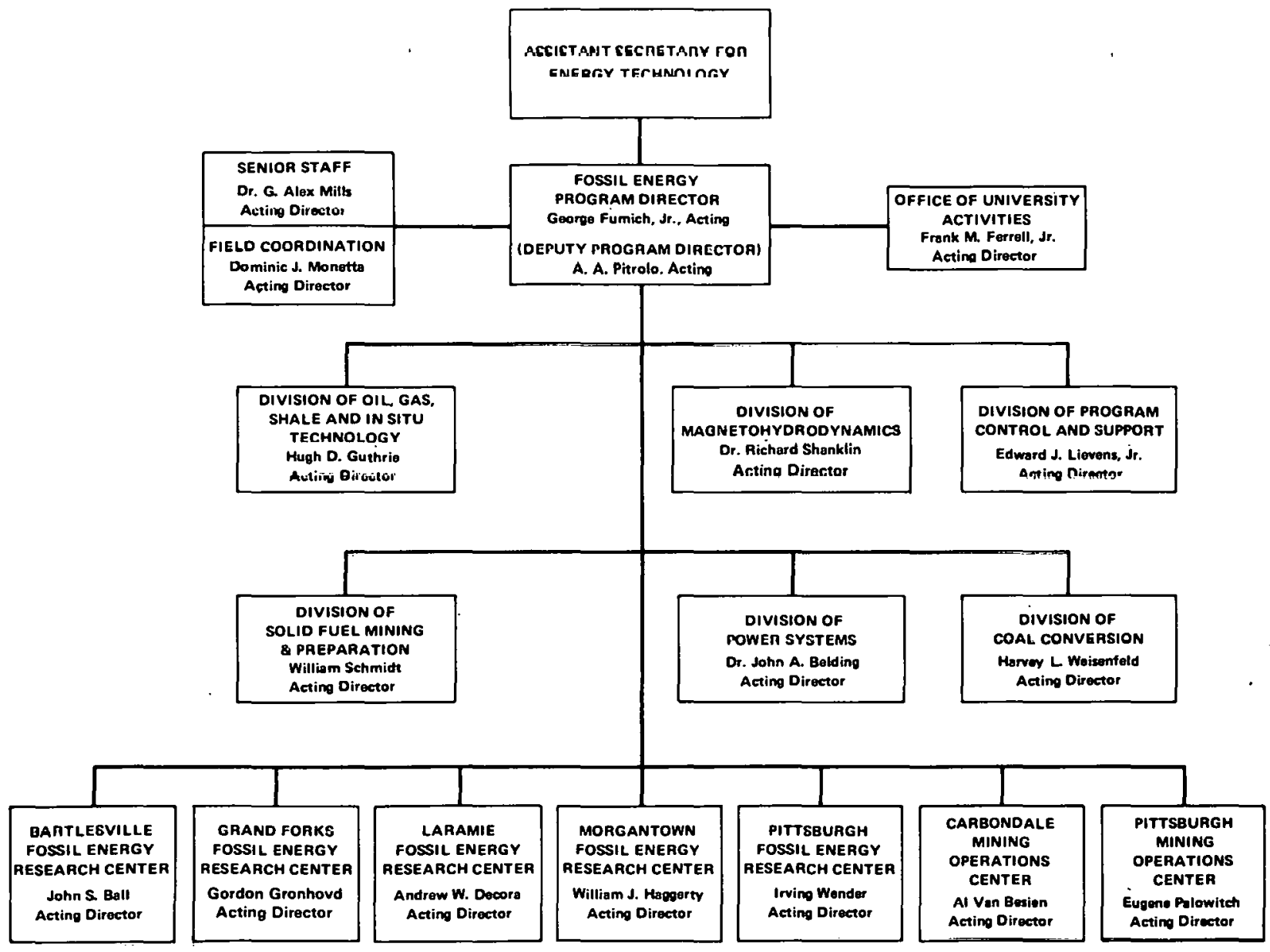

Figure 4 DOE Fossil Energy Organization

The new FE organization consists of six line divisions, two staff offices, five ERCs, two MOCs, and a small senior staff. The program management concept of large-scale projects is now one of matrix management and team participation for more effective and efficient operations. As now organized, five of these line divisions, Oil, Gas, Shale and In Situ Technology (OGSIST), Coal Conversion (CC), Magnetohydrodynamics (MHD), Solid Fuel Mining and Preparation (SFMP), 
and Power Systems (DPS) are primarily concerned with developing and managing various process development projects for extracting and/or using energy from fossil energy sources by means of applied research, technology, and engineering development, through the demonstration phase.

Table 6 presents programmatic responsibility by Division.

Table 6 Program Management Chart

\begin{tabular}{|l|c|c|c|c|c|}
\hline \multirow{2}{*}{ FY 1978 PROGRAM STRUCTURE } & \multicolumn{4}{|c|}{ PROGRAM DIVISION } \\
\cline { 2 - 6 } & $\mathrm{CC}$ & $\mathrm{PS}$ & OGIST & MHD & SFMP \\
\hline Mines RD\&D & & & & & $\mathrm{X}$ \\
Liquefaction & $\mathrm{X}$ & & & & \\
High-B tu Gasification & $\mathrm{X}$ & & & & \\
Low-B tu Gasification & $\mathrm{X}$ & & & & \\
In-Situ Coal Gasification & & & $\mathrm{X}$ & & \\
Advanced Power Systems & & $\mathrm{X}$ & & & \\
Direct Coal Combustion & & $\mathrm{X}$ & & & \\
Improved Conversion Efficiency & & $\mathrm{X}$ & & & \\
Advanced Research Sppt Tech & $\mathrm{X}$ & $\mathrm{X}$ & $\mathrm{X}$ & & \\
MHD & & & & $\mathrm{X}$ & \\
Enhanced Oil Recovery & & & $\mathrm{X}$ & & \\
Enhanced Gas Recovery & & & $\mathrm{X}$ & & \\
Drilling \& Offshore Tech & & & $\mathrm{X}$ & & \\
Processing \& Utilization & & & $\mathrm{X}$ & & \\
Oil Shale (Oil \& Gas) & & & $\mathrm{X}$ & & \\
\hline
\end{tabular}

In support of the five Divisions mentioned, the Division of Program Control and Support is responsible for providing Budget, Procurement, Program Planning and Integration, Management Review and Control, Administrative Policy Planning, Analytical, and Environmental Program Coordination Support.

The Senior Staff of the Program Director for Fossil Energy provides expert scientific, management, and programmatic counsel to the Program Director and appropriate divisions and offices of Fossil Energy. This Staff is also responsible for certain FE programs in the areas of international relations, advisory committees, and intergovernmental groups, and for specific projects such as the FE Authorization and Review Panel, which reviews all proposed Fossil Energy projects and contracts.

The Office of Field Coordination is responsible for overall coordination between DOE/FE headquarters and the FE related field activities.

The Office of University Activities is responsible for the following FE related functions: establishing policy for university activities, administering the small inventors program, acting as a focal point for university information and inquiries, and providing overview and coordination for sponsored university work, including exploratory and seed activities funded by other divisions and for field of fices. 
The mission of $\mathrm{FE}$ is the efficient and effective management of all fossil energy research, development, and demonstration activities. The objective of these RD\&D activities is to make available proven technology that will, when commercialized, assure in the national interest a dependable and timely flow of energy from fossil sources. The results of this work must also be designed to deliver sufficient environmentally acceptable energy to meet national fossil energy requirements at acceptable costs for industry, defense, the public sector, and private individuals.

FE accomplishes its mission primarily through the management of programs and projects contracted to industry. In addition to these contracts, some research and development activities are performed by FE/ERCs (either in-house or by contract), contractor-operated DOE National Laboratories (NLs), or by grants and/or contracts between the line divisions and the performing organization. More information on ERC, Mining Operation Centers (MOCs), and National Laboratory activities is provided in Cliapter IV 


\section{COAL RESOURCE}

\section{A. COAL RESOURCE OVERVIEW}

Coal is the nation's most plentiful fuel resource with enough reserve to last several centuries. It offers the greatest potential for achieving energy independence in the 1980s and relieving the current U.S. energy shortfall. For example, the United States has reserves estimated at 3.2 trillion tons of unmined coal, whereas supplies of oil and natural gas are becoming rapidly depleted. Major efforts of the Coal Research, Development, and Demonstration Program are aimed at tapping this abundant source of energy for direct use as a fuel in an efficient and environmentally acceptable manner, or for processing into synthetic fuels to provide a substitute for limited oil and natural gas resources.

The principal objectives of the Coal Resource program are: to accelerate the development of environmentally acceptable technology for extracting coal, converting coal to liquid and gaseous fuels by both surface and in situ processing; to stimulate improved methods for the direct combustion of coal; to foster rapid development of advanced power conversion systems, including fuél cells and magnetohydrodynamics, for generating electricity from coal; to validate technical, economic, and environmental acceptability of second-generation coal processes by design, construction, and operation of near-commercial scale modules; to expand the technological base and the supply of technically trained manpower, to support the evolving coal conversion and utilization technologies and to stimulate technology in the area of greater heat conversion efficiency from fossil fuel products.

The basic objectives of the Coal Resource program will be met by implementing activities in the areas of coal conversion and improved direct coal utilization. The Activity areas to be discussed include:

- Mines RD\&D

- Liquefaction

- Gasification

- Heat Engines and Heat Recovery

- Combustion Systems

- Fuel Cells

- Advanced Environmental Control Technology

- Advanced Research and Supporting Technology

- Magnetohydrodynamics 
The Mines Research, Development and Demonstration Activity supports the substitution of abundant energy sources (i.e., coal and oil shale) for less abundant sources (i.e., oil and natural gas) by developing technologies that will improve the economics of production; maximize resource recovery; protect the health and safety of mine workers; and protect the environment. Based upon the National Energy Plan and the major requirements of mining technologies identified above, the functions of the Mines, Research, Development and Demonstration Activity are conducted in underground coal mining, surface coal mining, and coal preparation.

Coal conversion activities develop processes to convert coal into products that substitute for those derived from oil and natural gas. These substitutes include crude oil, fuel oil, and distillates; chemical feedstock, pipeline quality (high-Btu) and fuel (low-and intermediate-Btu) gas; and other by-products, such as char, that may be useful in energy production. 'I'he Liquefaction and Gasification Activities address the development of these products and their use in the market.

Coal gasification processes have been commercially available for many years. Present technology is, however, high in cost, thermally inefficient, and in many cases limited in the kinds and sizes of processable coal. For example, coal liquefaction has only one available process which is very high in cost, and the fuels produced are not compatible with U.S. market requirements. The current coal conversion and utilization research and development effort is directed toward demonstrating second-generation technology on a near-commercial scale in the early 1980s. A variety of processes are being developed to convert eastern and western coals to liquids and gases. Although some processes may appear to be similar, technical differences in key aspects of the processes make then suited for a particular rank of coal and market use. In certain cases, a systems approach is required because the production of clean fuel must be coupled with a specific end-use, e.g., low-Btiu gas in a combined-cycle power plant.

Four new Activities, Heat Engines and Heat Recovery, Combustion Systems, Fuel Cells, and Advanced Environmental Control Technology, replace former activities in Advanced Power Systems, Direct Combustion and Improved Conversion Efficiency for discussion purposes in this document. The Fuel Cells Activity was transferred from the Conservation Program as well as the work in "Scrubbers" from the Environmental Protection Agency. (See Table 5, Chapter II.A, for budget comparability.) 
The Heat Engines and Heat Recovery Activity will develop technology to maximize energy savings in the utility, industrial, and residential/commercial market sectors. Energy savings opportunities in this tri-market area are estimated to be in excess of 1.5 Quads by 1985 and over 10 Quads by the year 2000. Three major objectives for achieving the goal are: to increase the direct utilization of coal in the utilities by developing advanced, highly efficient, integrated coal conversion/utilization systems; to develop advanced cogeneration systems that can supply both electric and thermal needs for the equivalent fuel energy now being used to generate basic electrical requirements; and to develop advanced heat recovery component technology for producing useful work from waste heat and minimizing heat rejection by the utilities, industrial, residential/commercial sectors.

The primary purposes of the Combustion Systems Activity are to: develop both atmospheric and pressurized fluidized-bed coal combustion systems capable of directly burning high-sulfur coals of all degrees of rank and quality in an environmentally acceptable and economic manner; develop technology to substitute coal for a substantial portion of oil in existing oil-fired combustors capable of firing coal-oil mixtures; improve reliability, efficiency, and fuel-switching capability of present boilers and furnaces; develop engine combustion components capable of operation with high efficiency on conventional and coal-derived fuels; develop practical combustion systems to utilize the fuel value of agricultural, forest, and industrial wastes and residues; and develop and demonstrate the technology required to capture and utilize methane from coal beds.

Fuel cells represent a new energy-conversion alternative which is highly efficient, flexible, modular, economically attractive, and environmentally acceptable. The high efficiency and clean, quiet operation of fuel cell power plants will permit location at the point of need.

The Advanced Research and Supporting Technology projects in the DOE Energy Research Centers, National Laboratories and other Government agencies, private industry and universities will develop the basic and applied technology and data upon which present and future fuel conversion and utilization processes depend. Included under this activity are program planning and development efforts essential to the formulation of fossil energy plans and policy.

The major objective of the MHD Power System Activity is the development of electrical, utility-sized combined MHD/steam-cycle power generating plants, utilizing coal as the primary fuel in a process that is significantly more efficient and environmentally acceptable than any other known process. Current efforts are focused on the CDIF as a first critical step in MHD systems development.

The Advanced Environmental Control Activity is directed toward developing technology to minimize the environmental impacts of new or existing fossil fuel utilization systems. 
The following table summarizes the funding level by Activity for the FY 1977 to 1979 period.

\begin{tabular}{|c|c|c|c|c|}
\hline COAL RESOURCE & \multicolumn{4}{|c|}{$\begin{array}{l}\text { BUDGET AUTHORITY } \\
\text { (OPERATING EXPENSES) } \\
\text { (DOLLARS IN THOUSANDS) }\end{array}$} \\
\hline ACTIVITIES & $\begin{array}{l}\text { ACTUAL } \\
\text { FY } 1977\end{array}$ & $\begin{array}{c}\text { APPROPRIATION } \\
\text { FY } 1978\end{array}$ & $\begin{array}{l}\text { ESTIMATE } \\
\text { FY } 1978\end{array}$ & $\begin{array}{l}\text { INCREASE } \\
\text { (DECREASE) }\end{array}$ \\
\hline $\begin{array}{l}\text { Mines RD\&D } \\
\text { Liquefaction } \\
\text { Gasification } \\
\text { Heat Engines \& Heat } \\
\text { Recovery } \\
\text { Combustion! Systems } \\
\text { Fugl Colls } \\
\text { Adivanren Researrh \& Siınnorting } \\
\text { Tcchnology } \\
\text { Magnetohydrodynamics } \\
\text { Advanced Environmental Control } \\
\text { Technology }\end{array}$ & $\begin{array}{r}\$ 51,855 \\
81,357 \\
125,942 \\
\\
28,201 \\
59.251 \\
31,000 \\
37,070 \\
34,990 \\
0\end{array}$ & $\begin{array}{r}\$ 62,780 \\
110.200 \\
141,600 \\
40,920 \\
74.680 \\
36,200 \\
40,000 \\
66,800 \\
0\end{array}$ & $\begin{array}{l}\$ 70,546 \\
104,866 \\
122,446 \\
\\
56,300 \\
\text { กn. } 1116 \\
36,600 \\
\\
57,826 \\
68,825 \\
14,000\end{array}$ & $\begin{array}{r}S+7,766 \\
.5,334 \\
-19,154 \\
+15,380 \\
-8 \cap n 64 \\
+300 \\
\\
117,820 \\
+2,025 \\
+14,000\end{array}$ \\
\hline TOTAL & $\$ 439,666$ & $\$ 572,180$ & $\$ 596,925$ & $\$+24,745$ \\
\hline
\end{tabular}




\section{B. MINES RESEARCH, DEVELOPMENT, AND DEMONSTRATION}

The mission of the Mines Research, Development, and Demonstration (MRD\&D) Activity is to develop and transfer to industry the technologies (both equipment and techniques) required to supply solid fuels at acceptable economic and social costs.

Activity objectives are: to improve systems technology; to develop cost-effective equipment and techniques; to develop, test, demonstrate, and transfer to industry new and innovative mining concepts; and to develop economically competitive preparation technologies required to assure that coal is an environmentally acceptable fuel.

These objectives will be met by implementing efforts in the following subactivities :

- Underground Coal Mining

- Surface Coal Mining

- Coal Preparation.

The Underground Coal Mining subactivity centers around coal mine development, room and pillar mining, panel mining, novel systems, and haulage. Subactivity emphasis is to improve existing technology, to develop novel systems for thick, multiple, and pitching seam mining, and to assure the lowest cost coal by integrating mining operations into a total system.

The Surface Coal Mining subactivity centers around equipment and systems for area and contour mining. Emphasis is on more effective use of standard equipment and improvement of present mining systems. However, newly developed equipment that can improve performance and be readily integrated into the mining cycle is also included.

The Coal Preparation subactivity is aimed at developing improved technologies for the upgrading of coal, including its desulfurization and identification, and the removal of trace fugitive elements in raw coal. Subactivity emphasis is on the development and demonstration of improved coal preparation technology to ensure an adequate supply of environmentally acceptable coal for utilities, industrial consumers, and home furnaces.

The MRD\&D Activity provides the technology for producing the nation's most plentiful fuel by satisfying four basic requirements:

- Improve the Economics of Production: through increasing capital and labor productivity by developing more efficient cutting and haulage systems and mine development methods; by increasing automation; by adopting labor-saving techniques; and by increasing machine reliability 
- Maximize Resource Recovery: by improving the efficiency of pillar recovery in room and pillar operations; by increasing the effectiveness of panel mining systems; and by developing techniques for the mining of thick, multiple, and pitching coal seams

- Protect the Health and Safety of Mine Workers: by providing remotely operated systems and automated roof support systems; by implementing improved ventilation and degasification techniques; and by providing improved monitoring/warning systems

- Protect the Environment: by improving the quality of coal preparation; by controlling subsidence; by reducing acid mine drainage; by minimizing the problems of waste disposal; by improving overburden handling; and by developing restoration techniques.

The following table summarizes the funding levels by subactivity for the FY 1977 to FY 1979 period.

\begin{tabular}{|c|c|c|c|c|c|}
\hline \multirow{2}{*}{$\begin{array}{l}\text { MINES RD\&D } \\
\text { SUBACTIVITIES }\end{array}$} & \multicolumn{4}{|c|}{$\begin{array}{l}\text { BUDGET AUTHORITY } \\
\text { (OPERATING EXPENSES) } \\
\text { (DOLLARS IN THOUSANDS) }\end{array}$} & \multirow[t]{2}{*}{$\begin{array}{l}\text { MAJOR } \\
\text { CHANGE. }\end{array}$} \\
\hline & $\begin{array}{l}\text { ACTUAL } \\
\text { FY } 1977\end{array}$ & $\begin{array}{c}\text { APPROPRIATION } \\
\text { FY } 1978\end{array}$ & $\begin{array}{l}\text { ESTIMATE } \\
\text { FY } 1979\end{array}$ & $\begin{array}{l}\text { INCREASE } \\
\text { (DECREASE) }\end{array}$ & \\
\hline $\begin{array}{l}\text { Underground Coal Mining } \\
\text { Surface Coal Mining } \\
\text { Coal Preparation Research }\end{array}$ & $\begin{array}{r}\$ 39,735 \\
10,000 \\
2,120\end{array}$ & $\begin{array}{r}\$ 46,285 \\
11,475 \\
5,020\end{array}$ & $\begin{array}{r}\$ 52,860 \\
12,615 \\
5,071\end{array}$ & $\begin{array}{c}\$+6,575 \\
+1,140 \\
+51\end{array}$ & \multirow[t]{2}{*}{$\begin{array}{ll}N & 1 \\
N & \end{array}$} \\
\hline TOTAL & $\$ 61,866$ & $\$ 62,780$ & $\$ 70,546$ & $\$+7,766$ & \\
\hline \multicolumn{3}{|c|}{$\begin{array}{l}\text { "KEY } \\
N=\text { New start (totally new project) } \\
S=\text { Scaleup (from bench to PDU or pilot plant) } \\
A=\text { Acceleration (shortening deadlines or } \\
\text { expansion of ongoing projects) }\end{array}$} & \multicolumn{3}{|c|}{$\begin{array}{l}P=\text { Phase completion or startup } \\
R=\text { Program redircction } \\
L=\text { Incremental cost requirement } \\
C=\text { Proiect completion or suspension }\end{array}$} \\
\hline
\end{tabular}

Throughout the following discussions of the Mines RD\&D Activity, both brief descriptions along with current status assessments are presented for the individual tasks that comprise the Underground Coal Mining, Surface Coal Mining and Coal Preparation Research subactivities. 


\subsection{UNDERGROUND COAL MINING}

Underground coal mining activities can be divided into the following four general areas:

- Mine planning and development

- Production mining

- Transport

- Other support.

Coal mine planning impacts the range of decisions that must be made in deciding how a particular area of coal will be recovered. Coal mine development involves the cutting of the access openings necessary to allow a production mining system to be applied. These access openings provide for ventilation, men and materials transportation, and coal transportation. They may be vertical or horizontal shafts (in-mine development). In addition the subject of methane drainage from the coal bed prior to mining is considered in the coal mine development area.

At the present time the majority of underground coal production in the United States results from two production methods, room and pillar mining and panel mining. Room and pillar, the source of 95 percent of our underground coal, is by far the predominant method. Panel mining, the source of the remaining 5 percent, offers the potential for increased productivity, worker safety, and decreased environmental impacts and is therefore being given research and development (R\&D) focus in the program.

In addition to concentrating on the two current dominant methods, efforts aimed at developing and evaluating novel mining systems are planned.

\subsection{COAL MINE SHAFT DEVELOPMENT (MINE PLANNING AND DEVELOPMENT)}

A key element in underground mining is the preparatory excavation required to construct ventilation shafts, man and material access shafts, and in-mine roadways (entries) requisite to coal production. These mine development activities affect the time required to open or expand mines and thus the cost of coal.

The present method of coal mine shaft sinking, which only achieves an average rate of 40 feet per month, uses a drill-blast-muck cycle. In this labor-intensive operation, crews must constantly be transported in and out of the shaft to accommodate blasting, they must remain idle as the shaft is cleared of dust and fumes, and a number of precautionary measures must be taken to ensure health and safety. In addition, the limited pool of skilled labor for conventional shaft sinking contributes to the method's high cost.

A program for the development of mechanized shaft-sinking systems to reduce the time and cost associated with current methods was initiated 
in 1975. This effort emphasizes development of: 1) a down-hole-powered (power supply at the cutting head) system for construction of man and material shafts, exceeding 20 feet in diameter, commensurate with the needs of major new mines; 2) a surface-powered system for construction of shafts up to 20 feet in diameter (a practical upper limit for such systems) for ventilation needs and lesser man and material requirements. Both systems have the design capability to sink the shafts blind, i.e., without having to depend on previous development in the mine itself.

\section{Blind Shaft Borer}

The blind shaft borer (BSB) is a system with the design capability of sinking greater than 20-foot-diameter shafts to depths of 2,000 feet, the minimum required to accommodate projected production capacities and increased depth of reserves. Fabrication of the blind shaft borer and related support systems is in process. The major BSB support systems are the secondary haulage (top of BSB to surface) and the lining systems (presently 12-inch-thick concrete). Even using state-of-the-art support systems for the first field trials, shaft construction rates of 36 feet per day are projected, an order of magnitude improvement over current rates.

The first equipment trials incorporating state-of-the-art support systems will start in mid-1978 with the construction of an 1,150-foot deep shaft at the Oakgrove Mine in Alabama. Trials will last about 18 months and will be followed by an evaluation and redesign phase. A second trial period incorporating newly designed support systems will concentrate on overall system performance and compatibility of support systems. A fullscale field demonstration will then be conducted to assess the ultimate performance and to assist in transferring the technology to industry.

\section{Rotary Drilling System}

In FY 1978, fabrication began on a surface-powered rotary drilling system capable of excavating up to 20 -foot diameter ventilation shafts and remotely placing a 12-inch thick concrete lining. This method uses scaledup oil-well drilling technology where men stay safely on the surface during the drilling operation. The lining placement system which is part of this development borrows from the civil construction and electronics industries, combining slip-forming and remote sensing and controls. The rate of excavation is expected to be comparable to that of the blind shaft borer Field trials leading to a full-scale demonstration will begin in FY 1979.

\subsection{IN-MINE DEVELOPMENT (MINE PLANNING AND DEVELOPMENT)}

Development of new areas for coal production typically involves the use of a continuous miner advancing a heading in sets of five roadways (entries). Ten to fifteen entries are generally required on a main heading. The large number of entries that are driven is largely due to ventilation and haulage demands and restrictions on entry dimensions. Continuous miners are not designed to cut roof or floor rocks; therefore, entry height is limited by coal seam thickness, and width is limited by roof stability. In addition, crosscuts between entries must be driven at intervals of 100 feet or less to meet current regulations. 
The large number of entries and crosscuts required, combined with roof support and ventilation considerations, dictates that the majority of time be spent in moving the continuous miner from one location to another and in preparing to cut coal. This is particularly true in development operations, because the coal pillars left between entries must be large in order to provide support for the life of the mine. The result is an extremely slow rate of development.

Despite the relatively large pillars left, ground control problems persist because of the number of entries involved. Continuous maintenance is required, therefore, and disruption of services results.

Research activities to alleviate the in-mine development problems have been done in part under the production related research, i.e., the development of a better continuous miner and the integration of bolting. Meanwhile, in the development area, other basic equipment, technology, and approaches have been examined.

Evaluations to date have focused on the potential of three basic applications: 1) slope access from the surface and main entry development (tunnel boring); 2) submain and panel development involving both the cutting of coal and roof and/or floor strata (mixed face); and 3) submain and panel development restricted to the coal seam (in-seam).

\section{Tunnel Boring System}

As a step toward alleviating development problems, a cost-sharing contract was undertaken to examine the technical and economic feasibility of applying tunnel boring machines (TBMs) to mine development.

TBMs (illustrated below) came into their own in the early 1970s in the civil construction industry, finding wide use in the construction of transportation tunnels, sewer systems, and other underground operations involving large-diameter openings in both hard and soft strata.

TBMs show potential for mine development because of the possible speed of excavation, often hundreds of feet per day in civil works projects; the stability of the circular opening; and the fact that large openings could be driven independent of strata considerations. As to the latter, it was determined that, from a ventilation standpoint, the 18-foot diameter TBM chosen for the cost-sharing project provided the equivalent of five entries in the particular mine involved. Stability of opening is important from a maintenance (and safety) standpoint, and speed is essential in addressing the basic development problem.

Under this joint effort, a 6,000-foot-long tunnel is being bored off the East Mains of the Federal No. 2 Mine to connect existing mine workings with an air shaft and to open the area for longwall mining. Technical and economic feasibility is being evaluated in view of the constraints relative to the hazardous environment and requirements imposed by Federal and State mining laws. Another major objective is to obtain the data requisit to developing specifications for a TBM system optimally designed for the coal industry . 
The system has now operated safely for 2,600 feet and remains in an operational state in a region previously shown to be too gassy for conventional development.

As a supplement to the TBM project, a study effort will be undertaken in FY 1978 to determine the optimum usage of a TBM system for new mine development and mine expansion. In FY 1979, development of an advanced tunnel boring system will be initiated, incorporating data from previous efforts.

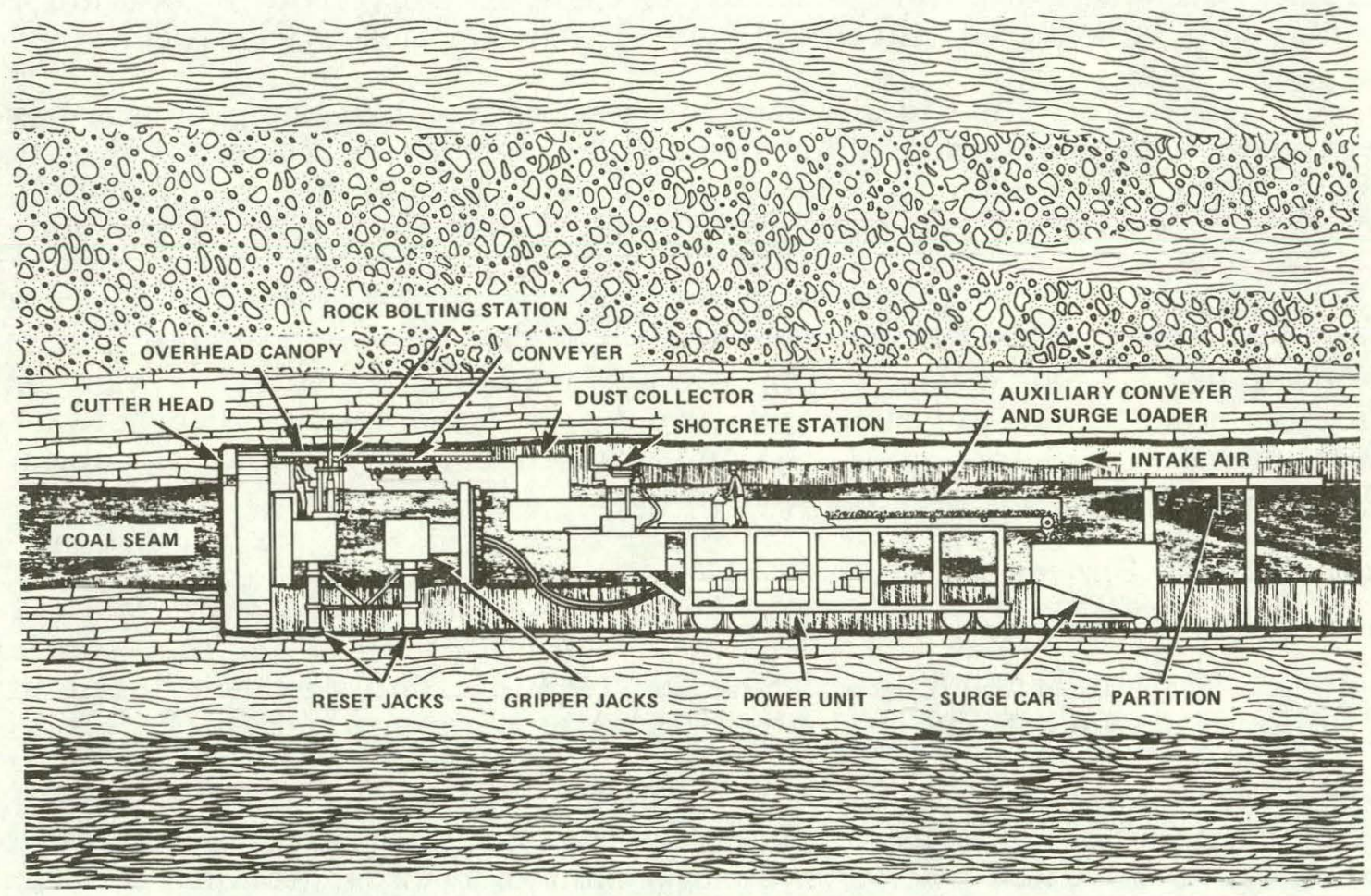

Tunnel Boring Machine

\section{Mixed Face System}

In cases where shorter distances are involved, as in submains (laterals) or panel development,a system more mobile andmaneuverable than tunnel boring machines is required. In the lower seam-height range of 30 to 60 inches, there is particular need for a system that can cut both the coal and adjacent strata to reduce the number of entries required and to provide greater freedom of movement.

There has been an ongoing examination of equipment, technology, and concepts both foreign (primarily through agreements with England, West Germany and Poland) and domestic having potential for this application. For example, investigations have been conducted on rock cutting machines such as roadheaders, dentheaders, and high energy impactors; augers as a crosscut excavation tool; monolithic packing systems, mechanical packers and foam concrete placement systems for roof support; self advancing and manually set temporary roof supports; concepts employing combinations of 
coal and rock cutting equipment; latest developments in roof bolting systems; and new technologies, such as water jets, to assist mechanical cutting of rock.

Available technology has been explored, shortcomings have been noted, and efforts initiated to advance that technology where required. Emphasis, however, will now be placed on incorporating present technology into an efficient system meeting industry needs.

Two basic approaches will be pursued in the system development: 1) a single-face, multiple-entry (SFME) concept; and 2) a multiple-face, continuous-drivage (MFCD) concept.

In the SFME approach, a wide face is cut by a single cutting machine, and $a$ number of entries are created to the rear by artificially placed structural walls. These walls provide the alternate escape-ways and ventilation splits required by mining law.

The MFCD approach is to achieve a continuous advance of more than one cutting machine and entry with a coal pillar or pillars between. This will require bringing to bear sensing and control technology to safely operate more than one cutting machine on a split of air; auxilliary cutting machines for crosscuts so the primary machines are not disrupted; and temporary support systems to reduce the interdependency of cutting and roof bolting.

Preliminary designs on both systems will be sought in FY 1978, and final design and subsystem tests will be initiated in FY 1979 on the most promising system(s).

\section{In-Seam System}

In cases where seam thickness permits efficient shaft development in the coal, the same basic approaches as outlined above will be pursued; however, the systems will involve coal cutting machines. Developments from production related research, such as the miner/bolters, may be incorporated into the systems, or such promising new machines as the inseam miner developed in England may be used.

The development process should parallel that of the Mixed-Face Systems.

\subsection{METHANE DRAINAGE}

Tremendous quantities of methane within coal seams and adjacent strata represent a vast energy resource, but also pose a major safety hazard in coal mining. The recent Scotia and earlier Farmington mine disasters serve as constant reminders of the dangers related to methane liberation in coal mines. Most of the extensive precautions taken regarding ventilation, haulage, and mining methods are in response to this hazard. 
To keep mines at safe methane concentration levels requires the circulation of large amounts of air throughout the mine. Regulations require the shutdown of equipment when methane concentrations reach 1 percent. Even with seemingly adequate air flow rates in production sections, cutting is often slowed or halted due to methane liberation, resulting in reduced efficiency and increased costs. For example, the production potential of the continuous miner, the basic mining tool presently used, is frequently not achieved.

Degasification, removing most of the methane from permeable coal before mining, can alleviate methane-related mining problems and also tap a significant natural resource. In a program begun several years ago, three basic degasification techniques are being developed: vertical wells; directional drilling; and horizontal drilling.

\section{Vertical Wells}

The vertical wells method involves the drilling of small bore vertical wells spaced throughout a mine property and hydraulically stimulated to propagate flow paths for the methane gas. In the Pittsburgh and Mary Lee coal beds, vertical wells have been effective in removing large quantities of gas, to the point where commercialization of the product appears economically feasible. This method cannot totally bleed off the methane in a region within a reasonable period of time. It can, however, isolate a region from the methane flow path by offering a path of less resistance (up the vertical wells). Efforts will continue to measure the effectiveness of the basic method in other coal seams and to determine optimum well spacing.

The characteristics of methane flow in and around the Pocahontas No. 3 coal seam are quite different from those of the Pittsburgh and Mary Lee beds. Trials will hegin in FY 1978 to dctcrmine the effectiveness of the vertical well method in this seam. Trials will also take place in the Beckley and Hartshorne seams and, in FY 1979, a demonstration in the Mariana seam is scheduled for completion.

\section{Directional Drilling}

The direntional drilling method, an extension of the vertical well technique, involves the drilling of a number of small bore wells from a single location, thus reducing time and cost for site preparation, mobilization, and securing property rights for well location. In the rough terrain of the eastern coal region, this can be a considerable savings.

Directional drilling methods were developed for oil fields. Although the technology exists, the effectiveness of the borehole, the stimulation methods, and dewatering techniques must be determined so the required pattern can be established and expected economies assessed.

Field trials of the technique will begin in FY 1978 in the Pittsburgh seam, where coal bed characteristics are known and vertical well spacing have been established. A demonstration of directional degasification drilling technology is scheduled to start in FY 1979. 


\section{Horizontal Drilling}

The horizontal drilling method involves the drilling of long horizontal small-bore wells from the bottom of a large diameter shaft. Horizontal drilling from a shaft bottom is known to be effective. Because a large shaft is required, the technique is only economical when carried out in conjunction with mine development.

At Federal No. 2 Mine, a series of horizontal boreholes, draining into a wide, multipurpose vertical borehole and then into an air shaft have been producing large quantities of methane for several years and will continue during FY 1979. It is anticipated that demonstration of horizontal drilling will become part of the full field trials of the blind shaft borer in FY 1980.

\subsection{ROOM AND PILLAR (PRODUCTION MINING)}

The initial production stage of a room and pillar operation involves the driving of a set of parallel interconnected entries (tunnels). Mining is accomplished by the cyclic performance of operations in cutting, loading, and roof support. The interconnection of the entries is necessitated by the requirement for closed loops for ventilation and produces a checkerboard pattern of pillars. The second production stage of the room and pillar mining method involves partial mining of the remaining pillars of coal:

The continuous miners used in room and pillar mining are capable of producing 6 to 12 tons per minute. However, they typically average only half that production for only 20 percent of the shift because of the nature of the method as currently practiced. The thrust of the room and pillar effort is to develop systems that will permit more-truly-continuous mining throughout the shift. The initial goal is to reduce lost production time through increased system reliability and improved combinations/cycling of machine functions. Once this is accomplished, emphasis will shift to raising the average production rate closer to the potential of the basic machinery.

\section{Continuous Roof Supports}

The continuous roof supports effort, an integrated part of room and pillar mining, deals with better permanent and temporary roof support methods. Focusing on roof support constraints, two parallel approaches are being undertaken: total system development and improved component development. The total system approach is used to get first-time prototype machines to the field quickly. These systems use continuous miners to which a simultaneous roof bolting capability has been added (miner/bolters). Laboratory testing is under way, and underground testing is scheduled for FY 1979. 


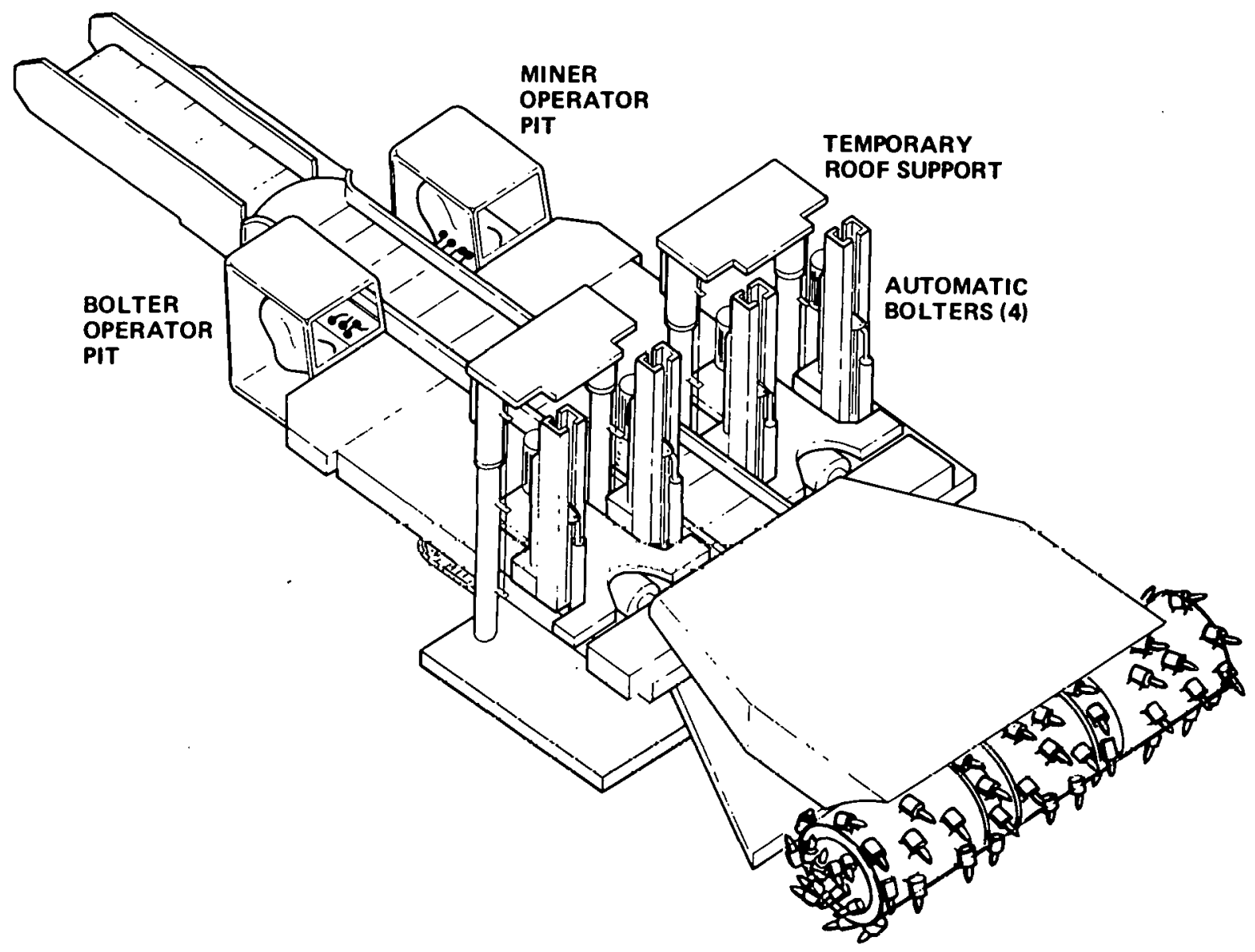

\section{Artist Concept-Miner/Bolter}

Meanwhile, major improvements are being made in the components used on these new complex systems. The component development work includes contracts for longer-than-seam height drills, high speed water jet drills, and bolter modules. Each of these elements is being perfected through a series of laboratory and underground tests by which design and reliability problems can be isolated and solved. This parallel effort allows a methodical development plan for the components simultaneously with investigation of system problems on the miner/bolters. As the components reach the high reliability needed for new complex systems, they will be combined to form a new advanced generation of miner/bolters. During FY 1978 and FY 1979, development of components and reliability testing will be continued. 


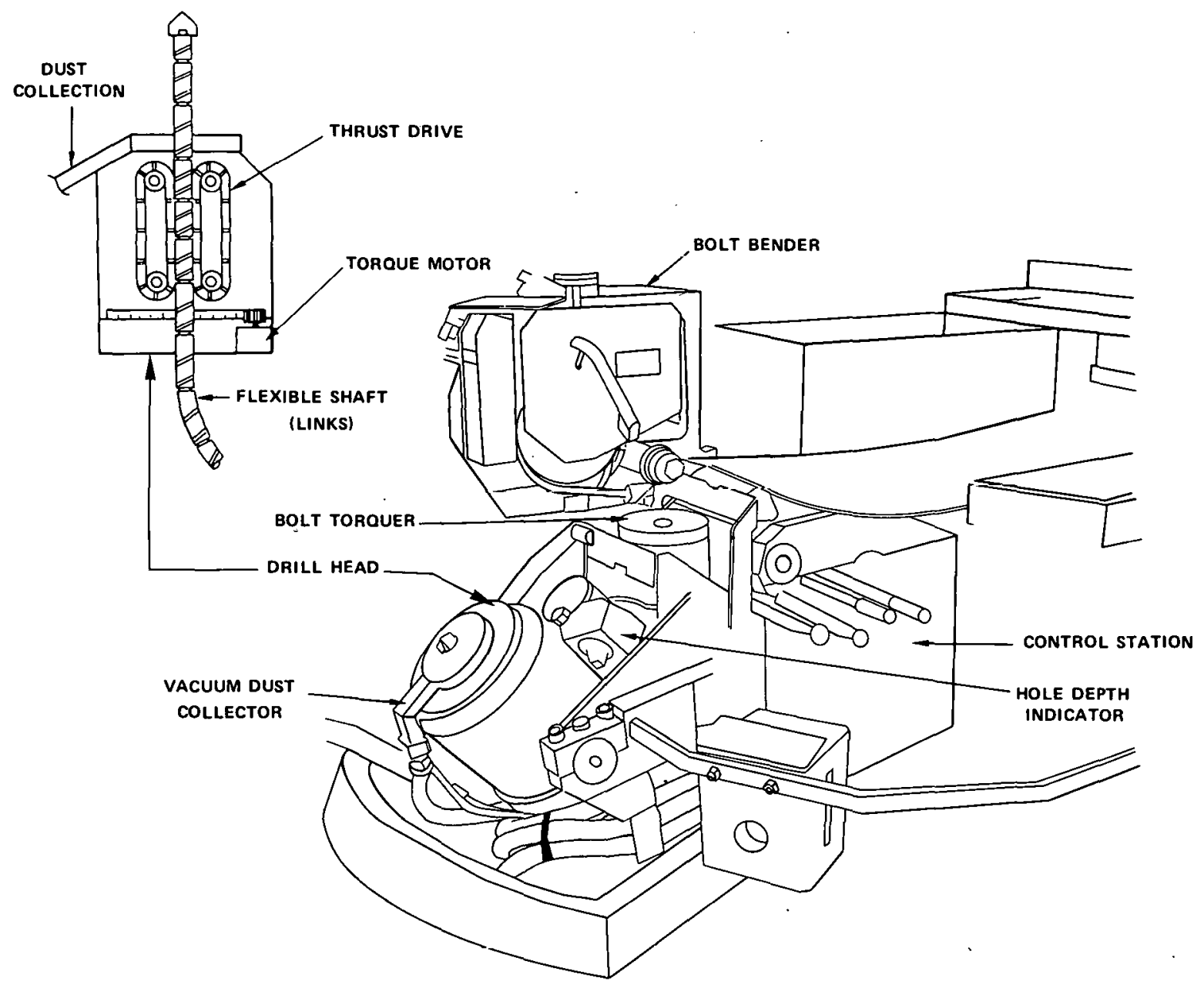

Remote Operated, Longer-Than-Seam-Height Drill

\section{Remote Controlled Continuous Miner}

The remote controlled continuous miner effort is progressing on a development plan similar to the roof support effort. The project, which includes both system and component development contracts, is aimed at the elimination of decision making constraints in the operation of the miner.

The Automated Extraction System (AES) is a full-face programmable continuous miner with roof bolting capability and self-advancing ventilation. During FY 1979, underground tests will be completed, and modifications and retesting will be continued. In the component development work, studies are being done to determine the degree of automation which can be implemented in underground systems and to develop scenarios for these systems. Some of the ancillary items which are being developed include coal interface detectors, guidance systems, and maintenance management systems. The project will include automation and integration of haulage, ventilation, rockdusting and methane monitoring, with the eventual goal of total system automation and remote supervisory control. . Development and testing of ancillary equipment will continue into FY 1980. 


\section{Face Haulage Vehicles}

In the U.S., nearly 75 percent of underground room and pillar mines use shuttle cars to transport mined coal from the working face to a secondary haulage system. The majority of these units are electric powered and, to transmit power to the vehicle, use a trailing cable from the reel on the shuttle car to a stationary tie-off point. This umbilical cord connection is a safety hazard, restricts underground travel, and limits the system to two operating vehicles. Application of a self-contained type of power source, eliminating the trailing cable restriction, would reduce costs, enhance miner safety, and permit use of more than two vehicles. Current battery-powered shuttle cars use large, heavy lead-acid battery packs, which take up a significant portion of the shuttle car and leave less space available for a payload of coal. An iron-nickel battery and charger system, which is lighter and occupies less volume than current systems, is being developed for use in a coal mine hauler. Surface field trials have heen started and upon completion will be followed by an underground test demonstration.

Another technology currently available to power shuttle cars is the energy accumulator and storage system of the flywheel. The flywheel can be recharged while the car is unloading and has the potential of producing three to five times the watt hours per pound available from lead-acid batteries. If development is successful, the flywheel-powered shuttle car will have inherent capabilities advantageous in the face haulage function. The power pack will be smaller and lighter than existing self-contained units; it will have fast recharge and high density; and it will be fumeless, clean, safe, and reliable. Evaluation of a high-strength low-mass flywheel in tandem with a hydraulic or electric drive system is currently in process. This will be followed by design and fabrication througl FY 1979, then surface test and demonstration.

\section{Continuous Face Haulage}

The introduction of continuous mining machines prompted the mining industry to reassess shuttle car batch-type haulage. Between location changes, the continuous miner can cut and load coal on a nearly continuous basis; however, after loading a shuttle car, the high capacity machine must wait while the second shuttle car is spotted under the miner cailboom . Delays in the haulage system, usually due to waiting for shuttle cars, take 25 percent of the continuous miner cycle-time. Computer simulations of a face operation indicate that up to a 45 percent increase in coal production could be realized through the use of a continuous haulage system associated with a secondary haulage system to handle the increased load.

Several types of continuous haulage systems are under study and development. These include a floor-mounted automated bridge conveyor train, monorail-mounted bridge conveyor system, extensible belt bridge conveyors, flexible belt conveyor train, coal injectors for hydraulic pipeline transport of coal from the mine face, and a multiple unit continuous haulage system. The latter is a series of self-propelled, fourwheeled steerable cars with conveyors mounted in such a way that one conveyor discharges onto a secondary conveyor in a continuous train. Underground demonstration will be initiated in FY 1978 and continue into 
FY 1979. Fabrication and surface testing of the monorail bridge conveyor, automated bridge conveyor train, and the coal injectors for hydraulic transportation of coal will be completed in FY 1979 and followed by underground demonstrations

\subsection{PANEL (PRODUCTION MINING)}

Panel mining is a high production approach to coal mining that is widely used in Europe but has found only recent acceptance in the United States. To date, this method accounts for only 4 percent of the coal mined by underground methods. Basically, large rectangular blocks of coal are defined and extracted by successively slicing one of the sides. For example, in retreat longwall panel mining, the predominant method now used in the U.S., the complete block of coal to be mined is usually 300 to 500 feet wide and 3,000 to 6,000 feet long. Up to 4,000 tons per shift have been extracted from a 7-foot seam. Typically, however, only 700 to 900 tons per shift are realized because of equipment problems and disruptive geological conditions. High capital requirement for the equipment is another constraint to the use of longwall mining.

The Panel Mining effort includes three major projects: improving longwall system performance; decreasing longwall system costs; and technology demonstrations to lower the perceived risk of panel mining.

\section{Improving Longwall System Performance}

Current longwall mining practice in this country involves the cutting of a thin slice of coal, generally less than 30 inches, from a block of coal about 500 feet long. One objective of this project is to realize a 30 to 100 percent increase in the thickness of this slice for the majority of the longwall faces in operation. A study is currently under way to establish the optimum value and upper limit of operation for the slice thickness in longwall mining operations. The impact on the related subsystems (i.e., roof support, haulage, etc.) will then be determined for the thickness selected. Hardware will be designed to demonstrate effectiveness of this modified longwall mining system, cutting at an optimum thickness. The cost-effectiveness of this modification will be established and the technology will be transferred to industry during the demonstration phase.

Another way to improve system performance is to increase the total length of face sliced per shift. Current longwall mining systems in this country cut approximately 2,500 feet of face on the average day that the mining system is in a production mode. The second objective of this project is a 100 percent increase in this length on the longwall faces (about 25 percent) geologically compatible for such increases. Progress toward this second objective may be realized through the following improvements: increasing the peak cutting speed at which the cutter can traverse the face; increasing the efficiency or use of this peak speed capability; and simultaneously using more than one machine at the face. At present, one of the techniques being explored for increasing cutter performance and reducing manual control restraints is the automated control of the cutter. 
In other studies planned for FY 1978, the entire range of constraints to increasing machine cutting speed will be investigated, and hardware required to eliminate or by-pass these constraints will be developed. The feasibility of multimachine operations, particularly the problems of dust generation and exposure, will also be assessed. An analysis of data on delays in longwall mining has revealed that the face conveyor is the principal on-face cause of cutting machine downtime. In FY 1978 design will begin on a face conveyor capable of more reliable operation and with the capacity to accommodate present and planned production rates.

\section{Decrease Longwall System Costs}

The capital cost of a longwall system can be as much as five times the cost of a single continuous miner production unit. Of this longwall capital equipment cost, 80 percent can be attributed to the roof support system. The objective of this project is to reduce roof support costs for the newly introduced longwall faces. In FY 1978 a study is being done to determine if roof supports are significantly underutilized and to establish more precise methods of estimating support requirements.

\section{Technology Demonstration}

Several ongoing demonstrations are designed to prove to industry the cost-effectiveness of longwall mining under unique geological conditions. In FY 1978, an advanced technology test site was made available to test and demonstrate the technology developed to increase system performance. This site will be used to investigate improved shearing, roof support, and conveyor technology as developed in the other projects in this activity. With this site, the entire system can be demonstrated as an operating unit.

\subsection{NOVEL SYSTEMS (PRODUCTION MINING)}

In the area of novel systems, attention is focused on the modification and application of existing mining systems to unique mining situations, (i.e., thick, multiple, and steeply pitching seams (TMSP)), and development of advanced mining systems which offer economic advantages over current systems.

Since the vast majority of coal mined underground is produced from coal seams less than 10 feet thick, the coal industry techniques and equipment which have been developed are quite naturally better suited to these thinner seams. In mining thick seam coal (10 to 40 feet) with present techniques, there has to be a compromise in recovery, safety, or profit; therefore, good recovery is usually sacrificed. Recovery percentages below 30 percent might be expected when present room and pillar techniques are applied to a coal seam 20 or more feet thick; the remaining 70 percent or more of the coal in place is lost. The effort to find a better way to mine thick coal seams is important from the standpoint of increased production of coal and improved resource recovery

The objective of the advanced mining systems effort in underground mining is to explore, develop, and evaluate innovative concepts for producing coal and reducing the cost per ton. Surveys of state-of-the- 
art, critical experiments, prototype development and testing, full-scale development and testing, and, finally, in-mine demonstration are performed to prove each concept.

\section{Longwall Multilift Method (TMSP)}

During FY 1979, site selection will be completed and a detailed mine design plan finalized for the first U.S. application tests of the longwall multilift method for extracting thick underground coal. The method consists of working a panel of longwall mining face starting at the top of the thick coal deposit and working down in horizontal slices. For example, in a 20-foot seam the first pass extracts the upper half of the seam and lays a screen mesh down on top of the remaining part of the seam. This screen acts as an artificial roof when the bottom half of the seam is mined. Resource recovery using the longwall multilift method will approach 60 percent, twice that of conventional room and pillar methods.

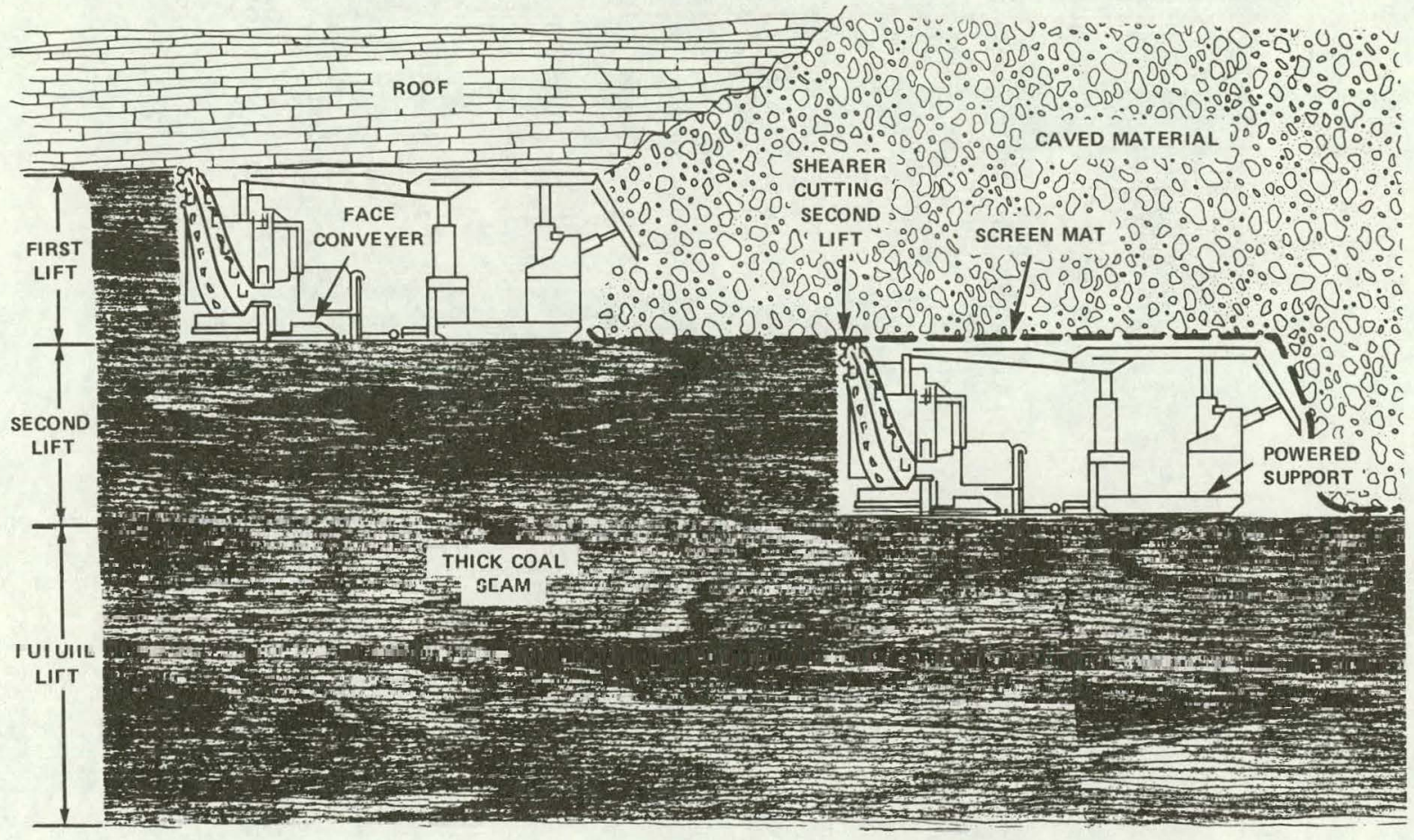

Longwall Multilift Mining Method

\section{Longwall in Steeply Pitching Seam (TMSP)}

Efforts will continue to develop methods to mine the large amounts of coal in steeply pitching seams, previously unrecoverable because the steep operating angle $\left(>25^{\circ}\right)$ precludes use of continuous mining methods. The alternative of longwall mining will be tested in Colorado. Planned development of the first pitching seam panel for actual operations will begin in FY 1979. 


\section{Longwall in Sublevel Caving (TMSP)}

Development and testing of a prototype longwall sublevel caving technique will continue. A field test planned for FY 1980 will be the first application of such a system in the United States. The method consists of working a longwall face along the bottom of the thick seam and drawing or recovering the top coal from the rubble as it caves into the extracted cut (gob). Gobbed coal is recovered on a conveyor either by gravitational flow or mechanically stimulated methods. Projected resource recovery for this method will approach 80 to 85 percent.

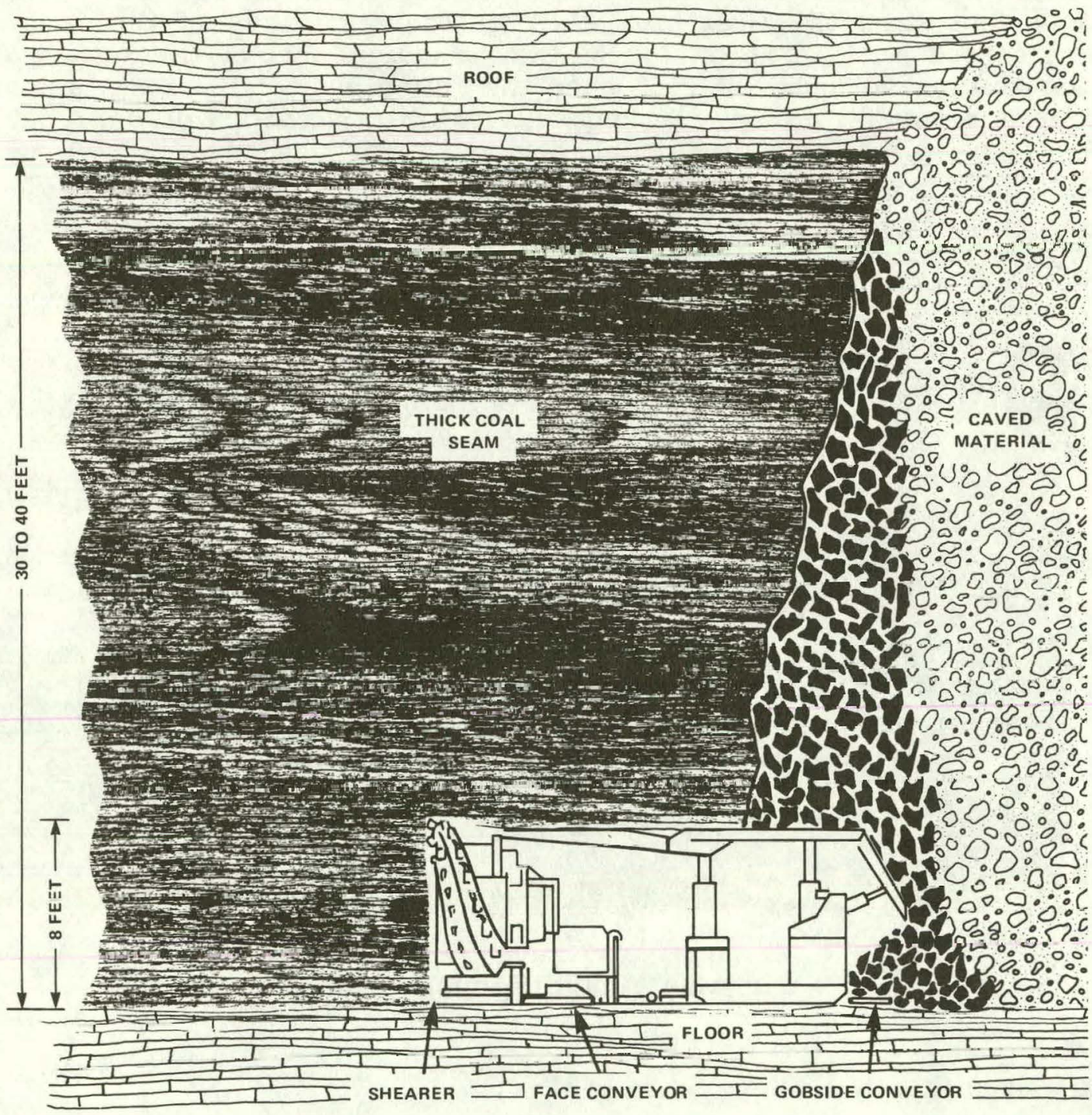

\section{Longwall Sublevel Caving Mining Method}

\section{Sublevel Caving with Pillar Extraction (TMSP)}

The sublevel caving with pillar extraction (SCPE) method is a modification of the normal method of pillar mining, with the addition of top coal recovery. Mine openings will be driven against the bottom of the seam 
using room and pillar techniques. Top coal recovery is accomplished on retreat by drilling and blasting the top coal in increments and loading out the fallen top coal with a continuous miner.

In FY 1979, an SCPE technique will be tested for process verification. SCPE uses the same equipment and employs methods that are similar to those used in room and pillar and continuous mining operations. The method is designed to provide for a 75 percent resource recovery rate of coal and is applicable where erratic seam thickness occurs.

\section{Advanced Mining Systems}

Efforts in high-volume hydraulic mining address the problems of recovering coal that lies in moderate to thick seams ( $\geq 6 \mathrm{feet}$ ) having pitch angles greater than 4 degrees. Most technology for hydraulic mining has been used in other countries. The purpose of this effort is to explore the technique's applicability to U.S. conditions. Studies have indicated that this method may be economically advantageous over other forms of mining for pitching coal seam conditions. The design phase for a practical system will be followed by construction of a prototype hydraulic coal mining system and a field demonstration.

Development work is under way on high energy, low volume hydraulic jet augmentation of mechanical mining systems. Use of cavitating, percussive, and continuous water jets is being investigated. An effort is under way to develop the best combination of a low volume jetting system with a boom-type miner to determine how much the jet increases production in coal and rock.

A variable wall miner being developed for panel mining uses a side cutter auger to cut and convey the coal, all with a single implement. A breadboard prototype is under design and will be constructed for testing in the Surface Test Facility in FY 1979.

A borehole mining system is being evaluated to prove a concept of an underground system operated at the surface. The prototype apparatus operates on a 16-inch diameter borehole drilled through the coal seam. A high-pressure water line, nozzle, and slurry pump combine to erode the coal, form a slurry, and pump the slurry to the surface. To date, coal has been produced at a rate of 10 tons $/ \mathrm{hr}$ from a depth of 90 feet in a pitching coal seam. During FY 1979, a full-scale borehole mining system will be designed and constructed.

\subsection{TRANSPORT AND OTHER SUPPORT}

Improved haulage systems to effectively move men, supplies, and mined coal between the mine working section and the surface are of utmost importance in overall development of a cost-effective underground coal mining system. The major project being studied is the automated rail haulage system. 


\section{Automated Rail Haulage}

An automated rail haulage system uses unit trains which circulate within the mine, without operator assistance, from various loading sites to the unloading point and back to the same or alternative site. The system requires a locomotive designed specifically for automation, with controls and sensors in the entire system necessary for unmanned operation. The overall system eliminates workers from the most hazardous portions of the rail haulage operation.

The automated rail haulage system is expected to reduce rail haulage costs 7-to-12 percent, to increase overall in-mine productivity 3-to-6.5 percent, and to reduce haulage accidents by 50 percent. Design and fabrication of components of the automated rail haulage system will be completed during FY 1979. A production prototype will undergo surface testing before underground demonstration.

\section{Surface Test Facility}

Surface testing of new and modified underground coal mining equipment is currently limited, in most cases, to functional check-out of major systems with no load applied. As a result, the first real tests of equipment performance under load are now conducted in underground production operations. The Surface Test Facility will provide capability to conduct and evaluate research and development efforts above ground on mine equipment and systems in a simulated underground mining environment. 'This will expedite the introduction of safer and more efficient technology in the underground mining operation. The test facility will be operational during FY 1979. Planned typical tasks for the facility include:

- The longwall cutter/loader will be evaluated for pitch, roll, yaw, and haulage parameters.

- The continuous miner will be evaluated for stability of controls and for reliability and effectiveness of the interface detectors and guidance control components .

- The variable wall miner will be evaluated to detcrminc its cutting and conveying capability.

\section{Environmental Studies}

Studies are under way to establish environmental impacts of the underground mining practice. Particular attention is focused on problems of surface subsidence, mine waste utilization, and acid mine drainage. In addition, possible modifications to mining systems and current mining practice aimed at minimizing environmental impacts will be investigated. 


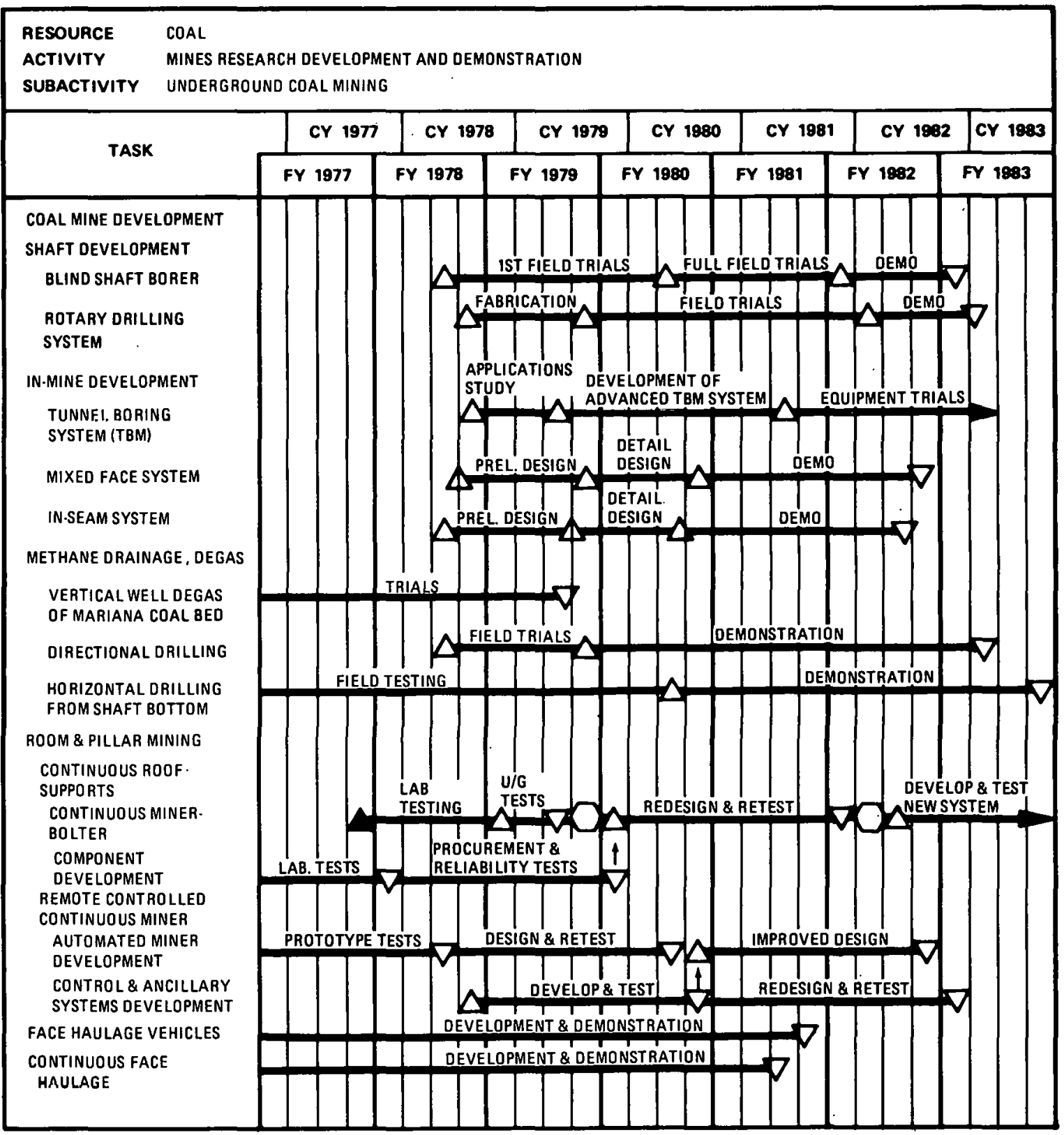

MILESTONE SYMBOLS ARE DEFINED ON LAST PAGE OF THIS DOCUMENT 


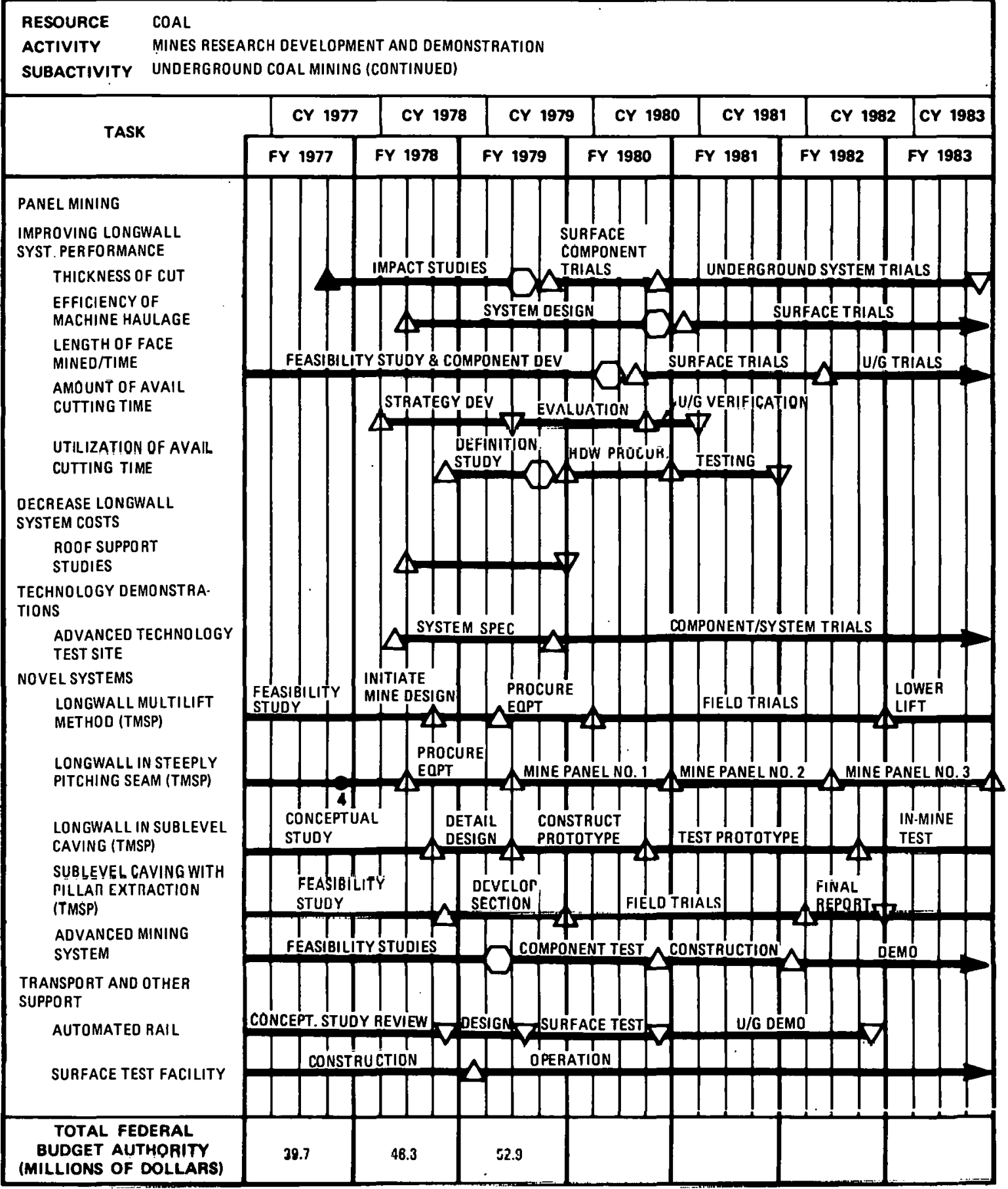

MILESTONE SYMBOLS ARE DEFINED ON LAST PAGE OF THIS DOCUMENT 


\subsection{SURFACE COAL MINING}

The Surface Coal Mining projects have been directed at development of surface mining and reclamation systems and development and demonstration of new or modified equipment for:

- Area mining

- Contour mining.

The subactivity takes advantage of the commonality of requirements in the areas of mine design and planning and reclamation. In general, problems associated with surface coal mining stem from the lack of a cost-effective systematic approach for removing the overburden (material above the coal seam), mining the coal, and reclaiming the land within statutory environmental requirements, including the recently enacted Surface Mining Control and Reclamation Act of 1977 (PL 95-87).

\subsection{AREA MINING}

Area mining involves making a trench or box cut through the overburden to expose the coal deposit, which is then removed. The first cut may be extended to the limits of the property or the deposit. As each succeeding parallel cut is made, the spoil (overburden) is deposited in the cut just previously excavated. The final cut leaves an open trench as deep as the thickness of the overburden plus the coal recovered, bounded on one side by the last spoil bank and on the other by the undisturbed highwall. Therefore, area mining, unless graded or leveled, usually resembles the ridges of a gigantic washboard. Historically, it has been practiced on relatively flat terrain. A major thrust of this subactivity is to investigate application of area mining techniques to thick, multiple, and steeply pitching seams of coal. Projects currently being pursued include mine design and planning, thick and multiple seam mining, and conventional mining equipment improvements.

\section{Mine Design and Planning}

The mine design and planning project emphasizes the more effective use of available mining and reclamation equipment and technology. This will be achieved largely through improvements in equipment combinations and design of layout and haulage configurations, and through mine site evaluation and preplanning of mining and reclamation activities.

During FY 1978, area mining requirements for moderately and steeply pitching coal seams were analyzed. During FY 1979, design parameters outlining site selection criteria will be assembled to combine proper equipment and mining methods for efficiently extracting surface coal reserves from areas where both the coal seam and surface topography can exceed an 8-degree pitch. A complementary effort to analyze the production efficiency of terrace-pit mining systems is also under way. Terrace-pit mining is a method for single or multiple coal seams where terrace or bench levels are used in the open pit design to optimize mine equipment combinations. It is advantageous because spoil placement is 
easily controlled, grading can be concurrent with production, equipment delivery time is shorter than with dragline methods, production loss from downtime is less, and spoil rehandling problems are eliminated. Field trials for the system to be initiated during FY 1979 will mark the first U.S. application of these techniques in a mine design.

During FY 1979, development will continue on an advanced underspoil haulage system which will impact future mine design. Underspoil haulage is a term applied to the transportation of coal in area strip mines from the pit to the surface by belt conveyors through tunnels under the spoil. This system will lower manpower requirements, reduce congestion around the pit (thereby increasing safety and efficiency), lessen the need for extensive maintenance facilities, and facilitate meeting reclamation requirements. Additionally, field trials will be initiated to demonstrate optimal methods and equipment for handling surface coal mine innerburden. Innerburden handling refers to the removal, transport, and segregation of material that lies between coal seams in a multiple seam mining nperation.

\section{Thick and Multiple Seam Mining}

The thick and multiple seam mining project is oriented primarily toward exploiting surface coal reserves west of the Mississippi. Even though geographic and geologic conditions are diverse in these new western surface coal mines, two basic mining methods, dragline casting, and shovel and truck mining, have historically been used. Draglines with booms of up to 300 feet and buckets with 60 to 70 cubic yard capacities are used. While draglines of this size are capable of digging overburden depths of 150 to 200 feet in one lift, they cannot effectively dispose of the spoil without rehandling. While truck and shovel operations provide a more flexible mining system than dragline casting, overburden handling can be three to four times more costly. The thick and multiple seam mining project is developing three new mining equipment systems designed to increase productivity at competitive economic cost: 1) mobile overburden conveyors and continuous spreaders in conjunction with existing excavators; 2) a continuous high-volume overburden excavation and handling system; and 3) a continuous high-volume coal excavation and handling system. In developing equipment specifications for each of these systems, the entire mining cycle from ground preparation and excavation through the transport, dumping, and leveling phases are considered and integrated.

In the area of mobile overburden conveyor's and continuous spreaders, four competing mobile cross-pit conveying systems (CPCS) have been designed that use a hopper to handle material from a dracline. and a spreader to distribute the spoil. These four systems are: 1) an inclined bridge with a shuttle conveyor for spreading spoil; 2) a direct bridge from the highwall to the spoil bank; 3) an inclined bridge with spreader; and 4) a steep-angle conveyor using an overlapping belt. Component testing of these systems will begin in FY 1978. Based upon results of the feasibility studies and component testing, one system will be chosen for construction and full-scale testing in FY 1979. 
Although a CPCS is a more efficient and economical spoil removal system than shovel/truck or conventional dragline methods, it is still costly since it requires a relatively expensive supplementary hopper to convert the system from a cyclic to a continuous operation. A truly continuous mining system could be even more efficient, eliminating the need for a dual material handling capacity and the cyclic excavating process. Therefore, a variety of highly mechanized equipment that can continuously excavate large volumes of overburden is being developed for use in the west. Depending upon the nature of the primary machine configuration involved, these continuous mining machines can be classified into four categories: boom-type bucket-wheel excavators; integral wheel bucket-wheel excavators; drum shearer and auger-cutter type excavators; and vertical-arm belt-loading excavators. Several of these machines can potentially be developed for use in both coal and overburden extraction. The project is pursuing development of two distinct systems, a continuous equipment system for coal and a continuous equipment system for overburden. Machines selected for use in either coal or overburden removal will be examined to determine their application to both systems.

Feasibility analyses and component testing of different concepts will be carried out during FY 1979. Based upon the results of these activities, detailed designs will be developed and the selected machines will be fabricated.

\section{Conventional Mining Equipment Improvements}

The conventional mining equipment improvements project stresses modification of equipment components, development of better maintenance techniques, upgrading of equipment operators' skills, and development of control assist devices for equipment operators. These efforts are geared to reduce operating costs and ultimately make existing surface coal mines more competitive with other energy sources. A wire rope fatigue testing machine has been developed which will be used to test dragline wire rope life during FY 1978. The machine is capable of testing 3-inch diameter ropes with loads of up to 500,000 pounds. Application of these test results should reduce industry's wire rope maintenance costs, which are estimated to be $\$ 15$ million per year. Efforts are also under way in dragline boom fatigue, dragline lubrication, and optimal dragline operating techniques. Based on the results of these studies, equipment will be designed and field tests will be initiated in FY 1980 .

The dozer draft power sensor, an electronic device attached to a tractor dozer, has been developed to measure the velocity of the tractor and the load on the dozer blade. It uses these factors to calculate a work rate (horsepower output). By using this device, an operator can maintain maximum production rates indefinitely. Initial field tests have been encouraging, and extended field tests will be conducted.

\subsection{CONTOUR MINING}

Contour mining consists of removing the overburden above the coal bed by starting at the coal outcrop and proceeding along the hillside. After the deposit is exposed and removed by this first cut, additional cuts 
are made until the ratio of overburden to coal brings the operation to a halt. This type of mining creates a shelf or "bench" on the hillside. On the inside, it is bordered by the highwall, which may range from a few to more than 100 feet in height; on the opposite or outer side, it is bordered by a rim below which there is frequently a precipitous downslope that has been covered by spoil material cast down the hillside. Projects currently under way include contour mining conveyor systems, crossridge demonstrations, and highwall mining systems.

\section{Conveyor Systems}

The contour mining conveyor systems project involves development of two separate systems: a low wall conveyor haulage system and a mountaintop conveyor system. The objective of developing these systems is to promote continuous overburden and coal removal activities at surface mines operating in steep terrain. 'I'hese systems can potentially be cost effective while achicving crccllent rcclamation and cnvironmental improvements.

A low wall conveyor haulage system has been developed for the recovery of coal in steep-slope areas of Appalachia. This method facilitates return of the mined area to its approximate original contour while minimizing or eliminating acid spoil problems. A series of field tests of this system will be carried out during FY 1978 and FY 1979. The system's range of operations will be investigated in FY 1978; variations for application in other areas will be designed in FY 1979.

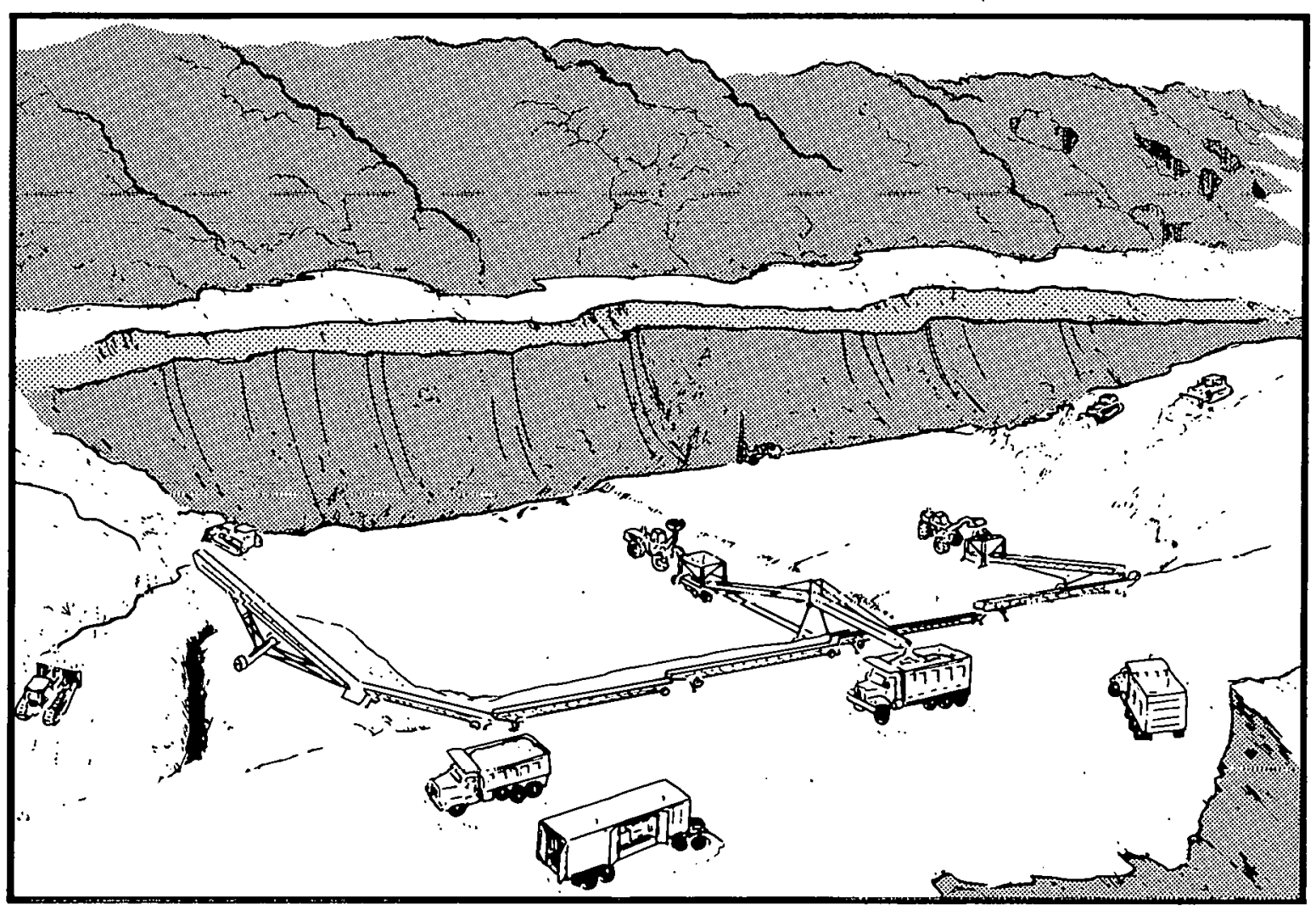

Longwall Conveyor Haulage 
The mountaintop conveyor system will enhance resource recovery while achieving excellent environmental and reclamation standards at surface mines operating in steep terrain. Systems and equipment have been analyzed and their potential for practical application determined. During FY 1979, detailed designs and specifications will be developed and a mountaintop site will be selected. Site specific planning for an extended field test will be initiated.

\section{Crossridge Demonstrations}

The crossridge mountaintop demonstration project involves a surface mining technique for mountaintop coal where the mining direction is perpendicular to the long axis of the ridge line.

Compared to conventional mountaintop removal, the crossridge technique increases resource recovery, reduces operating costs, reduces the area disturbed by mining, and facilitates compliance with reclamation requirements. A demonstration using existing equipment will be carried out, in cooperation with a coal company, in FY 1979 to verify the feasibility of this technique and transfer the technology to industry. Evaluation of the demonstration will also commence in FY 1979.

\section{Highwall Mining Systems}

The highwall mining system project will employ an extended depth auger to exploit the large quantities of coal that are left behind the highwall with conventional mining methods. Development of an extended depth auger will increase the total recovery of coal beds augered, provide favorable economics for total reclamation, increase coal production, and increase economically minable coal reserves. The auger being considered will be able to remotely mine coal in excess of 500 feet from the highwall.

Present efforts are concentrating on the development of sophisticated guidance systems for coal-rock boundary sensing and cut-thickness determination. Preliminary designs have been completed for two competing concepts, and a model of one machine has been constructed. Detailed engineering designs have been developed, and in FY 1979, fabrication of the aguer will be completed and field testing will be inilialed.

\subsection{RECLAMATION AND SUPPORTING STUDIES}

To support implementation of the more restrictive reclamation requirements of the Surface Mining Control and Reclamation Act of 1977 (PL 95-87), a number of studies will be undertaken. One group of studies will identify and evaluate the environmental effects of different types of surface mining techniques and related processes. A second group will examine techniques to mitigate the adverse environmental effects of surface mining.

The first group of studies will be pursued to provide regulatory authorities with basic information regarding extent and magnitude of the environmental impact of surface mining. Well documented information from 
scientific studies will allow regulatory authorities to determine whether changes in regulations are needed. Typical studies include hydrology and water quality of watersheds subjected to surface mining, and effects of noise and vibration from blasting.

The second group of studies will provide mine operators with information regarding technical and economically efficient methods of complying with various aspects of reclamation standards. Typical projects address the establishment of stable long-term vegetative cover, blasting: techniques to minimize vibrations and noise, and the quantity of topsoil necessary for effective reclamation.

Since it has been determined that topsoil handling and reclamation costs can range up to 28 percent of the total mining cost, efforts are also under way to develop topsoil rock removal equipment and topsoil handling equipment. The task of reclaiming surface mined land involves grading dowit the spuil material to some acceptable slope or rolling terrain approximating the original contour of the land. Four pieces of reclamation equipment with large tractor-mounted angled blades have been field tested, and the results are now being analyzed. Preliminary results indicate that these machines reclaim the land much more efficiently than conventional equipment now in use. Based upon the analysis, additional pieces of equipment will be designed and tested to further improve reclamation technology

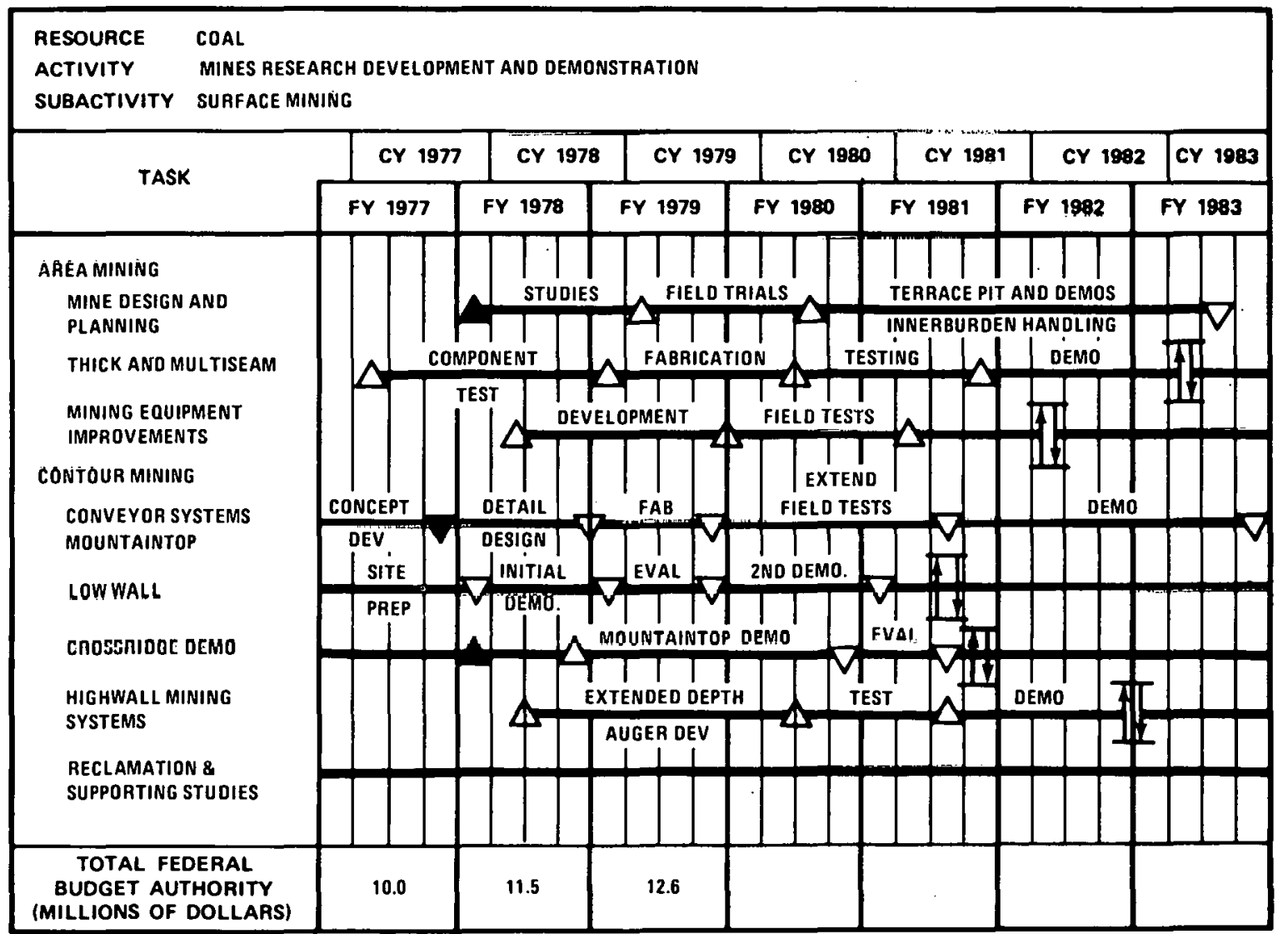

MILESTONE SYMBOLS ARE DEFINED ON LAST PAGE OF THIS DOCUMENT 


\subsection{COAL PREPARATION RESEARCH}

In response to the research impetus clearly mandated by the Clean Air Act of 1970, research in coal preparation focuses on three objectives: meeting $\mathrm{SO}_{\mathrm{X}}$ emission standards; identifying and monitoring trace fugitive elements present in the raw coal (i.e., coal preparation refuse, clean coal, fly ash, or emission exhaust); and meeting stringent standards on environmental effects of the coal preparation process itself. To satisfy these objectives, the Coal Preparation Research subactivity has established four projects:

$\begin{array}{ll}- & \text { Process test facility } \\ -\quad \text { Coal preparation technology } \\ \text { - } \quad \text { Suste utilization and control } \\ \text { - }\end{array}$

\subsection{PROCESS TEST FACILITY}

Presently in the U.S. there is no available fully integrated demonstration facility for testing a new coal washing technique, flow scheme, or piece of equipment. Consequently, a significant time lapse occurs between development of new equipment and techniques and their acceptance by the coal industry. Construction of a test facility began in FY 1978 and will be completed during FY 1979. Engineering data will be provided on a scope not previously possible. Moreover, the expense of developing various preparation techniques will be greatly reduced.

The plant will have a nominal capacity of 10 to 25 tons/hr of raw coal, depending on the flow scheme used. Process flexibility is a prime design requisite of this plant, which will use off-the-shelf commercial equipment. New coal washing circuits and crushing, screening, dewatering, and cleaning equipment will be evaluated. The plant will be used to process coal from various regions and to provide the optimum operating conditions necessary to produce a coal of acceptable sulfur, ash, and trace element content. An additional, but judiciously exercised, function of the demonstration plant will be to produce ton lots of specification coal for rombustion testing, stack gas scrubbing work, or as feedstock to coal conversion processes.

\subsection{COAL PREPARATION TECHNOLOGY}

To reduce the sulfur content of coal, improved and innovative physical separation technologies are being developed to effectively separate fine coal from pyrite. Desulfurization can be accomplished through physical processes such as gravity separation, flotation, and magnetic separation techniques or through varying chemical techniques that will remove most of the pyrite sulfur plus some of the organic sulfur intimately bonded within the coal molecule. During FY 1979, an oil agglomeration process demonstration for separating fine rock from powdered coal will be completed. If successful, the agglomeration process will be integrated with a wet high-gradient magnetic separation (HGMS) process to obtain a clean coal product low in moisture, ash, and pyrite. Tests of dry HGMS using 
prototype equipment will be continued: Chlorinolysis, a chemical desulfurization process developed at the Jet Propulsion Laboratory, has been shown to be both economically and technically feasible. A small-scale facility constructed in FY 1978 will be operated in FY 1979, further testing the feasibility of this process. Since physical desulfurization will remove only the sulfur-bearing mineral pyrite, efforts to combine physical and chemical desulfurization will be pursued if the tests demonstrate feasibility.

With the ever increasing growth in production of fine-size coal due to mining techniques or simply as a means to liberate impurities, it has become necessary to put the fine material in a more convenient form for handling, transporting, and storing. Preparation requirements for lignite and subbituminous coals include sodium reduction as well as the dewatering and pelletizing or briquetting necessary for bituminous coal. During FY 1979, efforts will continue to reduce the sodium in liguite and subbituminous coals. Initial efforts to determine the feasibility of lignite and subbituminous dewatering and pelletizing will be completed. Results of these studies will determine if a maior demonstration is warranted.

Efforts to reconstitute bituminous coal will also be pursued, focusing on briquetting and pelletizing. Since considerable knowledge has been accumulated concerning anthracite briquetting and lignite pelletizing, these efforts will concentrate on the engineering improvements of a known technology. Additionally, initial transport feasibility studies associated with coal/gelled oil mixtures and other fine coal transport systems will be initiated.

\subsection{WASTE UTILIZATION AND CONTROL}

Surface ground waters are contaminated from coal in several ways, including: leachants from waste piles; pollutants in the form of cucpcndcd solids from preparation plants; and leachants from surface water percolating through ground contaminated with airborne fallout from stack gases. To control water pollution from process wastes, studies will be initiated to develop a low cost method for dewatering fine wastes to obviate the need for tailing ponds. These studies will concentrate on the optimization of a filter design and disposal system, plus the pelletizing and firing of the fine waste in a fluidized bed to utilize the Btus associated with that waste. Pollution of land downstream from stark plumes will be minimized as efforts continue to reduce the hazardous trace elements in coal by precombustion cleaning.

\subsection{SUPPORTING STUDIES}

To better understand the characteristics and properties associated with the clean burning of coal, studies will be continued to identify and characterize coal macerals, carbon/sulfur compounds, and trace elements found in various coal seams in the United States. Washability studies, which show the release or liberation of pyrite at various screen sizes, will be continued until samples from most of the major seams have been tested. 
Long-term studies on the surface chemistry of coal, pyrite, and ash macerals will be continued in an effort to obtain fundamental knowledge of the effect of activators, collectors, and depressants on coal and mineral particles.

RESOURCE COAL

ACTIVITY MINES RESEARCH DEVELOPMENT AND DEMONSTRATION

SUBACTIVITY COAL PREPARATION RESEARCH

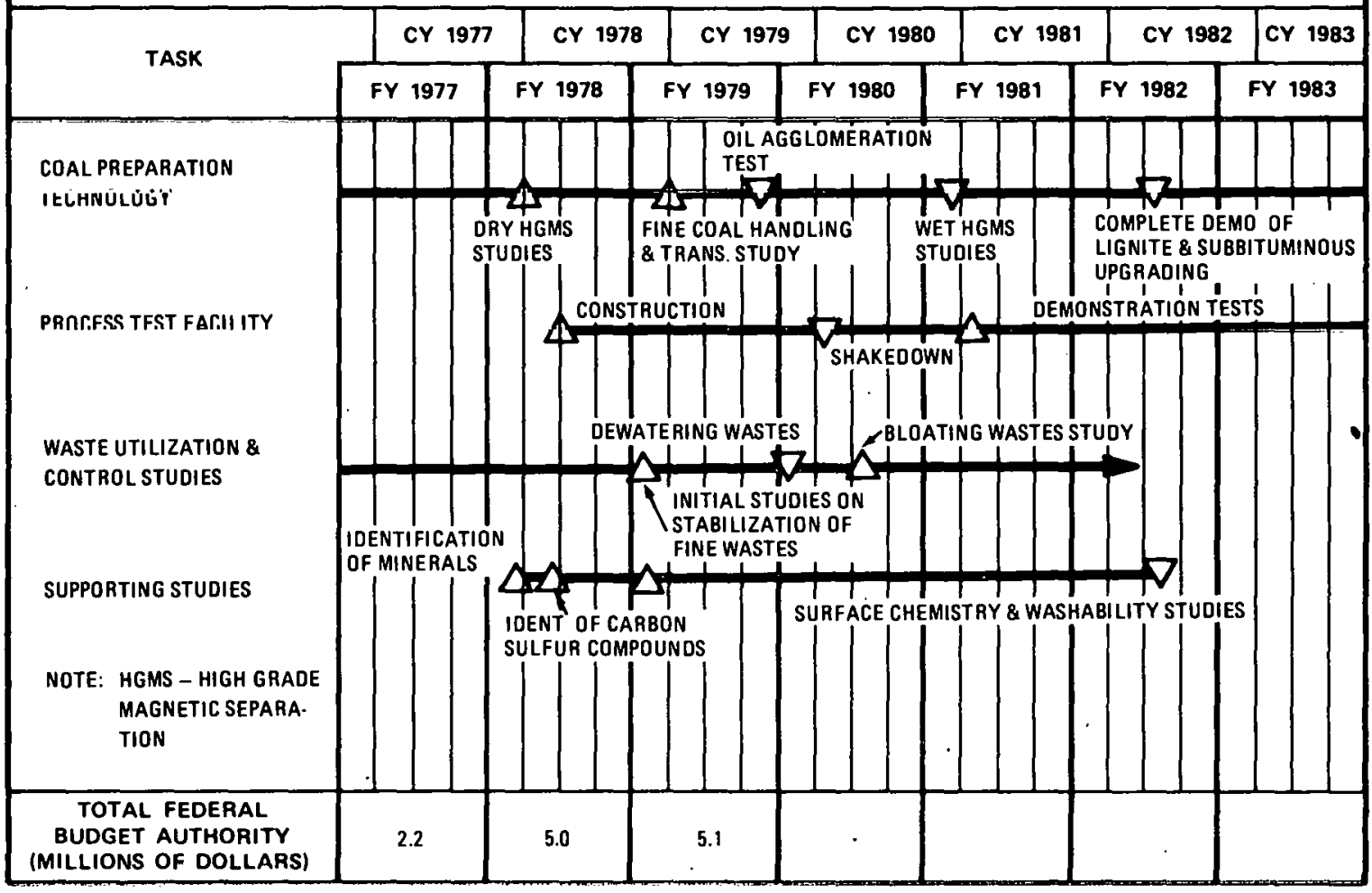

MILESTONE SYMBOLS ARE DEFINED ON LAST PAGE OF THIS DOCUMENT 


\section{COAL LIQUEFACTION}

The products derived from coal liquefaction processes can replace petroleum-refined products most effectively in two distinct markets. One market uses low-ash, low-sulfur boiler fuels suitable for clean electric power generation and industrial steam generation. The other market uses high-grade fuels such as gasoline, heating oil, and chemical feedstocks. The development of commercial coal liquefaction processes will provide a route to increased domestic production of clean fossil fuels and feedstocks that complies with all applicable environmental regulations. The specific objectives of the Liquefaction Activity are:

- To develop as candidates for commercialization, secondgeneration technology that will convert domestic coal into clean boiler fuel, distillate heating oil, gasoline, and chemiral feedstocks

- - To assure technology transfer and improved unit operations to support commercial liquefaction operations

- To perform laboratory studies and process development of thirdgeneration liquefaction processes

- To support commercial-scale implementation of second-generation liquefaction technology at the earliest feasible date.

The strategy of the Liquefaction Activity is to support a number of liquefaction processes in parallel, from laboratory scale through process development unit (PDU), with only promising processes going to the pilot plant stage. This approach is based on a number of considerations. The variety of coals to be processed, coupled with the requirements for a wide range of fuels, will necessitate commercialization of a number of liquefaction processes.

The processes described in this section support the Liquefaction strategy and the objective of first producing a clean-burning oil from coal, to release petroleum and natural gas presently being fired in power boilers for other uses. Subsequently, the synthetic crude oil produced from these processes can be upgraded to gasoline, fuel oil, and other fuels.

Projects are supported in three liquefaction areas: solvent extraction, direct hydrogenation, and pyrolysis. In addition to the development of individual liquefaction processes, several problems common to most liquefaction processes have become evident. Timely programs have been initiated to solve these problems. It is highly unlikely that any single second-generation process will be used exclusively. Two or more single-purpose processes may be selected depending on the coal type, the products sought, and the plant site selected. A broad program is being planned including 'production of sufficient quantities of representative types of coal-derived specification fuels. These fuels will be qualified as interchangeable with existing petroleum-derived fuels. 
The three subactivity areas have progressed to various stages of development:

- Direct Hydrogenation process: Operation of the H-Coal pilot plant will be initiated in FY 1979.

- Solvent Extraction processes: The 50-tons/day solvent refined coal (SRC) pilot plant is currently operating. Construction of a 250-tons/day donor solvent pilot plant is underway.

- Pyrolysis processes: A process development unit (PDU) on a flash hydropyrolysis process is operational.

The activity also includes support research and development to provide back-up for current second-generation process development and to develop novel liquefaction processes, third-generation improvements in the technology. Several problems common to most liquefaction processes are under study; for example, liquid-solid separation, utilization of solidcontaining bottoms for the hydrogen production, and durability of auxiliary equipment.

Environmental concerns associated with the development of coal liquefaction processes are primarily:

- Presence of potentially toxic and carcinogenic organic compounds in coal residues and products

- Potential presence of trace metal pollutants in the products and by-products.

These environmental and related concerns are dealt with in a program to characterize and analyze the constituents of process streams and significant emissions from liquefaction processes. Studies are also being conducted at pilot plants to develop adequate occupational safety and health procedures for worker protection.

The following table provides the funding levels by subactivity for the FY 1977 through FY 1979 period.

\begin{tabular}{|c|c|c|c|c|}
\hline LIQUEFACTION & \multicolumn{4}{|c|}{$\begin{array}{l}\text { BUDGET AUTHORITY } \\
\text { (OPERATING EXPENSES) } \\
\text { (DOLLARS IN THOUSANDS) }\end{array}$} \\
\hline SUBACTIVITIES & $\begin{array}{l}\text { ACTUAL } \\
\text { FY } 1977\end{array}$ & $\begin{array}{l}\text { APPROPRIATION } \\
\text { FY } 1978\end{array}$ & $\begin{array}{l}\text { ESTIMATE } \\
\text { FY } 1979\end{array}$ & $\begin{array}{l}\text { INCREASE } \\
\text { (DECREASE) }\end{array}$ \\
\hline $\begin{array}{l}\text { Direct Hydrogenation } \\
\text { Solvent Extraction } \\
\text { Indirect Liquefection } \\
\text { Pyrolysis } \\
\text { Support Studies \& Engineering } \\
\quad \text { Evaluations } \\
\text { Liquefaction Demonstration } \\
\text { Plants }\end{array}$ & $\begin{array}{r}\$ 31,701 \\
24,705 \\
1,1000 \\
5,400 \\
10,051 \\
8,400\end{array}$ & $\begin{array}{r}\$ 40,500 \\
47,200 \\
0 \\
2,000 \\
16,500 \\
4,000\end{array}$ & $\begin{array}{r}\$ 29,000 \\
49,740 \\
0 \\
2,000 \\
18,386 \\
\\
5,740\end{array}$ & $\begin{array}{r}\$ 11,500 \\
+2,540 \\
0 \\
0 \\
+1,886 \\
+1,740\end{array}$ \\
\hline TOTAL & $\$ 81,357$ & $\$ 110,200$ & $\$ 104,866$ & $\$ \quad-5,334$, \\
\hline
\end{tabular}




\subsection{DIRECT HYDROGENATION}

This subactivity includes the following processes in FY 1979:

- H-Coal

- Fixed-Bed Hydrogenation (Synthoil)

- Zinc Chloride Catalyst

- Disposable Catalyst Hydrogenation

- Multistage Liquefaction

These processes differ in the mechanics of the reactor and/or the kind of catalyst used. Otherwise, they are similar in that they catalytically add hydrogen to coal for liquefaction to oil and remove the sulfur as gaseous hydrugen sulfide, which is convertible to sulfur for sale or storage. Specific objectives are to determine operational reliability of each process and the ecunumic's wlich must ultimatcly provide an inrentive. for commercialization. The product distribution varies among the processes. The Synthoil process produces boiler fuel, the $\mathrm{H}$-Coal either boiler fuel or syncrude; Multistage Liquefaclion is aimed at syncrude, and the Zinc Chloride Catalyst is a severe hydrocracking process giving naphtha range liquid.

The table below summarizes the funding levels by task for the FY 1977 to FY 1979 period.

\begin{tabular}{|c|c|c|c|c|c|}
\hline DIRECT HYDROGENATION & \multicolumn{4}{|c|}{$\begin{array}{l}\text { BUDGET AUTHORITY } \\
\text { (OPERATING EXPENSES) } \\
\text { (DOLLARS IN THOUSANDS) }\end{array}$} & \multirow{2}{*}{$\begin{array}{l}\text { MAJOR } \\
\text { CHANGE* }\end{array}$} \\
\hline TASKS & $\begin{array}{l}\text { ACTUAL } \\
\text { FY } 1977\end{array}$ & $\begin{array}{c}\text { APPROPRIATION } \\
\text { FY } 1978\end{array}$ & $\begin{array}{l}\text { ESTIMATE } \\
\text { FY } 1979\end{array}$ & $\begin{array}{l}\text { INCREASE } \\
\text { (DECREASE) }\end{array}$ & \\
\hline $\begin{array}{l}\text { Ebullated-Bed H-Coal Pilot Plant } \\
\text { Fixed-Bed Hydrogenation } \\
\text { (Synthol) PDU } \\
\text { Zinc Chloride Catalyst } \\
\text { Disposable Catalyst Hydrogenation } \\
\text { Multistage Liquefaction }\end{array}$ & $\begin{array}{r}\$ 20,800 \\
7,900 \\
2,400 \\
601 \\
0\end{array}$ & $\begin{array}{r}\$ 26,000 \\
11,000 \\
2,000 \\
500 \\
1,000\end{array}$ & $\begin{array}{r}\$ 21,000 \\
4,889 \\
2,100 \\
1,011 \\
0\end{array}$ & $\begin{array}{r}\$-5,000 \\
-6,111 \\
+100 \\
+511 \\
-1,000\end{array}$ & \multirow[t]{2}{*}{$\begin{array}{l}P \\
P \\
R \\
C\end{array}$} \\
\hline TOTAL & $\$ 31,701$ & $\$ 40,500$ & $\$ 29,000$ & $\$-11,500$ & \\
\hline \multicolumn{3}{|c|}{$\begin{array}{l}\text { "KEY } \\
N=\text { New start (totally new project) } \\
S=\text { Sraleup (from hench to PDU or pilot plant) } \\
A=\text { Acceleration (shortening deadlines or } \\
\text { expansion of ongoing projects) }\end{array}$} & \multicolumn{3}{|c|}{$\begin{array}{l}F=\text { Phasc completion or startun } \\
R=\text { Program redirection } \\
I=\text { Incremontsl cult roquilement } \\
C=\text { Project completion or suspension }\end{array}$} \\
\hline
\end{tabular}

\subsection{EBULLATED-BED (H-COAL) PILOT PLANT}

The H-Coal process is a catalytic hydroliquefaction process that converts high-sulfur coal to either a boiler fuel that will meet sulfur emission regulations or to a refinery syncrude. Coal is dried and crushed to minus 40 mesh, then slurried with recycled oil and pumped to a pressure of 200 
atm. Compressed hydrogen is added to the slurry, and the mixture is preheated and charged continuously to the bottom of the ebullated-bed catalytic reactor. Upward passage of the internally recycled reaction mixture maintains the catalyst in a fluidized state (catalyst activity is maintained. by the semicontinuous addition of fresh catalyst and the withdrawal of spent catalyst). The temperature of the ebullated-bed catalytic reactor is controlled by adjusting the temperature of reactants entering from the preheater. Typically, temperature of the mixture entering the reactor is $650^{\circ} \mathrm{F}$ to $700^{\circ} \mathrm{F}$. Control of the ebullated-bed of catalyst is a function of many process parameters. The interrelationships of these parameters are the subject of ongoing research.

The vapor product leaving the top of the reactor is cooled to separate heavier components as a liquid. Light hydrocarbons, ammonia and hydrogen sulfide, are absorbed from the remaining gas leaving a hydrogen-rich gas which is recompressed and recycled to be combined with the input slurry. The liquid-solid product, containing unconverted coal, ash, and oil, is fed into a flash separator. The material that boils off is passed to an atmospheric distillation unit. The bottoms product (solids and heavy oil) is further separated with a hydroclone, a liquid-solid separator, and a vacuum still.

The gas and liquid products (hydrocarbon gas, hydrogen sulfide, ammonia, light distillate, heavy distillate, and residual fuel) may be further refined as necessary. Heavy distillate is recycled as the slurry medium. The stream containing unreacted carbon and some liquid will eventually be processed on-site to produce hydrogen needed for the process.

The specific conditions of the H-Coal process affect the type of fuel produced. For example, to produce refinery syncrude, more hydrogen is required and there is a lower yield of bottoms product. To produce a clean fuel gas and liquid low-sulfur boiler fuels, the through-put of the ebullated-bed reactor is increased and less hydrogen is required. If the end product is to be synthetic crude oil, separation of the solids (unconverted coal and ash) from the liquid products can be accomplished by vacuum distillation.

In a conceptual commercial plant, hydrogen would be supplied by partial oxidation of the ash containing residue fraction. In the $\mathrm{H}$-Coal pilot plant (discussed below), hydrogen will be supplied by the adjacent Ashland Oil refinery.

\section{Project Status}

The H-Coal process was developed by Hydrocarbon Research, Inc. (HRI), as a further application of the ebullated-bed processing technology originally used to convert heavy oil petroleum residues into lighter fractions ( $\mathrm{H}$-oil process). Early development of the $\mathrm{H}$-Coal process involved research with a bench-scale unit and a PDU and preparation of a conceptual process design. Independent evaluations in 1963 and in 1976 confirmed the technical and economic feasibility of the $\mathrm{H}$-Coal process. 
Since 1964, HRI has been developing the H-Coal process continuously under the mixed sponsorship of ERDA (now DOE) and a private industry consortium.

Based on experimental operations of bench-scale and a 2.5-tons/day PDU for synthetic crude oil and boiler fuel production, the preliminary design for construction of a 600-tons/day pilot plant has been completed. A detailed design of the pilot plant was completed by December 1977. .

The pilot plant site has been selected (Catlettsburg, Kentucky) by Fossil Energy, at the recommendation of HRI, from sites offered by the private partners. Environmental assessment has been completed and shows that the plant will not significantly affect the environment of the proposed site. Acquisition of all necessary environmental permits wac completed during FY 1978. Construction and operation of the pilot plant are the responsibility of Ashland Synthelle Fuels with technical support by cubcontract from HRI.

This consortium is presently composed of the Electric Power Research Institute (EPRI), Ashland Oil, Inc., Standard Oil of Indiana, Conoco Coal Development Company, Mobil Oil Company, and the Commonwealth of Kentucky. DOE is providing 80 percent of the funds, and the consortium is providing 20 percent.

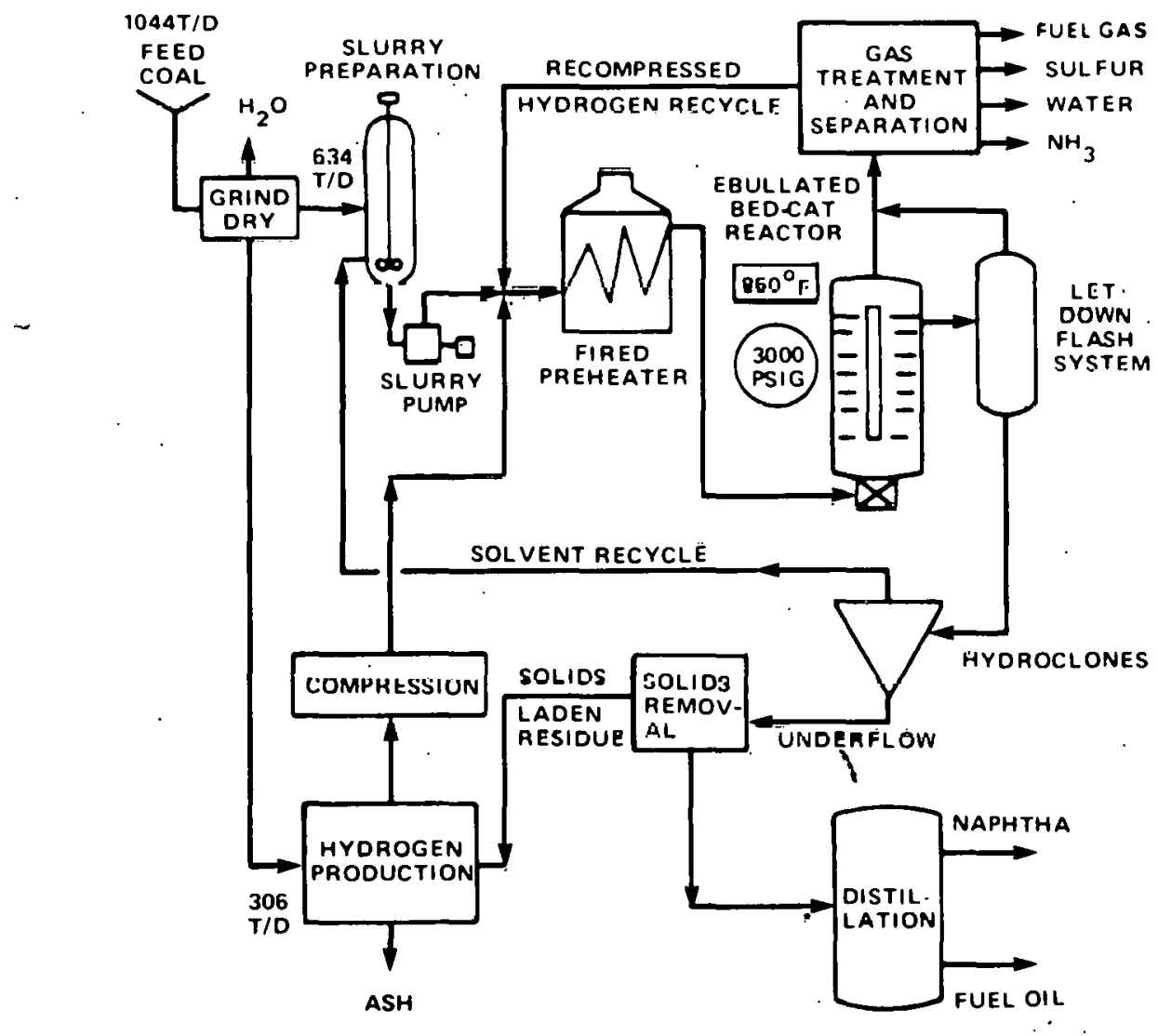

\section{H-Coal Process}


The pilot plant design effort resulted in a preliminary design nine months after the contract began and a 90-percent completed bid-package by March 1976. Construction of the pilot plant started in January 1977, with completion scheduled for late FY 1978. After plant startup, pilot plant operability will be demonstrated in both the syncrude and the boiler fuels modes. Material balance data around all process units will be used to establish process yield data as a function of coal type and operating conditions.

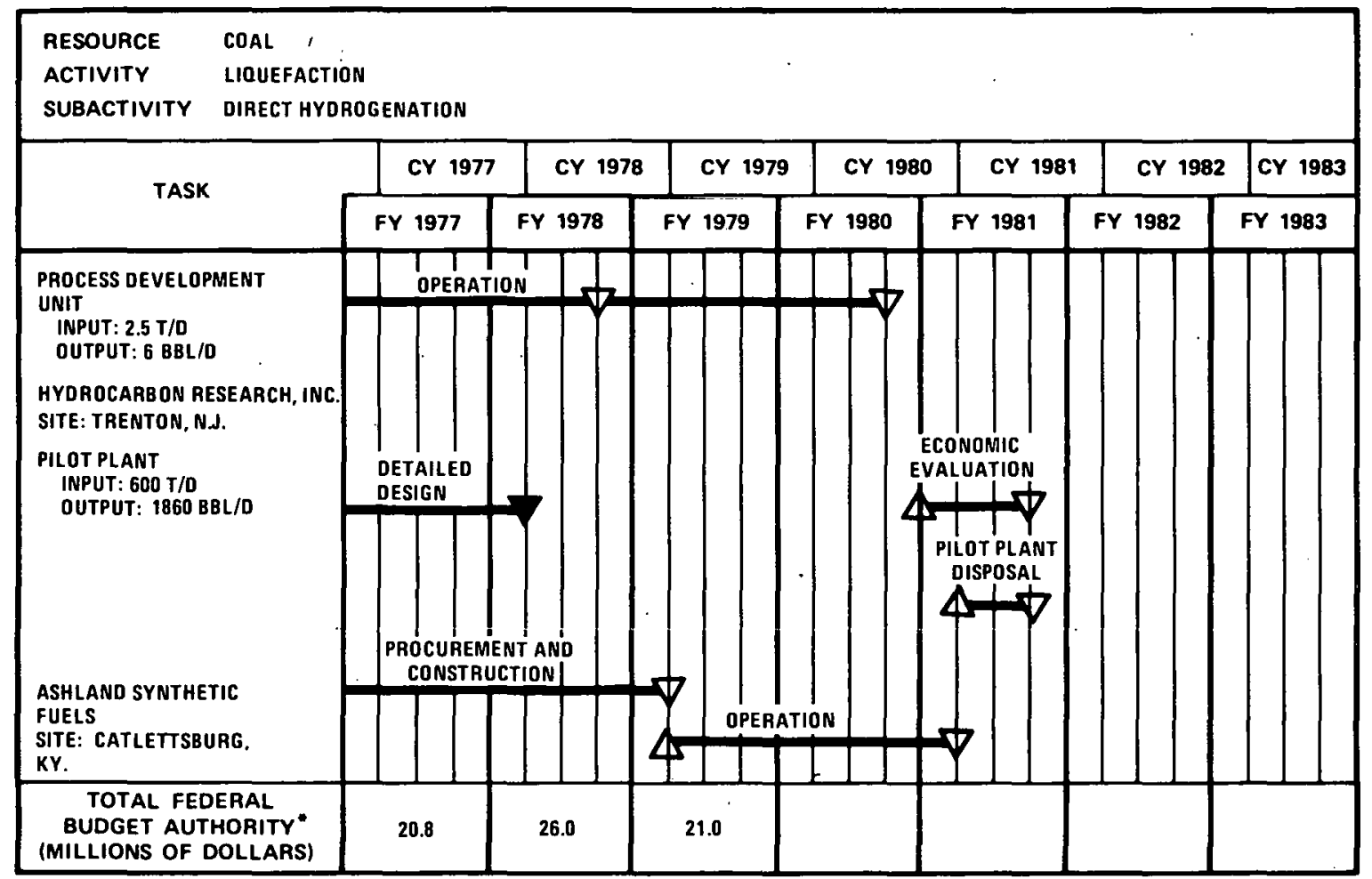

MILESTONE SYMBOLS ARE DEFINED ON LAST PAGE OF THIS UOCUMENT

"FURTHER BUDGET DETAILS ARE PROVIDED IN SECTION 6.0.

\subsection{FIXED-BED HYDROGENATION (SYNTHOIL) PDU}

The Synthoil process is a hydrodesulfurization process that converts high-sulfur coal to a low-sulfur, low-ash synthetic fuel oil. The coal is mixed with a portion of the product oil from the process and preheated. From the preheater, the slurry enters a fixed-bed reactor packed. with catalyst pellets of cobalt molybdate on silica-promoted alumina or with inert pellets. The mixture is then cooled and passed to a separator where the liquid and unreacted solids are separated from the gases.

The liquids and unreacted solids leave the bottom of the separator and pass into a centrifuge, where the solids are separated. The liquid product that leaves the centrifuge is a nonpolluting fuel oil. Part of the oil is recycled to the mixer to continue the process; the remainder is product oil. 
Gases coming off the top of the separator are sent through a gas purification system. The resulting hydrocarbon gases are sent to the gasifier where, together with the ash residue, they are combined with water and oxygen to form hydrogen for the process.

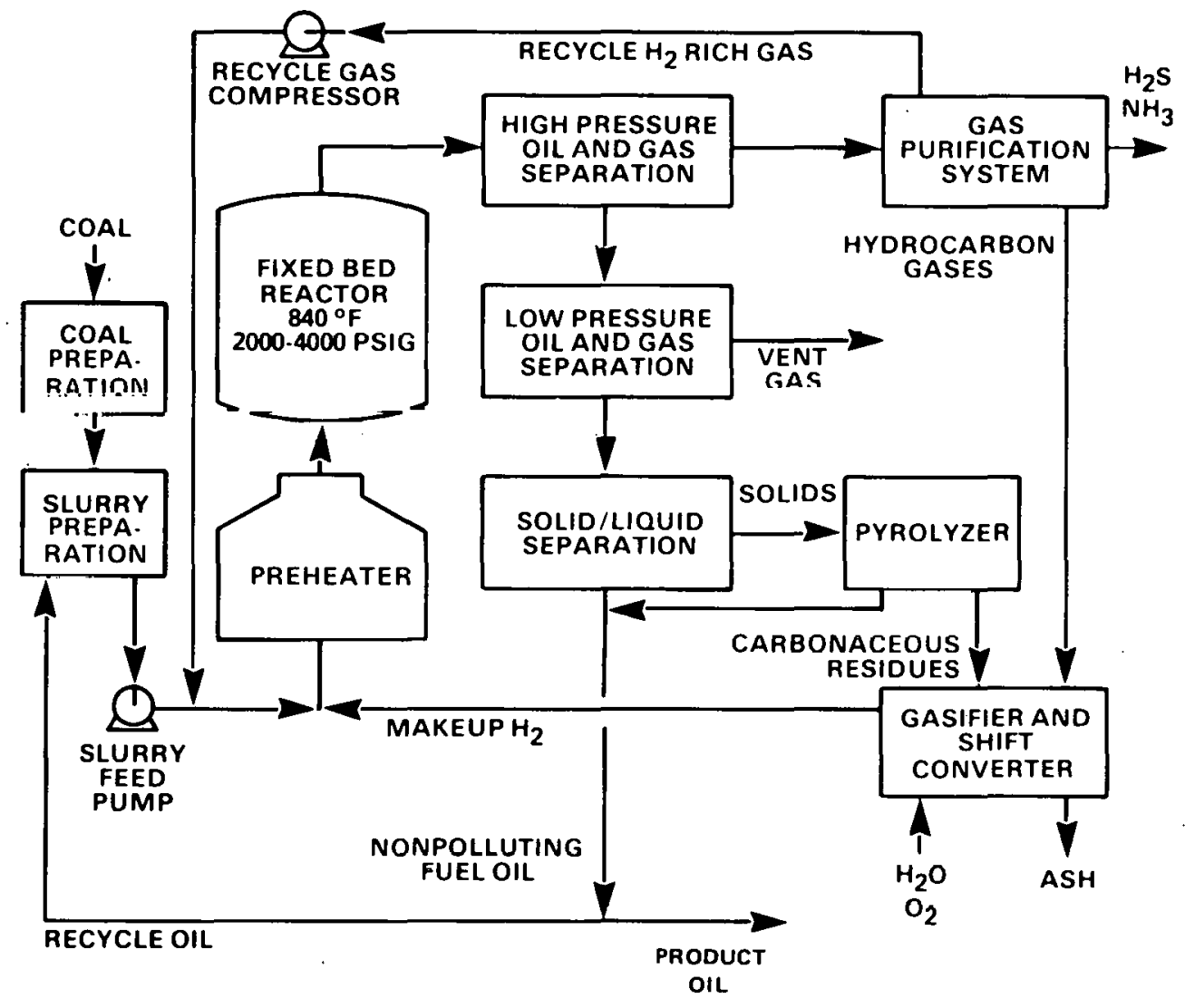

Synthoil Process

\section{Project Status}

Initfal work on the process, initiated in 1969 at Pittsburgh Energy Research Center (PERC), utilized a bench-scale unit capable of processing $5 \mathrm{lb} / \mathrm{hr}$ of coal slurry. Experimental work indicated that a wide variety of coals could be satisfactorily converted to a low-sulfur fuel oil, resulting in decisions to scaleup to larger units. Recent laboratory results have demonstrated the importance of thermal reactions in the synthoil process. Supporling research continues at $\mathrm{HEKC}$ to explore certain aspects of the process. Planned laboratory activities in FY 1979 include: determination of the role of inert cylinders in the packed bed versus thermal reactions in an empty bed; investigation of new catalysts; use of a continuous centrifuge to provide process solvent; and maximum throught-put. of c.nal in the existing continuous unit.

The 10-tons/day PDU will be constructed by FY 1979, and a decision is expected regarding selection of the operating contractor and process details for PDU operation. 


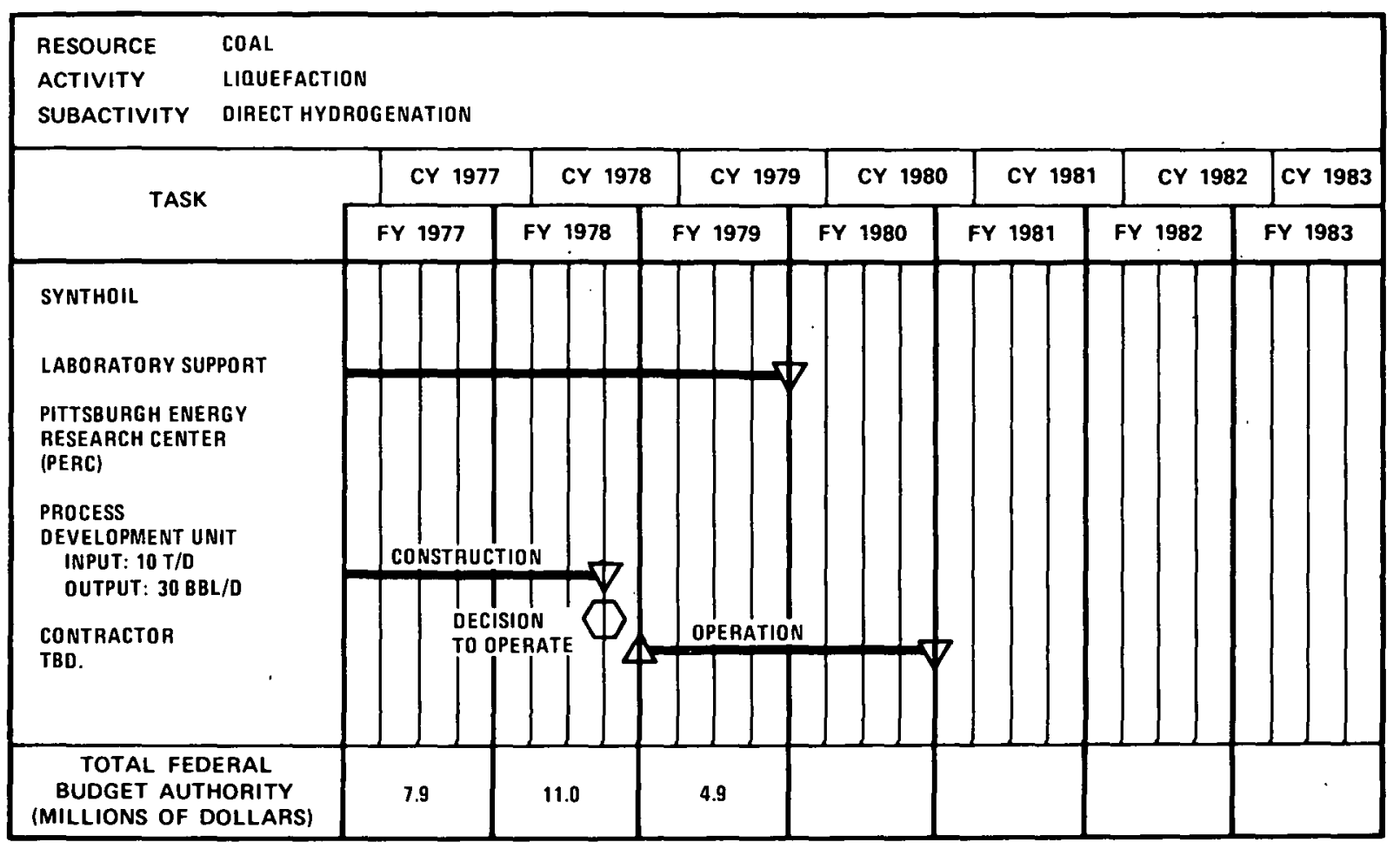

MILESTONE SYMBOLS ARE DEFINED ON LAST PAGE OF THIS DOCUMENT

\subsection{ZINC CHLORIDE CATALYST PDU}

The $\mathrm{ZnCl}_{2}$ catalyst process is designed to convert bituminous and subbituminous coal into distillates (in the gasoline range) by severe catalytic hydrocracking. The process may be applied either to coal as a one-step process or to coal extract as a two-step process. The process configuration will be set by economic considerations related primarily to the extent of catalyst recovery.

In the process, coal is dried and pulverized before introduction to a feed tank where it is slurried with a process-derived recycle oil. The shurry feed proceeds to the hydrocracking reactor where it is mixed with hydrogen and the $\mathrm{ZnCl}_{2}$ catalyst. The reactor operates between $675^{\circ} \mathrm{F}$ aind $825^{\circ} \mathrm{F}$ and between 1,500 and 3,500 psig. In the reactor, coal is cracked to distillates primarily in the gasoline range. All products go to a receiver where gas is separated from the liquid which is distilled. The gasoline and light fuel oil distillates are essentially solid-free.

Fresh spent-catalyst residue, which consists of nitrogen and sulfur compounds, ash, and carbonaceous residue, is fed to a fluidized-bed combustor for catalyst recovery. The combustor operates at $1700^{\circ} \mathrm{F}$ and 2 psig. The $\mathrm{AnCl}_{2}$ is separated from the rest of the residue as a vapor, condensed, and recycled back to the reactor section. Fresh make-up $\mathrm{ZnCl}_{2}$ is also added to the reactor.

Work being performed is aimed at developing a process with high specificity for producing high-octane gasoline, while also providing high reaction rate, constant catalyst aclivity, and high catalyet recovery by regeneration. 


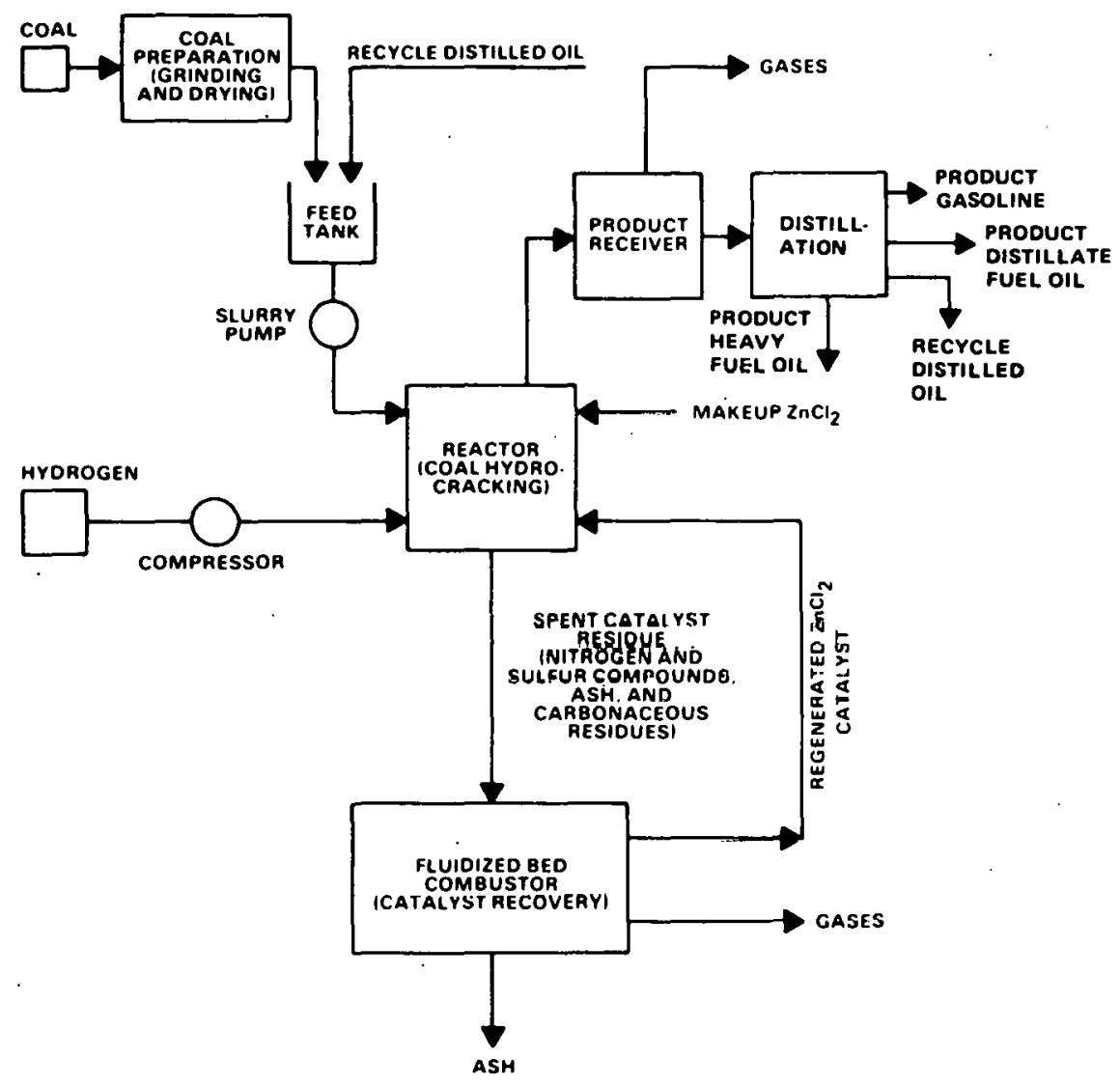

Zinc Chloride Catalyst Process

\section{Project Status}

Use of a molten zins halide as a catalyst for production of low-sulfur gaseous and liquid fuels was discovered and developed under the former Office of Coal Research (OCR) contract with Consolidation Coal Company (a subsidiary of Continental Oil Company) during the period of 1963 to 1968 .

Efforts during 1975 and 1976, under the present contract to Conoco Coal Development Company at Library, Pennsylvania, have utilized benchscale units to perform studies on the conversion of subbituminous coal into distillate products, and to investigate zinc chloride catalyst regeneration. In addition, process and detailed designs were completed for the PDU which can be fed $100 \mathrm{lb} / \mathrm{hr}$ of either coal or coal extract. Construction of the PDU began after authorization to proceed in July 1976.

During 1977, operation of the bench-scale units was completed. Process operating conditions were optimized and a reaction kinetic model was derived for subbituminous coal. Products from the zinc chloride process have been characterized as 90 Research Octane Number (RON) gasoline and as a very low sulfur and nitrogen content fuel oil. Secondary zinc chloride catalyst recovery has proven technically feasible achieving a 99.5 percent total catalyst recovery. Economic analysis indicates a 2-to-3 cent per gallon-of-gasoline advantage for secondary recovery as compared 
to primary catalyst regeneration only. Construction of the PDU hydrocracking section was completed in December, and completion of the regenerator section construction is projected for the second quarter of CY 1978 .

Solvent Refined Coal will be used for shakedown operation of the PDU hydrocracker during the first half of 1978, followed by an extended SRC material-balance run to confirm bench-scale yields for coal extract and to demonstrate PDU operability. Shakedown operation of the regenerator section and remaining PDU will commence during the second quarter followed by material-balance operation. Based on SRC operation and results of economic analyses, a decision will be made to proceed to directcoal PDU operation.

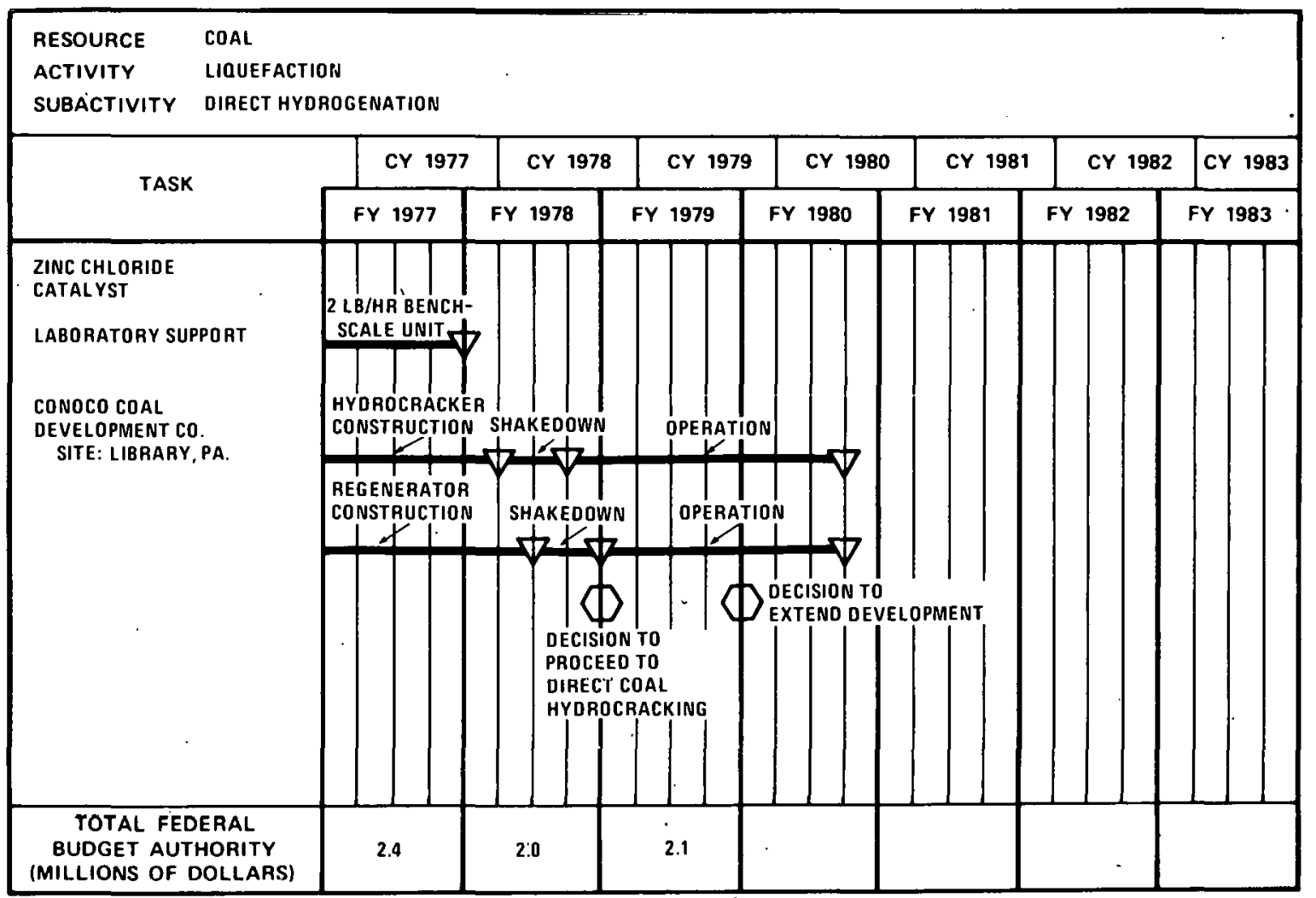

MILESTONE SYMBOLS ARE DEFINED ON LAST PAGE OF THIS DOCUMENT'

\subsection{DISPOSABLE CATALYST HYDROGENATION}

The Disposable Catalyst Hydrogeneration process will use inexpensive catalysts that avoid the expense of their recovery and reuse. During a single pass with coal through the hydrogenation reactor, the catalyst converts coal to sulfur-free fuel oil.

Coal is dried and mixed with a process-derived oil and the catalyst. The paste is compressed to 2,000-4,000 psi and preheated. Recycle gas and make-up hydrogen are added to the paste before hydrogenation 
reactions take place in the pressure vessel in the liquid phase. A gas stream and a sludge stream are sent from the reactor to a gas separator and letdown system. Part of the gas is recycled. The gaseous fuel product is composed of light hydrocarbons. The oil is distilled to obtain liquid fuel and pasting oil, while the residue and heavy oil are processed to recover light fractions, paste oil, and heavy liquid product.

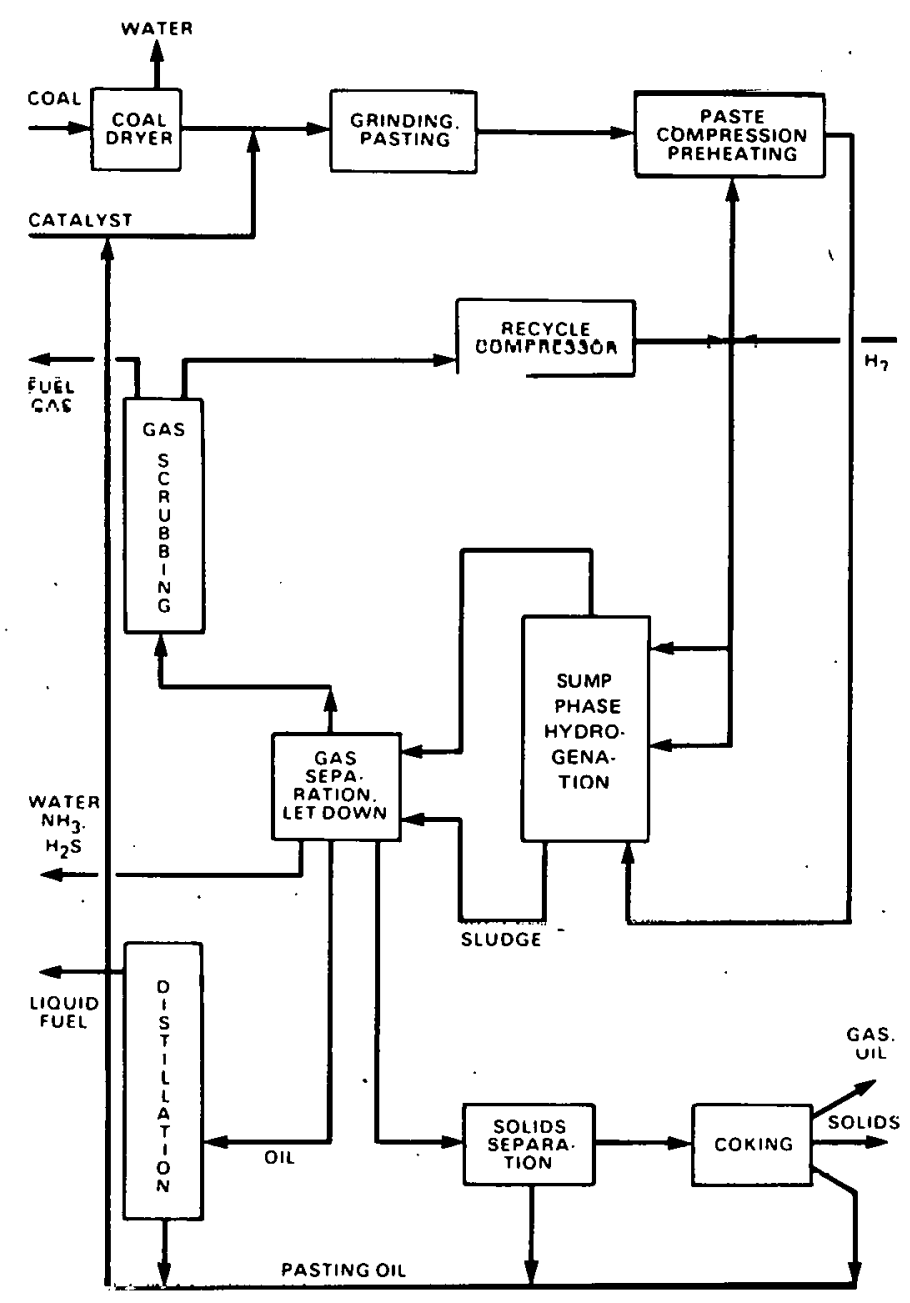

Disposable Catalyst Hydrogenation Process

\section{Project Status}

This process is under investigation at PERC where process conditions will be optimized in a 0.5-ton/day unit. Screening of catalysts in autoclaves in the $10-\mathrm{lb} / \mathrm{hr}$ continuous reactor will be continued. Construction of the 0.5 -tons/day unit was completed and operation will begin in FY 1978. Preliminary runs are under way in an 1/4-ton/day continuous unit. This recently initiated project is expected to improve on early German processes that used metal oxides as disposable catalysts. No catalysts have been selected for intensive development, but an objective is 
to specify the catalyst and reactor to achieve lower pressures and shorter residence time than was required in earlier processes. Metal oxides and sulfates are included in the catalysts under investigation.

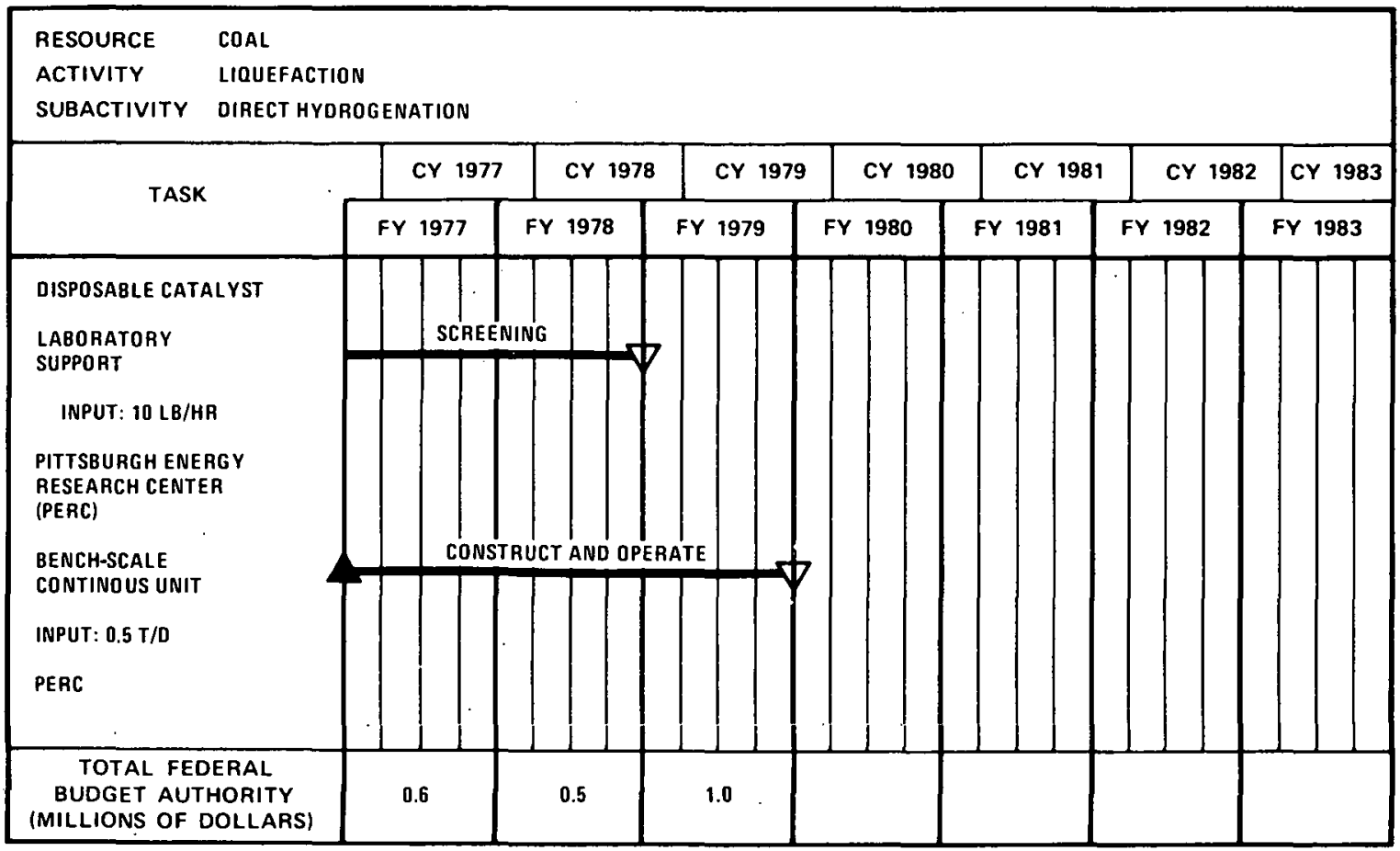

MILESTONE SYMBOLS ARE DEFINED ON LAST PAGE OF THIS DOCUMENT

\subsection{MULTISTAGE LIQUEFACTION PROCESS}

The Lummus Multistage process involves the catalytic hydroliquefaction of coal at elevated temperature and pressure in the presence of a catalyst. Fresh coal is crushed and dried before being fed to a mixing tank where it is slurried with a $600^{\circ} \mathrm{F}$ to $900^{\circ} \mathrm{F}$ nominal boilingpoint range aromatic recycle solvent. Coal slurry is then pumped to the hydroliquefaction section where reaction with hydrogen in the presence of catalyst at elevated pressure and temperature results in effective conversion of the coal to a low-sulfur liquid, which, after removal of unreacted coal and ash, is suitable as a clean boiler fuel.

An expanded-bed reactor system is used to overcome the plugging, catalyst deactivation, and liquid distribution problems of a fixed-bed reactor. No internal recycle pumps are used, and this process embodies the better features of a plug-flow and an expanded-bed reactor. The reactor is operated at a pressure of about 2,100 psig and outlet temperatures in the range of $780 \mathrm{~F}$ to $820^{\circ} \mathrm{F}$. Clean fuel product sulfur level of 0.3 weight percent can be readily achieved.

The liquid leaving the hydroliquefaction section is fractionated at slightly above atmospheric pressure to remove material boiling below about $690^{\circ} \mathrm{F}$. The material boiling below $690^{\circ} \mathrm{F}$ is further separated into a $\mathrm{C}_{1}-\mathrm{C}_{4}$ 
fuel gas stream, a $\mathrm{C}_{5} / 300^{\circ} \mathrm{F}$ naptha cut rich in $\mathrm{C}_{6}-\mathrm{C}_{8}$ aromatics, light atmospheric gas oil, and heavy atmospheric gas oil, a portion of which is also blended into the clean fuel product. The remaining portion of the heavy atmospheric gas oil constitutes the front end of the pasting solvent and is recycled to the coal slurry section. The $680^{\circ} \mathrm{F}+$ residue is routed to the de-ashing section, where it contacts an antisolvent that promotes the settling of an underflow. stream containing essentially all the ash in the coal feed to the plant. The unique antisolvent de-ashing method employed offers a means of effecting the essential step of ash removal, which may reduce both capital and operating costs in this process when compared with methods requiring filter or centrifuges. This method of de-ashing is generally adaptable to other liquefaction processes. The clean fuel product will have an ash content of under 0.1 weight percent. It can be used directly as a boiler fuel or upgraded to gasoline or home heating oil using conventional petroleum refining technology.

Successful completion of this activity will confinim a ruule for conversion of coal to a low-ash, low-sulfur, low-nitrogen industrial boiler fuel, and subsequent conversion of this industrial fuel to gasoline.

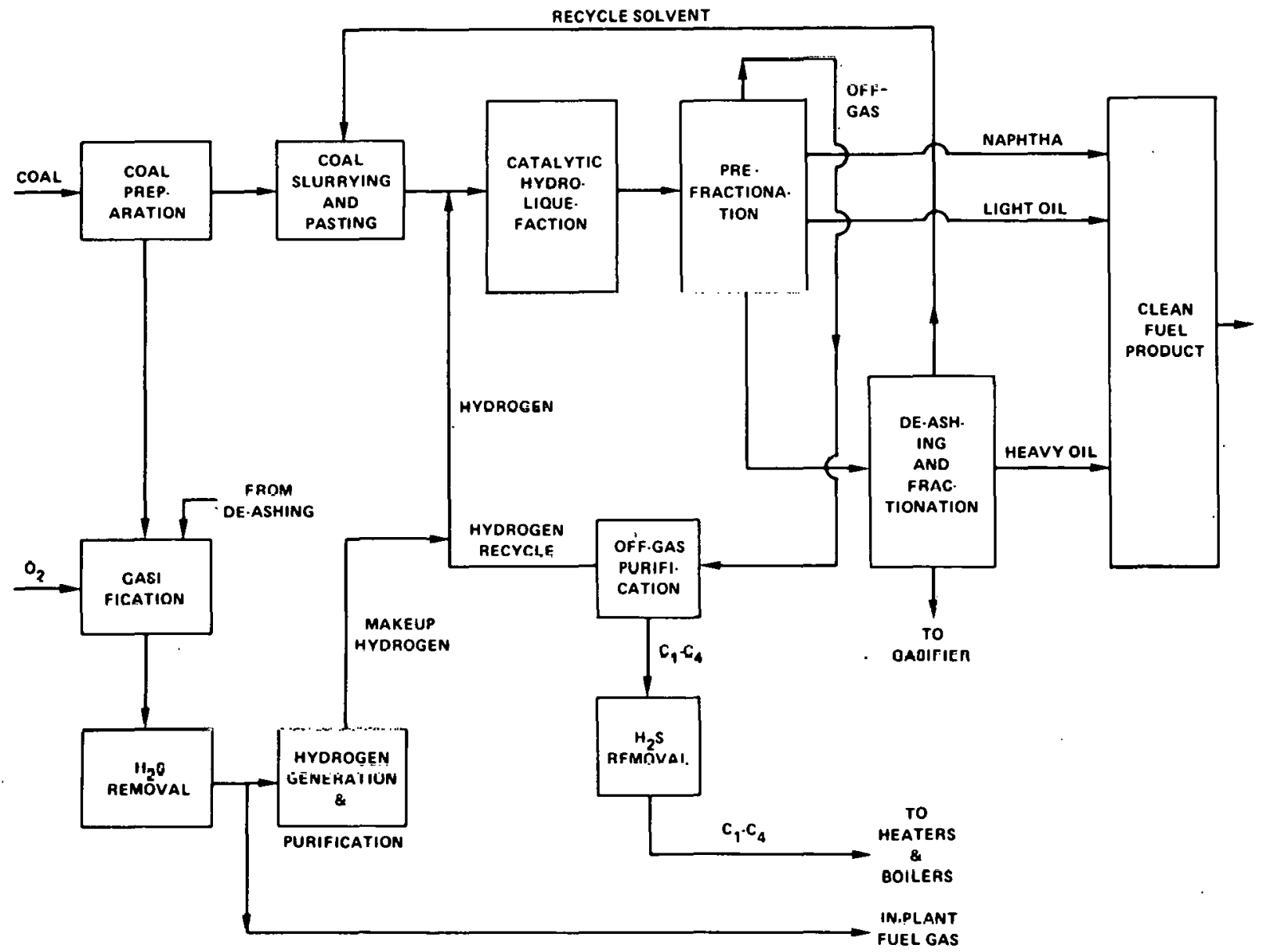

Multistage Liquefaction Process 


\section{Project Status}

The Lummus Clean Fuel from Coal process has been under private development since 1972. Several different coals have been successfully converted to low-sulfur coal liquids and a novel de-ashing technique has been demonstrated. Contract activities with DOE (then ERDA) were initiated on September 28, 1976. The work is being conducted at the Lummus Engineering Development Center in New Brunswick, New Jersey.

Work completed to date includes:

- Modifications of the PDU required to permit continuous integrated operation

- Preliminary operation of the unit to complete equipment checkout and establish initial operating conditions

- Bench-scale catalyst screening and catalyst selection for continuous unit operation.

The unit is now being operated to demonstrate process solvent selfsufficiency.

During the remainder of FY 1978 the PDU will be operated to:

- Complete demonstration of process solvent selfsufficiency

- Establish catalyst life characteristics

- Establish limiting reactor through-put

- Obtain feedstock for product hydrotreating/hydrocracking studies.

Work in FY 1979 will include hydrotreating/hydrocracking studies to upgrade liquefaction products to gasoline and home heating oil.

Data obtained will lead to a decision regarding scaleup of the process to pilot-scale and provide the data base required for pilot plant design. Consideration will be given to potential retrofitting of existing pilot plant facilities for this scaleup. 


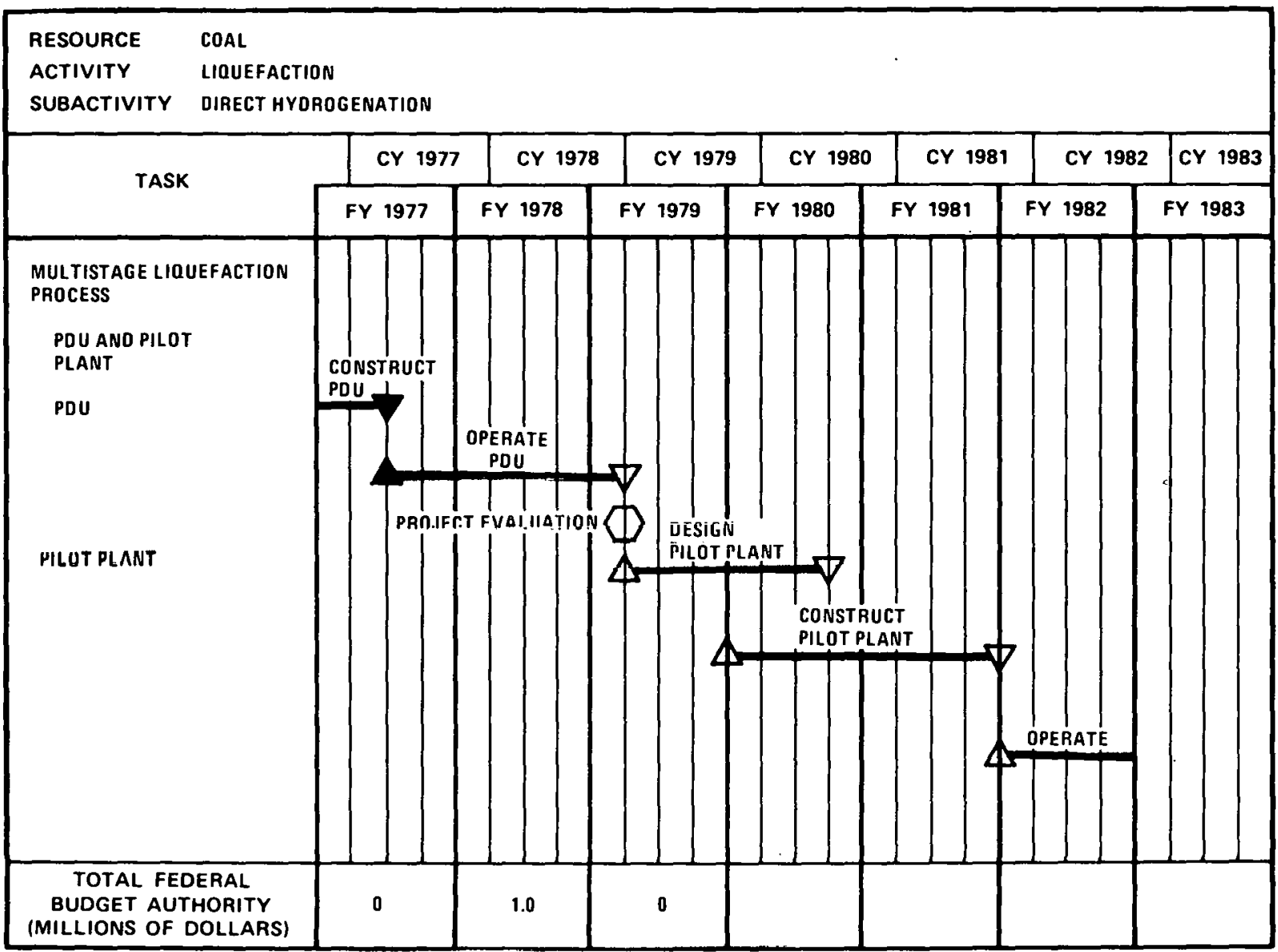

MILESTONE SYMBOLS ARE DEFINED ON LAST PAGE OF THIS DOCUMENT

\subsection{SOLVENT EXTRACTION PROJFCTS} 1979:

Solvent extraction projects include the following processes in FY

- Solvent Refined Coal (pilot plant operation)

- Solvent Refined Coal Utilization

- CO-Steam

- Donor Solvent Liquefaction.

These processes involve the use of a solvent to obtain a liquefied product from coal. The solvent acts as the agent which transfers hydrogen to the coal to promote liquefartion . 
The table below summarizes the funding levels by task for the FY 1977 to FY 1979 period.

\begin{tabular}{|c|c|c|c|c|c|}
\hline SOLVENT EXTRACTION & \multicolumn{4}{|c|}{$\begin{array}{l}\text { BUDGET AUTHORITY } \\
\text { (OPERATING EXPENSES) } \\
\text { (DOLLARS IN THOUSANDS) }\end{array}$} & \multirow{2}{*}{$\begin{array}{l}\text { MAJOR } \\
\text { CHANGE* }\end{array}$} \\
\hline TASKS & $\begin{array}{l}\text { ACTUAL } \\
\text { FY } 1977\end{array}$ & $\begin{array}{l}\text { APPROPRIATION } \\
\text { FY } 1978\end{array}$ & $\begin{array}{c}\text { ESTIMATE } \\
\text { FY } 1979\end{array}$ & $\begin{array}{l}\text { INCREASE } \\
\text { (DECREASE) }\end{array}$ & \\
\hline $\begin{array}{l}\text { Solvent Refined Coal Pilot Plant } \\
\text { Solvent Extraction of Lignite } \\
\text { CO-Steam Process } \\
\text { Chemicals from Coal } \\
\text { Donor Solvent Pilot Plant }\end{array}$ & $\begin{array}{r}\$ 20,755 \\
1.000 \\
500 \\
450 \\
2,000\end{array}$ & $\begin{array}{r}\$ 16,000 \\
0 \\
500 \\
400 \\
30,300\end{array}$ & $\begin{array}{r}\$ 14,500 \\
0 \\
640 \\
0 \\
34,600\end{array}$ & $\begin{array}{r}\$-1,500 \\
0 \\
+140 \\
+400 \\
+4,300\end{array}$ & \\
\hline TOTAL & $\$ 24,705$ & $\$ 47,200$ & $\$ 49,740$ & $\$+2,540$ & \\
\hline \multicolumn{3}{|c|}{$\begin{array}{l}\text { "KEY } \\
N=\text { New start (totally new project) } \\
S=\text { Scaleup (from bench to PDU or pilot plant) } \\
A=\text { Acceleration (shortening deadlines or } \\
\text { expansion of ongoing projects) }\end{array}$} & \multicolumn{3}{|c|}{$\begin{array}{l}P=\text { Phase completion or startup } \\
R=\text { Program redirection } \\
I=\text { Incremental cost requirement } \\
C=\text { Project completion or suspension }\end{array}$} \\
\hline
\end{tabular}

\subsection{SOLVENT REFined COAL (SRC) PILOT PLANT}

The SRC process converts high-sulfur, high-ash coals to a nearly ash-free low-sulfur fuel. The diagram below shows a schematic of the process. The coal is first pulverized and mixed with a coal-derived solvent in a slurry mix tank. The slurry is mixed with hydrogen, which is produced by other steps in the process, and is then pumped through a fired preheater and passed into a dissolver where about 90 percent of the moisture- and ash-free coal is dissolved. Several other reactions also occur in the dissolver: the coal is depolymerized and hydrogenated, which results in an overall decrease in product molecular weight; the solvent is hydrocracked to form lower-molecular-weight hydrocarbons that range from light oil to methane; and much of the organic sulfur is removed by hydrogenation in the form of hydrogen sulfide

From the dissolver, the mixture passes to a separator where the gases are separated from the slurry of undissolved solids and coal solution. Raw gas is sent to a hydrogen recovery and gas desulfurization unit. Hydrogen recovered is recycled with the slurry coming from the slurry mix tank. Hydrocarbon gases are given off and hydrogen sulfide is converted to elemental sulfur.

The slurry of undissolved solids and the coal solution pass to a filtration unit where undissolved solids are separated from the coal solution. In the commercial-scale process, the solids are sent to a gasifier-converter 
where they react with supplemental coal, steam, and oxygen to produce hydrogen for use in the process. The coal solution passes to the solvent recovery unit and the final liquid product, solvent refined coal, is produced. The solvent-refined coal has a solidification point of $350^{\circ}$ to $400^{\circ}$ and a heating value of about $16,000 \mathrm{Btu} / \mathrm{lb}$.

Bench-scale work is 'continuing to determine the effect of operating conditions on the solution of various coals from lignite to bituminous in rank. Typical properties of solid product from solvent refined coal are 0.1 percent ash and 0.8 percent sulfur obtained from a western Kentucky bituminous coal feed having 7.1 percent ash and 3.4 percent sulfur.

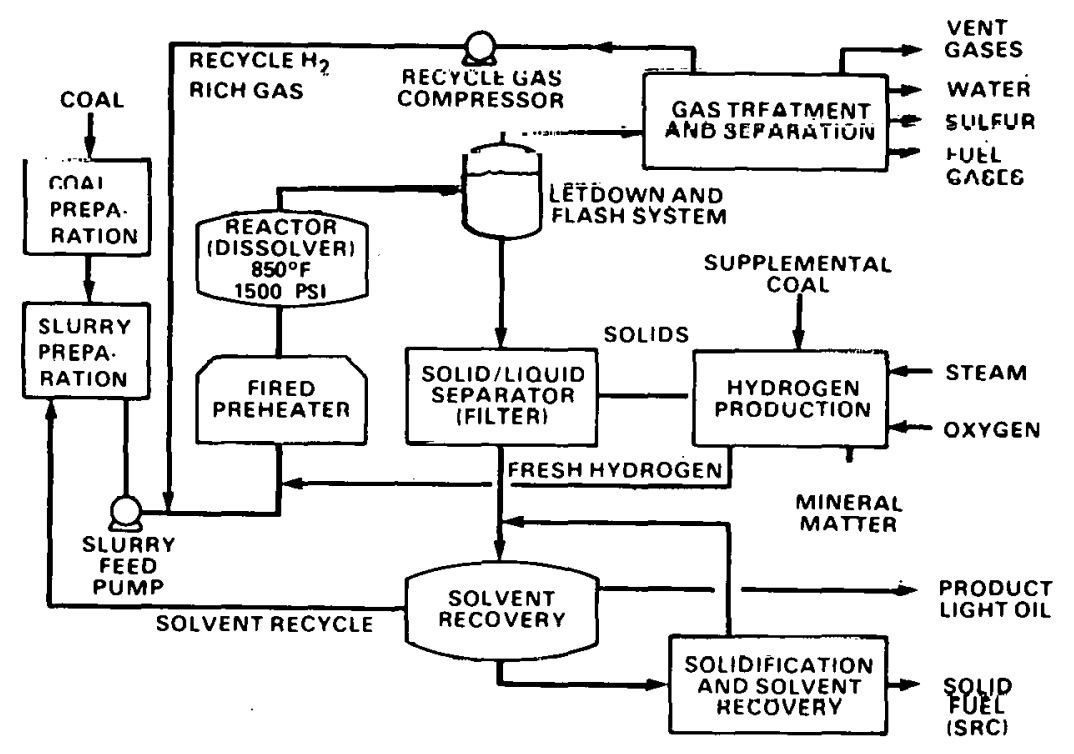

\section{Solvent Refined Coal Process and Utilization}

A modification of the SRC process produces an all-distillate liquid instead of a solid residual fuel as the principal product. In this modification, part of the product slurry is recycled as solvent for the pulverized coal feed instead of $450^{\circ} \mathrm{F}$-plus boiling-range distillate. As a result of increased severity of reaction conditions, hydrogen reaction is greater and a major part of the coal converted to a liquid-distillate product. The quantity of unconverted coal and vacuum residue is controlled so it is in balance with the requirements for gasifier feed to produce the process hydrogen requirements. This eliminates the solid/liquid separation step (filtration) required for production of fuel in solid form: 


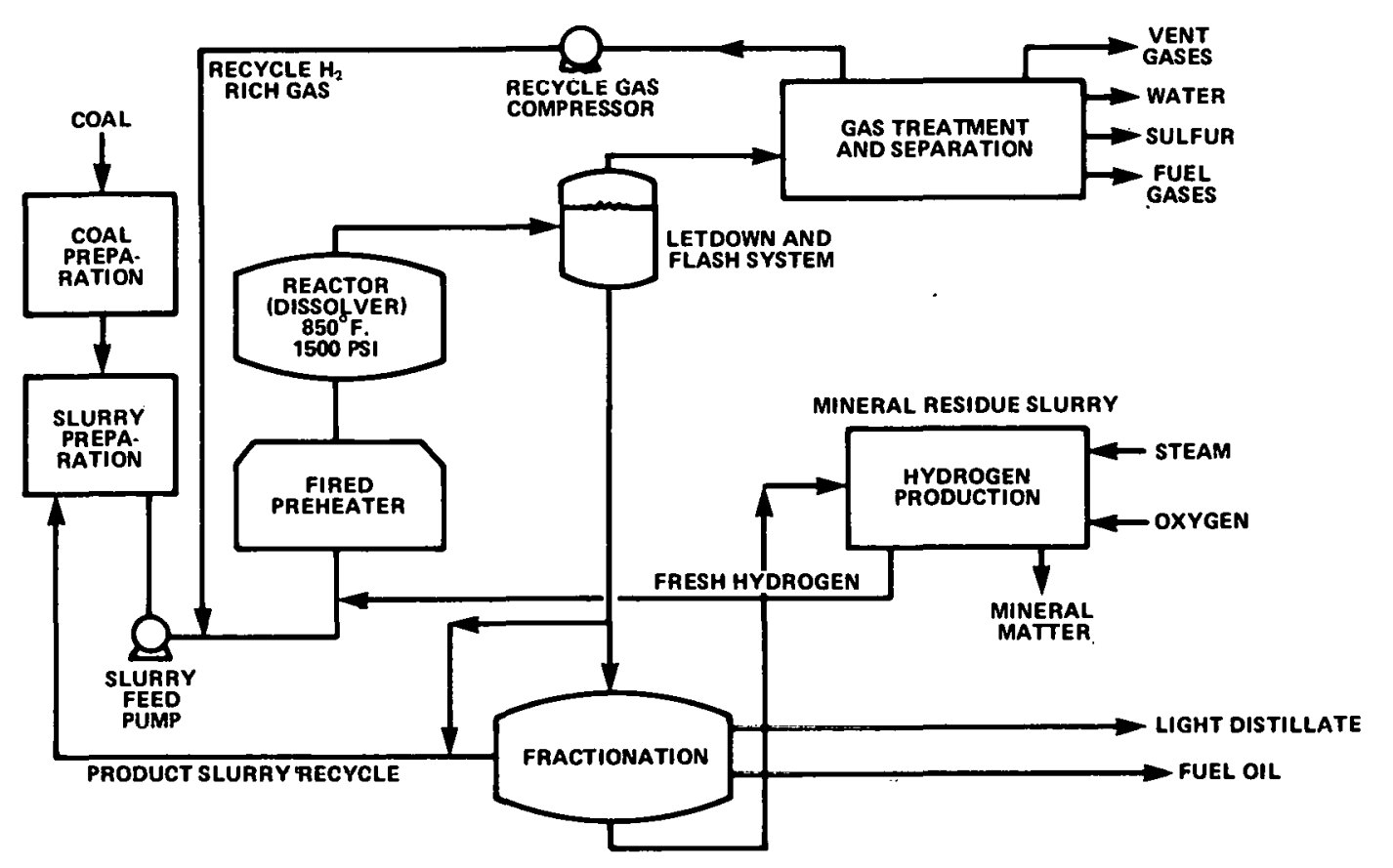

Modified SRC Process for Distillate Product

\section{Project Status}

The SRC project was begun in 1962, when Spencer Chemical Company was awarded a research contract by the former Office of Coal Research (now part of DOE) to study the technical feasibility of a coal-de-ashing process. In 1965, the process was successfully demonstrated in a $50-1 \mathrm{~b} / \mathrm{hr}$ continuous-flow unit, and work on the original contract scope was completed. During the term of the contract, Gulf Oil Corporation acquired Spencer Chemical Company. After reorganization, the contract was assigned and extended with the research department of Pittsburg and Midway ( $P \& M$ ) Coal Mining Company. Current efforts are under way at the Ft. Lewis pilot plant and the Wilsonville PDU. A combustion test of SRC product was performed by Southern Company Services in a 22.5-MW utility boiler, demonstrating capability to meet current emission standards for sulfur and nitrogen oxides.

\section{Fort Lewis Pilot Plant}

The objective of the 50-tons/day pilot plant located at Ft. Lewis, Washington, is to generate data which will provide a basis for the engineering design and economic feasibility study of commercial plants. Construction was completed by Rust Engineering in FY 1975. Operation of the pilot plant is under direction of P\&M Coal Mining Company. Feed rates exceeding design have been satisfactorily attained. Operations to produce 3,000 tons of solid product for full-scale combustion tests were completed during FY 1977. Pilot plant modifications, which permit the recycling of unconverted coal, were completed at the end of the second quarter of $F Y$ 1977. This modification was designed to producc a distillate solvent-refined 
coal product during operations in the latter half of FY 1977 and FY 1978. During FY 1978, an improved filter design and solvent de-ashing is being studied in the basic solid-fuel SRC mode of operation.

Pilot plant investigation includes an on-site and surrounding-area environmental monitoring program, to document the quality of the working and neighboring environment as affected by operation of the SRC process. In addition, toxicity of process liquids and solids is being studied.

\section{Wilsonville Process Development Unit}

Operation of the 6-tons/day SRC PDU at Wilsonville, Alabama, which was originally industry-financed through EPRI, has been supported jointly by EPRI and ERDA (now DOE) in 1976 and 1977, to supplement efforts at the 50-tons/day Fort Lewis pilot plant. This has provided a flexible test unit for screening additional coals for selection of various process improvement options for additional testing at Fort Lewis. A planned extension of this cooperative effort through FY 1978 and 1979 will explore further improvements in production of solid SRC fuel, including solidliquid separation methods.

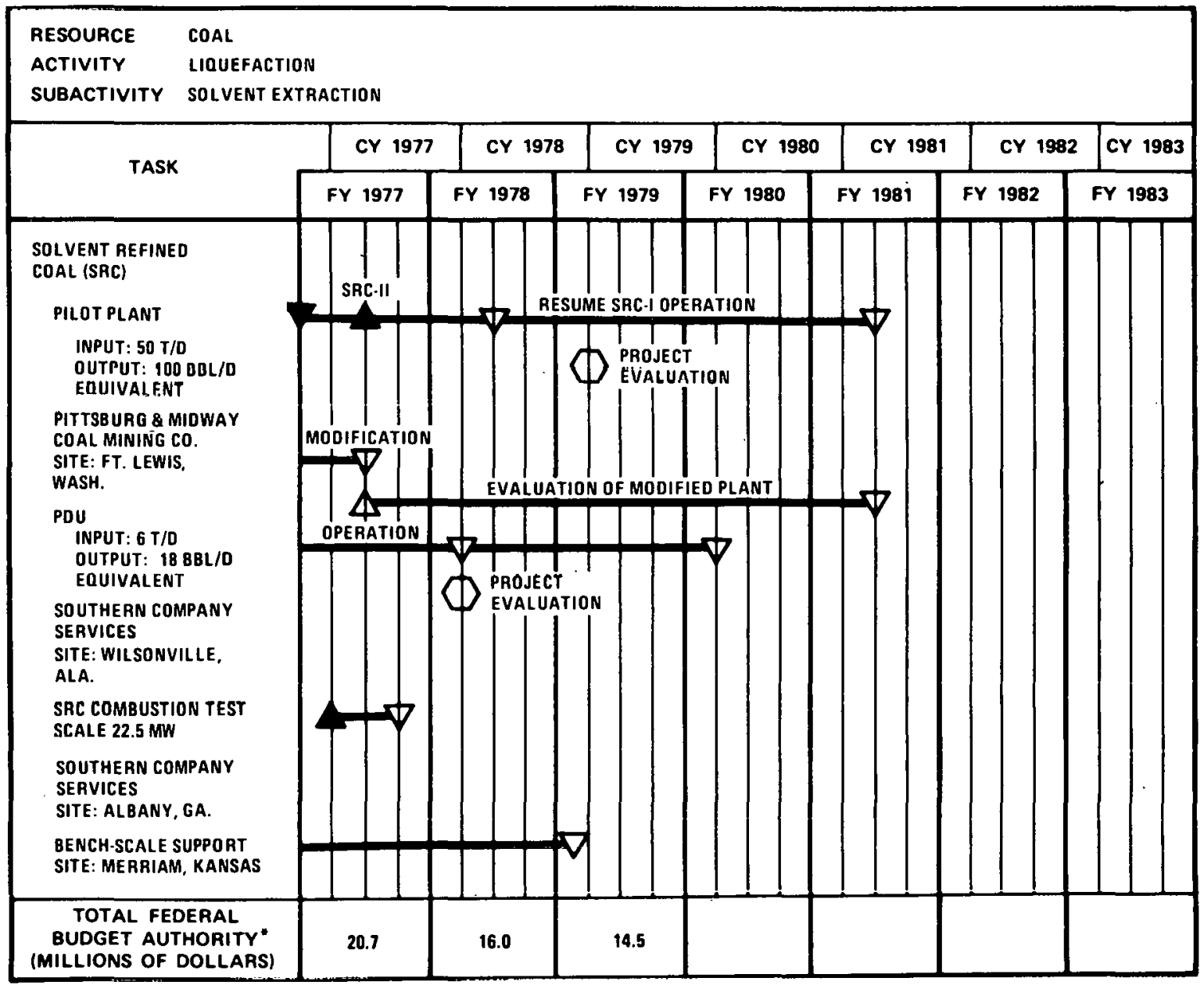

MILESTONE SYMBOLS ARE DEFINED ON LAST PAGE OF THIS DOCUMENT

-INCLUdES SRC UTILIZaTION. FURTHER BUdGet detaILS FOR SRC

PILOT PLANT ARE PAOVIOED IN SECTION 6.0. 


\subsection{SOLVENT REFINED COAL UTILIZATION}

The Solvent-Refined Coal Utilization project consists of three parts: solid SRC combustion, liquid SRC combustion, and use of molten SRC as a gas turbine fuel. In FY 1977, successful tests with pulverized SRC were made in a 22.5-MW boiler in the Georgia Power System, under a contract with Southern Company Services. Sufficient liquid SRC has been produced at the Fort Lewis pilot plant during FY 1977 and FY 1978, to conduct combustion tests during FY 1978 in a facility large enough (up to 100 million $\mathrm{Btu} / \mathrm{hr}$ ) to determine both the combustion characteristics of liquid SRC and the environmental effects of combustion.

To demonstrate the suitability of molten SRC as a gas turbine fuel, the work includes process development in a laboratory unit designed to wash alkali metals from the fuel, design and fabrication of a pilot SRC processing skid, and burning of the processed fuel in a turbine-type combuster.

\subsection{CO-STEAM PROCESS}

The CO-Steam process, developed at the Pittsburgh Energy Research Center, is designed to convert low-rank subbituminous coals, such as lignite, into a low-sulfur fuel oil by the noncatalytic reaction of a coal-oil slurry with carbon monoxide or synthesis gas. Grand Forks Energy Research Center (GFERC) is investigating this process to produce clean liquid fuel from an inexpensive raw material.

In the process, pulverized coal is introduced into a feed tank where it is slurried with a process-derived recycle oil. The slurry feed, along with $\mathrm{CO}$ or synthesis gas, is then fed into the stirred reactor at 4,000 psi and $800^{\circ} \mathrm{F}$. Since low-rank coals generally have significant moisture content, water for the reaction is provided by the coal. Hydrogen for the liquefaction of coal is provided through the water gas shift reaction: $\mathrm{CO}+$ $\mathrm{H}_{2} \mathrm{O} \rightarrow \mathrm{H}_{2}+\mathrm{H}_{2} \mathrm{O}$.

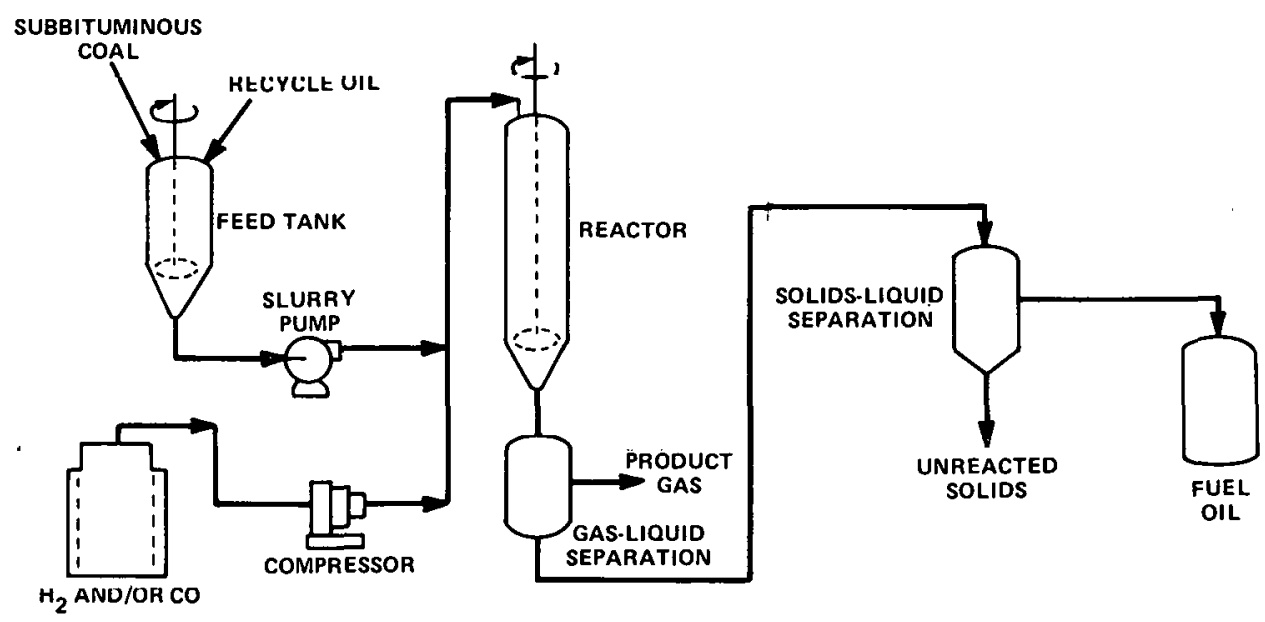

CO-Steam Process 


\section{Project Status}

Most processes for the conversion of coal to oil use hydrogen under conditions of high temperature and pressure in the presence of a catalyst. The advantage of the CO-Steam process is that it does not require a catalyst to convert low-rank coals, such as lignite, into a low-sulfur fuel oil. In addition to savings of catalyst costs, low-purity carbon monoxide or synthesis gas for this process may cost less than hydrogen.

GFERC has established advanced analytical techniques to study the reactions involved and constructed a small continuous unit for further process development. A continuing objective in FY 1979 is to demonstrate operability of the 3-to-5 lb/hr lignite continuous-process unit (CPU) with process-derived solvent. The role of mass transfer phenomena in the process is to be investigated and $\mathrm{H}_{2} / \mathrm{CO}$ ratios will be varied.

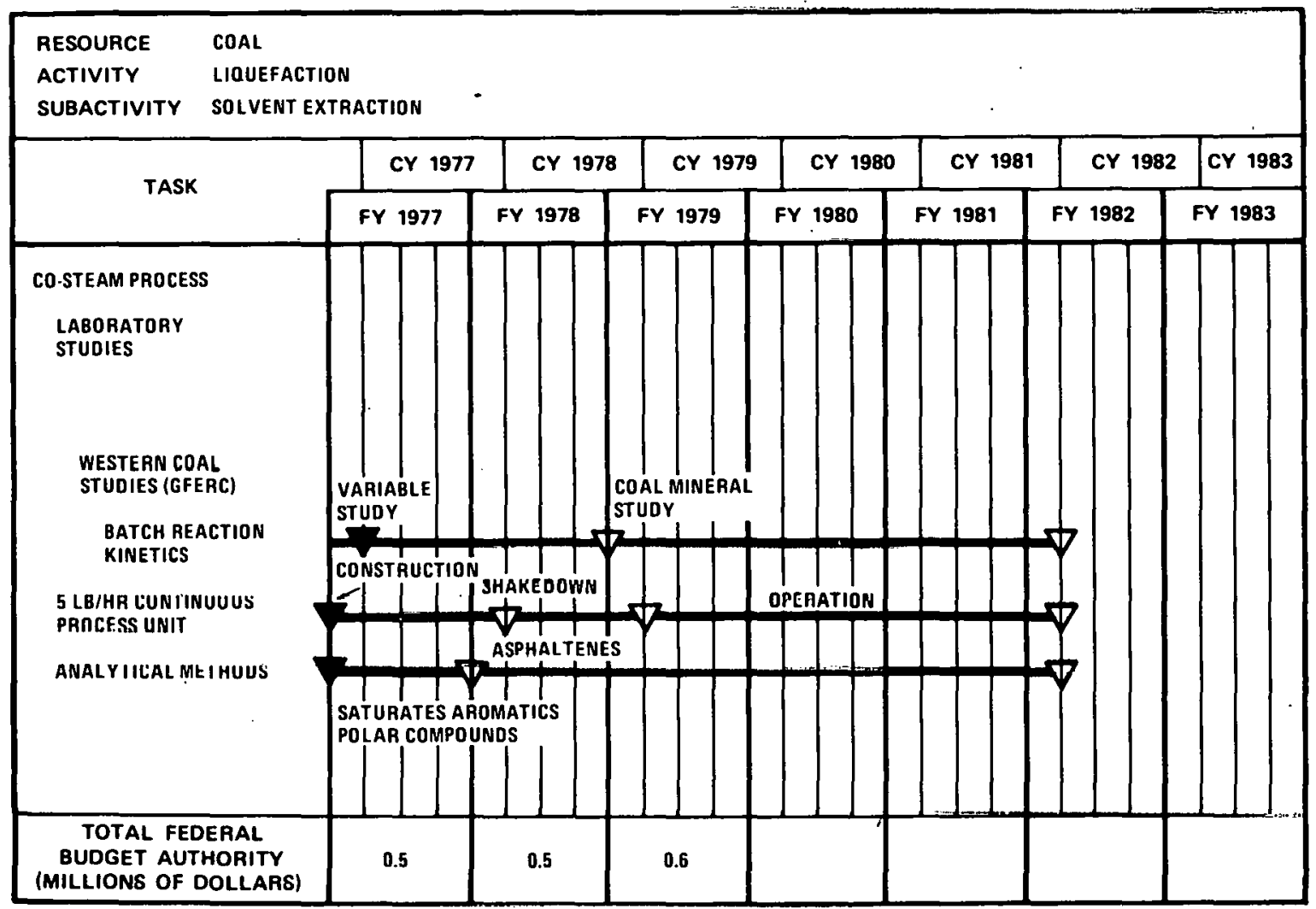

MILESTONE SYMBOLS ARE DEFINEO ON LAST PAGE OF THIS DOCUMENT

\subsection{DONOR SOLVENT PROCESS}

The Donor Solvent process is a noncatalytic process that liquefies coal by the use of a hydrogen donor solvent obtained from distillate coal products. The donor solvent transfers hydrogen to the coal, thus promoting liquefaction of the coal. The process is simple and utilizes engineering and design technology similar to that practiced in the petroleum industry. The process sequence allows for different coal feeds and varying product distribution based on market demand. 
Coal is ground and slurried with the recycle donor solvent. The slurry is heated by a fired heater, and heated molecular hydrogen is added. The reaction is carried out in a tubular reactor with no internals. The product from the liquefaction reactor is sent to the separation step where it is recovered as gas, naphtha, middle distillate, and bottoms that contain the unreacted coal and mineral matter. Using distillation for product separation avoids many problems associated with solid-liquid separation by mechanical means.

The heavy bottoms from distillation are sent to a FLEXICOKER to produce additional liquids and low-Btu gas for in-plant fuel use. Hydrogen for in-plant use is provided by steam reforming of $\mathrm{C}_{1}-\mathrm{C}_{2}$ gases produced in the process. The hydrogen is recycled to the liquefaction and solvent hydrogenation sections.

A portion of the middle distillate product is sent to the solvent hydrogenation step, using a catalytic fixed-bed reactor to produce donor solvent to be recycled to the slurry preparation step. Depending on the ultimate product utilization, the raw-coal liquid products may be further refined.

The plant is balanced in that it is self-sufficient in both process fuel and $\mathrm{H}_{2}$ requirements. The process gives high yields of low-sulfur liquids from bituminous or subbituminous coals or lignites. For Illinois bituminous coal, the liquid yield is 2.6 barrels of $\mathrm{C}_{4} / 1000^{\circ} \mathrm{F}$ liquids per ton of dry coal feed.

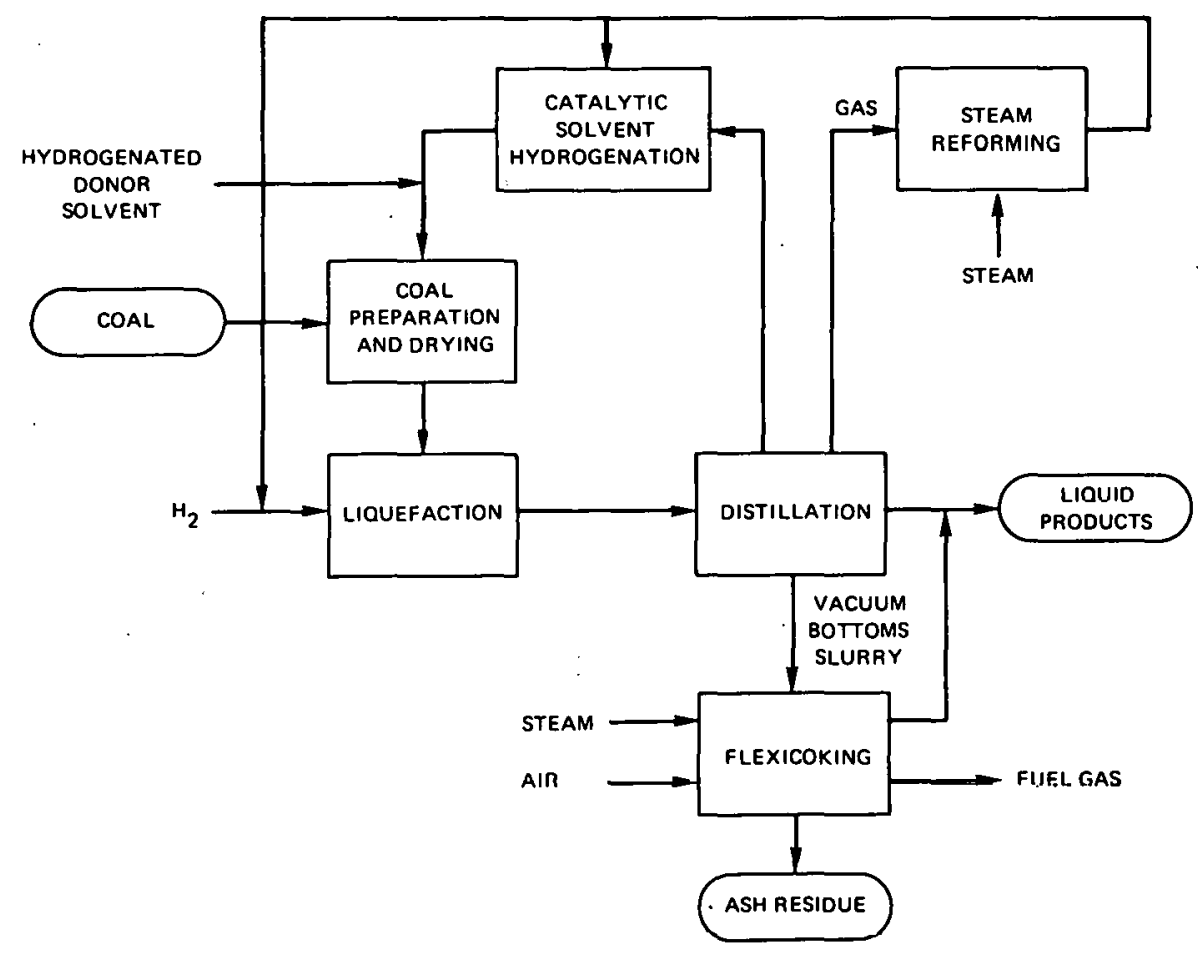

Donor Solvent Process 


\section{Project Status}

The project was started in 1966, solely with Exxon Research and Engineering Company (ER\&E) funding, to develop the process to the point of commercial readiness. It consists of five phases: Predevelopment; Planning and Design; Detailed Engineering; Construction; and Operation. Through 1975, ER\&E funds of $\$ 32$ million were expended on Phases I and II, resulting in the development and demonstration (on the laboratory scale of $1 / 2$ ton/day) of an advanced liquefaction process. With its foundation based on existing coal liquefaction technology, it promises several improvements over earlier processes.

In August 1975, ER\&E submitted an unsolicited proposal to ERDA (now DOE), to cost-share the $\$ 268$ million future-development cost on a $50 / 50$ basis. Because the project cost was substantial, ER\&E was seeking financial participation from ERDA as well as other industrial participants. The industrial cost-sharing participants were not firmed up at the time ER\&E submitted the proposal; therefore, the project could not proceed as planned. However, Phase III was divided into two phases:

- Phase IIIA: laboratory and engineering research and

- Phase IIIB : levelopment

Phase IIIA spanned the period between January 1976 and mid-1977, totaled $\$ 13$ million, and was cost-shared between ERDA and the private sector on a $50 / 50$ basis.

Phase IIIB $-V$ spans the period between mid-1977 and mid-1982, totals $\$ 227$ million plus contingency, and will likewise be proposed on a costshared basis between DOE and the private sector on a 50/50 basis.

During FY 1979, work emphasis will be as follows:

- Completion of detailed engineering and procurement for the pilot plant

- Construction of the pilot plant

- Preparation for pilot plant operation

- Operation on the third coal to be evaluated in the pilot plant

- Investipation of liquefaction/bottome prornsaing interactions

- Evaluation of process improvements

- Performance of liquefaction studies using model compounds

- Study of coal liquids compatability and storage behavior

- Development of mathematical model to describe coking of coalderived feed 
- Performance of coke gasification studies

- Investigation of fluid coking and coke gasification operability limits

- Performance of studies for noncoking bottoms processing options

- Investigation of fluid coking and FLEXICOKING operability in the $2-\mathrm{bbl} / \mathrm{d}$ integrated coker gasifier

- Planning of the pilot plant operation program

- Preparation of pilot plant startup procedures

- Preparation of plan for orderly takeover of pilot plant equipment from construction contractor

- Characterization of air and water emissions and evaluation of control techniques

- Preparation of industrial hygiene plan for pilot plant operating personnel

- Performance of studies on coal-derived liquids and emissions to support industrial hygiene plan

- Pressuration and operation of equipment in preparation for pilot plant startup

- Preparation of conceptual study design

- Evaluation of alternative methods of processing the coke scrubber liquids

- Evaluation of slurry dryer/mixer.

The major effort in FY 1979 will be completion of detailed engineering and procurement and the start of construction. The primary thrust in FY 1980 will bc completion of construction and the start of shakedown and operation, with the latter planned to end in FY 1982. 


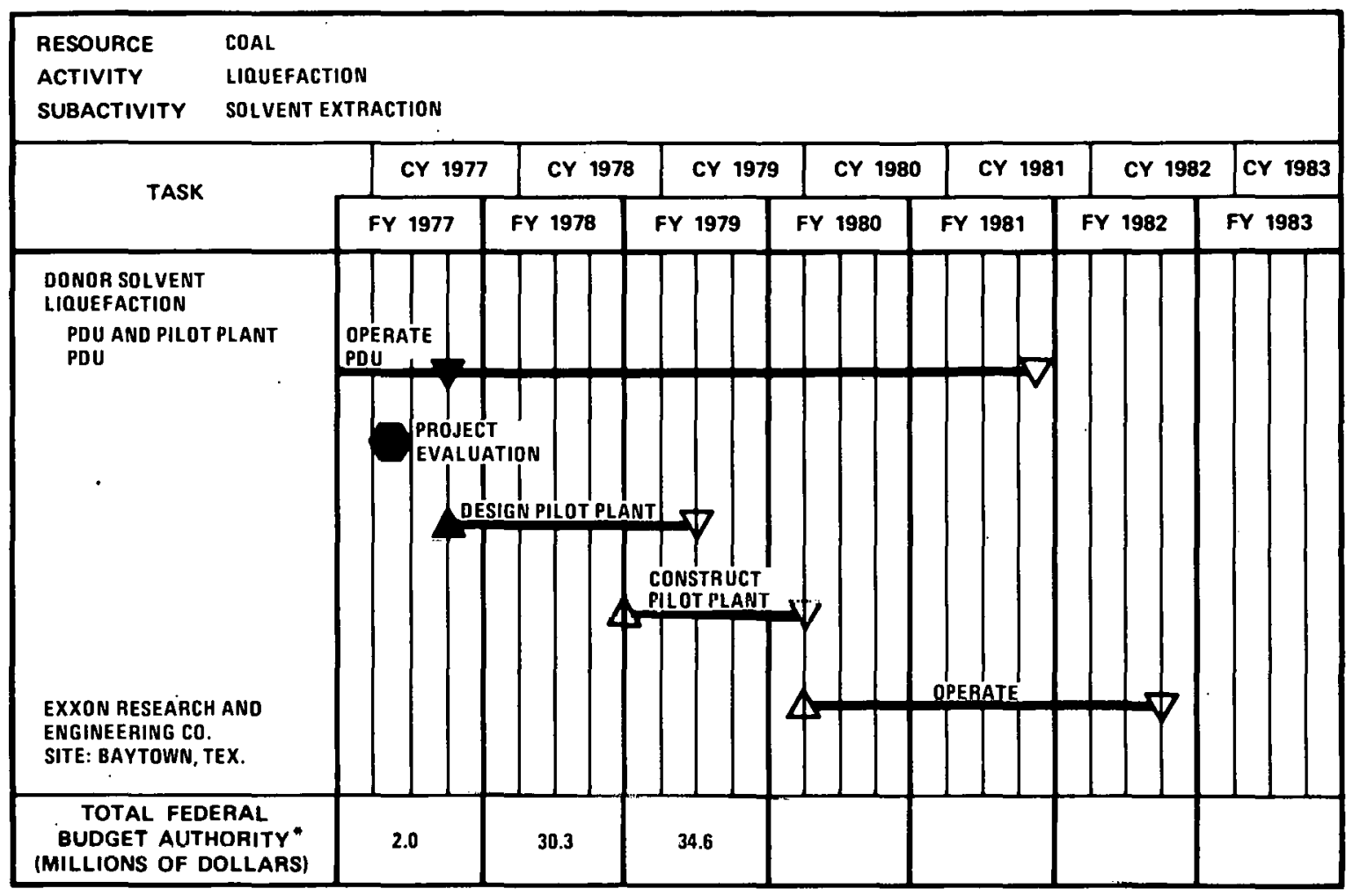

MILESTONE SYMBOLS ARE DEFINED ON LAST PAGE OF THIS DOCUMENT

"FURTHER BUDGET DETAILS ARE PROVIDED IN SECTION 6.0.

\subsection{PYROLYSIS PROJECTS}

Pyrolysis projects include the following processes in FY 1979:

- Entrained Pyrolysis

- Flash Liquefaction

- Fluid Coke

These processes involve some form of coal pyrolysis or carbonization which amounts to destructive distillation to yield liquid products, gaseous fuels, and char. They are aimed at maximizing liquid yield and utilizing the by-product char. 
The table below. summarizes the funding levels by task for the FY 1977 to FY 1979 period.

\begin{tabular}{|c|c|c|c|c|c|}
\hline \multirow{2}{*}{$\begin{array}{c}\text { PYROLYSIS } \\
\text { TASKS }\end{array}$} & \multicolumn{4}{|c|}{$\begin{array}{l}\text { BUDGET AUTHORITY } \\
\text { (OPERATING EXPENSES) } \\
\text { (DOLLARS IN THOUSANDS) }\end{array}$} & \multirow{2}{*}{$\begin{array}{l}\text { MAJOR } \\
\text { CHANGE * }\end{array}$} \\
\hline & $\begin{array}{l}\text { ACTUAL } \\
\text { FY } 1977\end{array}$ & $\begin{array}{l}\text { APPROPRIATION } \\
\text { FY } 1978\end{array}$ & $\begin{array}{l}\text { ESTIMATE } \\
\text { FY } 1979\end{array}$ & $\begin{array}{l}\text { INCREASE } \\
\text { (DECREASE) }\end{array}$ & \\
\hline $\begin{array}{l}\text { Clean Metallurgical Coke/Liquids } \\
\text { Entrained-Bed Pyrolysis } \\
\text { Flash Liquefaction } \\
\text { Hydrocarbonization } \\
\text { Fluid Coke }\end{array}$ & $\begin{array}{r}\$ 2,400 \\
900 \\
600 \\
900 \\
600\end{array}$ & $\begin{array}{r}\$ 0 \\
500 \\
500 \\
0 \\
1,000\end{array}$ & $\begin{array}{r}\$ \quad 0 \\
0 \\
2,000 \\
0 \\
0\end{array}$ & $\begin{array}{r}\$ \quad 0 \\
-500 \\
+1,500 \\
0 \\
-1,000\end{array}$ & \multirow[t]{2}{*}{$\begin{array}{l}\text { C } \\
\text { A }\end{array}$} \\
\hline TOTAL & $\$ 5,400$ & $\$ 2,000$ & $\$ 2,000$ & $\$ 0$ & \\
\hline \multicolumn{3}{|c|}{$\begin{array}{l}\text { "KEY } \\
N=\text { New start (totally new project) } \\
S=\text { Scaleup (from bench to PDU or pilot plant) } \\
A=\text { Acceleration (shortening deadlines or } \\
\text { expansion of ongoing projects) }\end{array}$} & \multicolumn{3}{|c|}{$\begin{array}{l}P=\text { Phase completion or startup } \\
R=\text { Program redirection } \\
l=\text { Incremental cost requirement } \\
C=\text { Project completion or suspension }\end{array}$} \\
\hline
\end{tabular}

\subsection{ENTRAINED PYROLYSIS PROCESS}

The Occidental Research Corporation (ORC) process is an entrainedbed, low-temperature carbonization system. Crushed, dried coal is conveyed by recycled product gas to the entrained-bed carbonizer (pyrolysis reactor). It is heated by recycle char from the char heater. Reactor temperature is maintained at about $1100^{\circ} \mathrm{F}$.

Effluent from the reactor passes through cyclones to separate char from gas. A portion of this is cooled to be product char. Remaining char is fed to the char heater, an entrained reactor where a portion is burned with air to reheat the remainder to a temperature of about $1400^{\circ} \mathrm{F}$. Heated char is recycled to the pyrolysis reactor.

The gaseous stream is cooled and scrubbed to remove tar. A portion of the gas stream is used for conveying coal and recycled char to the pyrolysis reactor. After acid gas removal, a portion of the gas is taken as product gas and may be further upgraded to pipeline quality. The remaining gas is used in the production of hydrogen which is then used to hydrntreat tar obtained from the coal pyrolysis to obtain synthetic crude oil or clean fuel oil.

The major problem in processing caking coal at elevated temperature is the tendency of coal particles to become sticky and agglomerate. The purpose of this project is to demonstrate the continuous processing of caking coals in a specially designed, single-stage pyrolysis reactor without oxidative pretreatment, and to demonstrate significantly higher liquid yields than other proposed pyrolysis processes. The higher liquid yields 
result from the absence of oxidative pretreatment and low residence time in the pyrolysis reactor. Because of the low residence time, the process is also referred to as Flash Pyrolysis.

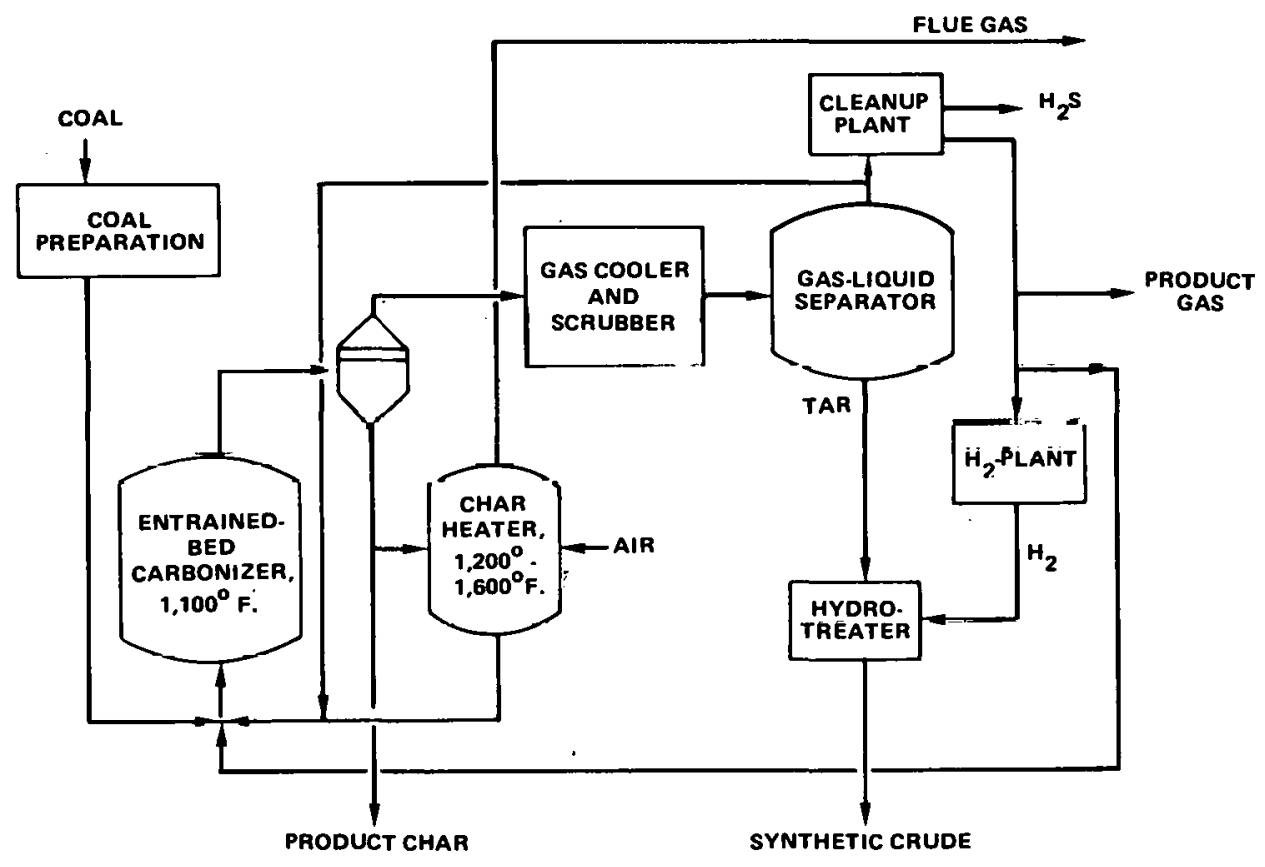

Entrained Pyrolysis Process.

\section{Project Status}

Occidental Research Corporation in LaVerne, California, hegan development of the Entrained Pyrolysis process in 1969 for operation with solid waste, subbituminous coal in a gasification mode, and all coals in a liquefaction mode. A 3-tons/day PDU was constructed and started up in 1971, with Environmental Protection Agency (EPA) support, for pyrolysis of solid waste, and a demonstration facility is nnw under construction in cooperation with EPA and the County. of San Diego, California. After experimental runs of coal pyrolysis in the PDU, the pyrolysis and tar collection facilities were extensively modified and improved by ORC for use in this contract for pyrolysis liquefaction.

The contract covers operation, maintenance, and modification of an experimental nature of the 3-tons/day PDU. Bench-scale tar hydrotreating to upgrade product tar to clean fuel oil or synthetic crude oil will be 
investigated. The process will be descriptively modeled where required to provide a basis for scaleup, and the commercial potential of the process will be evaluated.

Operation of the modified PDU will be accomplished with noncaking subbituminous coal, then with moderately caking bituminous coal, and finally with two different caking coals.

Shakedown of the PDU has been completed, and base line runs with subbituminous coal to demonstrate operability and material balance capability have started: Shakedown of the bench-scale tar hydrotreater and catalyst screening has been initiated.

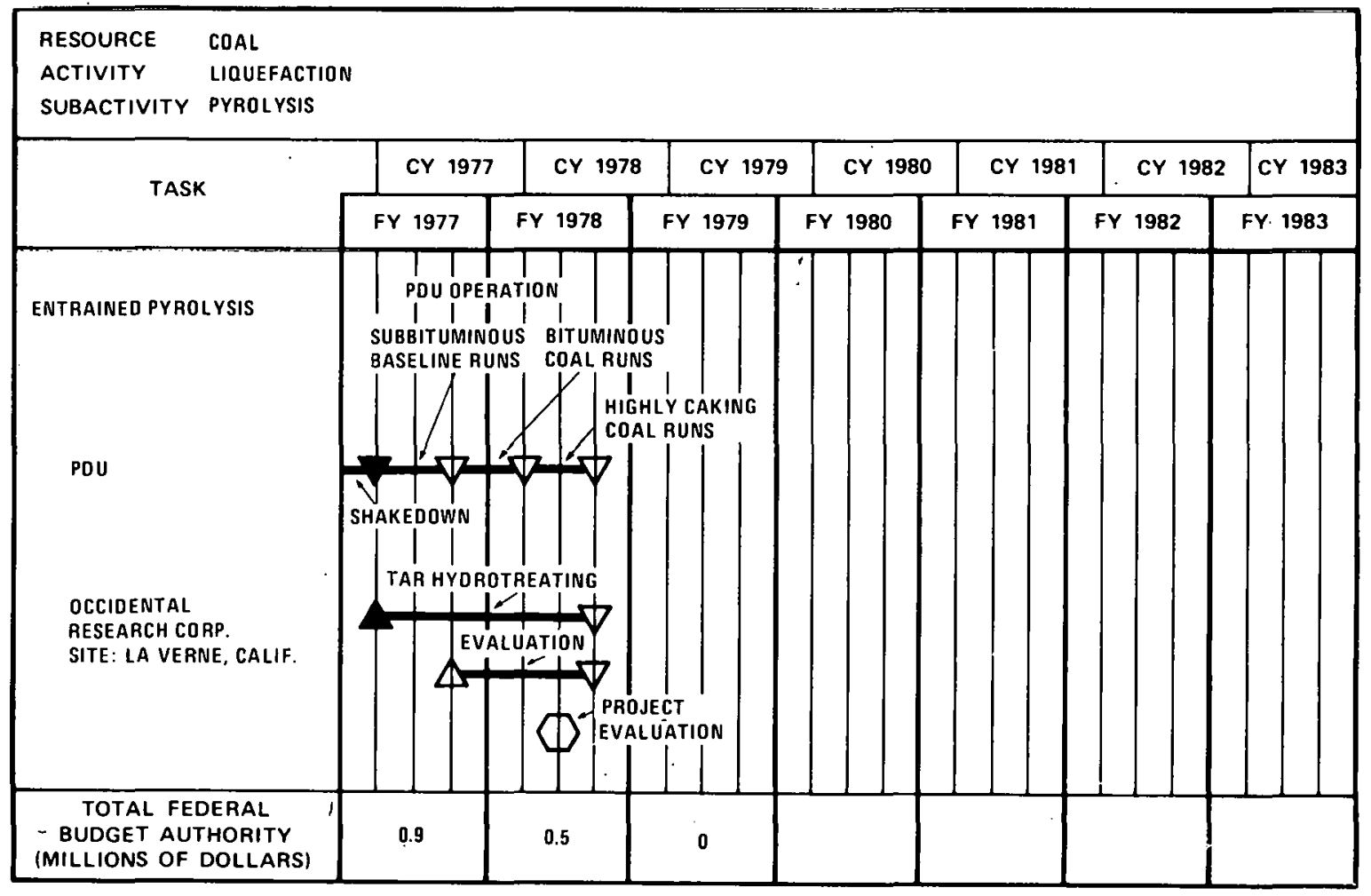

MILESTONE SYMBOLS ARE DEFINED ON LAST PAGE OF THIS DOCUMENT

8

\subsection{FLASH LIQUEFACTION PROCESS}

Flash Liquefaction (Partial Liquefaction by Direct Hydrogenation) is being developed to evaluate the concept of rapid mixing and the reaction of pulverized coal conveyed by hydrogen and injected into the reactor. Heated hydrogen $\left(1500^{\circ} \mathrm{F}\right)$ and oxygen, if required, are also injected into the reactor. Rapid mixing and reaction of coal and hydrogen take place in the reactor at about $1800^{\circ} \mathrm{F}$ and about $1,000 \mathrm{psi}$. The reaction time is of the order of 10-to-100 msec. The mixture is then quenched, char and tar are separated from the vapor phase, the vapor is condensed, and oil product and water phase are separated. 


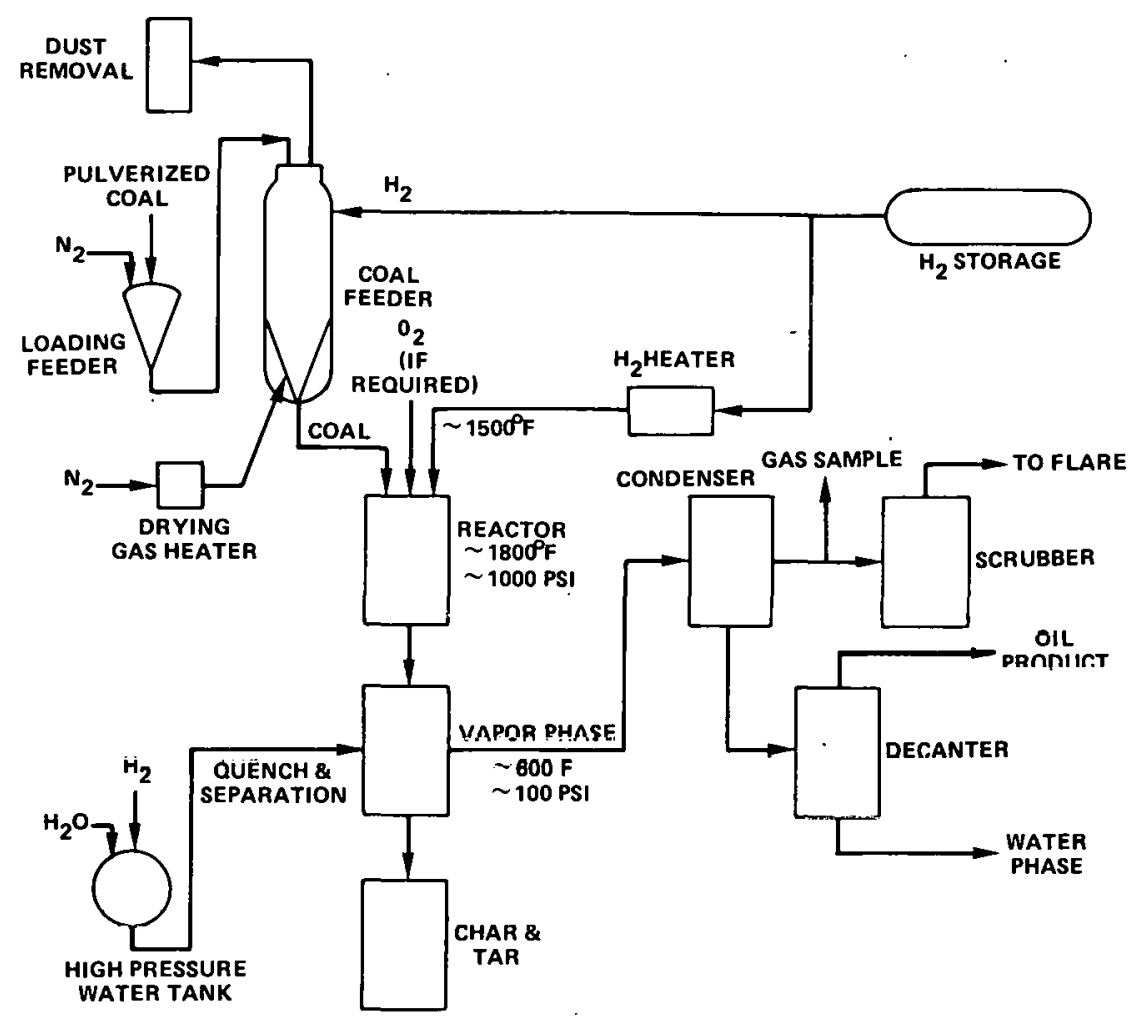

\section{Partial Liquefaction by Direct Hydrogenation (Flash Liquefaction) Process}

\section{Project Status}

During 1976, methods of transport and injection of the pulverized coal into the reactor were developed through use of cold-flow tests to determine flow behavior. Upon completion of the cold-flow testing, results were submitted to the DOE project management for a decision regarding continuation into Phase II. After receipt of authorization to proceed, testing was begun on a $0.25-$ ton $/ \mathrm{hr}$ reactor system. This reactor was used to evaluate the effects of reactor configuration and operating conditions. Based on these results, a larger scale reactor was designed and built and tested at a coal-flow rate of 1 -ton/hr for operating periods up to one hour. Results from all testing and analysis are being evaluated to determine process parameters. In addition to the contractually funded effort, research efforts to provide supporting information have been sponsored by 
Rocketdyne. During 1977, tests were conducted with the 1 -ton $/ \mathrm{hr}$ reactor system to further develop the process and provide the basis for decision on further work in FY 1978.

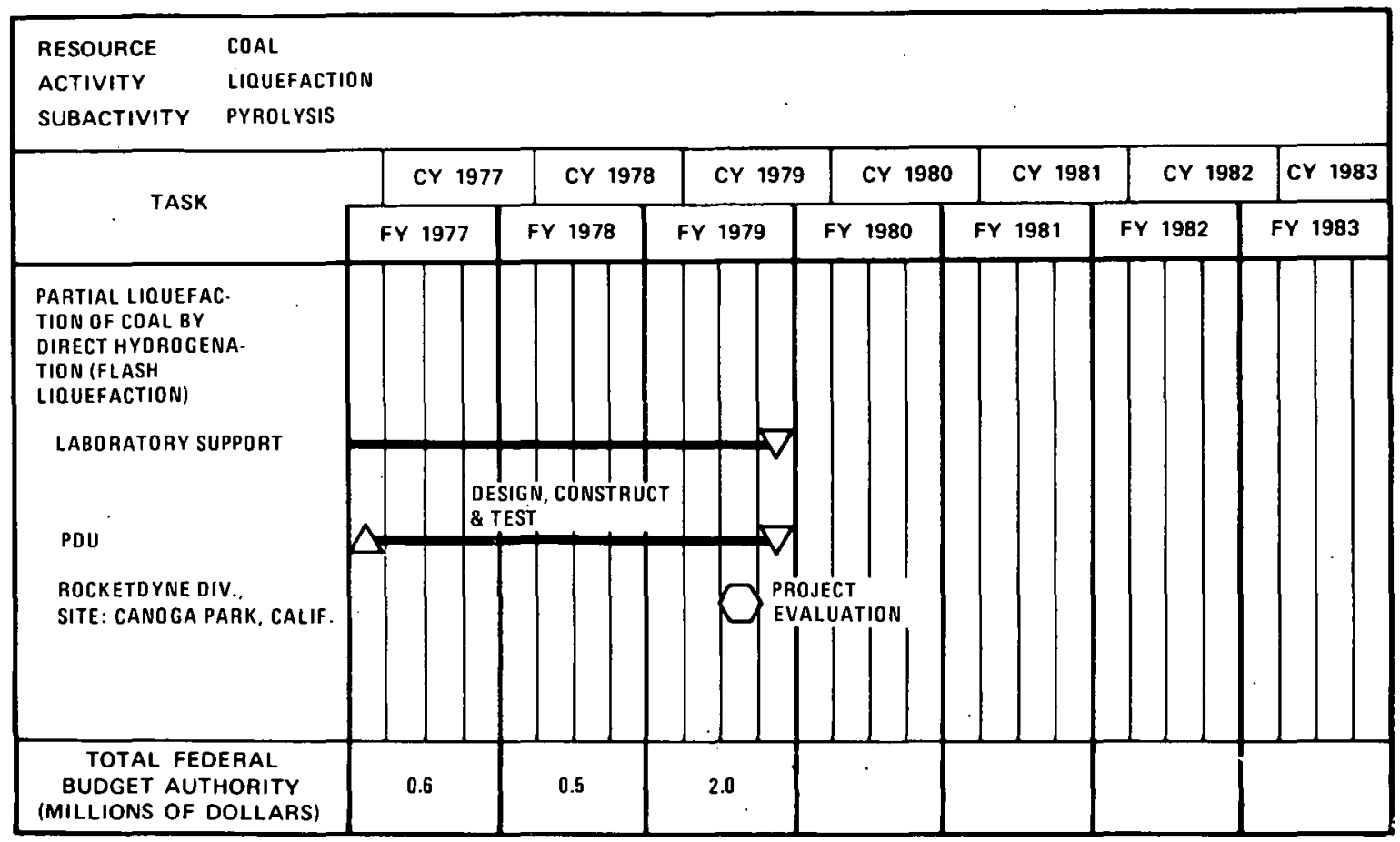

MILESTONE SYMBOLS ARE DEFINED ON LAST PAGE OF THIS DOCUMENT

\subsection{FLUID COKE PROCESS}

In the Fluid Coke process, residue feed is injected in to the reactor. There it is thermally cracked to a full range of vaporized products plus coke which is deposited on fluidized-coke particles. The cracked vapors are quenched in a scrubber section located on top of the reactor. Heavier fractions, material boiling above $950^{\circ} \mathrm{F}$ to $975^{\circ} \mathrm{F}$, are condensed in the scrubber and, if desired, can be recycled back to the coking reactor. The lighter fractions proceed overhead from the scrubber to a conventional fractionator. The heat required for endothermic reactions in the reactor is supplied by a circulating coke stream between the reactor and a heater vessel. In the heater, a portion of the coke is reacted with air at elevated temperature, to form a mixture of product gas, referred to as coke gas, which passes through two stages of cyclones and is discharged to the stack. Hot coke from the burner bed is returned to the reactor. Coke product is withdrawn from the system in order to keep the solids inventory from increasing. 


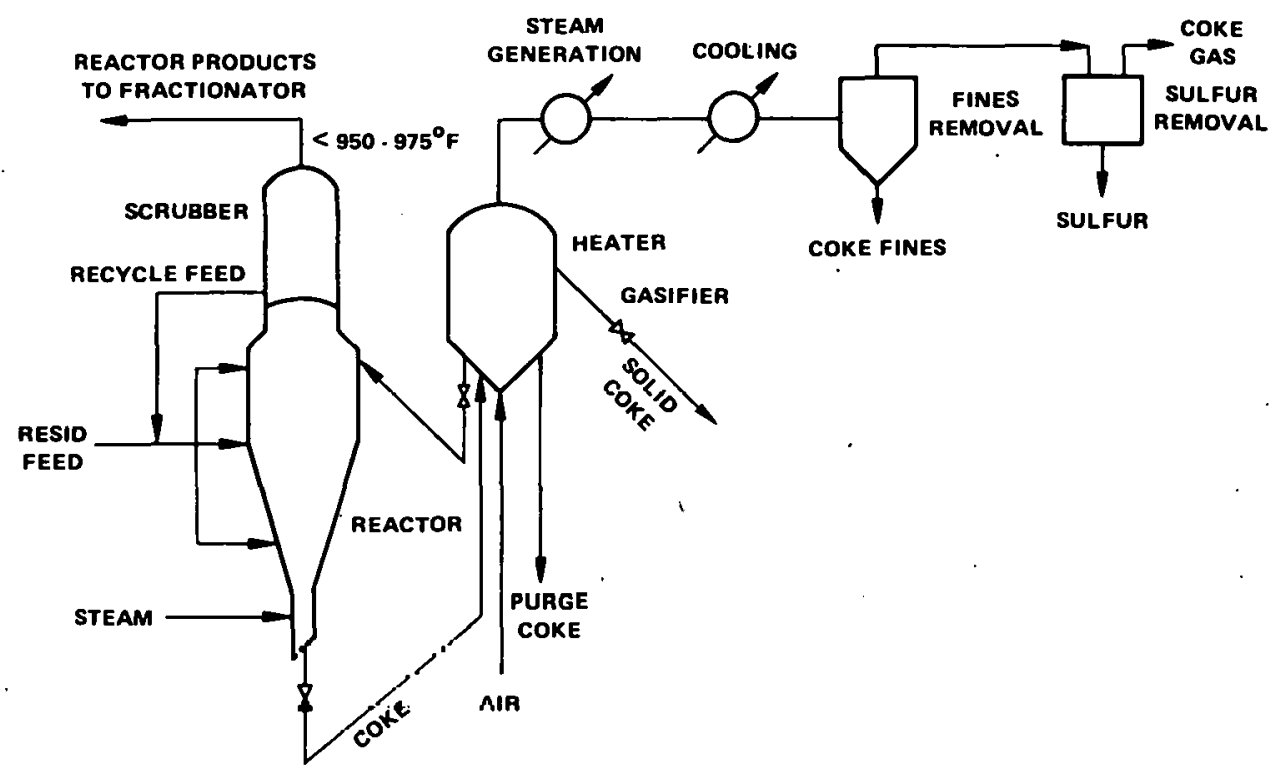

Fluid Coke Process

\section{Project Status}

This project, which started in late FY 1976, evaluates the applicability of current commercial fluid-coking technology to processing of residues from primary coal liquefaction processes. The work includes analytical and bench-scale testing of three candidate residues at the ER\&E Baytown, Texas, facilities. The most promising residue sample will be processed in a nominal 0.35 -ton/ day fluid-bed PDU. The units used in this project have successfully processed petroleum residues.

Solids are removed from primary coal liquids by methods such as hydrocyclones, vacuum distillation, and solvent de-ashing. The solidscontaining residues from these operations contain about 50 percent of oil, or 5-to-10 percent of the net oil produced by coal liquefaction. The retained oil must be recovered to result in favorable economics for any coal liquefaction process. Fluid coking is one of the most promising techniques to recover oil from these coal liquefaction residues.

The first sample studied was H-Coal precipitation underflow. Sample characteristics caused operational problems and render questionable the adequacy of the sample. The second sample was SRC precipitation underflow prepared by Conoco Coal Development Company. Only analytical tests and bench-screening study, was completed for this sample. The third sample studied was SRC precipitation underflow prepared by the C-E Lummus method. Inspection properties were determined and stirred coker yield studies were completed. The yield impact of operating the coker in a recycle mode is being evaluated.

The project was modified to include studies of a fourth sample, $\mathrm{H}$-Coal vacuum bottoms, to replace the unfinished work on the second sample. Evaluation will be completed in FY 1978. 
A choice between the SRC precipitation underflow from C-E Lummus and $\mathrm{H}$-Coal vacuum bottoms will be made and the selected sample will be processed in a 0.35 -ton/day PDU integrated two-vessel system. PDU operation has been rescheduled for FY 1979, because of earlier unavailability of sufficiently large quantity of feedstock.

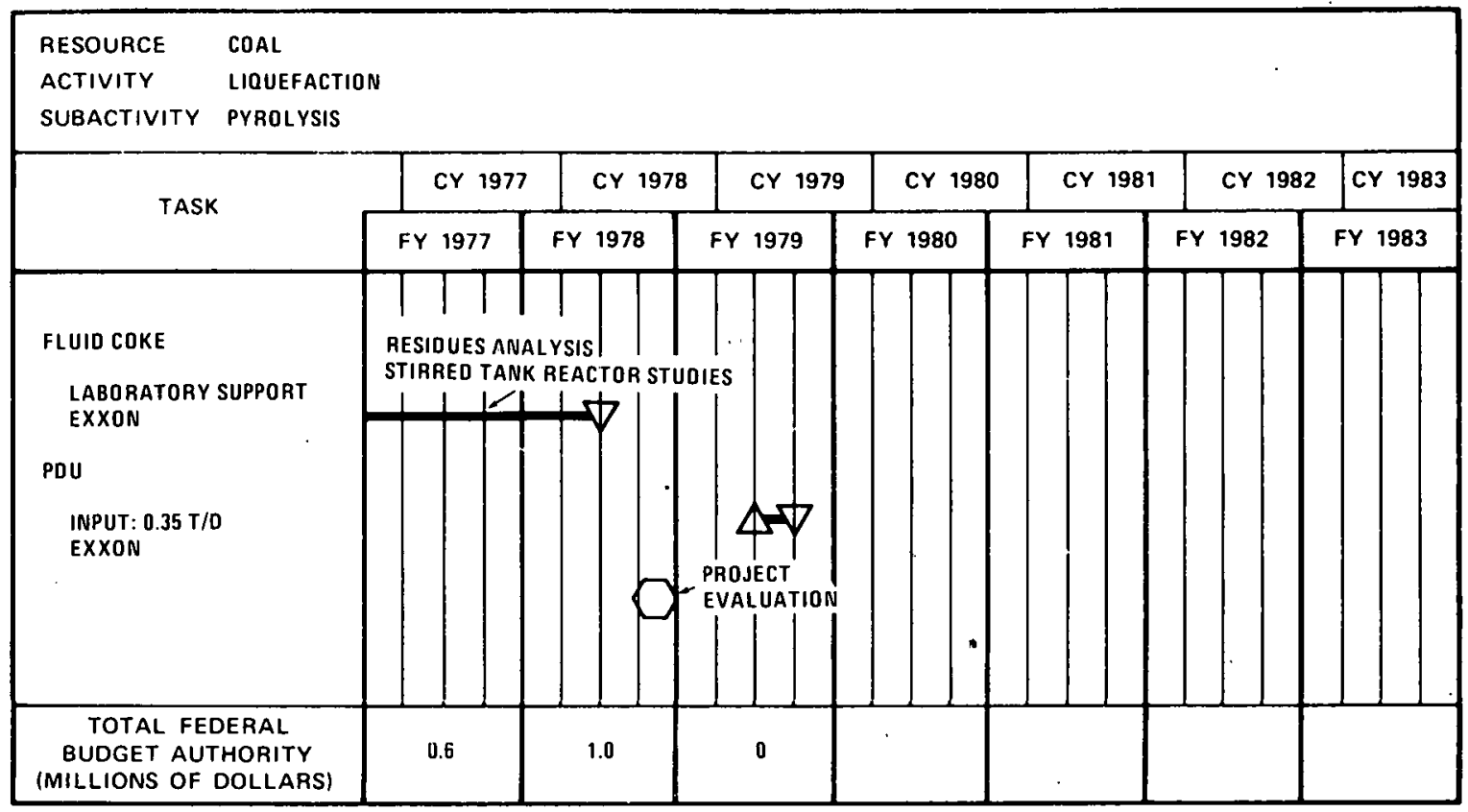

MILESTONE SYMBOLS ARE DEFINED ON LAST PAGE OF THIS DOCUMENT

\subsection{SUPPORT STUDIES AND ENGINEERING EVALUATIONS}

Liquefaction Support studies include engineering and other support. Support projects are necessary to facilitate development of the various liquefaction processes toward commercialization. Components of this project include; engineering evaluation; cost estimates; design services; a support project on hydrogen generation; characterization of liquid fuels from coal; upgrading and refining of synthetic fuels; and support program planning and reporting.

Experienced engineering firms are retained to conduct preliminary reviews of projects and to help appraise the technical status, commercial feasibility, and economic impact of the various processes. Cost estimates of alternative pilot plants are evaluated for information on the economic viability of alternative processes. Cost engineering and process economic studies will expedite selection of the processes most promising of meeting the nation's various liquid fuel needs. Research and enginecring efforts to ensure successful and timely development of these processes will be continued. include:

Studies currently under way in the Liquefaction Support studies area, 
- Cresap Test Facility (CTF)

- Coal Liquids Refining Facility

- Environmental Studies and Supporting Projects.

The table below summarizes the funding levels by task for the FY 1977 to FY 1979 period.

\begin{tabular}{|c|c|c|c|c|c|}
\hline \multirow{2}{*}{$\begin{array}{l}\text { LIQUEFACTION SUPPORT STUDIES } \\
\text { \& ENGINEERING EVALUATION } \\
\text {.. TASKS }\end{array}$} & \multicolumn{4}{|c|}{$\begin{array}{l}\text { BUDGET AUTHORITY } \\
\text { (OPERATING EXPENSES) } \\
\text { (DOLLARS IN THOUSANDS) }\end{array}$} & \multirow{2}{*}{$\begin{array}{l}\text { MAJOR } \\
\text { CHANGE }\end{array}$} \\
\hline & $\begin{array}{l}\text { ACTUAL } \\
\text { FY } 1977\end{array}$ & $\begin{array}{l}\text { APPROPRIATION } \\
\text { FY } 1978\end{array}$ & $\begin{array}{l}\text { ESTIMATE } \\
\text { FY } 1979\end{array}$ & $\begin{array}{l}\text { INCREASE } \\
\text { (DECREASE) }\end{array}$ & \\
\hline $\begin{array}{l}\text { Cresap Liquefaction Test Facility } \\
\text { Refining } \\
\text { tnvironmental Studiès, Ũnep } \\
\text { Support, and Special Projects }\end{array}$ & $\begin{array}{r}\$ 5,000 \\
1,300 \\
3,751\end{array}$ & $\begin{array}{r}\$ 12,500 \\
1,500 \\
2,500\end{array}$ & $\begin{array}{r}\$ 13,500 \\
0 \\
4,886\end{array}$ & $\begin{array}{r}\$+1,000 \\
-1,500 \\
+2,386\end{array}$ & \multirow[t]{2}{*}{$\begin{array}{l}F \\
\text { I }\end{array}$} \\
\hline TOTAL & $\$ 10,051$ & $\$ 16,500$ & $\$ 18,386$ & $\$+1,886$ & \\
\hline \multicolumn{3}{|c|}{$\begin{array}{l}\text { "KEY } \\
N=\text { New start (totally new project) } \\
S=\text { Scaleup (from bench to PDU or pilot plant) } \\
A=\text { Acceleration (shortening deadlines or } \\
\text { expansion of ongoing projects) }\end{array}$} & \multicolumn{3}{|c|}{$\begin{array}{l}P=\text { Phase completion or startup } \\
R=\text { Program redirection } \\
1=\text { Incremental cost requirement } \\
C=\text { Project completion or suspension }\end{array}$} \\
\hline
\end{tabular}

\subsection{CRESAP I.IQUEFACTION TEST FACILITY}

Fluor Engineers and Constructors, Inc., have refurbished the DOEowned facility at Cresap, West Virginia. The pilot plant, inactive since 1970 , is being reactivated to provide a site for development, test, and evaluation of the equipment critical to most coal liquefaction processes. The objectives of the forthcoming operations are to: (1) test equipment under actual liquefaction conditions; and. (2) demonstrate an integratcd process for the production of low-sulfur fuel oil.

For the results of equipment testing to be relevant, the equipment must be tested as part of an operating liquefaction pilot plant. The Consolidation Synthetic Fuel (CSF) process, for which the pilot plant was originally built, was refurbished and will be operated as a vehicle for the equipment testing.

In the CSF process as it will be operated at Cresap, coal is converted to low-sulfur liquid fuel. The coal is first crushed to 100 -mesh and then combined with a coal-derived solvent in a mixer. The mixture is pressurized and preheated. The slurry passes to an extractor where coal liquefaction occurs. The product is then treated in a liquid/solid 
separation unit where the ash and unreacted coal are removed. -Solids are removed as a concentrated slurry and sent to a carbonizer where the material is converted to char, oil, and gas. Oil is recycled to the liquid/solid separation unit, and the char and gas are recovered.

The solids-free oil leaving the liquid/solid separation unit is heated and fed into a flash still where the heavy components of the coal extract are separated from the light liquids. The light liquids are then fractionated into light and middle distillates. The middle distillate may either be recycled as a component of coal solvent or recovered as product fuel oil. The heavier components of the coal extract are heated in a fired preheater, hydrogenated, and fractionated into three distillate fractions. The middle distillate is used as donor solvent, and the heavy distillate is recovered as fuel oil product.

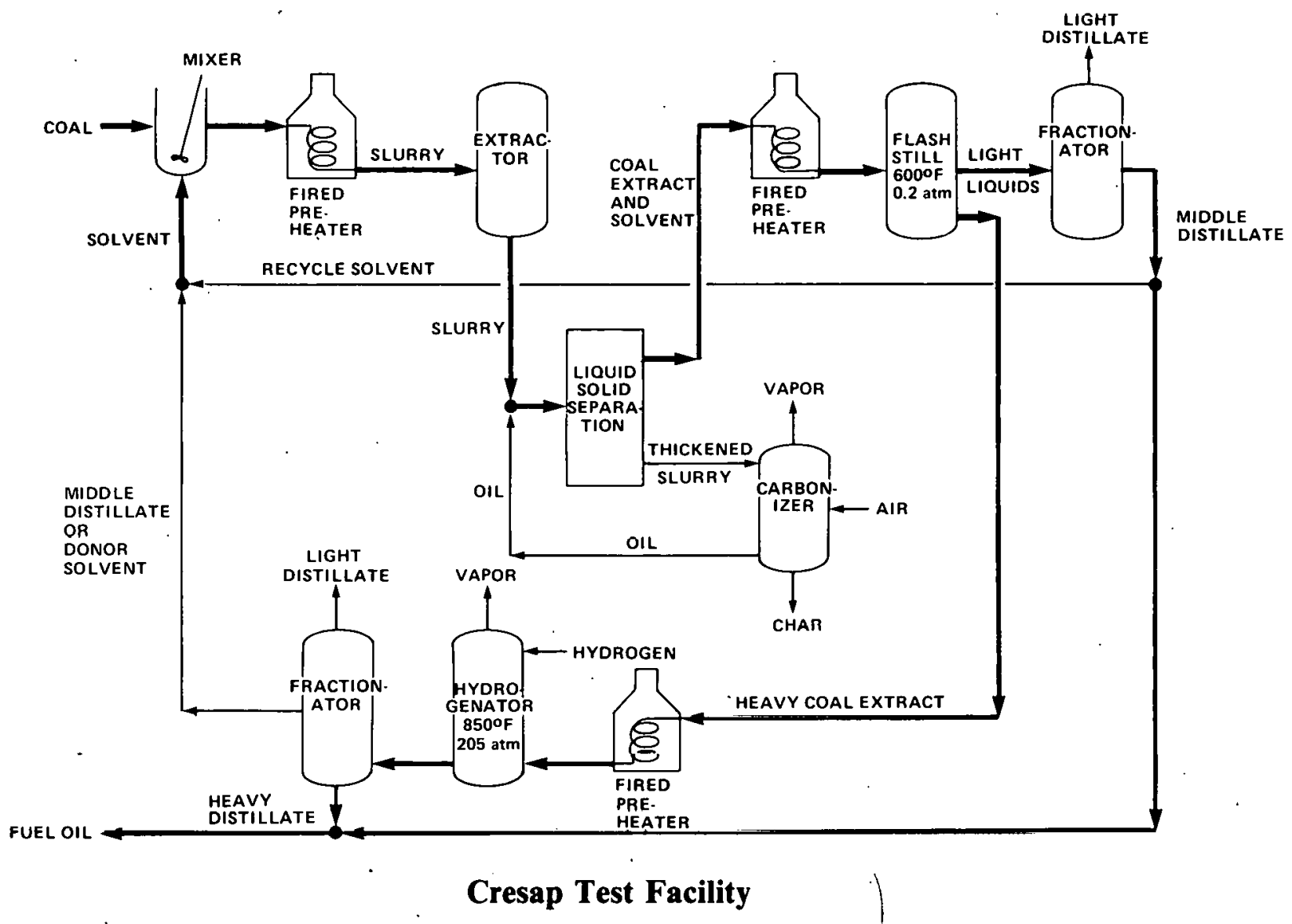

\section{Project Status}

The Cresap Test Facility at Cresap, West Virginia, is a support facility for all of the liquid fuels projects. Equipment testing at the CTF will be carried out under actual liquefaction conditions and will allow the process development project in other pilot plants to concentrate on the process aspect of their work and not be diverted by equipment development. All equipment to be evaluated at the CTF is of commercial design, so the test results will be appliçable to large-scale plants. 
Major objectives to be achieved are:

- Develop and evaluate solvent de-ashing as a nonmechanical liquid/solid separation process.

- Develop a program including procurement and installation of equipment to evaluate an improved rotary drum filter as a liquid/ solid separation device.

- Develop a program including procurement and installation of equipment to evaluate the use of a pressure leaf filter as a second-stage liquid/solid separation device.

- Develop a program including procurement and installation of equipment to evaluate the use of a cross flow filter as a secondstage liquid/solid separation device.

- Evaluate the effect of pump material and geometry on slurry pumps.

- Evaluate the effect of valve material and geometry on slurry valves.

- Evaluate the performance of slurry heaters and heat exchangers.

All of the above tests will be conducted concurrently with the further definition of critical portions of the liquefaction process.

In addition, a project has been developed for evaluating filtration as a means of liquid/solid separation. This project involves testing the efficacy of the rotary drum, the pressure leaf, and the cross-flow filters, and will be available for incorporation into the testing activity.

To devclop an intcgrated cquipment test center, reactivation of the Cresap Test Facility was initiated in May 1974. Extensive redesign was required not only to convert the process to low-sulfur boiler fuel production, but to meet environment requirements and current design standards of piping, electrical, and mechanical codes. The plant's extensive deterioration also had to be corrected. In addition, a hygienic program was developed to minimize and monitor any contacts that the operators might have with the coal-derived liquids. Skin tests and complete physicals will be performed periodically to monitor performance of the program.

Construction activity peaked in FY 1977, with plant mechanical completion achieved in August 1977.

All planning, procurement, installation of equipment, and test operating procedures for the first test phase have been completed.

The operations staff is at full strength, and all training courses have been completed. The plant utilities and analytical laboratory are operational. Startup of the process units is under way. 
Shakedown operations have been accomplished successfully for the processing units for coal handling, extraction, solids separation, carbonization, solvent recovery, and product separation. The shakedown operation for the high-pressure hydrogenation unit was started in September 1977 and scheduled for completion by the second quarter of 1978. The plant will then be operated as an integrated unit.

Following startup, test runs will begin. The first will be a two-month line outrun to establish the steady-state operating mode for the plant. All subsequent runs will be approximately five weeks in length, each followed by two weeks for equipment analysis and maintenance.

Toward the end of FY 1978, an evaluation will be made to determine the best method of enhancing continued plant operation. Plant operation and equipment testing will continue throughout FY 1979.

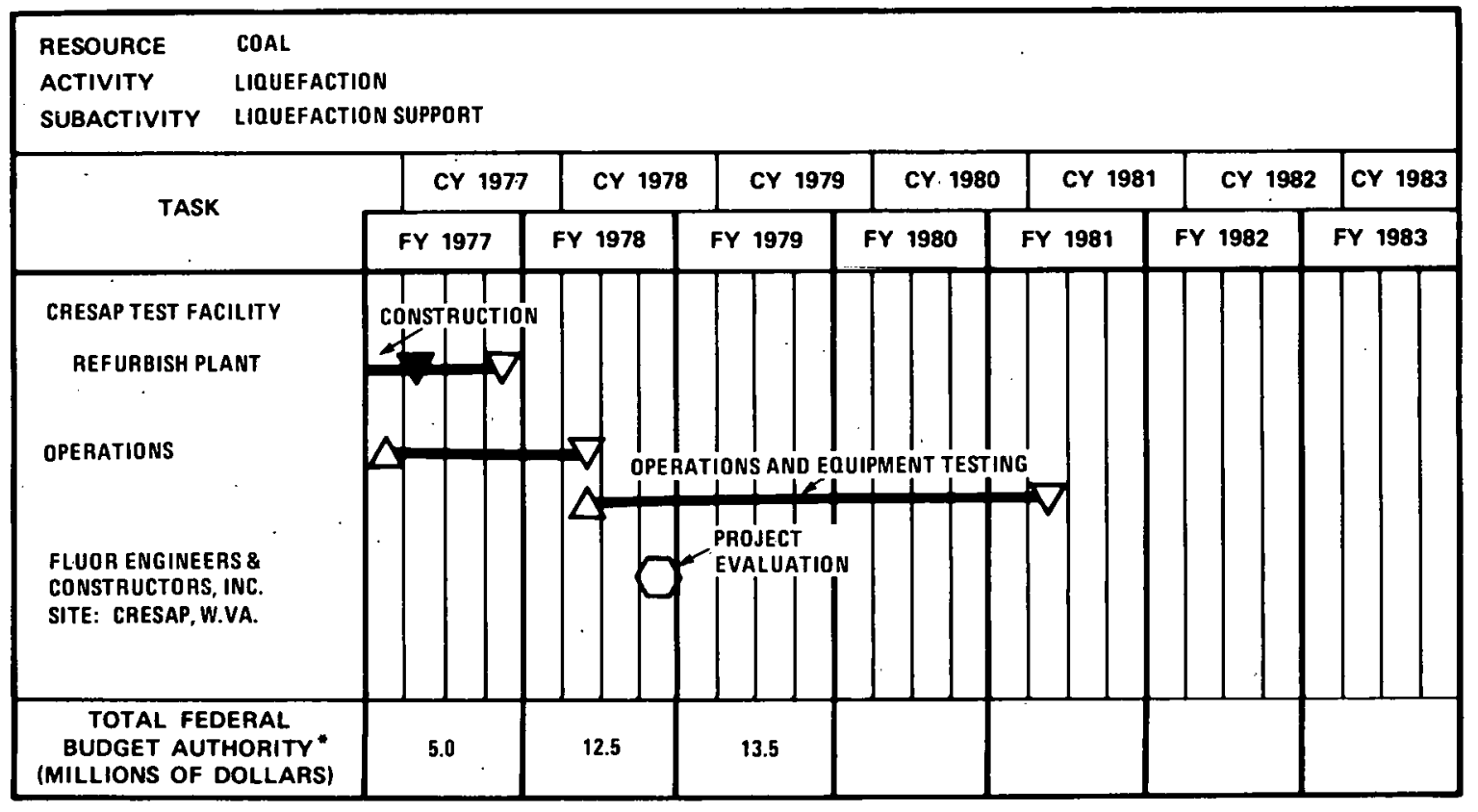

MILESTONE SYMBOLS ARE DEFINED ON LAST PAGE OF THIS DOCUMENT

*FURTHER BUD GET DETAILS ARE PROVIDED IN SECTION 6.0.

\subsection{COAL LIQUIDS REFINING}

The objective of the Coal Liquids Refining Facility support is to stimulate the early commercialization of technology to convert coal-derived synthetic crude oil to gasoline and No. 2 fuel oil, the principal consumer products currently made from petroleum.

Conversion of coal to gasoline and heating oil is a two-step process involving the transformation of coal to an ash-free liquid followed by the refining of this liquid to the desired end products. The latter step is the subject of this support project. A Program Opportunity Notice (PON) has 
been issued, directed at adapting current petroleum conversion and refining processes for production of marketable-quality gasoline and furnace oil (No. 2), and for combining these processes into an integrated operational facility having a minimum size of $100 \mathrm{bbl} / \mathrm{d}$. Synthetic crude oil will be supplied by DOE cosponsored coal liquefaction pilot plants. Liquid products provided by the refining facility will be subjected to a full-scale, end-use test activity with the objective of satisfying technical, economic, and environmental questions on the use of coal-derived gasoline and furnace oil. The contract award for the refining facility is expected about the middle of CY 1978, leading to operation of the facility starting in CY 1981. The overall process configuration for the facility, the particular processes to be used, and the geographical location will be specified by the responders to the PON.

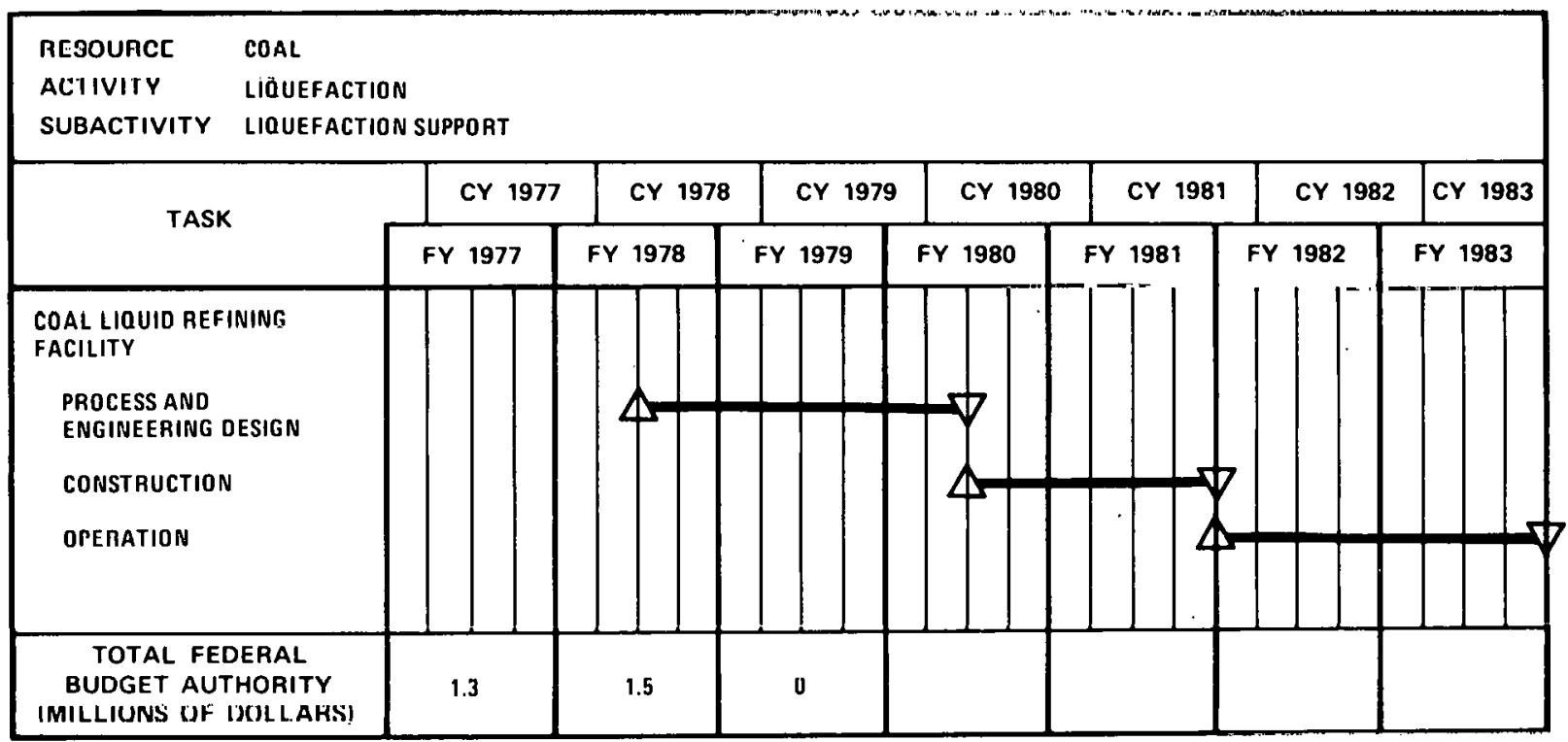

MILESTONE SYMBOLS ARE DEFINED ON LAST PAGE OF THIS DOCUMENT

\subsection{ENVIRONMENTAL STUDIES AND SUPPORTING PROJECTS}

\section{Engineering Evaluations}

The objective of engineering evaluations is to maintain a continuous review of the technical status of processes that are probable candidates for development as commercial plants, in order to ensure cost-effective application of research funds.

Preliminary reviews are being performed for all coal liquefaction projects. Engineering studies by independent third parties will be performed for the processes that appear to be more probable candidates for further development. 


\section{Upgrading of Coal Liquids (Universal Oil Products)}

The main goal of the Upgrading of Coal Liquids project is to determine the response of coal liquid distillates to two-stage hydrocracking and fluid catalytic cracking, to produce mostly motor gasoline and/or No. 2 fuel oil.

Processibility of coal liquid distillates by commercial Universal Oil Products (UOP), Inc. selected catalysts in bench-scale, fixed-bed hydrocracking and fluid catalytic cracking units are being evaluated. Oil products yield, composition, and properties are determined as function of temperature, residence time, and pressure. $\mathrm{H}$-Coal and Exxon Donor Solvent naphtha-reforming process-variable studies were completed and an interim report is being prepared. Two-stage hydrocracking of $\mathrm{H}$-Coal gasoil process-variable studies were completed, and recycle runs to maximize gasoline and fuel oil are in progress. Unifining process variable studies and preparation runs of $\mathrm{H}$-Coal gasoil for fluid catalyst cracking were also completed.

Exxon Donor Solvent gasoil has been received at UOP and the projected work is being performed during FY 1978 and will continue into mid-FY 1979.

\section{Solids/Liquids Separation (Johns-Manville)}

The ultimate objective of the Solids/Liquids Separation project is to achieve major improvements in conventional filtration equipment used in coal liquefaction processes. Specific goals are: significant increases in filtration rates; reduction of filter aid usage; and eventual demonstration of improvements at the pilot-plant scale.

The initial phase of the project is being implemented through: (1) laboratory-scale studies using a pressure precoat filter leaf system to simulate operation of a segment of rotary pressure precoat filter; and (2) consultation with and assistance to other DOE contractors in efforts to optimize filtration procedures in existing systems. During FY 1976, studies were conducted on unfiltered liquified coals from the SRC and Synthoil processes. During FY 1977, these studies continued and will be completed in FY 1078.

\section{Two-Stage Liquefaction (Cities Service)}

The objectives of the Two-Stage Liquefaction project are to: determine expanded-bed conditions required to hydrotreat SRC extract; upgrade a production quantity of SRC extract using commercial-scale expanded-bed equipment; and demonstrate that SRC and expanded-bed processing can be combined to provide a process for producing liquid fuel from coal.

Exploratory tests are being conducted to establish that the feed for the bench-scale unit and the feed for the large-scale unit are technically equivalent. Approximately $15,000 \mathrm{bbl}$ of SRC extract plus carrier solvent will be processed through a commercial-scale hydroprocessing unit if preliminary engineering studies indicate process feasibility and economic practicality. Bench-scale work is subcontracted to C-E Lummus and 
performed in the unit located at New Brunswick, New Jersey, laboratory . Koppers Creosote oil ( $\mathrm{KC}$-oil) was selected as the carrier solvent in the four 10-day runs. Three 30-day catalyst-aging runs were completed showing excellent catalyst stability at temperatures below $810^{\circ} \mathrm{F}$. Average 30-day conversion of 62-volume percent and nitrogen and sulfur removal of 57 and 91 percent of feed, respectively, were obtained. An extension of the existing project started in FY 1978, to test commercially available catalysts to improve nitrogen removal; evaluate recycling of unconverted bottoms; process SRC extracts produced from a western coal; and from a low severity run, study of the effect of ash on catalyst deactivation and evaluation of an expanded-bed guard chamber to remove the ash. Hydrogenated $\mathrm{KC}$-oil is used throughout the extension project.

The first task of the project was completed and commercial nickelmolybdenum was found superior in nitrogen removal than cohaltmolybdenum or nickel-tungsten catalysts, in that order. A selected Ni-Mo catalyst was used for a 30-day catalyst-aging run. The remainder of the project will extend through the first quarter of FY 1979.

\section{Liquefaction Residue Materials Gasification (Texaco, Inc.)}

The objective of the Liquefaction Residue Materials Gasification project is to evaluate materials from several coal liquefaction pilot plants to determine their suitability as feedstocks for the proprietary Texaco Coal Gasification process. All samples supplied by DOE will be evaluated initially in the laboratory. Large-scale pilot plant gasification runs will be completed on promising materials as defined by laboratory tests and as requested by DOE.

Testing is continuing during FY 1978. In addition to evaluation test and residue materials, a Type II 20-barrel test was performed on $\mathrm{H}$-Coal residue during FY 1977. The materials evaluated in laboratory tests in FY 1977 established the necessary physical and chemical properties required to estimate gasifier performance. It is anticipated that further large-scale pilot plant runs will be performed during the second quarter of FY 1978 . The project will proceed as materials for evaluation become available.

\section{Valuable Metals in Residues (Illinois Geologic Survey)}

The objective of the Valuable Metals in Residues project is to ascertain if the solid residues from various coal liquefaction processes contain recoverable and/or economical amounts of valuable or semivaluahle metals.

Analytical analysis of more than 60 elements eventually will be determined for coal liquefaction samples, for the feed coal, the liquefaction residues, and the low-temperature ash. The data contained will provide a basis for performing an economic study of the practicality of metals recovery. 


\subsection{LIQUEFACTION DEMONSTRATION PROJECTS}

The table below summarizes the funding levels by task for the FY 1977 to FY 1979 period.

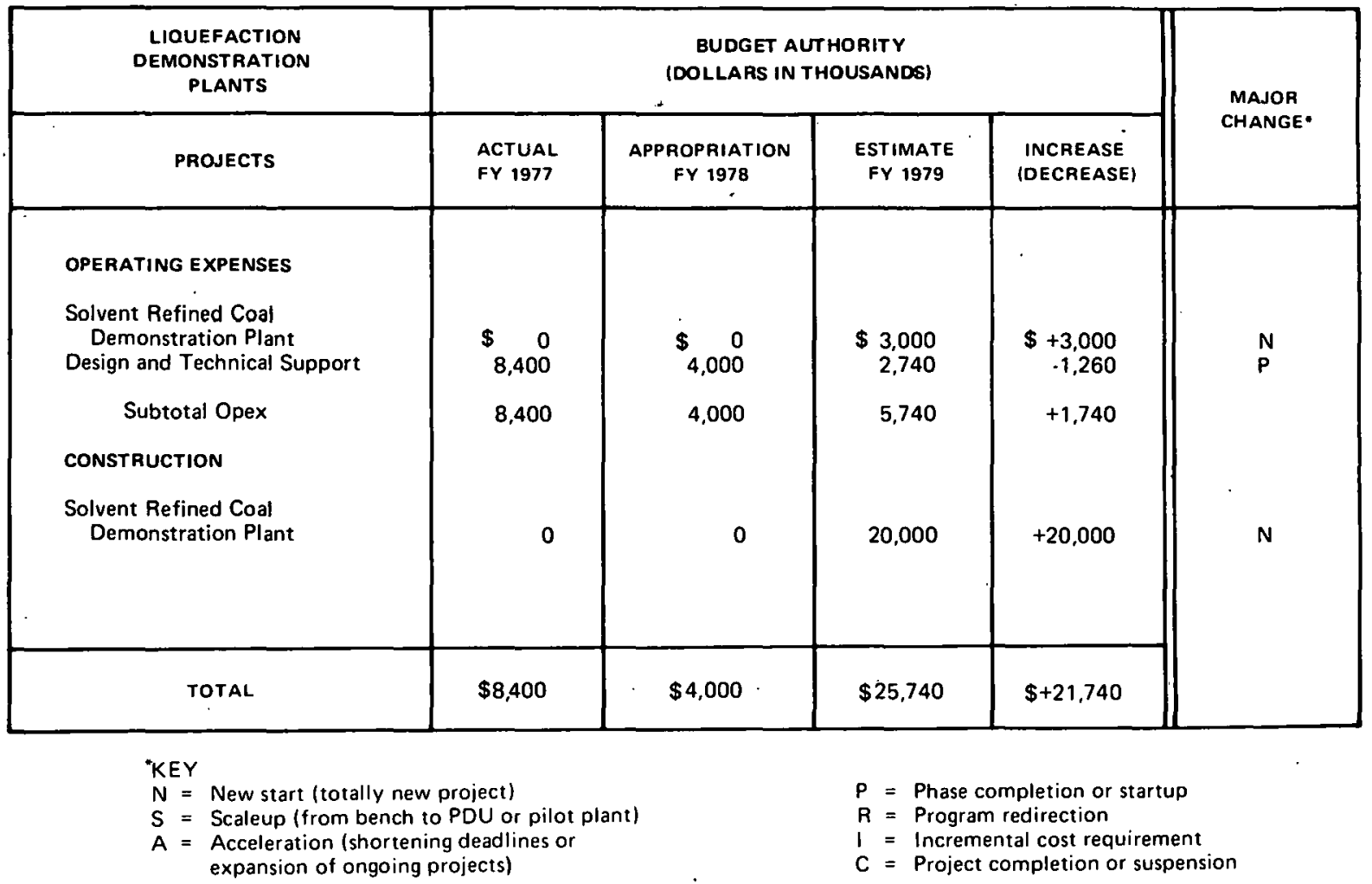

\subsection{SOLVENT REFINED COAL DEMONSTRATION PLANT}

The Solvent Refined Coal project was begun in 1962 when Spencer Chemical Company was awardẽd a research contract by OCR to study the technical feasibility of a coal de-ashing process (now called the SRC process). In 1965, the process was successfully demonstrated in a 50$\mathrm{lb} / \mathrm{hr}$ continuous-flow unit, and work on the contract was completed. During the term of the contract, Gulf Oil Corporation acquired Spencer Chemical Company. After reorganization, the contract was assigned to the research department of Pittsburg \& Midway Mining Company, a subsidiary of Gulf .

To further develop the SRC process, a contract was awarded to P\&M to design, construct, and operate a pilot plant that would be capable of processing 50 tons/day of coal. In 1969, Stearns-Roger Corporation completed the pilot plant design, but funds to begin construction were not available until late 1971. In June 1972, OCR extended its contract with P\&M for the construction and operation of the pilot plant. Rust Engineering 
Company began building the pilot plant in July 1972 at Ft. Lewis, Washington. As units were completed, preliminary tests of process equipment and instrumentation were performed. The pilot plant became fully operational in October 1974.

Additional information on the SRC process is contained in the Solvent Extraction Processes portion of this section.

The SRC process converts high-sulfur, high-ash coals to a clean, solid (or distillate) fuel and a clean high-Btu gas. The pulverized coal is mixed with a process derived solvent (or recycled slurry). Hydrogen is then added to the coal slurry. The mixture is pumped to a preheater and then fed into a single-stage reactor or dissolver which operates at $800^{\circ}$ to $875^{\circ} \mathrm{F}$, and a total pressure of $1,500 \mathrm{psi}$. Approximately 93 percent of the carbonaceous material in the coal feed is dissolved. Product gases from the dissolver are separated and sent to a cleanup system to remove the hydrogen sulfide (virtually all of the inorganic sulfur and about 60 percent of the organic sulfur in the coal is converted to hydrogen sulfide) and convert it to elemental sulfur. The ash and undissolved coal is then separated from the product which, depending upon the degree of hydrogenation, solidifies at about $350^{\circ} \mathrm{F}$ or remains a liquid similar to heavy fuel oil.

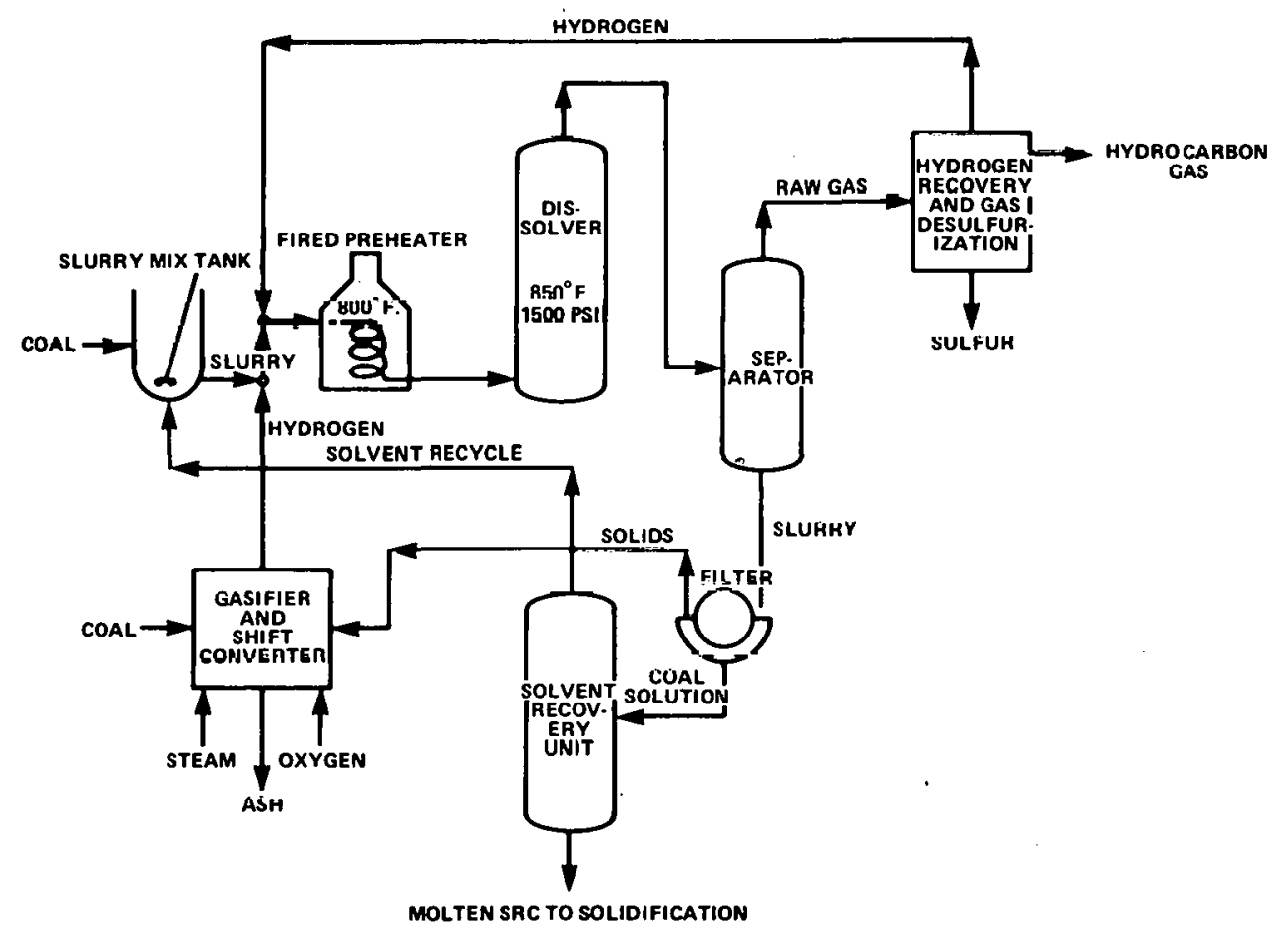

SRC. (Solid) Process 


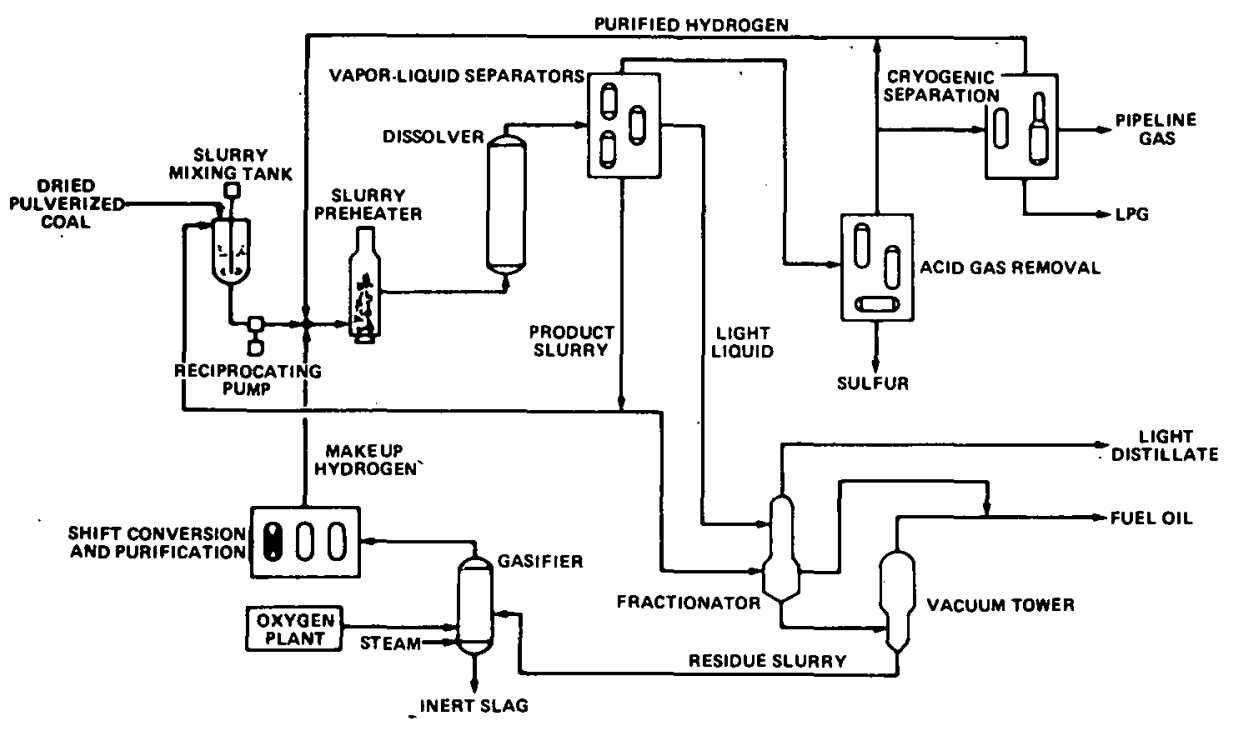

SRC (Liquid) Process

\section{Project Status}

The SRC process has been selected as a new demonstration project in FY 1978 because: 1) the technology is the most mature of the liquefaction processes; 2) the pilot plant has operated successfully, making solid and liquid fuels; and 3) the preliminary economical evaluations indicate that the process is competitive with other liquefaction processes. It provides an attractive route of conversion of high-sulfur coal to an environmentally acceptable clean-burning synthetic fuel. An SRC demonstration plant will:

- Provide an accurate basis for determining investment and operation costs for commercial-sized applications of this technology

- Prove the environmental acceptability of this fuel product for direct use in electric power generation

- Assess the marketability of a range of fuel products obtainable from a given coal and process

- Confirm the acceptability by utilities and industries of this fuel product with minimum burner retrofit

- Demonstrate the technical viability of the process by operating full-scale solid/liquid separation, hydrogen, generation and residue extraction systems, as well as by increasing confidence in the improved metals, design, and fabrication technologies needed for commercial-scale applications.

The SRC project strategy is to issue a PON with competitive bidding which will lead to award of contracts to design, construct, operate, and evaluate a demonstration plant.

Conceptual design of SRC demonstration plants has been initiated by proponents and can be finalized immediately upon contract award. Design of an SRC demonstration plant rnutd hegin in the first quarter of FY 1979. 


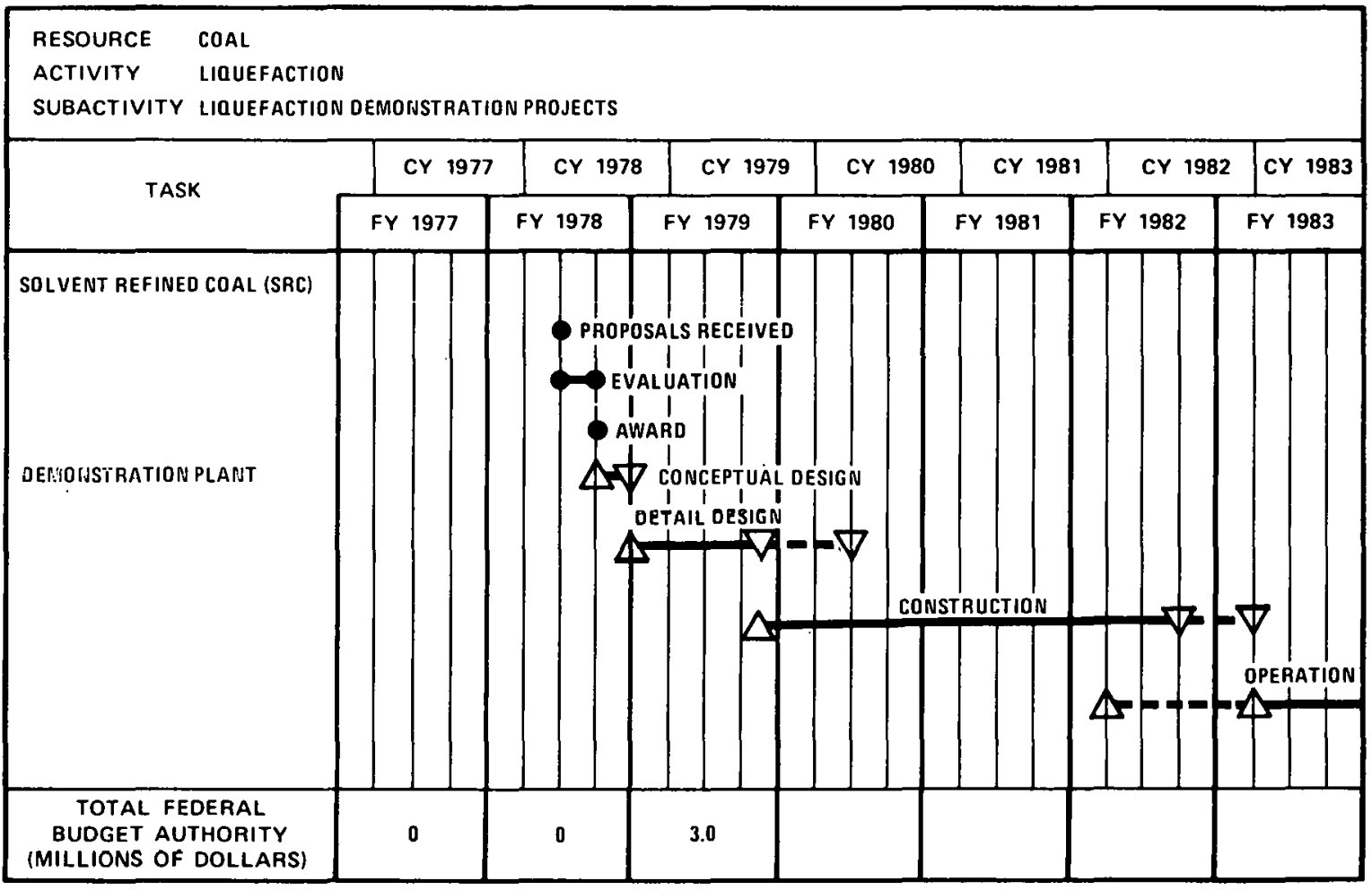

MILESTONE SYMBOLS ARE DEFINED ON LAST PAGE OF THIS DOCUMENT

\subsection{DESIGN AND TECHNICAL SUPPORT}

The Design and Technical Support areas for Liquefaction Demonstration Plants include the following:

- Equipment Development and Component l'esting: Successful operation of large-scale equipment and components is essential for commercial-plant success. There is an array of such equipments (i.e., large valves and coal feeders) which are generic to the operation of all demonstration plants and which must, therefore, be developed and tested hand-in-hand with the plants. Funding for this category is largely for continuation of work previously started.

- Engineering Support: Project technical support will be provided by the National Laboratories, Energy Research Centers (ERCs), U.S. Army Corps of Engineers, Department of the Army Recearch and Máterial Command, and various private engineering firms.

- Environmental and Socioeconomic Studies: Analysis of the environmental impact of large industrial development will continue: Potential social, ecological, aesthetic, and economic impacts and methods for achieving their equilibrium are studied.

- Planning and Program Support: These support tasks are largely a continuation of established activities. They include modeling and systems studies, economic and financial analyses, technical reports, and management support. 
- Operational Engineering: This support function provides guidance and engineering assistance to each demonstration plant program manager. and the industrial partner, followed by review and assessment during the design and construction phases of the program. This assistance relates to plant operability, maintainability, reliability, plant operator health and safety, and protection of the environment. Also provided is management of the test and evaluation activities during the demonstration phase of the program, to assist plant performance and viability.

\subsection{SUMMARY OF PILOT PLANTS, PDUs, AND MAJOR HARDWARE FABRICATION}

The following data summarize funding levels for the pilot plants, PDUs, and major hardware fabrication for projects supporting the coal liquefaction effort.

\section{LIQUEFACTION}

SUMMARY OF PILOT PLANTS, PDUS, AND MAJOR HARDWARE FABRICATION (DOLLARS IN THOUSANDS)

\begin{tabular}{ccccc}
$\begin{array}{c}\text { TOTALAL } \\
\text { ESTIMATED } \\
\text { COSTS }\end{array}$ & $\begin{array}{c}\text { CUMULATIVE } \\
\text { PRIOR YEAR }\end{array}$ ESTIMATE & FY 1979 & CUMULATIVE \\
\hline
\end{tabular}

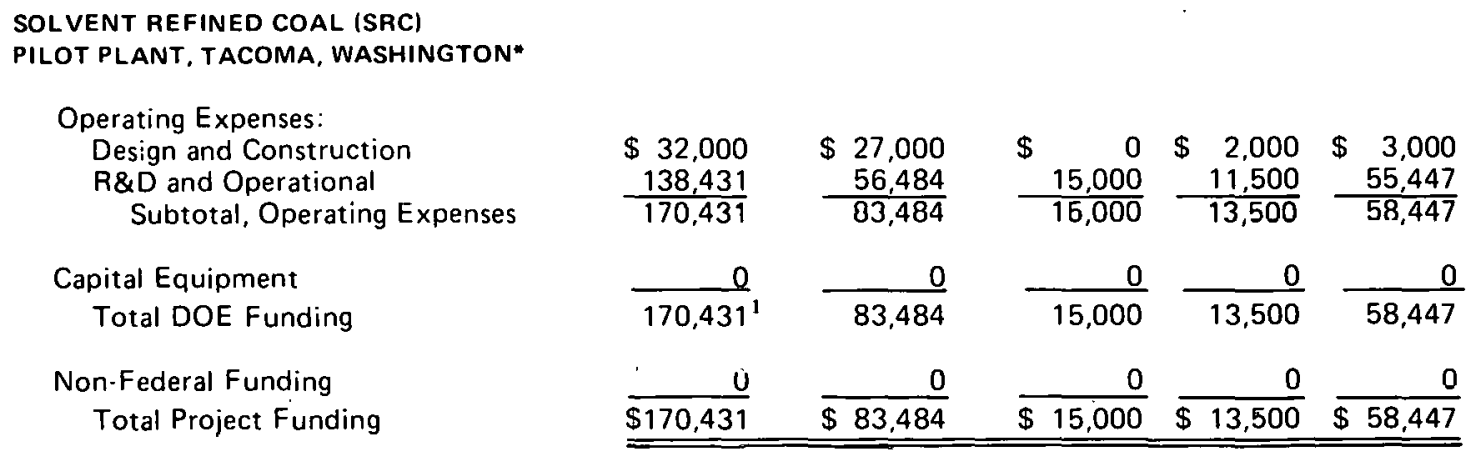

1. Based on contract and budget projection, and includes support activities at the Wilsonville, Alabama, plant.

* Refer to Chapter III, Part C. Section 2.1 


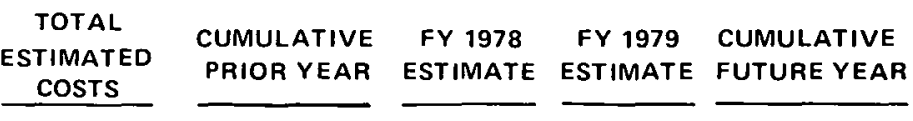

CRESAP TEST FACILITY, CRESAP, WEST VIRGINIA*

Operating Expenses:

Design and Construction

$R \& D$ and Operational

Subtotal, Operating Expenses

\begin{tabular}{rrrrrr}
$\$ 41,365$ & $\$ 35,365$ & $\$ 2,000$ & $\$ 1,000$ & $\$ 3,000$ \\
$\frac{68,135}{109,500}$ & $\frac{20,187}{55,552}$ & $\frac{10,500}{12,500}$ & $\frac{12,500}{13,500}$ & $\frac{24,948}{27,948}$ \\
$\frac{0}{109,500^{1}}$ & $\frac{0}{55,552}$ & & 0 & $\frac{0}{12,500}$ & 0 \\
$\frac{2,000^{2}}{13,500}$ & $\frac{0}{27,948}$ \\
\hline 111,500 & $\$ 57.552$ & $\$ 12,500$ & $\frac{000}{\$ 13,500}$ & $\frac{0}{\$ 27,040}$ \\
\hline \hline
\end{tabular}

Capital Equipment

Total DOE Funding

Non-Federal Organization Funding

Total Project Funding

1. Based on contract and budget projertion of operations thru FY 1001.

2. Actual contributions rereivert

"Refer tn ('hapter III, Port C, Ecction 4.1

\begin{tabular}{ccccc}
$\begin{array}{c}\text { TOTAL } \\
\text { ESTIMATED } \\
\text { COSTS }\end{array}$ & $\begin{array}{c}\text { CUMULATIVE } \\
\text { PRIOR YEAR }\end{array}$ ESTIMATE & FY 1979 & CUMULATIVE \\
\cline { 5 - 5 }
\end{tabular}

EBULLATED-BED (H-COAL) PILOT PLANT

CATLETTSBURG, KENTUCKY*

Operating Expenses:

Design and Construction

$R \& D$ and Operational

Subtotal, Operating Expenses

$\$ 88,617$

54,009

142.626

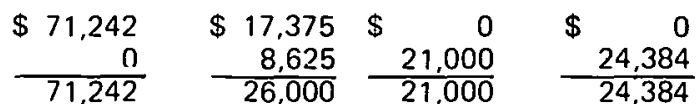

Capital Equipment

Total DOE Funding

$\frac{0}{142,626^{1}} \quad \frac{0}{71,242} \quad \frac{0}{26,000} \quad \frac{0}{21,000} \quad \frac{0}{24,384}$

Nun-Federal Organization Funding

Total Project Funding

$\begin{array}{llllr}\frac{36,248^{2}}{\$ 178.874} & \frac{17,362}{\$ 88,604} \quad \frac{7,535}{\$ 33,636} \quad \frac{6,675}{\$ 27,675} \quad \frac{4,676}{\$ 29,060}\end{array}$

1. Based on contract.

2. Based on signed agreements from the non-Federal cost-sharing participants.

* Refer to Chapter III, Part C. Section 1.1

\begin{tabular}{|c|c|c|c|c|c|}
\hline . & $\begin{array}{l}\text { TOTAL } \\
\text { ESTIMATED } \\
\text { CUSTS } \\
\end{array}$ & $\begin{array}{l}\text { CUNiULAIIVE } \\
\text { PKIUK VGAK }\end{array}$ & $\begin{array}{l}\text { PY } 1978 \\
\text { EETIMATE }\end{array}$ & $\begin{array}{l}\text { FY } 1979 \\
\text { ESTIMATE }\end{array}$ & $\begin{array}{l}\text { CUMULATIVE } \\
\text { FUTURE YEAI }\end{array}$ \\
\hline \multicolumn{6}{|l|}{$\begin{array}{l}\text { NOSNOR SOLVENT LIQULT ACTION } \\
\text { PILOT PLANT, BAYTOWN, TEXAS* }\end{array}$} \\
\hline $\begin{array}{l}\text { Operating Expenses: } \\
\text { Design and Construction } \\
\text { R\&D and Operational }\end{array}$ & $\begin{array}{r}60,700 \\
73,300 \\
\end{array}$ & $\begin{array}{r}0 \\
8,870 \\
\end{array}$ & $\begin{array}{r}\$ 24,000 \\
6,300 \\
\end{array}$ & $\begin{array}{r}\$ 32,300 \\
2,300 \\
\end{array}$ & $\begin{array}{r}\$, 4000 \\
55,830 \\
\end{array}$ \\
\hline Subtotal, Operating Expenses & 134,000 & 8,870 & 30,300 & 34,600 & 60,230 \\
\hline Capital Equipment & 0 & 0 & 0 & 0 & 0 \\
\hline Total DOE Funding & $134,000^{1}$ & 8,870 & 30,300 & 34,600 & 60,230 \\
\hline $\begin{array}{l}\text { Exxon Research \& Engineering, et al funding } \\
\text { Total Project Funding }\end{array}$ & $\frac{134,000^{1}}{\$ 268,000}$ & $\frac{8,870}{\$ 17,740}$ & $\frac{30,300}{\$ 60,600}$ & $\frac{34,600}{\$ 69,200}$ & $\frac{60,230}{\$ 120,460}$ \\
\hline
\end{tabular}

1. Based on contract

"Refer to Chapter III, Part C. Section 2.4 


\section{COAL GASIFICATION}

This Activity focuses on three main gasification subactivities: HighBtu Gasification for clean pipeline quality gas, Low-Btu Gasification for a clean industrial and utility fuel gas, and underground In Situ Coal Gasification technology for on-site conversion of coal to gas in unmineable seams.

\begin{tabular}{|c|c|c|c|c|}
\hline GASIFICATION & \multicolumn{4}{|c|}{$\begin{array}{l}\text { BUDGET AUTHORITY } \\
\text { IOPERATING EXPENSES) } \\
\text { (DOLLARS IN THOUSANDS) }\end{array}$} \\
\hline PROJECTS & $\begin{array}{l}\text { ACTUAL } \\
\text { FY } 1977\end{array}$ & $\begin{array}{c}\text { APPROPRIATION } \\
\text { FY } 1978\end{array}$ & $\begin{array}{l}\text { ESTIMATATE } \\
\text { FY } 1979\end{array}$ & $\begin{array}{c}\text { INCREASE } \\
\text { (DECREASE) }\end{array}$ \\
\hline $\begin{array}{l}\text { High-Btu Gasification } \\
\text { LowBtu Gasification } \\
\text { Special Projects and Support } \\
\text { Studies } \\
\text { In Situ Coal Gasification } \\
\text { Gasification Demonstration Plants }\end{array}$ & $\begin{array}{r}\$ 33,860 \\
28,650 \\
14,596 \\
8,236 \\
40,600\end{array}$ & $\begin{array}{r}\$ 26,000 \\
55,850 \\
\\
17,850 \\
11,000 \\
30,900\end{array}$ & $\begin{array}{c}\$ 31,266 \\
35,600 \\
\\
18,260 \\
11,800 \\
25,520\end{array}$ & $\begin{array}{r}\$+5,266 \\
-20,250 \\
+410 \\
+800 \\
-5,380\end{array}$ \\
\hline TOTAL & $\$ 125,942$ & $\$ 141,600$ & $\$ 122,446$ & $\$-19,154$ \\
\hline
\end{tabular}

\subsection{HIGH-BTU GASIFICATION}

Consumption of clean-burning natural gas has continued to increase annually, while proven reserves have decreased despite intensified drilling activity. The natural gas shortage identifies the need to rapidly develop alternate energy supplies. Therefore, the objectives of the High-Btu Gasification Activity are:

- To identify and develop, in an accelerated manner, promising third-generation technology aimed at implementation of more econnmical processes on a commercial scale in the 1985-2000 timc frame.

- To develop and demonstrate, in cooperation with industry, new and improved second-generation gasification technology necessary for the construction of commercial-scale plants for processes that convert domestic coal to Substitute Natural Gas (SNG) of pipeline quality .

- To support and improve first-generation processes being considered for commercial gasification facilities and to continue development of efficient third-generation technology.

The Government-supported High-Btu Gasification Activity includes four major second-generation projects for development of an improved process to manufacture SNG with the following specifications: 
- $\quad$ Heating value: 950 to $1,000 \mathrm{Btu} / \mathrm{scf}$

- Purity level: essentially free of sulfur and other potential pollutants and hazardous impurities

- Process gas exit pressure: approximately 1,000 psi

- Combustion characteristics: similar to natural gas.

Although many gasification processes under development are similar in objective, each is characterized by important differences that warrant concurrent development. These differences include reaction conditions, pretreatment, method of feed, reactor configuration, heat supply, gas purification, and methanation process. The processes are distinctive in that each represents a significantly different approach to high-Btu gas production. The Lurgi Gasification process has been utilized as the benchmark to asrertain if any of the processès currently under developiment show improvemente over the current state-nf-the-art. technology. Improvements upon present technology will be measured primarily in terms of comparative capital and operating costs of these processes and their ability to operate successfully with U.S. caking-type coals. Development of each promising process will continue to a point where industry can construct, with an acceptable degree of risk, a commercial plant based on one or more of the concepts.

The American Gas Association (AGA) is currently sharing approximately one-third of the cost of the HYGAS, Bi-Gas, and Steam Iron processes and engineering evaluation studies of various high-Btu coal gasification processes.

DOE's High-Btu Coal Gasification Activity is concerned with the development of processes to convert coals of varying qualities to a cleanburning natural gas substitute in an environmentally acceptable manner. Since each of the high-Btu processes employs different process schemes, the effluents and emissions characteristics of these processes are expected to vary. Process characterization studies are currently under way to provide adequate and representative data on the effluents and emissions of pilot plants. It is expected that these data will be useful to regulatory agencies for future development of environmental and occupational standards. The water resources requirements associated with commercialsize facilities are also of concern to high-Btu gasification development. Studies to determine the adequacy of water supplies and the feasibility of using low-quality water for process applications and recycle are also under way.

Processes currently being investigated and tested on a pilot-plant scale under High-Btu Gasification include:

\footnotetext{
- HYGAS

- Bi-Gas

- Synthane

- Steam Iron.
} 
The table below summarizes the funding levels by task for the FY 1977 to FY 1979 period.

\begin{tabular}{|c|c|c|c|c|c|}
\hline \multirow{2}{*}{$\begin{array}{l}\text { HIGH BTU } \\
\text { GASIFICATION } \\
\text { TASK }\end{array}$} & \multicolumn{4}{|c|}{$\begin{array}{l}\text { BUDGET AUTTHORITY } \\
\text { (OPERATING EXPENSES) } \\
\text { (DOLLARS IN THOUSANDS) }\end{array}$} & \multirow{2}{*}{$\begin{array}{l}\text { MAJOR } \\
\text { CHANGE }\end{array}$} \\
\hline & $\begin{array}{l}\text { ACTUAL } \\
\text { FY } 1977\end{array}$ & $\begin{array}{c}\text { APPROPRIATION } \\
\text { FY } 1978\end{array}$ & $\begin{array}{l}\text { ESTIMATE } \\
\text { FY } 1979\end{array}$ & $\begin{array}{l}\text { INCREASE } \\
\text { (DECREASE) }\end{array}$ & \\
\hline $\begin{array}{l}\text { Hygas Pilot Plant } \\
\mathrm{CO}_{2} \text { Acceptor Pilot Plant } \\
\text { Bi-Gas Pilot Plant } \\
\text { Self-Agglomerating Burner PDU } \\
\text { Synthane Pilot Plant } \\
\text { Hydrogasification } \\
\text { Steam Iron Pilot Plant } \\
\text { Catalytic Gasification Pilot Plant }\end{array}$ & $\begin{array}{r}\$ 2,800 \\
2,133 \\
9,800 \\
2,227 \\
10,500 \\
1,800 \\
4,600 \\
0\end{array}$ & $\begin{array}{r}0 \\
0 \\
3,000 \\
1,500 \\
14,500 \\
3,500 \\
0 \\
3,500\end{array}$ & $\begin{array}{r}0 \\
0 \\
7,900 \\
0 \\
9,991 \\
6,147 \\
0 \\
7,228\end{array}$ & $\begin{array}{r}\$ \\
0 \\
0 \\
+4,900 \\
+1,500 \\
-4,509 \\
+2,647 \\
0 \\
+3,728\end{array}$ & \multirow[t]{2}{*}{$\begin{array}{l}\mathrm{C} \\
\mathrm{C} \\
\mathrm{I} \\
\mathrm{C} \\
\mathrm{S} \\
\mathrm{C} \\
\mathrm{S}\end{array}$} \\
\hline TOTAL & $\$ 33,860$ & $\$ 26,000$ & $\$ 31,266$ & $\$+5,266$ & \\
\hline \multicolumn{3}{|c|}{$\begin{aligned} & \text { KEY } \\
N= & \text { New start (totally new project) } \\
S= & \text { Scaleup (from bench to PDU or pilot plant) } \\
A= & \text { Acceleration (shortening deadlines or } \\
& \text { expansion of ongoing projects) }\end{aligned}$} & \multicolumn{3}{|c|}{$\begin{array}{l}\mathbf{P}=\text { Phase completion or startup } \\
R=\text { Program redirection } \\
\mathbf{I}=\text { Incremental cost requirement } \\
\mathrm{C}=\text { Project completion or suspension }\end{array}$} \\
\hline
\end{tabular}

\subsection{HYGAS PILOT PLANT}

In the HYGAS process, coal is reacted with hydrogen-rich gases to produce methane directly in a hydrogasifier. It is a high-pressure process for all types of coals. The hydrogasifier consists of a slurry drier and three high-pressure fluidized-bed reactors. Coal is dried, crushed, slurried with a process-derived oil, and compressed to $1,500 \mathrm{psi}$. The slurry is then moved into the slurry drier section of the hydrogasifier, where it is sprayed on a fluidized bed. The oil is vaporized and removed with hot process gases rising through the bed from the lower stages of the gasifier. Vaporized oil is recovered by quenching and is reused. The dried coal is routed to the first stage of the gasifier which is located below the drier and above the second stage. The coal enters the gasifier at midheight and is heated to about $1200^{\circ} \mathrm{F}$ by the hot reaction gas from the second stage. The first stage $\left(1200^{\circ} \mathrm{F} ; 1,000 \mathrm{psi}\right)$ favors the direct production of methane from the coal. Solids are channeled to the second stage, where rising gases contact the char for further gasification at about $1700 \circ \mathrm{F}$. Unreacted char and ash drop into the steam-oxygen gasifier for final gasification, producing a hydrogen-rich gas and steam mixture, at about 1850 o F .

The raw gas leaves at the top of the slurry drying section through a quench tower which removes dusts, the slurry oil, and excess steam. Gas purification occurs in an acid removal system, which consists of an aminewater scrub followed by a caustic wash and a water wash. $\mathrm{CO}_{2}$ and $\mathrm{H}_{2} \mathrm{~S}$ removal are essentially complete after the amine-water scrub. A Claus plant converts the sulfur products to elemental sulfur. Methanation takes place in two packed-bed down-flow reactors. Heat release control is by 
the Institute of Gas Technology (IGT) split-flow recycle method. The Chem Systems Liquid-Phase Methanation Unit is also integrated into the HYGAS pilot plant for developmental purposes.

The experimental program for development of the HYGAS process involves operation of the pilot plant for extended periods to collect data that will provide reliability and cost estimates for a demonstration plant design.

\section{Project Status}

The HYGAS process is based on gasification studies which were started at IGT in 1944. Process development unit (PDU) studies were performed with Office of Coal Research (OCR)/AGA Eupport from 1964 to 1967. An 80-tons/day pilot plant was designed and constructed in rhirage from 1968 to $19^{\prime} 71$. The pilnt plant was oporated with hydrogein frum reforming natural gas from 1971 to 1974 . During the period of 1971 to 1974 , an electrothermal gasifier was constructed and operated as a potential alternate source of hydrogen for the process. Further development of this technique was stopped because of projected unfavorable economics for the commercial plant. During pilot plant operations, technical feasibility of the methanation process (packed-bed) was demonstrated using several coals.

The steam-oxygen char gasification system for hydrogen production was developed in a PDU reactor from 1971 to 1972 . A larger steam-oxygen gasification unit was designed, constructed, and integrated into the bottom of a HYGAS reactor during. 1974. Integrated operation of the pilot plant with the steam-oxygen system was achieved in mid-1974.

Since the operation of the pilot plant was started in 1971 , the principal objectives of the project have been achieved. These milestones include: successful processing of lignite, Illinois No. 6 bituminous (high presswelling index-' $)$, and subbituminous coals into a Btu gas; demonstration of key process concepts, as well as key unit operations; and integrated operation of all plant components over a long period of time. It is planned to operate the HYGAS pilot plant for an additional 15 months (beyond June 30, 1977) for the specific purpose of generating the data base required for optimization of a demonstration plant design for the production of pipeline gas from bituminous coal. Depending on the overall project, the HYGAS pilot plant must be operated for a certain period in FY 1979, for back-up in the detailed design of a demonstration plant.

Since March 1977, pilot plant operations have been carried out on a representative bituminous coal (Peabody No. 10 mine) from the Illinois basin. These runs have demonstrated coal conversions at the 84 percent level at an approximate through-puts of 2 tons/hr. After pilot plant data have been obtained at a design feed rate of 3 tons/hr (or higher) and at 
higher) and at coal conversions of 84 percent (or higher), operations will be carried out on an unwashed bituminous coal from the mine (Peabody No. 10). An attempt will be made to achieve the same foregoing goals. In addition, minimum pretreatment conditions will be investigated as well as the origin of finds. The latter task will be made by controlling the feed-particle size range.

The effect of process variables will be determined including temperature, steam/oxygen ratio, oxygen/carbon ratio, and reactants' residence time on conversion and yield in the hydrogasifier with the steam/oxygen system. Additional catalysts in the coal gas recycle methanator will be evaluated. Effluent treatment, water reuse, and construction materials will be evaluated.

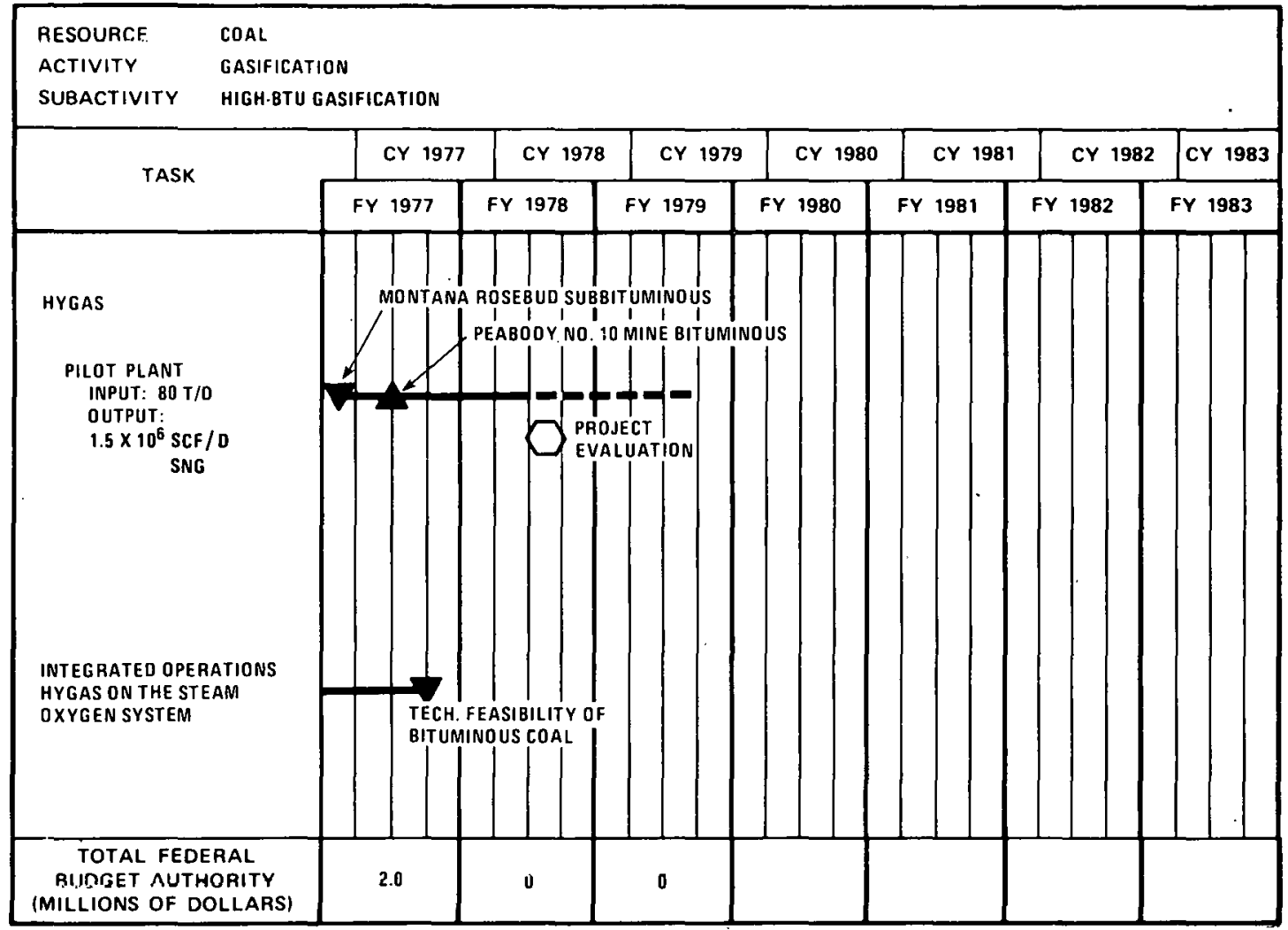

MILESTONE SYMBOLS ARE OEFINED ON LAST PAGE OF THIS DOCUMENT

\subsection{BI-GAS PILOT PLANT}

The $\mathrm{Bi}-\mathrm{Gas}$ reactor is a two-stage gasifier of the pressurized, entrained-flow, slagging type. The gasifier has three sections separated by formed restrictions. Stage two (top-most) receives dense phase coal in gas-entrained flow-through injectors located in a throat between stages two and one. Steam is also injected there. Process gas and char flow from the top of stage two of the gasifier to a cyclone. The char is recycled from the cyclone and fed to a steam injector nozzle and then, with oxygen and steam, to the bottom of stage one. The products of char gasification in stage one are hot gas feeding into stage two and slag dropping into stage three, the slag quench section. 
Molten slag runs down the walls of stage one of the pressurized gasifier.

Raw gas leaves the char recovery cyclone, passes through a water wash column and flows to the shift reactor where the $\mathrm{H}_{2}$-to-CO ratio is adjusted to the desired value. $\mathrm{H}_{2} \mathrm{~S}$ and part of the $\mathrm{CO}_{2}$ are removed in the Selexol unit upstream of the methanator. $\mathrm{H}_{2} \mathrm{~S}$ gas goes to a Claus unit. The product gas from the methanator goes through final $\mathrm{CO}_{2}$ removal in the Selexol unit. The methanator, a fluidized bed with embedded water-cooled tubes, offers great potential for commercial development.

The Bi-Gas reactor can handle all types of coal. Due to its high operating temperature of over $2500^{\circ} \mathrm{F}$, there is no tar in the product gas, thus simplifying the gas cleanup step. High methane yields are achieved withnut. methanation, and coals can be gasified without prior treatment since the process uses an entrainod- rather than a fixed-or fluidized-bed system.

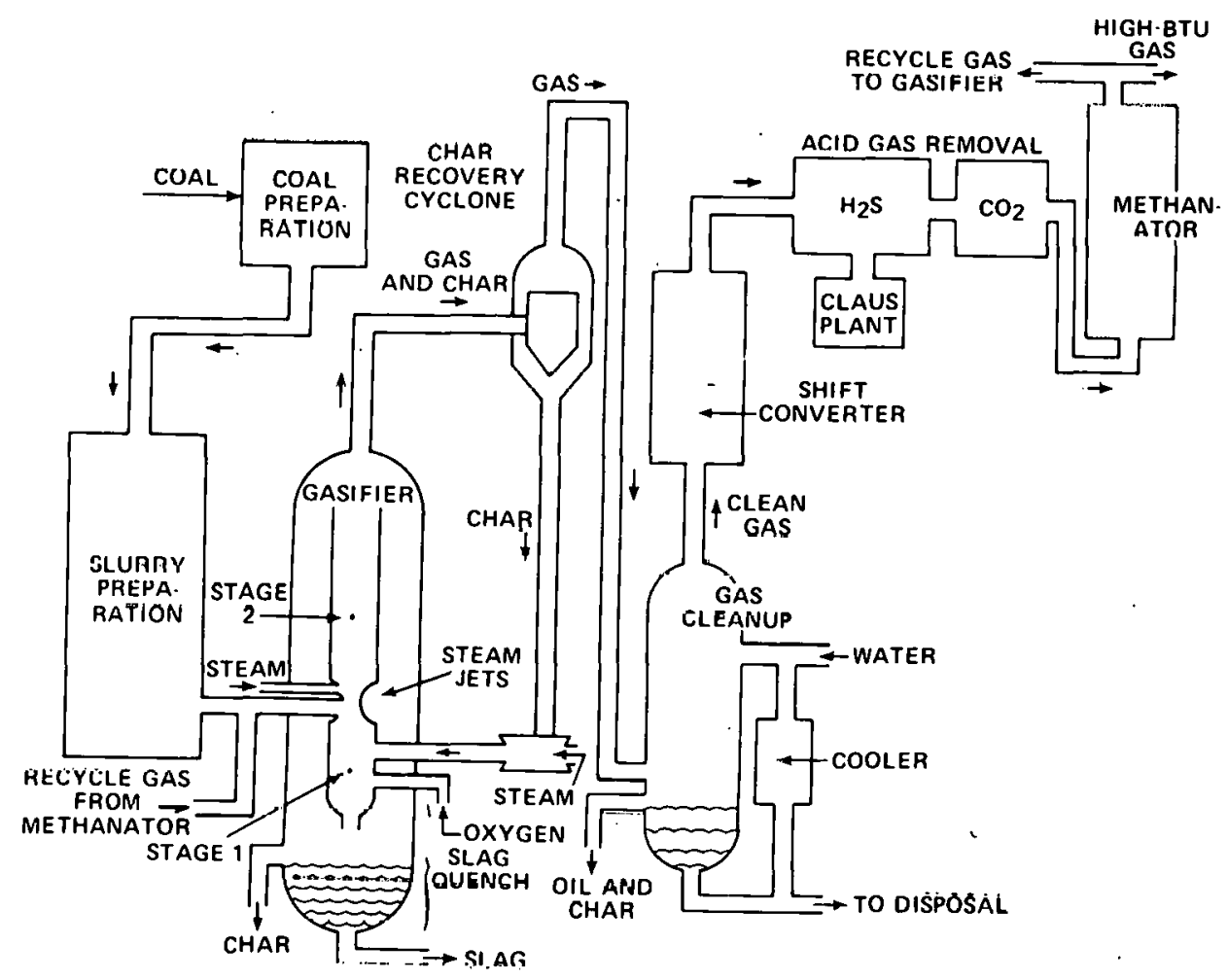

Bi-Gas Process

\section{Project Status}

The Bi-Gas process has been under development at Bituminous Coal Research, Inc. (BCR) since December 1963. BCR conducted PDU tests in a $5-1 b / h r$ unit to obtain scaleup information for pilot plant design. A 120-tons/day pilot plant was constructed by Stearns-Rogers, 
Inc., at Homer City, Pennsylvania, in FY 1976. Shakedown and startup activities were started in FY 1976. Phillips Petroleum Company has the overall responsibility for planning and conducting the pilot plant research program, which will run for approximately three years. At the end of FY 1979, a decision will be made to continue operation into FY 1980 or to discontinue the operation.

Pilot plant support work will be carried out at the facilities of BCR in Monroeville, Pennsylvania. Slag viscosity measurements, slag behavior with and without additives, and catalyst evaluation for the fluidized-bed methanation system are among the support tasks. The BiGas pilot plant operation will generate scaleup parameters for the design of a commercial-size demonstration plant.

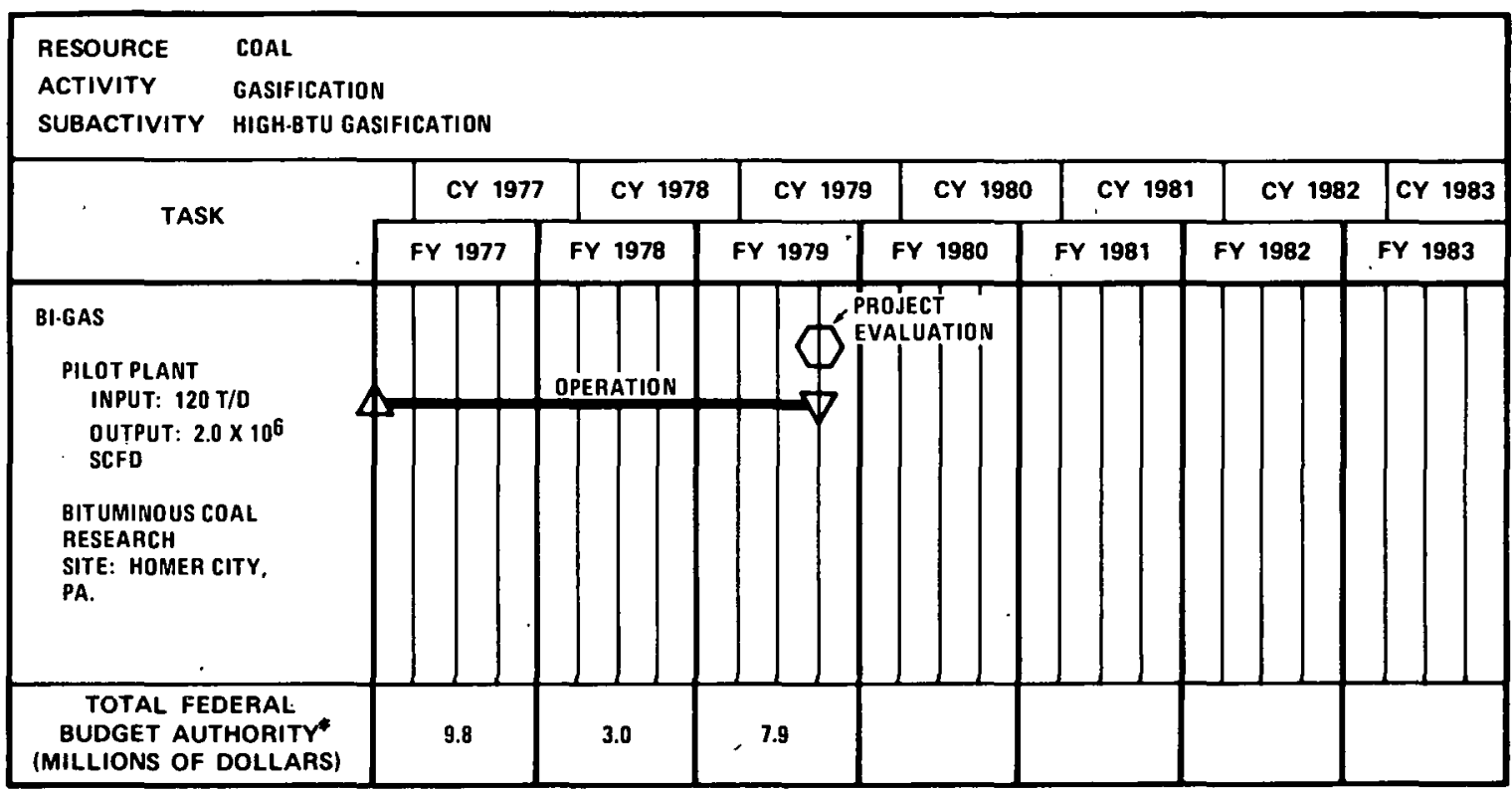

MILESTONE SYMBOLS ARE DEFINED ON LAST PAGE OF THIS DOCUMENT "FURTHER BUD GET DETAILS ÁRE PROVIDED IN SECTION 6.0.

\subsection{SYNTHANE PILOT PLANT}

The key feature of the Synthane process is that pretreatment of caking coals is integrated with gasification. Another feature is that gas with high methane content is produced directly and requires only light methanation to achieve high-Btu ratings. The process offers other advantages:

- Caking coals can be used directly, as can a wide range of other coals, including lignite.

- Hydrocarbons released during pretreatment are used within the system, thereby maximizing the efficiency of coal conversion to gas: 
- Oxygen requirements are reduced by maximizing methane production in the gasifier.

- The process flow system and equipment are relatively simple.

Coal crushed to -20 mesh is dried, pressurized to approximately 70 atm, and transferred into the fluidized-bed pretreater by means of highpressure steam and oxygen. Pretreatment provides a mild oxidation of the coal particle surface so that caking coals will not agglomerate in the gasifier. The coal overflows from the pretreater into the top of the fluidized-bed gasifier about 10 feet above the bed level, falls through hot gases rising from the fluidized bed, and is devolatilized. This devolatilization contributes significantly to the methane yield. Steam and oxygen occurs within the fluidized bed. Unreaster shar flows downward into a bed fluidized with the steam and water sprays and is removed through lock hoppers. 'l'he product. gas, rnntaining methane, hydrogen, carbon monoxide, carbon dioxide, cthane, and impurilies, is passed through a venturi scrubber and a water scrubber to remove carryover ash, char, and tars. The concentration of hydrogen and carbon monoxide in the gas is then adjusted to a three-to-one ratio in a shift converter. Acid gases are absorbed in a hot potassium-carbonate scrubber. The purified gas is then sent to a methanator for final upgrading.

Two methanation systems have been proposed: a tube wall reactor, in which the catalyst is sprayed onto the tube walls of an exchanger, and a hot-gas recycle methanator, in which the catalyst is sprayed onto metal plates.

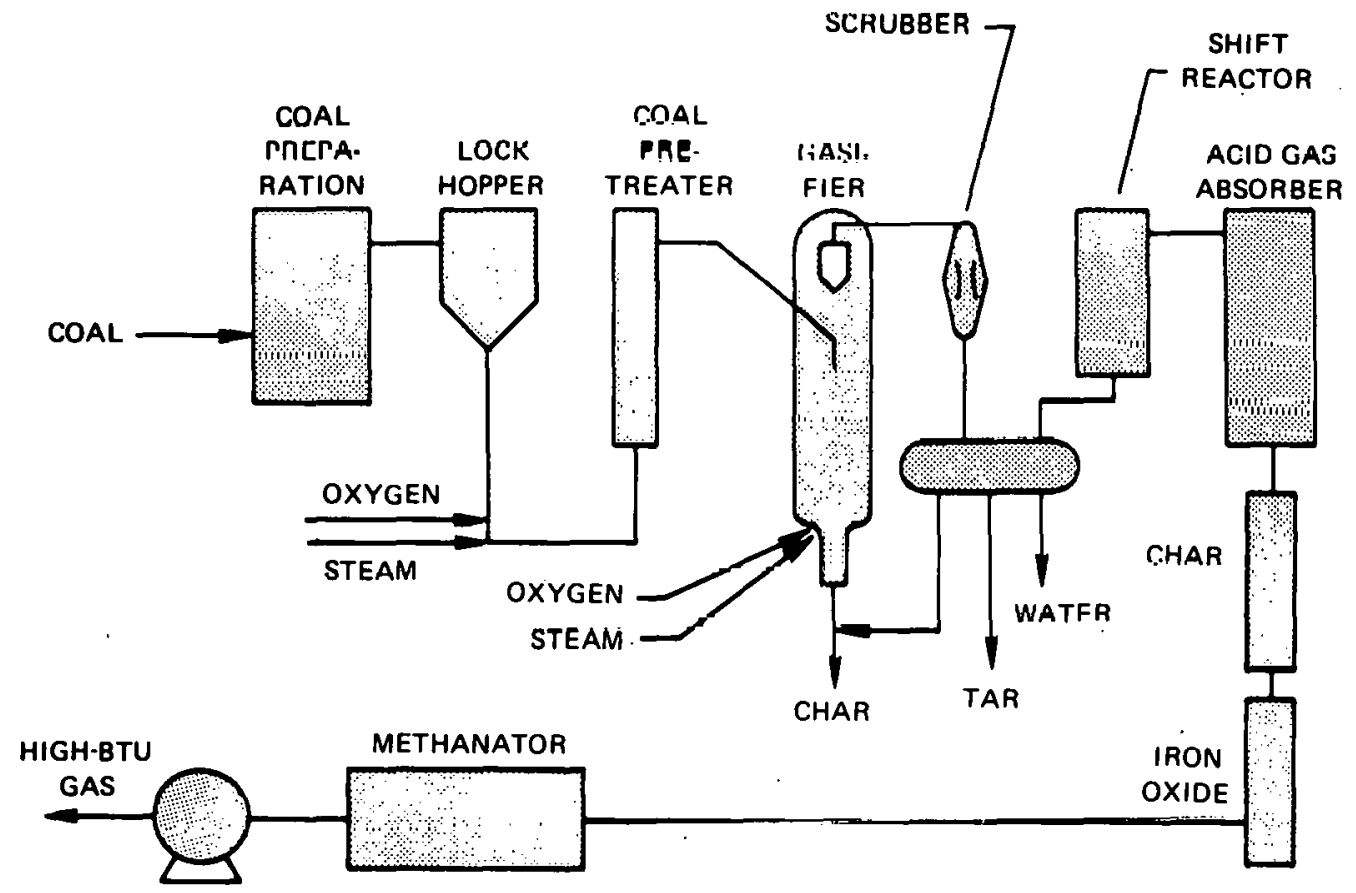

Synthane Process 


\section{Project Status}

The Synthane process has been under development by the Bureau of Mines (BOM) at Pittsburgh Energy Research Center (PERC), Bruceton, Pennsylvania, since the early 1960s. A preliminary design contract was awarded to M. W. Kellogg Company in 1970, to determine whether there were sufficient data to design a pilot plant. In June 1971, Lummus was awarded a contract to design a 75-tons/day Synthane pilot plant, which was built by Rust Engineering in 1975. Lummus is now operating the pilot plant to acquire data to evaluate technical and operational feasibility of the process and to provide information required for scaleup.

The following areas are being investigated on pilot scale:

- Solids handling: lock hoppers for coal feed and char removal

- Gasification: hydrogasification in fluidized beds and a steam jacketed reactor

- Purification: hot potassium carbonate in packed towers with char and iron oxide towers

- Methanation catalytic reactor systems: 1) tube wall reactor (catalyst sprayed on inside of tubes), and 2) hot product-gas recycle catalyst.

Final construction was completed in the end of CY 1976. Nonagglomerating coals were tested in FY 1977. Tests on agglomerating coals began in late FY 1977 and will continue to the end of FY 1978. In early FY 1979, mechanical reliability tests are planned, after which time a decision to cease or extend operations will be made.

The pilot plant has been successfully operated on Rosebud subbituminous coal. The results showed that pipeline gas from such coals could be produced for approximately $\$ 3.50 /$ million Btu. A feature of these pilot plant runs was demonstration that the environmental impact of the Synthane process could be minimized by adjustments to operating techniques. This resulted in a decrease in capital costs and an improvement in operating efficiency. Current operation is aimed at use of agglomerating, bituminous coals. 


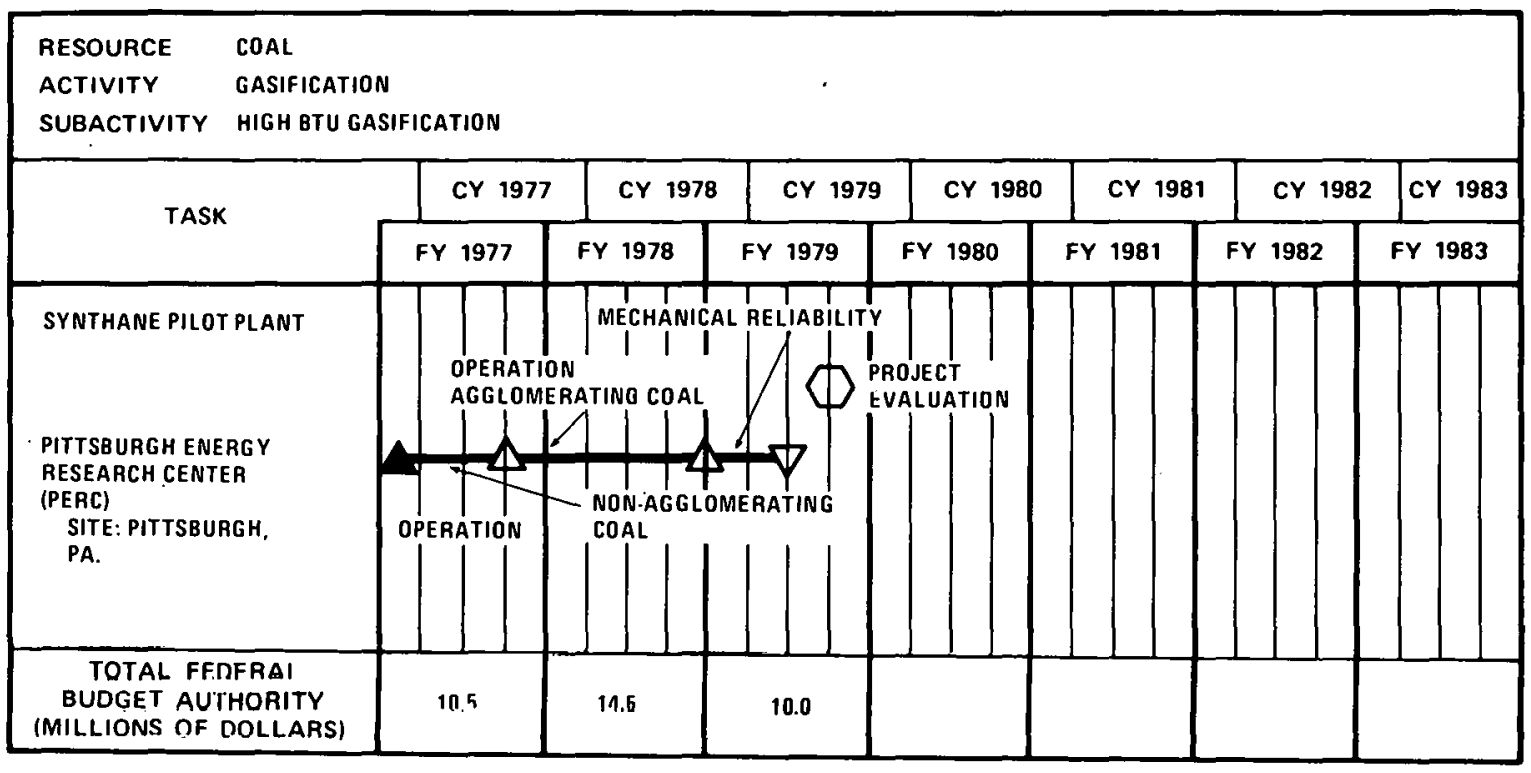

MILESTONE SYMBOLS ARE DEFINED ON LAST PAGE OF THIS DOCUMENT

\subsection{STEAM IRON PILOT PLANT}

The Steam Iron process is intended to produce hydrogen, which is used in the hydrogasification of coal. The system consists of two principal vessels: a producer, in which residual char is converted to $\mathrm{CO}$ and $\mathrm{H} 2$, and a steam iron reactor, in which iron ore is continuously and cyclically reduced by the $\mathrm{C} 0$ and $\mathrm{H}_{2}$ and oxidized with steam to produce hydrogen. The steam iron reactor is divided into two zones: reducer and oxidizer. Each zone contains two fluid beds. The reactor system can operate at a pressure of 1,100 psig and at temperatures up to $2000^{\circ}$ in the producer and $1600^{\circ} \mathrm{F}$ in the steam iron reactor. Other major equipment includes a highpressure slurry heater, spent-char pressure letdown vessel, and product gas-quenching and disposal system.

Char is fed into the producer vessel and reacts with air and steam to generate a reducing gas. The hot reducing gas is fed to the oxidizer where it contacts a recirculating steam of iron oxide to produce iron. The iron is then fed to the oxidizer and reoxidized to iron oxide, producing a mixture of hydrogen and steam in the process.

The Steam Iron process is relatively complex in comparison to other hydrogen-producing systems because it introduces another reactor system into the overall coal-to-gas process. This system requires solids recirculation at high pressure. However, the system offers potential advantages such as elimination of the need for a large oxygen plant, and reduction in the amount of carbon dioxide scrubbing. 


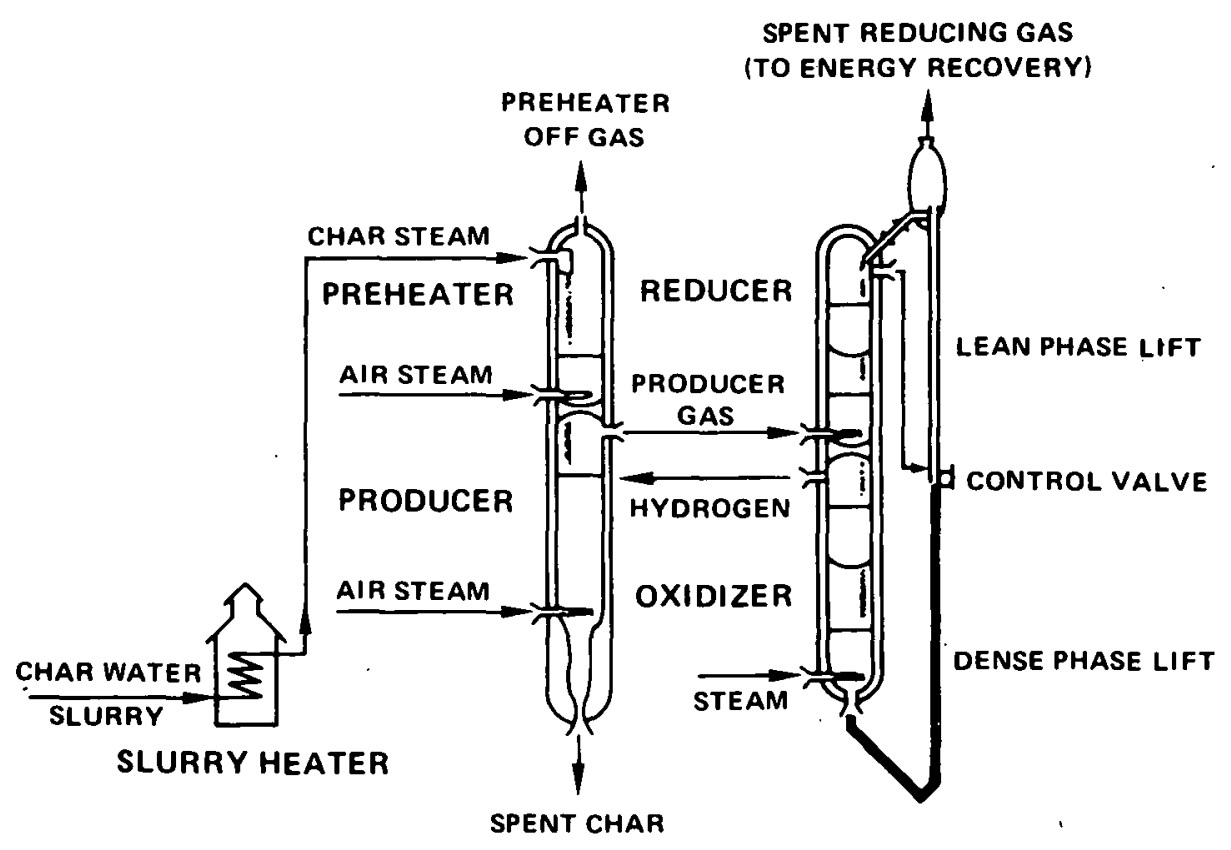

Steam Iron Process

\section{Project Status}

Although the fixed-bed Steam Iron process for making $\mathrm{H}_{2}$ is old, the IGT approach represents a novel application of fluidized-bed technology to produce hydrogen continuously at elevated pressures.

The development of this process involves design, construction, and operation of a pilot plant to generate data for the design of a commercial source of hydrogen for hydrogasification of coal.

The Steam Iron pilot plant was constructed by Dravo Corporation at IGT in Chicago. The startup phase began in July 1976, and continued through December 1977. The operational evaluation began in FY 1978. Considerable effort will be put into developing and solving problems related to lifting systems and attrition during FY 1978.

The principal effort in the operational evaluation phase will be directed at producing hydrogen, studying the major operating variables, and obtaining data necessary to optimize the process for scaleup. 


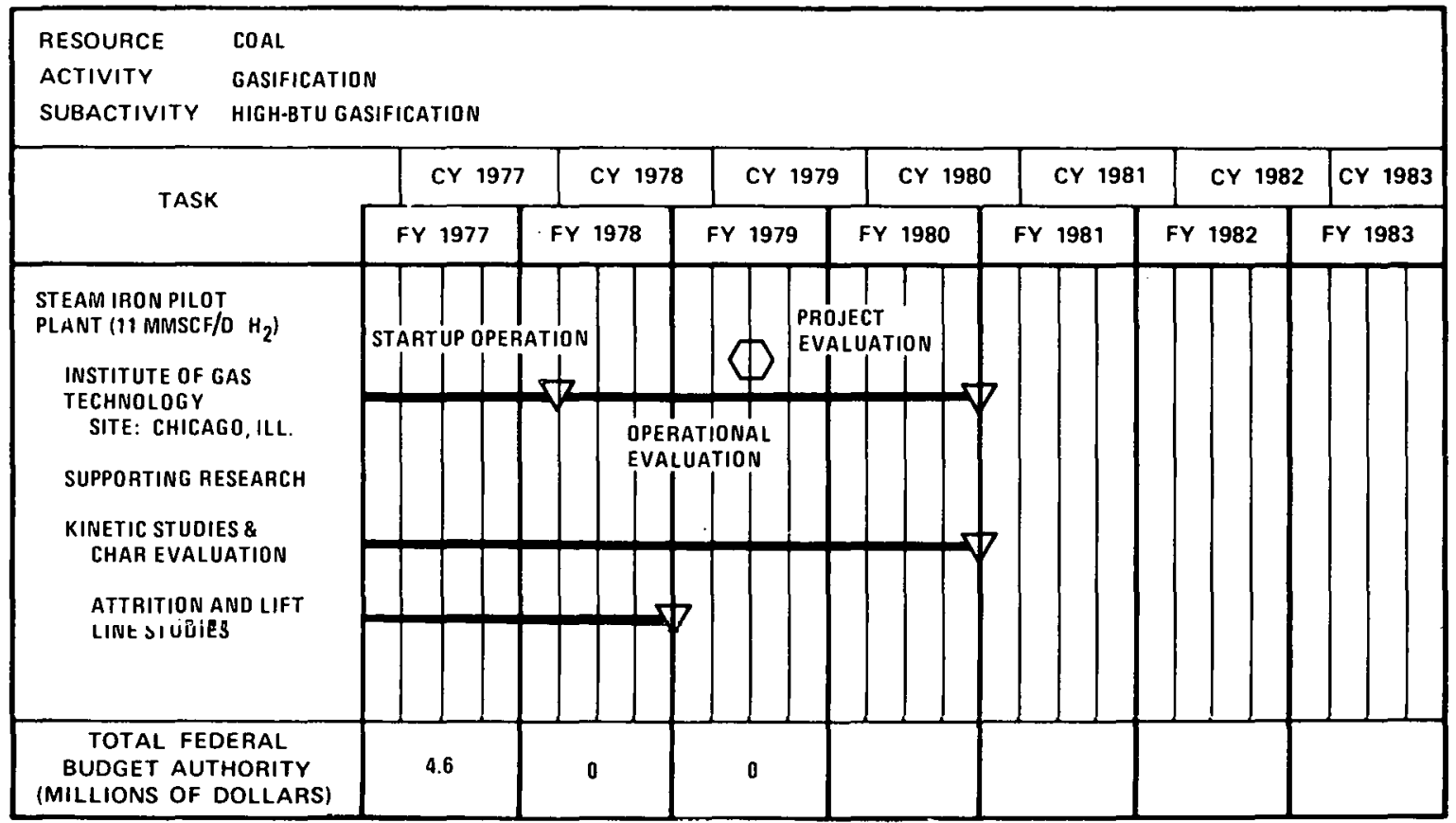

MILESTONE SYMBOLS ARE DEFINED ON LAST PAGE OF THIS DOCUMENT

\section{Third-Generation Gasification Techniques}

Two third-generation processes which offer greater economics potential are under development: .

- Hydrogasification

- Catalytic gasification .

\subsection{HYDROGASIFICATION}

Hydrogasification is a coal conversion process to produce high-Btu gas by the direct reaction of hydrogen with coal. From a thermodynamics standpoint, this method has excellent potential for maximizing thermal efficiency and producing the least costly synthetic pipeline gas. Elliot and von Fredersdorff, in the coal gasification chapter of Lowry's book Chemistry of Coal Utilization, state, "The hydrogasification of coal to produce methane has an inherent thermochemical advantage in comparison. with the catalytic methanation of synthesis gas produced by gasifying coal with oxygen and steam." This advantage was exploited in the early hydropyrolysis experimentation at the Bureau of Mines, which led to thc development of the lwo-slage Hydrane process. As this process matured to pilot plant status, two developments occurred independently. In the first, Cities Service demonstrated a laboratory-scale, entrained-bed, single-stage hydrogasifier with short-residence-time characteristics. In the second, Rocketdyne showed potential for using rocket combustor technology to achieve improved mixing with high mass fluc through=put in a hydrogen/coal reactor. It was determined that the two-stage Hydrane reactor was too complex for commercial application, and that a singlestage, short-residence-time hydrogasifier based on rocket principles was a much more viable option. A conceptual flowsheet for the overall process is shown below. 


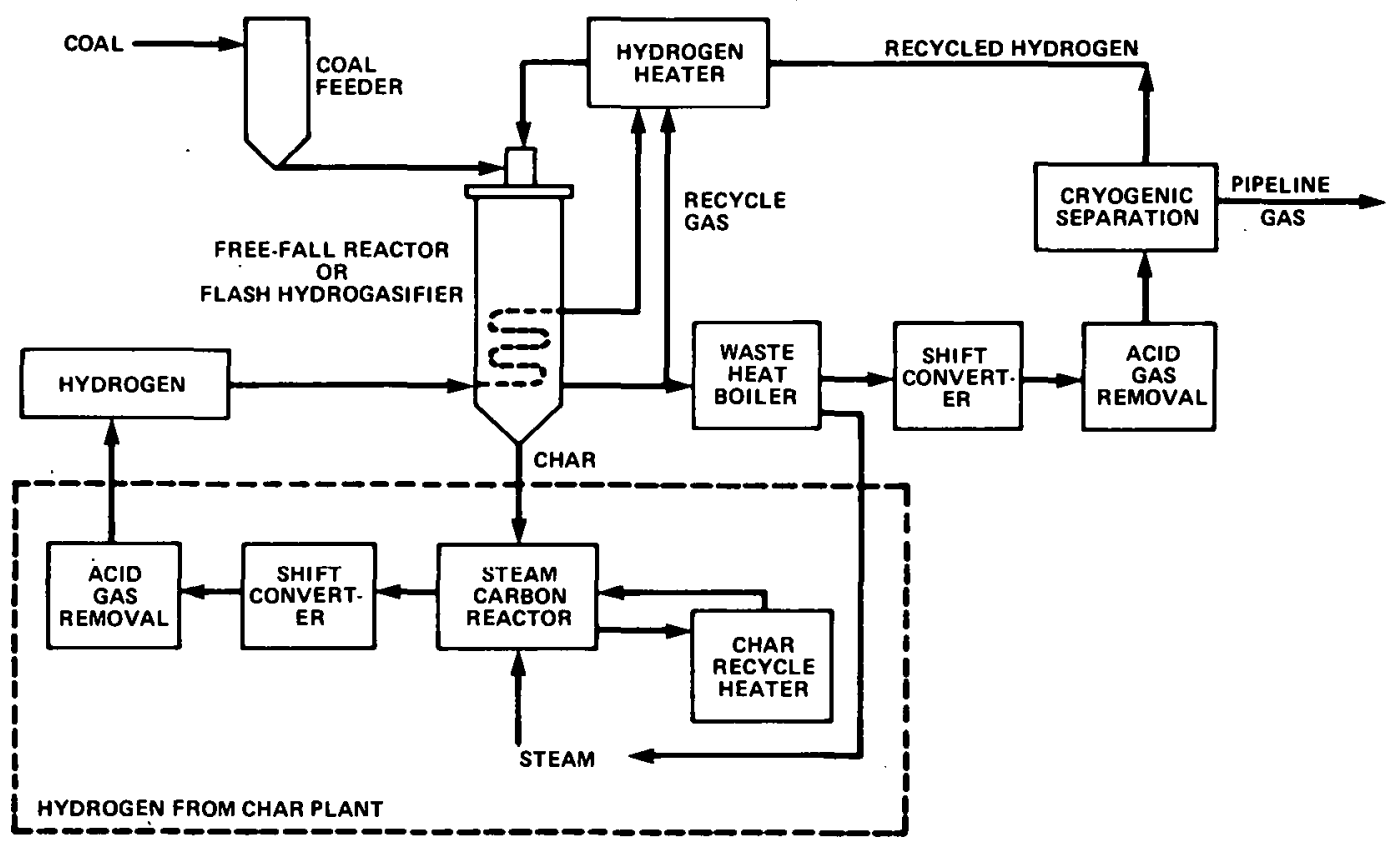

Hydrogasification Process

\section{Project Status}

Hydrogasification has been under development at the Pittsburgh Energy Research Center since the early 1960s. A principal result was the Hydrane reactor. Current contractual efforts are geared to development of an advanced reactor concept with superior commercial potential. Strategy involves testing and development to generate data for use in commercialscale plant design.

Present plans are based on the following:

- FY 1977-1978: Hydrogasification feasibility study

- FY 1978-1981: Advanced development and preliminary design

- FY 1980-1985: Design, construction, and operation of very large pilot or demonstration plant

Tests are currently under way at two levels of operation: $2-4 \mathrm{lb} / \mathrm{hr}$ and .25 ton/hr. Approximately 50 runs were completed with the best results for bituminous coal: carbon conversion, 59 percent; temperature, $1950^{\circ} \mathrm{F}$; pressure, $1,500 \mathrm{psig}$; residence time, $750 \mathrm{msec}$. 


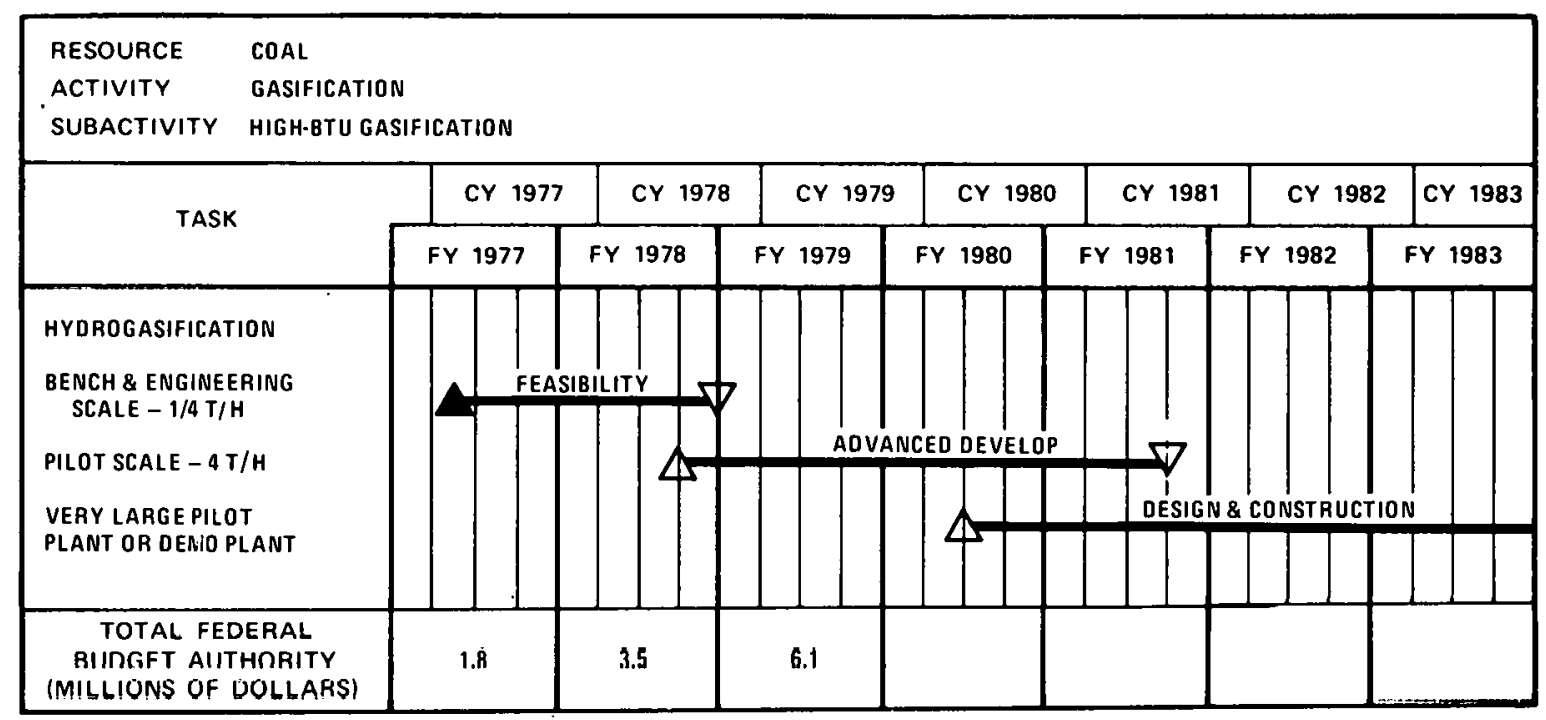

MILESTONE SYMBOLS ARE DEFINED ON LAST PAGE OF THIS DOCUMENT

\subsection{CATALYTIC GASIFICATION PILOT PLANT}

In the Exxon Catalytic Coal Gasification process, carbon monoxide and hydrogen are recycled to the reactor to keep the $\mathrm{CO} / \mathrm{H}_{2}$ content as high as possible, thus forcing the net products of gasification reactions to be $\mathrm{CO}_{2}$ and $\mathrm{CH}_{4}$. The recycle rate is set such that there is no net yield of $\mathrm{CO}$ and $\mathrm{H}_{2}$ in the gasifier.

Coal entering the system is impregnated with a recovered make-up catalyst prior to entering the reaction vessel, where the coal is gasified with steam at $1200^{\circ}$ to $1400^{\circ} \mathrm{F}$ in the presence of equilibrium concentrations of $\mathrm{CO}$ and $\mathrm{H}_{2}$. The gasifier product gas exchanges heat with incoming water, generating steam. The steam and recycled $\mathrm{CO} / \mathrm{H}_{2}$ are preheated to about $150^{\circ} \mathrm{F}$ above gasification temperatures prior to injection to balance system heat loss.

Char/ash residue containing catalyst is removed from the gasifier. Latalyst is recovered by water through a countercurrent leaching operation. It is estimated that 50 to 75 percent of the carbonate may be reclaimed in this manner. Some catalyst reacts with coal-ash to form an insoluble potassium aluminosilicate, with about 5-percent weight of coal feed estimated lost in the insoluble form. Recovery of the remaining potassium by routes such as acid wash of char is currently being investigated.

After cooling the product gas and generating the steam required for the process, the gas is sent to a series of separation steps to produce $\mathrm{CO}_{2}$ (which is vented), product methane, and recycle $\mathrm{CO} / \mathrm{H}_{2}$.

Advantages of the Catalytic SNG process are:

- Pretreatment is not required for caking coals. 
- The need for oxygen or other means of providing high level heat directly in the gasifier is eliminated.

- Gasifier temperatures are reduced.

- Shift and methanation steps are eliminated.

- Potentially higher thermal efficiency than that of thermal coal gasification processes is possible because of reduced need for high-level heat input and greatly reduced heating and cooling of gas streams.

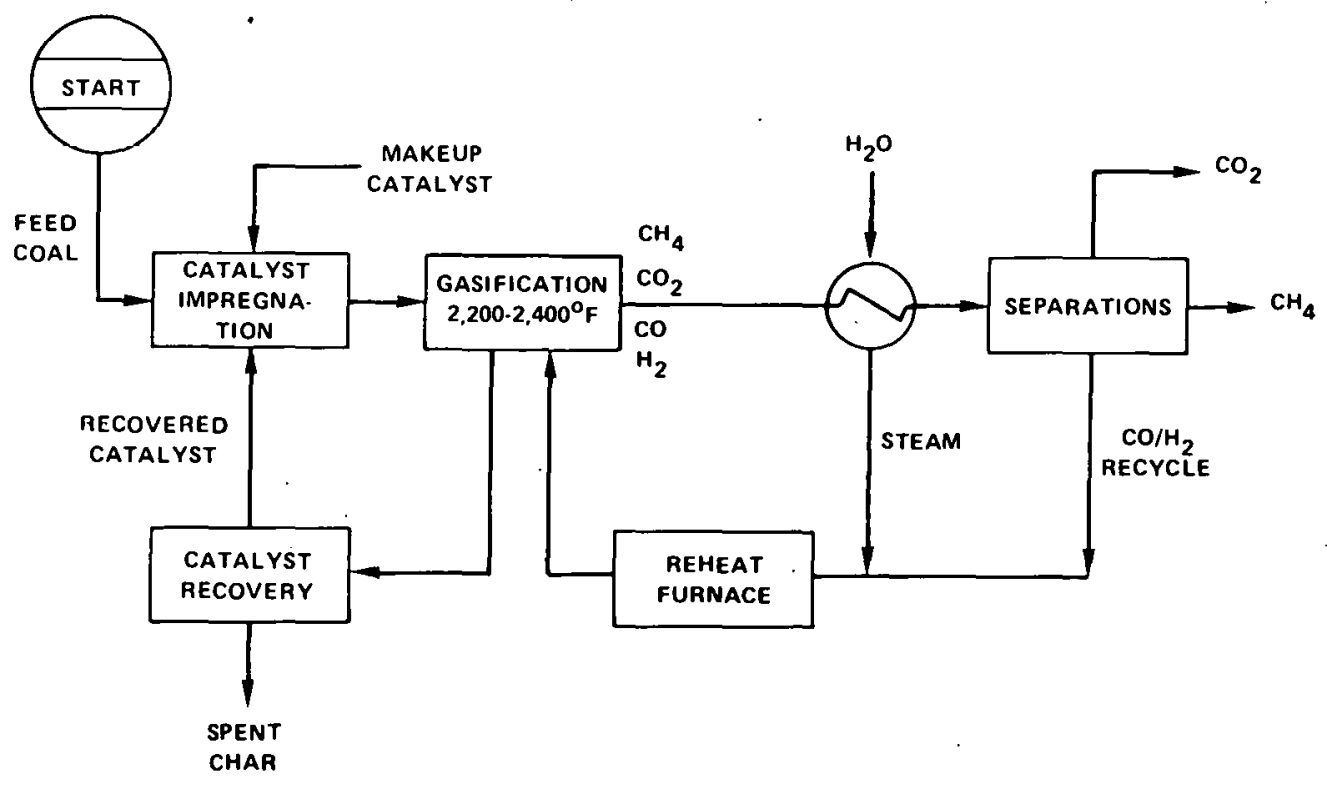

Catalytic Gasification Process

\section{Project Status}

The Exxon Catalytic Coal Gasification process is under development at Exxon's research facilities in Baytown, Texas, with DOE support. Benchscale work on catalytic gasification has been in progress since 1968. The current plan is to continue bench-scale development to obtain scaleup information for design and operation of a pilot plant. The PDU is being constructed during FY 1978. Operation will begin at that time and will continue to mid-FY 1980. Bench-scale research and development (R\&D) and engineering will be continuous through the entire time period.

There is a simultaneous feasibility study being performed by Exxon Research and Engineering Company (ER\&E) at Florham Park, New Jersey, to estimate the costs of conversion of an existing pilot plant, as opposed to new construction of a ground roots plant. This work is scheduled for implementation June 1978. To date the Synthane pilot plant appears most suitable for conversion. Basic and detailed design are to follow during FY 1979. 
COAL RESOURCE

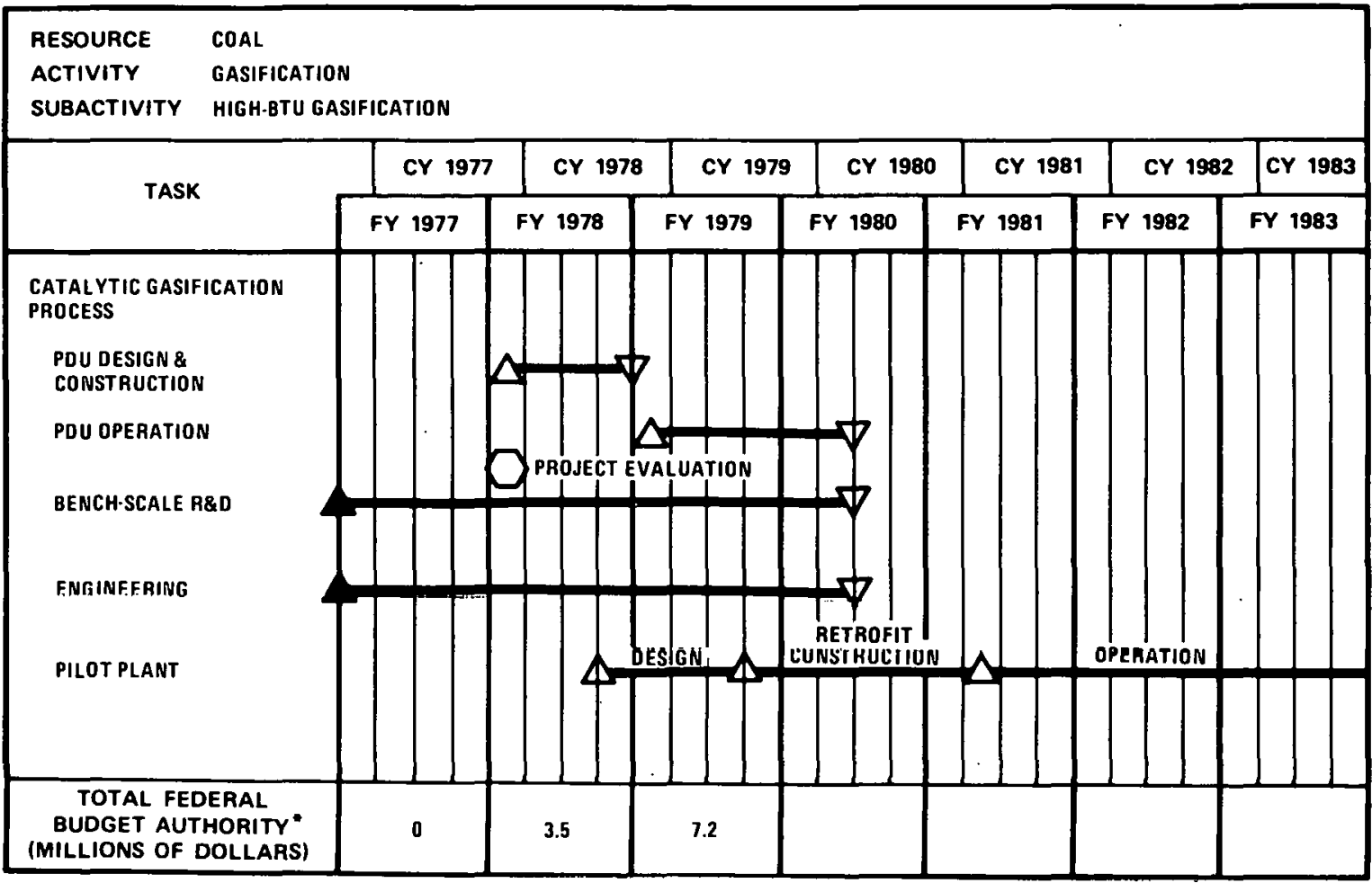

MILESTONE SYMBOLS ARE DEFINED ON LAST PAGE OF THIS DOCUMENT

"FURTHER BUDGET DETAILS ARE PROVIDED IN SECTION 6.0. 


\subsection{LOW-BTU GASIFICATION}

The potential market for clean-burning low-Btu gas as a fuel for electric utilities and industrial users and as a chemical feedstock has increased as a result of the energy crisis, the decrease in natural gas reserves, and more stringent environmental regulations.

The objectives of the Low-Btu Gasification Activity are:

- To develop and demonstrate, in cooperation with industry, the technology for construction of commercial-scale plants to convert coal to environmentally acceptable gaseous fuels with a heating value of 100 to $500 \mathrm{Btu} / \mathrm{scf}$

- To establish the required techniques for utilizing these coalderived gaseous fuels for chemical feedstocks, industrial fuels, and combined-cycle systems for electric power generation

- To provide incentives required to promote production and utilization of low-Btu gas by private industry.

Low-Btu gasification is a promising method of using coal as a utility and industrial fuel in an economic and environmentally acceptable manner. The generation of low-Btu gas from coal requires a less complex plant than that required for production of high-Btu gas. As a result, capital and operating costs are lower per equivalent Btu. For the most economical generation of electric power, low-Btu gas can fuel a gas turbine/steam turbine combined-power cycle. Low-Btu gas also can be used in industrial plants normally dependent on natural gas, oil, or coal. In all cases, the lower heating value of low-Btu gas compared to natural gas requires that the low-Btu gas be utilized at or near the production site

A recently identified opportunity for conversion of existing and new facilities normally designed for use of natural gas and fuel oil to coalderived gas exists through the production and end-use of medium-Btu gas. This coal-derived fuel gas with a heating value of 240 to $300 \mathrm{Btu} / \mathrm{scf}$ can be produced at lower cost than pipeline gas. It may be utilized with only minor modifications in most existing facilities designed for natural gas or fuel oil. A major effort is in progress to identify the potential of gasifiers currently in use or under development for conversion to the production of medium-Btu gas.

The primary activity of this subprogram is the economical integration of luw-Blu gasifiers, gas cleanup syctems, and end-use systems. Tn achieve this result for power generation, construction of the Powerton combined-cycle test facility at Pekin, Illinois, will begin in FY 1978. At this facility, state-of-the-art and advanced concepts for gasification and gas purification will be tested in an integrated system together with gas turbine generators. This program is aimed at achieving integrated operation by early FY 1979. 
For industrial use of low-Btu gas, Program Opportunity Notices (PONs) were released for the Gasifiers in Industry and the Hydrogen-from-Coal projects. Six proposals received in response to the Gasifiers in Industry RFP were selected for negotiation, covering a variety of industrial and institutional uses for low-Btu gas from coal. Proposals received for the Hydrogen-from-Coal facility are being evaluated and a contract for conceptual design of a facility is expected to be awarded in FY 1978 .

Concurrently, promising new concepts for improved gasification techniques are being actively researched at the PDU and pilot plant level. These include fixed-bed, entrained-bed, fluidized-bed, and molten salt systems. Improved gas cleanup methods that will operate at elevated temperature and pressure are under development. These will enhance the economic potential of low-Btu gas as a clean industrial and public utility fuel. These new techniques will be tested as components of integrated systems combining gas production, gas cleanup, and gas utilization units to establish their operability and economic potential.

Significant progress has been made in these development projects. The atmospheric pressure entrained-bed PDU is being constructed, with startup planned for late FY 1977. Successful, continuous operation of the devolatilization and gasifier sections of the two-stage fluidized-bed PDU has demonstrated that the unit can devolatilize caking coals without pretreatment and can successfully agglomerate a variety of coal and char feed materials. The molten salt gasification plant is currently in its final design stage at its new site in California. This plant was relocated from Connecticut to take advantage of better supporting facilities at the new site. Design data and a full plant definition are nearing completion for the pressurized entrained-bed pilot plant.

Although low-Btu coal gasification promotes the environmentally acceptable use of coal, environmental impacts are associated with the processing and conversion of coal. A major concern associated with the low-Btu activity is that air, water, and solid waste emissions may exceed local environmental standards for pilot plant facilities. This concern is being dealt with by Fossil Energy, in cooperation with the Environmental Protection Agency. Environmental monitoring and research studies of Puture low-Btu facilities are being coordinated. Environmental reviews and evaluations of proposed low-Btu sites are being made prior to selection in order to anticipate potential environmental and socioeconomic problems. Modern environmental control techniques are being used in the pilot plant designs to evaluate their acceptability. New techniques for trace element control, water reuse and cleanup, and control of very fine particulates are being researched to lessen the environmental impact of low-Btu gas utilization systems. 
Low-Btu gasification processes and techniques currently being investigated include:

- Fixed-Bed Gasification, Stirred Process

- Fixed-Bed Gasifier, Slagging Process

- Fluidized-Bed Gasification, Two-Stage Pressurized Process

- $\quad$ Fluidized-Bed Gasification, Fast Fluid-Bed Process

- Fluidized-Bed Gasification, Three-Stage Pressurized Process

- Entrained-Bed Gasification, Atmospheric Process

- Combined-Cycle Test Facility

- Molten Salt, Pressurized Process

- Hydrogen-from-Coal Process

- Ash Agglomeration

- Gasifier in Industry.

The table below summarizes the level of funding by task for the FY 1977 to FY 1979 period.

\begin{tabular}{|c|c|c|c|c|c|}
\hline \multirow{2}{*}{$\begin{array}{l}\text { LOW-BTU GASIFICATION } \\
\text { TASKS }\end{array}$} & \multicolumn{4}{|c|}{$\begin{array}{c}\text { BUDGET AUTHORITY } \\
\text { (OPERATING EXPENSES) } \\
\text { (OOLLARS IN THOUSANDS) }\end{array}$} & \multirow{2}{*}{$\begin{array}{l}\text { MAJOR } \\
\text { CHANGE. }\end{array}$} \\
\hline & $\begin{array}{l}\text { ACTUAL } \\
\text { FY } 1977\end{array}$ & $\begin{array}{c}\text { APPROPRIATION } \\
\text { FY } 1978\end{array}$ & $\begin{array}{l}\text { ESTIMATE } \\
\text { FY } 1979\end{array}$ & $\begin{array}{l}\text { INCREASE } \\
\text { (DECREASE) }\end{array}$ & \\
\hline $\begin{array}{l}\text { Fixed-Bed Gasification } \\
\text { Fluid-Bed Gasification } \\
\text { Entrained-Bed Gasification } \\
\text { Atmospheric PDU } \\
\text { Combined-Cycle Test Facility } \\
\text { Molten Salt Pressurized PDU } \\
\text { Hydrogen-from-Coal Facility } \\
\text { Ash Agglomeration } \\
\text { Gasifiers in Industry }\end{array}$ & $\begin{array}{r}\$ 2,950 \\
1,700 \\
\\
500 \\
16,500 \\
1,000 \\
5,000 \\
0 \\
1,000\end{array}$ & $\begin{array}{r}\$ 4,550 \\
5,000 \\
0 \\
0 \\
20,000 \\
0 \\
15,000 \\
1,300 \\
10,000\end{array}$ & $\begin{array}{r}\$ 6,500 \\
4,000 \\
1,490 \\
10,000 \\
0 \\
11,610 \\
0 \\
2,000\end{array}$ & $\begin{array}{r}\$+1,950 \\
-1,000 \\
+1,490 \\
-10,000 \\
0 \\
-3,390 \\
-1,300 \\
-8,000\end{array}$ & \multirow[t]{2}{*}{$\begin{array}{l}\text { A } \\
1 \\
P \\
1 \\
1 \\
C \\
1\end{array}$} \\
\hline TOTAL & $\$ 28,650$ & $\$ 55.850$ & $\$ 35,600$ & $\$-20,250$ & \\
\hline \multicolumn{3}{|c|}{$\begin{aligned} & \text { *KEY } \\
& N= \text { New start (totally new project) } \\
& S=\text { Scaleup (from bench to PDU or pilot plant) } \\
& A=\text { Acceleration (shortening deadlines or } \\
& \text { expansion of ongoing projects) }\end{aligned}$} & \multicolumn{3}{|c|}{$\begin{array}{l}P=\text { Phase completion or startup } \\
R=\text { Program redirection } \\
I=\text { Incremental cost requirement } \\
C=\text { Project completion or suspension }\end{array}$} \\
\hline
\end{tabular}

\subsection{FIXED-BED GASIFICATION, STIRRED PROCESS}

The objective of this project is to produce low-Btu gas for testing of cleanup and combustion systems. The current system consists of three major sections: gasification, particulate removal, and sulfur removal. A test combustion section will be added in the future.

Unsized coal is fed from lock hoppers into the top of the gasifier, which operates at $300 \mathrm{psi}$. Steam and air are introduced below the grate at 
the bottom. The nominal steam/coal feed ratio is $1: 2$ and the air/coal ratio is $3: 1$. Gasifier temperatures range from $2400^{\circ} \mathrm{F}$ just above the grate to $800^{\circ}$ to $1200^{\circ} \mathrm{F}$ at the gas exit. A water-cooled stirrer is used to control caking and to eliminate voids. The product gas has a heating value of 130 to $170 \mathrm{Btu} / \mathrm{scf}$.

From the gasifier, the gas is passed through a cyclone and a tar condenser to remove particulates and tar. It is then scrubbed with water in a venturi scrubber, a disengaging chamber, and a direct cooler/scrubber for final cleanup and cooling. $\mathrm{H}_{2} \mathrm{~S}$ is removed and converted to sulfur in a Stretford plant. The gas is passed through a pressure letdown valve and vented.

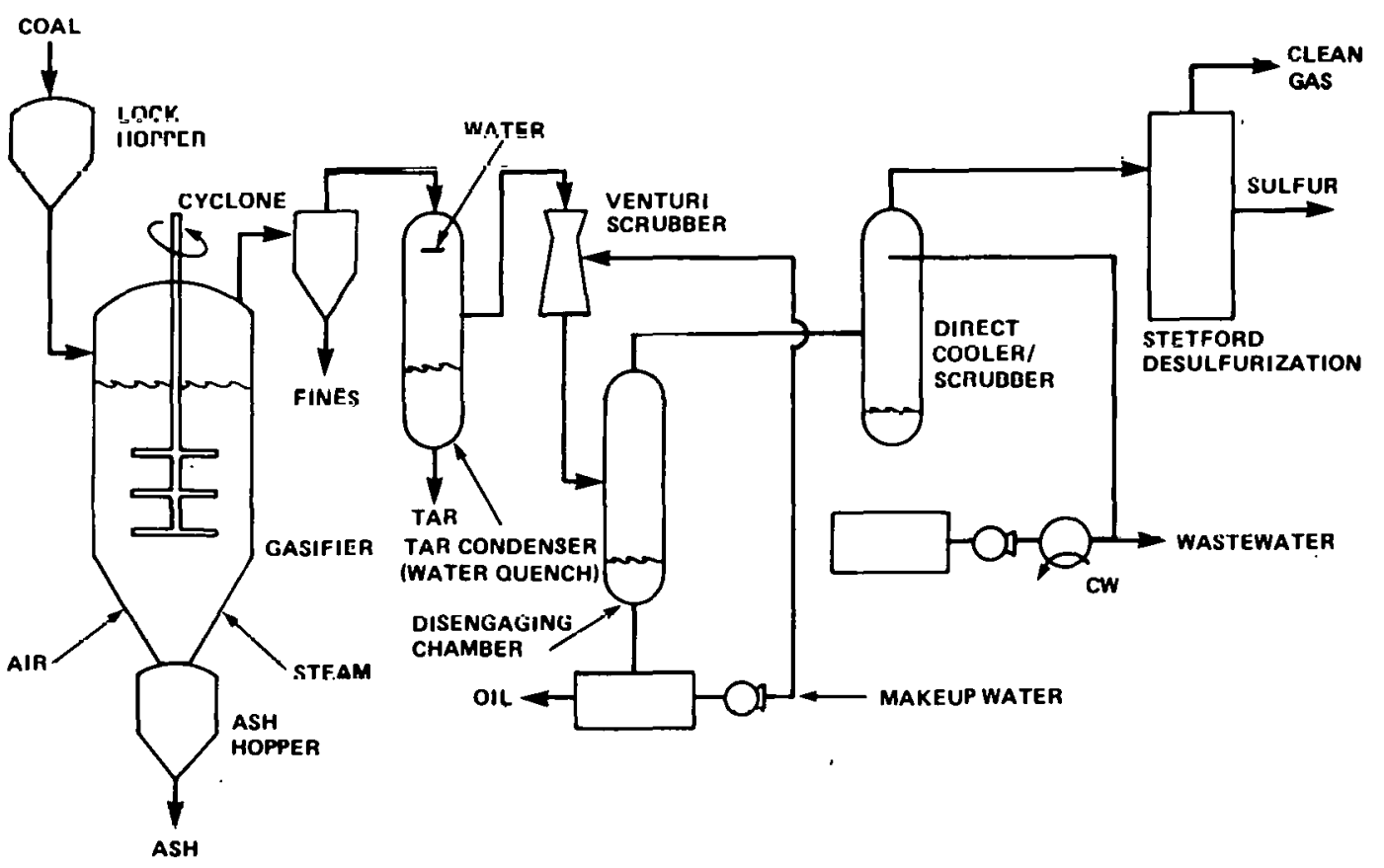

Fixed-Bed Gasification, Stirred Process

\section{Project Status}

The low-Btu gasification (moving fixed-bed) PDI has been operated at the Morgantown Energy Research Center (MERC) for several years. The system was modified in 1976 to provide improved methods for coal feeding, ash removal, stirring, lock hoppers, and data collection. The syslem is being fitted for use of oxygen as well as air.

A full flow system has been designed to clean producer gas of tars, particles, light oils, and alkali metals . 
A variety of test programs, including novel gas cleanup systems, combustion and equipment improvement, are planned. Operation of the fully integrated process, including gasifier, cleanup, and combustion, will begin in late FY 1978.

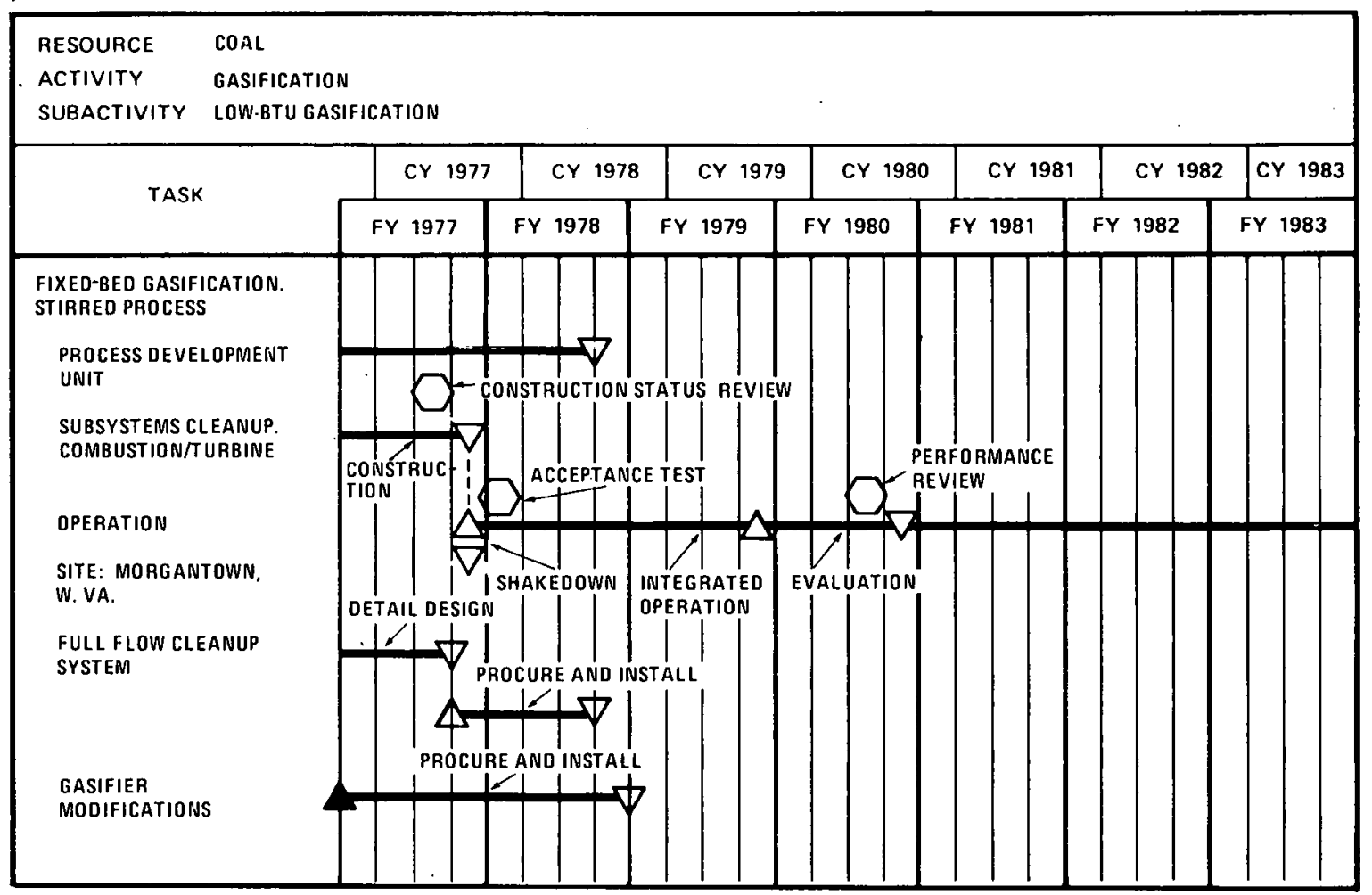

MILESTONE SYMBOLS ARE DEFINED ON LAST PAGE OF THIS DOCUMENT

\subsection{FIXED-BED GASIFIER, SLAGGING PROCESS}

Coal, periodically charged to the lock hopper, moves by gravity flow into the gas generator. Some cooled product gas is compressed and recycled through the coal lock to prevent steam and tar vapors from entering the coal lock and condensing on the incoming coal. The coal is continuously gasified by an oxygen-steam mixture introduced through four water-cooled tuyeres at the bottom of the gasifier. Molten slag is formed at the hearth and flows through a central one-inch diameter taphole into a water quench bath. Gas from the high-temperature reaction zone can be drawn through the taphole to aid slag flow. This gas is cooled and metered in a separate circuit.

The product gas leaving the gasifier contains water vapor and tar. It is scrubbed in a spray cooler with condensed recycle liquor. The gas liquor is periodically discharged from the spray cooler to a settling tank.

The washed gas is then cooled to $600 \mathrm{~F}$ in an indirect cooler before being sampled, metered, and flared. The heating value of this gas is 350 $\mathrm{Btu} / \mathrm{scf}$. 


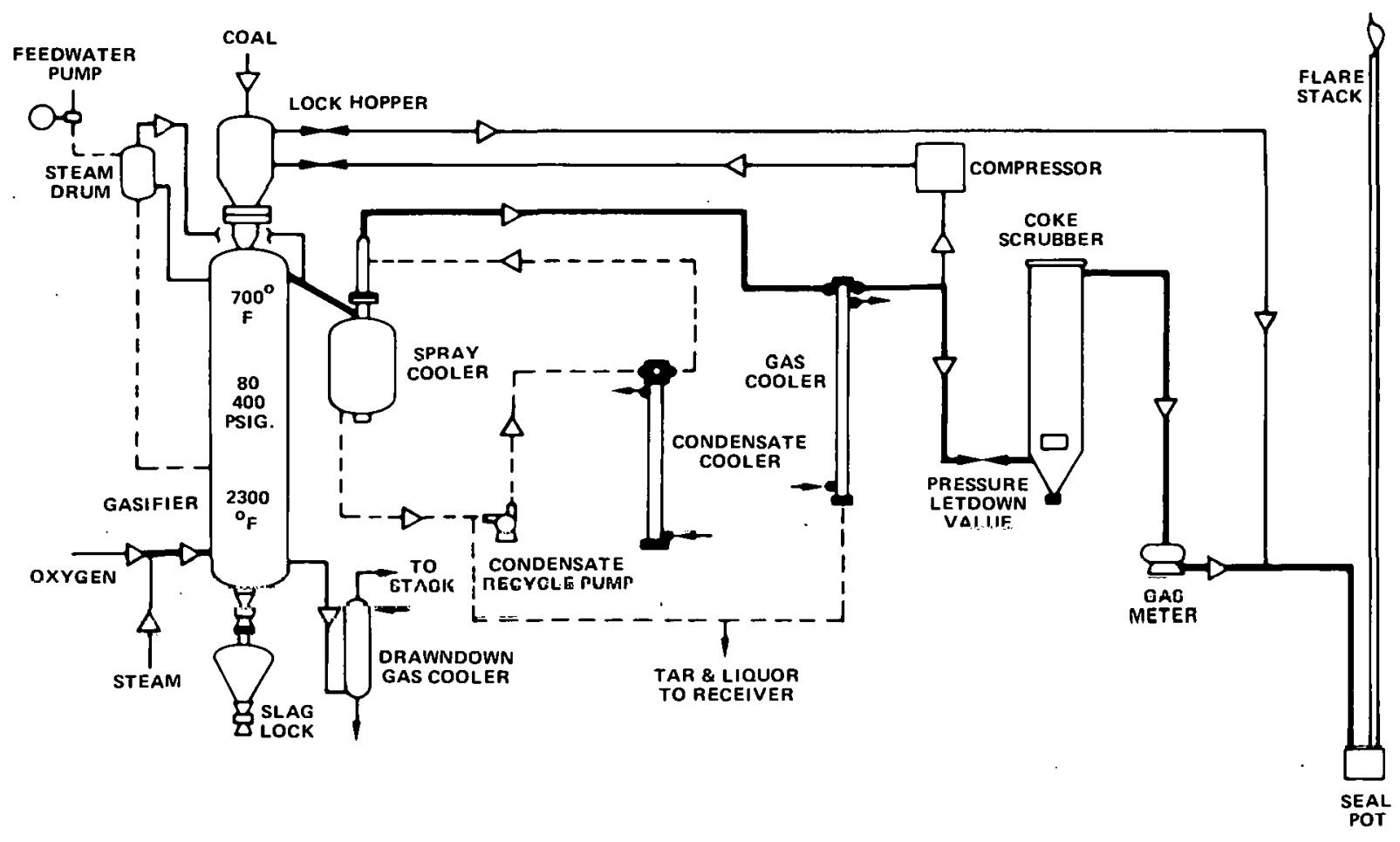

Fixed-Bed Gasifier, Slagging Process

\section{Project Status}

This projest was initiated in FY 1975 at the Grand Forks Energy Research Center and is using a 25-tons/day PDU-scale, slagging ash, fixed-bed coal gasification facility that had been constructed and operated in the late 1950 s and early $1961 / \mathrm{s}$ The results were vory favorablc in terms of capacity and steam requirements. Observations and results were reported, and the project terminated in 1966.

The reactivation of the process development gasifier is expected to be completed in early FY 1976. Methods and procedures for separating and collecting the liquid effluents from the unit will be developed. After shakedown and restoration of system operability, the priority will be to compare the liquid effluents from the pilnt unit to a commercialnscale dry ash gasifier and to an experimental slagging fixed-bed unit at Westfield, Scotland. It will be very important to determine the rate of production, characteristics, and composition of liquid effluents produced in fixed-bed gasificátion .

In FY 1977 and FY 1978, the project of comparing effluents from various western coals will be continued, and efforts will be directed to those techniques and methods by which the quantity of effluents and their composition can be altered to reduce treatment facilities required. It is also planned in FY 1978 to make modifications to the gasifier so caking as well as noncaking coals can be gasified. 


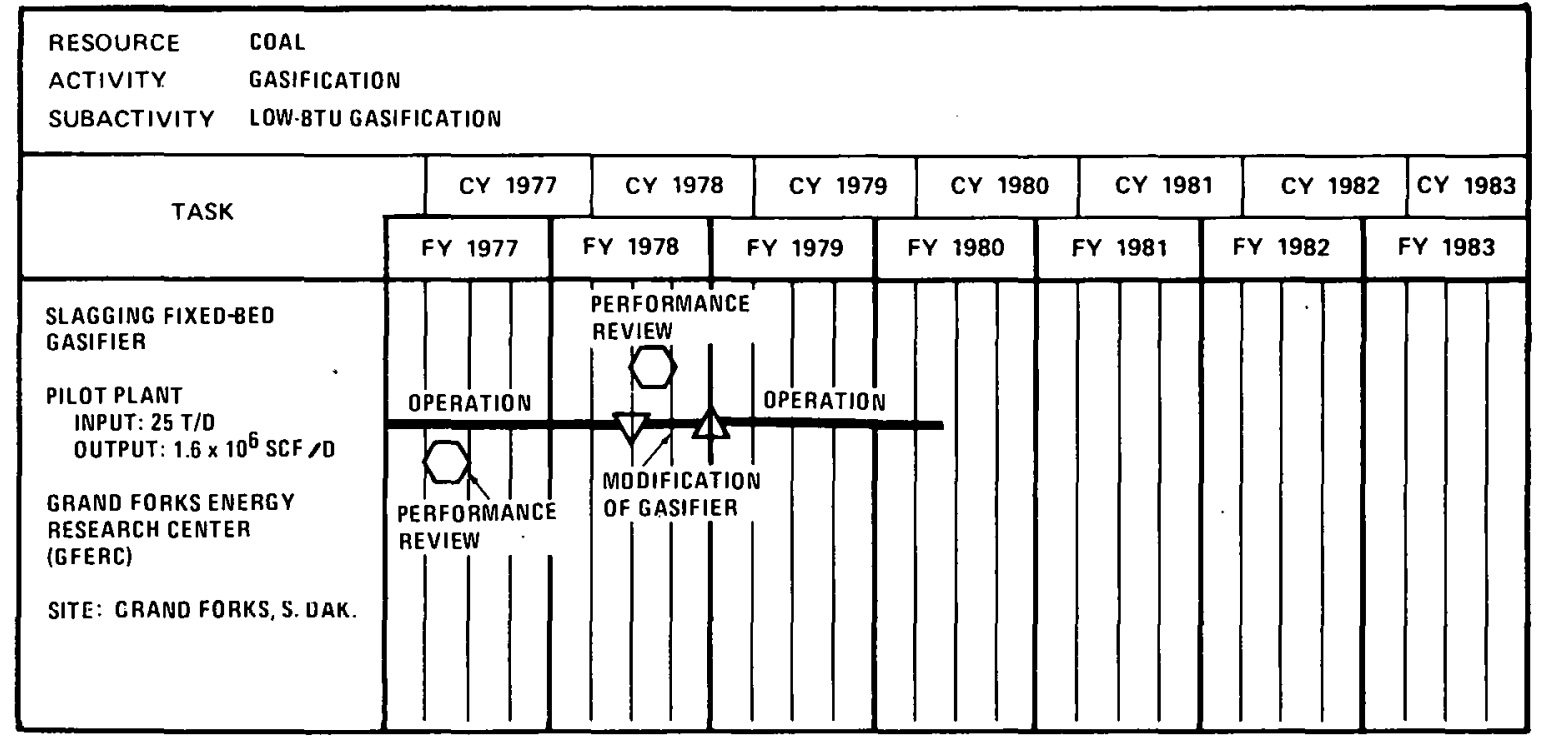

MILESTONE SYMBOLS ARE DEFINED ON LAST PAGE OF THIS DOCUMENT

\subsection{FLUIDIZED-BED GASIFICATION, TWO-STAGE PRESSURIZED}

This project focuses on the development of a low-Btu gasification process that can use caking coals without pretreatment. The conceptual process consists of two principal process units: a pressurized fluid-bed devolatilizer and a fluidized-bed gasifier-combustor.

Crushed coal is dried with recycled fuel in a fluidized-bed dryer and introduced to the devolatilizer unit through a central draft tube. The coal and rccirculating char are carried upward by hot gas flowing from the gasifier-combustor. This gas provides most of the heat to the unit; it devolatilizes and partially hydrogasifies the coal. The recycle solids, descending in the annular downcomer, are needed to dilute the feed coal and to temper the hot inlet gases. A high ratio (up to $100: 1$ ) of recycle solids to coal feed is maintained to prevent or control agglomeration of the coal as it passes through its plastic phase. A dense, dry char is withdrawn at the top of the draft tube.

Char from the devolatilizer and fines removed from the product gas are burned with air in the lower leg of the gasifier-combustor at $2100^{\circ} \mathrm{F}$ to provide gasification heat. Steam is injected into the same area for temperature control and to provide hydrogen for gasification. Ash from fines combustion agglomerates on the char ash and segregates in the lower leg for removal. Gasification occurs in a fluidized bed in the upper portion of the gasifier-combustor.

The hot low-Btu gas from the gasifier-combustor improves in heating value as it passes through the devolatilizer. The product gas from the devolatilizer is stripped of fines and ash in cyclones, cooled, and then scrubbed with water. The product gas heating value is 120 to $150 \mathrm{Btu} / \mathrm{scf}$. 


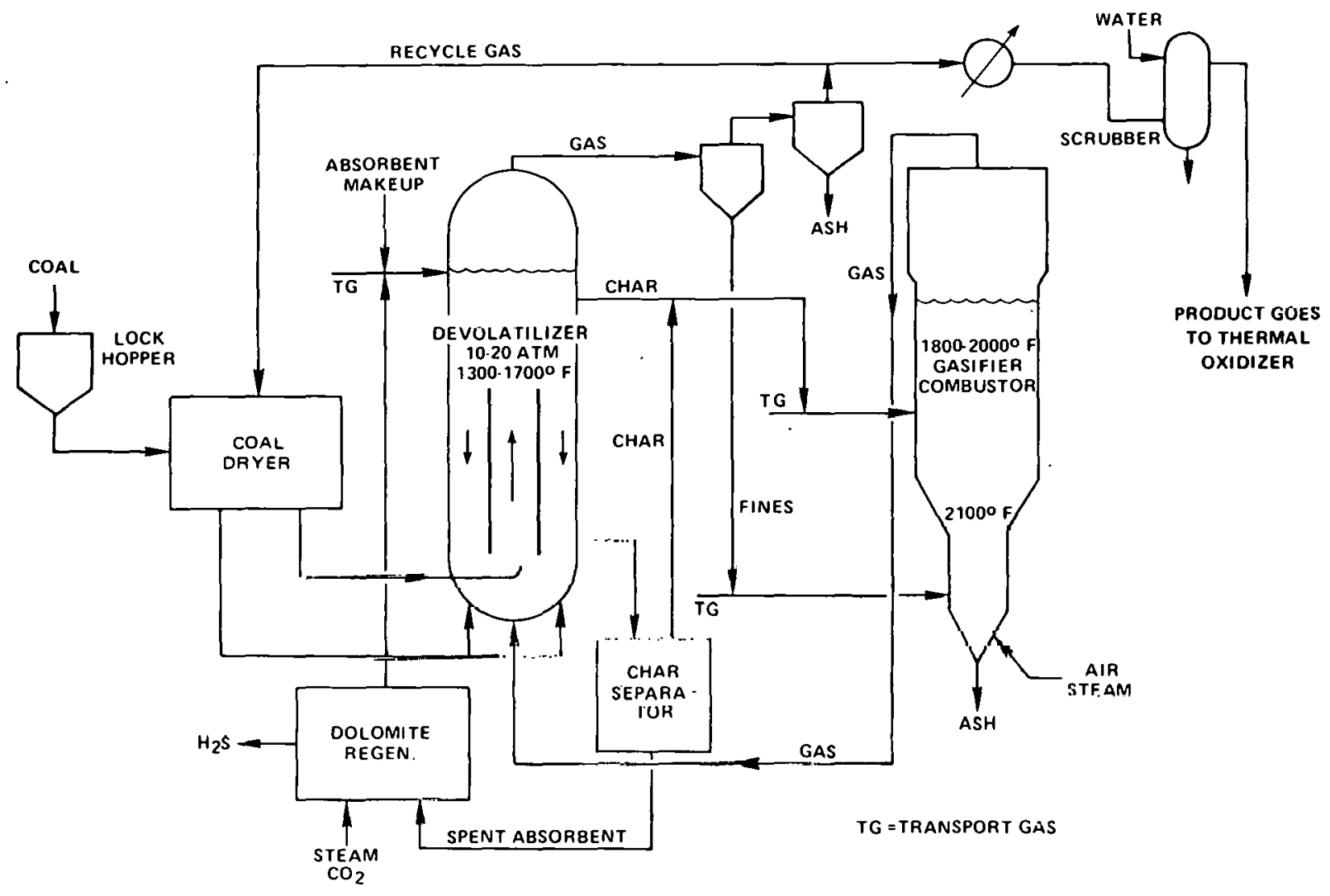

Fluidized-Bed Gasification, Two-Stage Pressurized Process

\section{Project Status}

Initial develupment of the concept involved laboratory research and the design and construction of a process devclopment unit with a coal feed design capacity of $1,200 \mathrm{lb} / \mathrm{hr}$. The PDU and its auxiliary subsystems were completed at the Westinghouse laboratory in Waltz Mill, Pennsylvania, in 1975. A test program was then initiated to establish the operating characteristics of the gasification system and to provide dala for developing scaleup factors for a pilot plant.

The test plan calls for commissioning each of the two major subsystems and then operating one independently of the other unit, until its characteristics are known and test data confirm its usefulness. Then the two units will be coupled together und the process tested as an integrated whole. A complete process, successfully operated in the PDU, should then be ready for demonstration on a pilot plant scale.

During FY 1976, operating tests of the devolatilizer subsystem were conducted with a variety of feed coals and conditions. Lengths of runs and caking tendency of coal were both progressively increased with experience. The final test, in early August 1976, was a seven-day continuous run on two highly caking Pittsburgh seam coals. These test runs demonstrated that the unit can devolatilize caking coals without 
pretreatment. The tests provided data useful in both understanding the phenomena observed and in projecting the design closer to pilot plant size. Particular attention was paid to char particle structures and to particlesize distributions measured in all the solids streams.

During FY 1977, operating tests of the gasifier-combustor were conducted with a variety of feed chars and conditions. Tests were also successfully run feeding coal directly to the gasifier-combustor. These tests demonstrated that this subsystem can gasify various feedstocks and generate a gas satisfactory for operation of the first stage of the process, i.e., the devolatilizer. The chars tested included coke breeze, COED char made from both western Kentucky and Utah coals, and PDU char made in the devolatilizer from the Pittsburgh seam coals.

During CY 1978, the complete coal gasification system will be operated in an integrated manner with both the devolatilizer, the gasifier, and all associated equipment. Test data will be obtained to determine process performance and to enable process economics calculating and scaleup of the process. A detailed analysis of the operational test data is scheduled for the end of FY 1978. By the end of CY 1978, a decision will be made on the need for further development of the process concept at a pilot plant scale.

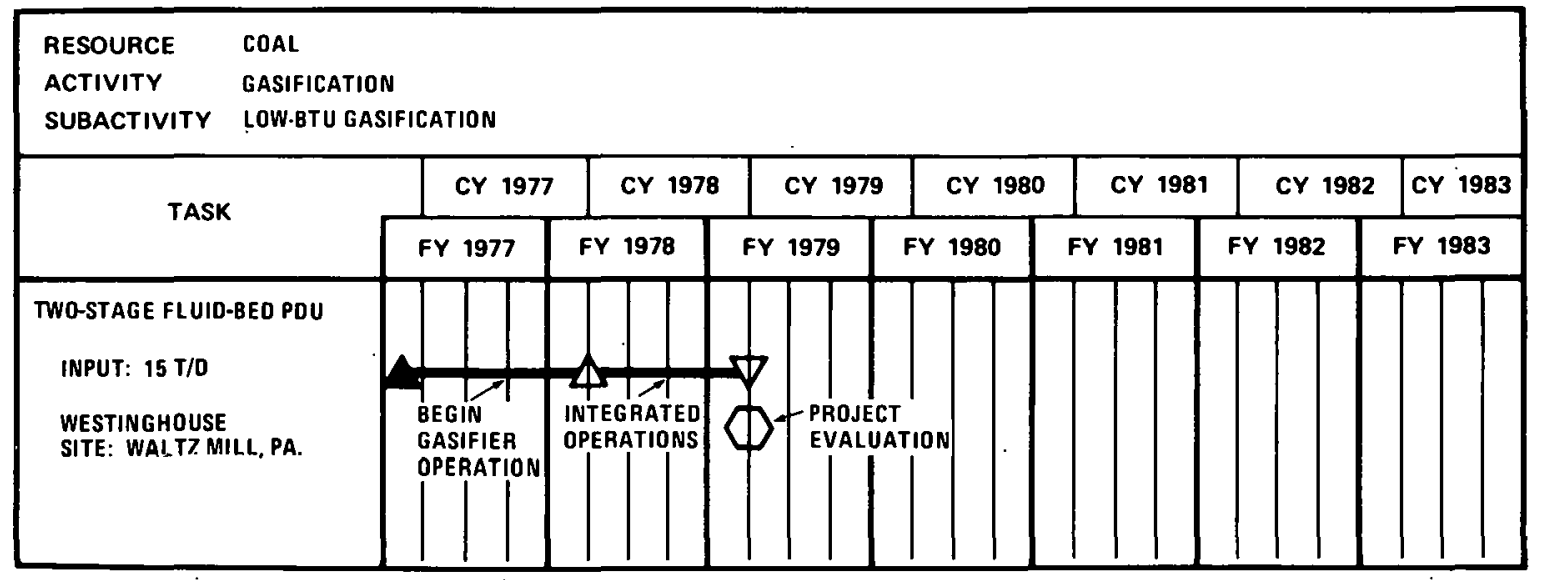

MILESTONE SYMBOLS ARE DEFINED ON LAST PAGE OF THIS DOCUMENT NOTE: BUDGET DETAILS ARE PROVIDED IN SECTION 6.O.

\subsection{FLUIDIZED-BED GASIFICATION, TRI-GAS PRESSURIZED}

The BCR pressurized fluidized-bed process consists of three fluidized beds. This approach is intended to permit operation with any rank coal without producing unwanted tars or oil as by-products.

Raw coal is fed into Stage 1 through lock hoppers. This stage functions as a pretreatment step, devolatilizing the coal with the off-gas from Stage 3. From the pretreatment step, the coal flows by gravity to Stage 2 where it is gasified with air and steam. Entrained tars and oils from the pretreatment step are also gasified. Stage 3 functions as a char combustion step. 
Product gas from the gasification step is quenched in a water spray tower prior to a sulfur removal step. The cleaned low-Btu gas, with a heating value of about $160 \mathrm{Btu} / \mathrm{scf}$, is available at elevated pressures for use in a combined-cycle electric generating plant. Medium-Btu gas, with a heating value of $300 \mathrm{Btu} / \mathrm{scf}$, is obtainable if oxygen is used instead of air as a fluidizing medium.

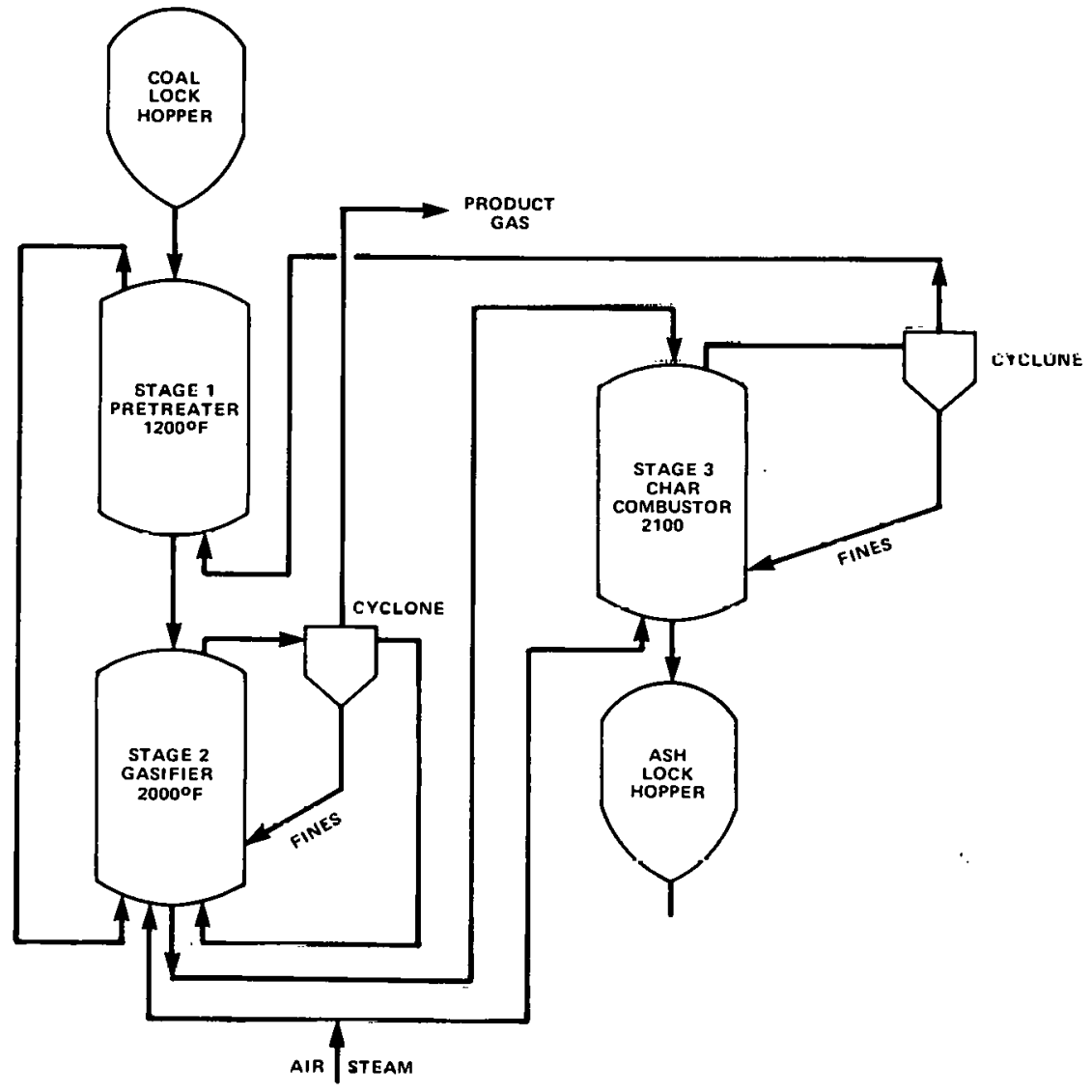

Fluidized-Bed Gasification, Three Stage Pressurized Process

\section{Project Status}

Initial development of the BCR process involved laboratory investigations to obtain kinetic data for various chars, or devolatilized coal, that would be produced in the first step of a multiple fluidized-bed gasification process. The successful laboratory studies led to the design of a process development unit (PDU) with a capacity of $100 \mathrm{lb} / \mathrm{hr}$ of coal. The design and definitive cost estimates were completed in December 1972, and construction of the PDU was completed in December 1975, at Monroeville, Pennsylvania.

Mechanical checkout and shakedown of the equipment was completed early in 1976. Testing in the Stage 1 reactor began using a western noncaking coal (Montana Rosebud). Correlations were developed for the 
properties of the product char as a function of Stage 1 operating temperature. During this phase of testing, the data acquisition system was developed and perfected.

Testing of a caking coal (Illinois No. 6) in Stage 1 began in mid-1976. A series of tests at low temperature (between $800^{\circ} \mathrm{F}$ and 900\% demonstrated the ability to produce a noncaking product char in Stage 1.

The current contract expired on October 20, 1977. A new contract will be awarded in FY 1978 to allow for reactor modifications, additional lab studies, and integrated operation of the unit.

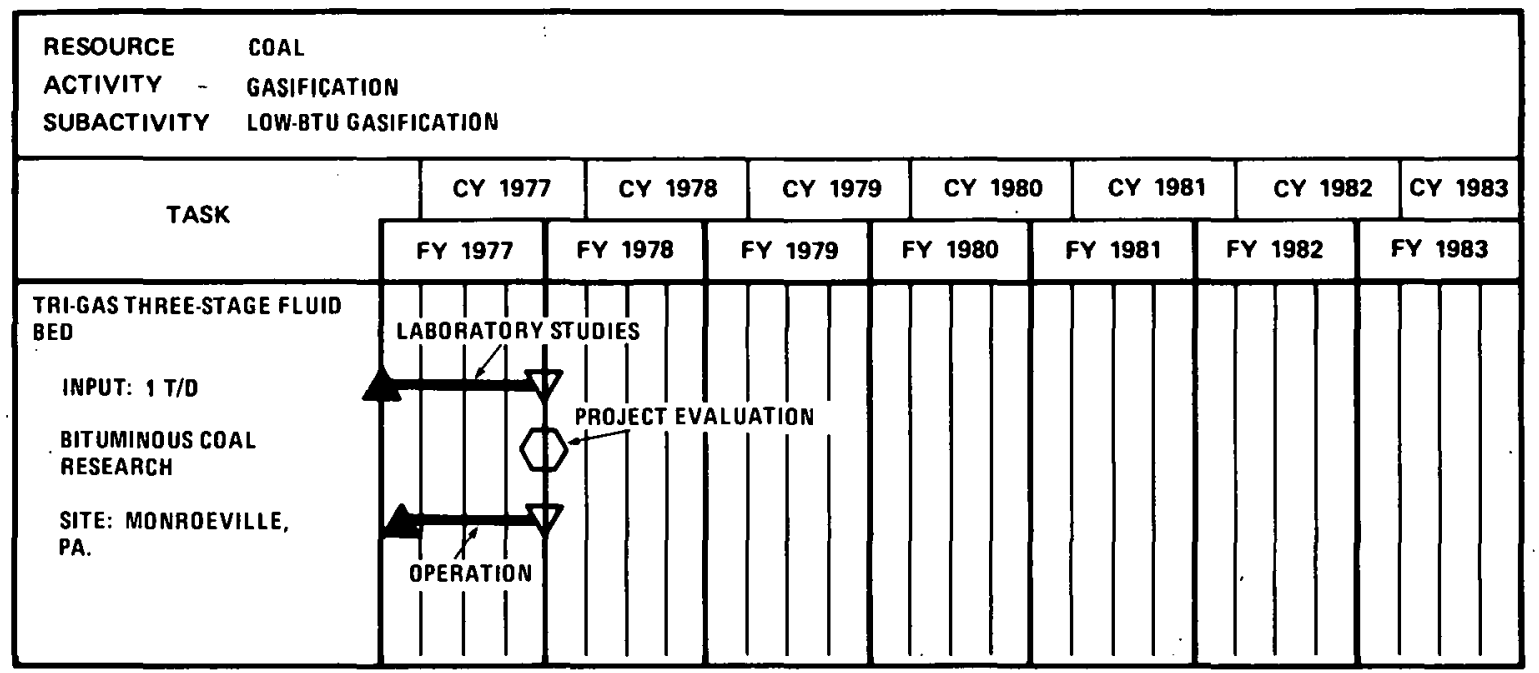

MILESTONE SYMBOLS ARE DEFINED ON LAST PAGE OF THIS DOCUMENT NOTE: BUDGET DETAILS ARE PROVIDEO IN SECTION 6.0.

A limited number of combustion tests were conducted in Stage 3 reactor to determine the ash agglomeration temperatures. The operation of three stage reactors as an integrated unit was handicapped because of the large heat loss in the Stage 3 reactor. For immediate remedy, a gas preheater is being installed between Stage 1 and Stage 3 reactors.

\subsection{FAST FLUID-BED PROCESS}

In the fast fluid-bed process, -20 mesh coal is fed into the lower section of the fast fluid-bed gasifier. The incoming coal is mixed with char fed from a companion slow fluid-bed gasifier at a rate of ten parts char to one part feed coal. The coal and char react with air and steam fed into the bottom of the generator. (The gasifier is operated at approximately $2000^{\circ}$ to $2400^{\circ} \mathrm{F}$ and $10 \mathrm{~atm}$.)

The gas/solids from the gasifier pass through a primary cyclone to remove practically all solids, which are then discharged into the nitrogengas charged fluidized-bed reactor directly below. The char from the slow bed reactor is then fed into the fast fluid-bed reactor via a transfer leg. Ash from the fast fluid-bed reactor drops to the bottom and is discharged. Gas and particulates from the primary cyclone are passed on to a secondary cyclone for further separaliois. 
The objective of this effort is to determine operating parameters, feasibility, and operability. Design parameters of the PDU are as follows:

- Coal Feed Rate:

- Solids Density in Fast Bed:

- Average Gas Velocity in Fast Bed:

- Average Temperature in Fast Bed:

- Pressure:
$600 \mathrm{lbs} / \mathrm{hr}$

$7 \mathrm{lbs} / \mathrm{scf}$

$10 \mathrm{ft} / \mathrm{sec}$

$1700^{\circ} \mathrm{F}$

150 psig

Gas-solid contact in the fast fluidization mode of operation occurs at high gas velocities in the range of 7.0 to 20.0 feet per second and high solids loading in the range of 10.0 to 20.0 pounds per cubic foot. This mode of operation can be considered an optimum region of operation between: 1) the (Standard) fluidized bed that operates in the range of 0.5 to 5.0 feet per second gas velocity and at solid loadings of 20.0 to 40.0 pounds per cubic foot; and 2) the entrained or dilute-phase traneport mode that operates in the range of 30.0 to 60.0 feet per second gas velocity with a solid loading in the range of 1.0 to 2.0 pounds per cubic foot.

The potential advantages for the fast fluid-bed coal gasification process include: 1) higher gasifier capacity by an order of magnitude over the standardized fluid bed,2) no tar formation, 3) higher turn down capacity with minimum loss in efficiency, 4) lower operating temperature than the entrained bed mode, allowing increased flexibility in the materials of construction, 5) decreased potential for the formation of explosive mixtures, and (6) pretreatment of caking coals may be unnecessary .

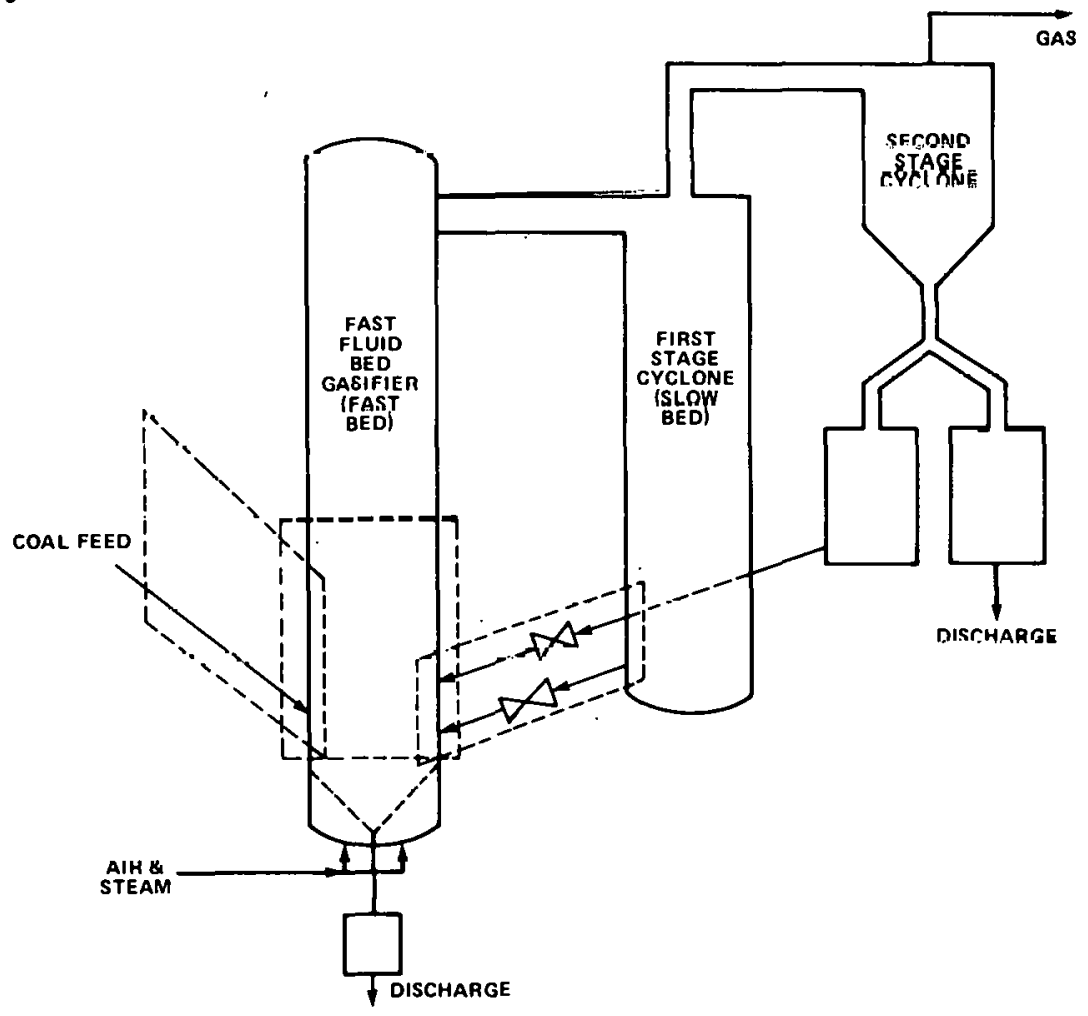

Fast Fluid Bed Process 


\section{Project Status}

The Fast Fluidized-Bed process is under development at Hydrocarbon Research, Inc. (HRI), Trenton, New Jersey, facilities. The current PDU program was initiated in July 1976, and is due to run approximately three years.

To date, design of PDU is complete. Construction of PDU and supportive structures is on schedule with gasifier foundation and major piping installed. Procurement and delivery of major equipment is under way. Under subcontract to HRI, City College of New York has been conducting cold-flow model tests to determine the solid flow dynamics for the design flow conditions specified under the current PDU effort. Testing was completed at the end of FY 1977.

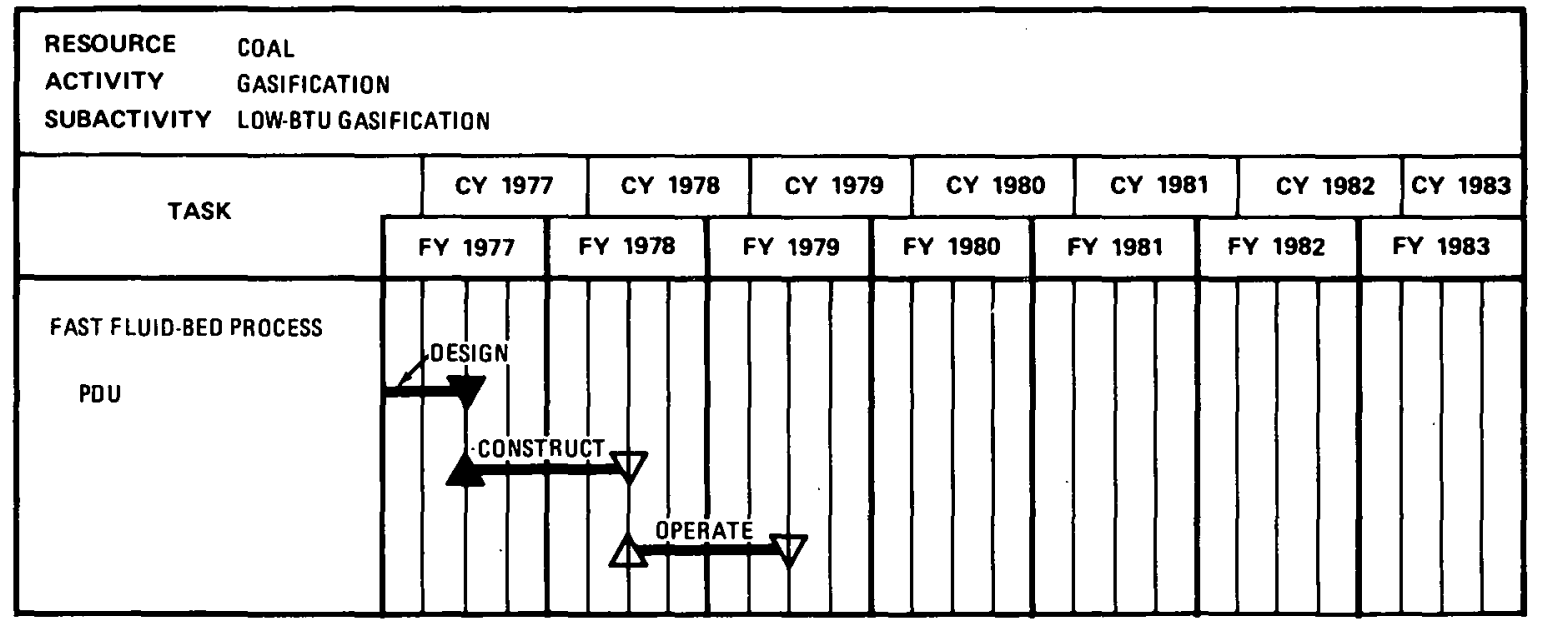

MILESTONE SYMBOLS ARE DEFINED ON LAST PAGE OF THIS DOCUMENT

NOTE: BUDGET DETAILS ARE PROVIOED IN SECTION 6.0.

\subsection{ENTRAINED-BED GASIFICATION, ATMOSPHERIC PROCESS}

This project is developing a gasification and cleanup system that can be integrated with an electric generation plant to operate at a heat rate $(10,200 \mathrm{Btu} / \mathrm{kWh})$ approaching cleanup, and power generation.

The Combustion Engineering gasifier consists of two sections: a combustion chamber that burns a portion of the pulverized coal and recycle char to provide heat to the gasifier, and a reducing chamber where the remainder of the pulverized coal is reacted with steam and hot gases from the combustor to produce low-Btu gas. Nearly all of the ash in the system is withdrawn from the combustor as molten slag. The gasifier is an entrained-bed reactor operating at atmospheric pressure.

The product gas, with an anticipated heating value of approximately $120 \mathrm{Btu} / \mathrm{scf}$, leaves the gasifier at $1600 \mathrm{~F}$ and enters the heat recovery train mounted on the gasifier. In this section, the hot gases pass over an evaporator and economizer to provide high-pressure steam for the steam turbine. A process steam boiler provides steam for the gasifier. The gas 
is further cooled by the liquid couple, leaving the heat recovery train at less than $300^{\circ} \mathrm{F}$.

The gas cleanup section includes a spray dryer, cyclone, and raw gas scrubber. Chars and fines from this operation are recycled to the combustor, and $\mathrm{H}_{2} \mathrm{~S}$ is removed by the Stretford absorber.

Product gas is burned with preheated air in a boiler providing additional heat to the steam from the evaporator-economizer system. Water and $\mathrm{CO}_{2}$ in the gas feed assist in reducing $\mathrm{NO}_{x}$ in the flue gas by reducing the temperature.

The atmospheric entrained-bed gasifier offers the following advantages:

- All coalo can be processed willigul pretreatment

- There is no net char production

- $\quad$ Fused ash is produced, minimizing disposal problems

- Virtually all carbon in the coal can be consumed

- All components except the gasifier are commercially available items with predictable operating characteristics.

\section{Project Status}

Combustion Engineering, Inc. has contracted for a three-phase project consisting of design, construction, and operation of a 5-ton $/ \mathrm{hr}$ pilot plant at Windsor, Connecticut. Under Phase I of the project, the pilot plant was designed and evaluated to determine technical and economic feastbllity of the procecs. This phase included the delatled engineering design of all componente, an cvaluation of materials of construction, a safety analysis, sampling requirements, an automatic data logging system, an environmental review, and mathematical modeling of the process. R\&D support consists of studies on corrosion and erosion of refractory material, and a dynamic flow model to provide design information for the optimization of gasifier geometry and for nozzle design and placement. A study of expected operating characteristics and control requirements of a commercial-size system was conducted to develop control system designs. A test project for operation of the pilot plant has been defined.

Phase II is the pilot plant construction and was completed in FY 1977. This phase involved site preparation, purchase and fabrication of equipment, and installation. Shakedown testing started in December 1977.

Operation of the pilot plant, Phase III, will occur in FY 1978 and FY 1979 and will determine the effects of such operating parameters as air coal ratio, coal steam ratio, and reaction temperature on the gas composition and heating value. An attempt will be made to operate the pilot plant on a continuous basis to demonstrate equipment reliability. Finally, cost and performance estimates for a commercial-size plant will be determined. 


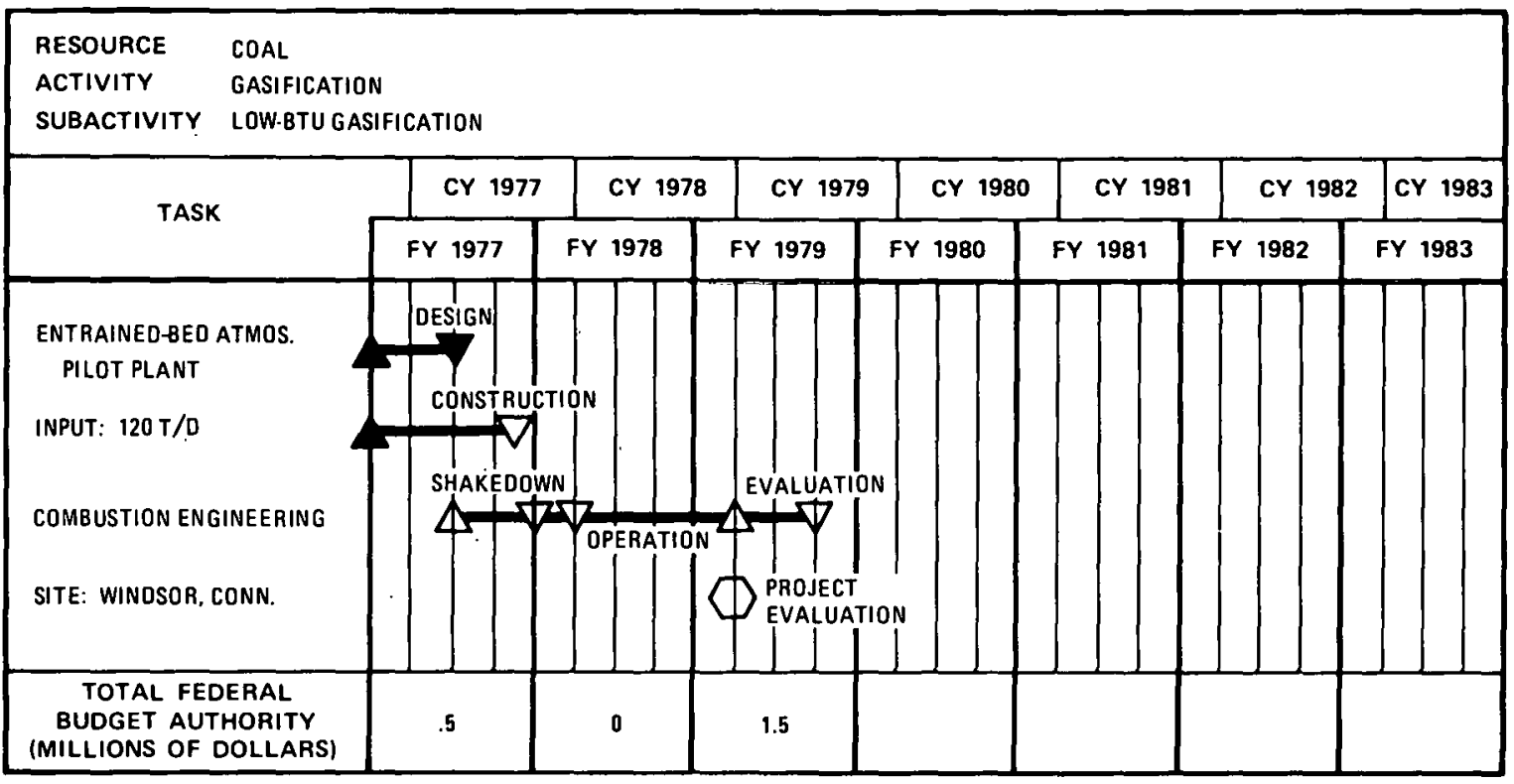

MILESTONE SYMBOLS ARE DEFINED ON LAST PAGE OF THIS DOCUMENT

\subsection{COMBINED - CYCLE TEST FACILITY}

The objective of this project is to adapt low-Btu gasification processes for use in combined-cycle power plants. Integration of the gasification and gas purification units with the gas turbine-electrical generating units is currently considered to be a major problem area.

The coal gasification combined-cycle test facility (Powerton) will produce a low-Btu gas to fuel a gas turbine-generator system exhausting to a heat recovery steam generator. A prime goal of the project is to ascertain the applicability of this system to future large-scale power stations. Gas cleanup processing is also to be investigated.

In addition to providing data for integration and control methodology of a gasifier with a combined-cycle power generation system, the Powerton plant will serve as a unique and flexible test facility. It will be possible to evaluate quickly and efficiently new coal gasification systems as well as advanced turbines, fuel cells and other conversion devices being developed by programs within the Department of Energy. The key features of this facility are the provision of allotted space for these advanced systems at the site; the in-place coal handling facilities which represent a major cost item; the in-place equipment for handling waste and effluents; and the ability to accept full-scale plant-product output from a gasification system. The latter provision is an exceptional feature since the existence of a 1,700-MW power plant at the site permits the use of the product gas as fuel or its conversion to electricity, and actually receive income for usable fuel or power generated. This will significantly reduce both cost and time required to bring new ideas to commercialization. 
The gasification facilities will consist of two Lurgi gasifiers. One gasifier will serve as a spare since one operating gasifier will satisfy the capacity of the gas turbine planned for the facility. It is planned to operate both gasifiers at various capacities .

Crude gas from the gasifiers will be cleaned of tars and oils in a quench scrubber, cooled, scrubbed for removal of hydrogen sulfide, and saturated with water before passing to the gas turbine test facility. Sulfur removal will be by hot potassium carbonate scrubbing. The acid gas from this system will be scrubbed to remove ammonia and converted to elemental sulfur in the sulfur recovery unit. Tar and oily condensates will be collected and gravity separated in the tar-oil separation unit. Tar will be recycled to the gasifier.

A General Electric Frame 5 gas turbine with an output capability of about $20 \mathrm{MW}$, is being modified for testing in the first phase of the privisiun.

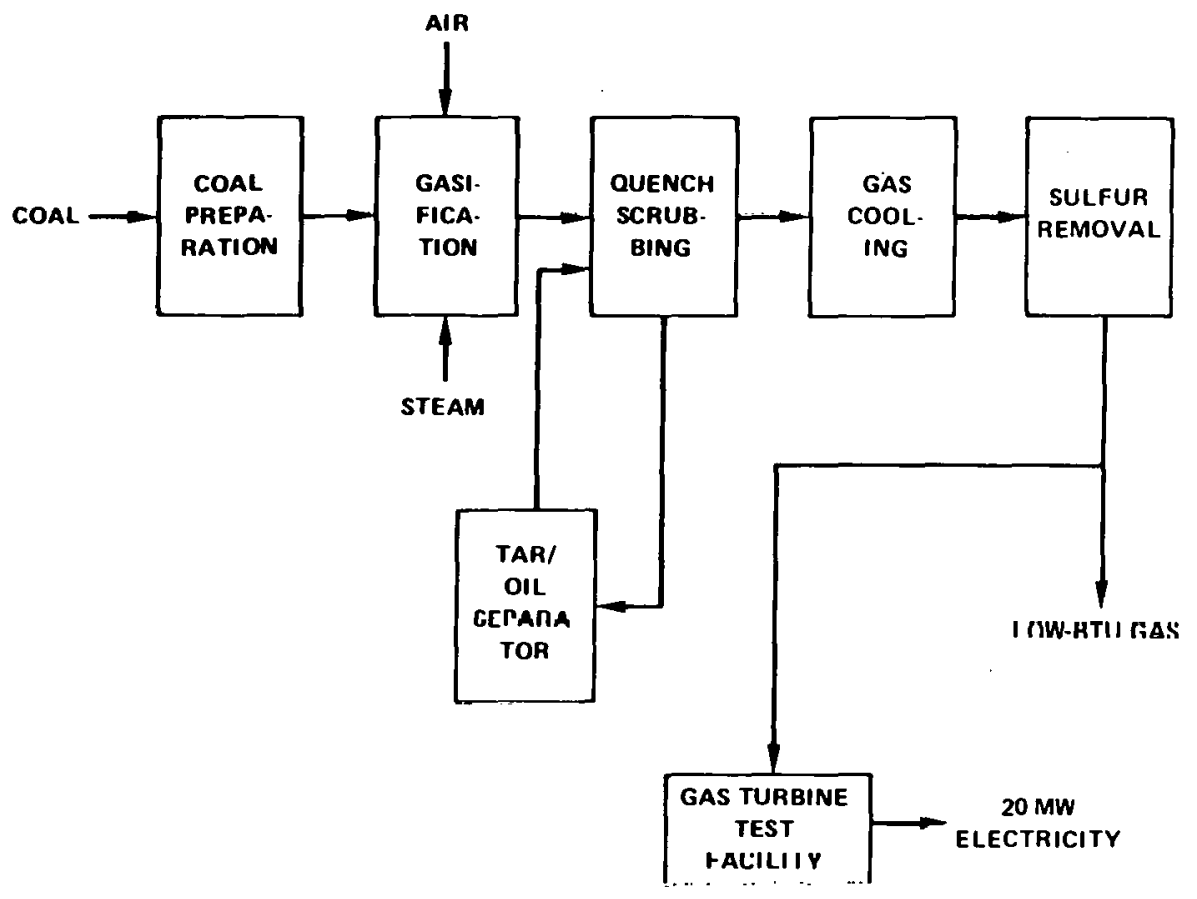

Combined-Cycle Test Facility

\section{Project Stạtus}

Construction of a pilot plant at Pekin, Illinois, is planned to begin in the last quarter of FY 1978. The Powerton pilot plant will process 480 tons/day of coal; convert the coal to a purified low-Btu gas, and utilize the gas to drive a combustion turbine for electric power generation. The preliminary design of the facility has been completed, cost estimates have been made, and the Lurgi gasifiers have been purchased. 
Current planning also encompasses the integration of future improved gasification and purification units with second-generation higher-temperature combustion turbines. Load-following characteristics of the various components will be evaluated. Cost-sharing commitments for the project have been made with 70 percent being paid by the government and 30 percent by industry (Commonwealth Edison, EPRI, and the State of Illinois).

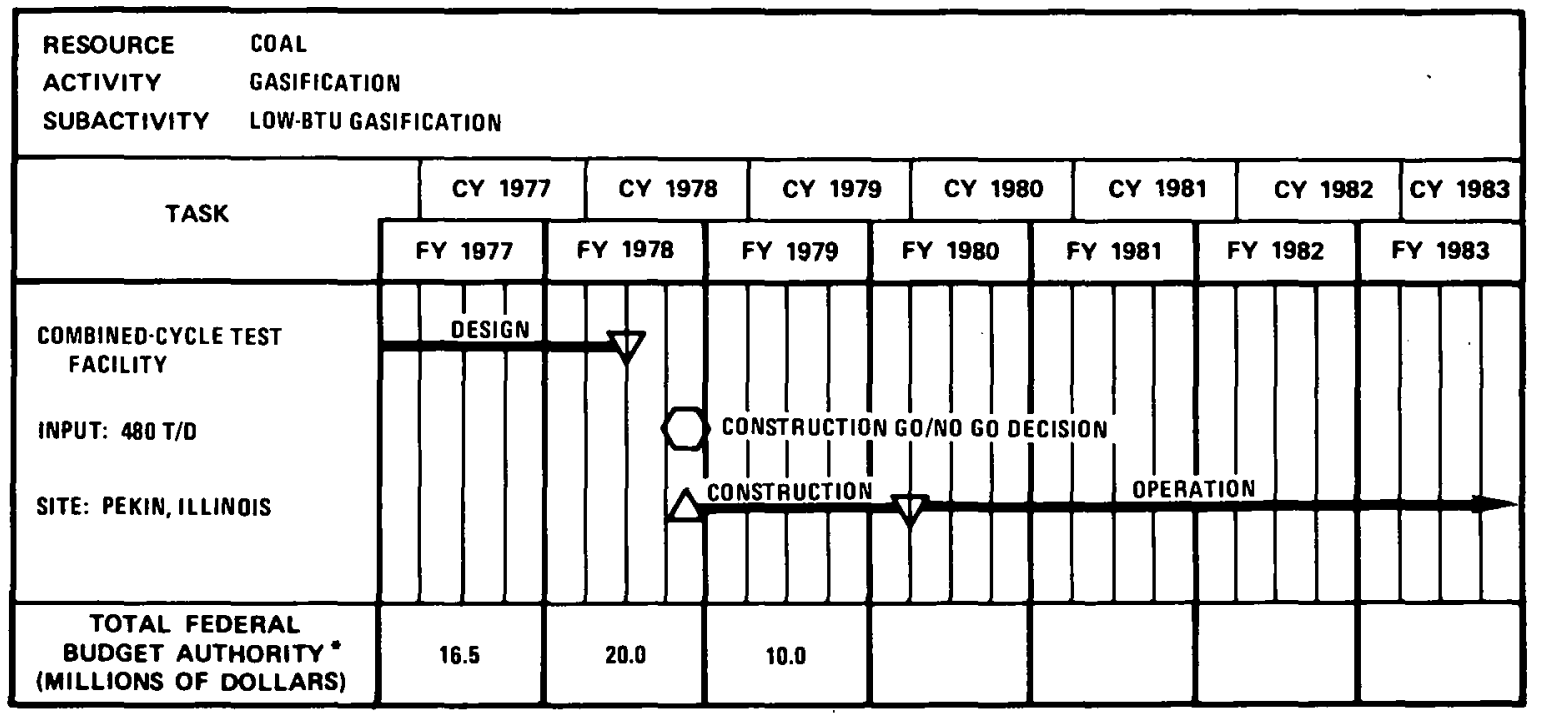

MILESTONE SYMBOLS ARE DEFINED ON LAST PAGE OF THIS DOCUMENT

"FURTHER BUDGET DETAILS ARE PROVIOED IN SECTION 6.0.

\subsection{MOLTEN SALT PRESSURIZED PROCESS}

The molten salt coal gasification process offers a number of potential advantages:

- The process cé 2 handle caking coals without pretreatment.

- The coal need not be finely pulverized, yet fines can be handlcd effectively.

- The gas as it comes from the gasifier is essentially free of sulfur compounds, ash, coal tar, and nitrogen oxides.

- The gasification reaction zone and hence the gasifier vessel are small because of the catalytic effect of the molten salt.

- The process has good load-following capability because gasifier operation is not strongly affected by gas velocity.

- A major part ( $\sim 90$ percent) of the heating value of the coal is retained in the product gas.

In the molten salt process, coal is crushed, dried, and sent to storage. From storage it goes to the feed hopper where it is conveyed by nitrogen dud air to thc molten salt reartor. The sodium carbonatc also is conveyed by air from the carbonate feed hopper to the reactor. 
In the molten salt reactor, coal is gasified in a molten pool of sodium carbonate, sulfide, and sulfate through which air is blown. Conducting gasification reactions in the molten salt medium permits very high oxidation rates (about five times higher than the corresponding gas-solid reaction rates) and results in trapping ash and sulfur in the melt. Process economics favor operation of the gasifier at elevated pressure (e.g., $10 \mathrm{~atm}$ ) with recovery of energy from the product gas.

Since ash and sulfur are retained in the molten salt pool, the melt must be continuously withdrawn from the gasifier and fresh sodium carbonate added. The melt stream is regenerated by an aqueous process in which the melt is quenched and mixed with water to dissolve the salt; insoluble ash components are removed by settling and/or filtration; and the dissolved sodium sulfide is converted to hydrogen sulfide and sodium carbunate (or bicarbonate) by reaction with carbon dioxide. The resulting hydrogen eulfide is oxidized to elemental sulfur in a Claus sulfur plant, and the regenerater sodium carbonate is returned to the gasifier vessel.

The product gas has a heating value on the order of $150 \mathrm{Btu} / \mathrm{scf}$ and is predominantly carbon monoxide, hydrogen, and nitrogen. The product gas is cooled and cleaned of entrained-salt particles; it can then be used as a low-Btu feed to a conventional boiler or a combined-cycle system.

\section{Project Status}

Before December 1974, Atomics International did extensive experimental work to develop the molten salt gasification process. Tests were carried out, first in a laboratory-scale unit and later in a benchscale unit. Based on these experiments, Atomics International concluded that the molten salt process was sound and that a pilot plant should be constructed and operated to further explore and demonstrate its potential for commorcialization.

The tactics involved conducting a development test program, which included the operation of Rockwell International's 3-foot inside diameter test reactor. This was conducted during FY 1976. The preliminary engineering of a 120-tons/day PDU was conducted concurrently with this activity. The preliminary engineering phase of the project included preliminary sizing of components, identification of long-lead items, and preliminary mass and energy balances. This project was terminated in March 1976.

A new project was established in April 1976, to design, construct, and operate a 1 ton/hr PDU which will be located at Santa Susana, California. It will be designed for operation at $1800^{\circ} \mathrm{F}$ and pressures up to 20 atm. Preliminary engineering was completed in August 1976. Detail design began in June 1976 and was completed in June 1977. To avoid delay in construction of the PDU, key components were ordered in the first quarter of FY 1977. Procurement of other equipment will continue until 
February 1978. Construction began on the PDU in the third quarter of FY 1977 and should be completed by mid-April 1978. A 20-month period of test operations, including startup and shakedown, will follow. The project is scheduled to be completed in FY 1980.

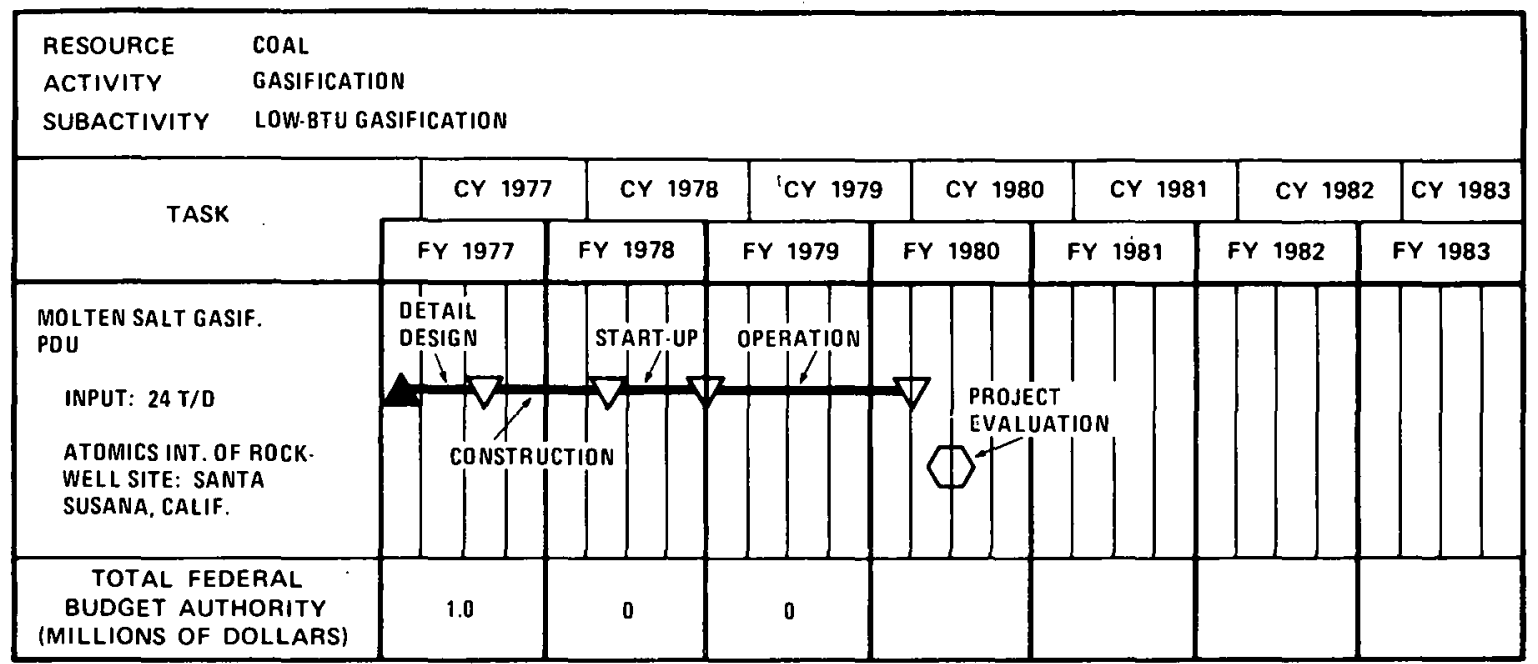

MILESTONE SYMBOI,S ARE DEFINED ON LAST PAGE OF THIS DOCUMENT

\subsection{HYDROGEN-FROM-COAL FACILITY}

The demonstration of economically viable, environmentally sound, and energy efficient integrated technology for the production of hydrogen from coal will become an increasingly important factor in providing industry with a hydrogen supply. This is due to the decreasing supplies and increasing cost of natural gas and naphtha, the primary feed stocks currently being used for hydrogen production.

The production of hydrogen from coal requires the conversion of coal to synthesis gas by reaction with steam and oxygen in a commercial gasifier. The resulting Syngas (primarily $\mathrm{CO}+\mathrm{H}_{2}$ ) is passed through a shift reactor to react the $\mathrm{CO}$ with steam for additional hydrogen production, followed by acid gas removal. All of these process steps downstream of the gasifier involve conventional processes that are widely used in industry today, but have not been applied to a syngas derived from coal. Hydrogen of at least 95 percent purity must be produced. However, depending on the industrial use selected for the hydrogen, the hydrogen may require further purification. By operating a nearcommercial-scale plant, DOE expects to obtain data on costs of operation, integration of major components into an operating plant, control and safety systems, and environmental characteristics of operational commercial coal gasification facilities. The data will be made available to industry. 


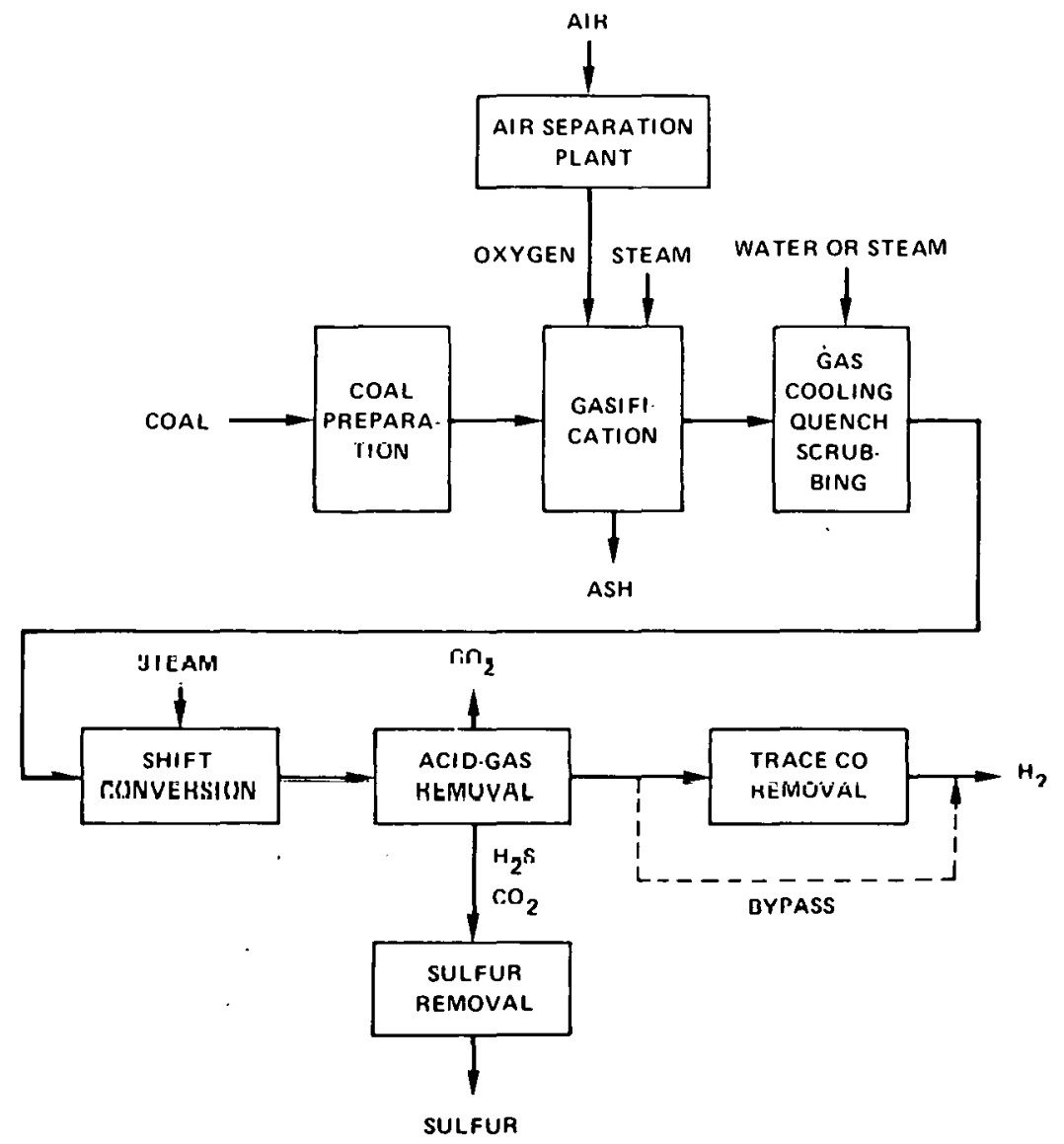

\section{Hydrogen-From-Cogil Facility}

\section{Project Status}

Air Products and Chemicals, Inc., Allentown, Pennsylvania, has been selected for negotiations for the design, construction, and operation of a facility to produce hydrogen from gasification of coal for use in industrial processes.

Air Products was one of three contracls submitting proposals for conceptual design of a hydrogen-from-coal facility in response to a Program Opportunity Notice (PON-FE6), distributed throughout industry by DOE in late 1976.

Located at Ccdur Buyuu (ntur Baytown), Texas, the proposed Hydrogen from Coal Facility will use 1,210 tons/day of Texas lignite to produce 29.5 million standard cubic feet of hydrogen and 7 million cubic feet of carbon monoxide per day. The gaseous end product will be distributed through an existing pipeline to industries using hydrogen in the manufacture of chemicals in the Gulf Codsl region.

The process and design engineering and definitive cost estimate to be provided in Phase I will require 15 months. The construction, Phase II, will require approximately 33 months, with operation expected to begin in 
1982. During the first three years of operation, DOE will obtain and evaluate economic, technical, and environmental data for scaleup to larger plants for the commercial production of hydrogen. The facility is designed to operate for a minimum of 15 years.

The two Koppers-Totzek gasifiers, a type which has been on the commercial market for 20 to 25 years, will use dried lignite ground to fine particles. The particles are blown into the gasifiers with steam and oxygen under atmospheric pressure. Temperatures of nearly $3500^{\circ} \mathrm{F}$ are achieved in producing the gaseous products. The product hydrogen will have a purity of 99-plus percent.

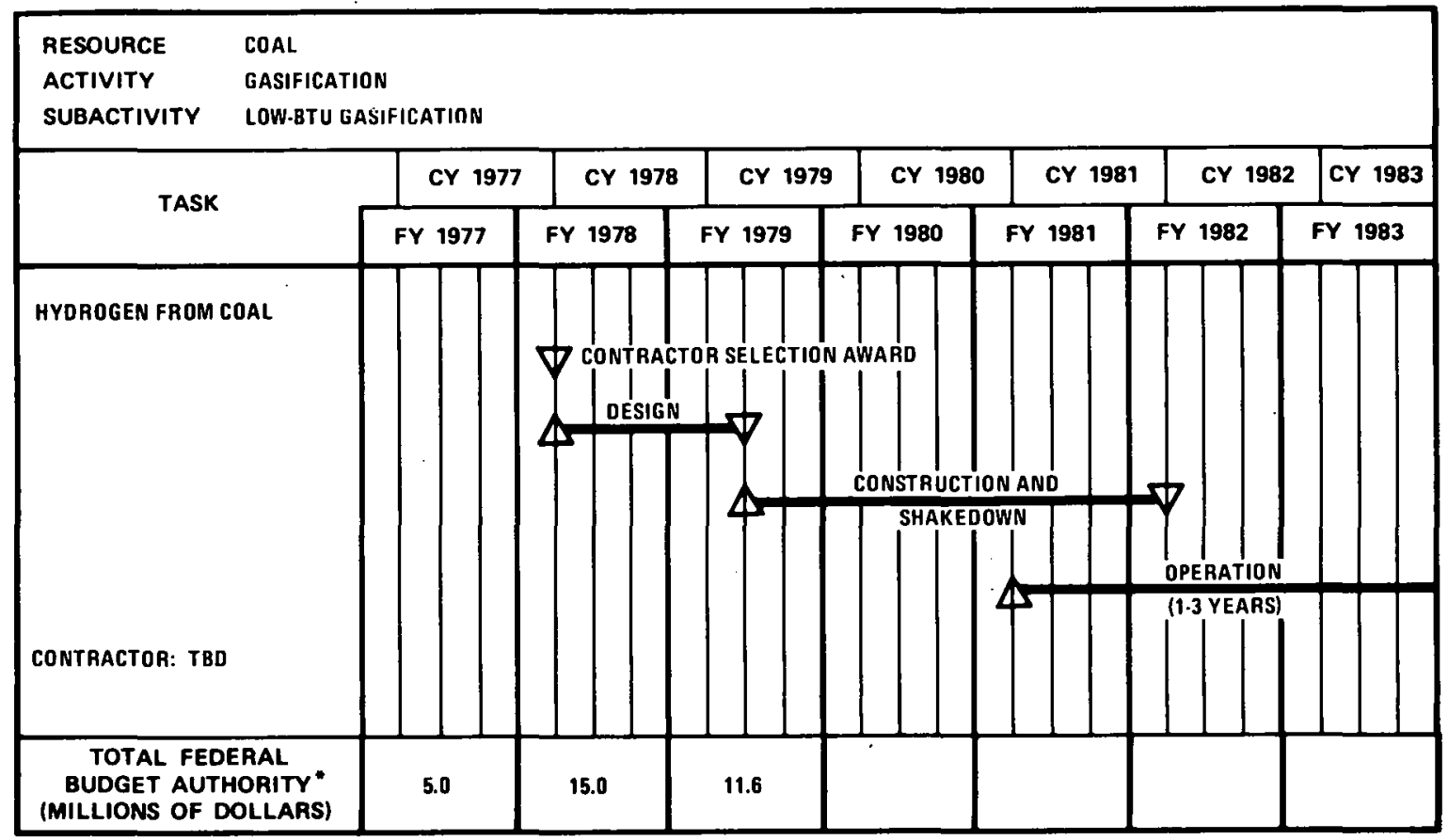

MILESTONE SYMBOLS ARE DEFINED ON LAST PAGE OF. THIS DOCUMENT

"FURTHER BUDGET DETAILS ARE PROVIDED IN SECTION 6.0.

\subsection{ASH AGGLOMERATION}

The objective of this project is to successfully demonstrate that high carbon utilization can be obtained under ash agglomerating conditions with various types of coal.

The Agglomerating Ash Gasifier (AAG) process has been under development at IGT with DOE support as part of the HYGAS effort. This AAG process uses a single-stage fluidized-bed reactor that incorporates an ash agglomeration technique to achieve high-carbon utilization and to simplify residue handling. The AAG process has been successfully tested at atmospheric pressure with coke breeze as feed.

Coal of any rank is crushed, preferably to $1 / 4-X-0$.size. Pretreatment of caking coals, if required, is accomplished by bringing the coal into contact with air in a fluidized bed at atmospheric pressure and at temperatures of 7000 to $800^{\circ} \mathrm{F}$. For cokes and noncaking coals, this 
pretreatment step is not necessary. The coal is introduced into the gasifier fluid-bed where it is gasified by reacting with steam and air in a single-stage fluidized-bed at atmospheric pressure. Residence time is of the order of 45 minutes. Fluidizing velocity is in the range of 1 to 2.5 $\mathrm{ft} / \mathrm{sec}$. Simultaneously with coal gasification, the ash is agglomerated into larger and heavier particles for selective separation from the bed. The agglomeration takes place at temperatures in the $1850^{\circ}$ to $2000^{\circ} \mathrm{F}$ range. Fines elutriated from the fluid bed are separated from the raw gas in cyclones and will be returned to the gasifier.

The existing AAG pilot plant system, which was suitable for use with char or coke breeze, is being modified to allow for extended operational periods with coal as the feed and improved data collection.

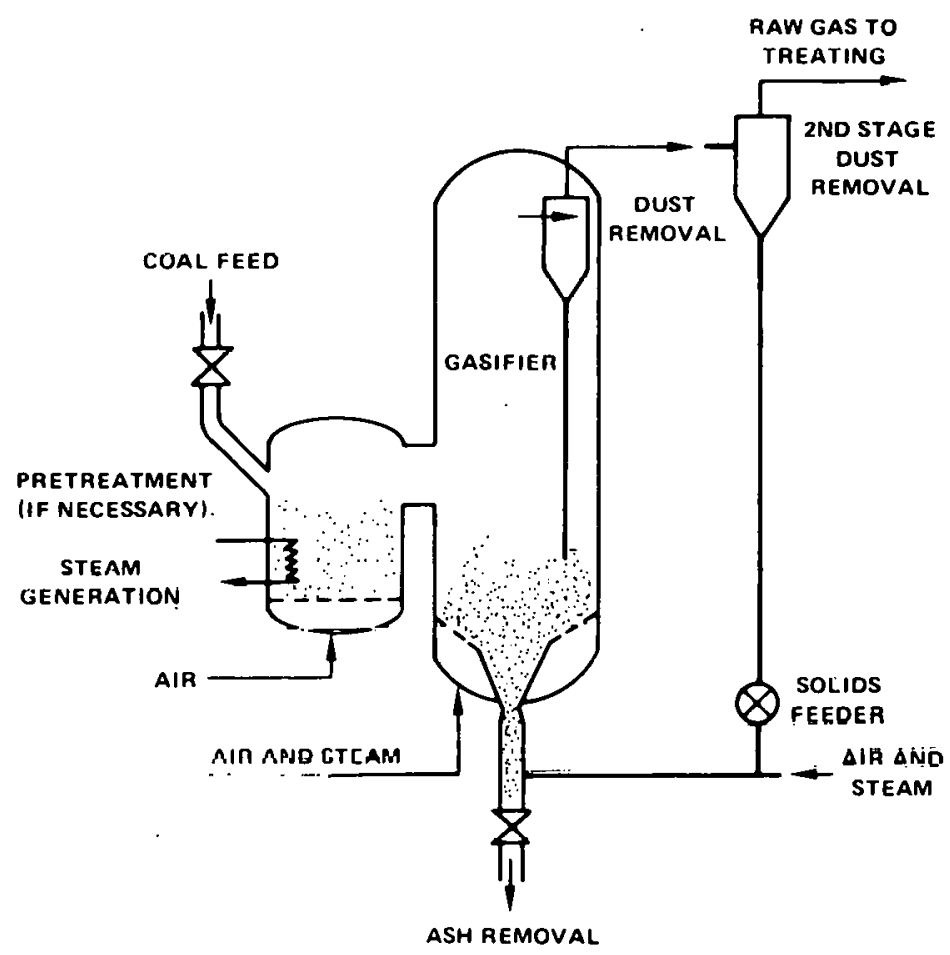

Așh Agglomeration

\section{Project Status}

IGT has previously operated the agglomerating ash gasifier (6 to 7 lons/day capacity) on coke as feed material under the HYGAS effort. In the present effort, the atmospheric agglomerating-ash gasifier has been modified to permit operation on coal for extended periods of time.

The modified PDU program was divined into four tasks with an estimated duration of 22 months:

Task 1. Modification and shakedown of existing agglomerating ash gasifier including addition of thermal oxidier (10 months) 
Task 2. Operation of PDU for sustained period of time (12 months)

Task 3. Design and cost estimate for atmospheric pressure commercial-size gasifier (during same time period as Task 2)

Task 4. Design and cost estimate for pressurized (100 to $350 \mathrm{psi}$ ) test gasifier (during same time period as Task 2).

The initial shakedown tests were completed in May 1977. To date, some 15 test runs have been completed on coke breeze, subbituminous and bituminous coals. Consistent agglomeration can be obtained with coke breezes. The subbituminous coal, a Montana coal containing about 20 percent moisture, is limited to about a $1650^{\circ} \mathrm{F}$ bed temperature and, although continuous operation was possible on air with no fines recycle, agglomerates were not obtained.

When the coal. was changed to a caking bituminous coal, Illinois No. 6 with about 10 percent moisture and higher heating value, operating temperatures of about $1820^{\circ} \mathrm{F}$ were possible. With the addition of oxygen to enrich the air, temperatures of up to $1870^{\circ} \mathrm{F}$ were obtained. Agglomerates were formed, but not on a continuous basis due to clinker problems. These problems are being addressed at the present time.

As of January 1, 1978, the pilot plant Test Operation, Task II, will be discontinued in this contract for six months, while the equipment is used in support of the Memphis Light, Gas, and Water (MLGW)Industrial Fuel Gas Demo Plant Program Contract. Upon completion of this support, the Task II Scope of Work will be re-evaluated against results obtained. Task IV Design and Cost Estimate for Presurized Pilot Plant will be done.

Task III, Design and Cost Estimate for a commercial-size gasifier at atmospheric pressure will be achieved by the MLGW program which will provide the same information on a low pressure system. The contract will be extended through October 1978, in order to allow time to complete the original Task II Scope of Work, if it is determined appropriate to do so after review of the MLGW support work. 


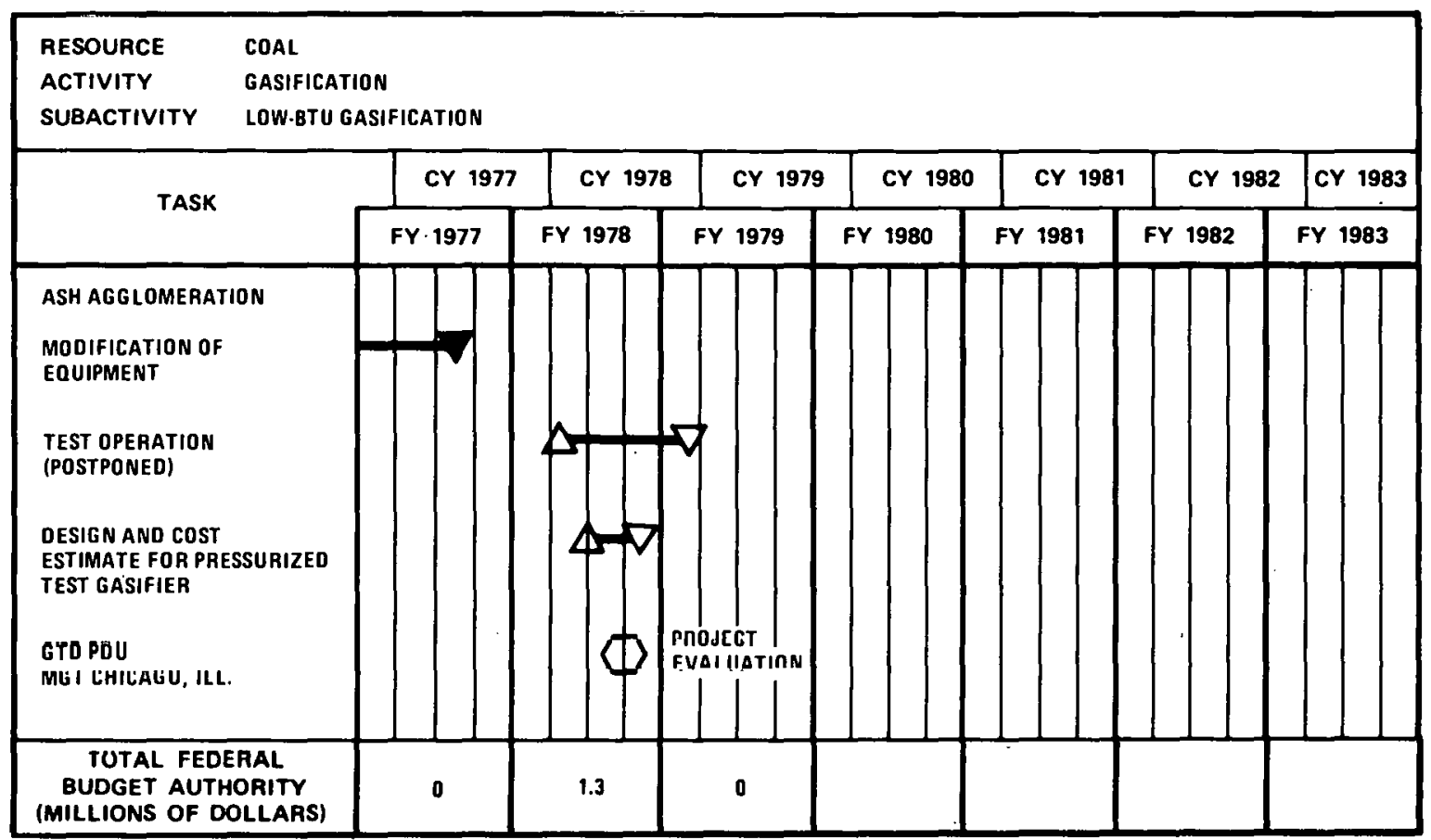

MILESTONE SYMBOLS ARE DEFINED ON LAST PAGE OF THIS DOCUMENT

\subsection{GASIFIERS IN INDUSTRY}

This program involves the direct use of low-Btu gas in one or more industrial processes, or as a fuel for steam boilers, as direct process heat, and in industrial dryers. The objective is to demonstrate the integration of a gasification system with an industrial end-use for the lowBtu gas produced, using state-of-the-art components.

Coal is prepared for gasification and cunverted to a fuel gas in a gasifier located at the industrial plant. The fuel gas is purified as required for the specific application and used in the industrial plant. Since low-Btu gas must be utilized near its point of production because of prohibitive cost of transporting, factors controlling the connection of the gasifier to an end-user of the gas must be evaluated. These factors will determine acceptability of future advanced gasification techniques. 


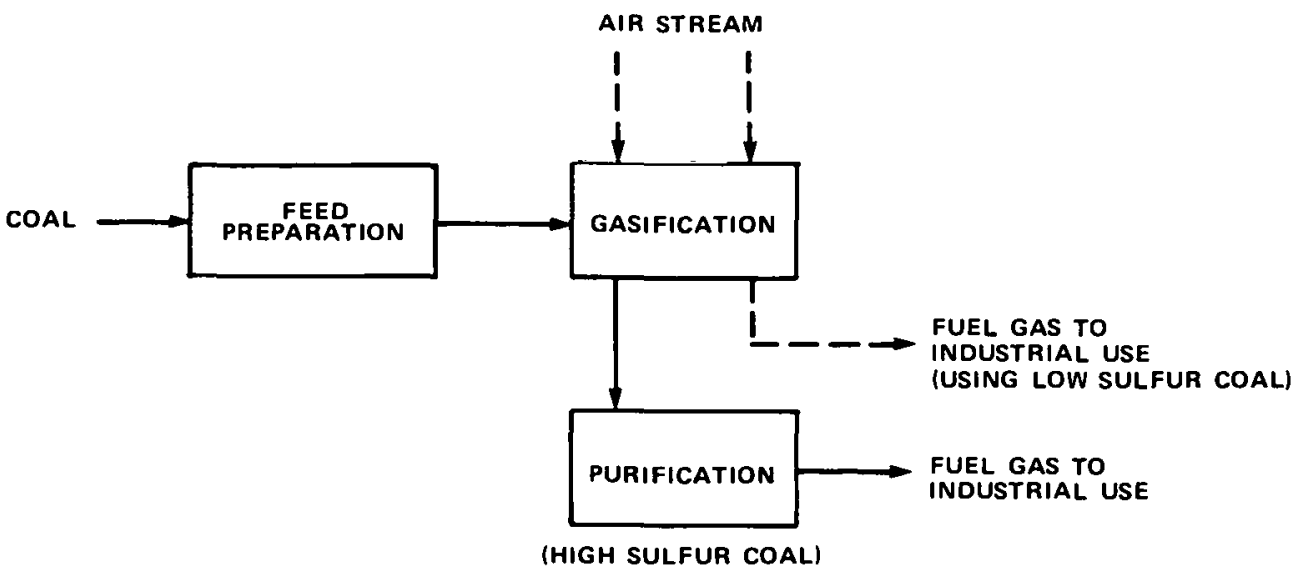

Gasifiers in Industry

\section{Project Status}

Small-sized individual gasifiers are currently available and will be the first application of synthetic fuel conversion from coal in industry. Government involvement in this area is of short duration and focuses on use of these gasifiers for caking coals, the use of two-stage 'gasifiers which have not yet been demonstrated on U.S. coals, and evaluating environmental safety. These projects will be heavily cost-shared by industry. A recent PON called for proposals to achieve these objectives. Six proposals were selected for negotiation; these are discussed invididually below, and significant milestones are shown for each program on the chart following the discussion.

1. The Glen Gery Brick Company (with Acurex-Aerotherm) has instrumented an existing Wellman-Galusha gasifier. This gasifier is producing low-Btu gas from Anthracite coal, and the gas is being used to fire a brick kiln at Glen Gery's plant in York, Pennsylvania. Valuable information has been obtained on selection and operation of instruments for measuring gasifier performance. Operational data, including material and energy balances are being collected. Completion of the operation of this gasifier under the DOE agreement is scheduled for the first quarter of FY 1979. A complete report on the operation will be available shortly thereafter. Total estimated cost is $\$ 1.2$ million with the DOE share being $\$ 0.6$ million (50 percent cost-sharing).

2. University of Minnesota (with Foster Wheeler) will use a low-sulfur Wyoming bituminous coal to produce low-Btu gas as fuel for an existing natural gas fired boiler. A two-stage STOIC gasifier will be used to produce a gas low in particulate matter. The tar contained in the top gas will be removed by an electrostatic precipitator and collected. This oil has properties similar to No. 6 oil and will be stored for use during the coldest months.

The design effort on this project has shown that substantial modifications of existing foreign designs are required to provide reliable, environmentally acceptable operation in the U.S. Construction is 
continuing on this project and startup will be completed in the fourth quarter FY 1978. The first year of continuous operation and detailed data gathering will be FY 1979.

DOE is planning a large environmental effort on this project which will define and characterize emissions from this plant and their effects on the environment. This program is also being coordinated with EPA and NIOSH so that information collected will be useful to all concerned parties. Total estimated cost is $\$ 4.8$ million and the DOE share is $\$ 2.2$ million (46 percent cost-sharing).

3. Pike County, Kentucky (with Mason and Hanger and the Kentucky Center for Energy Research) will produce gas from a low-sulfur Kentucky bituminous coal. Since this is a caking coal, a gasifier with an agitate must be used. A Wellman-Galusha gasifier equipped with particulate removal devices will be used.

The gas will be used in a boiler to produce steam. The steam will be used for heating and cooling several facilities within the development including housing, a school, a nursing home, a fire station and commercial facilities.

Detailed design and procurcment of long lead-time items is currently under way. Design will be completed and construction begun during the third quarter of FY 1978. Activities during FY 1979 will include completion of construction, startup and shakedown, and the first few months of steady operation.

The environmental aspects of this installation will also be monitored in the joint DOE, EPA, NIOSH program. The details of this program are currently being developed. A second stage of this project is envisioned by Pike County, which would include addition of a sulfur removal plant and use of the clean, desulfurized low-Btu gas as a fuel for industrial clients in an adjacent industrial park. DOE is not currently participating in this phase of the project.

Estimated cost of this project is $\$ 5.8$ million and the DOE share is 2.9 million ( 50 percent cost-sharing).

4. General Refractories (with Holly, Kenney, Schott and WoodallDuckham) will use gas to fuel tunnel kilns, periodic kilns and dryers at its Hitchins, Kentucky, plant. A Woodall-Duckham two-stage gasifier will be used. Particulates will be removed, but most of the tar will be retained in the gas.

Process and preliminary designs as well as the cost estimate will be completed during FY 1978. FY 1979 work includes completion of detailed design and the start of construction.

Estimated project cost is $\$ 4.2$ million and DOE share is $\$ 2.1$ million (50 percent cost-sharing). 
5. Land O'Lakes (with Applied Technology Company) will use low-Btu gas to fire a boiler and a spray dryer at their Perham, Minnesota, plant. Using low-Btu gas to spray-dry dairy products is a unique use and requires careful design and extensive testing.

A Wellman-Incandescent two-stage gasifier will be used. The design will include extensive particulate removal for the stream to be used in spray drying. Particulates and condensibles will be removed from the remainder of the gas. A low-sulfur, nonagglomerating bituminous coal from Utah will be used.

Total estimated cost is $\$ 6.5$ million and the DOE share will be $\$ 3.25$ million (50 percent cost-sharing).

6. Irvin Industries (with Mason and Hanger and the Kentucky. Center for Energy Research) will use the gas as fuel for a 172 acre industrial park at Georgetown, Kentucky. Two Wellman-Galusha gasifiers with stirrers will be used. The coal will be a moderate-sulfur, agglomerating bituminous coal from eastern Kentucky.

At the present time an environmental impact statement (EIS) is being prepared and a water assessment has been requested from the Water Resources Council. No decision will be made until actions on the water assessment and EIS are completed. These should be achieved early in FY 1979. At that time the project will be re-evaluated by DOE and if the review is favorable and all other conditions have been met a contract will be negotiated for this project. Total estimated cost is $\$ 5.6$ million and DOE share is $\$ 2.8$ million (50 percent cost-sharing). 


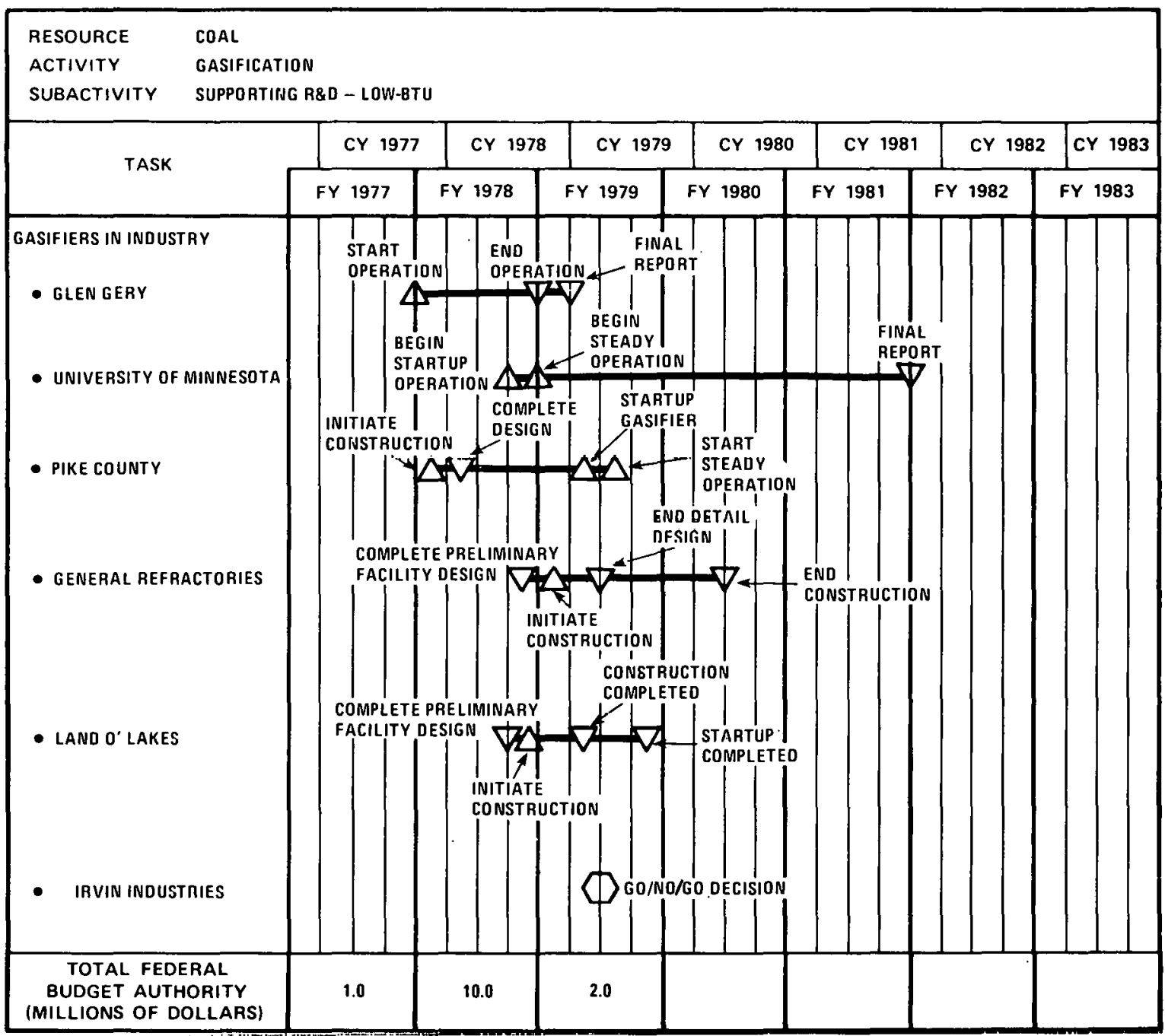

MILESTONE SYMBOLS ARE DEFINED ON LAST PAGE OF THIS DOCUMENT 


\subsection{SPECIAL PROJECTS AND SUPPORT STUDIES}

This area includes engineering and other support. Support projects are necessary to facilitate development of the various gasification processes toward commercialization. Included are hot-gas cleanup methods, environmental studies, equipment and materials development, and system engineering studies.

The table below summarizes the funding levels by task for the FY 1977 to FY 1979 period.

\begin{tabular}{|c|c|c|c|c|c|}
\hline $\begin{array}{l}\text { SPECIAL PROJECT \& } \\
\text { SUPPORT STUDIES }\end{array}$ & \multicolumn{4}{|c|}{$\begin{array}{l}\text { BUDGET AUTHORITY } \\
\text { (OPERATING EXPENSES) } \\
\text { (DOLLARS IN THOUSANDS) }\end{array}$} & \multirow{2}{*}{$\begin{array}{l}\text { MAJOR } \\
\text { CHANGE* }\end{array}$} \\
\hline TASKS & $\begin{array}{l}\text { ACTUAL } \\
\text { FY } 1977\end{array}$ & $\begin{array}{l}\text { APPROPRIATION } \\
\text { FY } 1978\end{array}$ & $\begin{array}{l}\text { ESTIMATE } \\
\text { FY } 1979\end{array}$ & $\begin{array}{l}\text { INCREASE } \\
\text { (DECREASE) }\end{array}$ & \\
\hline $\begin{array}{l}\text { Hot-Gas Cleanup } \\
\text { Engineering Evaluations } \\
\text { Equipment, Materials \& Process } \\
\text { Development } \\
\text { Environmental Studies \& } \\
\text { Other Support }\end{array}$ & $\begin{array}{r}\$ 2,600 \\
1,600 \\
4,557 \\
5,839\end{array}$ & $\begin{array}{r}\$ 3,600 \\
3,000 \\
4,100 \\
7,150\end{array}$ & $\begin{array}{r}\$ 1,400 \\
2,900 \\
2,844 \\
11,116\end{array}$ & $\begin{array}{r}\$-2,200 \\
-100 \\
-1,256 \\
+3,966\end{array}$ & 1 \\
\hline TOTAL & $\$ 14,596$ & $\$ 17,850$ & $\$ 18,260$ & $\$+410$ & \\
\hline \multicolumn{3}{|c|}{$\begin{array}{l}\text { *KEY } \\
N=\text { New start (totally new project) } \\
S=\text { Scaleup (from bench to PDU or pilot plant) } \\
\quad A=\text { Acceleration (shortening deadlines or } \\
\text { expansion of ongoing projerts) }\end{array}$} & \multicolumn{3}{|c|}{$\begin{array}{l}P=\text { Phase completion or startup } \\
R=\text { Program redirection } \\
I=\text { Incremental cost requirement } \\
C=\text { Project completion or suspension }\end{array}$} \\
\hline
\end{tabular}

\subsection{HOT-GAS CLEANUP, MOLTEN SALT PROCESS}

To maximize the overall efficiency of combined-cycle power production, the sensible heat in low-Btu gas must be conserved. The gas must be cleaned to remove particles and sulfur compounds before it enters the gas turbines. Existing cleanup technologies require the gas to be cooled, thus wasting its sensible heat. The Molten Salt Cleanup process will operate at much higher temperatures, allowing more efficient use of high-sulfur coals for production of power.

The fused salt scrubber system consists of an extraction section, where $\mathrm{H}_{2} \mathrm{~S}$ is removed from the gas, and a regeneration section, where sulfur compounds are expelled from the molten salt. Raw low-Btu gas is heated and supplied to a vertical venturi scrubber. The gas is accelerated in the throat of the venturi, where it atomizes and disperses the molten salt in the gas phase. The salt used is à mixture of $\mathrm{CaCO}_{3}, \mathrm{Na}_{2} \mathrm{CO}_{3}$, $\mathrm{Li}_{2} \mathrm{CO}_{3}$, and $\mathrm{K}_{2} \mathrm{CO}_{3}$. The venturi operates at a temperature between $1300^{\circ}$ and $1500^{\circ} \mathrm{F}$. The demister separates the gas and salt in a packed bed of $\mathrm{Al}_{2} \mathrm{O}_{3}$ raschig rings. This may be followed by a bed of silica gel for the removal of very fine salt particles. 
The molten salt is cooled in a shell-and-tube heat exchanger with the salt on the tube side and the air on the shell side. The regenerator is a tray column where $\mathrm{CO}_{2}$ and steam flow countercurrent to the salt to remove sulfur as $\mathrm{H}_{2} \mathrm{~S}$. The Claus process can be applied to recover elemental sulfur from the concentrated $\mathrm{H}_{2} \mathrm{~S}$ stream.

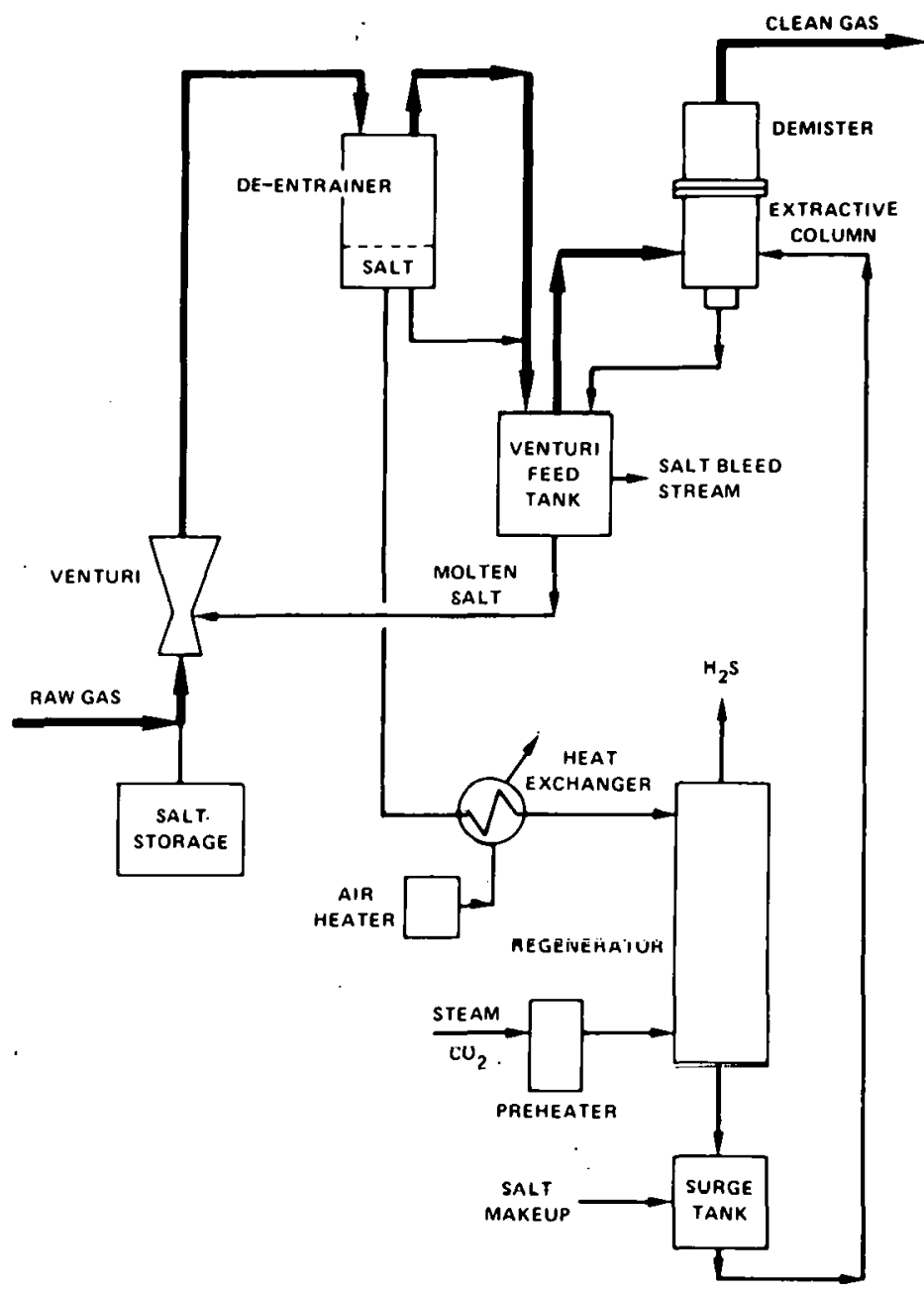

Hot-Gas Cleanup, Molten Salt Process

\section{Project Status}

Battclle Northwest Laboratories' existing PDU at Richland, Washington, operates in batch mode and is capable of processing 50-to-100 $\mathrm{scf} / \mathrm{min}$. The venturi accelerates the gas to a velocity of $250 \mathrm{ft} / \mathrm{sec}$ and recycles the molten salt at a rate of $1 \mathrm{gal} / \mathrm{min}$. It has been demonstrated that the batch process will recover 93 to 99 percent of the sulfur in the raw gas. The unrecovered sulfur consists primarily of carbonyl sulfide (COS). 
The objective of this project is to modify the existing batch system to demonstrate process feasibility in the continuous operating mode described above. The work is presently concerned with construction and operation of the modified PDU. Additional modifications will be performed to correct problems encountered thus far.

Equipment required for conversion of the PDU to a continuous operating mode is being designed and procured. The subsystems, regenerator, and filter will be tested independently to resolve operating problems. It is then planned to operate the integrated PDU continuously, with simultaneous extraction and regeneration to demonstrate process viability and permit a reliability assessment of the materials of construction.

Upon completion of the operation of the PDU, the derived data will be used to conduct cost analyses for the design and construction of a hot-gas cleanup facility for a 50-MW electric power generating plant.

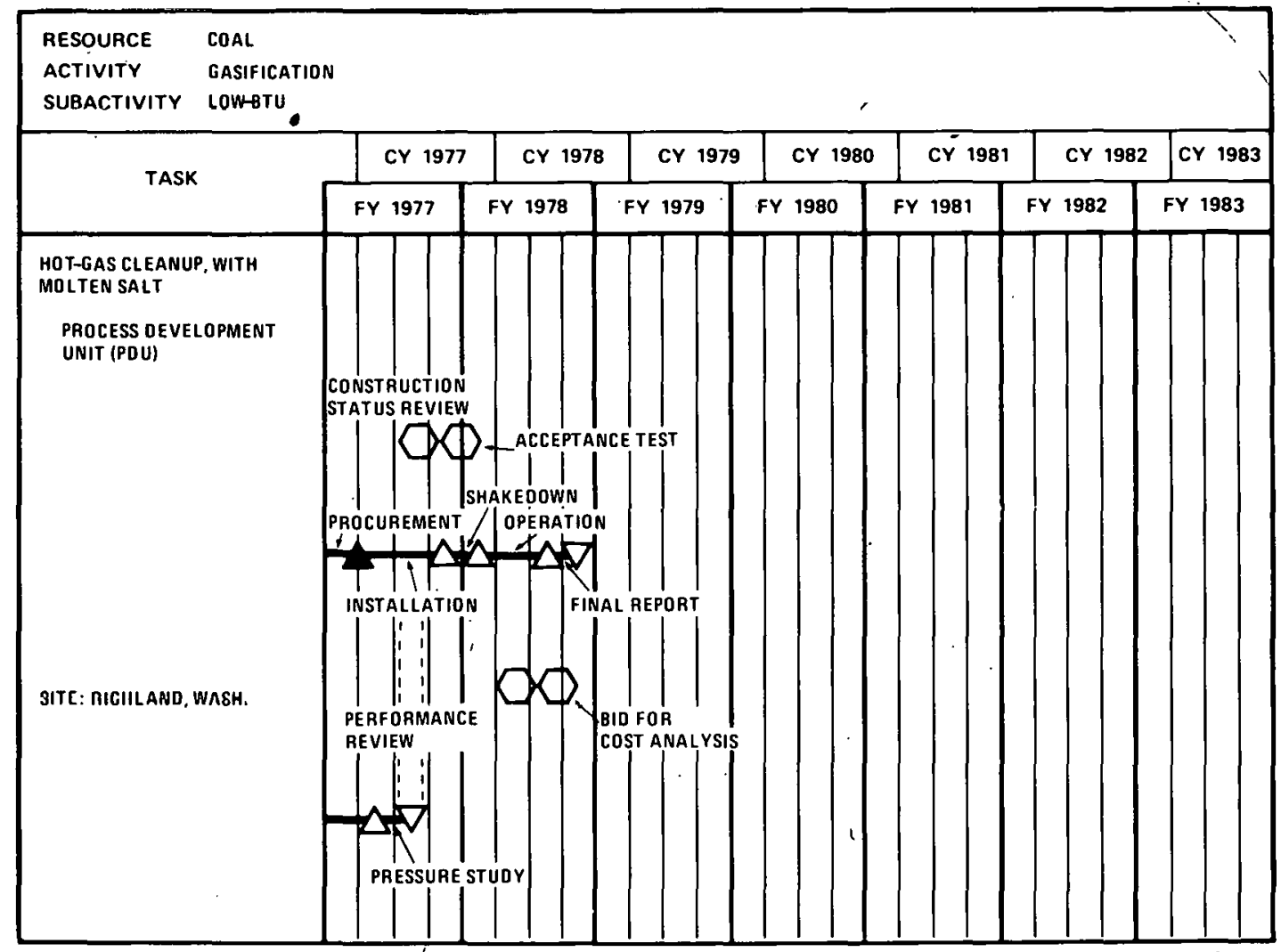

MILESTONE SYMBOLS ARE DEFINED ON LAST PAGE OF THIS DOCUMENT

\subsection{HOT-GAS CLEANUP, IRON OXIDE PROCESS}

The objective of this project is to develop a solid absorbent for $\mathrm{H}_{2} \mathrm{~S}$ removal from hot $\left(1000^{\circ}\right.$ to $\left.1500^{\circ} \mathrm{F}\right)$ low-Btu gases at near atmospheric pressure. This will improve the overall thermal efficiency of low-Btu gasification/electric generation systems. 
The conceptual design of an iron oxide hot-gas cleanup system consists of four steps: particulate removal, $\mathrm{H}_{2} \mathrm{~S}$ removal, sorbent regeneration, and sulfur recovery.

Particulates in a hot $\left(1000^{\circ}\right.$ to $\left.1500^{\circ} \mathrm{F}\right)$ raw gas stream from a gasifier are removed in a cyclone. The gas is then passed through an absorber containing an iron oxide fly-ash sorbent where the iron oxide is converted to iron sulfides.

When the sorbent becomes saturated, indicated by an increase in the $\mathrm{H}_{2} \mathrm{~S}$ concentration in the product gas, the gas flow is shifted to the second absorber. The first absorber is then regenerated by oxidation with air, converting the sorbent back to iron oxide and releasing $\mathrm{SO}_{2}$. Steam and nitrogen also can be introduced during regeneration to moderate the absorber temperature.

The of $f$-gases from the regenerator are reduced in a carbon-bed catalytic reactor, producing elemental sulfur from sulfur dioxide. It has been demonstrated that 96 percent of the sulfur in the raw gas can be collected as elemental sulfur.

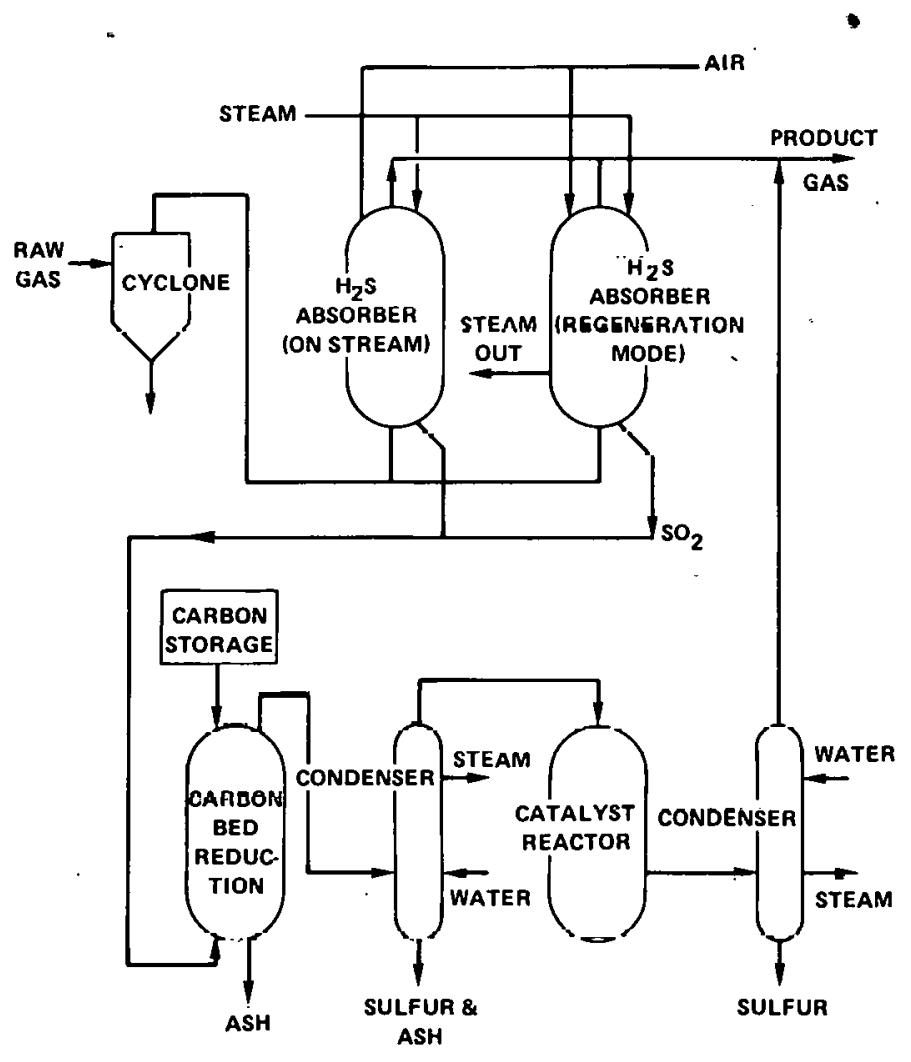

Hot-Gas Cleanup, Iron Oxide Process 


\section{Project Status}

At present, solid absorbents for $\mathrm{H}_{2} \mathrm{~S}$ cleanup are being developed and tested on a laboratory scale (30-to-50 scf/hr feed-gas rate). A benchscale unit $(10,000 \mathrm{scf} / \mathrm{hr})$ has been constructed at Morgantown Energy Research Center (MERC), and operations are continuing.

Elemental sulfur production during $\mathrm{S}_{2}$ regeneration of $\mathrm{Fe}_{2} \mathrm{O}_{3}$ sorbentbed is being investigated. A prototype of the alkali monitor developed for MERC by Ames National Laboratory is being tested.

A gasification simulator is being designed to produce major gas components, heteroatomic compounds, tars, and particulates at gasification temperatures in lab gasification studies.

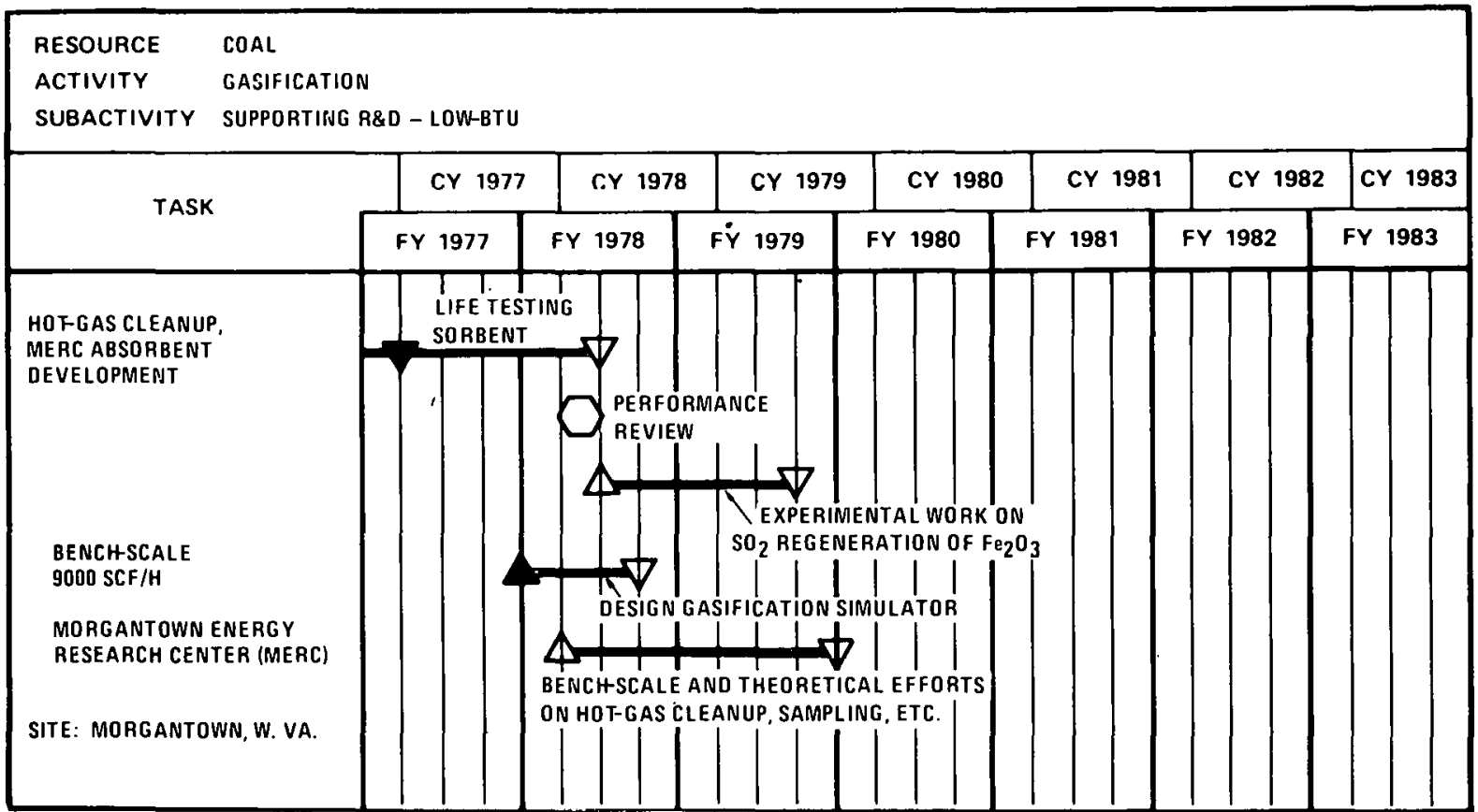

MILESTONE SYMBOLS ARE DEFINED ON LAST PAGE OF THIS DOCUMENT

\subsection{ENGINEERING EVALUATIONS}

The objective of the Engineering Evaluations task is to support the joint DOE/AGA High-Btu Gasification Activity by acting as a technical extension to the Fossil Energy (FE) staff. The approach is to develop each process to its maximum potential; gather data essential in determining advantages and disadvantages of each process; determine that process or combination of component processing steps that will have the greatest economic potential when constructed as a commercial facility; carry out commercial concept designs; and determine areas where additional studies are necessary to make available data, materials, and equipment required to construct a commercial gasification facility , 


\section{Project Status} follows :

The status of engineering evaluations of high-Btu processes is as

- Monitoring and evaluation of the status of Bi-Gas, HYGAS Steam-Oxygen, Steam Iron, and Synthane pilot plants are in progress.

- Commercial concept designs for HYGAS Steam Iron $\mathrm{C}_{2}$ Acceptor, $\mathrm{Bi}-\mathrm{Gas}$ and Synthane have been developed for producing 250 billion Btu/day SNG from Montana subbituminous coal. A parallel design on eastern Pittsburgh seam coal is in progress. Alco, a conceptual commercial prucess design will be completed which will compare the $\mathrm{C}_{2} 2$ Acceptor process against. the Turgi process utilizing lignite as lie feed cual.

- Process studies are being performed, or have been completed, for the following unit operations: 1) coal preparation and handling; 2) coal pretreatment; 3) coal feed injection; 4) gas purification; 5) shift conversion; 6) methanation; and 7) effluent treatment.

- Mechanical development requirements for commercial-size components have been completed. These studies reaffirm and/or modify those problem areas where mechanical development and/or engineering studies are required to meet the anticipated needs of demonstration and/or commercial gasification facilities for commercial-sized equipment.

\subsection{EQUIPMENT, MATERIALS, AND PROCESS DEVELOPMENT}

\section{New Equipment Development}

The objective is to generate new concepts for specialized equipment and to modify the most suitable commercial equipment or, if unavailable, to design new equipment that will be needed in a commercial-scale facility. The approach is to review requirements and define project needs. When defined, studies will be implemented for the development of suitable grinders, valves, separators, and power recovery turbines.

\section{Lock Hopper Valve Development}

The objective is to develop valves for lock hopper systems for feeding dry, crushed coal and to eliminate problems of gas leakage, sealing, erosion, and tar deposits. The approach is to complete design of components, construct and install the system, purchase valves, utilize lock hopper valve system, and make report on the valves tested. 


\section{Materials and Metallurgical Development}

The objective is to develop wear-resistant valve materials and improved ceramic materials for the gasifier. The approach is to develop a Raney nickel rod for flame spraying for methanation and to involve the Metallurgy Research Centers of the BOM to conduct bench-scale tests on catalyst efficiency, corrosion, erosion, and wear-resistance.

\section{Materials Development :}

The objective is to determine the performance of candidate metals and ceramics used in gasification plant construction under corrosive and abrasive environments. The approach is to subject a wide range of ceramics and materials of construction to actual conditions of temperature, pressure, and gaseous components currently existing or anticipated in each coal conversion facility.

\section{Novel High-Btu Gasification Processes}

The objective is to advance development of unique reactor designs and heat transfer techniques that may increase the efficiency of coal gasification and synthesis gas methanation processes. The approach is to evaluate candidate processes and implement individual studies after they are defined. Based on evolved concepts, system analysis will be prepared.

\section{Peat Gasification}

The objective is to develop a process for the conversion of peat into pipeline quality gas. The approach is to perform bench-scale studies and engineering evaluation needed to develop a general process for peat gasification. Physical studies are under way on size reduction, fluidization, and slurrying characteristics of peat. Thermobalance studies on gasification rates of peat with $\mathrm{H}_{2}$ and $\mathrm{H}_{2} \mathrm{O}$ mixtures have been completed. During FY 1978 and FY 1979, reaction rates will be studied in coiled-tube and lift-line reactors. A steam-oxygen char (peat) gasifier also is being studied.

\section{Gasification (Synthane Support)}

The objective is to develop new and improved technology for gasification of coal for making high-Btu gas and provide laboratory backup for operation of a 75-tons/day Synthane gasifier. The approach is to pretreat and decake coal at 40 and $70 \mathrm{~atm}$; erect a $70 \mathrm{~atm}$ pretreater system; develop hot-rhar let.down, a coal-oil slurry feeder, water purification system, heat exchange, and tar removal.

\section{Catalytic Methanation (Synthane Support)}

The objective is to develop new and improved technology for catalytic conversion of synthesis gas to high-Btu gas and provide laboratory backup for operation of the 75-tons/day Synthane plant. The approach is to improve catalyst life and productivity, increase rate and reduce cost of Raney nickel coatings, and minimize cost of catalytic methanation. 


\section{Catalyst Development (Synthane Support)}

The objective is to determine factors that affect life and activity of tube-wall reactor catalyst. The approach is to identify factors related to catalyst deactivation, prepare deactivation resistant catalysts, and test longevity of new catalysts.

\section{Systems Engineering/Planning}

The objective is to provide engineering support and planning services to assure technical achievement of gasification activity goals within cost and schedule constraints. The approach is to review and evaluate technical and programmatic progress of gasification projects; review and identify objectives for each project; and provide organization and management tools for planning and control of project implementation.

\subsection{ENVIRONMENTAL STUDIES}

The objective is to support generic studies that will assess environmental problems applicable to many or all high- and low-Btu gasification projects. The approach is to perform environmental assessments and begin to characterize process emissions and effluent discharges.

\subsection{OTHER SUPPORT AND SPECIAL PROJECTS}

\section{Low-Btu Gasification}

Technical and engineering services, including assistanr.e in proreiss evaluation, process selection, preparation of cost estimates, mathematical modeling of gasification processes, preliminary engineering design, and engineering evaluation are required as essential components of the Low-Btu Gasification Activity. Compilation of the Coal Conversion Data Book will be continued in FY 1978. This handbook will be a comprehensive source of data on coal conversion systems and will be valuable to the entire Fossil Energy Research and Development Program. It will provide information on which to base the design and operation of coal conversion systems.

The development of gasifiers and auxiliary systems for the generation of a fuel gas must have associated with it a project directed specifically to solving the unique processing requirements imposed upon the equipment and their materials of construction. It is essential, prior to the expenditure of large sums of money for complex equipment, to know and understand the behavior of many candidate metals and ceramics under actual use conditions. The data generated in these programs are used to solve specific materials and equipment problems that will be encountered in pilot plant operation. 
Other support projects consist of continued review of the overall program objectives as well as redefinition of program tasks. Some support projects have been changed in format and/or phased out as the requirement for the data has been satisfied. This continuing activity is necessary to ensure that funding resources are directed into research and development channels that offer the greatest potential for near- and longrange solutions to energy problems.

\section{High-Btu Gasification}

Exploratory development and applied research for high-Btu gasification include applied chemical research and engineering development for processes that encompass:

- Chemical kinetics and reaction mechanisms of gasification and methanation

- Development of methanation catalysts

- Development of economic schemes for regenerating spent or poisoned catalysts

- Mathematical modeling of reactor systems

- Development of pressurized coal-feeding techniques

- Development of methanation reactors

- Removal of coal tars

- Development of systems for removing char and ash from the gasifiers

- Development of satisfactory methods to burn the by-product char

- Development of basic engineering data needed for operating fluid beds at high temperatures and pressures

- Development of methods of processing coal for gasification. 


\subsection{IN SITU COAL GASIFICATION (UNDERGROUND COAL CONVERSION)}

More than 85 percent of our nation's vast coal resource is not economically recoverable by conventional underground or strip mining. Underground coal conversion processes could recover an estimated 1,795 billion tons of this unmineable coal by converting it in place to cleanburning gaseous and liquid fuels. As a complement to mining plus surfacebased coal conversion processes, the development of underground conversion processes could significantly expand the economic extraction of energy from coal in environmentally acceptable ways.

Underground coal gasification (UCG) can produce low-Btu gas for local use in electric power generation and as an industrial fuel. Medium-

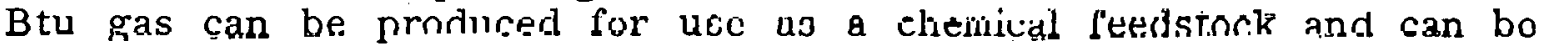
cconomically Lransported to nearby markets High-Btu oynthetic natural gas ( $S N G^{\prime}$ ) can be produced by upgrading the medium-Btu gas in surface facilities and can be pipelined directly into existing natural gas transmission systems.

Underground coal liquefaction (UCL) can produce liquid products for use as refincry feedstocks to produce a wide range of fuel products.

The objective of the DOE Underground Coal Conversion program is to develop commercially viable underground conversion processes for extracting energy from coal. Through government and industry joint participation, the technology will be developed, proved on a large scale, and transferred to the private sector. Data will also be provided to predict the economics of a commercial operation. The near-term goal is to develop at least one commercial underground conversion process by 1985 to 1987 and assure technology transfer to the industrial sector. The mid-terim goal is to develop advanced concept.s, i.e., Increased resource recovery, reduced water usage, and reduced dependence on underground characteristics.

These program goals directly support our national energy goals for (1) expanding the domestic supply of economically recoverable cnergyproducing raw material and (2) efficiently traneforming fuel resuurces into more desirable forms.

One future coal-based energy scenario* puts the potential contribution of UCG in perspective by showing that electrical and SNG "mine mouth" UCG plants alone could comprise about 15 percent of the total coal usage by the year 2000 and 35 percent by 2050 . The primary reason for this optimistic appraisal of UCG's potential is that compared to conventional mining of coal combined with surface gasification, UCG offers a number of significant potential advantages. Some of these advantages

*Dickson, E. E., et al, "Synthetic Liquid Fuels Development: Assessment of Critical Factors, Vol. III Coal Resource Depletion," Draft, Jan. 1977 


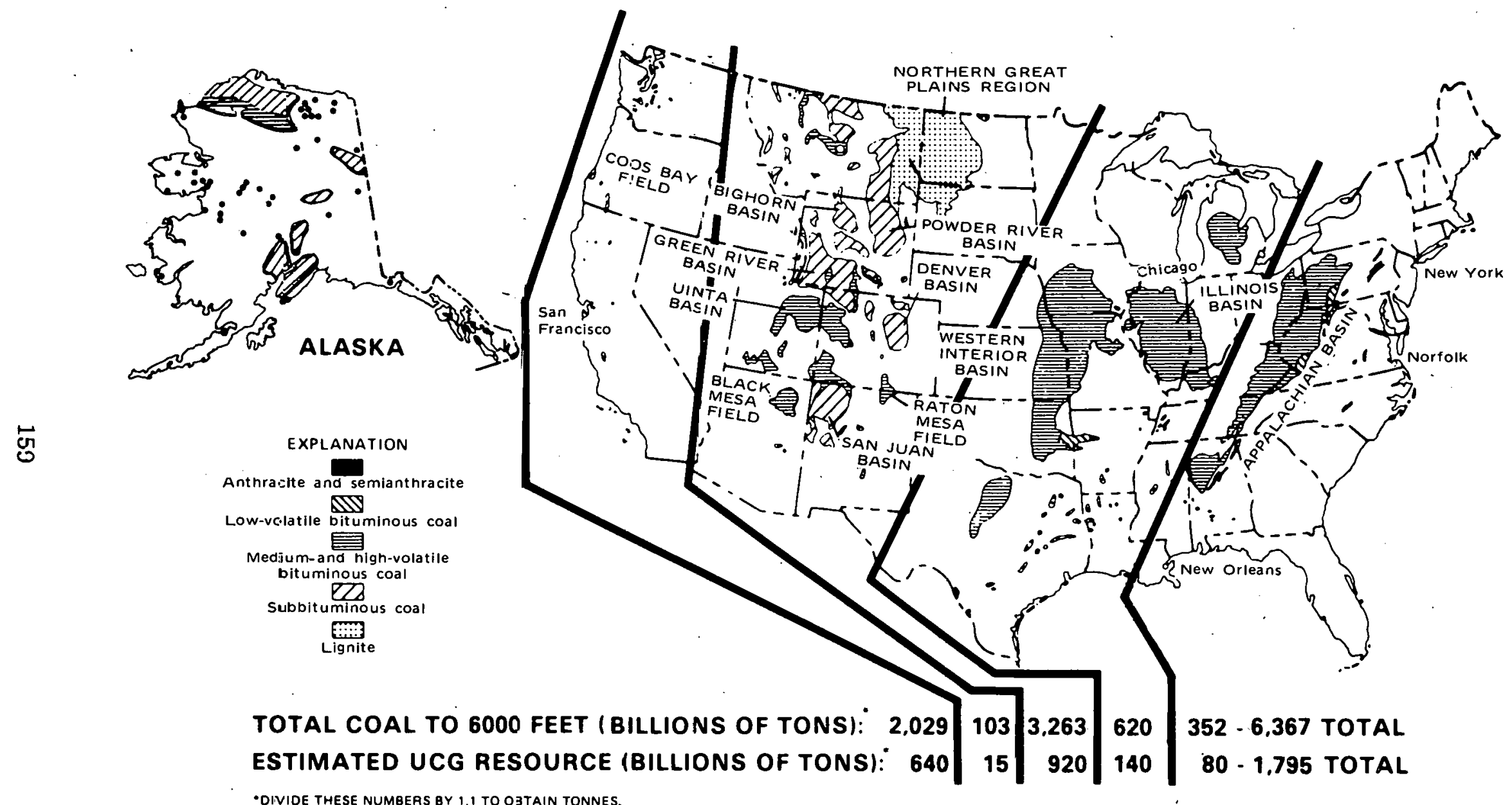

Coal Fields of the United States 
have not yet been proven, but DOE's program is designed to show that, in addition to tripling our recoverable coal reserves, UCG: minimizes health and safety problems associated with conventional coal extraction techniques since no mining is required; produces less surface disruption than strip mining and brings less solid waste to the surface; consumes less water and generates less atmospheric pollution; reduces the socioeconomic impact since fewer operators are required; and reduces both capital investment and gas costs by at least 25 percent.

The primary disadvantages of UCG are possible contamination of surface water and underground aquifers and subsidence of the surface. In order to minimize the impact of these potential problems, extensive environmental monitoring before, during, and after each field test along with the development of environmental control technningy, lab simulations, and andytical modeling are included as integral parts of each field project.

The technical feasibility of MCG has been proven by the British and, most notably, the Russians who have had commercial UCG plants in operation for 20 years. Building on the available UCG technology, DOE's Laramie Energy Research Center (LERC) and Lawrence Livermore Laboratory (LLL) have conducted highly successful subpilot-scale field tests at Hanna and Gillette, Wyoming, respectively. Low- and medium-Btu gases have been produced for sustained periods and successful control of important process variables has been demonstrated. Proving economic feasibility is the key to commercialization of UCG in this country and will require demonstration of efficient use of the coal resource, controllability of the underground process (including environmental affects), reliable long-term operation at high production rates, and verification of the process design at several sites.

These requirements are being fulfilled through an integrated program of field tests, instrumentation and process model develupment, and Jaboratory-Eupporting research.

The four major UCG process options being developed as part of DOE's Underground Coal Conversion program address the wide range of chemical and physical properties of the coal seams and surrounding geology found in this country. The Western Low-Btu Gas project is concentrating on gasifying western subbituminous coal using Linked Vertical Well (LVW) technology with air injection and has the highest potential for commercialization by 1985. The Western Medium-Btu Gas project is concentrating on gasifying western subbituminous coal with oxygen and steam injection, instead of air, using LVW, Packed Bed (PB) and other technologies. The Eastern Coal Technology project, using Longwall Generator (LG) technology, is concentrating on gasifying highly swelling eastern bituminous coals which are more difficult to gasify, but are closer to large consumer markets. The Steeply Dipping Beds (SDB) project is concentrating on coal seams which dip more than $35^{\circ}$ and are not exploitable with conventional mining technology. The Environmental support and Supporting Research projects contribute to all four major projects by bringing new technology into the program. One example is the new university research study being conducted to determine the feasibility of underground coal liquefaction. 
The table below summarizes the funding levels by task for FY 1977 to FY 1979 period.

\begin{tabular}{|c|c|c|c|c|c|}
\hline $\begin{array}{l}\text { IN SITU COAL } \\
\text { GASIFICATION }\end{array}$ & \multicolumn{4}{|c|}{$\begin{array}{c}\text { BUDGET AUTHORITY } \\
\text { (OPERATING EXPENSES) } \\
\text { (DOLLARS IN THOUSANDS) }\end{array}$} & \multirow{2}{*}{$\begin{array}{l}\text { MAJOR } \\
\text { CHANGE. }\end{array}$} \\
\hline TASKS & $\begin{array}{l}\text { ACTUAL } \\
\text { FY } 1977\end{array}$ & $\begin{array}{c}\text { APPROPRIATION } \\
\text { FY } 1978\end{array}$ & $\begin{array}{c}\text { ESTIMATE } \\
\text { FY } 1979\end{array}$ & $\begin{array}{l}\text { INCREASE } \\
\text { (DECREASE) }\end{array}$ & \\
\hline $\begin{array}{l}\text { Linked Vertical Wells } \\
\text { (Western Low-Btu Gas) } \\
\text { Packed-Bed (Western } \\
\text { Medium-Btu Gas) } \\
\text { Longwall Generator (Eastern } \\
\text { Coal Technology) } \\
\text { Steeply Dipping Beds } \\
\text { Environmental Support } \\
\text { Advanced Concepts \& } \\
\text { Supporting Research }\end{array}$ & $\begin{array}{r}\$ 3,100 \\
2,500 \\
900 \\
400 \\
500 \\
836\end{array}$ & $\begin{array}{r}\$ 4,200 \\
2,200 \\
1,200 \\
1,100 \\
1,200 \\
1,100\end{array}$ & $\begin{array}{r}\$ .4,300 \\
2,450 \\
0 \\
2,050 \\
900 \\
2,100\end{array}$ & $\begin{array}{r}\$+100 \\
+250 \\
\\
-1,200 \\
+950 \\
-300 \\
+1,000\end{array}$ & \multirow[t]{2}{*}{ C } \\
\hline TOTAL & $\$ 8,236$ & $\$ 11,000$ & $\$ 11,800$ & $\$+800$ & \\
\hline \multicolumn{3}{|c|}{$\begin{array}{l}\text { "KEY } \\
N=\text { New start (totally new project) } \\
S=\text { Scaleup (from bench to PDU or pilot plant) } \\
A=\text { Acceleration (shortening deadlines or } \\
\text { expansion of ongoing projects) }\end{array}$} & \multicolumn{3}{|c|}{$\begin{array}{l}P=\text { Phase completion or startup } \\
R=\text { Program redirection } \\
I=\text { Incremental cost requirement } \\
C=\text { Project completion or suspension }\end{array}$} \\
\hline
\end{tabular}

\subsection{WESTERN LOW-BTU GAS (LINKED VERTICAL WELLS)}

The Laramie Energy Research Center is conducting the Western LowBtu Gas project in a 30-foot thick subbituminous coal seam in the Hanna Field in Wyoming. The objective of this project is to develop a process for gasifying coal in place to produce a low-Btu gas for utility power generation or industrial use. Linked Vertical Wells with air injection is one of the simplest processes to execute. It requires minimal seam preparation and has a high probability of success in coal seams that have adequate natural permeability .

The LVW process is applied by drilling vertical wells into the coal seam to provide for injection of air and collection of product gases. Reverse combustion is used to link the wells through the coal seam, followed by forward gasification of the coal between the linked wells.

In the diagram below, the center and right wells are linked by reverse combustion. High pressure air is injected in the right well and flows to the center production well through naturally occuring cracks and paths in the coal. The combustion zone advances from center well to right well (injection well) against the gas flow creating a hot char channel between the wells. Once two wells are linked, the gasification front reverses direction moving with the gas flow. This second stage, called 
forward gasification, is shown between left and center wells in the diagram. Forward gasification proceeds along the linked passage which widens and caves in to expose more coal.

As illustrated, one pair of wells (one module) can be linked while the coal between a second pair is being gasified. When the gasification zone passes the center well, that well is switched to injection and the right well is switched to production. A link is then started to a new well, yet farther to the right. Thus, the gasification proceeds in a line although it expands appreciably to either side of the line. Lines of wells are drilled close enough so the gasification cavities overlap using as much of the coal as possible. Success of the process depends on controlled movement of the reaction zone between vertical wells and efficient use of the coal resource.

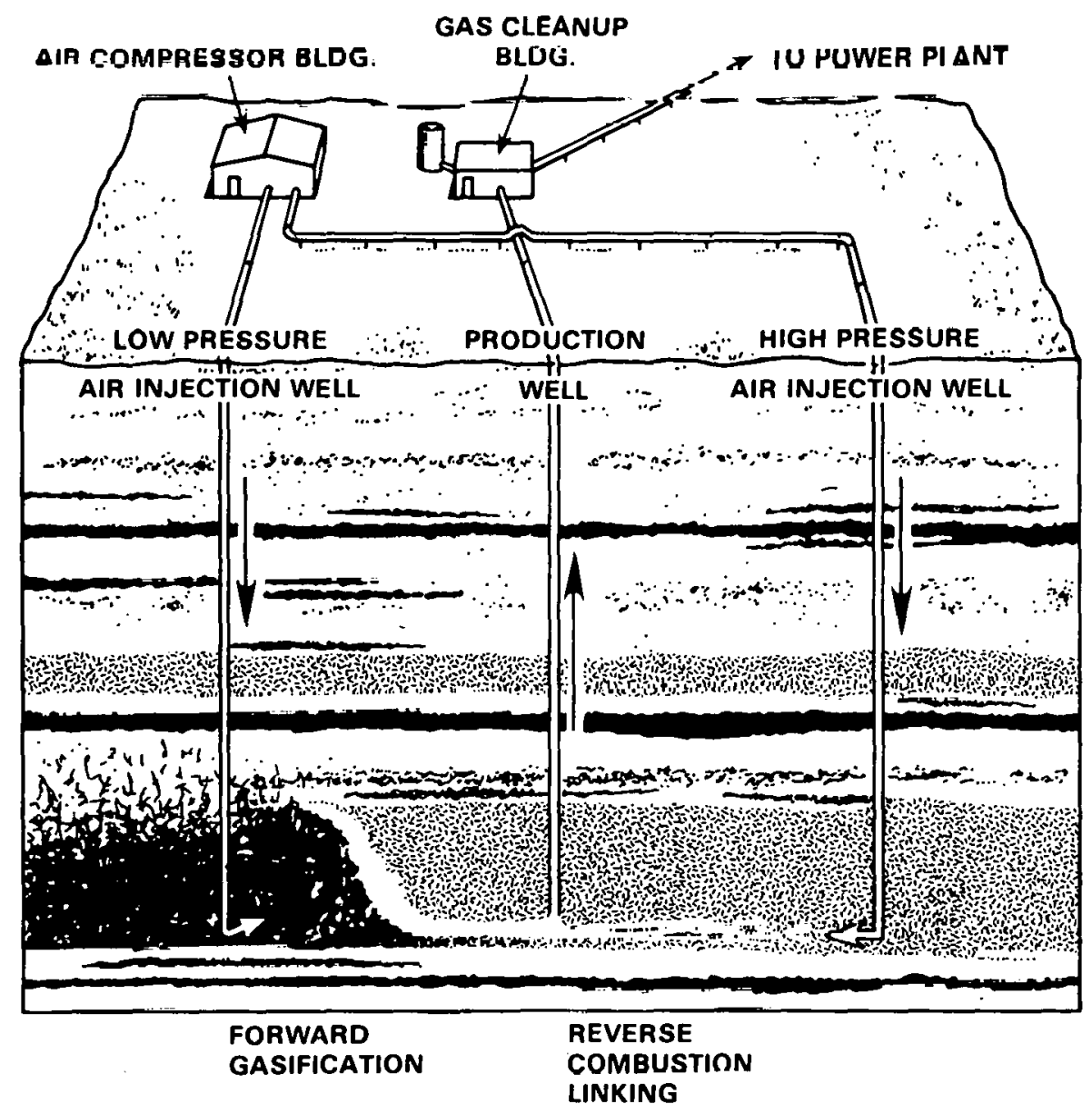

Linked Vertical Wells Process 


\section{Project Status}

Development of the LVW process started in 1972. In Hanna l, the first field tests, gas with an average heating value of $126 \mathrm{Btu} / \mathrm{scf}$ was produced for about six months, ending in March 1974. The test was quite successful since energy. production was four times energy use. Hanna 2, completed in

the summer of 1976, produced an average of 8.5 million scf/day of 172 $\mathrm{Btu} / \mathrm{scf}$ gas. This is equivalent to the electrical needs for a town with a population of 6,000 .

This test demonstrated a very high areal sweep efficiency by gasifying a total of 6,700 tons of coal from a fourwell square pattern that enclosed 4,600 tons of coal. The Hanna 3 environmental test was completed in July 1977. This was a highly instrumented two-well experiment designed primarily to measure the effects of the process on underground water flows and compositions and to further refine the LVW operating and control procedures. Analysis of the results will continue for more than a year.

Beginning with Hanna 2, a major instrumentation effort was fielded by Sandia Labs, making these the most. instrumented UCG tests ever conducted.

Development of a detailed math model of the process was initiated, using a combination of field and laboratory data plus theoretical considerations. Refinement of this model will provide design information for applying LVW to other sites.

The Hanna 4 test was initiated in the Fall of 1977, to test the LVW process over greater well spacing and to develop a standard test for this process at other sites.

In FY 1978, Hanna 5 will be the first attempt to scaleup the process, by operating side-by-side units simultaneously. Maximum gas production should exceed 90 million scf/day. During this same period, Lawrence Livermore Laboratory and Morgantown Energy Research Center (MERC) will run LVW site applicability tests at Hoe Creek, Wyoming, and Pricetown, West Virginia. At least two additional site tests will be conducted by industry contractors with help from LERC.

This project will culminate in the design and operation of an LVW pilot plant in FY 1980. It will run for two to three years producing 50-60 MW of electric power from 130 million scf/day of the low-Btu product gas. This test will verify the reliable operation of a fully integrated UCG process and provide the economic, environmental, and operating data required to transfer commercially acceptable terhnology to the private sector. The pilot plant will be designed by an industrial firm under contract to DOE. The successful completion of the pilot test could make the LVW process ready for commercialization by 1985 . 


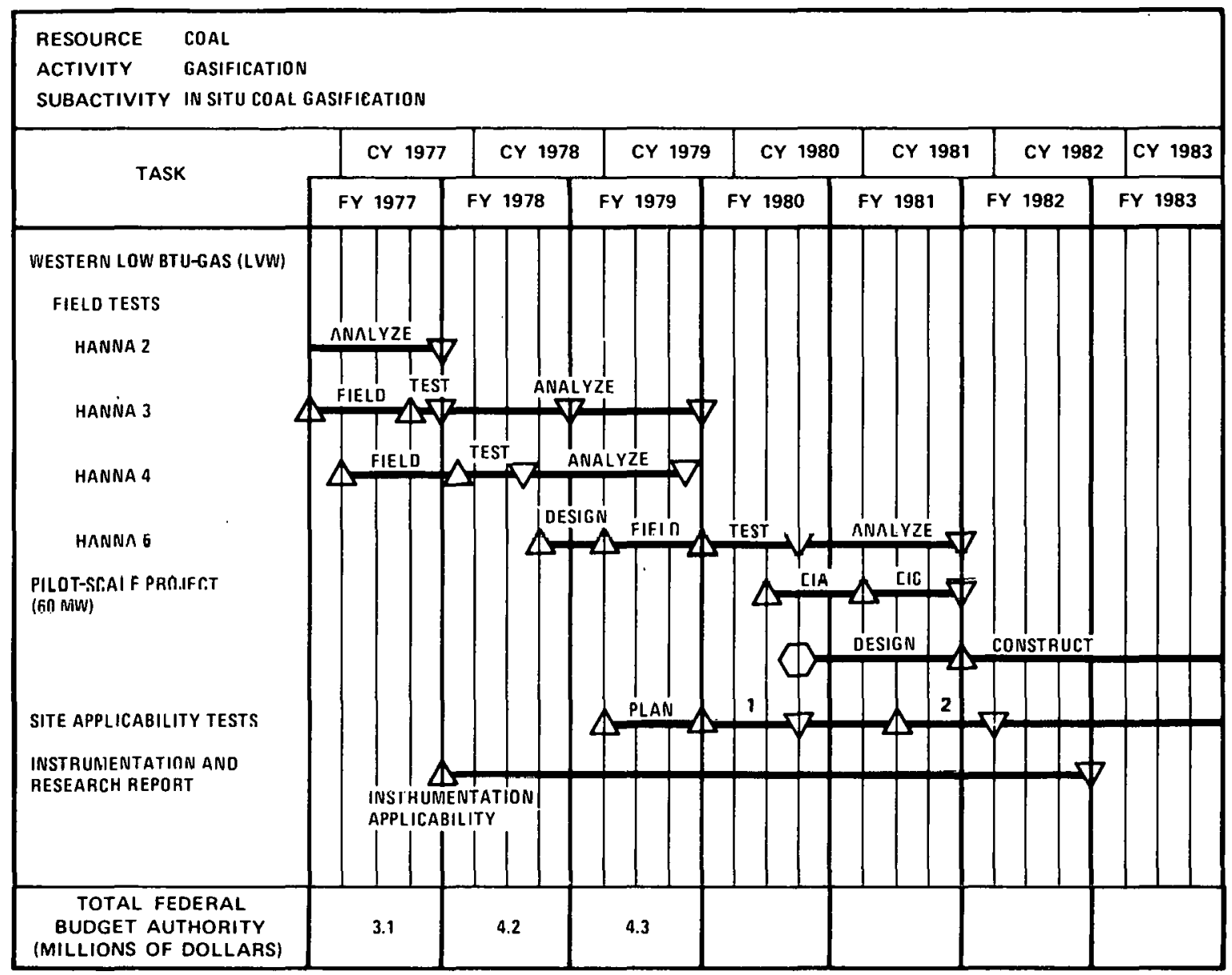

MILESTONE SYMBOLS ARE DEFINED ON LAST PAGE OF THIS DOCUMENT

\subsection{WESTERN MEDIUM-BTU GAS (PACKED-BED)}

Lawrence Livermore Laboratory (LLL) is conducting the Western Medium-Btu Gas project in a 25-foot thick subbituminous coal seam at Hoe Creek, Wyoming. The objective of this project is to develop a commercial process based on LVW technology, using oxygen and steam injection to produce medium-Btu gas for use as a chemical feedstock or upgrading to SNG. Well-linking methods, other than reverse combustion, will be developed for application of this technology to a wide variety of resource/process combinations (especially very deep, thick coal seams).

One alternate linking technology is the Packed-Bed process. This process uses chemical explosives to fracture thr cosl deposit creiting a permeable zone. The coal in a permeable fractured bed has a large surface area which increases contact between the coal and the gaseous reactants. 
Collection wells are drilled to the bottom of the fractured zone along its perimeter; injection wells are drilled to the top of the zone. Gasification with steam and oxygen begins at the top of the fractured zone and moves downward and outward. The liquid products drain downward through the bed where they are removed through production wells. This reduces liquid plugging and gas override. As the coal is gasified, fractured coal falls into open channels and prevents short circuiting between the injection and production wells.

The PB process could offer several improvements over LVW for gasifying deep coal seams. Since deeper seams generally have lower natural permeability, the LVW process may not work on deep coal without artificially enhancing permeability. If the permeability created by fracturing in the $\mathrm{PB}$ process can be predicted and controlled, greater reliability in linking would result regardless of the natural permeability of the coal. If sufficient flow capacity results from the explosive fracture, the reverse link could be avoided entirely, possibly reducing costs. Finally, directed explosives (such as shaped charges) could produce horizontal holes in the coal to link wells, provide cost benefits, and even lead to process designs for use in thin eastern coal seams.

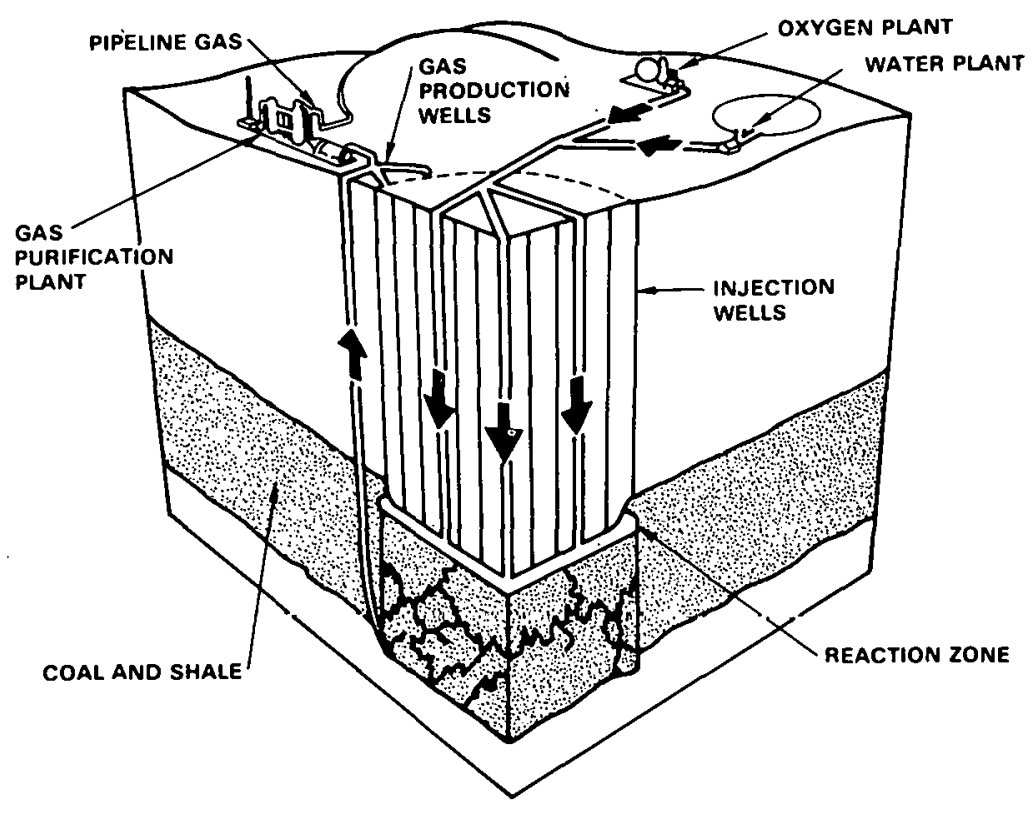

Packed-Bed Process 


\section{Project Status}

LLL has been running the PB project since its inception in FY 1975. The suitability of a site at Hoe Creek in the Powder River Basin near Gillete, Wyoming, was verified. In FY 1977 a preliminary test of a two-shot fracture and forward gasification with air was run in a shallow coal seam at the Hoe Creek site. Although the desired permeability distribution was not achieved, the reverse linking step was successfully omitted. Data reduction, groundwater monitoring, and post burn coring activities are in progress .

The PB process is in an early stage of development and may require extensive laboratory testing before further field trials can be made.

Directed explosives, such as shaped charges, could produce horizontal holes in the coal to link wells at low cost. Methods for accurately implanting shaped charges in coal seams and cleaning out the hole afterwards must be perfected. Preliminary shaped charge tests in exposed coal seáms have been very successful. Plans are being made for further design and field testing.

One site applicability test for LERC's LVW process was completed in Fall 1977. This test (Hoe Creek 2) used coal that was more uniform, considerably wetter and more reactive than the coal at Hanna. During this test, oxygen and steam were injected for three days. Medium-Btu gas was successfully produced with a heating value that averaged $260 \mathrm{Btu} / \mathrm{scf}$ and ranged up to $300 \mathrm{Btu} / \mathrm{scf}$.

L.I.I. plans a series of field tests using steam/oxygen injection to produce medium-Btu gas. Hoe Creek 3, during FY 1978 to FY 1979, will be the first complete steam/oxygen gasification experiment in the DOE UCG program, and will draw upon the experience with low-Btu gasification at Hanna and Hoe Creek, the supporting laboratory program, and analysis of the Russian steam-enriched air gasification tests. The most promising technique among reverse combustion, explosive fracturing, and shaped charges will be used to link the two-process well pattern. If successful, this will be the final shallow gasification experiment by LLL. The results of Hoe Creek 3, combined with data from characterization of the selected deep site, will be used to design deep steam/oxygen test 4 . This will be the first definitive test of LLL's UCG technolngy on the target resonrce, deep, thick western subbituminous coal. Deep steam/oxygen test 5 will. use a process module large enough to develop design criteria for the pilotscale test. The pilot-scale steam/oxygen test will provide final technical, environmental, and economic data for scaleup to commercial operations. 


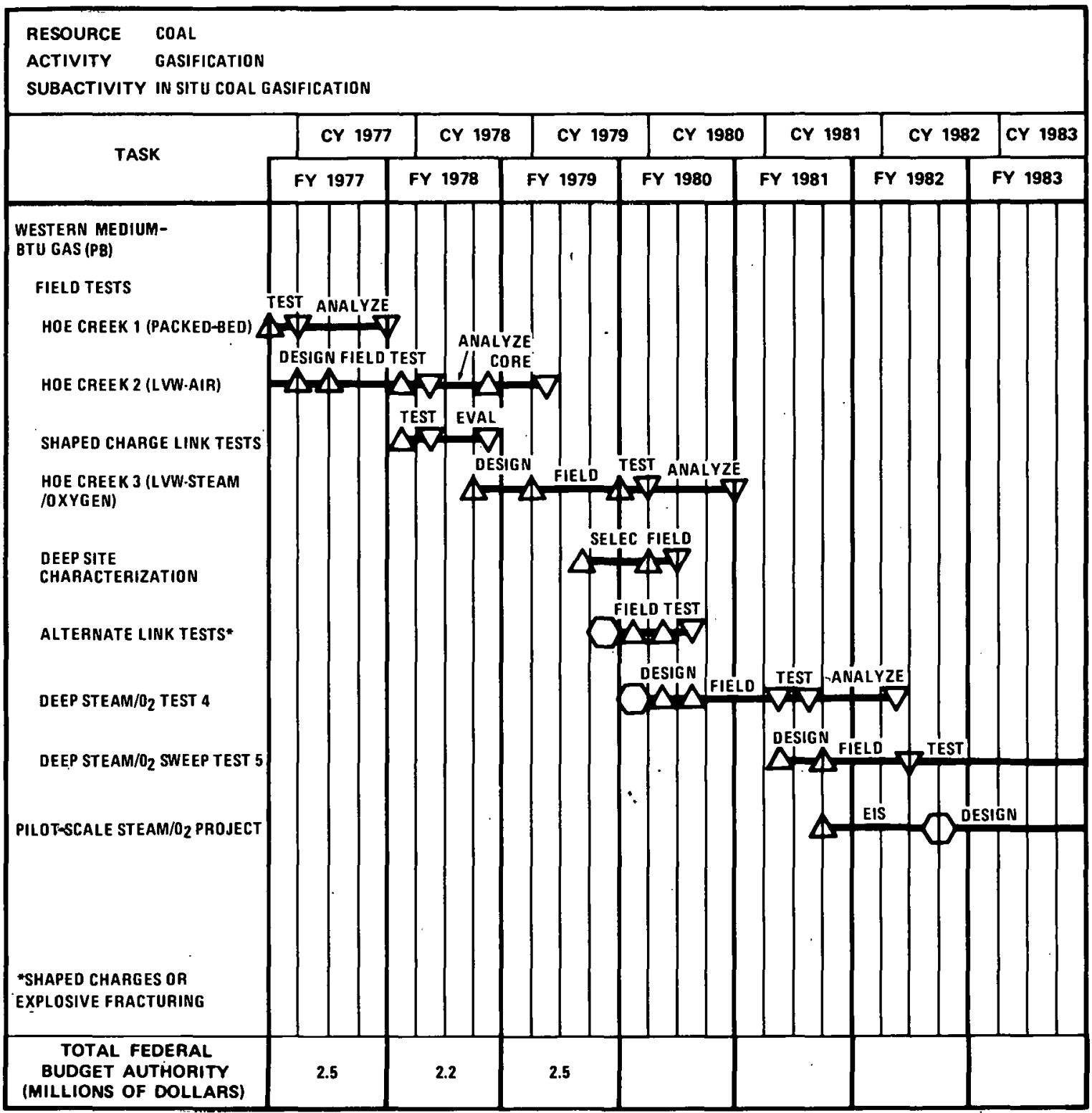

MILESTONE SYMBOLS ARE DEFINED ON L,AST PAGE OF THIS MOGUMENT

\subsection{EASTERN COAL TECHNOLOGY (LONGWALL GENERATOR)}

The objective of the Eastern Coal Technology project (being run by MERC) is to develop a method of gasification for eastern coals that cannot be mined easily. Thin, low-permeability, high-swelling eastern coal seams are most difficult to gasify by underground methods. The Longwall Generator process has been conceptualized and may be applicable to" eastern coal. Rugged terrain and densely populated areas in the east make drilling closely spaced (100 feet or less) vertical wells difficult. Directional drilling and the LG process may solve this problem. Deviated holes provide the best means of developing the underground manifold if they can be drilled economically. 
The LG process uses directionally drilled holes aligned perpendicular to the orientation of the major fracture system to provide the maximum coal surface for the gasification reaction. Deep seams of bituminous coal 5 to 15 feet thick will be gasified with air to produce low-Btu gas for power generation or industrial use. Deviated wells are drilled from the surface and curved to produce long boreholes lying in rows within the coal seam. The coal is burned between the parallel rows of horizontal holes that serve as the injection and production wells. The product gases flow through the coal in the direction of maximum permeability, eventually reaching the production wells. This may eliminate the need to fracture the coal.

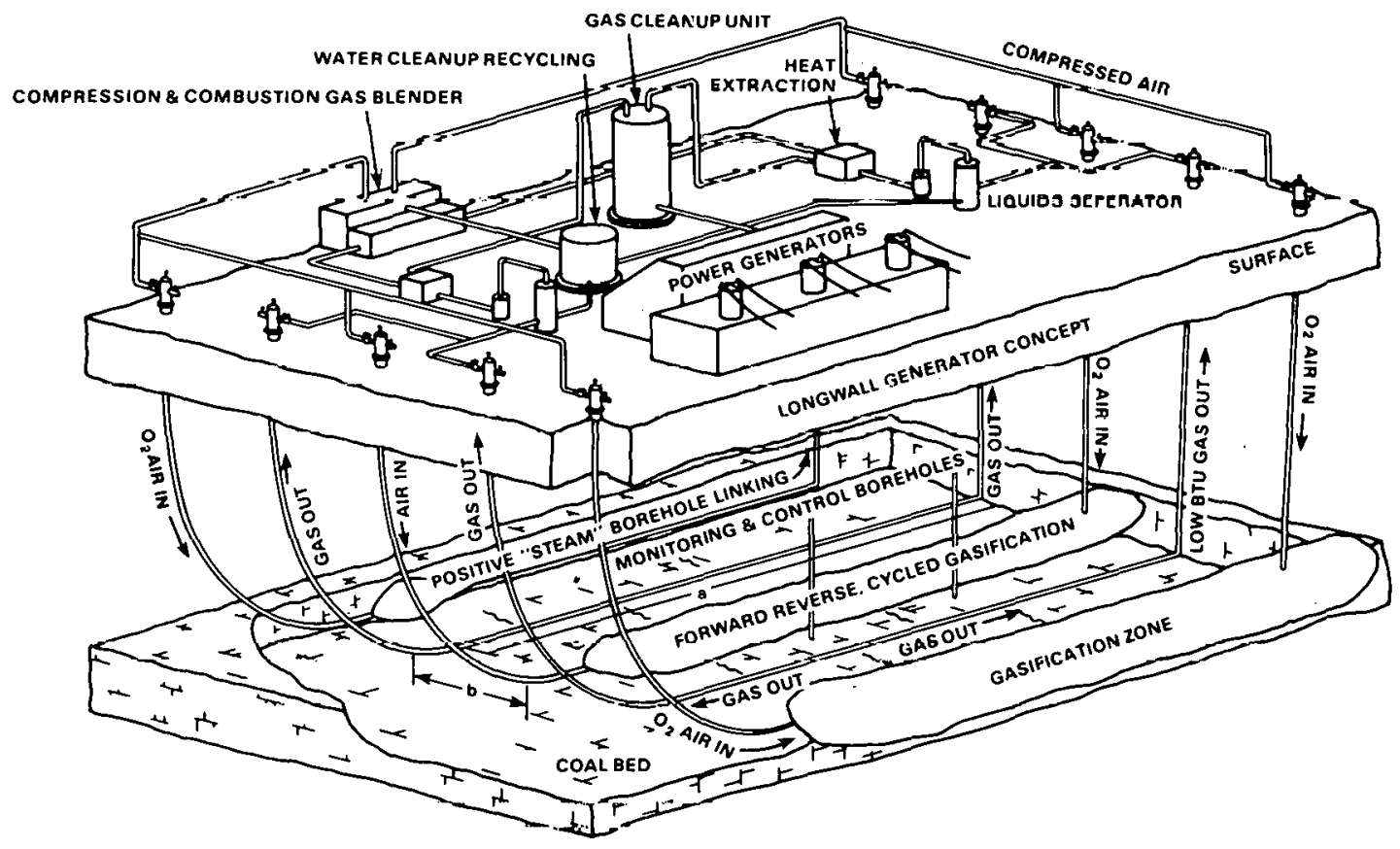

Longwall Generator Concept

\section{Project Status}

Field experimentation has concentrated on site selection, resource evaluation, and preparation of an environmental impact assessment (EIA). A site near Pricetown, West Virginia, was selected for the initial test in the bituminous Pittsburgh seam. One deviated well has been drilled by MERC to the 6-foot thick seam under 850 feet of overburden. The well is 2,000 feet long with the final 500 feet lying within the coal seam. The flow characteristics of the well will be tested in FY 1977 for gasification in FY 1978 as part of the Pricetown 2 field test. An LVW test (Pricetown 1) is being prepared for the first part of FY 1978. This will be the first site applicability trial of the LVW concept in an eastern coal seam. It will also give data on the maximum well spacing that can be used in the LG concept to be used for the Pricetown 2 test. 
The laboratory program has centered on determining the mechanical and physical properties (especially natural permeability and fracturing characteristics) of coal under overburden stress. A series of experiments that simulates the field tests was completed in the latter half of FY 1977. The supporting research program also includes theoretical modeling and the development of methods to control the gasification process.

The long-range program consists of advancing directional drilling technology to ensure a flow capacity within the coal seam sufficient to accommodate the reactant gases, tests of forward and reverse gasification modes, and scaleup and application of the process to various thin coal seams.

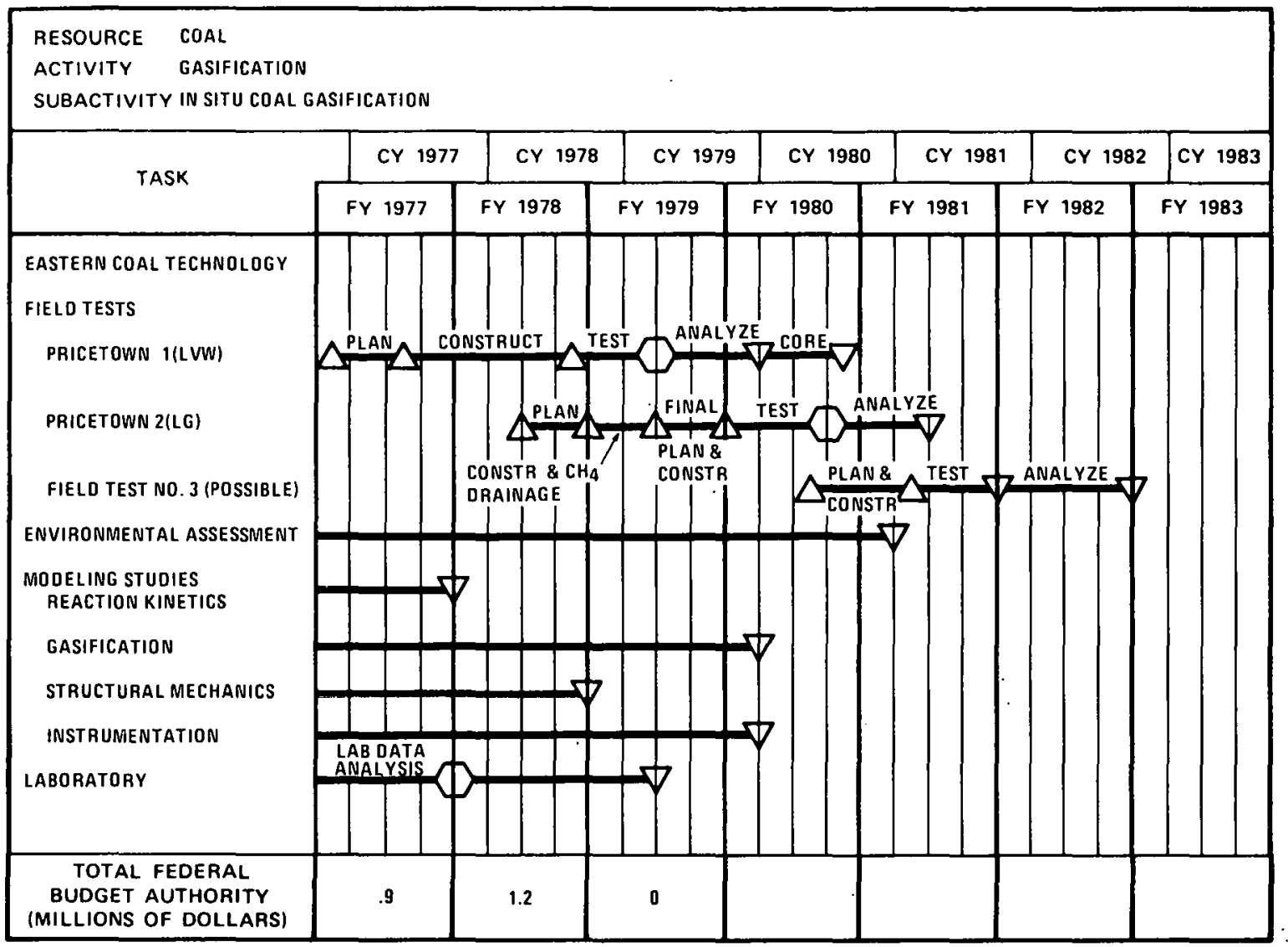

MILESTONE SYMBOLS ARE DEFINED ON LAST PAGE OF THIS DOCUMENT

\subsection{STEEPLY DIPPING BEDS}

The objective of this project is to develop a process for gasifying coal seams that dip at angles greater than about $35^{\circ}$. This coal is not recoverable by existing mining methods. Drilling requirements and subsidence problems are less for the SDB process than for the other in situ gasification processes. 
As illustrated below, slanted holes, cased only through the overburden, are drilled into and through the coal bed following the dip. A channel connects the lower ends of these slanted production wells. Air

injection wells are drilled either vertically, slanted underneath the coal bed, or in the coal bed itself to intersect the horizontal channel connecting the uncased production holes. Product gases are withdrawn through the slanted holes in the coal bed midway between the injection holes. Reducing reactions occur on the surface of the slanted, uncased exhaust holes. As the coal above and along the horizontal channel burns away, the fire zone advances updip.

Over 100 billion tons of SDB coal are estimated to exist in the United States. A large percentage of the Pacific coast coal is steeply dipping so commercialization of an SDB process could contribute to the future energy supply of the populous west. rnast. There are alsn suhstantial snR deposits in the Rocky Mountain area and lesser amounts in the Appalachian and Interior coal regions.

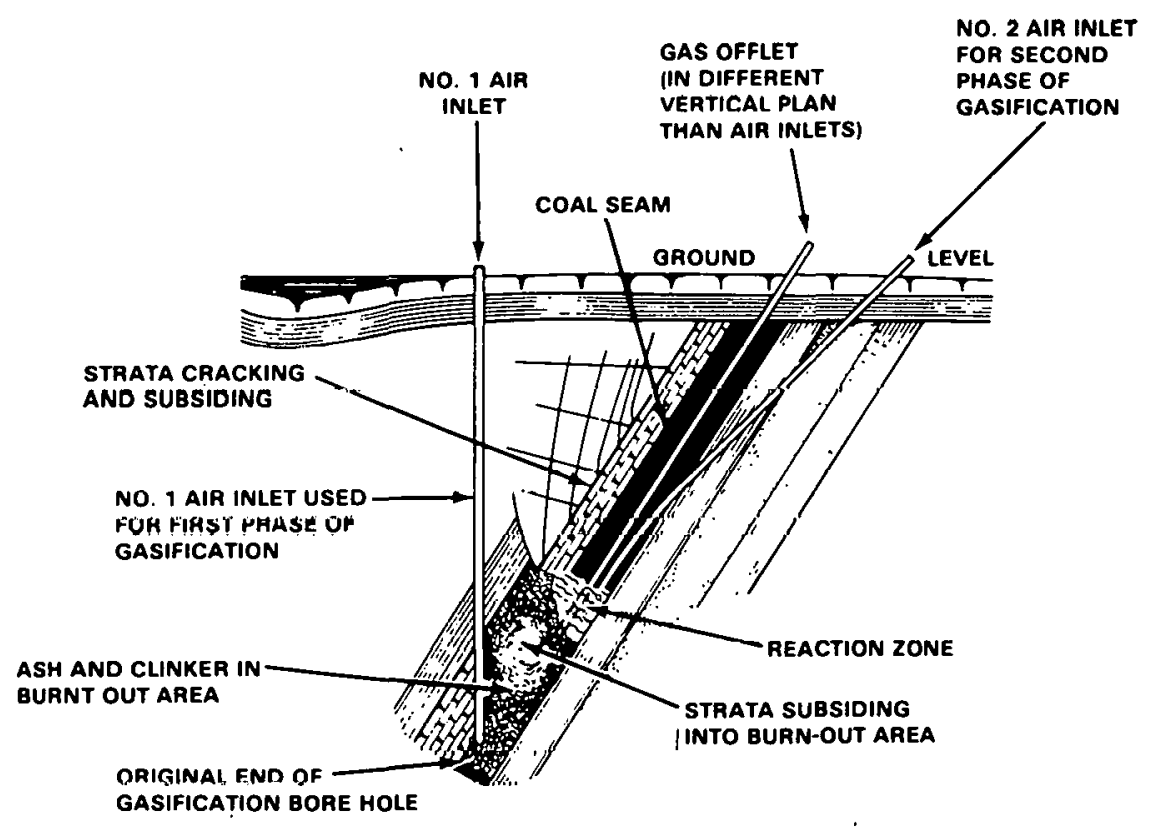

Steeply Dipping Bed Concept 


\section{Project Status}

Planning for the SDB project began in FY 1976 to bring an industrial participant into the UCG program to implement the project. During the planning period Soviet reports were obtained showing their success in gasifying SDB. It appears that there could be direct transfer of this technology from the open literature, minimizing the technical risks. In addition, preliminary technical and economic analyses of SDB gasification indicate significant potential advantages over gasification of flat-lying coal.

In September, 1977, Gulf R\&D Company (GR\&DC) signed a contract with DOE to conduct the Steeply Dipping Beds project during FY 1978 to FY 1982 .

Building on the Soviet techniques described in the literature plus the practical experience gained in the LVW field tests at Hanna and Hoe Creek, Wyoming, Gulf should be able to develop SDB technology to the point of pilot-scale readiness in a five-year period. The project requires a minimum of basic research and modeling activities, and focuses almost entirely on engineering and field test operations.

The project is divided into four phases as follows:

- Phase I: Feasibility Study and Program Plan Preparation (October 1977-March 1978) includes site selection, environmental and parametric cost analyses of the design concept, and detailed project and cost plan preparation.

- Phase II: Site Characterization, Environmental Assessment (April 1978-September 1979) includes detailed site characterization, base line environmental monitoring, definition of critical process parameters, scaling factors, field test systems requirements, and Environmental Impact Assessment preparation.

- Phase III: (October 1979-March 1982) includes field site installation, Field Tests 1, 2, and 3, and technical, economic, and environmental analysis of test results.

- Phase IV: Pilot Plant Design Estimate (April-September 1982) includes preparation of a preliminary design and cost estimates for an SDB pilot plant. 


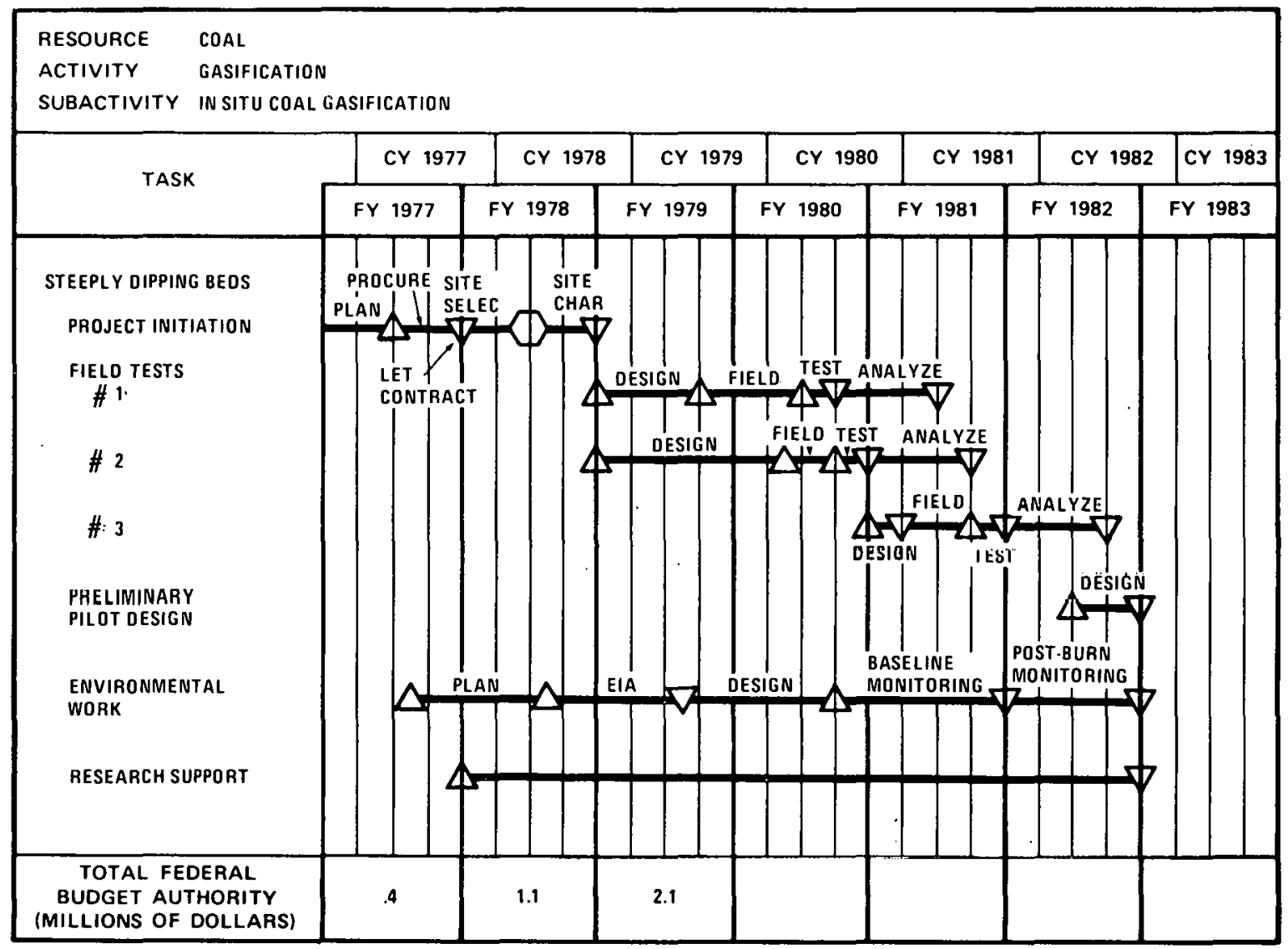

MILESTONE SYMBOLS ARE DEFINED ON LAST PAGE OF THIS DOCUMENT

\subsection{ENVIRONMENTAL SUPPORT}

Environmental problems associated with in situ coal conversion may he less serious than those with mining and surface gasification. The biggest problem could be the disruption and contamination of local aquifers. This area requires further research; however, overall water usage should be lower for in situ than for surface gasification. Air emissions should be no worse than those from surface gasification and will be controllable by similar' methods. Surface disruption due to subsidence should be negligible and easily repaired in comparison to strip mining.

Environmental support work determines the true impact of environmental problems associated with in situ coal gasification and methods for controlling them. Since environmental problems are commnn tn all in situ concepts, environmental support crosscuts all four major projects.

\section{Project Status}

An Environmental Development Plan has been drafted and will be approved in mid-FY 1978. It will provide for the implementation of a comprehensive environmental plan for in situ coal gasification projects to ensure that all environmental issues are fully considered in decision making. 
Measurement of gaseous emissions was made during the Hanna 2 test of LVW. Emissions were equal to or less than those from surface gasifiers. Base line water quality and postburn changes have been measured in both the Hanna and Hoe Creek tests. Detailed hydrologic and geologic studies have been made in the Pricetown site area to provide base line environmental data. LLL has run laboratory tests which show that surrounding coal can cleanse subsurface water of harmful pollutants. The tar produced in the Hanna 2 test revealed potentially carcinogenic compounds. Evidently these components were trapped and reacted underground.

The primary objective of Hanna 3 is measuring underground water quality and determining the effects of in situ coal gasification on it. Longer and more detailed air-emission measurements will be made on Hanna 4 and extensive subsidence measurements on Hanna 5. A small test of gas cleanup will be tried on one or both of these gasification tests.

LLL has a cooperative agreement with Environmental Protection Agency (EPA) to conduct a more extensive laboratory program to determine the amount of water cleanup required to remove organic and inorganic contaminants. They will also use mathematical models to predict surface subsidence. MERC will compare water quality data they obtain before, during, and after the minitest. As part of the SDB project, site data for an environmental assessment will be obtained in FY 1978.

\subsection{ADVANCED CONCEPTS AND SUPPORTING RESEARCH}

This category contains the scientific and engineering studies that support the total program plus preliminary work on new concepts that could lead to improved processes.

\section{Project Status}

Ongoing work includes laboratory experiments on the pyrolysis of large blocks of coal and on char gasification under simulated in situ conditions. The data are used in process models for predicting performance of the field tests. Several university projects are analyzing underground cavity formation, seam dewatering, combustion in small cracks in the coal, and underground instrumentation. Much of this work will continue into FY 1978. An engineering analysis of systems requirements for gasification processes will be started. Feasibility and process studies in New England, Texas, ănd Alabama coals will also be considered for FY 1978. 


\subsection{GASIFICATION DEMONSTRATION PROJECTS}

The table below summarizes the funding by task for the FY 1977 to FY 1979 period.

\begin{tabular}{|c|c|c|c|c|}
\hline $\begin{array}{c}\text { GASIFICATION } \\
\text { DEMONSTRATION PLANTS }\end{array}$ & \multicolumn{4}{|c|}{$\begin{array}{l}\text { BUDGET AUTHORITY } \\
\text { (OPERATING EXPENSES) } \\
\text { (DOLLARS IN THOUSANDS) }\end{array}$} \\
\hline TASKS & $\begin{array}{l}\text { ACTUAL } \\
\text { FY } 1977\end{array}$ & $\begin{array}{l}\text { APPROPRIATION } \\
\text { FY } 1978\end{array}$ & $\begin{array}{l}\text { ESTIMATE } \\
\text { FY } 1979\end{array}$ & $\begin{array}{l}\text { INCREASE } \\
\text { (DECREASE) }\end{array}$ \\
\hline $\begin{array}{l}\text { High-Btu Demonstration Plants } \\
\text { Low-Btu Demonstration Plants } \\
\text { Design \& Technical Support }\end{array}$ & $\begin{array}{r}\$ 10,000 \\
12,000 \\
18,600\end{array}$ & $\begin{array}{r}\$ 5,000 \\
11,500 \\
14,400\end{array}$ & $\begin{array}{r}\$ 10,000 \\
7,300 \\
8,220\end{array}$ & $\begin{array}{r}\$+5,000 \\
-4,200 \\
\quad-6,180\end{array}$ \\
\hline TOTAL & $\$ 40,600$ & $\$ 30,900$ & $\$ 25,520$ & $\$-5,380$ \\
\hline
\end{tabular}

\section{High-Btu Demonstration Plants}

The High-Btu Gasification Demonstration task includes the following plants which are described below:

- Pipeline Gas (A\&B Conceptual Designs)

- HYGAS

\subsection{HIGH-BTU PIPELINE GAS DEMONSTRATION PROJECT}

The two processes that will be evaluated as part of the high-Btu pipeline gas project (Slagging Lurgi and Cogas) are described below:

- Slagging Lurgi fixed-bed gasifier (Conceptual Design A)

- Feed coal washed and sized to $1 / 4^{\prime \prime} \times 1-1 / 2^{\prime \prime}$

- Four gasifiers (in parallel) at $445 \mathrm{psig}$ and $>2000^{\circ} \mathrm{F}$

- Shift conversion

- Sulfur removal and gas cleanup

- Methanation

- Gas drying and compression to 850 psig

- Phenol extraction and ammonia recovery from wastewater i i

- Cogas Gasifier (Conceptual Design B)

- Feed coal is dried and crushed

- Pyrolyzed in four fluidized beds in successive stages, oil condensed from pyrolysis volatiles

- Rcsultant char gasificd in two-part gasifier (on stcam reactor and char combustion with air feed) 
- Sulfur removal and gas cleaning

- Methanation, gas drying; and compression to 1,000 psig.

The table below summarizes funding at the demonstration plant subtask level for the FY 1977 to FY 1979 period.

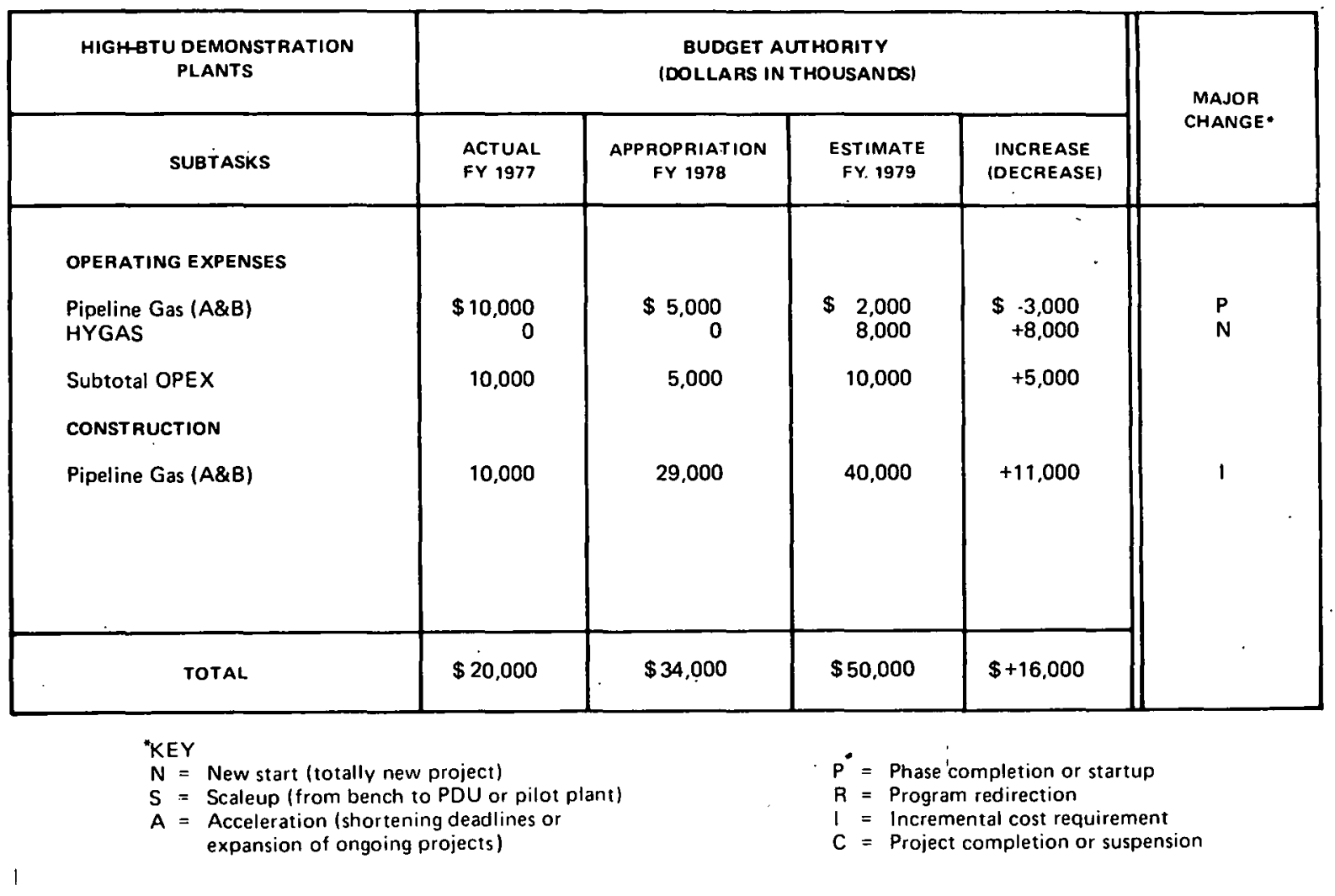

\section{Slagging Lurgi Process}

The objective of the Conoco project is to verify the technical, economic, and environmental acceptability of the Lurgi/British Gas process by building, operating, and evaluating a demonstration plant.

The slagging Lurgi process is a modification of the existing commercial Lurgi process in that it will accept caking coals and operate at higher temperatures. The slagging process reduces the carbon content of the molten ash stream and thereby increases the conversion of carbon in coal to gas. The process also produces less tar, phenol, and heavy hydrocarbons than the older commercial Lurgi process units. 
Gases leaving the gasifiers are cooled by quenching with a gas liquor (recycled water)' spray. The $\mathrm{H}_{2} / \mathrm{CO}$ ratio as required for downstream methanation is adjusted by shift conversion. A major portion of the crude gas passes through the converter while the remainder by-passes the converter. In the purification step, naphtha and water are separated by condensation, while hydrogen sulfide and carbon dioxide are removed by the Lurgi rectisol process. In the methanation step, methane is produced from carbon monoxide and hydrogen over a fixed-bed nickel catalyst.

In the gas liquor separator, coal fines, tar, and tar oil are removed from water. The fines with tar and oil are recycled to extinction in the gasifiers. The Lurgi phenosolvan process extracts phenols from the water. Ammonia is removed from the gas by the CLL process to produce aqueous ammonia. An air separation plant will produce oxygen which is a necessary part of the process in making pipeline quality gas.

In addition to tar precipation, oil separation, and phenol extraction processes, the plant will include all the service sections required, such as steam production, water purification, air separation plant, incineration, waste treatment, as well as product loading, tankage, and buildings.

This process is one of the candidates for the plant for which funds have been authorized and appropriated by Congress.

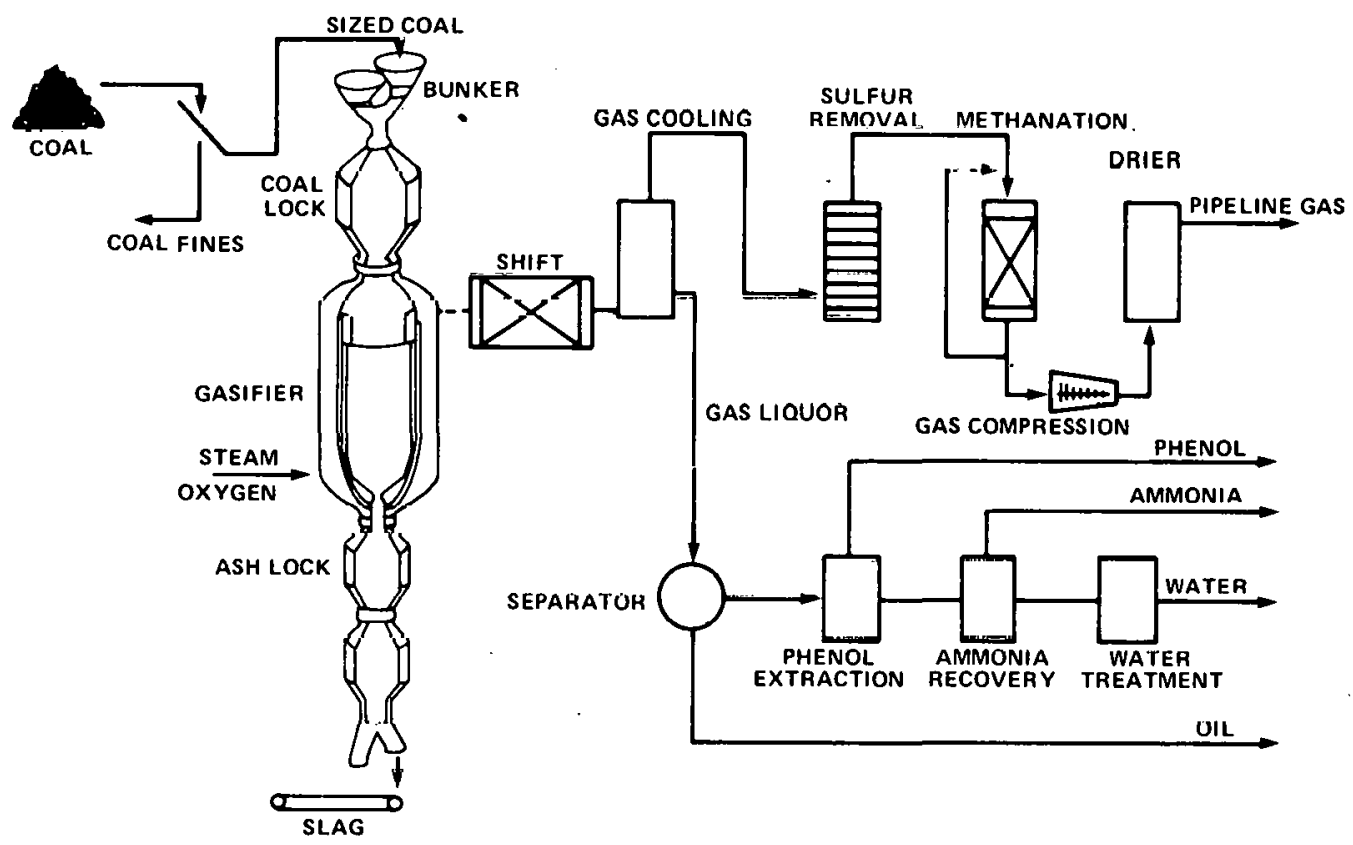

High-Btu Pipeline Gas “A” 


\section{COGAS Process}

Dried crushed coal is treated in up to four fluidized-bed stages at successively high temperatures until a major fraction of the volatile matter of the coal is evolved. Heat for this pyrolysis is obtained from the gasifier by burning a portion of the char with air. Hot gases from the gasifier then flow counter-currently to the coal and constitute the fluidizing gas and heat supply for the third and second stages in order. Hot char from the fourth stage and the third stage may be recycled to supplement the heat from the gases. The first-stage fluidizing medium is supplied as flue gas from the gasifier where a portion of the char is burned with air. Gas and oil are recovered by cooling and condensing the volatiles from the pyrolysis. A 36-tons/day of coal pilot plant for the pyrolysis process was in operation starting in August 1970, and was shut down in 1975. A 50tons/day char gasifier pilot plant is located at Leatherhead, England, and the pilot plant test program is scheduled through February 1978.

The char product of pyrolysis is fed to the gasifier while the remaining product, the raw oil, may be upgraded by hydrogenation to a high-grade synthetic crude oil or, by using less hydrogen in this step, to a low-sulfur No. 4 or No. 5 fuel oil. The hydrogen for this oil hydrotreating is supplied by reforming a portion of the product gas. From the gasifier, the synthesis gas is raised to a minimum pressure and cleaned to reduce particulates and sulfur compounds to a level acceptable for methanation. The resultant product gas is then methanated, dried, and compressed for utilization as a pipeline gas .

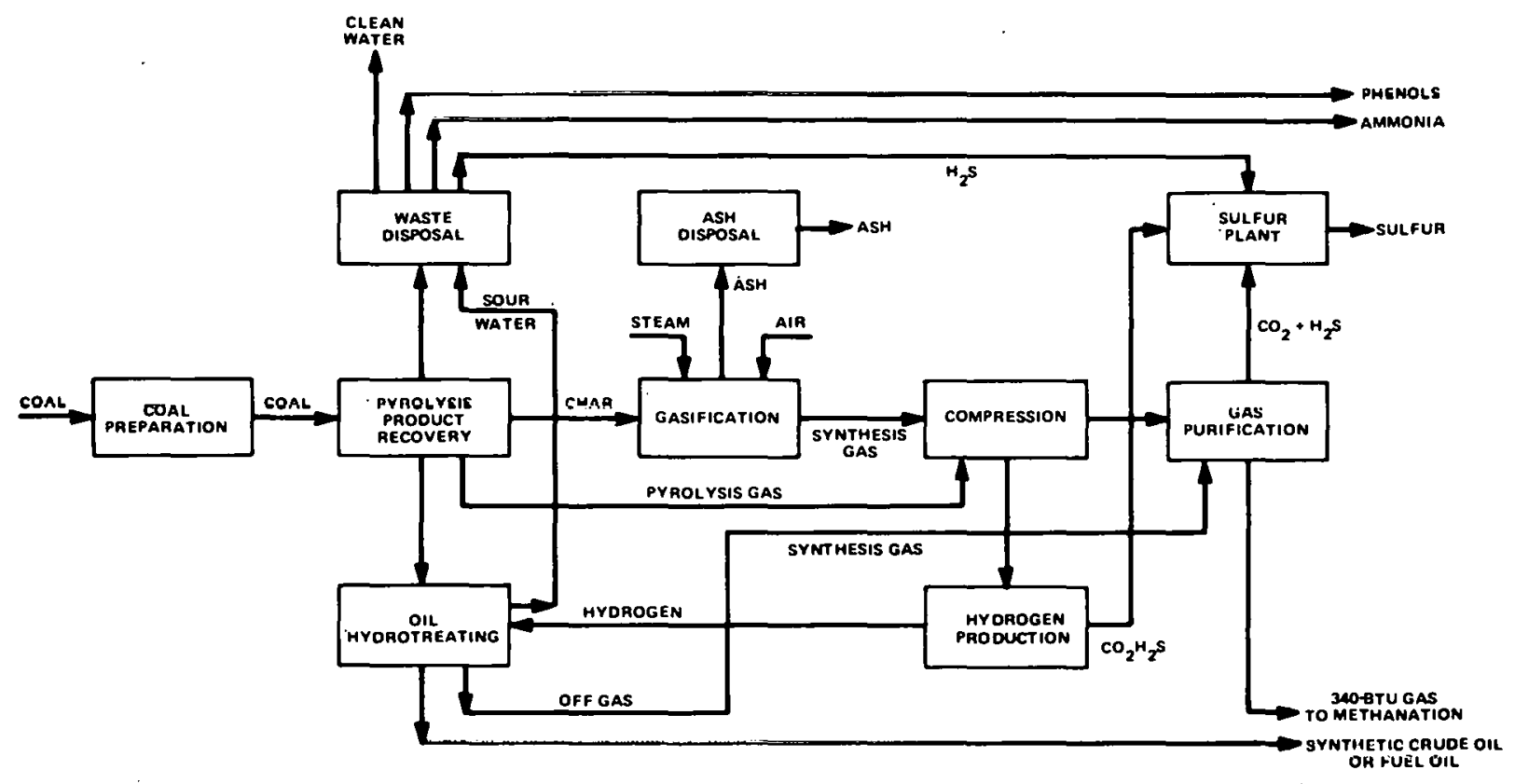

COGAS Process 


\section{Project Status}

The prime fuel product of this project is a direct substitute for natural gas in all applications. Five proposals were received in response to an RFP issued by ERDA in October 1975, for the design, construction, and operation of a demonstration plant. Two respondents, the Conoco Coal Development Company (CCDC) and the Illinois Coal Gasification Group (ICGG) were selected and contracts were awarded and work began in mid 1977. The CCDC proposed process is based upon the Slagging Lurgi Fixed-Bed Gasifier concept developed by British Gas at Westfield, Scotland; this project has been identified as the "High-Btu Pipeline Gas A." The ICGG proposed process is based upon the COED coal pyrolysis concept and char air blown gasifier concept developed by the Cogas Development Company, Princeton, New Jersey. The Cogas pilot plant is located at Leatherhead, England; this project is known as "High-Btu Pipcline Gas B." The pilot facilities are being used as pilot plants to confirm the operability of the processes using U.S. agglomerating coals, or for the Cogas process, on char derived from U.S. agglomerating coal. Both CCDC and ICGG are develuping conceptual designs and economic analyses of the commercial plants, conceptual designs of the demonstration plants, and conducting confirmatory tests in the pilot plants.

The conceptual designs, economics, and operability of the processes on agglomerating coals will be compared, and in mid-1978, one of the contractors will be selected to complete the detailed design of demonstration plant and proceed with construction and operation to verify the selected plant process economics and environmental acceptability.

Management of the project will be broken into three phases:

- Phase I includes both preliminary conceptual design for a commercial process and a demonstration plant for that process, as well as final engineering design for the dcmonstration plant.

- Phase II includes plant construction and all supporting activities, equipment purchases, etc.

- Phase III includes nperation of the plant and final process evaluạation.

The schedule below is typical of both the CCDC and ICGG projects. 


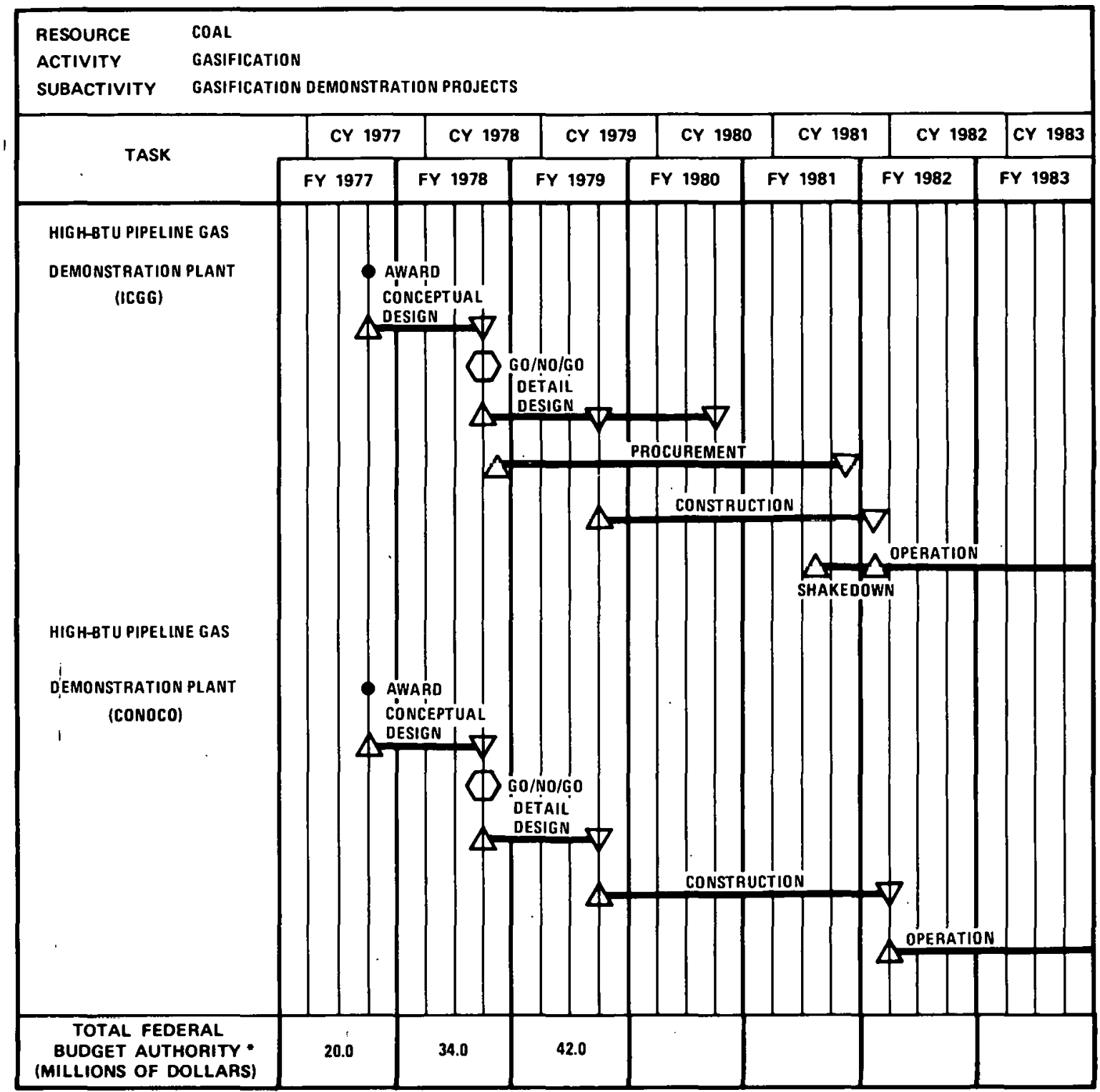

MILESTONE SYMBOLS ARE DEFINED ON LAST PAGE OF THIS DOCUMENT

- INCLUDES BOTII OREX AND CONGTAUCTION FUNDING

\subsection{HYGAS DEMONSTRATION PLANT}

In the HYGAS process, crushed coal from the feed hopper is screened, weighed, and fed to an agitated tank where it is mixed with light oil. A centrifugal pump feeds slurry to the suction of a positive displacement pump which discharges at high pressure into the drying bed at the top of the hydrogasifier reactor vessel. The reactor vessel has four internally-connected fluidized-bed contact stages. It operates at 1,000 psig and different temperature zones in the fluidized beds. The dried coal flows by gravity into a vertical lift line which is the first stage of hydrogasification. Here, coal particles are heated to $1100^{\circ} \mathrm{F}$ by hot gases from the lower stage, and hydrogen contained in the gases reacts with about 20 percent of the coal to produce methane. 
The partially reacted coal (now char) flows to the second-stage gasifier where it is heated in a fluidized bed to about $1700^{\circ} \mathrm{F}$ and is further gasified by the steam and hydrogen-rich gas rising from the steam-oxygen gasification stage below.

In this second stage of the reactor, temperature control is maintained by the balance exothermic producing methane and the endothermic reaction producing carbon monoxide and hydrogen. About 25 percent of the original coal is converted in this reaction stage, with the total conversion about 45 percent in the first and second stages of hydrogasification. The residual char from this stage is the feed to the final reactor stage where steam and oxygen are introduced. This stage operates at $1850^{\circ} \mathrm{F}$ and converts char into hydrogen and carbon oxides. Fluidizing gas velocity is sufficiently high in this stage to prevent slagging of the ash which is discharged through the bottom of the gasifier.

$\Lambda$ sh from the base of the rcaction system vessel is discharged through a solids control valve and transferred by carrier steam flow into a quench vessel at system pressure. The hot ash is cooled by contact water sprays and the carrier steam is condensed. A circulating pump provides ashwater slurry mixing and maintains even slurry consistency. Slurry concentrations of up to 30 weight percent solids can be readily handled. The coal high-pressure water-ash slurry is reduced in pressure using a special tungsten-carbide coated valve and filtered at low pressure. The filtrate is recycled to the quench vessel.

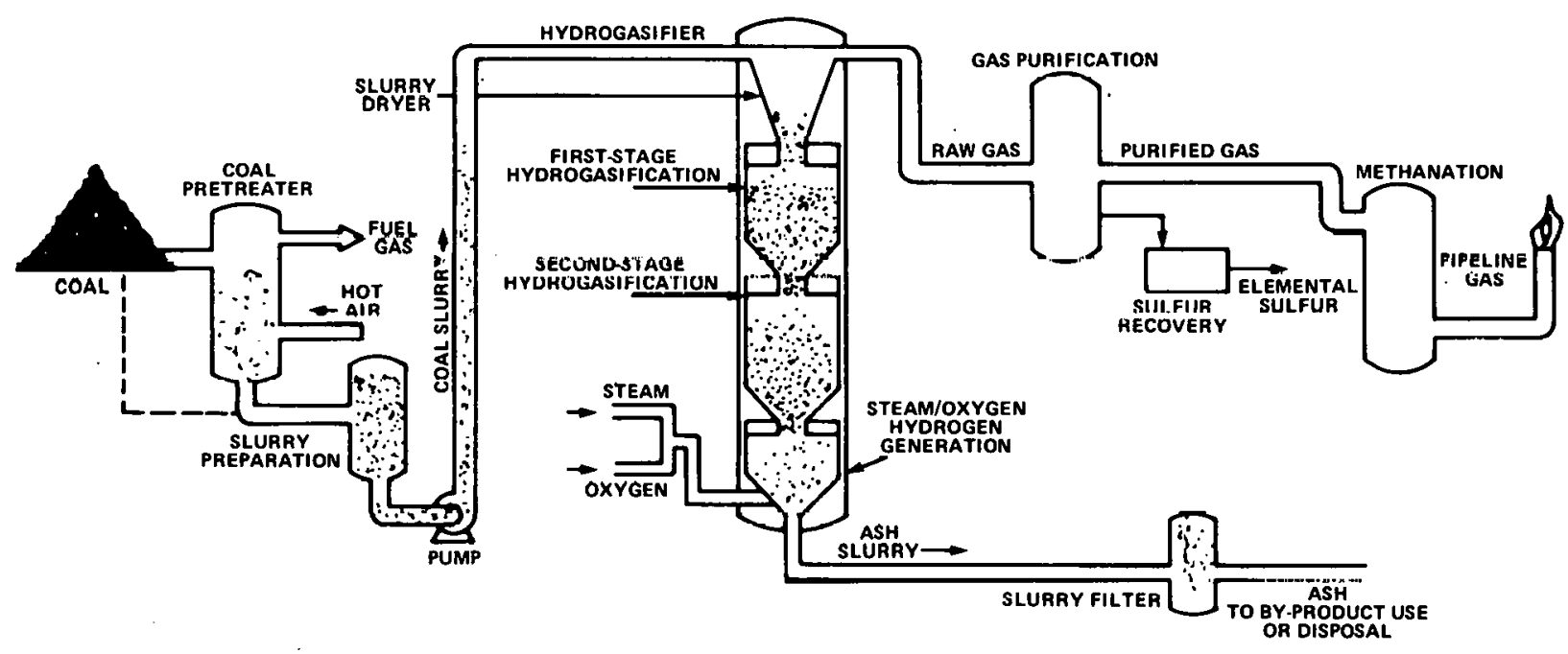

HYGAS Pilot Plant Configuration

\section{Project Status}

A conceptual design of a commercial-scale plant to convert coal to pipeline-quality synthetic gas utilizing the HYGAS Process will be completed mid-FY 1978. The design will be used to evaluate the HYGAS process and determine the feasibility of proceeding with a demonstration plant design based upon this process to be completed by April 1979. 
If the process design looks promising and the economic advantage over other gasification projects is substantial, authorization for a demonstration program will be requested.

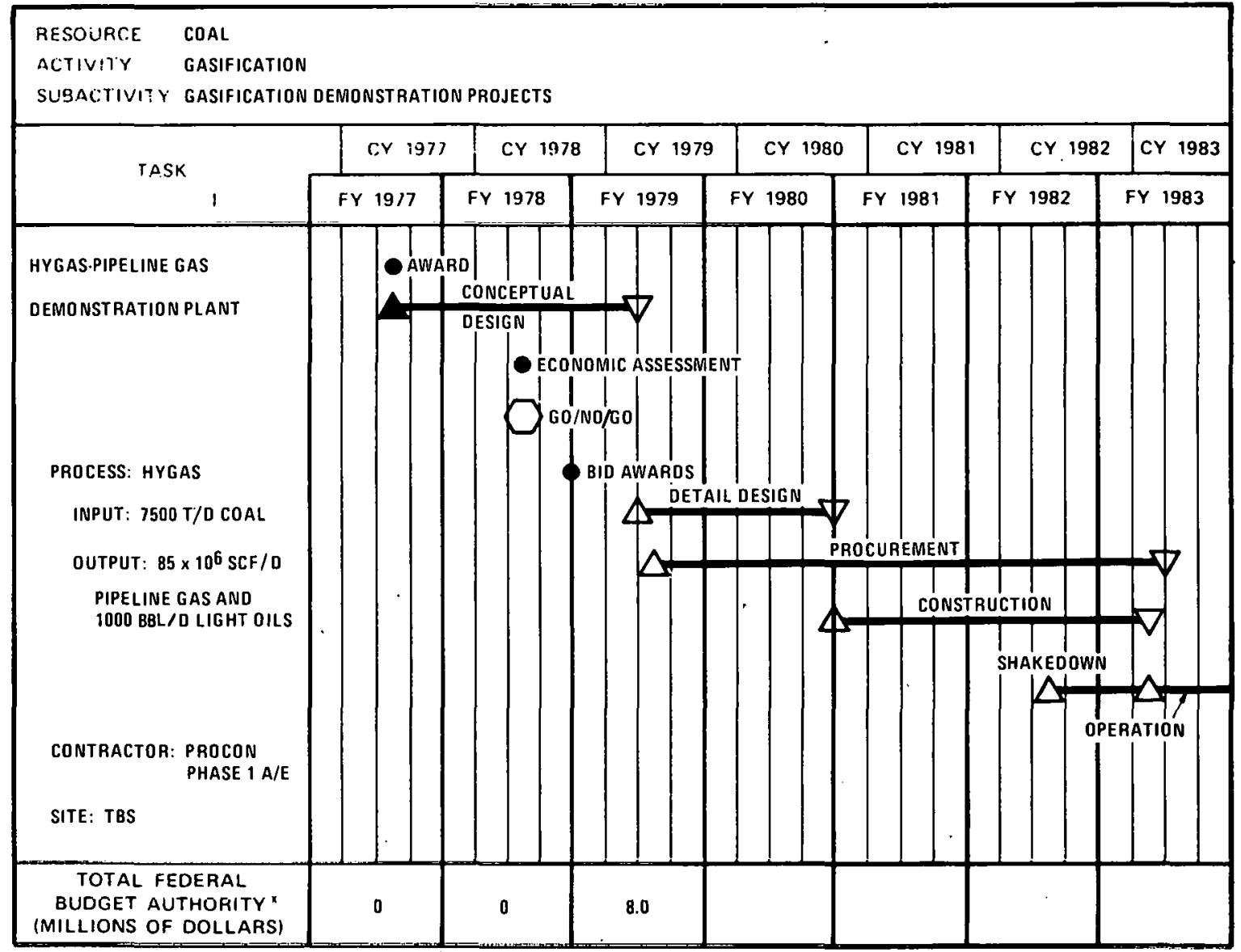

MILESTONE SYMBOLS ARE DEFINED ON LAST PAGE OF THIS DOCUMENT

- inCludes both OPEX AND CONSTRUCTION FUNDING

\section{Low-Btu Demonstraton Plants}

Low-Btu Demonstration projects include the following Demonstration Plants:

- Fuel gas, industrial (A\&B Conceptual Designs)

- Fuel gas, utility

- Fuel gas, small industrial 
The table below summarizes funding at the demonstration plant subtask level for the FY 1977 to FY 1979 period.

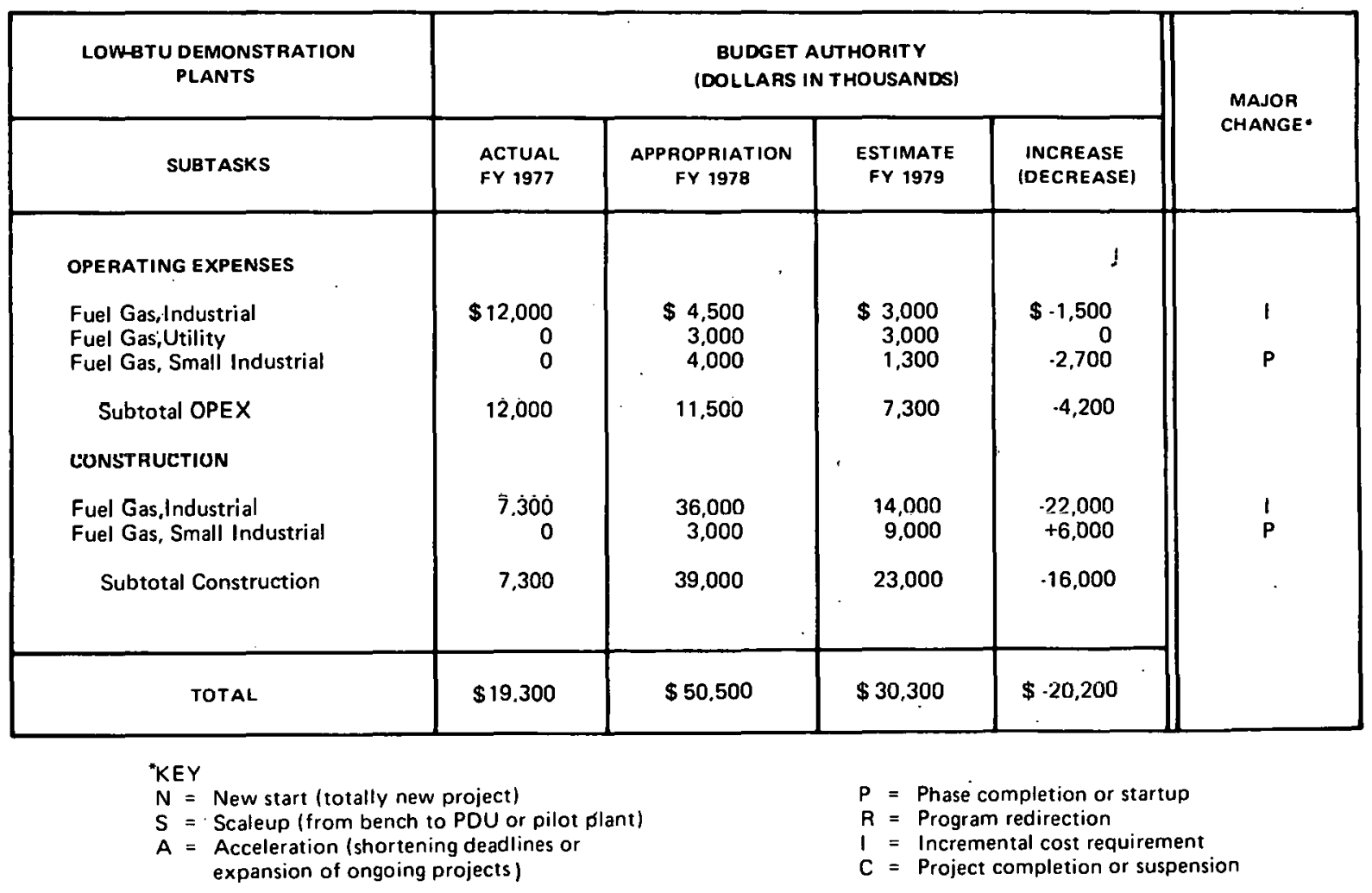

Fuel gas technologies have the potential for pervasive substitution of natural gas supplies, especially for industrial and power generation utility users. DOE in February 1976 issued an RFP to invite consideration of plants to demonstrate coal-to-fuel gas conversion for: 1) industrial use (i.e., a large gasifier supplying an industrial community); 2) small industrial/institutional use (a single industrial user, a hospital, a commercial/residential complex, etc.); and 3) utility use (to substitute for recaptured natural gas for direct boiler firing, or as a sourc̀e of energy for combined cycle (steam/gas turbine) generation).

\subsection{FUEL GAS, INDUSTRIAL - A \& B}

Contract negotiations for the large industrial-user-dedicated plant have been initiated with GRACE/EBASCO and with the City of Memphis (Memph1s Light, Water and (ias) for a design competition which will lead to construction and operation of a demonstration plant. The two competing projects, Fuel Gas Industrial A and B, are described below. 


\section{Fuel Gas, Industrial-Conceptual Design A}

The Memphis Light, Gas and Water Division (a department of the city of Memphis), in association with Delta Refining Company, Foster Wheeler Energy Corporation, and the Institute of Gas Technology (IGT), has a fuel gas demonstration program based upon the U-GAS process to produce and deliver to Memphis industrial consumers, via a pipeline distribution system, 175 million CFPD (50 billion Btu/day) of industrial fuel gas having a nominal gross heating value of $284 \mathrm{Btu} / \mathrm{scf}$. This is equivalent to 50 million CFPD of natural gas. The IGT U-GAS process is a fluidized-bed, oxygen-steam gasification process operating under conditions which promote the formation of ash agglomerates in the lower part of the bed.

The gasifier for the project is an extension of the U-GAS reactor concept under development by IGT. The principal new development is operation of the gasifier at 90 psig.

Crushed coal is fed to a pretreator and then contacted in the gasifier with an oxygen-steam mixture in a fluidized bed. Operating temperatures are $1870^{\circ}$ to $2050^{\circ} \mathrm{F}$. Fines elutriated from the fluidized bed with the raw fuel gas are returned to the gasifier through external cyclones. The ash agglomerates from the gasifier drop into a water-filled hopper where they are quenched by a circulating stream of water and withdrawn from the hopper in the form of a water slurry. The hot, raw fuel gas is partially cooled in a waste heat boiler and fed to a venturi scrubber for the removal of ammonia, hydrogen sulfide, and coal dust. The fuel gas is then compressed to $195 \mathrm{psig}$ and treated in a Seloxol acid-gas absorption process to remove essentially all of the hydrogen sulfide and organic sulfur compounds and part of the carbon dioxide. The purified gas from the Selexol unit is ready for distribution.

Acid gas containing hydrogen sulfide is fed to a conventional Claus process. In the Claus unit the $\mathrm{H}_{2} \mathrm{~S}$ is partially oxidized to form elemental sulfur and water. The off-gas from the Claus unit, is processed to a SCOT tail-gas unit, to recover remaining $\mathrm{H}_{2} \mathrm{~S}$ and recycle it back to the Claus plant. The off-gas from the SCOT process is environmentally acceptable to vent.

This process is one of the candidates for which a plant has been authorized and funds appropriated by Congress but subject to the competitive selection in 1979 . 


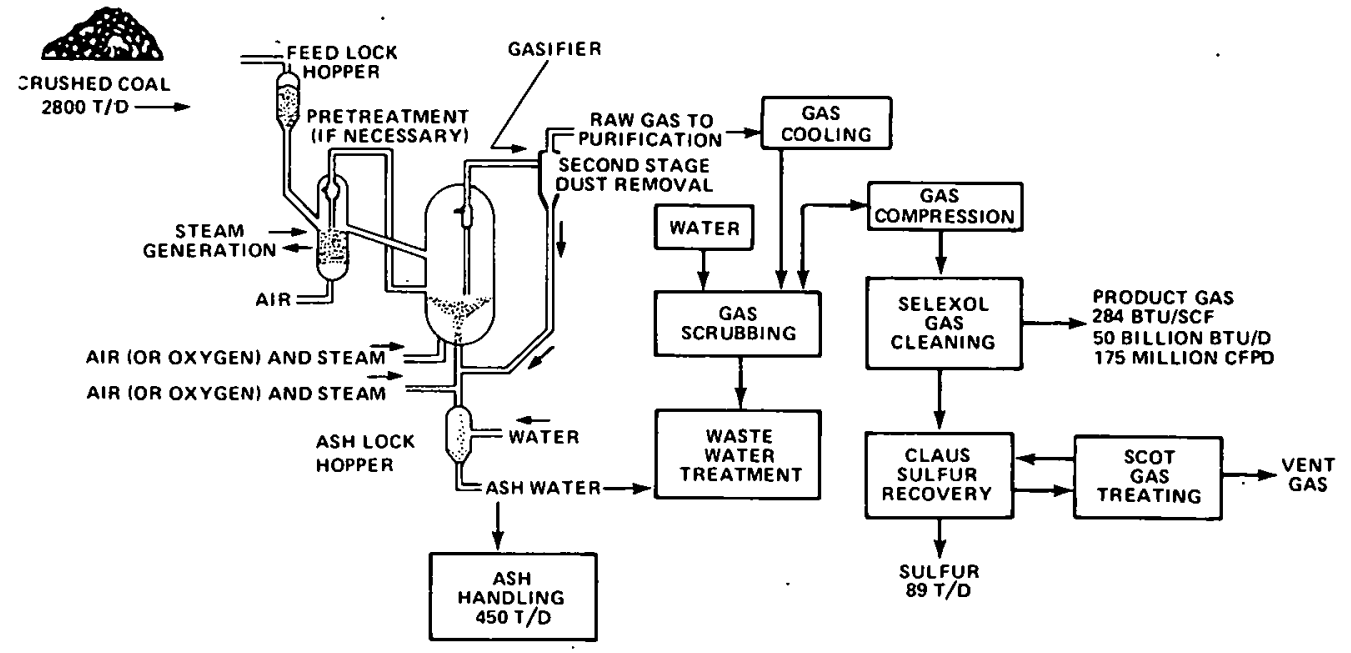

\section{Low-Btu Fuel Gas, Industrial "A"}

\section{Fuel Gas, Industrial-Conceptual Design B}

W. R. Grace \& Company proposes a facility to produce synthcsis gas (a mixture of hydrogen and nitrogen) for ammonia production. The demonstration plant would bc located in western Kentucky. Because ammonia formation is favored at high pressure, the synthesis step requires pressures exceeding 3,500 psi. Accordingly, a Texaco gasifier operating at 2,500 psig is the process that has been chosen for this project.

Coal feedstock is prepared by grinding the coal and slurrying in water, with the coal content of the slurry ranging from 50 to 60 percent weight. The slurry is blended with oxygen for high-pressure injection into the gasifier. The resultant gas containing carbon and fly-ash flow to a scrubber where carbon is recovered and recycled to the gas generator. The synthesis gas from the gas generator, rich in carbon monoxide, is converted to hydrogen by the water gas shift reaction. Hydrogen sulfidc and carbon dioxide removal is accomplished by physical absorption in refrigerated methanol. Liquid nitrogen scrubbing is utilized for final removal of residual unconverted carbon monoxide, residual methane and argon gases. The product gas is blended with nitrogen and is the feedstock for the ammonia synthesis step.

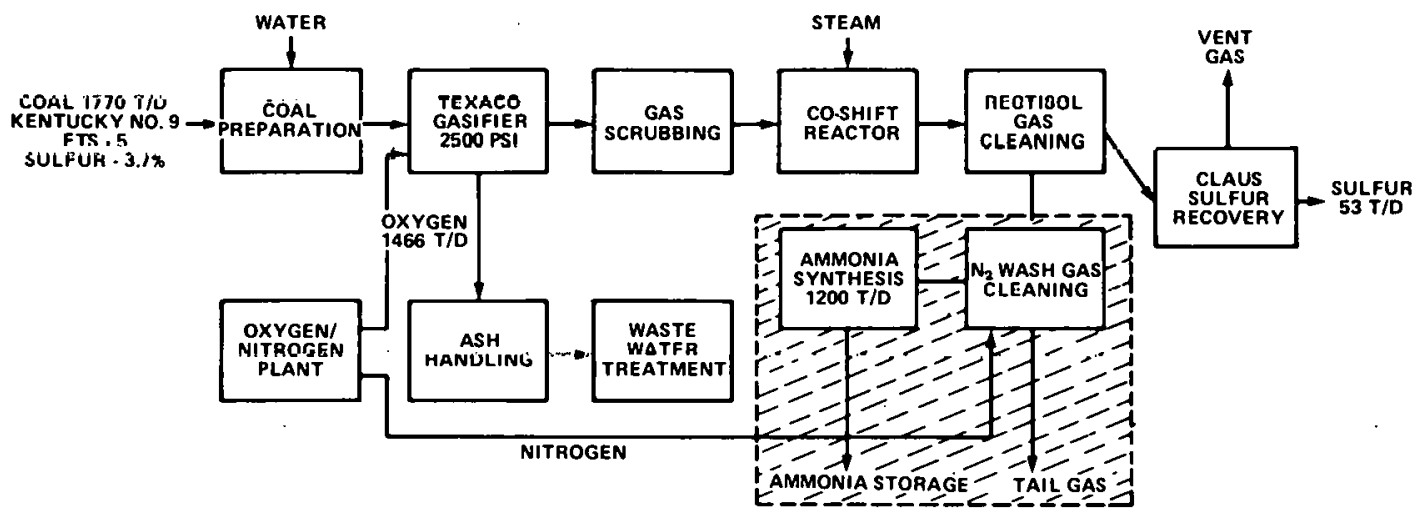

Low-Btu Fuel Gas, Industrial "B" 


\section{Project Status}

Fuel Gas Industrial A. A contract has been awarded for the large industrial-user-dedicated plant to Memphis Light, Gas and Water Division, City of Memphis, for a design that could lead to construction and operation of a 2800-tons/day low-Btu Fuel Gas demonstration plant utilizing 2,800 tons/day of Kentucky No. 9 coal.

Fuel Gas Industrial B. A contract has been awarded to W. R. Grace and Company for conceptual design of a demonstration plant utilizing 1,700 tons/day of Kentucky No. 9 coal feed in an ash agglomerating gasifier, to produce 1,200 tons/day of ammonia at an adjacent facility. Conceptual designs of these proposed alternatives are scheduled to begin immediately and will continue through FY 1978 up to May 1979 before the next major decision milestone is reached.

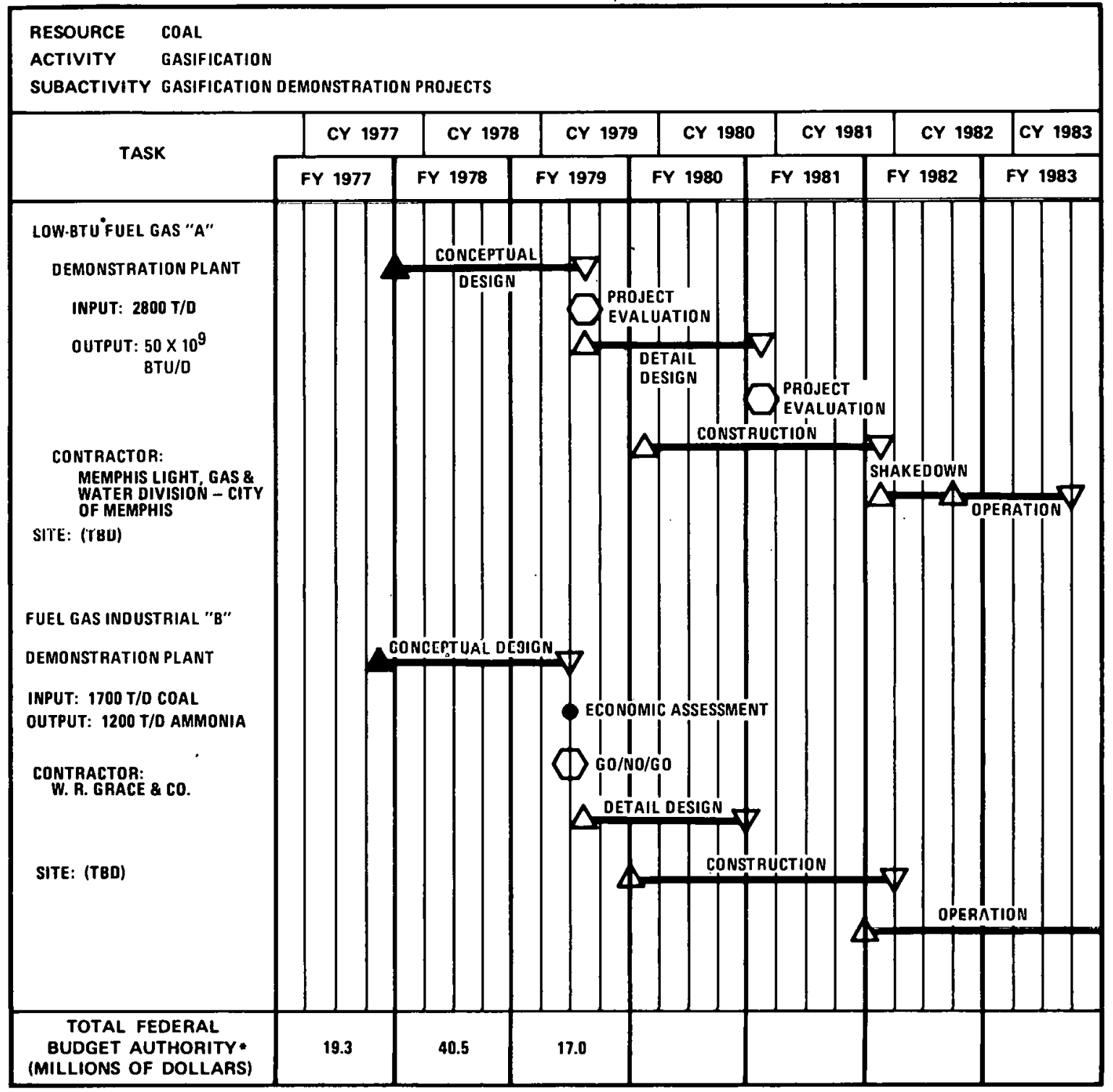

MILESTONE SYMBOLS ARE DEFINED ON LAST PAGE OF THIS DOCUMMENT

- INCLUDES BOTH OPEX AND CONSTRUCTION FUNDING 


\subsection{FUEL GAS, UTILITY PLANT}

In the utility project the contractor is required to use secondgeneration coal gasification technology. Second-generation technology is defined as technology in the pilot plant stage which has not been scaled up to commercial-size. The objective of the utility project is to produce a fuel gas suitable for use in utility applications and which is economically and environmentally acceptable.

Potential markets for utility industry application of coal gasification technology are as follows:

- $\quad$ Existing boilers currently capable of burning coal but not doing so because of the cost of environmental controls

- Existing boilers currently burning oil and gac whero fuel gas produced from cual may be less expensive

- Future coal-fired boilers where fuel gas produced from coal may be less expensive than stack gas cleaning or the transportating of low sulfur coal

- Coal gasification combined-cycle or intermediate base load generation.

\section{Project Status}

The fuel gas utility project is currently being evaluated by a Source Evaluation Board. It is expected that the Source Selection Official (SSO) will make selection in February 1978.

Using data extracted from the proposals, a milestone schedule has been prepared which is illustrative of a contract awarded under this program. The funding profile is representative of a single contract award. 


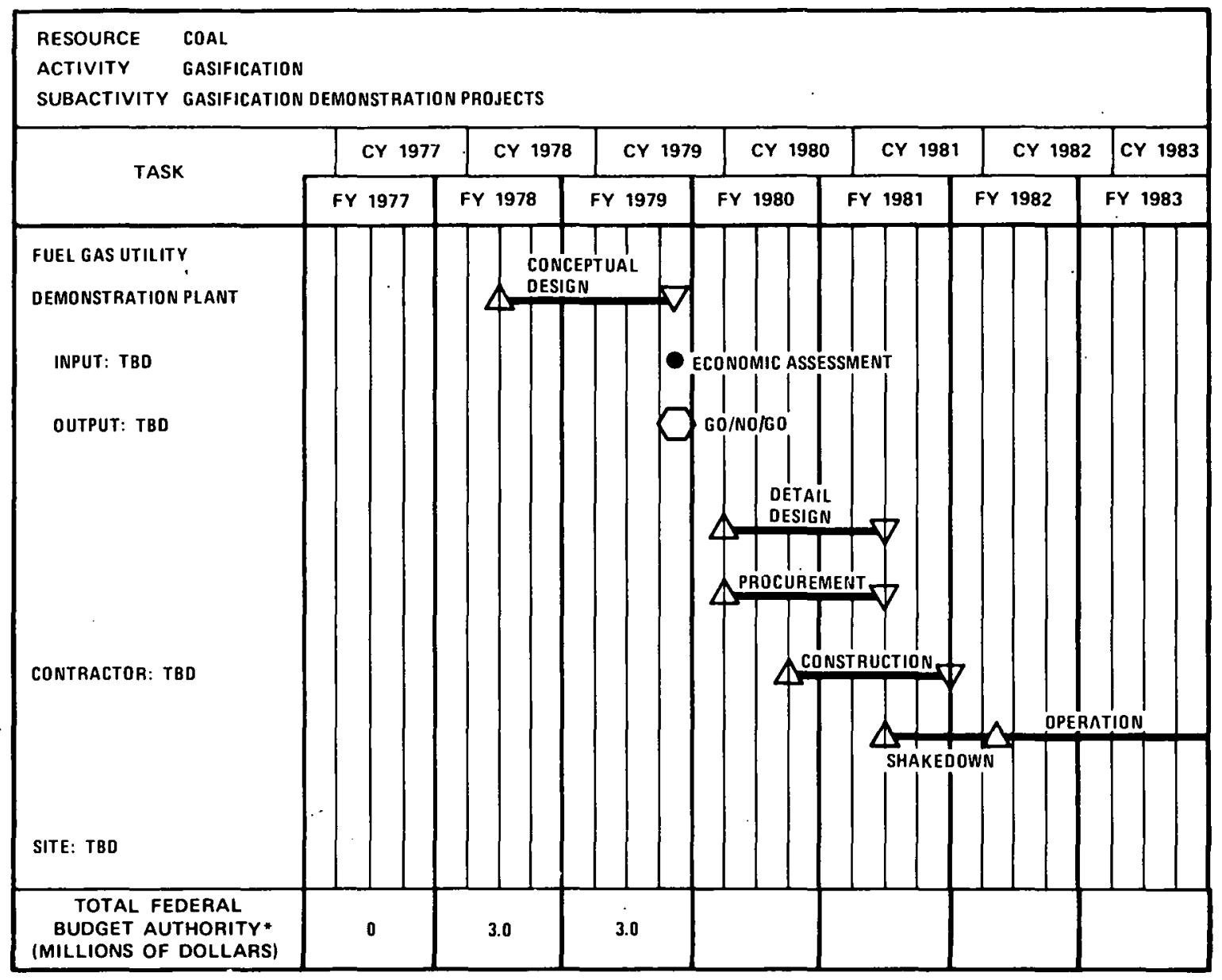

MILESTONE SYMBOLS ARE DEFINED ON LAST PAGE OF THIS DOCUMENT

* INCLUDES BOTH OPEX AND CONSTRUCTION FUNDING

\subsection{FUEL GAS, SMALL INDUSTRIAL PLANT}

In the small-scale industrial project the contractor will use commercial gasification systems; however, the objective is to expand the process to insure the product gas is environmentally and economically acceptable.

Erie Mining has selected a two-stage fixed-bed air blown gasifier with the exact technology to be specified early in the contract.

Coal is brought to the coal handling area by railroad cars and is either transferred via feeders and belt conveyors to a line storage pile or to a dead storage area. The coal is crushed in a roll crusher to $3 / 8$-inch by 1-1/4-inch size. The sized coal is fed to a two-stage gasifier through lock hoppers. Five gasifiers will be constructed in the demonstration program. A steam and air mixture is fed to the base of each gasifier through a water cooled revolving grate which also removes ash. A portion of the gas flows from the top of the gasifier at about $250^{\circ} \mathrm{F}$ and contains volatilized tar and oils and water vapor. 
The tar is pumped from the precipitators to a storage tank. This tar can be used as standby fuel in the event of gasifier shutdown. The remaining portion of the produced gas flows from the gasification zone, exiting at $1200^{\circ} \mathrm{F}$.

The hot gas is passed through cyclones to remove particulates and then through a waste heat recovery system to produce steam.

Ash is discharged from the lock hoppers at the base of the gasifier and collected on belt conveyors. A bucket elevator lifts the ash to the top of the ash storage silo which is sized to hold a day's ash production, and ultimately ash will be disposed of to a land fill.

The two product gas streams are mixed and the $2250 \mathrm{~F}$ gas from the gasification system is cooled to about $100^{\circ} \mathrm{F}$ and compressed. The compressed gas is again cooled down to $100^{\circ} \mathrm{F}$ and fed to a Strctford unit. In the Stretford process, hydrogen sulfide is removed from the gas and converted to elemental sulfur. About 8 tons/day of sulfur is produced of sulfur is produced in the process which could be sold or used as land fill. The clean gas from the Stretford unit is piped to the pellet plant for direct use in the furnaces.

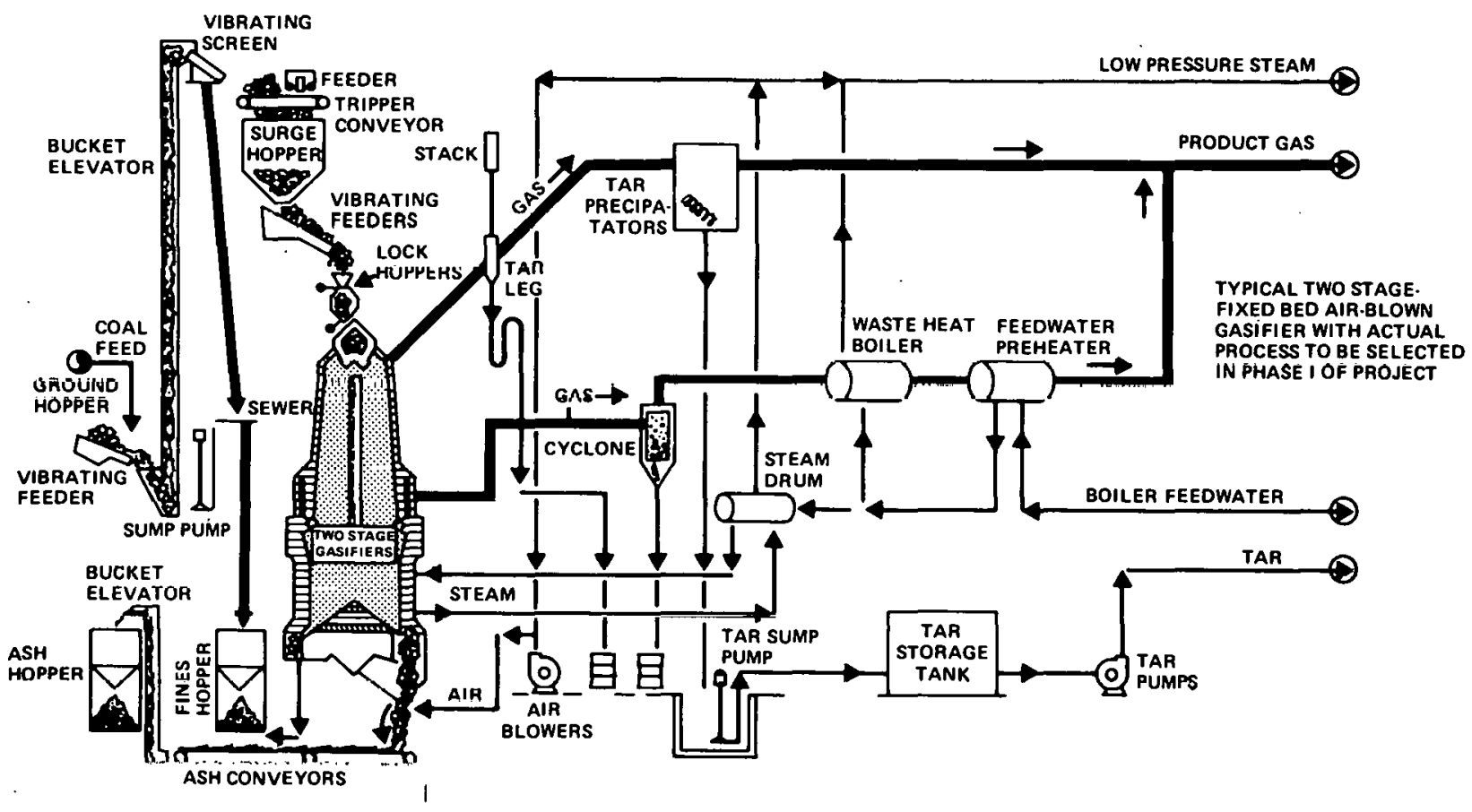

Fuel Gas, Smalt-Scale Industrial 


\section{Project Status}

Erie Mining was selected for contract negotiation in May 1977, and a contract was awarded in October 1977. The work will be accomplished in three phases: Phase I is conceptual design; Phase II is detailed design and construction; and Phase III is operation and evaluation. The government will provide all funds for Phase I, while Phases II and III will be cost-shared on a 50/50 basis by the government and Erie Mining. At the completion of Phase III, Erie Mining will purchase the government's share of the gasification plant.

Erie Mining will use the fuel gas to produce taconite iron ore. They currently produce 13 percent of the U.S. output. The technology application exists for other taconite producers who currently account for 67 percent of the total U.S. iron ore production.

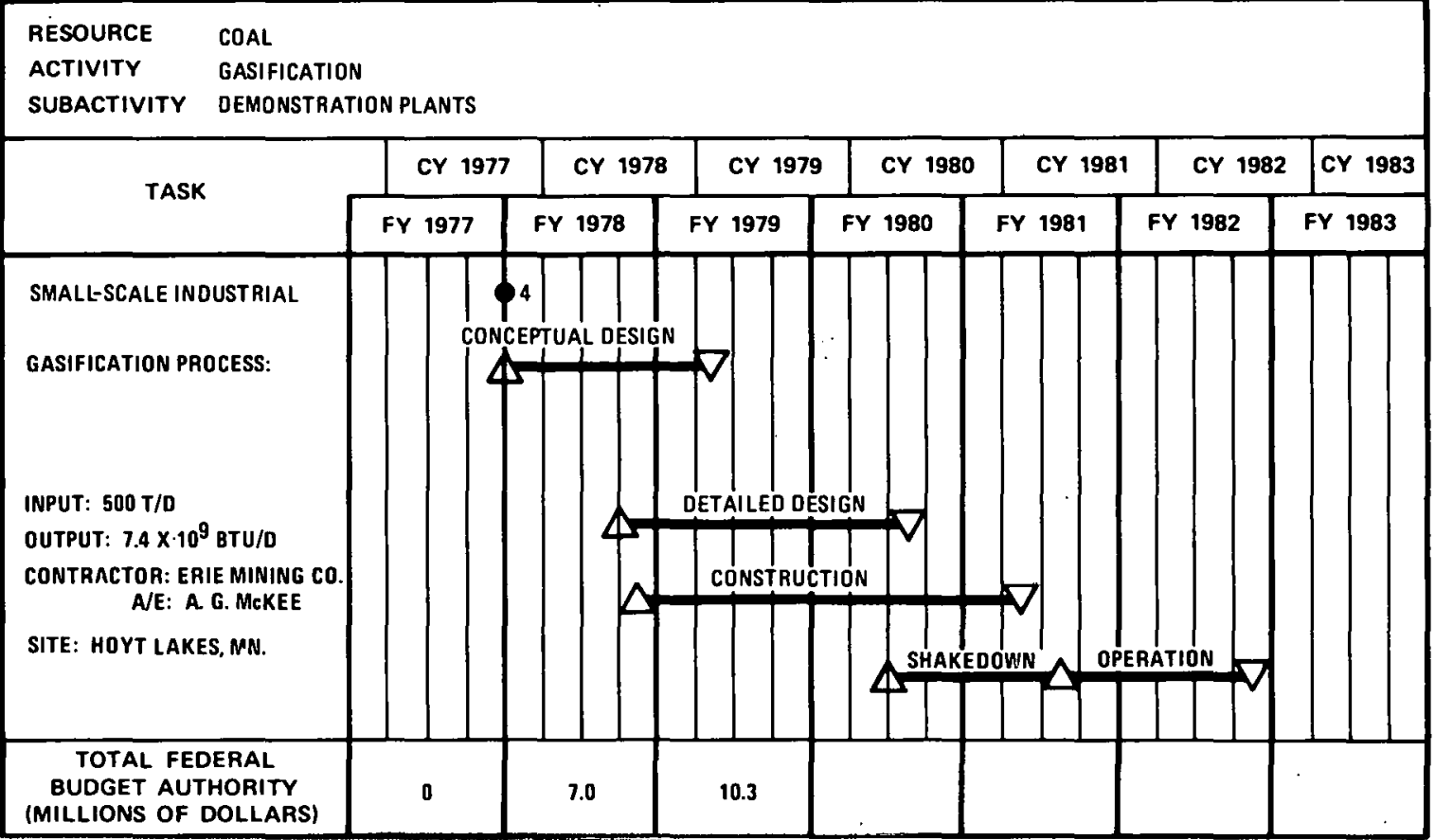

MILESTONE SYMBOLS ARE DEFINED ON LAST PAGE OF THIS DOCUMENT 


\subsection{DESIGN AND TECHNICAL SUPPORT}

This activity includes the following:

- Equipment Development and Component Testing: Successful operation of large-scale equipment and components is essential for commercial-plant success. There is an array of such equipments which are generic to the operation of all demonstration plants and which must, therefore, be developed and tested hand-in-hand with the plants. Funding for this category is largely for continuation of work previously started.

- Engineering Support: Project technical support will be provided by the Naliunal Laboratories, Energy Research Centers (ERCs), U.S. Army Corps of Engineers, Department of the Army Reisedrch and Materlal Command, and various private engineering firms .

- Environmental and Socioeconomic Studies: Analysis of the environmental impact of large industrial development will continue. Potential social, ecological, aesthetic, and economic impacts and methods for achieving their equilibrium are studied.

- Planning and Support Studies: These support tasks are largely a continuation of established activities. They include modeling and systems studies, economic and financial analyses, technical reports, and management support.

- Operational Engineering: This support function provides guidance and engineering assistance to each demonstration plant program manager and the industrial partner, followed by review and acocosment during the desigin and consl.ruction phases of the program. This assistance relates to plant. nperahility, maintainability, reliability, plant operation health and safety, and environmental protection. Also provided is management of the test and evaluation activities during the demonstration phase of the program, to assist planl performance and vlability. 


\subsection{SUMMARY OF PILOT PLANTS, PDUs, AND MAJOR HARDWARE FABRICATION}

The following data summarize funding levels for the pilot plants, PDUs, and major hardware fabrication for the projects supporting the gasification effort.

\section{Gasification \\ Summary of Pilot Plants, PDUs, and Major Hardware Fabrication (Dollars in Thousands)}

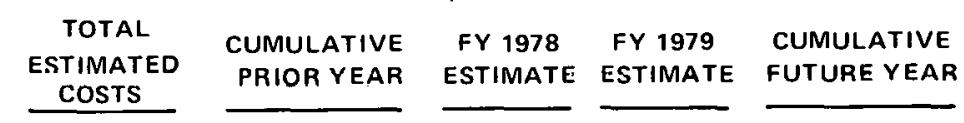

BI-GAS PILOT PLANT, HOMER CITY, PA."

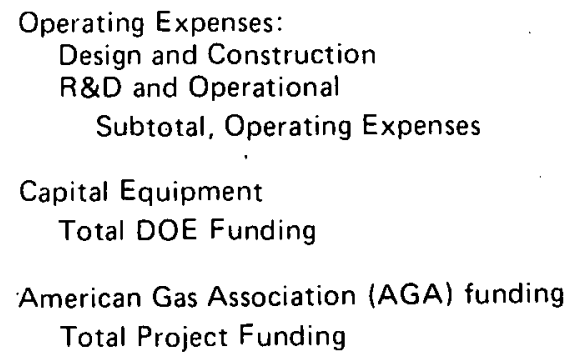

Capital Equipment

Total DOE Funding

American Gas Association (AGA) funding

Total Project Funding

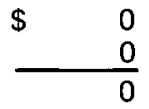

$$
\frac{0}{65,541^{\prime}}
$$$$
\frac{0}{54,641}
$$$$
\frac{0}{3,000}-\frac{0}{7,900}
$$

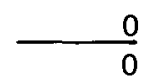

$27,918^{2}$

$\$ 93,459$

$\frac{19,500}{\$ 74,141}$

$\frac{4,468}{\$ 7,468} \frac{3,950}{\$ 11,850}$

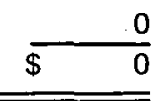

1. Based on contract and estimated operational cost through FY 1979.

2. Based on DOE/AGA agreement.

${ }^{*}$ Refer to Chapter III, Part D, Section 1.2

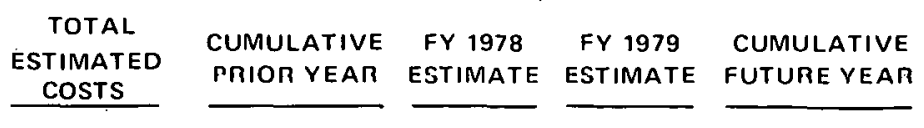

FLUID.BED, 2-STAGE GASIFICATION

PDU, WALTZ MILL, PA.*

Operating Expenses:

Design and Construction

$R \& D$ and Operational

Subtotal, Operating Expenses

$\begin{array}{r}10,124 \\ 20,626 \\ \hline 30,750\end{array}$

S 10,124

$\frac{19.126}{29,250}$

\begin{tabular}{rr}
$S \quad 0$ \\
$\quad 1,500$ \\
\hline 1,500
\end{tabular}

$S(4,000)^{\prime}$

$\frac{0}{30,750^{2}}$

$\frac{0}{29,250}$

$\frac{0}{1.500}$

$(4,000)$

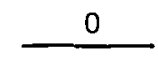

Capital Equipment

Total DOE Funding

$\frac{1,053^{2}}{\$ 34,803}$

$\frac{1,053}{\$ 33,303}$

$\begin{array}{rr}\$ 1,500 & 0 \\ \$(4,000)\end{array}$

$\begin{array}{r}0 \\ (4,000) \\ 0 \\ (4,000) \\ \hline\end{array}$

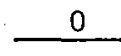

Westinghouse Electric Corp. Funding Total Project Funding

978 whether to proceed with fur ther development of th

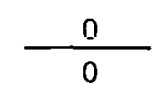

1. Contingent on decision to be made in $F Y 1978$ whether to proceed with further development of. this fluidized-bed gasification process, $\$ 4,000,000$ is included for design and construction of a pilot plant.

2. Based on contract.

* Refer to Chapter III, Part D. Section 2.3 


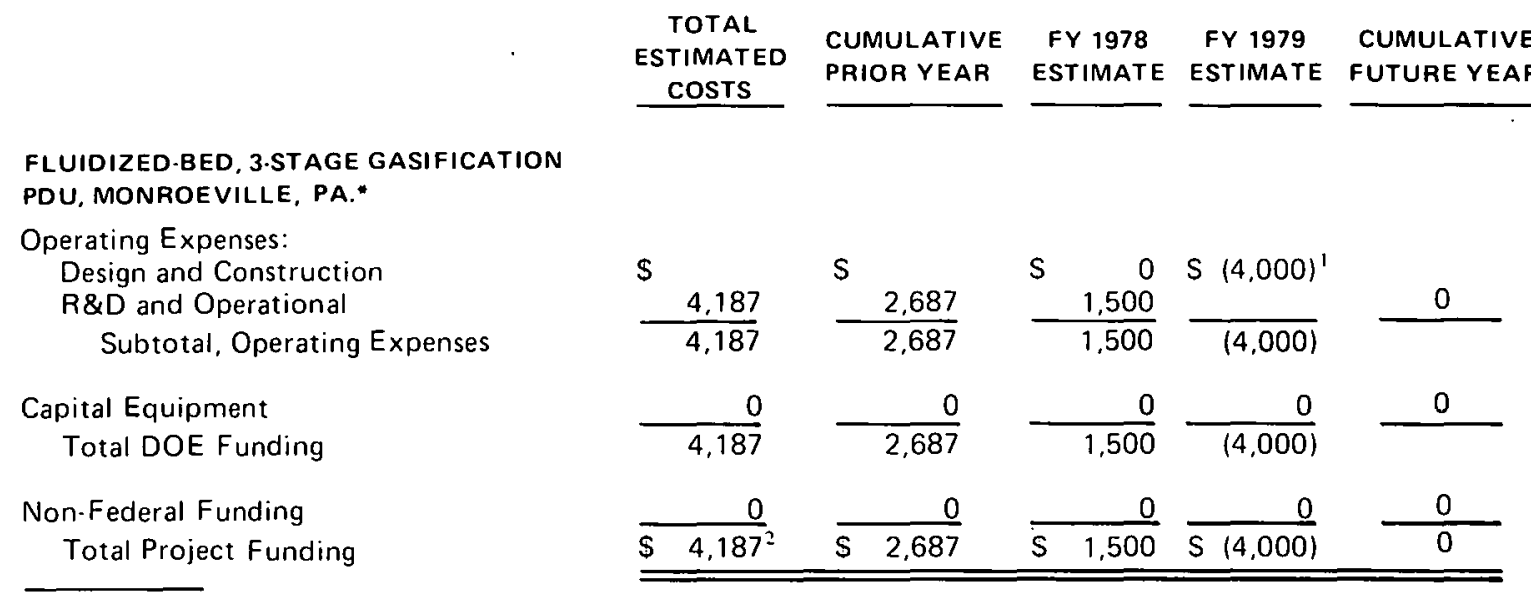

$\overline{\text { 1. Contingent }}$ on decision to be made in FY 1978 whether to proceed with further development of this fluidized-bed gasification process, $\$ 4,000,000$ is included for design and construction of a pilot plant.

2. Based on contract.

* Refer to Chapter III, Part D, Section 2.4

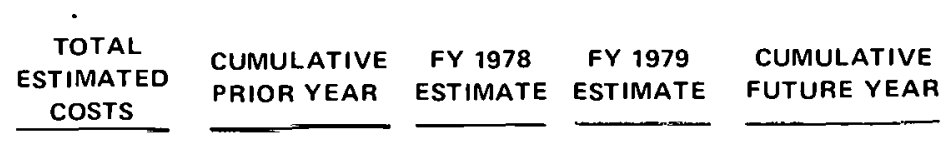

FLUID.BED, FAST-FLUID GASIFICATION

HOU. TRENTON, NEW JERSEY*

Operating Expenses:

Design and Construction

$R \& D$ and Operational

Subtotal, Operating txpenses

$\begin{array}{r}\$ \quad 2,300 \\ 2,719 \\ \hline 5,019\end{array}$

$\begin{array}{r}\$ 2,300 \\ 1,719 \\ \hline 4,019\end{array}$

$\begin{array}{lrr}\$ \quad 0 & \$(4,000)^{1} \\ & 1,000 & \frac{0}{(4,000)}\end{array}$

0

Capital Equipment

Total DOE Funding

Non. Federal Organization Funding Total Project Funding

\begin{tabular}{|c|c|c|c|c|c|c|c|}
\hline & $\underline{0}$ & & 0 & & 0 & 0 & 0 \\
\hline & 0 & & 0 & & 0 & 0 & 0 \\
\hline$\$$ & $5,019^{2}$ & $\$$ & $\overline{4,019}$ & $\$$ & 1,000 & $\overline{\$(4,000)}$ & 0 \\
\hline
\end{tabular}

1. Contingent on decision to be made in FY 1978 and FY 1979 whether to proceed with further development of this fluidized-bed gasification process, $\$ 4,000,000$ is included for design and construction of a pilot plant.

2. Based on contract.

* Refer to Chapter III, Part D, Section 2.5

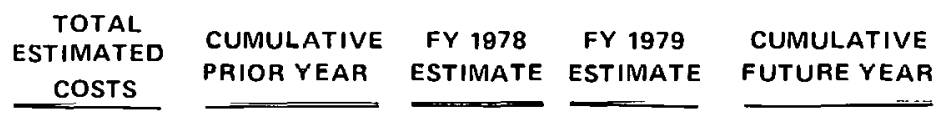

COMBINED-CYCLE TEST FACILITY, PEKIN,

ILLINUIS"

Operating Expenses:

Design and Construction

$R \& D$ and Operational

Subtotal, Operating Expenses

\begin{tabular}{|c|c|c|c|c|c|}
\hline $\begin{array}{r}\$ 64,550 \\
51,050\end{array}$ & $\begin{array}{r}\$ 29,095 \\
0\end{array}$ & $\$ 20,000$ & $\begin{array}{r}\$ 10,000 \\
0\end{array}$ & $\$$ & $\begin{array}{r}5,455 \\
51,060\end{array}$ \\
\hline 115,600 & 29,095 & 20,000 & 10,000 & & 56,505 \\
\hline 0 & 0 & 0 & 0 & & 0 \\
\hline $115,600^{1}$ & 29,095 & 20,000 & 10,000 & & 56,505 \\
\hline $51,400^{2}$ & 25,000 & 10,000 & 16,400 & & 0 \\
\hline$\overline{\$ 167,000}$ & $\overline{\$ 54,095}$ & $\$ 30,000$ & $\$ 26,400$ & $\$$ & 56,505 \\
\hline
\end{tabular}

Capital Equipment

Total DOE Funding

Non-Federal Organization Funding

Total Project Funding

estimates prepared for contractor.

1. Based on Fluor Engineering detailed cost estimates prepared for contractor.

2. Based on commitment from co-funding non. Federal organization including Commonwealth Edison, EPRI and the State of Illinois.

* Refer to Chapter III, Part D. Section 2.7 


\begin{tabular}{ccccc}
$\begin{array}{c}\text { TOTAL } \\
\text { ESTIMATED } \\
\text { COSTS }\end{array}$ & $\begin{array}{l}\text { CUMULATIVE } \\
\text { PRIOR YEAR }\end{array}$ & $\begin{array}{c}\text { FY } 1978 \\
\text { ESTIMATE }\end{array}$ & $\begin{array}{c}\text { FY } 1979 \\
\text { ESTIMATE }\end{array}$ & $\begin{array}{c}\text { CUMULATIVE } \\
\text { FUTURE YEAR }\end{array}$ \\
\hline
\end{tabular}

HYDROGEN-FROM COAL FACILITY, CEDAR BAYOU, TEXAS*

Operating Expenses:

Design and Construction

$R \& D$ and Operational

Subtotal, Operating Expenses

$\$ 72,000$

15,000

87,000

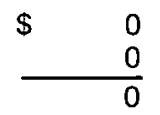

$\$ 15,000$

$\frac{2,000}{17,000}$

$\$ 11,610$

$\$ 45,390$

$\frac{0}{87,000^{1}}$

$\frac{0}{0}$

$\frac{0}{17,000} \frac{0}{11,610}$

$\frac{13,000}{58,390}$

Capital Equipment

Total DOE Funding

Air Products \& Chemicals Funding Total Project Funding
$87,000^{2}$ $\$ 174,000$

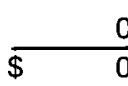

$\frac{17,000}{\$ 34,000} \frac{11,610}{\$ 23,220}$

$\frac{0}{58,390}$

58,390

1. Based on DOE estimate.

2. Based on terms of contract.

* Refer to Chapter III, Part D, Section 2.9

CATALYTIC GASIFICATION PILOT PLANT,
$\begin{aligned} & \text { COSTS } \\ & \text { (LOCATION TO BE DETERMINED)* }\end{aligned}$

1. Based on Exxon's current conceptual design.

- Refer to Chapter III, Part D, Section 1.6 


\section{E. HEAT ENGINES \& HEAT RECOVERY}

\section{Objectives}

The goal of the Heat Engines and Heat Recovery Activity is to develop technology for maximizing energy savings in the utility, industrial, and residential/commercial market sectors. Energy savings opportunities in this tri-market area are estimated to be in excess of 1.5 Quads by 1985 and over 10 Quads by the year 2000. There are three major objectives for achieving the goal:

- Increase the direct utilization of coal in the utilities by developing advanced, highly efficient integrated coal sonversion/utilization systems that can efficiently dieplaoe critical oil and gas fuels.

- Improve fuel utilization in the industrial and residential/commercial sectors by developing advanced cogeneration systems that can supply both electric and thermal needs for the equivalent fuel energy now being used to generate just their electrical requirements.

- Develop advanced heat recovery component technology for producing useful work from waste heat rejected by the utilities, industrial and residential/commercial sectors, including the recovery and utilization of waste heat from Federally owned facilities based on the best available current technology.

\section{R\&D Activities}

The interdependent fuel usage and energy consumption patterns along with the interrelated technology needs in the stationary power markets of the utilities, industrial and residential/commercial sectors were analyzed under the previous Energy Research and Development Administration (ERDA). It was determined that a focused program addressing both heat engines and heat recovery technology was needed to best achieve the energy savings potential in these markets. Consequently, the U.S. Department of Energy (DOE) reorganization centralized these previously separate research and development (R\&D) activities within the Division of Power Systems under the DOE Fossil Energy (FE) Program in October 1977.

There are three subactivities included under the Ileat Engines and Heat Recovery Activity:

- Integrated Coal Conversion and Utilization Systems

- Advanced Cogeneration Systems

- Heat Kecovery Component 'l'echnology 
In the previous fiscal year, Integrated Coal Conversion and Utilization Systems was Advanced Power Systems in ERDA's Fossil Energy Program area. Advanced Cogeneration Systems was Components and Heat Engines, and Heat Recovery Component Technology was Heat Utilization; both were in the Improved Conversion Efficiency Subprogram in the ERDA Office of Conservation.

Technology development pursued in the Heat Engines and Heat Recovery Activity is targeted for commercialization in the stationary power markets of the utility, industrial, and residential/commercial sectors. Opportunities for improved technology in this tri-market sector are shown in the following figure, which illustrates both the interrelation between the Quads of fossil fuel consumption $\left(Q_{f}\right)$ in each market and the associated Quads of heat rejection $\left(Q_{r}\right)$.

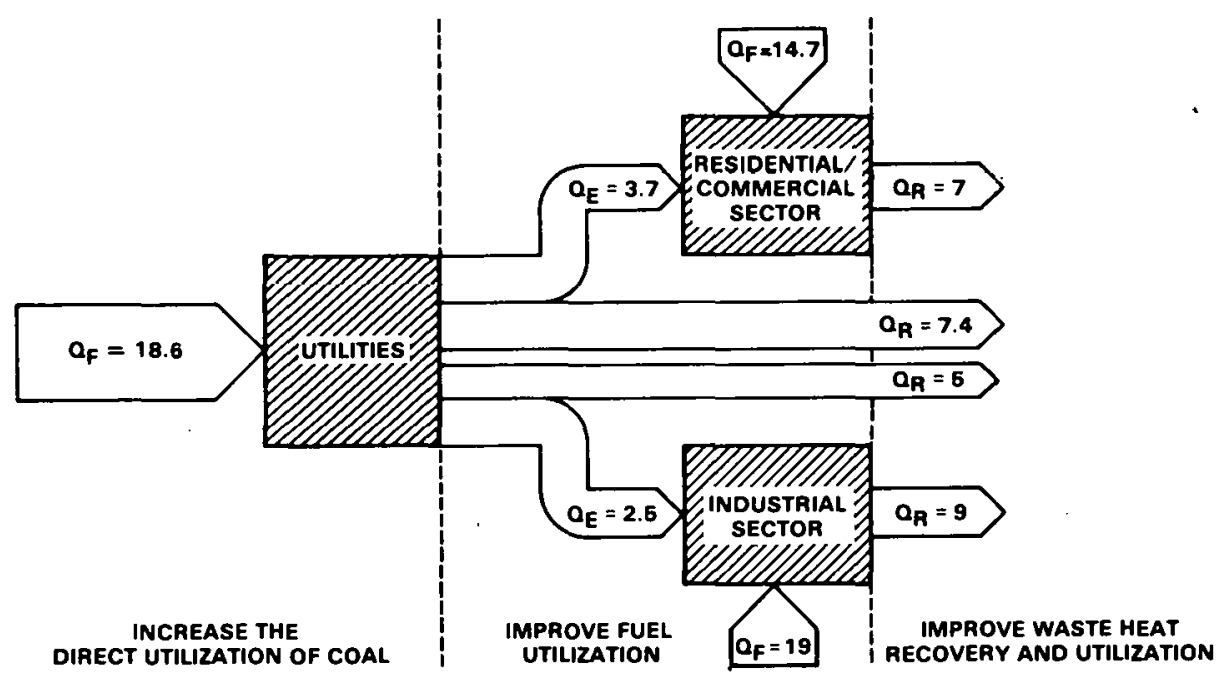

Opportunities for Heat Engine and Heat Recovery Technology

As shown, the utilities currently consume over 18 Quads of fuel energy to produce a little over 6 Quads of electrical energy $\left(Q_{e}\right)$. This electrical energy is distributed to customers in the residential/commercial and industrial sectors, while two-thirds of the fuel consumed by the utilities is rejected as waste heat. Meanwhile, the industrial sector consumes more fuel than the utilities in order to produce heat for various process needs. The residential/commercial sector consumes a significant quantity of fuel energy $(\mathrm{Qf}=14.7)$ for space heating, hot water, etc. A substantial portion of that energy consumption is also rejected without extracting any useful work. The opportunities for improving this wasteful tri-market energy pattern are the focus of the subactivities within the Heat Engine and Heat Recovery Activity. 
Integrated coal conversion and utilization systems show the most promise for efficiently using coal in an economic and environmentally acceptable manner. Successful development of these advanced technology systems would permit the utilities to increase the utilization of our abundant coal resources thereby displacing critical oil and gas for use in other domestic markets.

Advanced cogeneration systems have been shown to be one of the most efficient means of improving fuel utilization by the residential/commercial and industrial sectors. The concept of simultaneously producing both electricity and process heat on the industrial or residential/commercial site is known as cogeneration. Examples of residential/commercial cogeneration are small dispersed total energy systems for multifamily buildings, or larger integrated energy systems for communities that can efficiently supply both the electrical and heating needs of residential/commercial complexes. The waste heat recovered from the electrical generation process in these total energy systems can supply space heating hot water, and even cooling by combining absorption air conditioning operating directly from low grade waste heat. Cogeneration in industrial plants can also supply their electrical needs and heat for the various processes. Industrial processes generally require higher temperature heat than residential/commercial applications, so the equipment for the two applications. differ in their overall size as well as in the temperature of the heat produced.

Heat recovery component technology can provide a means to effectively recover waste heat and convert it to useful purposes thus offsetting fuel now burned to produce that equivalent work. Considering the current total 52 Quads of fuel energy usage by the tri-market sector, it is estimated that approximately 28 Quads are rejected to the atmosphere and rivers in the form of waste heat. Effective recovery and utilization of even a fraction of this reject heat could reduce dependence on foreign energy imports, alleviate the associated balance of payments problem, and help reduce the cost of energy to the American public. The technology related to improved waste recovery and utilization would have important applications in all three market sectors.

Achievable energy savings for successfully developing the technologies of these three subactivities are estimated as follows:

\section{Quads Saved}

Subactivity

Integrated Coal Conversion and Utilization

Advanced Cogeneration Systems

Heat Recovery Component Technology $\underline{1985}$

$-\quad 4.0$

1.0

.50 $\underline{2000}$

4.0

4.5

1.5 
The following table summarizes the funding levels by subactivity for the FY 1977 to FY 1979 period. (Refer to Chapter II.A, Table 5 for budget comparability .)

\begin{tabular}{|c|c|c|c|c|c|}
\hline $\begin{array}{l}\text { HEAT ENGINES \& HEAT } \\
\text { RECOVERY }\end{array}$ & \multicolumn{4}{|c|}{$\begin{array}{l}\text { BUDGET AUTHORITY } \\
\text { (OPERATING EXPENSES) } \\
\text { (DOLLARS IN THOUSANDS) }\end{array}$} & \multirow{2}{*}{$\begin{array}{l}\text { MAJOR } \\
\text { CHANGE. }\end{array}$} \\
\hline SUBACTIVITIES & $\begin{array}{l}\text { ACTUAL } \\
\text { FY } 1977\end{array}$ & $\begin{array}{l}\text { APPROPRIATION } \\
\text { FY } 1978\end{array}$ & $\begin{array}{l}\text { ESTIMATE } \\
\text { FY } 1979\end{array}$ & $\begin{array}{l}\text { INCREASE } \\
\text { (DECREASE) }\end{array}$ & \\
\hline $\begin{array}{l}\text { Integrated Coal Conversion } \\
\& \text { Utilization Systems } \\
\text { (Advanced Power Systems) } \\
\text { Improved Conversion Efficiency } \\
\text { R\&D in Advanced Cogeneration } \\
\text { and Heal Recovery Component } \\
\text { Technology }\end{array}$ & $\$ 22,500$ & $\$ 25,500$ & $\$ 26,700$ & $\$+1,200$ & \multirow[t]{2}{*}{$A, 1$} \\
\hline TOTAL & $\$ 25,800$ & $\$ 42,100$ & $\$ 56,300$ & $\$ 14,200$ & \\
\hline \multicolumn{3}{|c|}{$\begin{array}{l}\text { "KEY } \\
N=\text { New start (tulally new project) } \\
S=\text { Scaleup (from bench to PDU or pilot plant) } \\
A=\text { Acceleration (shortening deadlines or } \\
\text { expansion of ongoing projects) }\end{array}$} & \multicolumn{3}{|c|}{$\begin{array}{l}\mathbf{P}=\text { Phase completion or startup } \\
\mathrm{R}=\text { Program redirection } \\
\mathrm{I}=\text { Incremental cost requirement } \\
\mathrm{C}=\text { Project completion or suspension }\end{array}$} \\
\hline
\end{tabular}

\subsection{INTEGRATED COAL CONVERSION UTILIZATION (ADVANCED POWER) SYSTEMS}

The major applications of technology under development in Integrated Coal Conversion and Utilization Systems is for base load electrical generation by central station utilities. Coal and coal-derived fuels are projected to be the predominate fossil energy resource for electric utilities in the future. The effort is arranged in three tasks discussed herein: 1) Open-Cycle Gas Turbine, 2) Closed-Cycle Power Systems, and 3) Support and Additional Programs, Engineering Analysis, Evaluation and Assessmeril. They are almed toward providing technology for increasing the utilization of our abundant coal fuel resources in order to offset the use of critical oil and gas in the utility market.

Integrated coal conversion and utilization systems have shown to be a most promising option for efficiently using coal in an economic and environmentally acceptable manner. Specifically, the integrated hightemperature gas turbine/low-Btu coal gasification combined-cycle holds the most promise for achieving the high efficiency needed to offset energy lusses in gasifying and cleaning the coal; therefore, electricity can be produced for a cost comparable to those of oil-fired steam and nuclear base load systems.

Closed-cycle power systems integrated with a primary heater or a fluidized-bed combustor represent another environmentally promising approach for utilizing coal directly in utility base-load service. Though with current technology this option is potentially less efficient than the 
advanced combined-cycle gasification plant, closed-cycle systems can be considerably more efficient than conventional coal-fired boiler systems. In fact, they have found widespread use in Europe, particularly in central station cogeneration applications where waste heat is recovered and hot water distributed to residential/commercial customers, a concept known as district heating. If the cycle temperature could be increased, advanced closed-cycle power systems could have the potential for competing on the basis of efficiency and cost-of-electricity with other advanced base load options.

The major technical problems are:

- Materials compatibility

- High-temperature turbine cooling for open-cycle systems

- Heat exchanger componenls fur elosed-cycle systcmo opcrating at high pressure and temperature

- Bearings, seals, and auxiliaries of adequate durability for these systems

- Efficient and economic low- and/or high-temperature gas cleanup for open-cycle systems.

- Efficient economic low-Btu gas source in open-cycle systems .

Projects initiated in FY 1976 using open-cycle gas turbines as the topping portion of combined-cycles have continued in FY 1977. These projects started with system definition studies to determine both technical and economic factors for promising gas turbine designs. Efforts in blade and vane cooling, ceramic component evaluation, and materials corrosion and reliability studies, which were initiated in FY 1976 and FY 1977, are continuing during FY 1978. Projects started to evaluate improved blade durability, cleanup of particulate matter from turbine inlet yas, and coalm derived fuel cleanup methods will continue during FY 1977.

In the closed-power systems area, work has proceeded on the hightemperature heater and boiler, on materials evaluation, and on system studies to evaluate overall power generating costs. Work on the boiler technology for alkali metal vapor topping turbine system is continuing at Oak Ridge National Laboratory (ORNL) and will lead to completion of shakedown tests on the alkali metal vapor boiler in FY 1978.

The overall environmental impacts of the advanced power systems technologies should be much less than those for conventional boilers because of the high efficiencies associated with them, and the fact that the turbines do not exhaust directly to the environment.

There are, nevertheless, two major environmental concerns associated with the Advanced Power Systems project: 1) possible $\mathrm{NO}_{\mathbf{X}}$ emissions greater than conventional coal-fired boilers; and 2) control of particulate matter under the high temperature conditions associated with these 
technologies. The latter concern is both an environmental problem and a technology need to reduce particulate levels prior to the hot gas entrance into the turbines. The environmental problem is being studied within DOE and by the Environmental Protection Agency (EPA) and is common to many Fossil Energy technologies.

\begin{tabular}{|c|c|c|c|c|c|}
\hline \multirow{2}{*}{$\begin{array}{c}\text { INTEGRATED COAL CONVERSION } \\
\text { \& UTILIZATION SYSTEMS } \\
\text { (ADVANCED POWER SYSTEMS) } \\
\text { TASKS }\end{array}$} & \multicolumn{4}{|c|}{$\begin{array}{c}\text { BUDGET AUTHORITY } \\
\text { (OPERATING EXPENSES) } \\
\text { (DOLLARS IN THOUSANDS) }\end{array}$} & \multirow{2}{*}{$\begin{array}{l}\text { MAJOR } \\
\text { CHANGE: }\end{array}$} \\
\hline & $\begin{array}{l}\text { ACTUAL } \\
\text { FY } 1977\end{array}$ & $\begin{array}{l}\text { APPROPRIATION } \\
\text { FY } 1978\end{array}$ & $\begin{array}{l}\text { ESTIMATE } \\
\text { FY } 1979\end{array}$ & $\begin{array}{l}\text { INCREASE } \\
\text { (DECREASE) }\end{array}$ & \\
\hline Open-Cycle Turbine Systems & $\$ 16,400$ & $\$ 18,700$ & $\$ 24,350$ & $\$+5,650$ & $\mathbf{R}$ \\
\hline Closed Power Systems & 2,880 & 3,500 & 0 & $-3,500$ & $\mathbf{R}$ \\
\hline Support and Additional Programs & 3,220 & 3,300 & 2,350 & -950 & \\
\hline TOTAL & $\$ 22,500$ & $\$ 25,500$ & $\$ 26,700$ & $\$+1,200$ & \\
\hline \multicolumn{3}{|c|}{$\begin{aligned} & K E Y \\
N= & \text { New start (totally new project) } \\
S= & \text { Scaleup (from bench to PDU or pilot plant) } \\
A= & \text { Acceleration (shortening deadlines or } \\
& \text { expansion of ongoing projects) }\end{aligned}$} & \multicolumn{3}{|c|}{$\begin{array}{l}P=\text { Phase completion or startup } \\
R=\text { Program redirection } \\
A=\text { Incremental cost requirement } \\
C=\text { Project completion or suspension }\end{array}$} \\
\hline
\end{tabular}

\subsection{OPEN-CYCLE GAS TURBINE SYSTEMS}

The concept of this advanced system is to burn coal or coal-derived gaseous or liquid fuels in air to produce a high-temperature gas (combustion products at 2600 F or higher) before expanding it through the turbine to produce electricity. After expansion, remaining hot gases can be used to generate steam in conventional steam plants to produce additional electricity. Such a supplemental power-producing stage is called a bottoming cycle. The Open-Cycle Gas Turbine (OCGT)/steam system forms a combined-cycle power plant with potentially greater, efficiency than today's standard steam plant. The approach in designing a gas turbine to burn coal having been identified as most promising from the standpoints of efficiency, cost of electricity, and emissions involves a combined-cycle system integrated with a low-Btu coal gasifier.

With this system, crushed coal, water, and compressed air are fed into the gasifier. Hot gases are passed through a cleanup system for removal of particulates and chemical contaminants, and are burned in a combustor prior to driving the gas turbine electric generator. From the turbine, the expanded gases are routed through a steam generator, relinquish their remaining heat, and are exhausted to the atmosphere. Steam thus generated is expanded through a steam turbine driving an electric power generator. Exhausted steam is condensed, and a pump arrangement feeds the fluid back through the steam generator. 


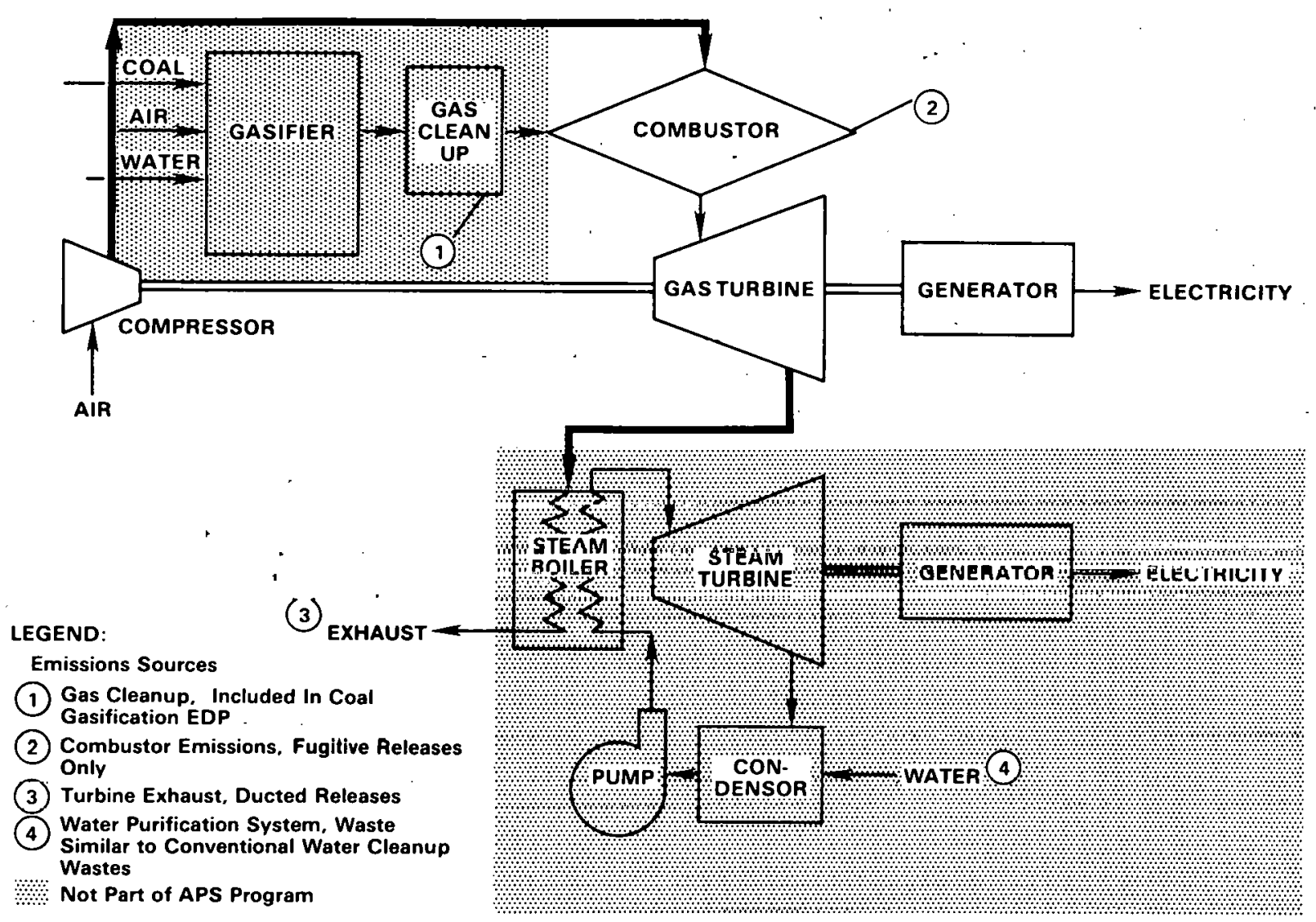

\section{Open-Cycle Gas Turbine/Steam Turbine System}

\section{Project Status}

The open-cycle gas turbine technology base is quite advanced with clean fuels such as oil and natural gas. Valuable infrirmation has been developed through military and commercial R\&D. Industrial units with clean fuels are presently in wide use for utility peaking service, as are clean fuel-fired gas turbine/steam turbine combined-cycles for intermediate-duty service.

Adaptation of new gas turbine technology for use with coal and coalderived fuels will require development of three key capabilities:

- Compatibility with coal and coal-derived fuels

- Improved endurance of materials for turbine blades, vanes, and combustors to meet long-term base load service

- Practical turbine cooling methods to withstand higher turbine inlet temperature, which will in turn produce higher efficiencies 
Turbine component durability is dependent on a combination of factors such as stress, temperature, and hot corrosion/erosion. The strategy for the open-cycle gas turbine project is to achieve technology readiness by developing key components for incorporation into a prototype advanced high-temperature gas turbine.

The open-cycle turbine project will be implemented by advancing the technology of a $2600^{\circ} \mathrm{F}$ multistage turbine subsystem to technology-ready status within a 10-year period. The project is divided in to three phases:

- Phase I: . Project and System Definition

- Phase II: Technology Test and Test Support Studies

- Phase III: Technology Readiness Verification Tests

Successful completion of these phases will provide technology readiness, and commercial demonstration is expected to follow.

The key area of this project concerns development of advanced cooling concepts, such as film and transpiration cooling and water/steam cooling of turbine blades and nozzles, along with development of material alternatives (superalloy metals and ceramics) for combustor liners, transition sections, and appropriate hot section parts. An assessment of ceramics for key high temperature open-cycle turbine components is included as a project element, since impurities that may be in coal-derived fuels may seriously degrade the metals and coatings conventionally used in gas turbines".

An additional project element is the development of combustors to ensure that the gas temperature profile is carefully controlled to prevent uneven temperature distribution or "hot spots" on turbine components and to ensure that the exhaust meets emission standards. Design data for combustors using coal fuels must be developed. Two specific approaches aimed at the "temperature profile" goals are: to improve combustion control by premixing of fuel and air in a separate upstream section of the burner; and to use catalytic combustion. 


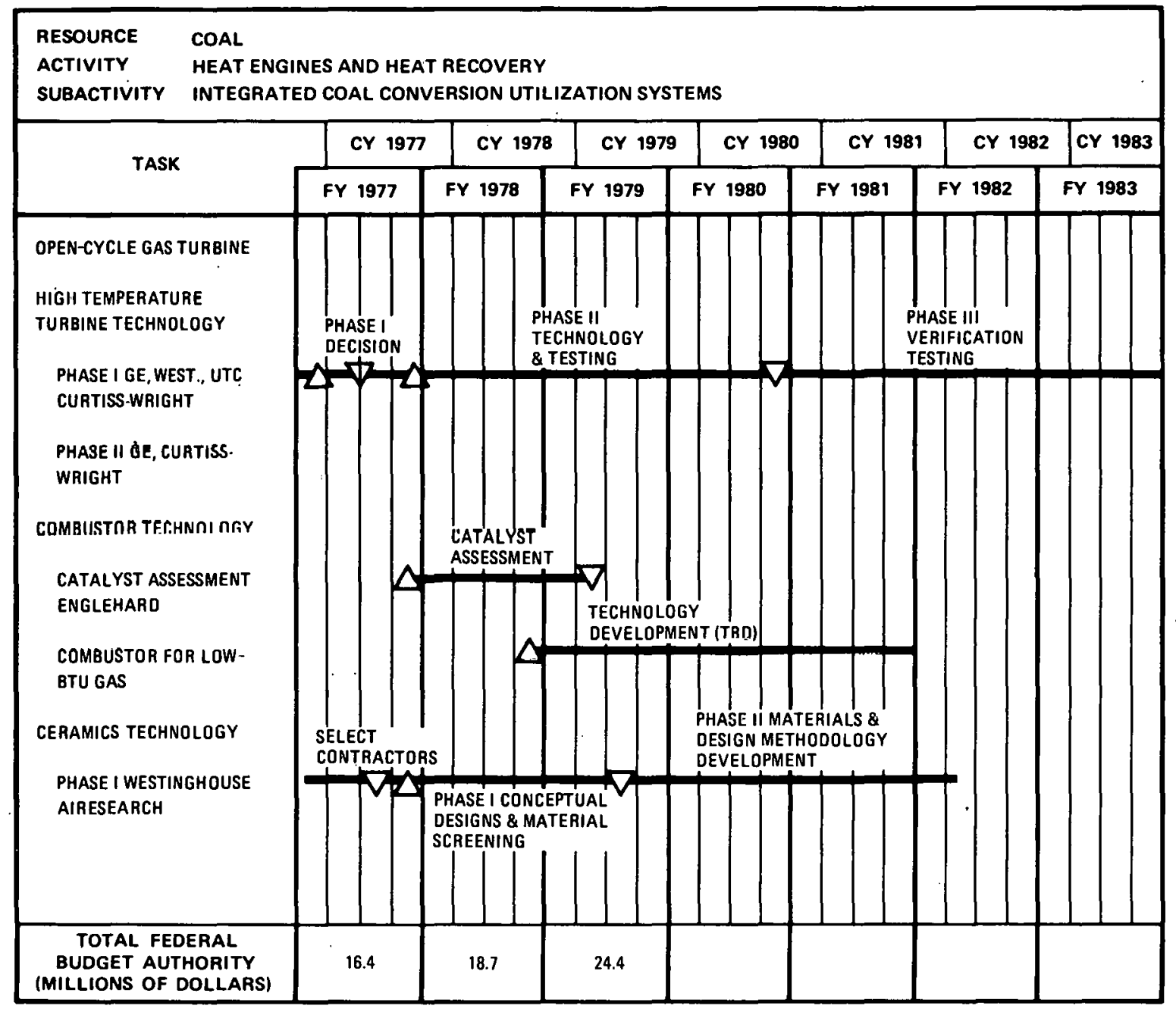

MILESTONE SYMBOLS ARE DEFINED ON LAST PAGE OF THIS DOCUMENT

\subsection{CLOSED-POWER SYSTEMS}

Two cycles are being investigated in the Closed-Cycle Fower Systems task. These are the closed-cycle gas turbine power cycle and the alkali metal vapor topping cycle. Both can be used in conjunction with a steam turbine bottoming system, to more efficiently utilize coal in fuels in central station utility power generation.

As in the open-cycle gas turbine system, the closed-cycle system can burn coal or coal-derived fuels. Because the working fluid is contained within a sealed system and is recirculated with negligible loss, working fluids (such as helium, nitrogen, carbon dioxide, and air) can be used. Since this gas turbine can be driven by relatively noncorrosive or inert working fluids such as helium, it can operate at higher temperatures (1550\%F and higher) than a standard steam system. After expansion through the turbine, remaining heat can be used in a conventional steam bottoming cycle or in a lower temperature bottoming cycle with an organic working fluid. 
The gaseous working fluid is compressed and then heated by the primary heat exchanger. It is then expanded through the gas turbine driving an electric power generator. The expanded gas rejects heat to the steam generator and heat rejection heat exchanger. The fluid then is recycled through the system by being recompressed. Steam thus generated is expanded through a steam turbine driving an electric power generator, the exhausted steam is condensed, and a pump arrangement feeds the fluid back through the steam generator.

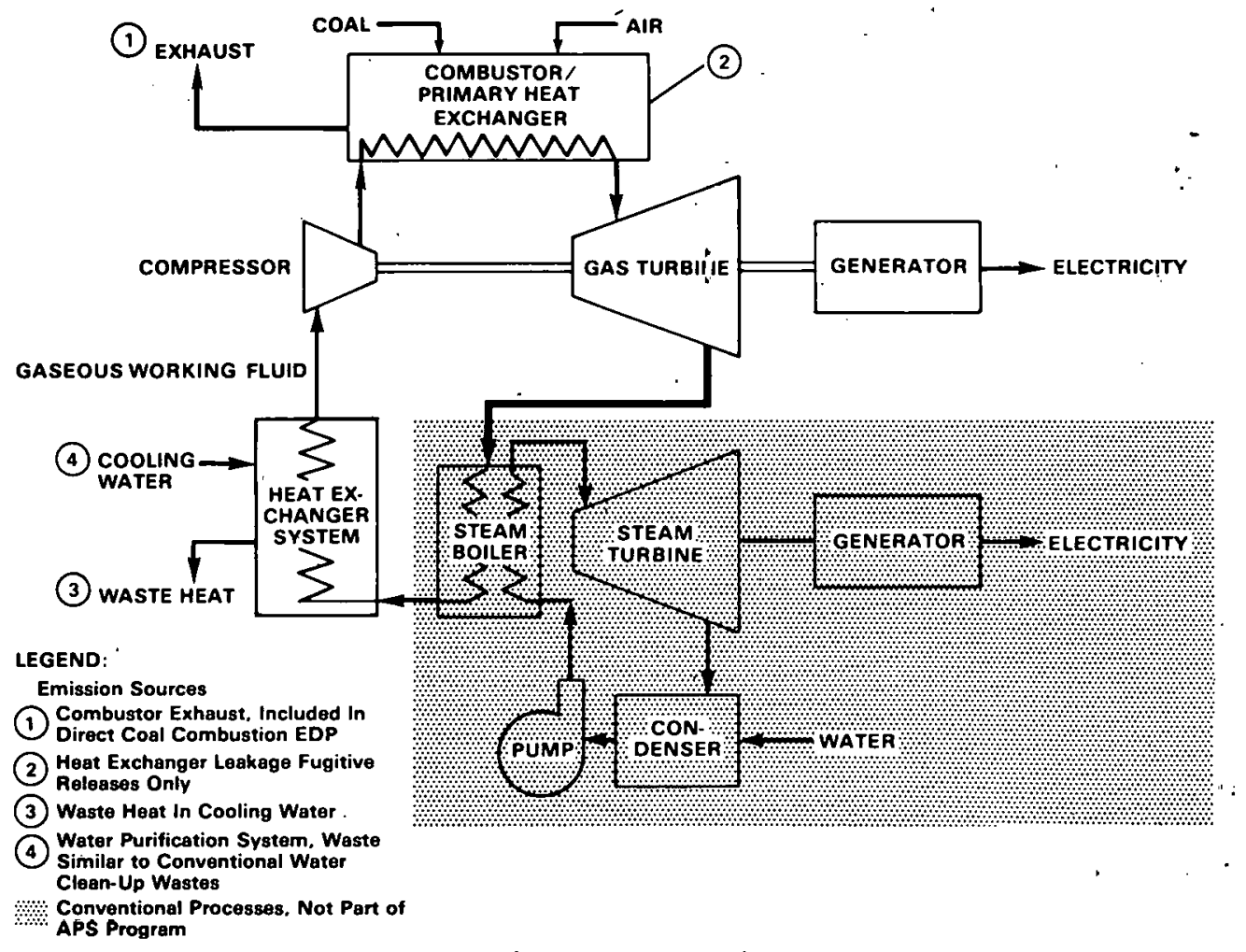

\section{Combined Closed-Cycle Gas Turbine/Steam Turbine System}

The alkali metal vapor turbine is also a closed system. It differs significantly from the closed-cycle gas turbine systems in that a vaporized liquid metal, such as potassium or cesium is used as a working fluid. Peak temperatures are in the range of 14000 to $1600^{\circ} \mathrm{F}$. The fluidized-bed combustor is the most likely candidate for supplying heat. This system will be combined with a steam bottoming cycle.

The liquid metal vapor passes through a pressurized primary'heater system, is heated and then expanded through a metal vapor turbine (which drives an electric power generator). It is then passed through a condenser/steam boiler and pumped back through the primary heater. Steam leaving the condenser/boiler is expanded through a steam turbine 
(which drives an electric power generator), rejects heat to a condenser, and is pumped back through a feedwater heater into the condenser/boiler. A turbine powered by exhaust gases from the primary heater drives a compressor which supplies combustor air to the primary heater. Gas turbine exhaust gases provide heat to a feedwater heater for the steam system and exit to the stack.

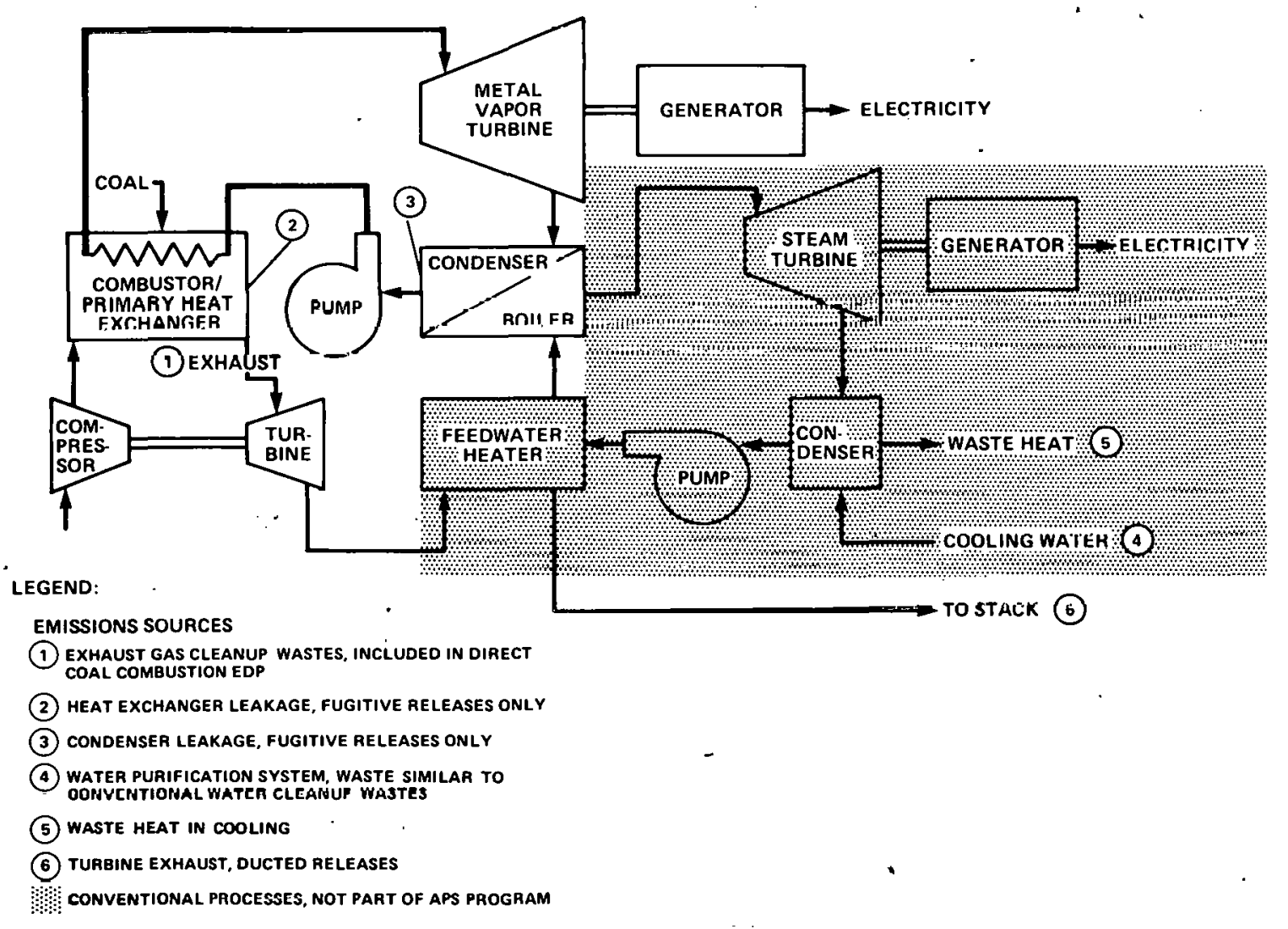

Alkali Metal Vapor Turbine

\section{Project Status}

Plans for the closed-cycle gas turbine system, which is not considered as advanced as the open-cycle system, are to limit the work to system definition and optimization studies and critical component feasibility investigations. Concurrently, the technology development foriuses on the key component which is judged to be the primary heat exchanger. Phase I of the closed-cycle primary heater was begun; with contracts at two major industries to conduct the system definition efforts of the project. These include system analysis, multiple conceptual designs, preliminary detailed 
heat exchanger designs, program plan, and establishment of a reference power system design. Phase IA commenced in FY 1978, covering central station district heating applications for the closed-cycle power system technology. Phase II was begun late in the year. FY 1978 funding will provide for procurement of the test equipment in Phase II and subsequent component verification tests in FY 1980. At that point in time a decision will be made with regard to the program plan for subsequent heat exchanger module tests leading to full-scale demonstration in the mid1980s. No funding beyond FY 1978 is planned at the present time for the alkali metal vapor system.

To determine the technical feasibility and define initial systems configurations for the closed alkali metal (potassium or cesium) topping cycle, optimization studies address specific critical areas such as:

- Fireside boiler corrosion at high temperatures with coal and coalderived fuels

- Long-term liquid metal corrosion effects

- Working fluid properties' effect on cycle performance

- Power conversion system preliminary design

- Overall plant performance analysis

- High-strength, high-temperature turbine component alloys

- High component reliability of alkali metal boilers, condensers, valves, pumps, and turbines.

Preliminary data indicate that this turbine system could be quite successful as a topping unit for a conventional steam system. The boiler test of the alkali metal vapor turbine was completed in FY 1978. Further efforts with FY 1979 funding are not contemplated; a complete assessment of closed-cycle power systems will determine the need for subsequent development. 


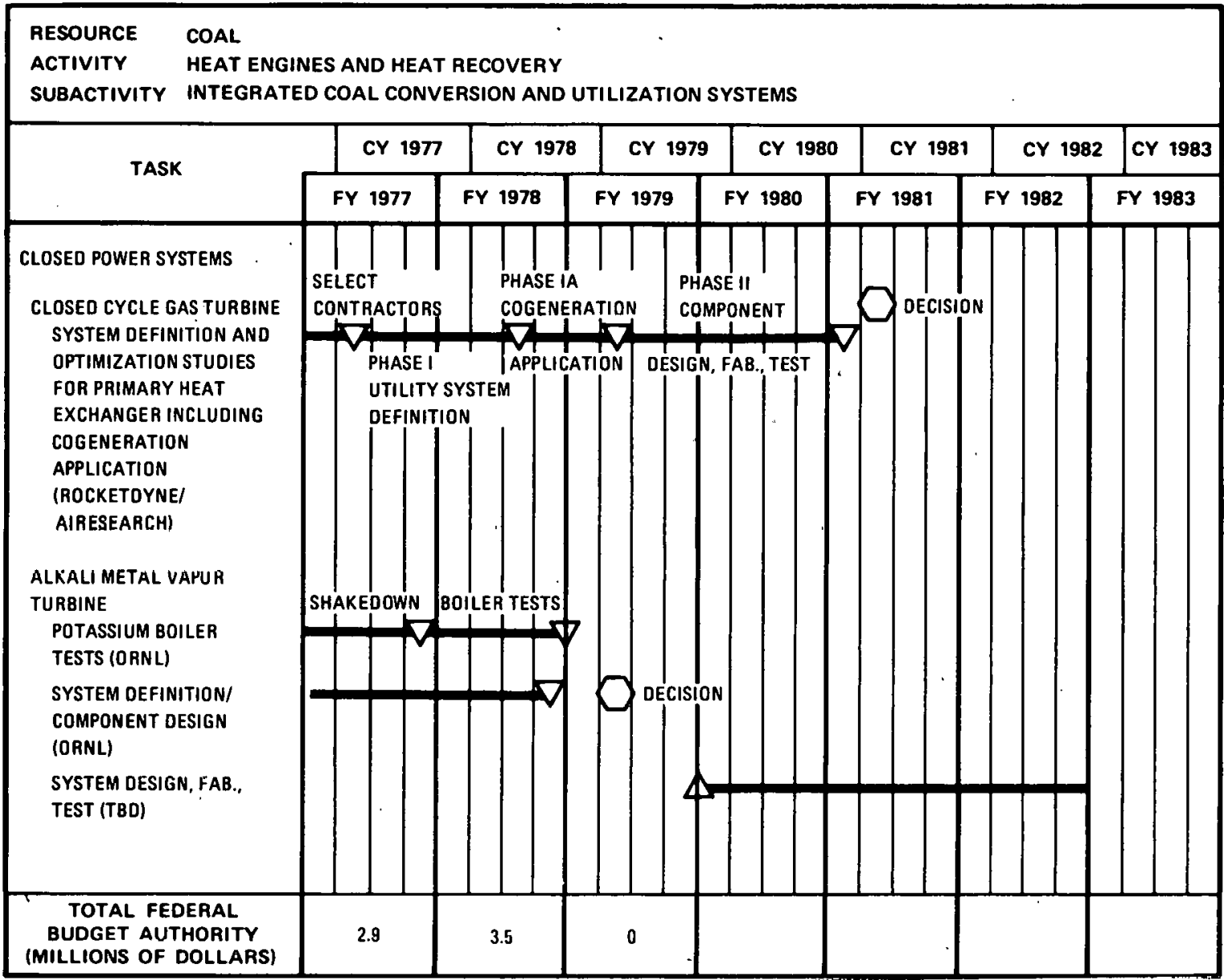

MILESTONE SYMBOLS ARE DEFINED ON LAST PAGE OF THIS DOCUMENT

\subsection{SUPPORT AND ADDITIONAL PROGRAMS}

Supporting technology for the Integrated Coal Conversion and Utilization Systems is required in many areas. Within DOE there must be close coordination in this technology development to avoid duplication. In addition, strong coordination is required and will be maintained with other Federal agencies, National Aeronautics and Space Administration (NASA), Electric Power Research Institute (EPRI), and industry .

Studies will be conducted to determine the overall economics of various closed-power system approaches. Coal-derived liquid fuel/opencycle gas turbine interface studies are also planned. These studies will assess the economical technological trade-off for coal fuel conversion and gas turbine technology development (e.g., optimum level of coal liquid fuel cleanliness considering the projected turbine technology).

Effort will continue on various support studies and engineering evaluations relating to the following areas:

- Key component studies and design of turbine bearings, seals, rotors, heat exchangers, controls, and instrumentation 
- Power system technology testing and application of component design and development

- Coal-based fuel-fired advanced combustor design

- $\quad$ Fireside corrosion studies, test, and evaluation

- Advanced power system studies.

1

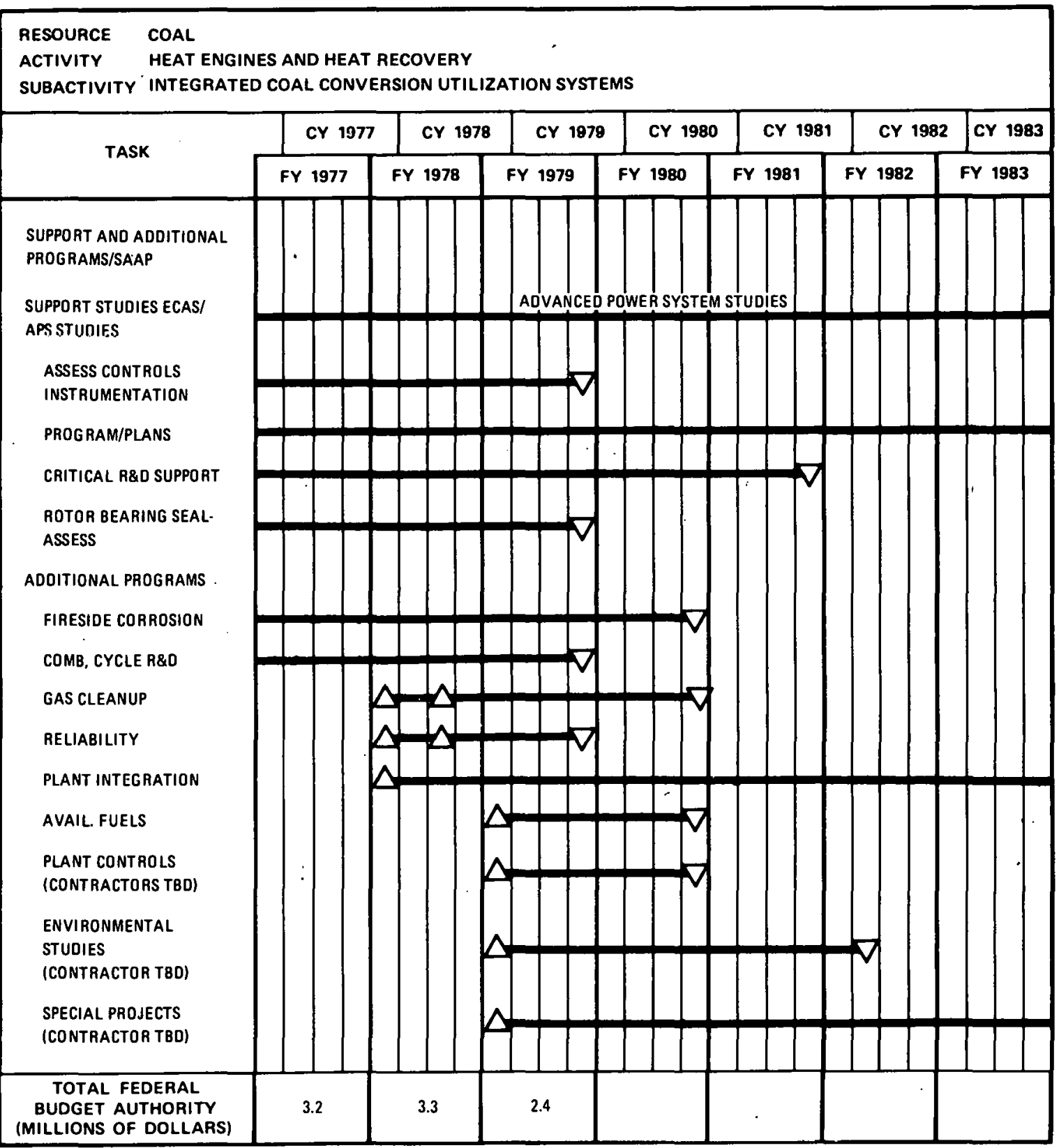

MILESTONE SYMBOLS ARE DEFINED ON LAST PAGE OF THIS DOCUMENT 


\subsection{ADVANCED COGENERATION SYSTEMS}

Technology for improving fuel utilization in the industrial and residential/ commercial sectors under development in Advanced Cogeneration Systems (ACS) is expected to save critical gas and oil in these markets by providing cogeneration systems optimized for energy savings and capable of operating on alternate fuels. With advanced technology, cogeneration can improve fuel utilization in the industrial and residential/commercial sectors by potentially supplying both their electrical and thermal needs for essentially no more than the equivalent fuel energy now being used to generate just their electrical requirements.

A great increase in the future use of coal is projected by the utilities, with little or no increase in fuel oil consumption. In the industrial sector, it is estimated that fuel oil consumption will increase to over four times that consumed by the utilities in 1985. Natural gas consumption is expected to decrease somewhat in both the industrial and utility sectors. Both natural gas and oil, however, will remain the predominate fuels used in the residential/commercial sector. Studies have shown that cogeneration is one of the most promising concepts for improving the utilization of critical fuels within these predominately oil and gas consuming sectors.

Prime mover options currently available for cogeneration are steam turbine, gas turbines, diesel and gas engines. Of these, the only presently available system that can use coal or synthetic fuels directly is fired boilers utilizing a noncondensing steam turbine. Gas turbine or diesel cogenerating installations, although dependent on distillate or gaseous fuels, can produce a significantly higher ratio of electrical energy per pound of steam generation than the noncondensing steam turbine system. Thus, these two directly fired engine options have become widely used in today's existing cogeneration systems.

Natural gas and the higher distillate petroleum are the best fuels for present generation gas turbines and diesel engines. In areas where coal is not a practical alternative, use of oil and gas in cogeneration is a far more efficient use of these resources.

Proposing cogeneration with oil- and gas-fired systems for those parts of the country where coal and alternate fuels are available would be, in the long range, contrary to current policies which favor moving energy use away from oil and gas. Development of efficient and environmentally clean power plants which can be fueled from a variety of alternate fuels in the sizes appropriate to dispersed, load-center based power systems is the 
major role of technology in cogeneration. This is also the focus of the three tasks comprising the Advanced Cogeneration activity: 1) Prototype system assessment; 2) Directly-fired heat cycles; and 3) Externally-fired heat cycles.

\subsection{PROTOTYPE SYSTEMS ASSESSMENT}

The effort in this task consists of advanced cogeneration systems analysis plus selected hardware verification development and systems integration. The objective of the work is to define optimum cogeneration systems for the benefit of the industrial, residential/commercial sectors and to provide such hardware as is required to integrate all components and subsystems into advanced prototype systems.

Studies will continue on a major sector basis to define the specific cogeneration systems and subsystems, and components which should be developed with primary focus in the area of advanced fuel-flexible energy conversion systems configured for cogeneration. Generalized schematics are shown below to illustrate several concepts of generating both electricity and process heat using different prime movers. The analysis will include environmental, economic, industry-specific, as well as equipment configurations and opportunities for energy savings through cogeneration.

In the residential/commercial sector, analyses will continue with primary emphasis on defining the impact of advanced fuel-flexible heat engines for total energy systems to serve this sector. Since particular heat engines are being analyzed, analyses will output specific development requirements for the engine technologies, including critical components within the engines.

In the industrial sector, analyses will continue with primary emphasis on defining the development requirements for advanced fuel-flexible heat engines that show substantial advantages when used as major cogeneration subsystems in the six high energy usage industries. In this sector, one advanced cogeneration system appears to be ready for design, fabrication, assembly and test - a 2-MW organic Rankine engine which operates from the waste heat of a cement manufacturing kiln, an important member in the above six industry classifications. 

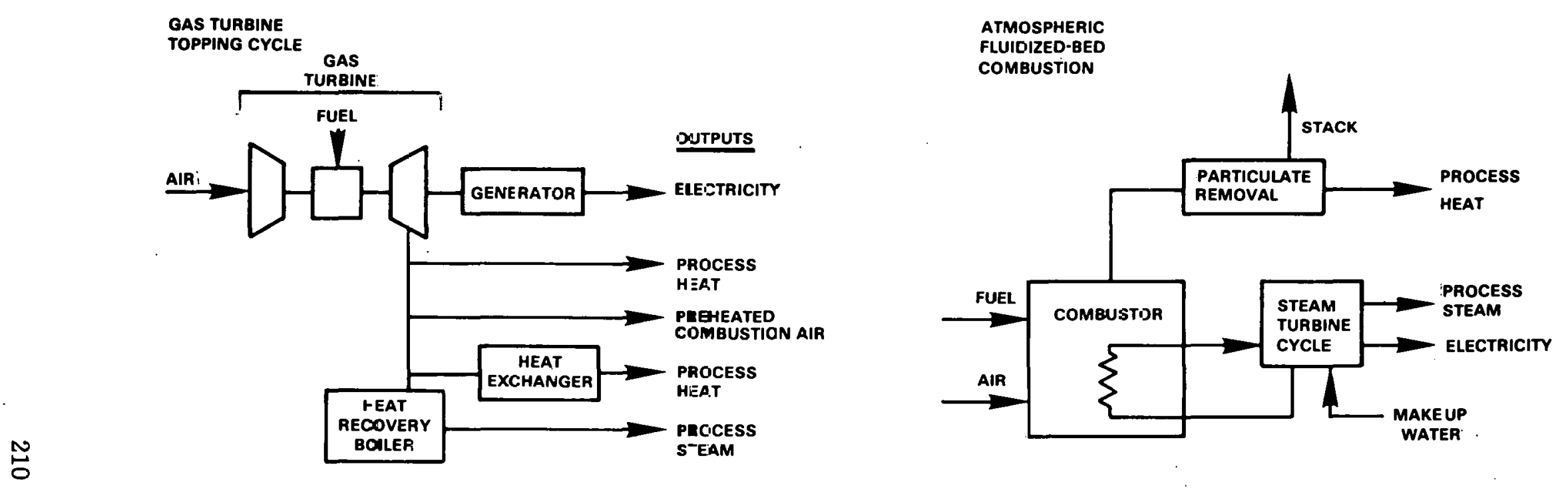

DIESEL ENGINE

TOPPING CYCLE
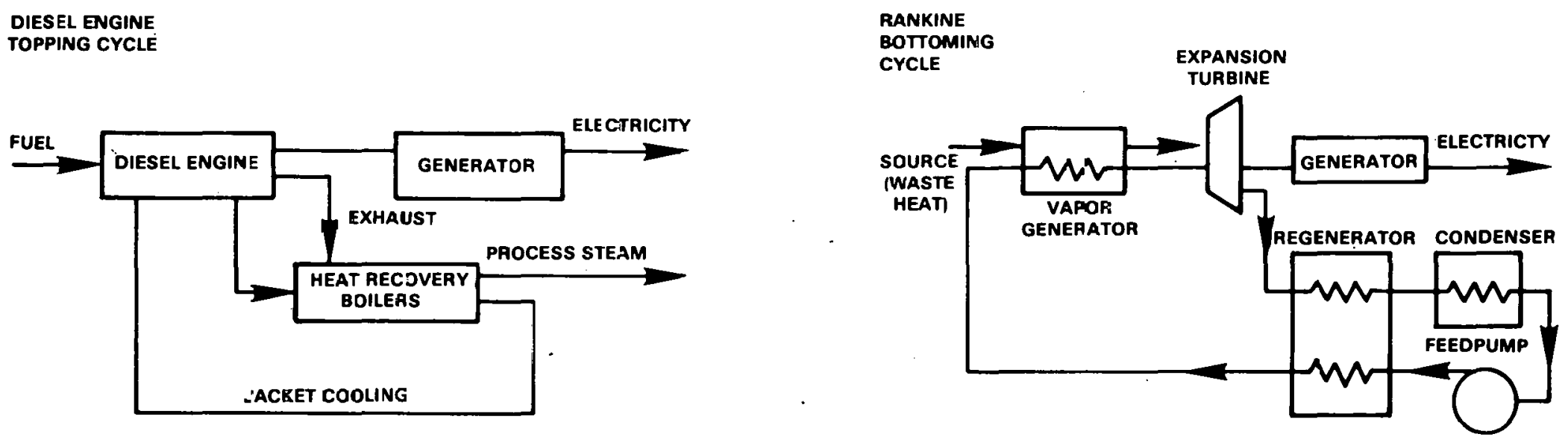

Examples of Cogeneration Concepts 


\section{Project Status}

The Total Energy Technology Assessment Study (TETAS) was initiated in late FY 1977, to define the most promising advanced total energy systems for commercialization in the residential/commercial market sector. During FY 1978, system energy demands were defined, along with the evaluation of fuel-flexible heat engines (gas turbines, stirling engines, and steam turbines) as prime movers for these total energy systems. FY 1979 will cover the evaluation of heat pumps to enhance overall efficiency and definition of optimum systems.

In the industrial sector, the focus is on defining advanced cogeneration opportunities for the six major industries that currently consume 70 percent of the nation's industrial process heat. This effort, the Cogeneration Technology Alternative Study (CTAS), was started with two prime contractors and their industry teams in mid-FY 1978 and is scheduled for completion by mid-FY 1979. During FY 1978, very specific industrial process requirements were defined and computer-modeled on an energy balance basis. The energy balance characteristics of current technology and advanced energy conversion systems (gas turbines, diesels, Stirlings, steam, organic Rankine cycles, fuel cells, heat pumps and energy storage) were also defined, computer modeled, and matched against the industrial process requirements to define the technical impact of advanced engines in cogeneration. FY 1979 will complete the evaluation by identifying energy savings, industry specific economics, and energy conversion R\&D requirements to bring these advanced systems to commercial readiness in the 1985-to-2000 time frame. Final reports will be available, and a public briefing is to be held on the outcome of the study in Spring 1979.

Both TETAS and CTAS focus on new technologies that can be commercialized in the 1985-to-2000 time period. To evaluate a promising advanced system with near-term (1982 to 1985) potential for industrial cogeneration applications, the design and analysis of a prototype 2-MW organic Rankine-cycle process development unit (PDU) was completed in FY 1978. It was sized for installation in the waste heat exhaust stream of a major U.S. cement factory. Detailed design of the complete system, principally a metal heat exchanger and an organic fluid. (Water-Methyl Pyridine) turbine, with complete manufacturing drawings is now targeted to begin in FY 1980. With this extended schedule, fabrication, test, and complete systems evaluation of the PDU is targeted for completion by late FY 1982. The design is to be scalable to $6 \mathrm{MW}$. 


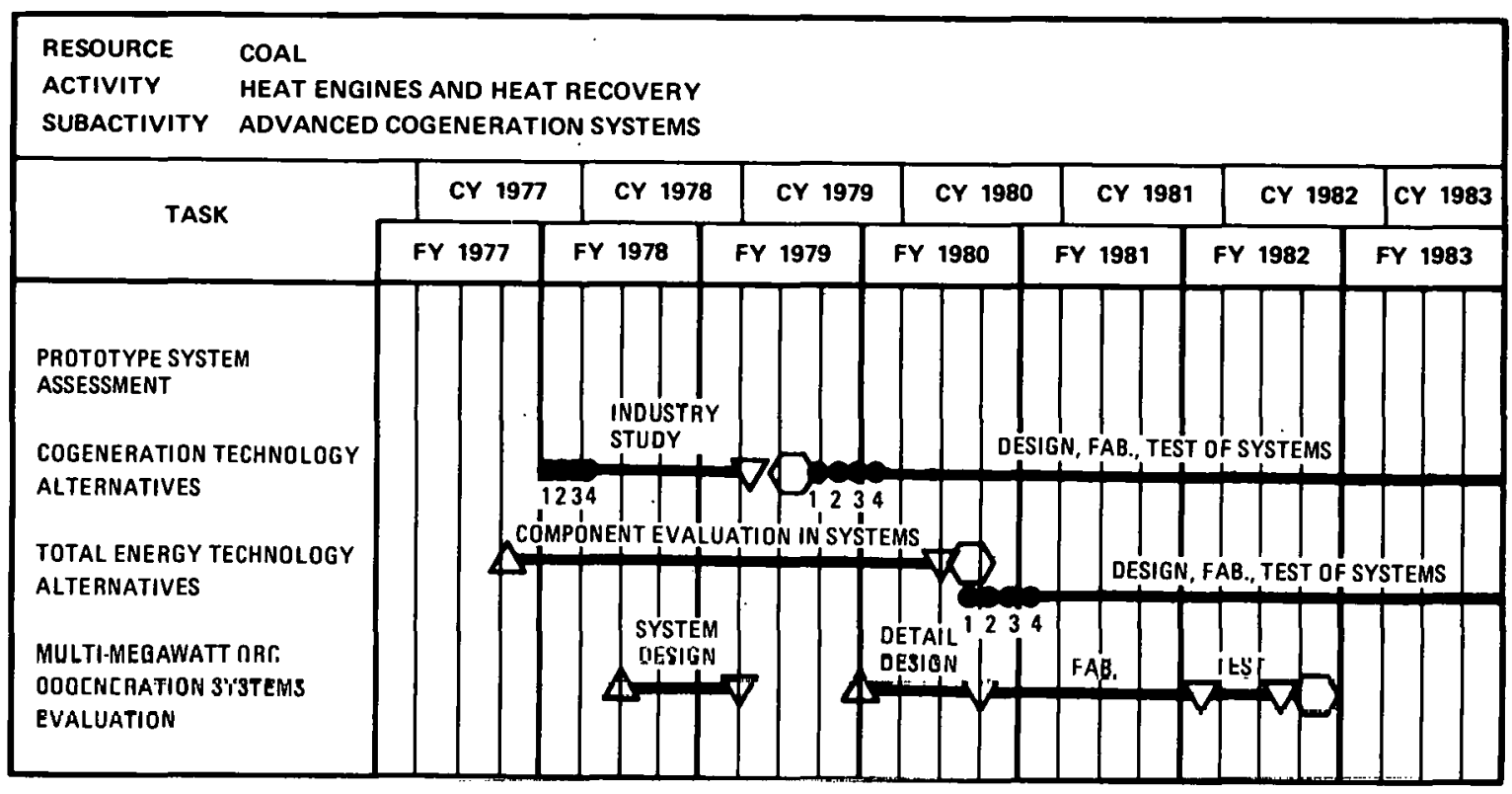

MILESTONE SYMBOLS ARE DEFINED ON LAST PAGE OF THIS DOCUMENT

\subsection{DIRECTLY-FIRED HEAT CYCLES}

The objective of the directly-fired heat cycles task is to provide the heat engine technology for promoting a smooth transition from today's clean light distillate fuels to future minimally-processed coal-derived liquid fuels.

Major near-term emphasis is placed on technology improvements for directly-fired heat cycles, such as diesels and gas turbines, to facilitate retrofit. of these present technology prime movers that now require distillate or natural gas fuels. The $R \& D$ is directed toward permitting durable operation on lower grade heavy petroleum fuels with an ultimate capability for conversion to synthetic or alternate fuels when they are commercially available.

Petroleum based liquid fuels are projected to be shorter in supply toward the mid-1980s, many years before synthetic liquid fuels from coal become available in sufficient commercial quantities to replace them. Studies show a significant shift in industrial and utility markets from light distillate toward heavy petroleum residual fuels. 'This is projected to occur not so much because there will be dramatic cost advantages for burning residuals compared to distillate, but rather because of their availability. As shown, high-quality distillate consumption by the residential/commercial and transportation sectors is projected to remain quite high, and there will 
be considerable competition for these clean, lighter petroleum fractions. Those markets such as industry and the utilities are even now more adaptable to lower grade fuels and will tend toward increased usage of these fuels by 1985. These markets will offer the earliest penetration of synthetic coal-derived liquids as they become available, providing they are economically competitive with petroleum based fuels. Thus, heat engine technology that will permit a smooth transition through this changing and, as of now, uncertain fuels scenario is particularly important.

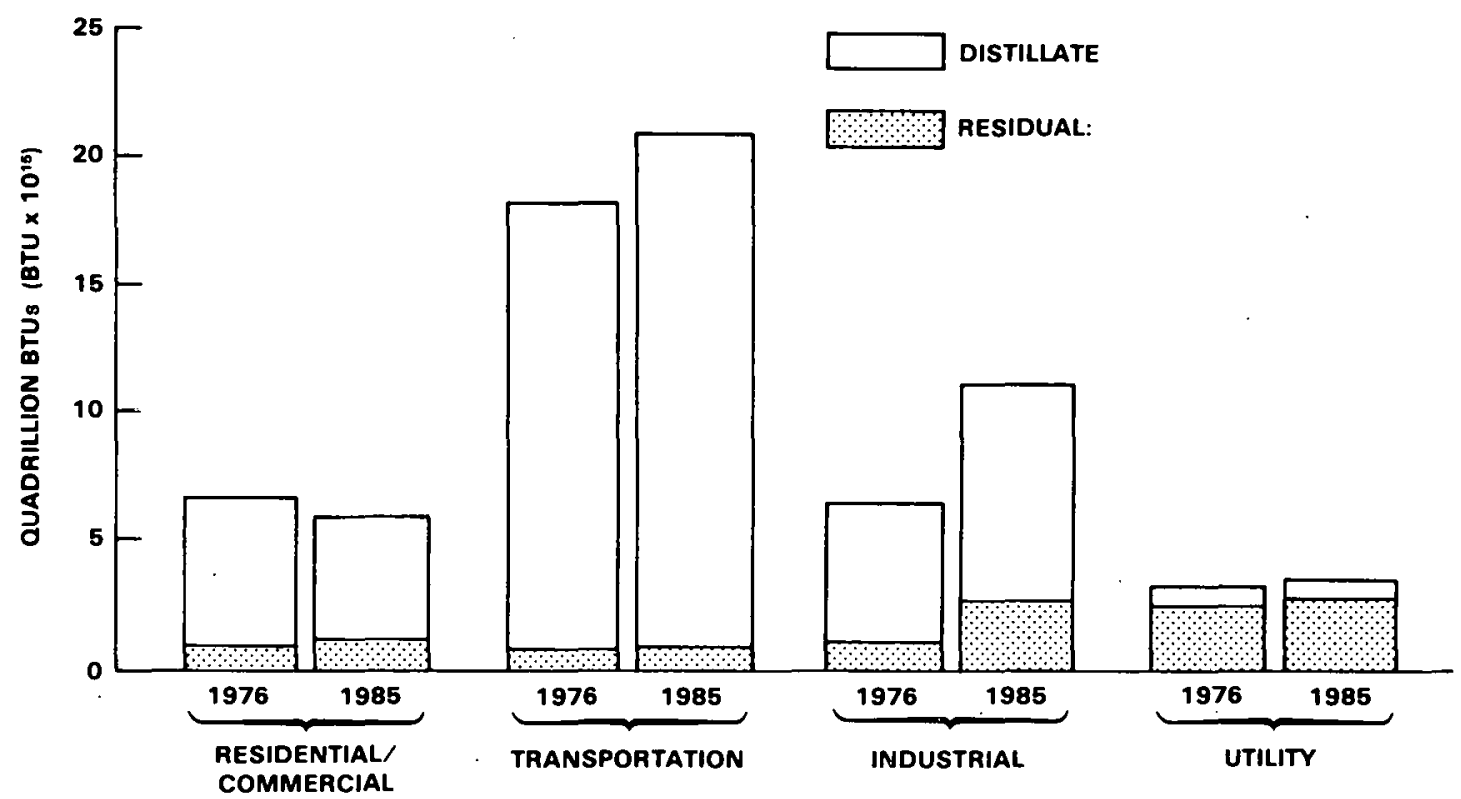

Distillate and Residual Oil Consumption by Sector

To be economically competitive, synthetic liquids must be minimally processed, i.e., hydrogenation of coal-derived crudes must be kept to an absolute minimum. Definition of a specification for such minimallyprocessed fuels depends upon the ability of heat engines using them to meet emissions standards and demonstrate acceptable durability. The table below illustrates the problems that low grade fuels, both petroleum-derived and coal-derived, will present in this regard. As shown though, much of the R\&D to effectively use them is common to both fuels . 


\begin{tabular}{|c|c|c|c|c|c|}
\hline $\begin{array}{l}\text { CHARACTERISTICS } \\
\text { OF CONCERN }\end{array}$ & $\begin{array}{l}\text { TODAY'S } \\
\text { FUEL CLEAN } \\
\text { NO. } 2 \text { OIL }\end{array}$ & $\begin{array}{l}\text { NEAR-TERM } \\
\text { RESIDUAL } \\
\text { OIL }\end{array}$ & $\begin{array}{l}\text { FUTURE COAL } \\
\text { DERIVED } \\
\text { LIQUIDS }\end{array}$ & $\begin{array}{l}\text { PROBLEM IN } \\
\text { TURBINES }\end{array}$ & $\begin{array}{l}\text { R\&D COMMON } \\
\text { TO RESIDUAL } \\
\text { AND COAL } \\
\text { DERIVED LIQUIOS }\end{array}$ \\
\hline $\begin{array}{l}\text { Fuel bound } \\
\text { nitrogen }\end{array}$ & Low & High & Higher & Environmental & $\begin{array}{l}\text { Combustor design, } \\
\text { fuel cleaning }\end{array}$ \\
\hline $\begin{array}{l}\text { Hydrogen/ } \\
\text { carbon ratio }\end{array}$ & High & Low & Lower & $\begin{array}{l}\text { Luminous } \\
\text { flame }\end{array}$ & $\begin{array}{l}\text { Combustor } \\
\text { cooling, coatings } \\
\text { and material }\end{array}$ \\
\hline $\begin{array}{l}\text { Alkali metal } \\
\text { content }\end{array}$ & Low & High & High & Corrosion & $\begin{array}{l}\text { Component } \\
\text { cooling, coatings } \\
\text { and material }\end{array}$ \\
\hline Viscosity & Low & High & High & $\begin{array}{l}\text { Pumping and } \\
\text { atumizatiun }\end{array}$ & $\begin{array}{l}\text { Fuel handling, } \\
\text { cleaning, additivc3, } \\
\text { tucl injection and } \\
\text { combustor design }\end{array}$ \\
\hline Ash & Low & High & High & $\begin{array}{c}\text { Erosion/ } \\
\text { deposition }\end{array}$ & $\begin{array}{l}\text { Fuel cleaning. } \\
\text { additives, coatings } \\
\text { and materials }\end{array}$ \\
\hline
\end{tabular}

\section{Low Grade Fuels}

The goal of the Directly-Fired Heat Cycles task is to develop technology permitting directly-fired engines (e.g., gas turbines and diesels) to burn low-grade petroleum fuels in an efficient, environmentally acceptable, and reliable manner. Subsequently, that same technology would allow these engines to be adaptable in the field to utilize synthetic liquids. $\Lambda \mathrm{n}$ important part of this $R \& D$ is to establish, via cngine technology devcloped for residual petroleum, a minimum quality fuel specification for future coal-derived liquids.

The technology for achieving these goals is planned for near-term commercialization. 'I'wo major thrusts are included: 1) the development of technology for a reliable advanced gas turbine capable of utilizing liquid coal-derived fuels; and 2) technology development permitting operation of large stationary dresels on coal-derived liquids. Doth of thcse advanced liquid-fueled engines are expected to see commercialization in the industrial market where significant petroleum fuels usage will continue as well as in certain utility applications where liquid fuels will be allowed due to exemption from coal conversion regulations. 


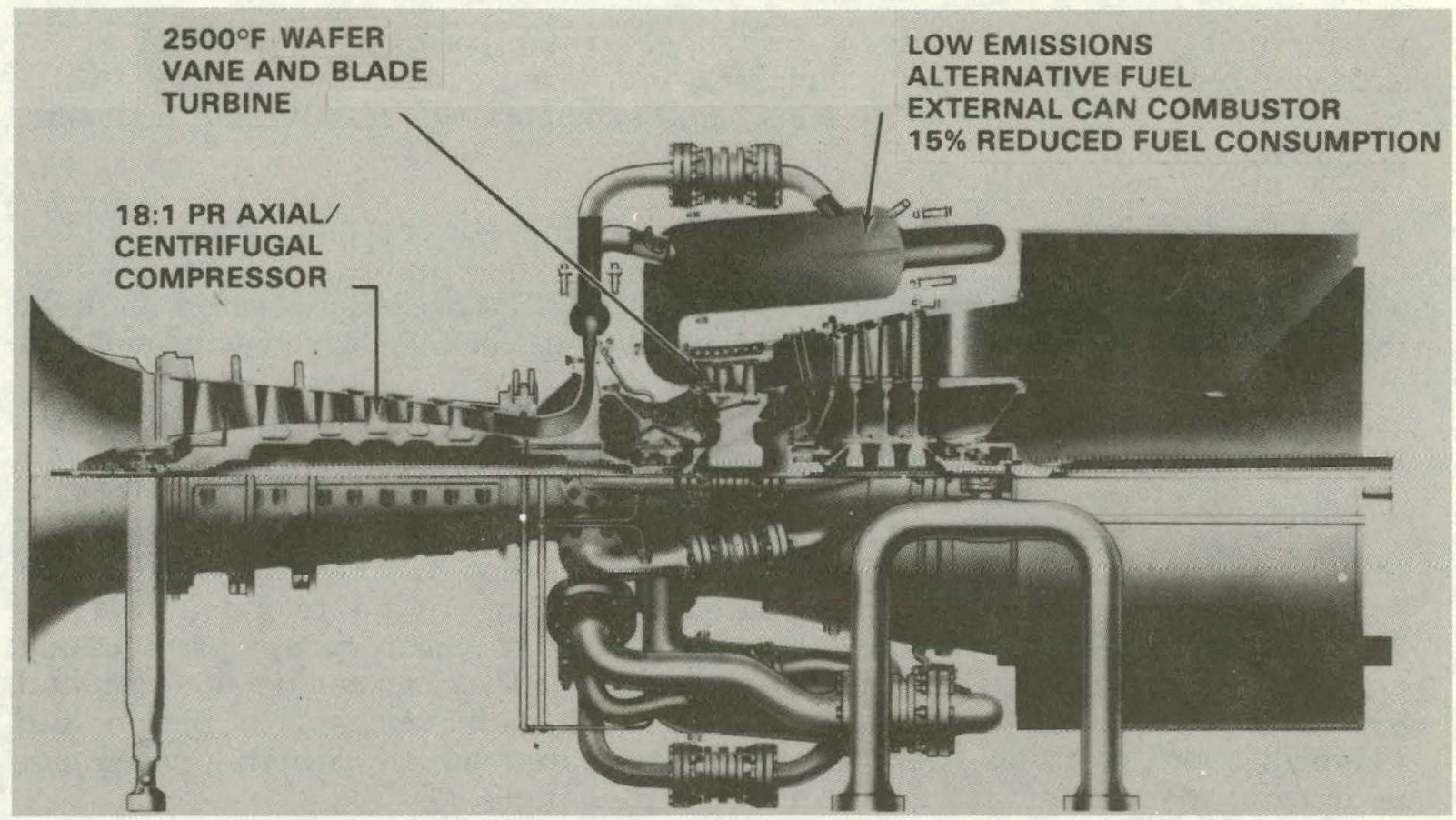

DIRECTLY FIRED HEAT CYCLES - 10 MW INDUSTRIAL GAS TURBINE

\section{Directly-Fired Heat Cycles-10 MW Industrial}

\section{Project Status}

The reliable advanced liquid fuel gas turbine project is planned as a cooperative DOE/EPRI R\&D effort. It is envisioned as a six-year effort leading to commercialization of engines compatible with minimally processed coal-derived liquid fuels. The technology advances in coatings, cooling, combustors, and compressors will be incorporated in a reference engine design study. The results of these co-funded efforts are being directed toward a joint DOE/EPRI decision-point target in late FY 1981. At that time the need for a new engine development program will be determined.

An assessment of alternate means of incorporating this technology will also be thoroughly investigated by DOE/EPRI and engine manufacturers at the decision point milestone. It may be proven equally as effective to pursue "dash" engines, or modified versions of today's engines which incorporate new technology for improved efficiency and fuel flexibility, in lieu of a new engine development. Either the new engine development program or a development program involving modified "dash" engines would be structured to best support the needs of both industrial and utility gas turbine users, where liquid fuels are predominate.

Current work focuses on technology aspects for improved performance and fuel flexibility. Work is now under way on: 1) thermal barrier coatings for turbine hot part protection; 2) heavy fuel low- $\mathrm{NO}_{\mathrm{x}}$ combustor technology for burning fuels high in fuel bound nitrogen while being able to meet $\mathrm{NO}_{\mathrm{X}}$ emissions standards; 3 ) advanced convectively cooled turbine airfoils for enhanced cooling and improved durability with ash bearing low 
grade fuels; and 4) advanced low aspect ratio compressor technology to maximize cycle efficiency through increased pressure ratios while minimizing the number of parts and complexity relative to current technology compressors.

An experimental evaluation of a promising convectively cooled airfoil design was completed in FY 1978 where the highest known cooling effectiveness for a convectively cooled airfoil was demonstrated in heat transfer cascade tests. A major effort both in combustor development and in thermal barrier coatings was initiated in FY 1978. The low aspect ratio axial/centrifugal compressor work initiated late in FY 1977 continued in FY 1978 toward the verification testing scheduled in FY 1979.

The stationary diesel engine development program is comprised of three basic elements as follows: 1) the feasibility of operating diesels on coal based fuels is being investigated based on engine test program; 2) Tribulugical effects of current and candidate materials, particmlarly ceramics, is being investigated to reduce friction and leakage losses; and 3) Ceramic coatings that have demonstrated improvements in piston and valve life on residual fuel will be investigated as a promising means of improving diesel life with coal-derived liquid fuels.

Coal based fuel testing will be completed in FY 1978 on a singlccylinder research engine to determine feasibility of operating the two stroke, slow speed, large bore diesel on these fuels. The test plan involves three fuels starting with relatively clean de-ashed and desulfurized Coal Oil Energy Development (COED) fuels and progressively approaching the Solvent Refined Coal (SRC) type fuels. Fuel injection studies will investigate the most promising methods for handling and injecting the highly viscous SRC-type fuels. These data will be assessed with economic considerations to identify follow-on work for advancing the operation of diesels on coal base fuels.

The tribology work with diesel engine materials is the implomentation of the recommendations from the DOE Working Group on Tribology at MIT in FY 1978. In FY 1978 an effort to define friction and wear characteristics of current materials was initiated. Using these data for comparative purposcs, a study of candidate ceramic materials will begin late in FY 1978. Wear and scuffing of sliding surfaces will be tested to establish a design data base. The reduction of engine friction can result in improved fuel efficiency; ceramic components can further improve efficiency by reducing heat losses. Ceramic pistons or ceramic coated piston crowns will require very high temperalure lubricants having viscosities that can maintain low friction Talakge by piston rings is a area that innovative ideas with ceramics might produce meaningful results. These data will be assessed for engine use in follow-on work beginning in FY 1979.

Ceramic coatings, or thermal barrier coatings, on piston crowns, valves, combustion chamber liners have proved very successful in Norweigan work. Piston life improvements from 10,000 hours to over 30,000 hours have been demonstrated while operating on residual petroleum based fuel. The Norweigan experience is being coupled with U.S. expertise in coating technology to provide a very near-term, high-payoff technology 
development with a very high probability of success for use with coalderived liquid fuels. Automated plasma spray èquipment that could coat thousands of piston crowns will be used in the experimental work. The thermal barrier coated components are retrofitable to most of the hundreds of thousand diesel engines in use in the United States. Engine test validation of thermal barrier coatings on diesel components will begin in CY 1978 .

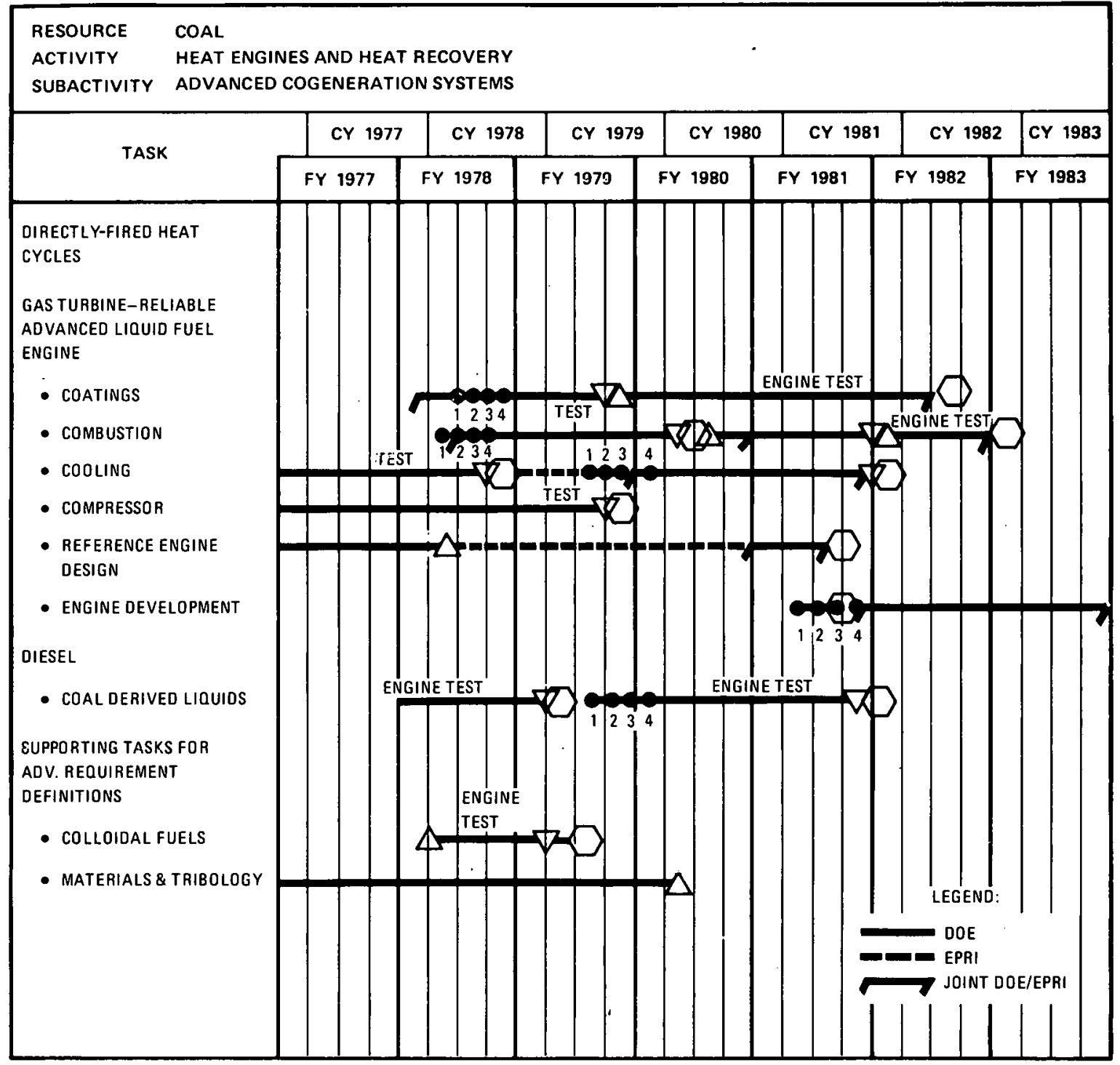

MILESTONE SYMBOLS ARE DEFINED ON LAST PAGE OF THIS DUCUMENI 


\subsection{EXTERNALLY-FIRED HEAT CYCLES}

The development of a prototype externally-fired engine capable of virtually complete fuel flexibility is the longer range thrust of the cogeneration heat engines R\&D. Such an engine in appropriate sizes will permit cogeneration power plants to be optimized for a variety of domestic fuel resources both liquid and solid. These fuels are typically low-grade petroleum fractions, industrial by-products, forest and agriculture residues, municipal refuse-derived fuels, as well as coal and coal-derived solid/liquids. Here emphasis shall be on development of a common engine with a family of combustor options to provide a maximum degree of fuel flexibility .

The objective of the externally-fired heat cycle task is to provide the technology-base for development of industrial size externally-fired engines

- capable of competing with diesels, spark ignition engines, and gas turbines for stationary power applications while providing maximum possible fuel flexibility. Within the objective are two primary thrusts: 1) the development of a Stirling engine as a prime mover for residential/commercial total energy systems; and 2) the development of an externally-fired Brayton engine for industrial cogeneration applications. Both of these engines are capable of using a variety of fuels including liquids, solid, gaseous fuels, and even waste heat to provide the necessary thermal input.

The following figure illustrates a total energy system with a Stirling engine as a prime mover. The Stirling engine extracts heat from the external combustor and through a generator converts the heat into electricity for use at the site which may be a hospital, apartment complex, or other similar application requiring electricity, heat and cooling. The unused heat from the combustor is passed through a heat exchanger to transfer energy to a water circulation loop that can provide either space heating or cooling via absorption air conditioning.

Only relatively small-operation Stirling units directed toward automotive applications have been developed, although the concept has existed for many years. The major development effort will be to progress from the lightweight automotive-type engine to the stationary power generation engines $(1,000 \mathrm{hp})$ where efficiency and long life are important. Initial effort will include definition of the technical problems which must be solved to develop commercially competitive stationary Stirling engines. Critical component development, detail engine design, engine fabrication, and engine testing would follow. 


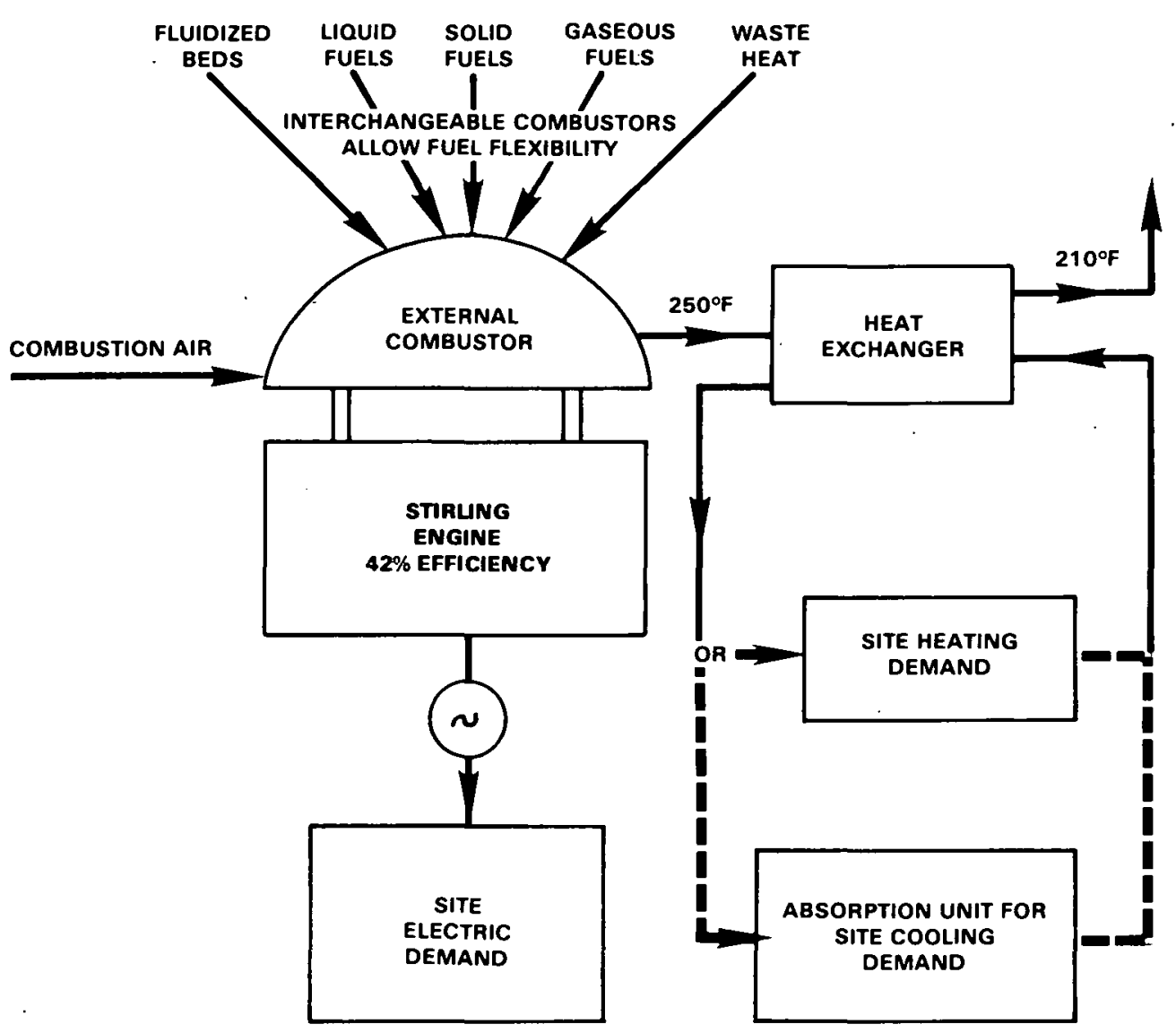

\section{Stirling Engine Total Energy System}

The following figure shows the externally-fired Brayton cycle in either an industrial cogeneration or a combined-cycle application. Heat is supplied to the working fluid (air) in the Brayton cycle through a heat exchanger. The hot air exhaust from the power turbine is then used in the external combustor where it is heated before entering the heat exchanger. The combustion gas exhaust may be used for either process heat (cogeneration) or in a waste heat boiler and the resulting steam expanded through a small steam turbine (combined-cycle).

Few externally-fired Brayton cycle engines are in use because of the limit in turbine inlet temperature as a result of metal temperature limits in the heat exchanger which results in relatively low efficiency. Cycle development and heat exchanger technology improvements for high temperatures and pressures are required for successful commercial externally-fired Brayton cycles. In addition, the combined-cycle version requires an efficient low-pressure small steam turbine. The efficiency of current steam turbines below $6,000 \mathrm{hp}$ can drop as low as 30 percent and typically is only 45 to 50 percent. 


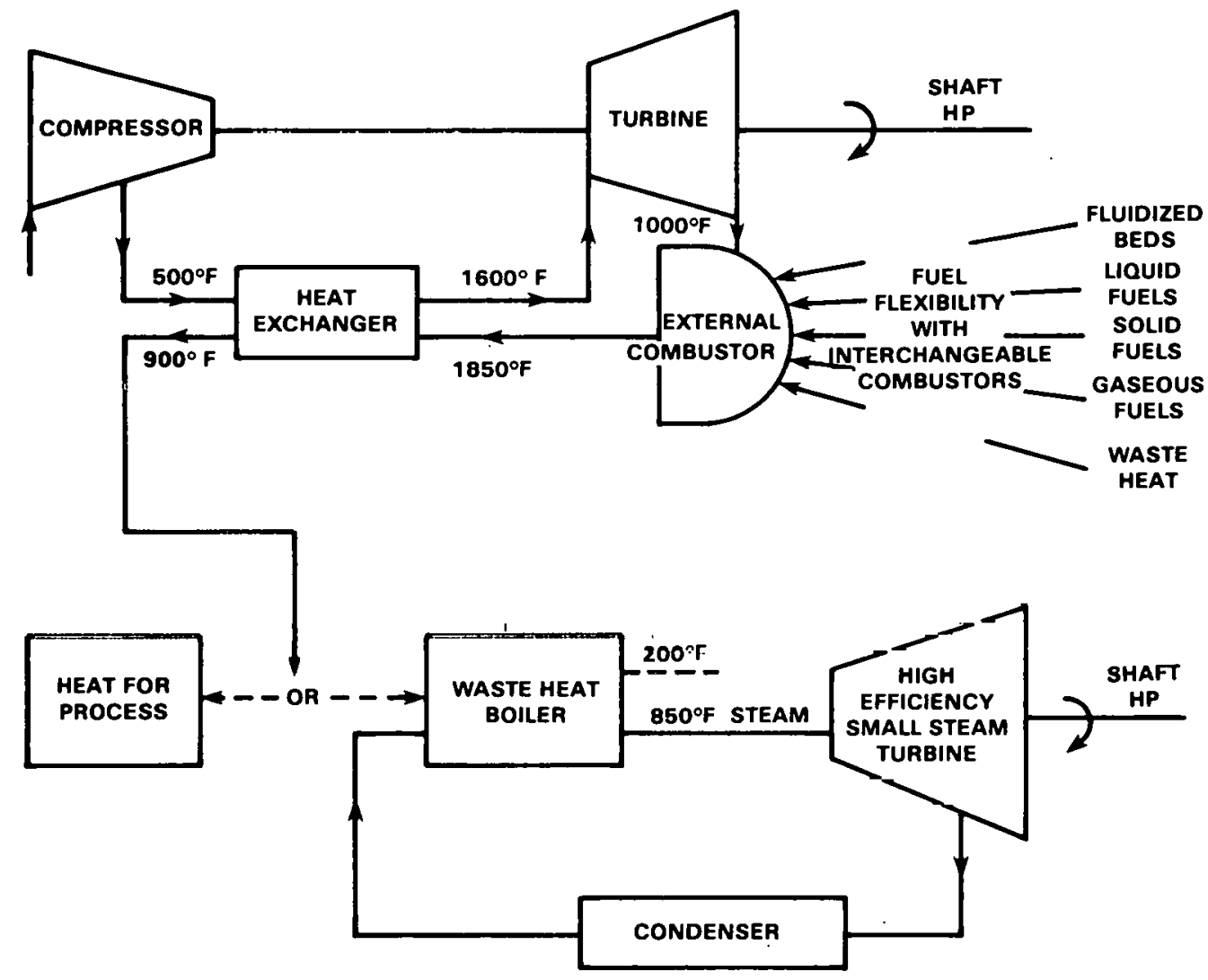

\section{Externally-Fired Brayton Cycle}

\section{Project Status}

The Stirling engine development program is cnvisioncd as a five-year effort, going through key phases of design and critical technology development, after which a project evaluation will be performed. Subsequently, a prototype construction phase, and an engine testing phase is planned to establish engine performance and capability with various fuels sources. The present work involves defining the practicality of scaling up Stirling engine technology to sizes of $1,000 \mathrm{hp}$ or greater, as well as determining economic viability of the stationary Stirling.

An evaluation has been completed on the theoretical performance of Stirling cycle engines in various total energy systems. The best designs for residential and hospital sites indicated that Stirling systems offer very attractive rates of return ( $>25$ percent) when purchased electricity is greater than $\$ 0.04 / \mathrm{kWh}$. By the end of FY 1978 a preliminary engine evaluation will have been completed to determine the critical engine design problems in scaling up a Stirling engine to the greater than $1,000 \mathrm{hp}$ level. A second evaluation will have defined the technical problems which must be solved to develop commercially competitive Stirling engines in the 500 to $2,000 \mathrm{hp}$ range. Compared to the diesel and gas turbine engines, Stirling engine offers high efficiency, high reliability, quiet operation and multifuel capability. Work will also have been completed on the Stirling's 
applications which include an adjunct to fluidized-bed. combustors, the utilization of industrial and commercial waste heat, small municipal utility power generation, total and integrated energy system, and the utilization of noncritical or unconventional fuels. Also, another evaluation will have completed the investigation of the feasibility of a Stirling engine for industrial applications that utilize a vapor working fluid in lieu of monotomic gases that are now commonly used. By using a condensing vapor as a working fluid, many of the problems, of gas Stirling engines could be solved. These include uniform heat transfer to heater tubes, engine control, unswept volume caused by heat exchangers for cooling the working fluid, and the criticality of loss of gaseous working fluids. The information gathered from these various sources will be used by the selected contractors in the design and critical component development work to be initiated in FY 1979.

The externally-fired Brayton cycle program is envisioned as a five year effort going through key phases of design and critical technology development followed construction and testing of a prototype engine. The engine testing will emphasize performance improvement in terms of efficiency and capability of the system to use of various fuel sources. The present work involves defining practical cycles that will provide desired efficiencies and demonstrating the capability of these cycles to perform as theoretically defined. As part of the effort to define cycles a small contract was issued to design, fabricate and test an external combustion steam injected gas turbine. This project has the primary emphasis on the control problem involved in modulating power and startup and shutdown of this type of cycle. It also will evaluate steam injection as a means of varying the ratio of electrical to thermal power output, an essential variable parameter when considering the typical variation in electrical to thermal requirements in industrial plants.

A project to develop small steam turbines will be under contract by the end of FY 1978 as shown in the figure. This project addresses the low efficiency and high cost of small steam turbines that would be used in dispersed combined-cycle power units. The specific objective is to raise current efficiency levels of approximately 30 to 50 percent up to 75 percent or greater and reduce specific costs so that small steam turbines can be efficient and economically competitive as a prime mover component in small dispersed power systems. The range of horsepower to be addressed is from 500 to $6,000 \mathrm{hp}$. During FY 1979 the design will be completed and fabrication of feasibility verification hardware begun. 


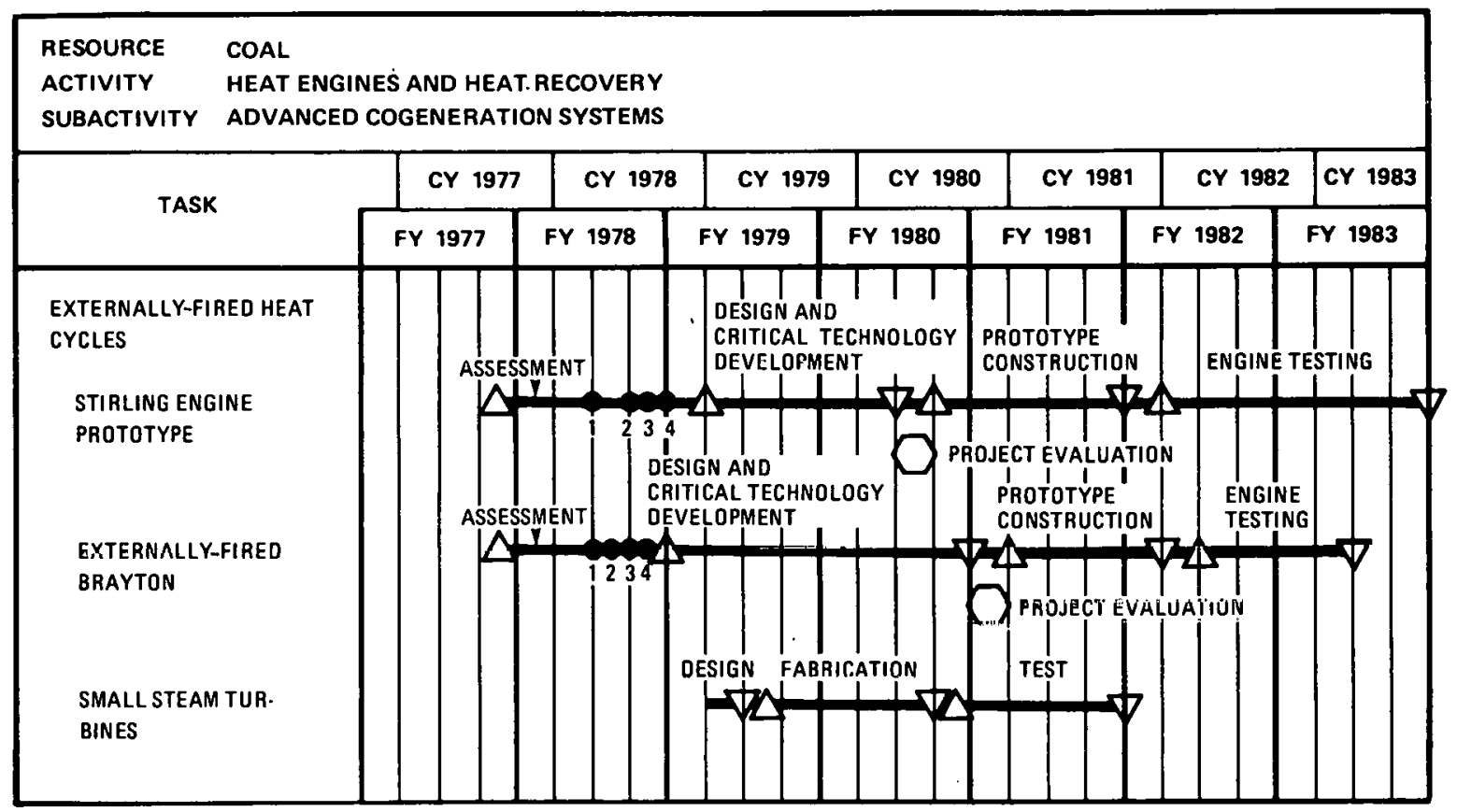

MILESTONE SYMBOLS ARE DEFINED ON LAST PAGE OF THIS DOCUMENT

\subsection{HEAT RECOVERY COMPONENT TECHNOLOGY}

The goal of the Heat Recovery Components Technology subactivity is to develop the required technology base and to demonstrate the technological feasibility of cost effective components and systems for the recovery and utilization of waste heat. Widespread use of waste heat as an equivalent fuel source is at present limited by the availability of cost effective recovery and utilization systems and the lack of sufficient technological options. Technology development is organized in three tasks: 1) Low Grade Heat Recovery, 2) High Grade Heat Recovery, and 3) Heat Exchanger Technology. The dividing line betwcen low grade heat and high grade heat has been arbitrarily defined as $2000 \mathrm{~F}$. A breakout into these two broad areas was made because the types of utilization systems and the associated technological problems are quite different for each. Heat Exchanger Technology has been singled out for emphasis because of its widespread use in all waste heat recovery and utilization systems. In many cases, it is the most expensive component of the system. Quite often, technology developments will be applicable to both the low grade and high grade applications. It is therefore highly desirable to maintain a coherent, directed effort in heat exchanger technology with input from this task to the other two tasks.

Primary emphasis in the low grade task is to study the recovery and offsite utilization of energy rejected by Federal facilities using available technology. In addition, technology development has been initiated to expand the number of available utilization options as well as to improve the efficiency of the components in heat recovery systems so that sizes and 
costs can be reduced or performance can be increased to make the systems economically viable. Low cost, high effectiveness heat exchangers for low temperature heat recovery, are being developed under the heat exchanger task in support of this goal. Other major areas of $R \& D$ are novel heat engine concepts for power generation that offer the potential of reduced costs per $\mathrm{kWh}$ output as well as an effort to develop the capability of provicing space cooling from lower temperature waste heat sources. The area of low temperature waste heat utilization also includes a focused $R \& D$ effort to develop industrial heat pumps. These heat pumps would take the energy from the low temperature stream and using either additional energy from the stream or an external energy source, pump it up to a temperature suitable for industrial process use.

With regard to higher grade heat, the major technology need is to provide capabilities that do not exist. $\Lambda$ t the present time, we are limited to using fuels in the generation of steam at about $1000^{\circ} \mathrm{F}$ maximum temperatures. Since the energy available in the combustion process is generally in the range of $3000^{\circ} \mathrm{F}$, the thermodynamics availability, or the capability to convert thermal to mechanical energy is severely inhibited by degrading it to $1000 \mathrm{OF}$ before extracting work. Technology development in the area of therminonics is being conducted for application to high temperature topping cycles. In the area below $1000 \circ \mathrm{F}$ and below, representative of the exhaust profiles of stationary diesels and gas turbines as well as many industrial process, the efficiency of power recovery cycles using steam as a working fluid drops off sharply. Cycles using organic working fluids are being developed for application in this regime. Also, many industrial processes today discharge high quality waste heat from furnaces in the 2000 F to $30000 \mathrm{~F}$ temperature range. There presently are no durable heat exchangers available to effectively recovery this energy for either power generation or preheating incoming combustion air. The application of high temperature materials to heat exchangers is the major technology effort to develop this capability under the Heat Exchanger Technology task.

\subsection{LOW GRADE HEAT RECOVERY}

Low grade heat recovery technology is being developed for application to heat sources with temperatures generally at $200 \% \mathrm{~F}$ or less. This effort is directed at utilizing the very abundant, replenishable energy from low temperature sources such as oceanic, geologic, unfocused solar, and waste heat from industrial processes and power production. It has been estimated, for example, that approximately 6,000 MW of thermal energy from conventional and nuclear power plants is available as a potential source of recoverable low grade heat.

The major objectives of this effort which are directly related to DOE national goals are: elimination of avoidable energy losses to reduce energy consumption; improvements in the efficiency of existing and future energy converters; and development of alternate energy sources to reduce both consumption rates of domestic fuel sources and importation rates of foreign fuels. 
The Low Grade Heat Recovery project is divided into two major efforts: 1) Use of Energy Rejected from Federal Facilities, and 2) Low Temperature Technology Development.

In the program entitled "Use of Energy Rejected from Federal Facilities," feasibility evaluations are currently under way to determine the technical, economic and institutional viability of utilizing energy currently being rejected by DOE owned facilities. The efforts are directed to the three uranium enrichment gaseous diffusion plants located in Oak Ridge, 'Tennessee; Paducah, Kentucky; and Portsmouth, Ohio, and the Savannah River Facility, in South Carolina. These facilities reject a combined total of 12,000 MW of low grade thermal energy. It is expected that solution to utilizing these high quantities of virtually steady state energy will not be a trivial one. Because of institutional barriers predicted for possible applications, direct use applications such as agriculture and aquaculture will not comprise the total solution. The following figure represents a possible complete approach to utilizing this source. It is apparent that complex and innovative definition and full-scale optimization must be successfully accomplished to ultimately exploit this energy source.

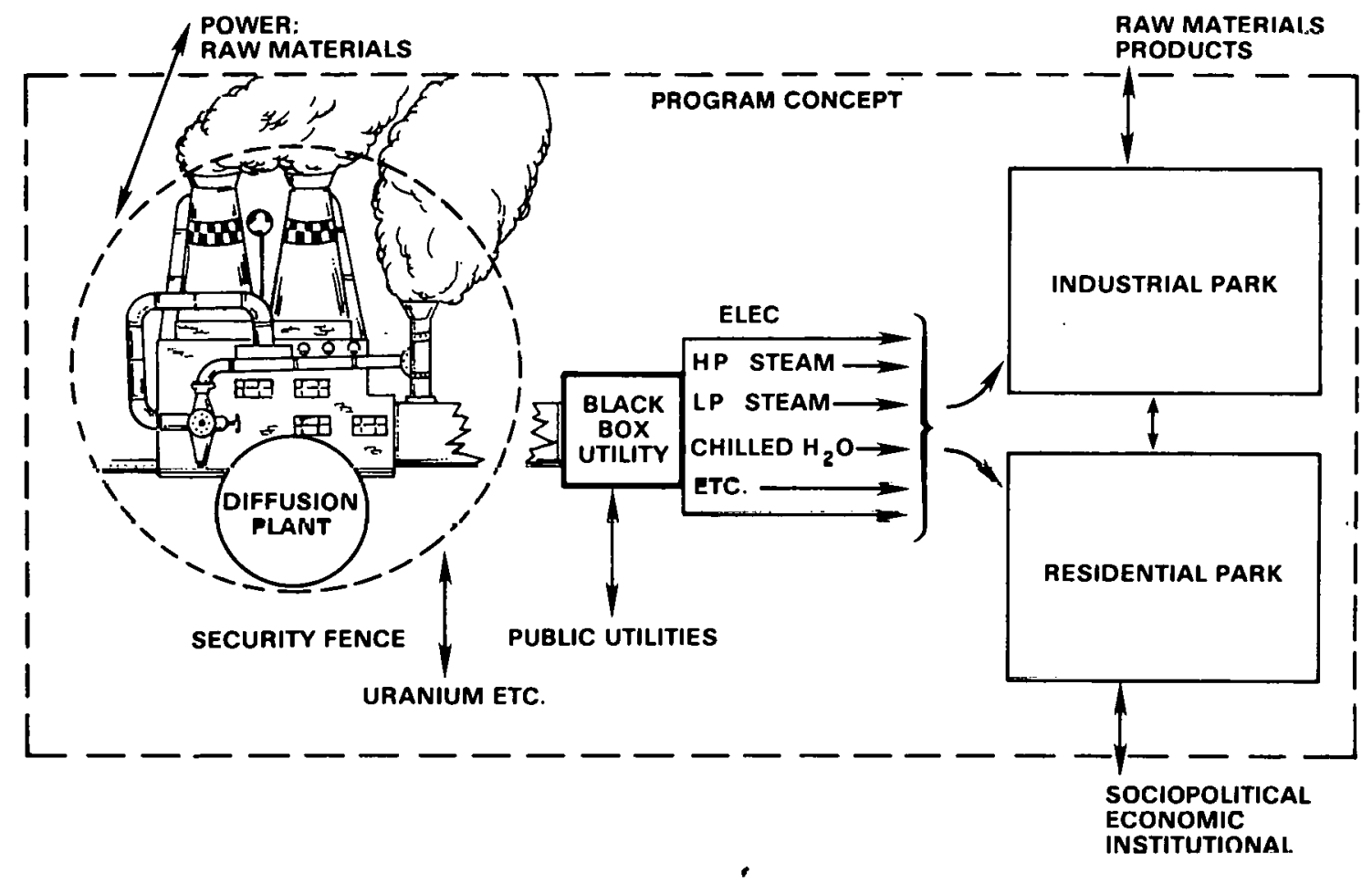

\section{Low Grade Heat Recovery-Schematic Concept for Use of Energy Rejected by Federal Facilities}

The $200^{\circ} \mathrm{F}$ range of waste heat is a relatively uncharted area in terms of productive heat utilization. The Low Grade Heat Recovery project is designed to determine the feasibility of developing heat recovery systems 
which can economically convert the thermal energy available at these temperatures to productive use. Because of the paucity of such systems, a major project effort must, of necessity, be devoted to determining the requirements that have to be met to utilize low temperature energy and to identify opportunities for applying the low temperature heat utilization systems that are the object of the development program.

In recent years, a few sporadic attempts have been made to develop low temperature heat utilization systems. For the most part, however, sufficient information has not been available to adequately evaluate the technological problems involved in scaling up these prototype systems to size suitable for commercialization.

In FY 1978, a Low Temperature Technology Development program was initiated to address the evaluation, and conceptual design aspects of candidate heat engines and recovery devices. In addition to low temperature heat exchanger enhancement and effectiveness improvement, novel heat engine concepts such as elastomer heat engines, nitinol heat engines and engines employing the concept of pressure retarded osmosis are being evaluated. Other areas being investigated are heat pumps and absorption refrigeration. The uniqueness aspect of each of these concepts falls into the area of ideas developed from concepts that are used in other applications today.

\section{Project Status}

Both major efforts in the Low Grade Heat Recovery project are currently in the feasibility evaluation phase. "The Use of Energy Rejected from Federal Facilities" program was officially initiated in FY 1977 . Phase I - Feasibility Evaluation results are expected by late spring and a formal decision to proceed will be requested before the end of FY 1978.

The Low Temperature Technology Development program was initiated in early FY 1978. The first 12 months of the activities will examine the potential feasibility of the aforementioned novel concepts. As this area is directed to development of conversion and recovery devices that are far from being considered as state-of-the-art technology, plans are being developed to prove viable technology by the early 1980 s. 


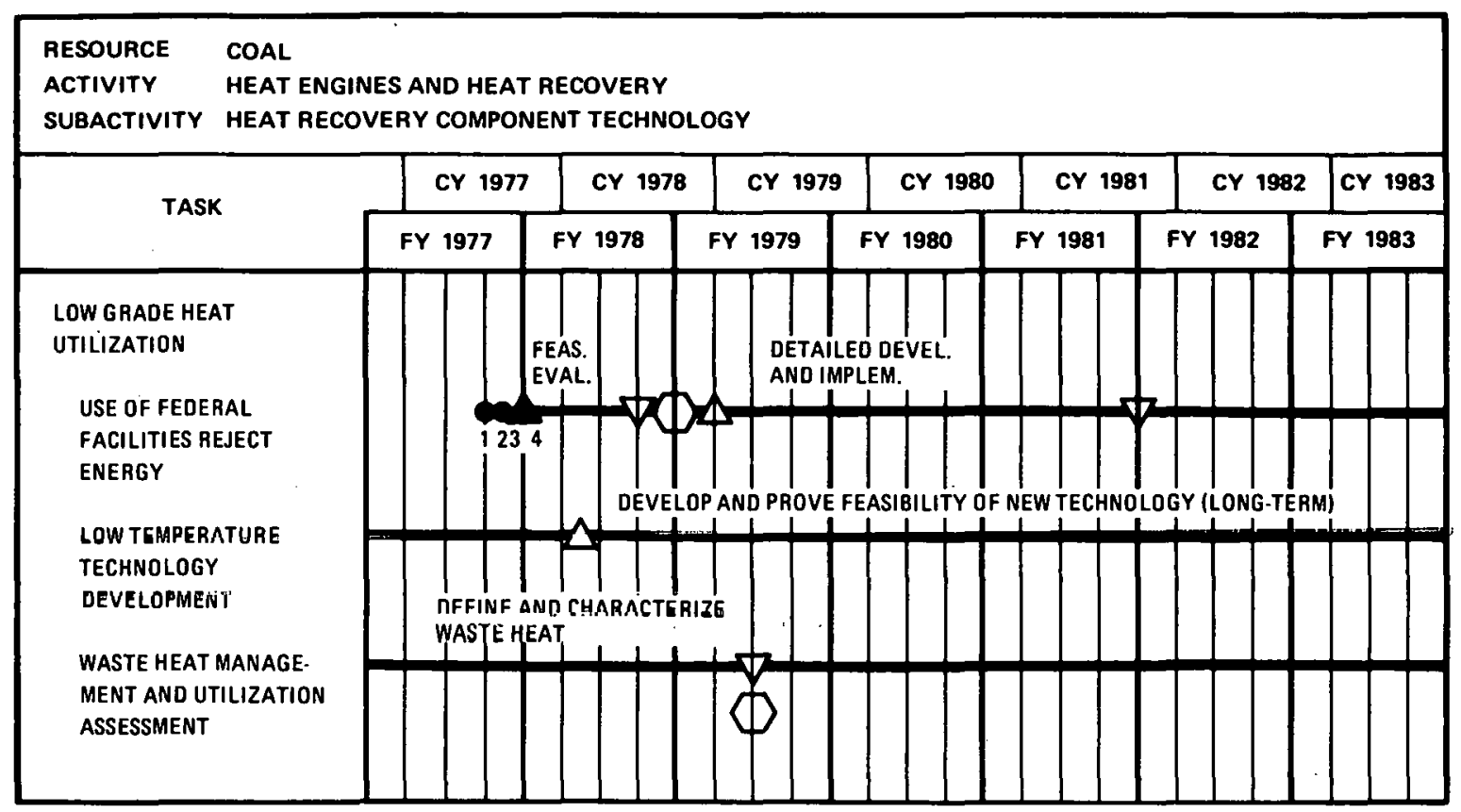

MILESTONE SYMBOLS ARE DEFINED ON LAST PAGE OF THIS DÓCUMENT

\subsection{HIGH GRADE HEAT RECOVERY}

High grade heat recovery technology is being developed for application to heat sources available at temperatures generally well above $200 \mathrm{~F}$. This effort is directed at recovering and utilizing energy rejected by prime movers such as diesel engines and gas turbines, energy expanded in large central station power plants and industrial process heat streams.

In FY 1976 a six month technology assessment, entitled Industrial Applications Study, was performed to develop a profile of energy consumption and waste heat availability for all Standard Industrial Code (SIC) two-digit industries. Because of the success of this effort, a followon study, to extend the data bank to all SIC four-digit industries, was initiated late in FY 1977. This is a major undertaking which, when completed, will provide the most complete and detailed data bank of waste heat resources to date for the planning of future energy conservation efforts. The effort is expected to take approximately 1.5 years. It is planned to use the results as a basis for the determination of additional high payoff areas of the higher grade waste heat utilization.

The Bottoming Cycle Systems program covers technology suitable for application to waste heat streams with temperatures between $200 \% \mathrm{~F}$ and $1000^{\circ} \mathrm{F}$. This temperature range includes most existing industrial and 
commercial waste heat sources. The program is directed towards the nearterm utilization of these sources through the development of waste heat recovery systems. Efforts have been initiated to design, develop and field test three competing Rankine cycle-based systems suitable for operation of public and municipal utility and industrial diesel power plants. Illustrated is a typical bottoming system that employs an organic working fluid. The waste heat stream is passed through a heat exchanger (vaporizer) to vaporize the organic fluid; this vapor is expanded through a turbine to produce a shaft work output; the vapor at a lower temperature and pressure is the condensed back to a liquid state, compressed and then revaporized. In general, higher availability and greater recoverability is provided by using organic working fluids than for steam in this temperature regime.

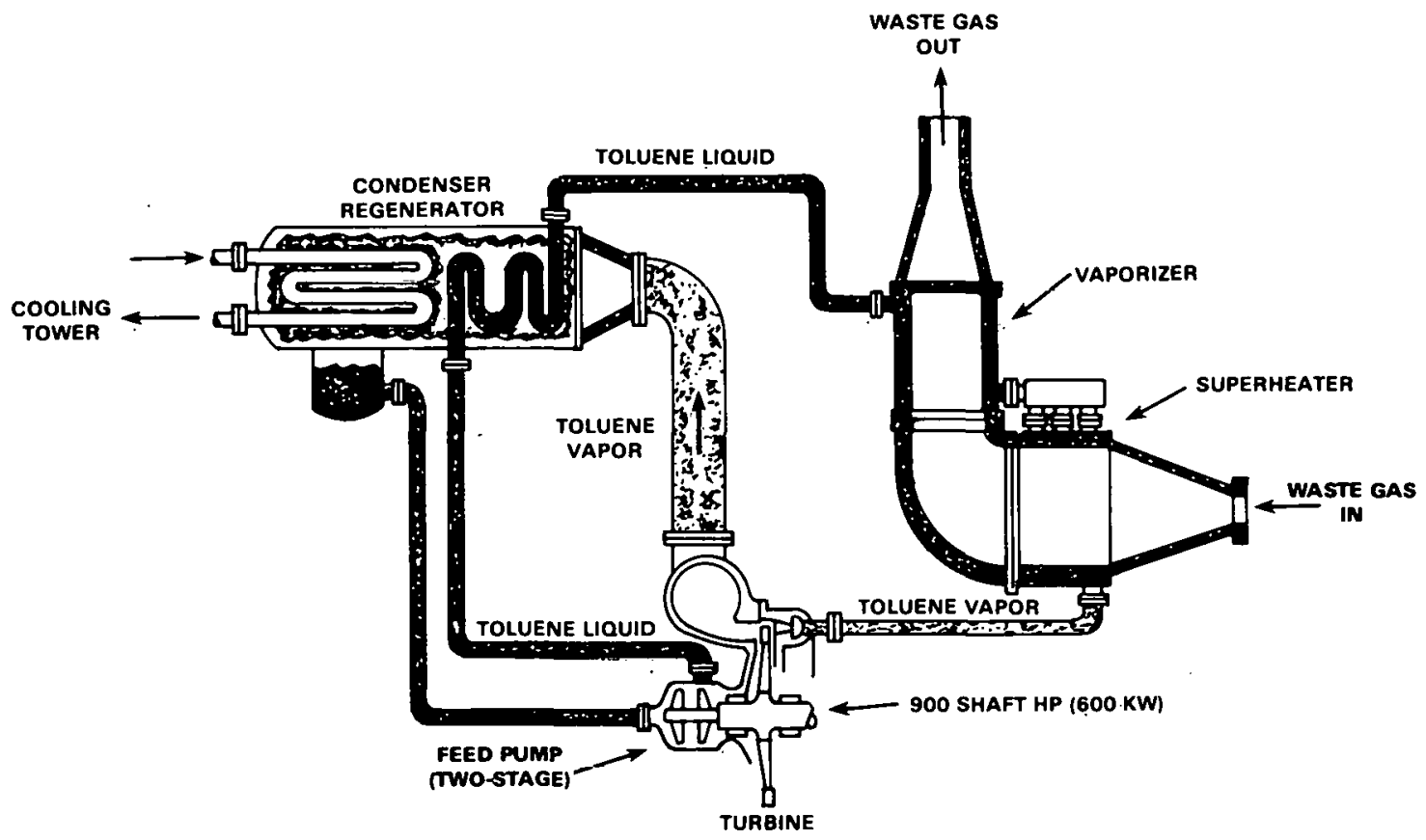

\section{Organic Rankine Bottoming Cycle}

At this time the one major effort under way in the Topping Cycle Systems area is the Thermionic Energy Conversion Development project. Thermionic energy conversion has several distinct advantages which make it attractive as a topping cycle, in addition to its high heat rejection temperature. Thermionic converters have no moving parts, a characteristic which is important for high reliability at high temperature. Since thermionic converter's operate with very low internal gas pressure, material stress is minimized, also an important characteristic at high temperatures where material strengths are lower. In addition, thermionic converters are well suited to fabrication as self-contained modules, an approach which provides both higher overall system reliability and significantly lower development costs. 
Thermionic conversion is a method for converting heat directly into electrical work through the use of thermionic emission. The thermionic device consists of, as a minimum, one electrode connected to a heat source, a second electrode connected to a heat sink separated from the first by an intervening space; there are also leads connecting the electrodes to an electrical load and an enclosure. The enclosure is either highly evacuated or filled with a suitable rarefied vapor.. The concept has had widespread use in space propulsion technology. The thrust of this effort, however, will be to develop thermionics as a viable power producing device for ground based energy needs where waste heat is utilized as the primary fuel.

The overall objective of the thermionic energy conversion development effort is to define, develop and demonstrate thermionic modules to the degree necessary to encourage commercial participation and acceptance. Accomplishment of this objective will provide the country with a new and attractive energy conversion alternative which can potentially save a substantial proportion of our energy resources. The task scope includes all aspects of thermionic energy conversion: research on fundamental processes affecting performance, development of suitable converter materials and assemblies, demonstration of component and module performance and reliability, and studies of the use of thermionic modules in promising applications. The task is closely coordinated with programs supported by other government agencies, such as the current NASA program.

Studies performed by DOE have defined many potential benefits which could be derived from thermionic energy conversion. Strong interest and encouragement has been provided by major power plant component manufacturers, A\&E firms, and private sector research organizations such as EPRI. However, the technology is still too young and the risks too high for industry to make a major commitment in this field. Rapid development of the thermionic technology will require Federal assistance to demonstrate it.s hasir feasibility in ground based power applicationo and to insure its maintenance as a potentially significant energy conversion alternative for the mid-term.

\section{Project Status}

The Organic Rankine Bottoming Cycle Systems (ORBCS) program has been under way since FY 1976. Hardware development activities arc currently being pursued with accompanying development testing ongoing. By mid-FY 1979, field test demonstrations will be conducted in real.world environments for a final technology development rheckout. The technology will be considered demonstration ready at the successful completion of these tests.

The Topping Cycle Systems program was originally sponsored primarily by the ERDA Nuclear Research and Applications group. In FY 1978, the entire Thermionic Energy Conversion program was transferred to the Division of Power Systems. Past accomplishments have been confined to the identification of systems and the continuation of applied research. A study was prepared in 1975, and another in early 1977, to show conceptual designs, feasibility, and cost estimated for two different approaches to a thermionic topping cycle system. 
During FY 1978, in addition to the ongoing engineering development of the thermionic converter, a program was initiated leading to the early development of a first generation prototype topping cycle system. This will be used to establish the engineering feasibility of the thermionic topping cycle concept. This effort will be continued through FY 1979, and concluded early in FY 1980.

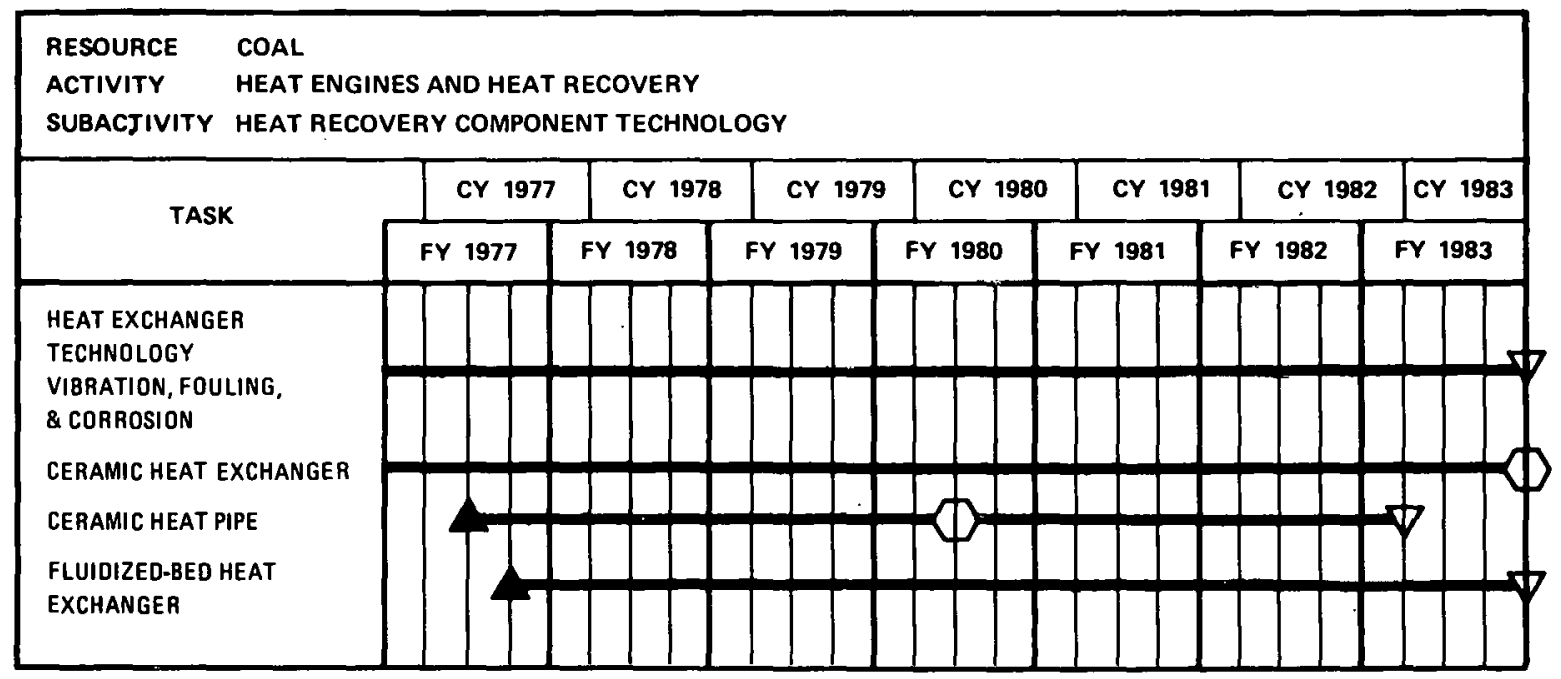

MILESTONE SYMBOLS ARE DEFINED ON LAST PAGE OF THIS DOCUMENT

\subsection{HEAT EXCHANGER TECHNOLOGY}

In the past, the heat exchanger was viewed as a simple device for industrial processes. Standard design and selection criteria incorporated sizeable heat transfer coefficient margins to account for uncertainties such as fouling, scaling, fluid properties, two-phase flow effects, and flow maldistribution. Large structural safety maryins were incorporated in designs to compensate for uncertainties in material properties, flowinduced vibration, corrosion, and thermal stress. As a result, the heat exr.hangers of this period were fairly large and clumsy, and relatively unsophisticated and inefficient, but they worked. Since fuel costs wcre relatively low, there was no compelling need or interest in developing heat exchangers for coal-gas applications or waste heat recovery. As a result, little effort was expended in improving heat exchanger design tools, increasing efficiency or reducing costs.

Today that situation has changed. The desire to speed the development of advanced energy systems has uncovered a number of deficiencies in heat exchanger design, materials, and fabrication techniques. Furthermore, as we try to extract more heat from exhaust streams, heat exchangers get larger and more expensive. 
Flow-induced tube vibration is a key factor in limiting heat exchanger reliability and lifetime. Numerous failures have been recorded in industrial operations. Current practice is to overdesign for size, therefore driving up the price. Since heat exchangers are the major cost items in heat recovery/utilization systems, the cost penalty incurred by vibration will limit system market penetration potential and hence, energy savings.

A growing concern with efforts to efficiently recover waste heat in diesel exhaust streams is the lack of reliable information with which to accurately predict acid dewpoints, corrosion rates, and the extent of fouling for various heat exchanger configurations and materials.

One of the driving forces in this task is the need to reduce costs. By increasing heat transfer effectiveness, the size and cost of an exchanger for a given duty can be reduced. Laboratory tests indicate that local heat transfer coefficients can be improved hy one to two ordere of magnitude through the application of fluidized-bed technology. This is as yet a relatively unexploited area of great potential.

Another heat exchanger deficiency uncovered in the desire to rapidly implement advanced energy systems is the lack of a high temperature capability. This capability is required in order to implement closed Brayton topping cycles and industrial recuperators for utilization of high grade waste heat. Potential developments in ceramic materials technolngy offer promise in extending the upper temperature limit of heat exchangers.

One more area of concern is the inefficiency of low temperature heat exchangers. Development of more effective heat exchangers would represent a major step toward the recovery of energy from one of the nation's largest waste heat sources: the cooling water from the DOE gaseous diffusion plants. Promising concepts to efficiency enhancement involving advanced heat transfer surface design configurations will be evaluatcd.

The objectives of the Heat Exchanger Technology task are as follows:

- Increase upper temperature limit sapahility of heat exchangers to greater than $2000^{\circ} \mathrm{F}$

- Increase heat exchanger reliability and lifetime by up to 50 percent. Demonstrated reliability and lifetime capability are prerequisitcs to the commcrcialization of heat exchangers per se, or as system romponents

- Reduce heat exchanger costs by as much as 50 percent

Increase heat transfer effectiveness by up to 50 percent. Gains in effertiveness can also bc traded off to reduce costs. 


\section{Project Status}

Milestones for the projects comprising the Heat Exchange Technology task are provided in the accompanying figure. The initial project shown is being conducted as part of the International Energy Agency Heat Transfer and Heat Exchanger project under the Energy Conservation Working Group.

This subtask will test variable geometry, segmentally-baffled, shelland-tube heat exchangers for the purpose of obtaining tube vibration data under controlled conditions. The data are required to evaluate the validity of presently used heat exchanger predictive methods and design criteria. The purpose of the evaluation is to assure that reliability and lifetime requirements are met with minimum design safety margins and associated cost penalties. Concurrently, a data bank of field operating experience is being developed that will be used to evaluate the validity of existing and new empirical correlations.

The presence and extent of fouling and acid corrosion of candidate heat exchanger configurations in stationary diesel exhaust streams along with the experimental determination of sulfuric acid dewpoint is being determined. Methods are being devised for predicting and alleviating the resultant adverse effects on exhaust side thermal resistance and pressure drop. The compilation of a reliable waste heat boiler corrosion and fouling data base has begun.

The approach being taken to achieve the high temperature capability $\left(2000^{\circ} \mathrm{F}\right)$ required to recover heat from high temperature industrial furnaces is the exploitation of ceramic materials, primarily silicon carbide. Other applications for this technology are in coal-fired, closed Brayton and indirect-fired, open-Brayton cycles where this temperature capability would make these concepts very attractive for power generation from a thermodynamic efficiency standpoint. The high temperature project is conducted in close coordination with the Electric Power Research Institute. Active project elements currently include the following:

- Evaluation of thermal, mechanical, and physical properties of tubing manufactured by a number of processes

- Development of stress relieving joining techniques for ceramic tubing

- Assessment of nondestructive test and evaluation techniques for application to ceramic heat exchangers and components

- Development of a ceramic heat pipe using a liquid metal working fluid. This is an attractive alternative to a conventional heat exchanger configuration from the standpoint of minimizing thermal stress.

In support of the low grade heat recovery task, a concerted effort has been mounted to develop and evaluate heat transfer augmentation techniques such as enhanced surfaces to improve heat transfer 
effectiveness and reduce costs. Surveys to identify promising approaches are under way. Heat transfer measurements of new concepts are being made in the laboratory. This will be followed by full-scale heat exchanger design and cost analysis. Another approach being evaluated to reduce costs is the application of plastics to heat exchanger fabrication.

Laboratory studies of heat transfer in fluidized beds have demonstrated heat transfer coefficients of two orders of magnitude greater than for conventional heat exchanger configurations. Thus, it is an attractive technological option for the improvement of heat transfer effectiveness which can then be traded off, if desired, against cost. An experimental evaluation of a unit commercially marketed for waste heat recovery has been completed. Based on these results, evaluation of this concept for application to the waste heat boiler in a diesel bottoming rycle is being made. Another application under evaluation is to the evaporator and condenser of rcsidential heat pumps. BV improving the air-side heat transfer coefficient, the temperatiure drops across the hoat cxchangers can be increased. This will reduce the cycle irreversibility and increase the coefficient of performance. Further increases in performances will be attained by removal of frost from the evaporator in winter. This will eliminate the need for a defrost cycle with its consequent energy penalty.

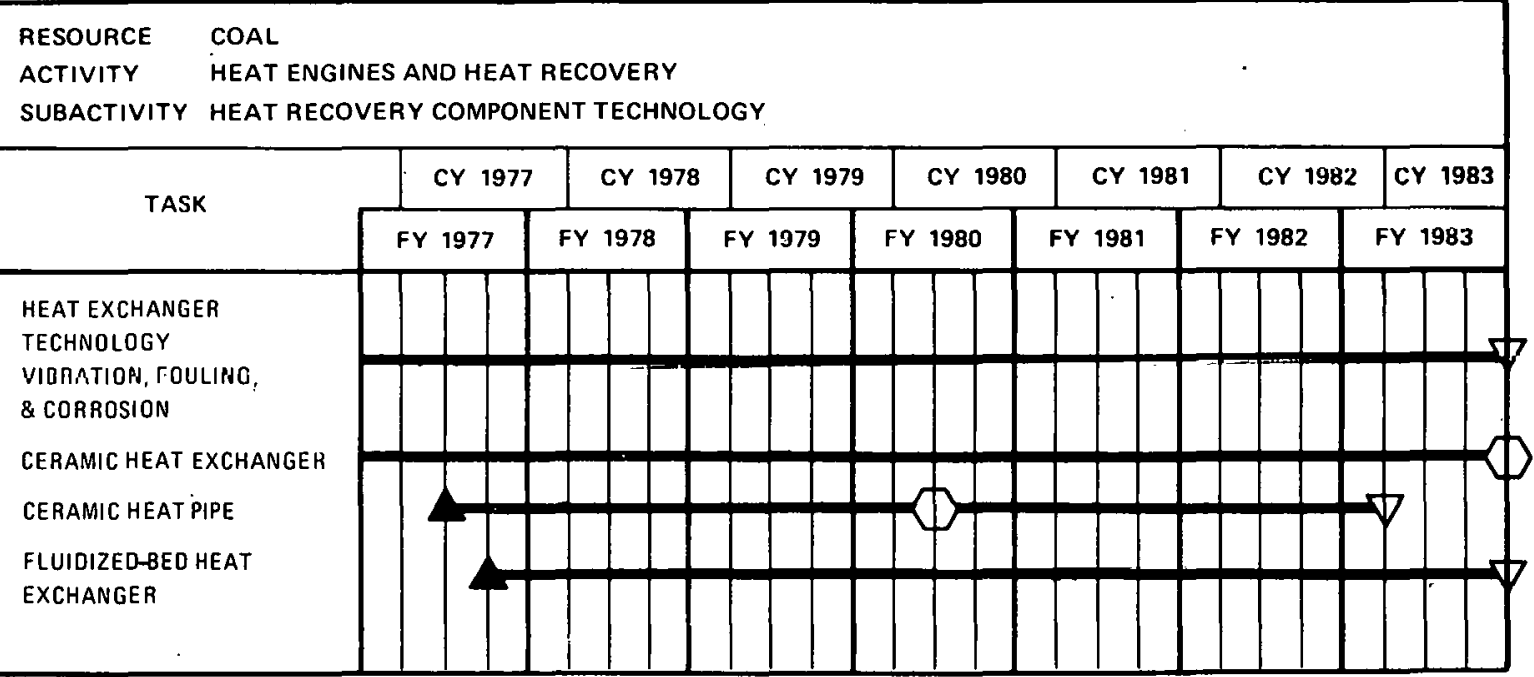

MILESTONE SYMBOLS ARE DEFINED ON LAST PAGE OF THIS DOCUMENT 


\section{F. COMBUSTION SYSTEMS}

Combustion is involved in over 90 percent of the fuel utilization processes in this country and, even under the most optimistic predictions for alternatives, will continue to dominate our energy usage. Because of the former low price of oil and gas, our most abundant resource, coal, accounts for less than 20 percent of our current fuel utilization. In addition, the combustion processes responsible for most of our premium fuel utilization have a high potential for efficiency improvement. The tasks under the Combustion Systems Activity are selected on the basis of their potential for reducing oil and natural gas consumption by developing the technology required for substitution of alternatives, i.e., coal, coal-derived fuels, wastes and combustible residues for oil and gas, and by increasing the efficiency with which the premium fuels are used.

Coal is the nation's most abundant domestic fuel. Yet, coal represents less than 55 percent of the fossil fuel consumed by steamelectric utilities. National emission standards for stationary coal-fired steam generators presently limit sulfur dioxide ( $\mathrm{SO}_{2}$ ) emissions to 1.2 $\mathrm{lb} / \mathrm{MM} \mathrm{Btu}$, and nitrogen oxides $\left(\mathrm{NO}_{\mathrm{X}}\right)$ to $0.7 \mathrm{lb} / \mathrm{MM} \mathrm{Btu}$. Sulfur dioxide is present only in relatively low concentrations, and the high cost of removing it from large volumes of stack gases has restricted the use of sulfur coals. Approximately 50 percent of coal presently being mined can meet present emission standards for new sources without some kind of $\left(\mathrm{SO}_{2}\right)$ emission suppression. Indications are that future standards will require greater cleanup of combustion products. Because fluidized-bed combustion (FBC) boilers, atmospheric and pressurized, absorb the majority of $\mathrm{SO}_{2}$ in the combustion process and produce considerably less $\mathrm{NO}_{\mathbf{X}}$ than conventional coal-fired boilers, the technology should enable increased coal utilization in an environmentally acceptable manner. Particulate matter emissions can also be reduced to environmentally acceptable levels. Even though greater quantities of particulates appear to be emitted from FBCs, these can be controlled with existing technology. The major environmental concern with FBCs is, however, disposal of the large quantities of solid wastes produced from the fly-ash and the bed itself. Many programs are presently under way to study the characteristics and demonstrate possible uses for the materials.

Industrial, forest, and agricultural wastes and residues represent an annual renewable energy resource which could furnish 4 Quads per year by 1985. At present, these resources supply less than 1 Quad per year.

The present generation of automotive engines evolved during a period of plentiful inexpensive petroleum-derived fuels. In spite of recent modifications to increase their efficiency, a potential 20 percent improvement remains to be realized through a new generation of combustion components. 
An estimated 800 Quads of methane is trapped in the coal beds of this nation. The recovery of 300 Quads of this resource appears commercially feasible with the development of advanced recovery and utilization methods.

The objectives of the Combustion Systems Activity are:

- To develop fluidized-bed combustion systems capable of directly burning high-sulfur and other coals of all ranks and quality in an environmentally acceptable manner

- To develop technology to substitute coal for a substantial portion of oil in combustors capable of firing coal-oil mixtures

- To improve the reliability and efficiency of present boilers and furnaccs

- To develop the technology and systems required for economic utilization of coal bed methane

- To develop combustion systems for economic utilization of waste and residue fuels

- To develop the combustion technology required for improved automotive engines capable of operation on present and future fuels.

To realize these objectives, research efforts are being directed toward development of environmentally acceptable methods of combustion and improved combustion efficiency. The total effort has been integrated into subactivities on the basis of both broad technical approach and specific technical components. Specific areas of research and develupmeni. include:

- $\quad$ Fluidized-bed combustion (atmospheric and pressurized) with particular attention to achieving high combustion efficiency, acceptable component durability, minimum emission of particulates and sulfur and nitrngen exides, and reliable operation of combined-cycle systems

- Combustivin aud heal lransfer charácteristics of chars, coaloil slurries, solvent-refined coal, coal-derived liquid fuels, and wastes when burned in conventional equipment and the application of such data to improved combustion component design

- Causes of adherent slag and ash deposits, and development of methods for minimizing these reliability- and efficiencydegrading problems

- Identification and control of toxic elements evolved during the direct combustion of coal 
- Technology options for utilization of coal bed methane from sources of varying flow rate and $B$ tu content with varying on site requirements including mining operation heating, on-site power generation, liquefied natural gas (LNG) and ammonia production

- Small-scale systems for heating and power generation using agricultural and wood residues and composite industrial wastes

- Engine combustion components for increased efficiency, emissions control and broadened fuel capability.

The following accomplishments have been made: The $30 \mathrm{MWe}$ atmospheric, fluidized-bed boiler project, located at the Monongahela Power Company plant at Rivesville, West Virginia, began operation in FY 1977 and will continue in FY 1978. Architect-engineer contractors were selected for the atmospheric and pressurized FBC component test and integration units. Detailed designs for both facilities are now under way with construction to be initiated in FY 1978. For the FBC industrial applications effort, five contractors have been selected to design the systems that are to be built in industrial and institutional facilities. A Program Opportunity Notice (PON) was issued in FY 1977 for the design and construction of industrial/utility applications for the atmospheric FBC concept using anthracite/anthracite culm material as a fuel source. This is a cost-shared program with nearterm commercialization potential. One or more contracts are expected to be awarded in FY 1978. Accomplishments in the pressurized fluidized-bed effort include the design of a combined-cycle pilot plant of approximately 13 MW capacity which was initiated in FY 1976. Multiple contracts were awarded during FY 1977 to retrofit, operate, and test existing boilers, heaters and furnaces, to demonstrate the use of and to evaluate the practicality and economics of burning coal-oil slurries as a primary fuel in place of oil. A comprehensive RD\&D plan for coal bed methane utilization has been completed and two recovery/utilization projects have been initiated. A program plan for near-term small-scale utilization of agricultural and forest residues has been completed and partially implemented. A comprehensive program on direct injected stratified charge engines has been fully implemented and the pre-combustion modeling and verification efforts of the first phase have been completed.

In addition to these projects, laboratory studies, other feasibility studies, systems and analyses, etc., are under way in support of the development programs for atmospheric and pressurized fluidized-bed boilers. 
The following table summarizes the funding levels by subactivity for the FY 1977 to FY 1979 period. (Refer to Chapter II.A, Table 5, for budget comparability.)

\begin{tabular}{|c|c|c|c|c|c|}
\hline COMBUSTION SYSTEMS & \multicolumn{4}{|c|}{$\begin{array}{l}\text { BUDGET AUTHORITY } \\
\text { (OPERATING EXPENSES) } \\
\text { (DOLLARS IN THOUSANDS) }\end{array}$} & \multirow{2}{*}{$\begin{array}{l}\text { MAJOR } \\
\text { CHANGE* }\end{array}$} \\
\hline SUBACTIVITY & $\begin{array}{l}\text { ACTUAL } \\
\text { FY } 1977\end{array}$ & $\begin{array}{l}\text { APPROPRIATION } \\
\text { FY } 1978\end{array}$ & $\begin{array}{l}\text { ESTIMATE } \\
\text { FY } 1979\end{array}$ & $\begin{array}{l}\text { INCREASE } \\
\text { (DECREASE) }\end{array}$ & \\
\hline $\begin{array}{l}\text { Atmospheric Fluidized-Beds } \\
\text { Pressurized Fluidized-Beds } \\
\text { Coal-Oil Mixture } \\
\text { Coal Combustion Support } \\
\text { Combustion Demonstration Plants } \\
\text { Subtotal-Direct Combustion } \\
\\
\text { Improved Curversion Efficiency } \\
\text { R\&D in Advanced Combustion } \\
\text { Technology and Alternate } \\
\text { Fuel Utilization }\end{array}$ & $\begin{array}{r}\$ 21,165 \\
17,200 \\
4,300 \\
9,236 \\
4,000 \\
55,901 \\
\\
\\
\\
850\end{array}$ & $\begin{array}{r}\$ 29,500 \\
15,229 \\
3,000 \\
10,471 \\
10,000 \\
68,200\end{array}$ & $\begin{array}{r}\$ 25,400 \\
12,576 \\
5,450 \\
7,450 \\
3,840 \\
54,716\end{array}$ & $\begin{array}{r}\$-4,100 \\
-2,653 \\
+2,450 \\
-3,021 \\
-6,160 \\
-13,484\end{array}$ & \multirow[t]{2}{*}{$\begin{array}{l}\text { See } \\
\text { Detail } \\
\text { Charts }\end{array}$} \\
\hline TOTAL & $\$ 56,751$ & $\$ 71,680$ & $\$ 66,616$ & $\$ .-8,064$ & \\
\hline \multicolumn{3}{|c|}{$\begin{array}{l}\text { KEY } \\
N=\text { New start (totally new project) } \\
S=\text { Scaleup (from bench to PDU or pilot plant) } \\
A=\text { Acceleration (shortening deadlines or } \\
\text { expansion of ongoing projects) }\end{array}$} & \multicolumn{3}{|c|}{$\begin{array}{l}P=\text { Phase completion or startup } \\
R=\text { Program redirection } \\
I=\text { Incremental cost requirement } \\
C=\text { Project completion or suspension }\end{array}$} \\
\hline
\end{tabular}

\subsection{ATMOSPHERIC FLUIDIZED-BEDS (AFB)}

Processes currently being investigated and tested include:

- Fluidized-Bed Boiler, $30 \mathrm{MWe}$ Process

- Industrial Applications

- Atmospheric Fluidized-Bed Component Test and Integration Unit (AFB/CTIU)

- Atmospheric Fluidized-Bed Coal Combustion Closed-Cycle Gas Turbine Technology Test Unit (TTU) (formerly MIUS)

- Anthracite Applications .

Coal-fired fluidized-bed boilers are more attractive for commercial use than conventional coal-fired boilers with stack gas scrubbers. They show potential for improving net power generation efficiency and heat transfer rates while lowering emissions of sulfur and nitrogen oxides. The capital cost of such systems is expected to be less than that of conventional systems with stack gas scrubbers. 
Emission control for fluidized-bed boilers is centered in the combustion zone. Sized coal is burned in a fluidized-bed of inert ash and limestone or dolomite. The limestone or dolomite reacts with $\mathrm{SO}_{2}$ to form a solid sulfate material that can be regenerated or disposed of with the ash as an inert granular landfill. Regeneration will produce a reuseable sorbent and either a stable sulfur compound or a marketable sulfurous material. Fluidized-bed boilers can operate at combustion temperatures lower than conventional boilers, thus inhibiting formation of nitrogen oxides. An atmospheric pressure, coal-fired, fluidized-bed boiler having a capacity of $5,000 \mathrm{lb} / \mathrm{hr}$ of steam has been operated successfully at furnace temperatures of approximately $1600^{\circ} \mathrm{F}$ since 1967. It has demonstrated that all types of coal, char, and coal wastes can be burned in an environmentally acceptable manner.

An investigation is currently being conducted concerning utilization of FBC solid waste material for use in agriculture and for neutralization of acid mine spoils. Another investigation is being considered for subsoil stabilization in connection with highway problems. A third program is directed to the development of commercial applications such as low-grade concrete, for the materials present in the waste and the production of an environmentally safe material that can serve as a suitable land-fill.

The table below summarizes the funding levels by task for the FY 1977 to FY 1979 period.

\begin{tabular}{|c|c|c|c|c|c|}
\hline \multirow[t]{2}{*}{$\begin{array}{l}\text { ATMOSPHERIC FLUIDIZED } \\
\text { BEDS }\end{array}$} & \multicolumn{4}{|c|}{$\begin{array}{c}\text { BUDGET AUTHORITY } \\
\text { (OPERATING EXPENSES) } \\
\text { (DOLLARS IN THOUSANDS) }\end{array}$} & \multirow{2}{*}{$\begin{array}{l}\text { MAJOR } \\
\text { CHANGE* }\end{array}$} \\
\hline & $\begin{array}{l}\text { ACTUAL } \\
\text { FY } 1977\end{array}$ & $\begin{array}{l}\text { APPROPRIATION } \\
\text { FY } 1978\end{array}$ & $\begin{array}{l}\text { ESTIMATE } \\
\text { FY } 1979\end{array}$ & $\begin{array}{l}\text { INCREASE } \\
\text { (DECREASE) }\end{array}$ & \\
\hline $\begin{array}{l}\text { Fluidized-Bed Boiler, } 30 \mathrm{MW} \\
\text { Industrial Applications } \\
\text { AFB-Technology Test Unit } \\
\text { AFB-CTIU } \\
\text { Plant Conversion } \\
\text { Anthracite Applications }\end{array}$ & $\begin{array}{r}3,000 \\
10,000 \\
1,700 \\
4,365 \\
1,100 \\
1,000\end{array}$ & $\begin{array}{r}\$ 4,000 \\
10,000 \\
2,000 \\
13,500 \\
0 \\
0\end{array}$ & $\begin{array}{r}\$ 8,700 \\
2,000 \\
714 \\
11,800 \\
0 \\
2,186\end{array}$ & $\begin{array}{r}\$+4,700 \\
-8,000 \\
-1,286 \\
-1,700 \\
0 \\
+2,186\end{array}$ & \multirow[t]{2}{*}{$\begin{array}{l}1 \\
1 \\
1 \\
P\end{array}$} \\
\hline TOTAL & $\$ 21,165$ & $\$ 29,500$ & $\$ 25,400$ & $\$-4,100$ & \\
\hline \multicolumn{6}{|c|}{$\begin{array}{ll}\text { "KEY } & \\
N=\text { New start (totally new project) } & P=\text { Phase completion or startup } \\
S=\text { Scaleup (from bench to PDU or pilot plant) } & R=\text { Program redirection } \\
A=\text { Acceleration (shortening deadlines or } & 1=\text { Incremental cost requirement } \\
\text { expansion of ongoing projects) } & C=\text { Project completion or suspension }\end{array}$} \\
\hline
\end{tabular}




\subsection{AFB BOILER, $30 \mathrm{MWe}$}

The objective of the current DOE Fossil Energy $30 \mathrm{MWe}$ task is to design, construct, test, and evaluate a $300,000 \mathrm{lb} / \mathrm{hr}$ capacity multicell fluidized-bed boiler (MFB) as a pollution-free method of burning highsulfur content or slagging coals in a practical manner under actual electrical utility conditions. Steam pressure, temperature, and circuitry of the boiler, therefore, were designed to meet requirements of the selected Monongahela Power Company (Allegheny Power System), Rivesville, West Virginia, power station.

Successful development of the atmospheric fluidized-bed boiler is seen as a necessary first step toward the better use of high-sulfur and slagging coals. Based on the successful performance of this first 30 $\mathrm{MWe}$ unit and a subsequent demonstration plant, it is expected that several electric utilities will commit to the installation of atmospheris fluidized-bed boilers in the 200-to-800 MWC capacity range.

The MFB boiler consists of four adjacent combustion cells. This unit of cells is $21 \mathrm{ft}$ high $\times 39 \mathrm{ft}$ long $\times 12 \mathrm{ft}$ wide. The three primary cells ( A, B, and C) operate at 15500F while the carbon burnup cell (CBC) operates at up to $2000^{\circ} \mathrm{F}$. Boiler tubes are arranged in horizontal bundles to control bed temperature, generate and superheat steam. Each of the four cells has economizer tubes in the upper convection region, which is heated by exhaust gases. The three primary cells have boiler tubes immediately above the fluidized-bed section, and cell $C$ has boiler tubes deep within the hed. Cells $A$ and $B$ both have superheater tubes immersed deeply into the bed region. This fluidized-bed boiler has produced over $300,000 \mathrm{lb} / \mathrm{hr}$ of steam at $9300 \mathrm{~F}$ and $1,280 \mathrm{psi}$. the temperature and pressure determined by the requirements of the boiler installation site.

Crushed coal (1/4-in top-size) and limestone (1/8-in top-size) are supplied to the system by weight hoppers and blown into the combustor unit with a stream of air. Coal and limestone are fed to cells $A, B$, and $C$ at a 4:1 weight ratio. Unburned carbon supplied by the exhaust cyclone separator above the primary cells is fed to the carbon burnup cell. The total coal feed rate is ahnut 15 tons $/ \mathrm{hr}$. Air for bcd fluidization is supplied to the burner cells by a common plenum. Low excess oxygen is maintained in the cells. The exhaust gas cleanup system is comprised of cyclone separators trailed by an electrostatic precipitator.

There are several advantages to the fluidized-bed boiler:

- Sulfur dioxide and nitrogen oxide emissions are well within Environmental Protection Agency (EPA) standards using high-sulfur coal; expensive, difficult to operate and maintain, and energy-consuming flue gas cleaning equipment is not required

- $\mathrm{NO}_{\mathbf{X}}$ emission levels are lower than those from conventional equipment 
- Low-quality coal can be burned without danger of slagging and fouling because of low combustion temperatures

- The heat release and heat transfer coefficients are high, reducing boiler size, weight, and cost. Cost analyses indicate that the $200-\mathrm{MW}$-size, fluidized-bed boiler will weigh less and will cost proportionately less

- The overall operating efficiency of a fluidized-bed boiler power plant is projected to be 36 percent, compared to approximately 34 percent for a conventional coal-fired plant with stack-gas cleanup operating with the same coal and at the same steam pressure and temperature.

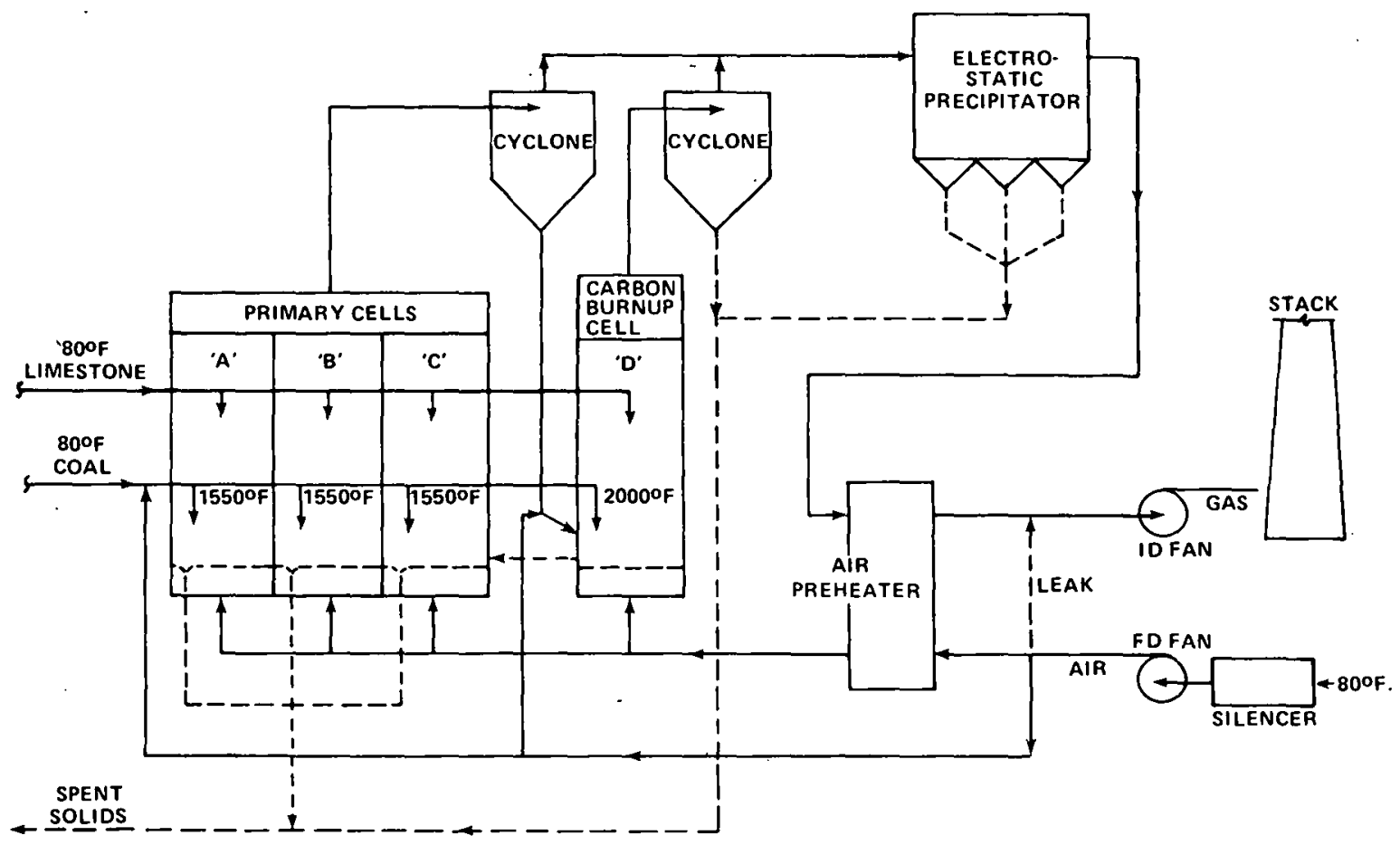

Fluidized-Bed Boiler, $30 \mathrm{MW}_{\mathrm{e}}$

\section{Project Status}

Since 1965 Pope, Evans and Robbins, Inc., has been investigating atmospheric fluidized-bed combustors (AFBC) in its Alexandria, Virginia, facility. A $0.5-\mathrm{MW}$ AFBC PDU has been operated in Alexandria to support the pilot plant design, cnnstruction, and operation. Construction of a 30MWe-size multicell fluidized-bed boiler (MFB) pilot plant was completed in 1976 at the Monongahela Power Company's plant at Rivesville, West Virginia, by Pope, Evans and Robbins, Inc. Initial light-off of the boiler with coal was successfully accomplished on December 7, 1976. Operation and testing of the pilot plant to demonstrate the applicability of the MFB for steam-electric power generation has been carried out during 1977 and will be continued in FY 1978. On September 30, 1977, the unit achieved its 
full nameplate rating. In the fall of 1977, it produced steam for use in power generation on several occasions. Modifications are being made in 1978, to improve the reliability of components and to add combustor instrumentation.

The Rivesville facility is the first major step toward the commercial size central station power program. The combustor for Rivesville represents an initial design to be used as the basis for $200 \mathrm{MW} e$ and eventually to $800 \mathrm{MW}_{\mathrm{e}}$ plants.

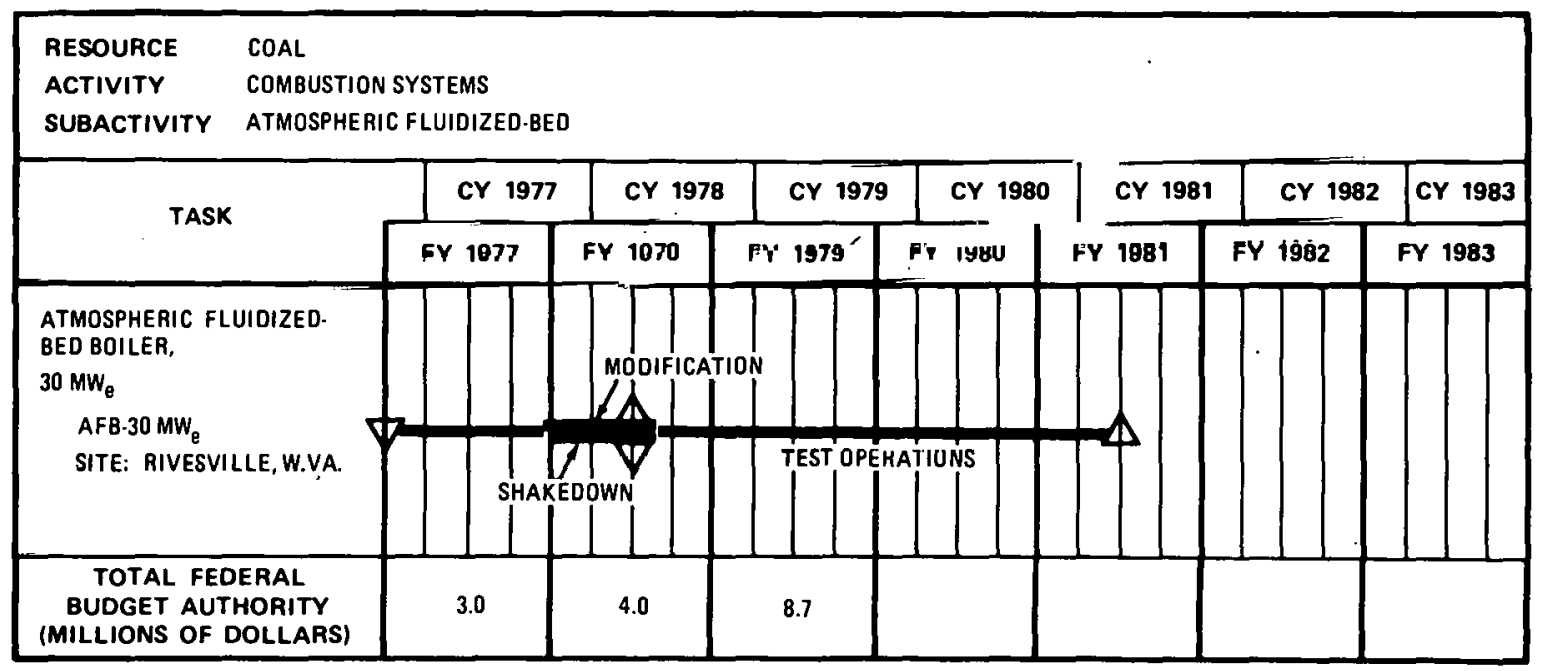

MILESTONE SYMBOLS ARE DEFINED ON LAST PAGE OF THIS DOCUMENT

\subsection{AFB INDUSTRIAL APPLICATIONS}

These projcets consist of develurment and demonetration FBC boilers and heaters for industrial applications, using the atmospherio fluidiesd bed concept, and operation of prototypes on industrial sites for such purposes as steam raising, process heat, and cogeneration. Objectives are:

- Design, build, operate, test, and demonstrate prototype boilers and heaters to establish the practicality of hurning high-sulfur coals and other fuels for industrial applications

- Obtain sufficient data from prototype operations to enable the industry to design, construct, and operale the selected prototypes in full plant-sized installations.

Although industrial boiler and process heater needs are quite diversified, a relatively small number of equipment configurations define the majority of applications. Thus, key components will be constructed on an industrial scale to determine applicability of fluidized-bed combustors to industrial units. 
Three areas of industrial applications are being investigated:

- Saturated Steam Boiler: capable of producing steam of the quality and in the quantity suitable for process heating and space heating requirements of industrial or institutional facilities. The individual boiler capacity is predicated on the intended application

- Superheated Steam Generator: capable of producing steam of the quality and quantity for both cogeneration via back-pressure turbines and industrial process and heating requirements

- Indirect-Fired Process Heater: utilizing tubes or other heatexchange devices to heat process liquids or gases.

\section{Project Status}

Five contractors (or groups) were selected to design, construct, and test industrial boilers or industrial heaters using atmospheric fluidized-bed combustors:

\begin{tabular}{|c|c|c|}
\hline & Steam Rate & Coal Rate \\
\hline $\begin{array}{l}\text { Georgetown University/Fluidized } \\
\text { Combustion Corp } \\
\text { Washington, D.C. }\end{array}$ & $\begin{array}{l}100,000 \mathrm{lb} / \mathrm{hr} \\
\text { saturated steam }\end{array}$ & 5 tons $/ \mathrm{hr}$ \\
\hline $\begin{array}{l}\text { Combustion Engineering } \\
\text { Great Lakes Naval Training } \\
\text { Center }\end{array}$ & $\begin{array}{l}50,000 \mathrm{lb} / \mathrm{hr} \\
\text { superheated steam }\end{array}$ & 2.5 tons $/ \mathrm{hr}$ \\
\hline $\begin{array}{l}\text { Battelle/Fluidized Combustion } \\
\text { Columbus, Ohio }\end{array}$ & $\begin{array}{l}25,000 \mathrm{lb} / \mathrm{hr} . \\
\text { saturated steam }\end{array}$ & $1 \mathrm{ton} / \mathrm{hr}$ \\
\hline $\begin{array}{l}\text { Fluidyne/Owatonna Tool Co. } \\
\text { Owatonna, Minnesota }\end{array}$ & $\begin{array}{l}\text { Heated Air } / \text { Metal } \\
\text { Working, } 800^{\circ} \mathrm{F}\end{array}$ & 1.5 tons $/ \mathrm{hr}$ \\
\hline $\begin{array}{l}\text { Exxon Research \& Engineering C } \\
\text { Linden, New Jersey }\end{array}$ & $\begin{array}{l}\text { Tube Still, } \\
\text { 15M Btu/hr }\end{array}$ & .75 ton $/ \mathrm{hr}$ \\
\hline
\end{tabular}

Arthur G. McKee \& Co. is providing technical assistance and services to DOE in developing the industrial applications of AFBC. 


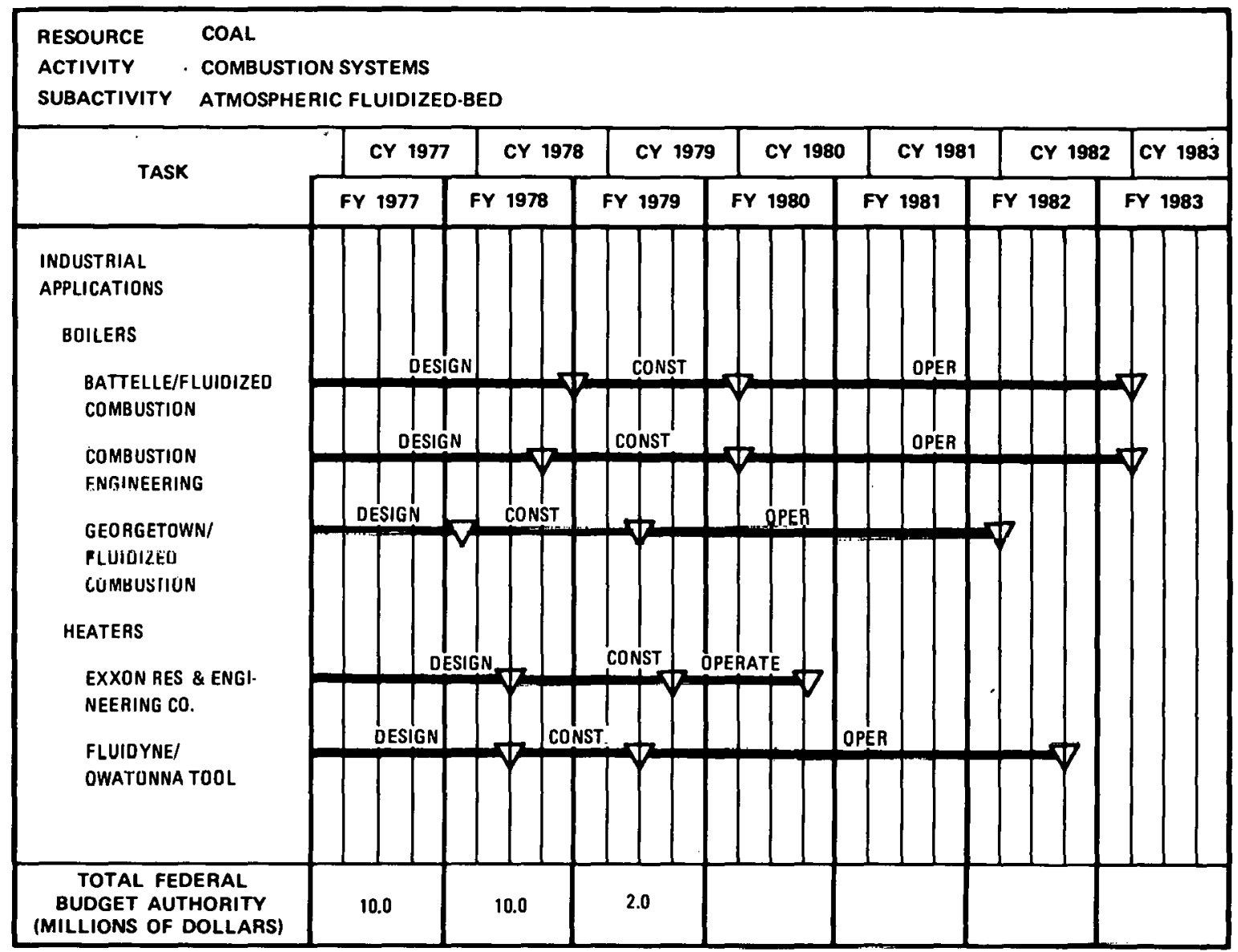

MILESTONE SYMBOLS ARE DEFINED ON LAST PAGE OF THIS DOCUMENT

\subsection{AFB CLOSED-CYCLE GAS TURBINE TTU}

The development of an Atmospheric Fluidized-Bed Coal Combustion Closed-Cycle Hot-Air Gas Turbine Technology Test Unit (TTU) was initiated by Oak Ridge National Laboratory (ORNL) under technical direction from ERDA/FE (then DOI/ OCR) as a coal-fired application to the existing Housing and Urban Development (HUD)-MTTIS program. The TTU effort complements the overall DOE fluidized-bed combustion effort well by providing investigation of a potentially viable technology option that is not being addressed elsewhere in the existing program.

The MIUS concept was originally based on efficient utilization of mechanical and thermal energies derived hy burning a variety of fucls ranging from natural gas to inferior coals and municipal and process wastes in an environmentally acceptable manner. Such a total energy utilization systems concept can result in a 60 to 85 percent overall thermal efficiency. Prior to the oil boycott, coal was not a serious economic contender for application to MIUS concepts. Post-boycott conditions liave put AFBC systems in the forefront for many diverse applications of coal utilization.

Based on the original MIUS objectives and goals, ORNL has completed two of the total four phases. Phase I, which included several technology studies and preliminary engineering and economic analyses, 
concluded that a coal-fueled atmospheric FBC unit coupled to a closedcycle, externally-fired, hot-air turbine is the most promising subsystem for MIUS application.

Phase II was undertaken to further investigate the systems and configurations chosen in Phase I and to complete the conceptual design for the most promising configuration. As a result of this study, the work to date has yielded a conceptual design for the TTU.

The TTU will consist of a coal-burning atmospheric FBC system coupled ultimately to a closed-cycle, hot-air gas turbine generator. This test unit will have basic electrical capability from 300 to $500 \mathrm{~kW}$ plus approximately $2.5 \times 10 \mathrm{Btu} / \mathrm{hr}$ of recoverable waste heat. This size test unit will provide credible scaleup data to the 5-to-20 MW range for commercial application in the industrial/institutional sector for cogeneration applications.

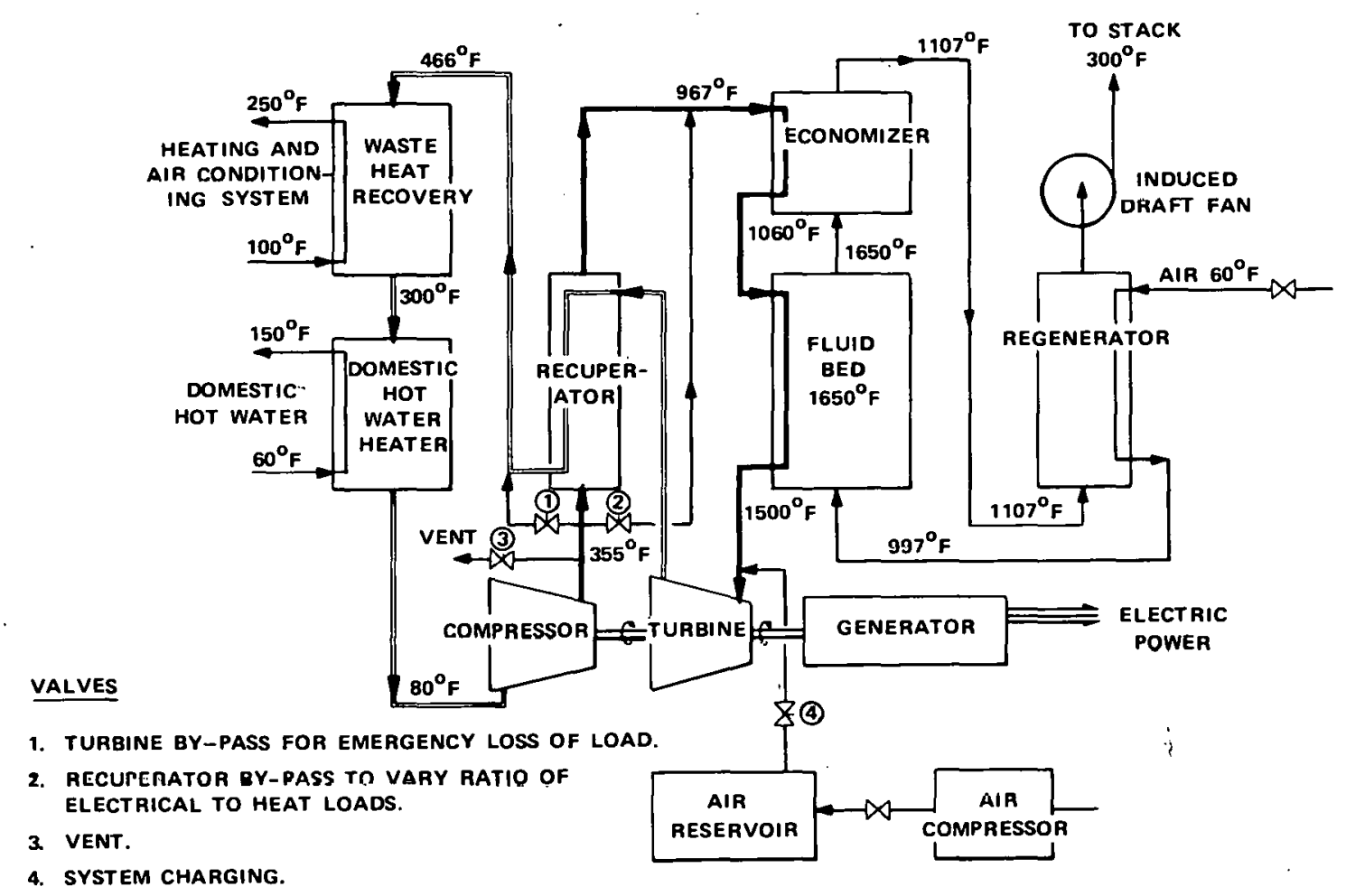

\section{Atmospheric Fluidized-Bed Coal Combustion Closed-Cycle Gas Turbine Technology Test Unit}

\section{Project Status}

The TTU is in the detailed design phase and will proceed to construction in FY 1978 at Oak Ridge National Laboratory, Oak Ridge, Tennessee. Construction is expected to be completed in FY 1979 when testing will commence. The two-year testing period is planned to be completed in FY 1981, at. which time operational data will be available which may lead to commercialization of the coal-fueled total energy system. 


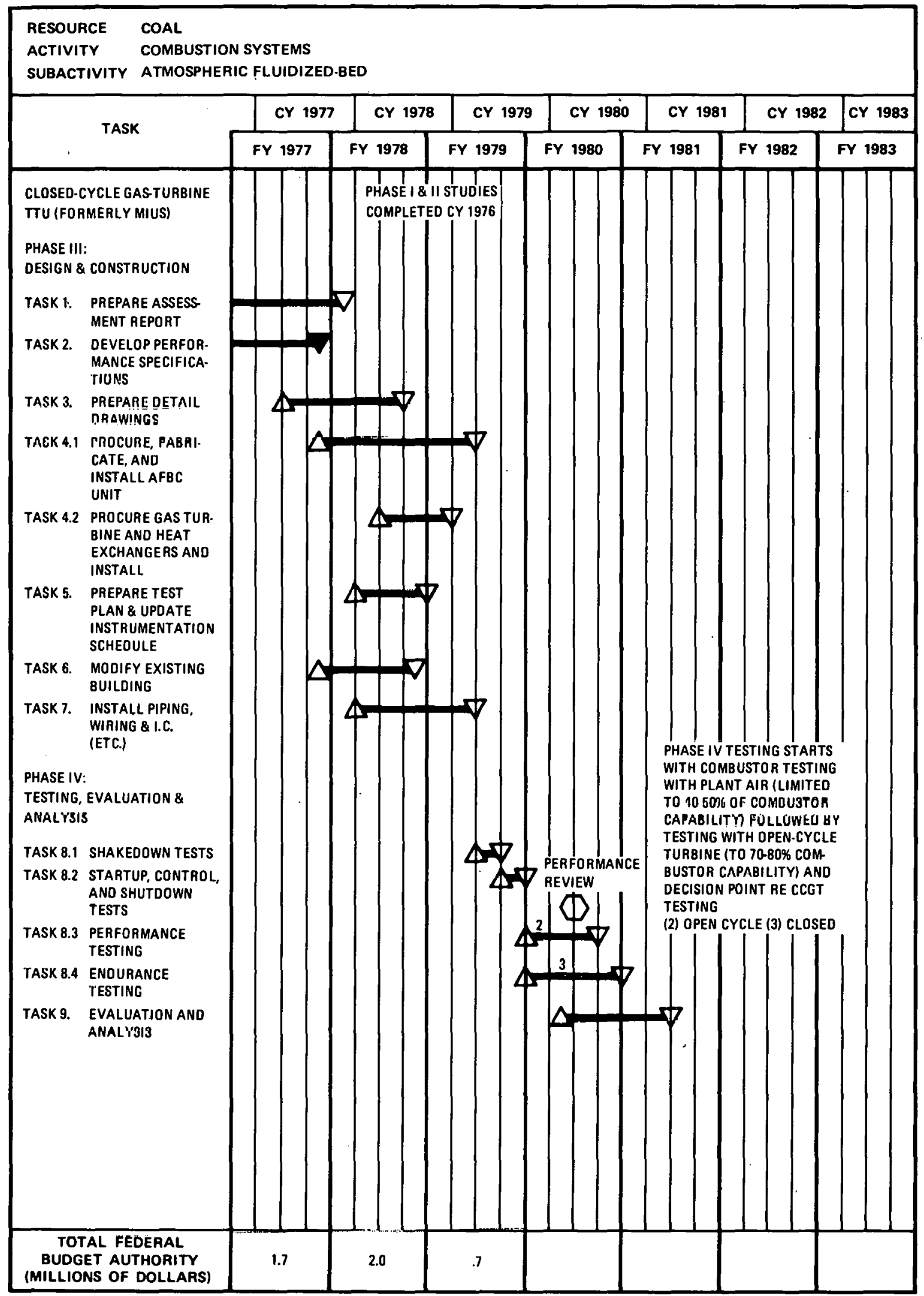

MILESTONE SYMBOLS ARE DEFINED ON LAST PAGE OF THIS DOCUMENT 


\subsection{AFB COMPONENT TEST AND INTEGRATION UNIT}

The AFB/CTIU is a flexible, instrumented research and development facility at the smallest-scale at which data applies to full-size systems. It consists of a three-cell fluidized-bed combustor with its heat recovery system: ash removal from flue gases will be in cyclone separators with reinjection for carbon burnup in a separate carbon burnup cell or within either coal-burning cell; final gas cleaning will be effected by bag filter collectors. Provision is made for coal, limestone, and additive receiving, preparation, and feeding into the combustor cells. The spent-bed material is removed, purified by size classification and magnetic separation, and stored hot for reinjection into any of the combustor cells. Air for fluidization and injection is provided by primary and auxiliary forced-draft fans. An induced-draft fan moves the flue gases through the dust removal system and vents into the stack. The complete system is designed with sophisticated analytical instrumentation, computerized data acquisition, and electronic control systems so that the maximum amount of useful data can be obtained in the operation of the unit.

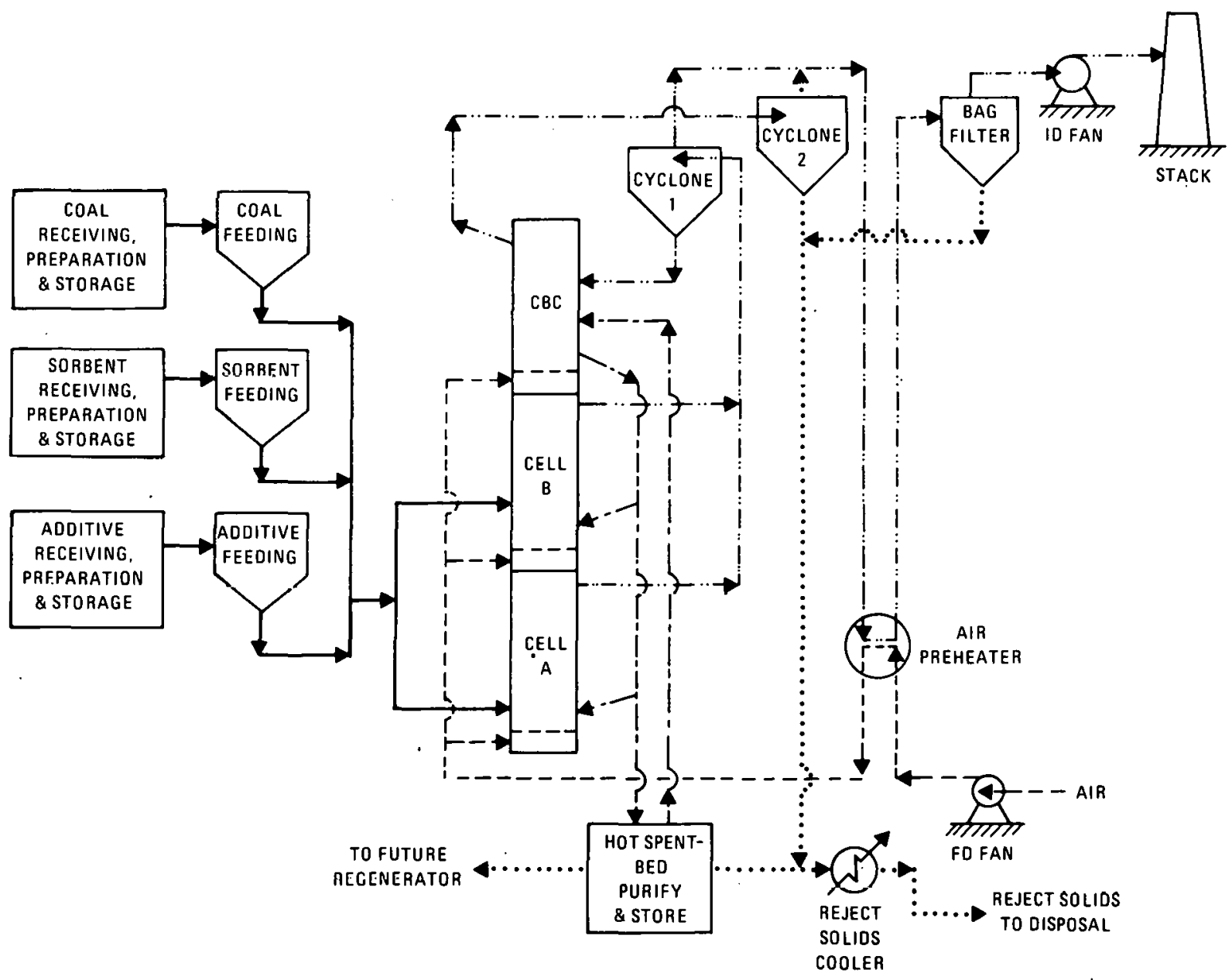

Atmospheric Fluidized-Bed Component Test and Integration Unit (AFB/CTIU) 


\section{Project Status}

This component test and integration unit will be located in Morgantown, West Virginia, to obtain data on bed fluidization, combustion, emissions, sorbent performance and to test new atmospheric fluidized-bed combustion systems and components at an intermediate size scale and to act as an investigative facility for problems developed in the $30 \mathrm{MWe}$ boiler test project. Design of the CTIU started in FY 1976. Fabrication and field erection has started in FY 1978 and operations will begin in FY 1980. The CTIU will test improved solids-handling systems, develop technology for vertical stacking of multiple beds, and serve as a boiler development laboratory to test tube bundle geometries and materials in operating fluidized-bed combustors.

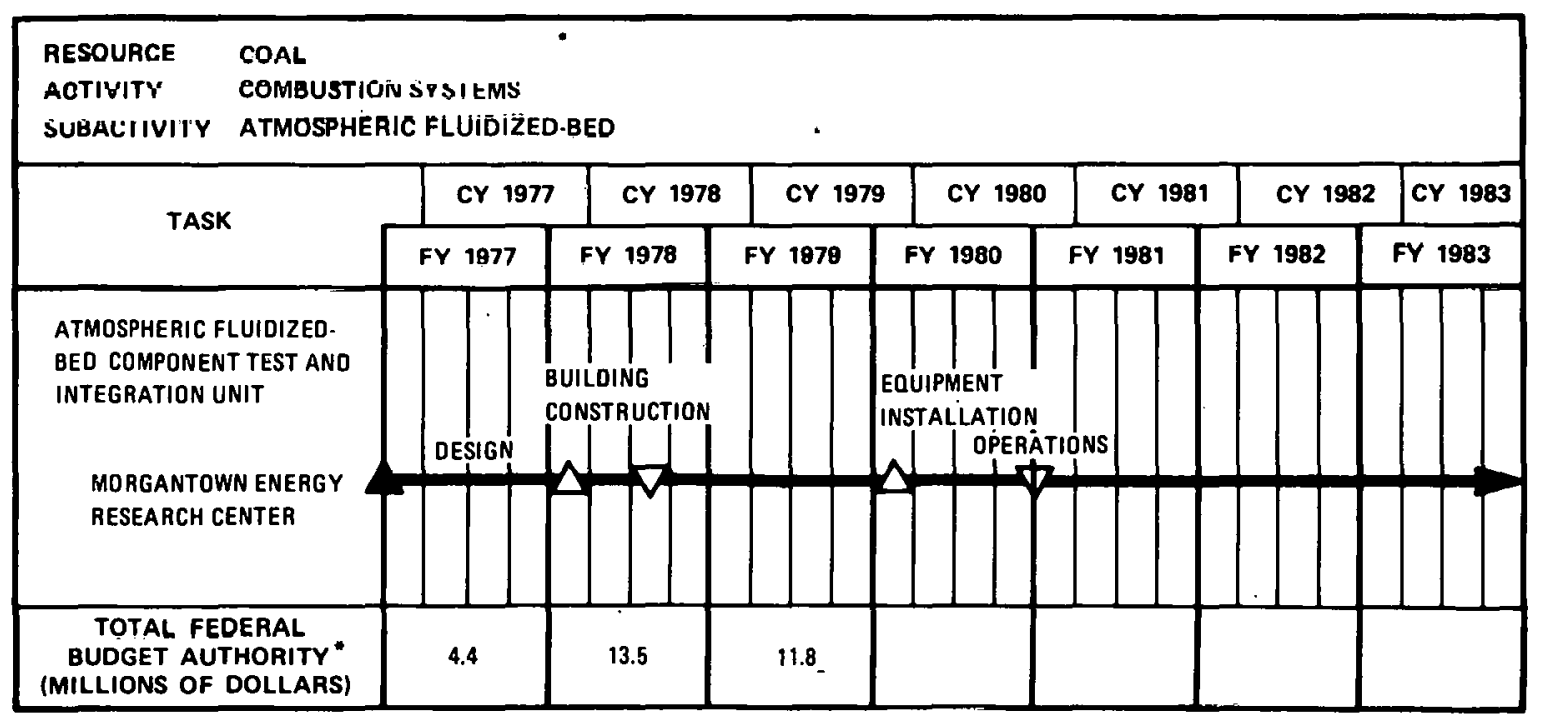

MILESTONE SYMBOLS ARE DEFINED ON LASTT PAG̣E OF THIS ROCIIMFNT

"FurTHER bUdGet UetaILS ARE PROVIDFo IN SECTION 6.0.

\subsection{AFB ANTHRACITE APPLICATIONS}

This effort is designed to investigate the combustion of anthracite culm in fluidized beds and other direct culm-burning prosesses in an environmentally acceptable manner in industrial/utility boilers and heaters. The waste material resulting from the mining and cleaning of anthracite coal (principally in northeastern Pennsylvania) contains a substantial amount of fuel value, which can be recovered in fluidized-bed or other direct combustion boilers/combustors in an environmentally acceptable manner.

In the anthracite mining region, this refuse material is piled in a densely populated, geographically small area of about 480 square miles. It is estimated by the U.S. Bureau of Mines (BOM) that 800 banks containing 900 million yards of refuse can be found within the anthracite mining fields.

DOE has begun a program of extending the combustion characteristics of these refuse materials by fluidized-bed combustion. The value of this 
refuse as a fuel is important in the anthracite region because of the decline in mining in the area, which has led to a growing dependence on oil and gas.

\section{Project Status}

A Program Opportunity Notice was released in the second quarter of FY 1977. The major activity in FY 1977 was the evaluation of proposals. The effort during FY 1978 will be the selection of potential contractors and the initiation of conceptual designs, which will proceed to prototype equipment development.

\subsection{PRESSURIZED FLUIDIZED-BEDS (PFB)}

Projects currently under way in this area include:

- Pressurized Fluidized-Bed Combined-Cycle Pilot Plant, 13 MWe Process

- Pressurized Fluidized-Bed Component Test and Integration Unit (PFB/CTIU)

- Granular-Bed Filter/Hot-Gas Cleanup

- International Energy Agency.

Pressurization of the fluidized-bed combustor is a means of potentially effecting an increase in power-generation efficiency with the possibility of reducing the cost of power generation.

The basic technology is that the coal and bed material must be injected into a pressurized combustion chamber and the process converted to a gas-turbine, steam-turbine, combined-cycle system. The pressurized system further reduces the size of the combustor and thus the capital cost. The use of combined-cycle systems increases overall plant efficiency.

Objectives for the pressurized program are similar to the atmospheric, except that developmental problems are greater and more complex, and the first commercial units are expected to be operational at an appreciably later date. Limited tests of American coal have been performed at five atmospheres in a test unit at Leatherhead, England, and have shown that this approach is technically feasible. Additional work is required and is being performed to accomplish cleanup of the hot gases produced from pressurized FBC. This work is necessary to produce the high turbine reliability and long life required for practical power-generation application and control of emissions to the atmosphere. The use of gas turbines at low turbine blade temperatures $\left(1200^{\circ} \mathrm{F}\right.$ to $\left.1300^{\circ} \mathrm{F}\right)$ to avoid the hot corrosion problems is also being investigated. While such systems are not as high in efficiency as those with higher temperatures, $1600 \circ \mathrm{F}$, they are still higher in efficiency than $\mathrm{AFB}$ systems and require less $\mathrm{SO}_{2}$ sorbent and emit less $\mathrm{NO}_{\mathbf{X}}$. 
In the same respect as atmospheric fluidized-bed boilers, the utilization of solid waste material is being considered in agriculture and highway programs.

The table below summarizes the funding levels by task for the FY 1977 to FY 1979 period.

\begin{tabular}{|c|c|c|c|c|c|}
\hline \multirow{2}{*}{$\begin{array}{l}\text { PRESSURIZED FLUIDIZED-BEDS } \\
\text { TASKS }\end{array}$} & \multicolumn{4}{|c|}{$\begin{array}{c}\text { BUDGET AUTHORITY } \\
\text { (OPERATING EXPENSES) } \\
\text { (DOLLARS IN THOUSANDS) }\end{array}$} & \multirow{2}{*}{$\begin{array}{l}\text { MAJOR } \\
\text { CHANGE. }\end{array}$} \\
\hline & $\begin{array}{l}\text { ACTUAL } \\
\text { FY } 1977\end{array}$ & $\begin{array}{c}\text { APPROPRIATION } \\
\text { FY } 1978\end{array}$ & $\begin{array}{l}\text { ESTIMATE } \\
\text { FY } 1979\end{array}$ & $\begin{array}{l}\text { INCAEASE } \\
\text { (DECREASE) }\end{array}$ & \\
\hline $\begin{array}{l}\text { PFB Combined-Cycle } \\
\text { Pilot Plant } \\
\text { PFB / CTIII } \\
\text { Granular Rert Filter/Hnt } \\
\text { Gas Cleanup } \\
\text { PFB Technology } \\
\text { International Energy Agency }\end{array}$ & $\begin{array}{c}\$ 6,00 n \\
5,100 \\
1,500 \\
1,600 \\
3,000\end{array}$ & $\begin{array}{r}\$ 7,000 \\
4,729 \\
1,500 \\
0 \\
2,000\end{array}$ & $\begin{array}{r}\$ 2,500 \\
3,800 \\
2,876 \\
0 \\
3,400\end{array}$ & $\begin{array}{r}\$ 4.300 \\
.929 \\
+1,376 \\
0 \\
+1,400\end{array}$ & $\begin{array}{l}1 \\
1 \\
1\end{array}$ \\
\hline TOTAL. & $\$ 17.200$ & $\$ 15,229$ & $\$ 12,576$ & $\$-2,65,3$ & \\
\hline \multicolumn{3}{|c|}{ 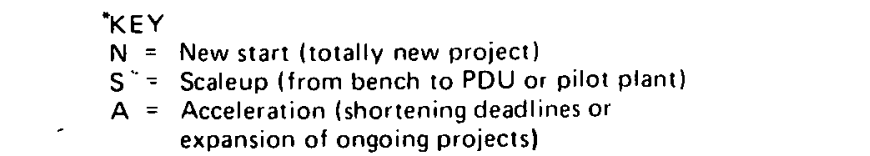 } & \multicolumn{3}{|c|}{$\begin{array}{l}P=\text { Phase completion or startup } \\
R=\text { Program redirection } \\
I=\text { Incremental cost requirement } \\
C=\text { Project completion or suspension }\end{array}$} \\
\hline
\end{tabular}

\subsection{PFB COMBINED-CYCLE PILOT PI.ANT, 13 MWe}

The combination of pressurized fluidized-bed (PFB) technology with the gas turbine, steam turbine, combined-cycle power system offers the unique opportunity for the production of clean cost-competitive electric power from the combustion of high-sulfur coal.

The Curtiss-Wright Corporation is designing, constructing, operating, and evaluating a coal-fired gas turbine pilot electric power plant. The pilot plant, which will produce an equivalent of $13 \mathrm{MWe}$, will address a number of key technical issues assoniated with PFB development. Environmental considerations, maintenance, reliability, and durability of the PFB and turbine will be evaluated. The program will provide design data to verify scaleup of the gas turbine and PFB units to commercial plant size for the utilities industry.

The project objective is to conduct a pilot plant test program to obtain data on gas turbine operation on coal combustion products and to evaluate the validity of the commercial plant design concept. The test program will

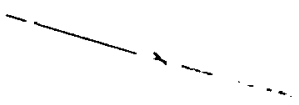


identify and seek solutions for design or component deficiencies, establish operating characteristics under normal and off-design conditions, and provide a firm engineering base for full-scale plant development decisions.

The pilot plant program is a five-year multiphase cost-shared effort. Phase $I$ is a 14-month program to provide the following:

- Conceptual commercial design of a coal-fired 300 to $500 \mathrm{MW}_{\mathrm{e}}$ combined-cycle generating station using the PFB combustion technique

- Pilot plant design that is representative of the commercial concept

- Site and environmental assessment study

- Technology support programs that resolve technical issues and provide data on the performance of the selected PFB design.

Phase II is an 8-month effort to complete the detail design drawings and specifications of the pilot plant, prepare a construction bid package, and obtain and evaluate bids.

Phase III is a 20-month construction period for the manufacturing, buildup, and installation of the pilot plant."

Phase IV is a 24-month effort to operate and evaluate the pilot plant operating parameters and durability on several coal types. At the conclusion of this phase, a reassessment of the commercial plant conceptual design will be completed. follows:

The pressurized fluidized-bed process used is briefly described as

Air is compressed to approximately $8 \mathrm{~atm}$ and fed into the pressurized fluidized-bed combustor (PFBC) where combustion takes place at 16500F. The gases are passed through a two-stage cyclone separator and a hot-gas cleanup system prior to expansion through a gas turbine, which drives an electric power generator. From the gas turbine, the gases pass through a heat recovery boiler, generating steam which in turn drives a steam turbine/electric generator. 


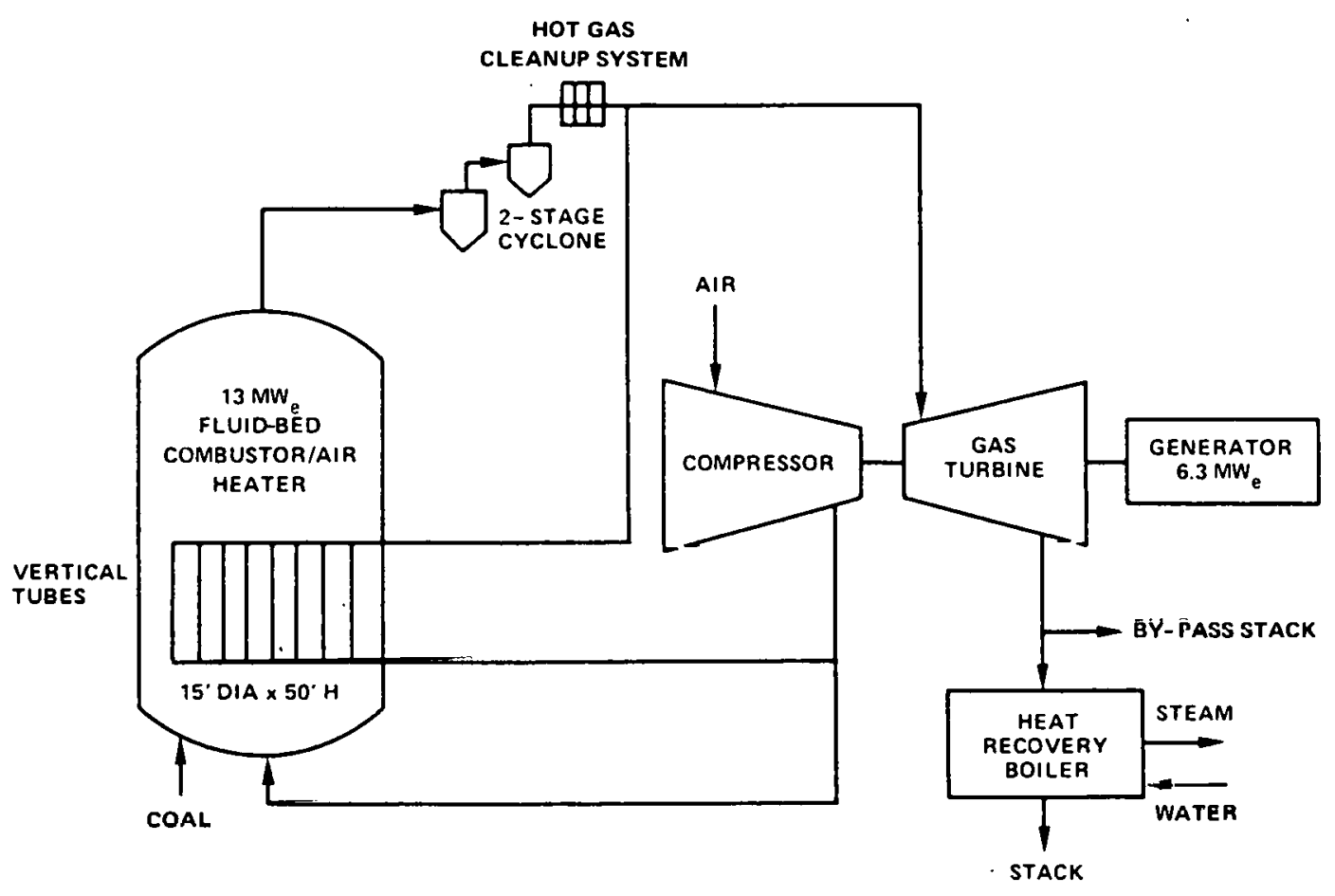

Pressurized Fluidized-Bed Combined-Cycle Pilot Plant $13 \mathrm{MW}_{\mathbf{e}}$

\section{Project Status}

This project includes design, construction, and operation of a $13-\mathrm{MW}_{\mathrm{e}}$ coal-fired, pressurized fluidized-bed combined-cycle pilot plant to be located at the Curtiss-Wright Corporation, Wood-Ridge, New Jersey, factlity. This prototype module is to be designed as a basic element of a central station power plant so that operating, engineering, and economic data can be fully evaluated. An existing combined-cycle electrical powergenerating station for the pilot plant is planned for conversion to a PFB system. The pilot plant facilities will include a 12 -ft diameter by $50-\mathrm{ft}$-high pressurized fluidized-bed combustor, the $\mathrm{CW} 6515$ gas turbine, and a waste heat boiler capable of generating $175 \mathrm{psig} / 3770 \mathrm{~F}$ steam. The basic module will be about one-fifth the scale of commercial plant components. Phase I of the project is presently under way. This is a study of comparative commercial systems and a preliminary design of the pilot plant. Phase I also includes the operation of a small gas turbine test rig, which is a $3-\mathrm{ft}$ diameter section of the full combustor, together with a turbine materials test program. Data is being obtained on the corrosion and erosion of turbine materials and the protection offered in transpired air. Phase I will be completed in mid-FY 1978. Phase II is the detailed design of the pilot plant to be completed in mid-FY 1978. Phase III, construction of the pilot plant and shakedown testing, will occur in FY 1978 and FY 1979. Phase IV, operational testing and evaluation, will be performed in FY 1980 and FY 1981. 


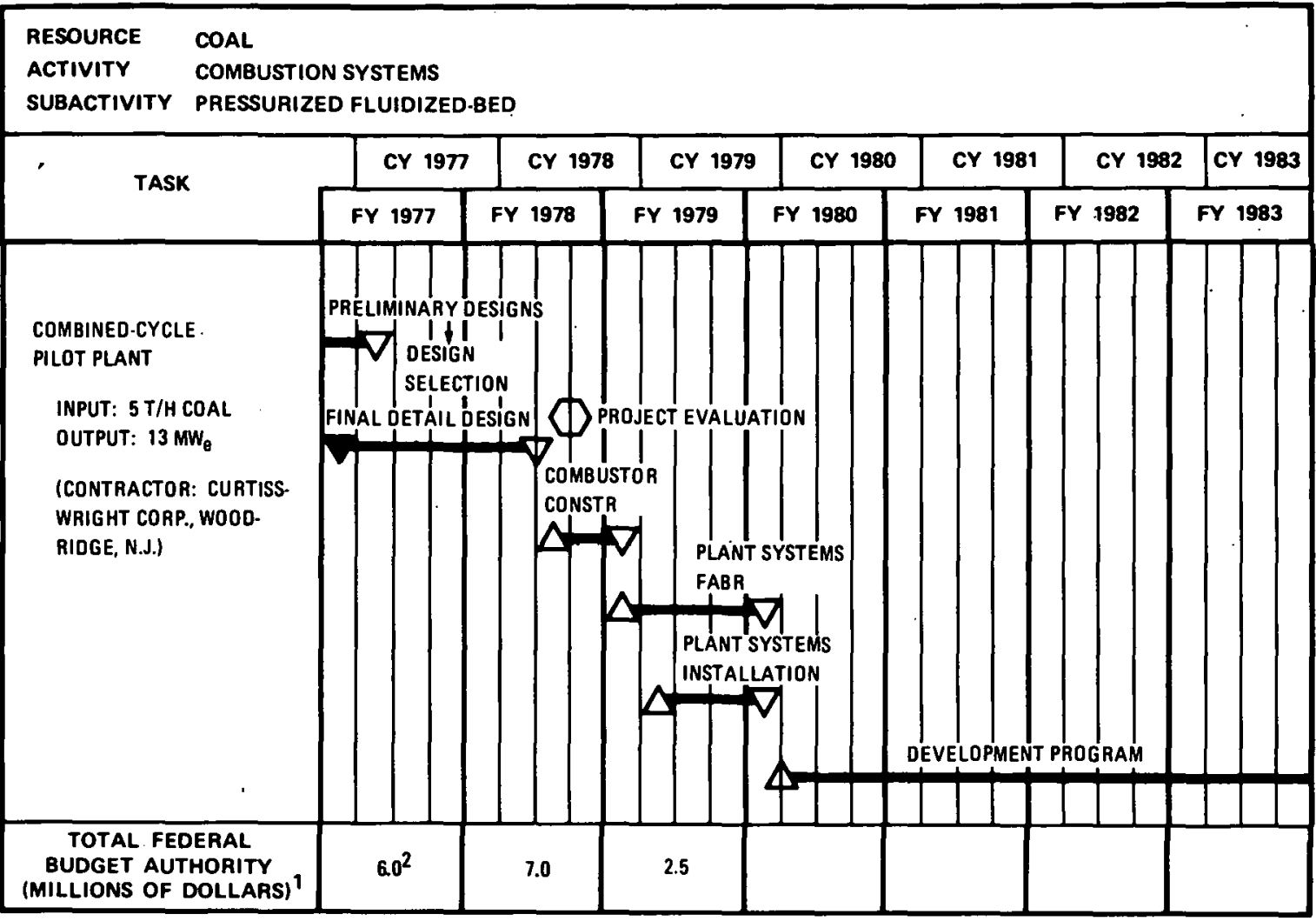

MILESTONE SYMBOLS ARE DEFINED ON LAST PAGE OF THIS DOCUMENT 1FURTHER BUDGET DETAILS ARE PROVIDEO IN SECTION 6.0.

2DOES NOT INCLUDE PFB TECHNOLOGY STUDIES.

\subsection{PFB COMPONENT TEST AND INTEGRATION UNIT}

In May 1975, Argonne National Laboratory (ANL) completed a conceptual design of a 3-MWe Component. Test and Integration Unit that was intended to support the PFBC development program by providing the flexibility to investigate alternative and advanced concepts of $\mathrm{PFBC}$ and to allow testing of components, instrumentation, and materials on a scale that is large enough to utilize commercial-scale equipment yet small enough to allow rapid modification of equipment and operating conditions. The CTIU will provide combustion, emissions, and sorbent performance data on a scale large enough to be meaningful for industrial decisions.

Specifically, the PFBC/CTIU is to provide the capability for research in the following areas:

- Evaluation of the technical feasibility of the proposed operating conditions for the larger-scale pilnt plant(s)

- Investigation of the ability of gas-cleaning devices to reduce particulate and corrosive-impurity loadings in the combustor offgas to levels that are consistent with requirements for satisfactory gas turbine operation and sufficient to meet the EPA particulate emission standard 
- Assessment of potential erosion, corrosion, and fouling problems of gas turbine components caused by constituents in the off-gas of a PFBC unit

- Evaluation of an additive regeneration scheme that will be incorporated into the $\mathrm{PFBC} / \mathrm{PDF}$ if the results of smaller scale experiments indicate that this process step is ready for scaleup

- Investigation of alternative PFBC second-generation system concepts.

Stearns Roger Corporation of Denver, Colorado, is currently working on the final plant definition.

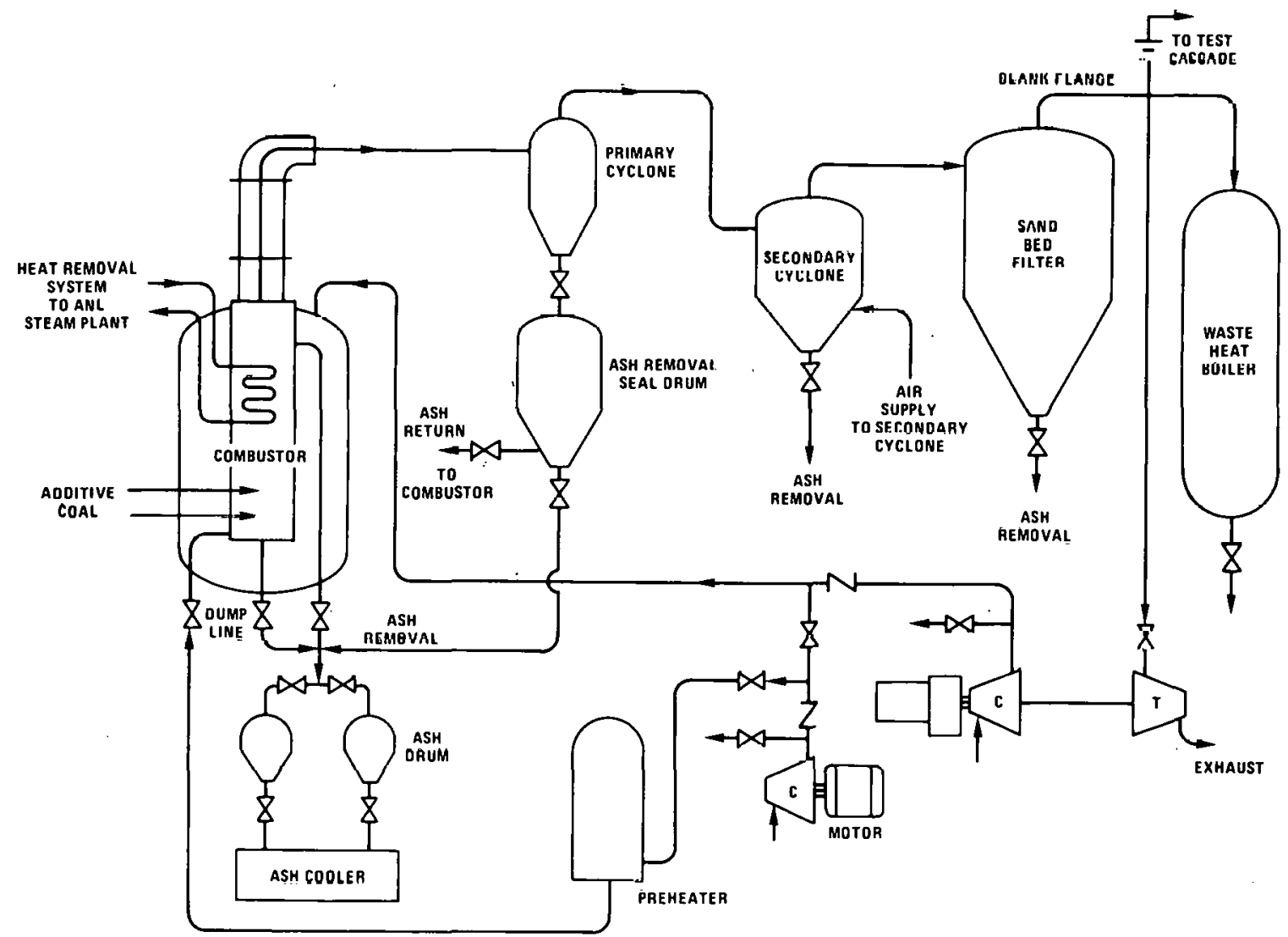

\section{Pressurized Fluidized-Bed Component Test and Integration I/nit (PFB/CTIU)}

\section{Project Status}

In April 1976, ERDA gave approval to ANL to proceed with the CTIU conceptual design, which will serve to test components and support the pilot plant, and will be translated into a detail design by a competitively selected architect/engineer. Following design, the facility will be constructed starting in FY 1979 with initial operations starting in early FY 1982 . 


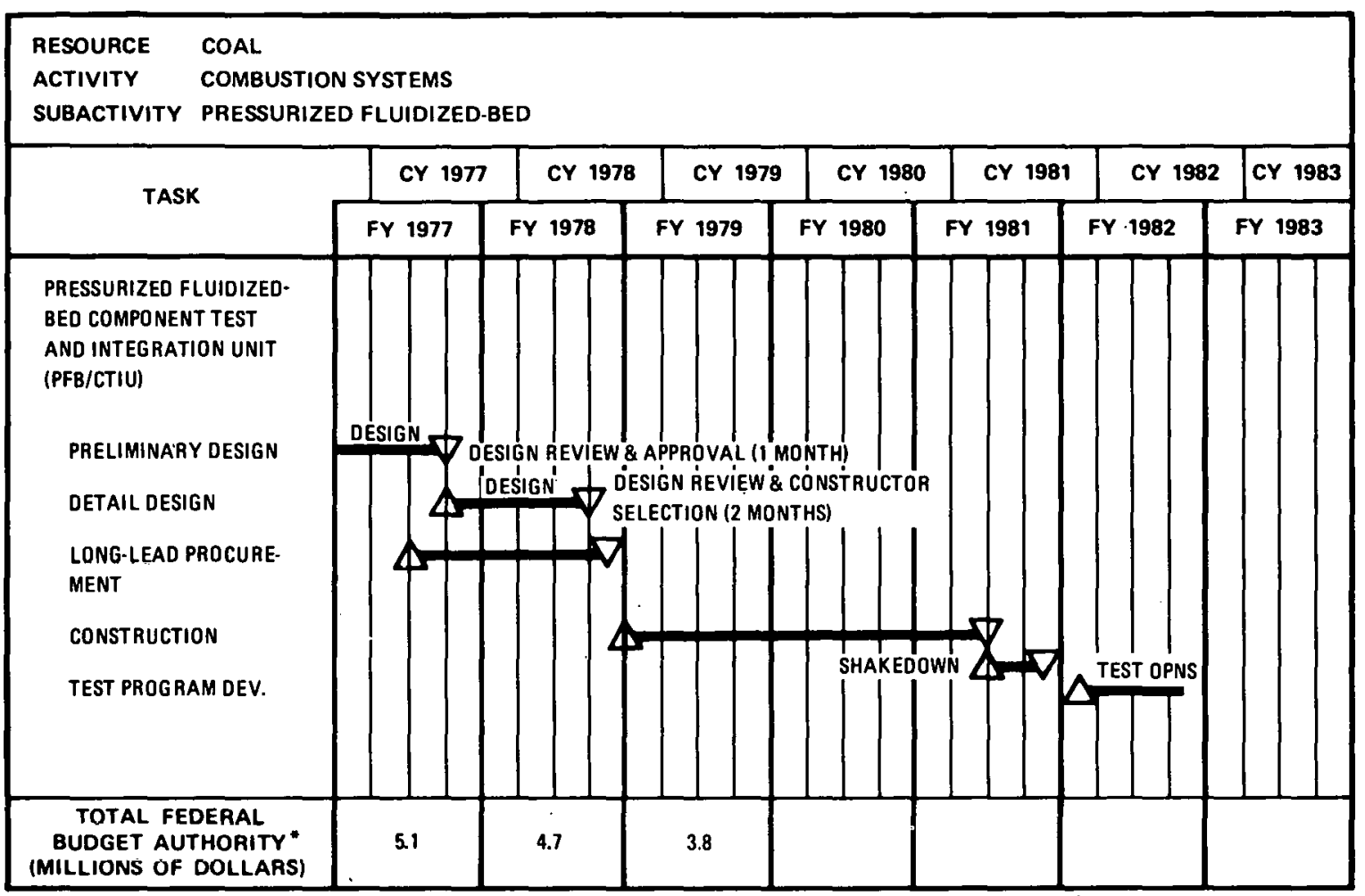

MILESTONE SYMBOLS ARE DEFINED ON LAST PAGE OF THIS DOCUMENT

"FURTHER BUDGET DETAILS ARE PROVIDED IN SECTION 6.0.

\subsection{HOT-GÁS CLEANUP}

In FY 1977, a contract was awarded to the Combustion Power Company to determine the scientific and engineering principles upon which granularbed filtration operates. The first phase of this program will develop the theoretical analysis of the moving-bed filtration process and perform verification testing at ambient temperature.

\section{Project Status}

In January 1977, the Combustion Power Company initiated a 12-month program to develop the following:

- Theoretical analysis, mathematical model development, computer simulation and test data correlation

- Design and construction of a cold-flow Moving-Bed Granular-Bed Filter Device (GBF)

- Design and implementation of a GBF test program

- Determination of filter scrèen deposition mechanisms, test and evaluation of various mechanical deposit removal devices. 
Following successful completion of the cold-flow model and the front face cleaning for GBF, the program will proceed with design and construction of a high pressure, high temperature granular-bed filter, to correlate the mathematical model with experimental data and to evaluate GBF performance under long-duration testing.

\subsection{INTERNATIONAL ENERGY AGENCY}

As part of the activities of the International Energy Agency (IEA), consisting of a joint effort by the United Kingdom, the Federal Republic of Germany, and the United States, a combustion test facility for the development of the pressurized fluidized-bed combustor will be constructed in Grimethorpe, United Kingdom. As shown in the following milestone chart, the facility will be started in FY 1977 and be completed hy FY 1979. See Chapter VII for further details. The unit will be used to obtain detailed data on the PFB combustion process in equinment large enough to apply to utility systems. Such data will include profiles of fluidization, bed-mixing, coal injection, combustion and sorbent kinetics, particle and alkali elutriation, and associated information necessary to enginoer rcliable utility systems.

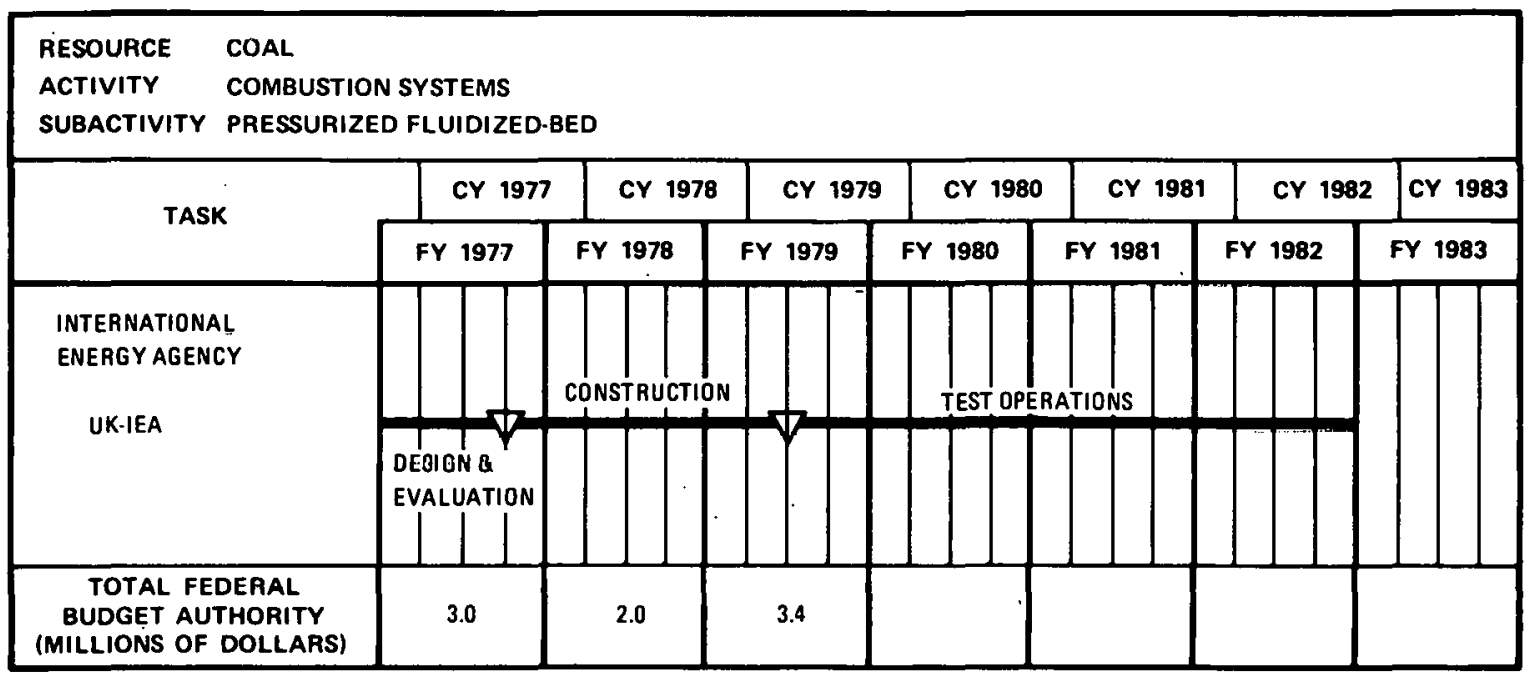

MILESTONE SYMBOLS ARE DEFINED ON LAST PAGE OF THIS DOCUMENT

\subsection{ADVANCED COMBUSTION TECHNOLOGY}

Tasks under this subactivity are:

- Engine Combustion Technology

- Improved oil and gas burners

- Coal Combustion Support.

The present gencration of production engines evolved during a period of relatively inexpensive petroleum-derived fuels when performance rather than efficiency or emission constraints governed their development. As a result neither the engines themselves nor the design techniques by which they have been incrementally improved are readily adapted to emerging 
requirements in terms of efficiency, emissions, and broadened fuel tolerance. While there have been advances in the past few years with an introduction of stratified charge, and lean-burn engines, only a fraction of the 20 to 30 percent efficiency improvements inherent in these concepts have been obtained. In cooperation with industry, investigations are currently being conducted on prototype design concepts for a generation of engines specifically tailored for realizing these potentials in different engine classes.

Present industrial design practices for furnaces and boilers are based on experience with specific equipment and are, to a large extent, empirical. The requirements imposed by conserving fuel and protecting the environment present manufacturers with a need to develop, test, and verify scientifically new ways of designing and operating boilers and furnaces. This R\&D effort is concerned with the evaluation and the development of combustion technology for boilers and furnaces in residential, commercial, and industrial use. Such technology development should improve the efficiencies, controls, and heat transfer and fuel utilization properties of boilers and furnaces.

Laboratory and design studies now in progress support the direct coal combustion development projects. These studies are designed to promote optimum coal utilization by supplying data essential for application of direct combustion units to public utility and industrial systems. Key components of the total system, including processing, handling, and transport equipment, will be considered in the context of operability and design optimization. Component corrosion and fouling studies will be made and methods will be developed for minimizing these problems.

\subsection{ENGINE COMBUSTION TECHNOLOGY}

This task supports the development of advanced combustion technology nesessary to increase fuel efficiency, control emissions, and broaden the range of useable fuels for automotive and stationary engines. The approach is to apply the advanced research capabilities of the DOE multi-purpose laboratories, the universities and selected private $R \& D$ laboratories to the solution of critical problems in engine systems under advanced development in industry. The effort is directed primarily toward four engine classes: (a) direct injected stratified charge, (b) lean-burn homogeneous charge, (c) diesel, and (d) gas turbines. The subtasks complement traditional engineering research in industry and involve major industry participation. Relevance and technology transfer to the manufacturers development laboratories are accomplished by their direct involvement in program definition, execution, and review. Research results from this task have immediate impact on industry design commitments for their near-term developments and will accelerate the energy savings to be achieved with these engine design concepts. 


\section{Project Status}

Accomplishments in FY 1977 and FY 1978:

- Conducted cooperative research program in direct injected stratified charge (DISC) engines involving Sandia, Lawrence Livermore Laboratory (LLL), Los Alamos Scientific Laboratory (LASL), Princeton University, and General Motors Research Laboratories. Generated noncombusting model of DISC engine aerodynamics

- Demonstrated stratified-charge diagnostic systems using combustion bomb facility loaned to Sandia by Volkswagon Research as part of international cooperative program

- Received cooperative financial support from the Motor Vehicless Manufacturing Association (MVMA) for engine combustion technology program and thus formulated MVMA engine combustion research review committee representing all of the auto industry

- Organized joint engine research program, through IEA, with US, UK, and Sweden participation. Staff exchange has occurred between Sandia (US) and Harwell (UK) laboratories to accelerate technology sharing

- Initiated major cooperative research program in direct combustion aimed at identifying and controlling particulate formation, noise, and carcinogenic aromatic hydrocarbon emissions.

Expected accomplishments in FY 1979 and FY 1980:

- Develop a 2-dimensional working model of DISC engine operation capable of providing simple engineering design tradeoff calculations

- Demonstrate enhanced combustion in lean-burn homogeneous charge engines

- Demonstrate improved injection for diesels

- Complete catalytic combustion characterization for continuous combustion systems 


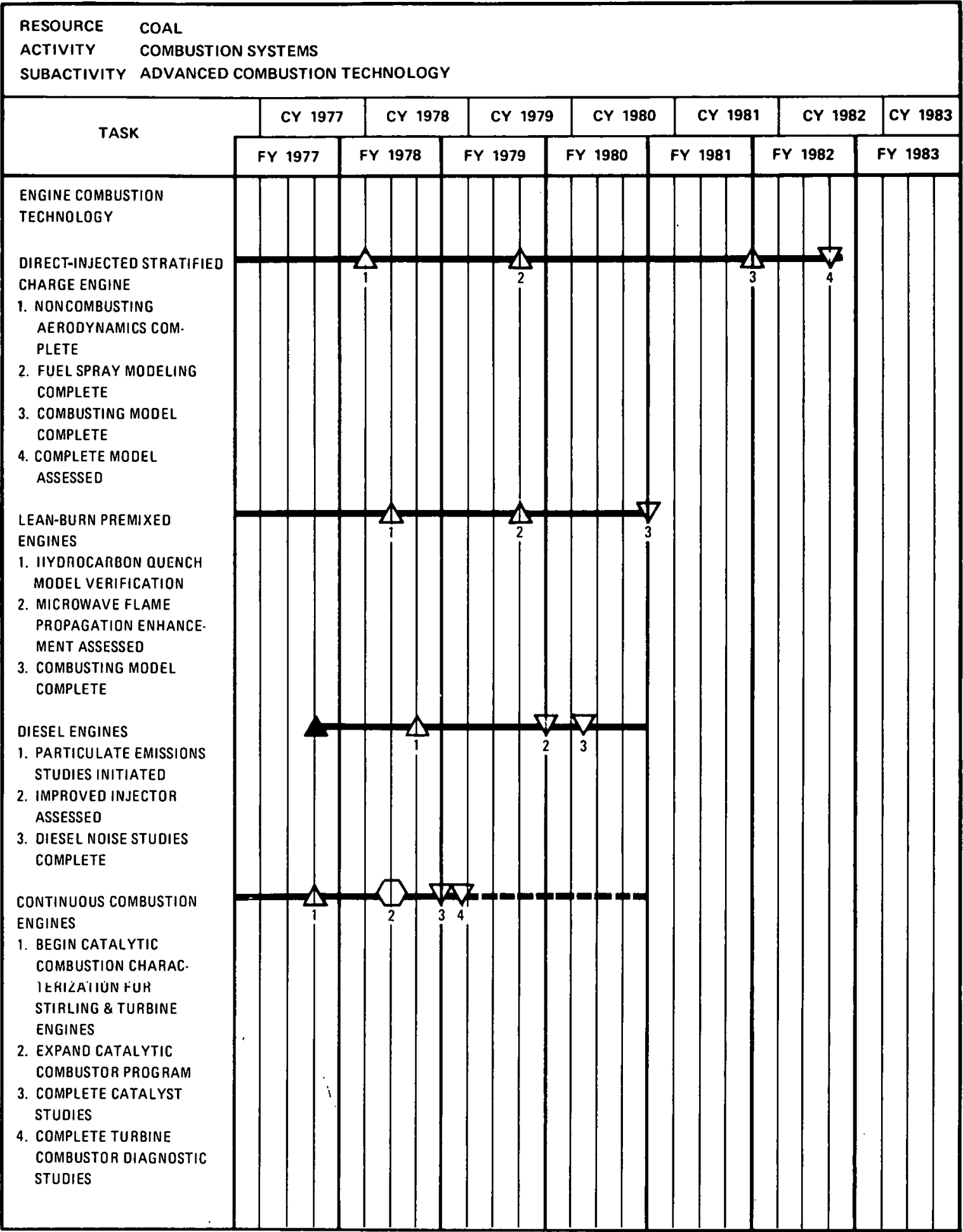

MILESTONE SYMBOLS ARE DEFINED ON LAST PAGE OF THIS DOCUMENT 


\subsection{IMPROVED OIL AND GAS BURNERS}

The overall objective of this project is to improve the utilization of gas and oil by modification (including retrofit) of the combustion equipment and processes. Of particular importance is the ability to provide means for switching to more readily available fuels (e.g., low-Btu gases for natural gas), and to improve the efficiency of boilers and furnaces burning lowgrade residual oils so that they will be capable of burning the synthetic fuels of the future cleanly and efficiently.

\section{Project Status}

This project was started in the second quarter of FY 1977, so it is still largely in the planning stages. The following efforts will be made in FY 1979:

- Pulse-combustor designs, offering great promise for residential heating (but currently unacceptable for that purpose), will be improved

- Scaling criteria for oil and gas furnaces, leading to more confident transfer of information from small scale to boiler design, will be evaluated

- The design of boiler components (e.g., atomizers) will be evaluated with the goal of achieving minimum excess-air operation consistent with clean exhaust requirements .

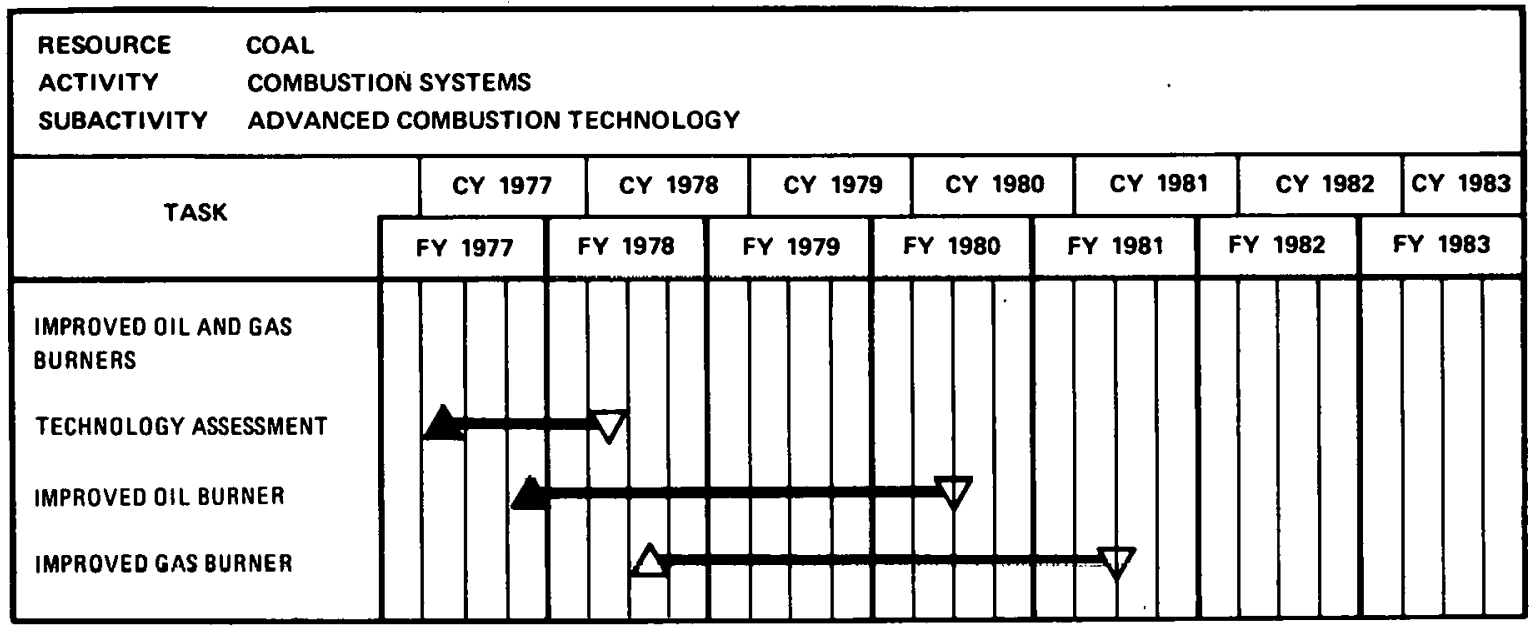

MILESTONE SYMBOLS ARE DEFINED ON LAST PAGE OF THIS DOCUMENT

\subsection{COAL COMBUSTION SUPPORT AND ENGINEERING EVALUATIONS}

Laboratory and design studies now in progress which support the combustion systems development projects are designed to promote optimum coal utilization by supplying data essential for application of direct combustion units to public utility and industrial systems. 
Key components of the total system, including processing, handling, and transport equipment will be considered in the context of operability and design optimization. Component corrosion and fouling studies are being made, and methods will be developed for minimizing these problems. Optimum design of combustors capable of efficiently burning synthetic fuels will be promoted by characterizing fuels such as chars, coal wastes, low-Btu gas, solvent refined coal, and synthetic liquid fuels in terms of heat transfer and combustion properties.

The table below summarizes the funding levels for this task for the FY 1977 to FY 1979 period.

\begin{tabular}{|c|c|c|c|c|c|}
\hline \multirow{2}{*}{$\begin{array}{l}\text { COAL COMBUSTION SUPPORT } \\
\text { AND ENGINEERING EVALUATIONS } \\
\text { TASKS }\end{array}$} & \multicolumn{4}{|c|}{$\begin{array}{l}\text { BUDGET AUTHORITY } \\
\text { (OPERATING EXPENSES) } \\
\text { (DOLLARS IN THOUSANDS) }\end{array}$} & \multirow{2}{*}{$\begin{array}{l}\text { MAJOR } \\
\text { CHANGE* }\end{array}$} \\
\hline & $\begin{array}{l}\text { ACTUAL } \\
\text { FY } 1977\end{array}$ & $\begin{array}{c}\text { APPROPRIATION } \\
\text { FY } 1978\end{array}$ & $\begin{array}{c}\text { ESTIMATE } \\
\text { FY } 1979\end{array}$ & $\begin{array}{l}\text { INCREASE } \\
\text { (DECREASE) }\end{array}$ & \\
\hline $\begin{array}{l}\text { Engineering Studies } \\
\text { Nonffluidized-Bed Combustion } \\
\text { Regeneration } \\
\text { Environmental Studies \& Other } \\
\text { Support }\end{array}$ & $\begin{array}{r}\$, 5,101 \\
1,500 \\
0 \\
2,635\end{array}$ & $\begin{array}{r}\$ 4,471 \\
4,000 \\
0 \\
2,000\end{array}$ & $\begin{array}{r}\$ 2,887 \\
545 \\
563 \\
\\
3,455\end{array}$ & $\begin{array}{r}\$ \cdot 1,584 \\
-3,455 \\
+563 \\
+1,455\end{array}$ & \multirow[t]{2}{*}{$\begin{array}{l}\text { I } \\
\text { A }\end{array}$} \\
\hline TOTAL & $\$ 9,236$ & $\$ 10,471$ & $\$ 7,450$ & $\$-3,021$ & \\
\hline \multicolumn{3}{|c|}{$\begin{array}{l}{ }^{*} K E Y \\
N=\text { New start (totally new project) } \\
S=\text { Scaleup (from bench to PDU or pilot plant) } \\
A=\text { Acceleration (shortening deadlines or } \\
\quad \text { expansion of ongoing projects) }\end{array}$} & \multicolumn{3}{|c|}{$\begin{array}{l}P=\text { Phase completion or startup } \\
R=\text { Program redirection } \\
I=\text { Incremental cost requirement } \\
C=\text { Project completion or suspension }\end{array}$} \\
\hline
\end{tabular}

Studies currently under way in the support studies and engineering evaluations area include:

- $\quad$ Engineering Support Studies

- Nonfluidized-Bed Combustion

- Environmental Studies and Supporting Projects.

\section{Engineering Support Studies}

Laboratory studies, feasibility studies, and systems analysis support development projects for atmospheric and pressurized fluidized-bed coal combustion are being conducted. Problems of regeneration, waste disposal, and emission control are also being addressed. An analytical model of the elemental processes of such combustors will be developed and experimentally verified. This model will assist design optimization of fluidized-bed combustors for advanced conversion systems. 


\section{Nonfluidized-Bed Combustion}

The objective of this effort is to demonstrate the commercial feasibility of utilizing direct substitution of coal, coal-derived chars, and solvent refined coal for oil and gas in existing industrial processes. This is expected to involve minor modification of the burners and combustion chambers and the addition of necessary fly-ash collection equipment. Federal participation is required due to the high costs and risks associated with the development of improved technologies and to ensure wide dissemination of the demonstrated technology. The program will be costshared with industry in the construction and operation phases. areas:

The program as envisioned to date is divided into the following major

- Direct sulustitutioni of cual for short. sunply fliels

- Increased utility boiler reliability and efficiency

- American Boiler Manufacturers Association industrial stoker program

- In-house, solid fuel combustion research.

\section{Regeneration}

ANL will initiate regeneration process development studies in FY 1979. For combustion-regeneration studies, ANL has a 6-inch-diameter cumbustion and 4-inch-diameter regeneration process development units as well as laboratory-scale equipment for supportive studies. The combustor can be operated at bed temperatures up to $950^{\circ} \mathrm{C}$ and pressures up to 10 atmospheres. The regenerator can be operated at $1100^{\circ} \mathrm{C}$ and 10 atmospheres.

\section{Environmental Studies and Supporting Projects}

Environmental studies is a newly defined effort to support gencric studies applicable to many or all direst combustion projects and to provide support to new project. starts. Such studies will consist of, but are not limited to, envirommental assessments, process emissions, and effluent characteristics.

Special projects include process ecnnomic evaluations; interprogram trade-off analysis; new technology development (coal preparation, pretreatments, gas cleanup, coal feeder, ash disposal); process design and analysis for overall process optimization; and process reliability and maintainability . 
Other support includes efforts to assist with detailed technical support of project planning, monitoring, and evaluation, and the development and integration of R\&D technical programs. The support services include assistance in developing and supporting technically sound and economically defensible programs.

Some specific projects within the area of support studies include:

Evaluation of Flue Gas Desulfurization (FGD) in the Unitec States - FY $\underline{1977}$

This study is being performed by the Tennessee Valley Authority to assess the latest available technology on FGD for utility application.

Particulate Analysis Instrumentation

Leeds \& Northrup Co. and Spectron Development Laboratory are developing an on-line instrument for measuring particulate loadings and particle size distribution in high-temperature pressurized gas streams for application to PFBC.

Stoker-Fired Boiler Testing Program

A testing program to obtain basic data on emissions and to update equipment specifications and design criteria for stoker-fired boilers has been undertaken by the American Boiler Manufacturers Association. This contract is jointly funded by DOE and EPA.

Utilization of Fluidized-Bed Combustion Bed Material: Remedial Treatment of Soils

Since FY 1971, the Federal Highway Administration has engaged in a continuing research project titled "Use of Waste as Material for Highways." Since August 1, 1976, as a part of this project, FBC wastes have been mixed with fine-grain soil samples collected from various geographic areas. This is being done to determine whether the use of this waste material could eliminate or curtail the use of Portland cement for stabilizing finegrain soils when they are tlie sublbase for highways.

$\underline{\text { Agronomic Evaluation of Fluidized-Bed Boiler Waste Material }}$

The project continues studies that have been done for the past year on the use of atmospheric fluidized-bed combustion waste bed material as a nutrient and as a source of lime for the neutralizing of acid soils. It also 
expands its previous scope to determine whether the utilization of the waste on peanut crops in Alabama will give similar benefits to those obtained where different soil and climatic conditions exist. It proposes also to determine the maximum nontoxic loading rates of the waste for various soils and crops.

Utilization of Fluidized-Bed Combustion Bed Material Soil-Plant Nutrient Plant Nutrient Relationship in Peanuts

The project continues studies that have been done for the past three years on the use of atmospheric fluidized-bed combustion waste bed material as a nutrient source of calcium for peanut crops in Virginia. The previous studies have shown that the application of this waste material in increasing the crop yield was almost as effective as the application of a commercially procured calcium source.

Agricultural Utilization Studies: Fluidized-Bed Combustion Waste Materials

Working through the Agricultural Research Service (ARS), U.S. Department of Agriculture, DOE will study the utilization of waste material from the fluidized-bed combustion process. ARS will perform greenhouse and growth chamber testing at selected agricultural experiment stations. Where indicated, field tests of FBC waste material will be conducted to determine its effects on land reclamation, forage, plant growth response, and soil conditioning.

Nonagricultural Utilization Studies: Fluidized-Bed Combustion Waste Materials

A comprehensive program involving both laboratory and field demonstration activities has been initiated to evaluate nonagricultural utilization of fluidized-bed combustion waste materials. Applications include use of the material in flue gas desulfurization, water and seweragc treatment, highway subsoil stabilization, acid mine drainage neutralization, and cementitious mixtures.

Pressurized Fluidized-Bed Coal-Fired Combined Cycle Development Project (CFCC) (General Electric Company)

The coal-fired combined-cycle design is the particular version of a combined steam and gas power plant cycle, utilizing a pressurized fluidized-bed combustor burning coal. The CFCC approach provides cooling of the fluid bed combustor through use of steam tubes in the bed, which supply a steam turbine generator. The partially cooled combustion gases existing from the combustor drive a gas turbine generator after passing through a hot-gas cleanup train. This approach has been evaluated, beginning in January 1974, by a study team including representatives from General Electric, Foster-Wheeler, Exxon, and Combustion Systems Limited. Based on these previous studies and recent confirming work, General Electric believes that the CFCC approach offers important advantages over alternate approaches including: higher powerplant efficiency in the range of interest, reduced corrosion potentials due to low fluid bed tube temperature, and reduced hot-gas cleanup flow rate. 
Evaluation of a Pressurized Fluidized-Bed Combustion Combined-Cycle Power Plant (Burns \& Roe Industrial Services Corporation)

The project will provide an evaluation of a coal-fired combined-cycle power plant conceptual design using a pressurized fluidized-bed combustor air heater cycle with a unique supplemental fired atmospheric fluidized-bed heat recovery boiler for obtaining high efficiency .

Improvement in the above cycle can be achieved by reheating the gas turbine effluent in a PFB or by additional heating of the gas turbine effluent in the atmospheric pressure fluidized-bed heat recovery boiler with supplemental coal firing. Increases in turbine inlet temperatures by utilizing multiple PFB arrangements with ash removal prior to the gas turbine give promise of additional efficiency gains. This technology is applicable to fluidized-beds firing coal with limestone and dolomite and is enhanced by utilizing air as the cooling medium in the fluidized-bed. The use of the pressurized fluidized-bed with an atmospheric fluidized-bed (with steam cooling) and a variable firing rate gives the cycle a load following capability which cannot easily be met by steam cooled fluidizedbed or other fluidized-bed alternates. The ability to achieve high efficiencies at a wide load spectrum appears to be unique to this technology.

Pressurized Fluidized-Bed Combustion (British Coal Utilization Research Association (BCURA) Leatherhead, England)

Between August 1972 and June 1975, BCURA Ltd. carried out a series of five tests for ERDA (now DOE) and the then Office of Coal Research on the pressurized fluidized-bed combustor at Leatherhead, England. The original scope of work has now been extended to investigate the effect on (1) fouling erosion and corrosion of a static cascade of turbine blades and of target rods, (2) $\mathrm{SO}_{2}, \mathrm{NOx}$ and alkali emissions, and (3) behavior of operating a deep bed $(8 \mathrm{ft}$ ) at fluidizing velocities of 2.5 and $7 \mathrm{ft} / \mathrm{sec}$ and a combustor pressure of $6 \mathrm{~atm}$ absolute. The unit was modified during FY 1976, and testing has taken place during FY 1977. Additional tests are being run in FY 1978 in support of prospective industrial demonstration plants.

For the Environmental Protection Agency, an extra program of analysis is being carried out on at least one of the test runs, aimed at detailed characterization of the effluents from pressurized fluidized-bed combustion. The extra analytical program is carried out through the DOE contract with workscope extension agreed with EPA.

Atmospheric Fluidized-Bed Combustion: Bench-Scale Studies (Morgantown Energy Research Center)

The MERC bench-scale atmospheric pressure fluidized-bed combustion (FBC) facilities will be operated to: (1) define operating characteristics of anthracite mining and cleaning wastes in FBC in sufficient detail to design a fluidized-bed boiler for commercial demonstration in the anthracite mining region; (2) evaluate other low-quality fuels such as bituminous and lignite wastes, oil shales, high-ash chars as fuels for FBC in detail for the definition of operating characteristics; (3) examine the effects of input coal 
composition and operating parameters on emission of sulfur oxides, nitrogen oxides, carbon monoxide, hydrocarbons and trace metals as they relate to environmental and process considerations; (4) study heat transfer, bubble formation, sulfur sorbents, etc., in support of DOEsponsored modelling and development programs; and (5) study advanced heat transfer concepts for power cycles utilizing the FBC as the heat source.

The program tasks will be carried out in two 18-inch combustors. One unit will be used to continue the testing of low-quality fuels, including Texas lignites, for fouling behavior. The second combustor will be used to study fluidized-bed chemistry and fluid dynamics as they affect combustion efficiency, heat transfer and sulfur sorbent utilization.

Western Coals Utilization (Grand Forks Energy Research Center)

The GFERC support studies are aimed at developing improved technology for direct-firing western coals in an environmentally acceptable manner. Ongoing goals include; (1) to develon improved methnds for using alkaline coal ash as a reagent for wet scrubbing and for disposal or use of the waste produced; (2) to determine the extent of sulfur retention on coal ash during fluidized-bed combustion; and (3) to develop design information for electrostatic precipitators for removing high-resistivity western fly-ash from stack gases.

The 120-scfm pilot scrubber at GFERC will continue to be used to evaluate a wide variety of fly-ashes. Alkali availability, $\mathrm{SO}_{2}$ removal efficiencies, and scaling rates will continue to be investigated.

The 6-inch fluidized-bed combustor will continue to be used to survey retention characteristics of western ashes produced by FBC. Variables are ash analysis, bed temperature, and residence time in the bed, with and without ash reinjection. Plans will be laid for scaleup of FBC for western U.S. coals .

Pressurized Fluidized-Bed Combustion: Bench-Scale Studies (Argonne National Laboratory)

These ongoing studies support the development program for atmospheric and pressurized fluidized-bed coal combustion. Laboratory and bench-scale studies aimed at providing needed information on combustion optimization, regeneration process development, solid waste disposal, synthetic $\mathrm{SO}_{2}$-sorbent studies, emission control, and other tasks are included. Characterization of a variety of limestones and dolomites 
from various parts of the country for suitability in fluidized-bed combustors is also included. Reduction in solid waste volumes to reduce the environmental impact of the waste-sulfated limestone is one of the major goals of this program. These studies are designed to supply data essential for the application of fluidized-bed combustion units to public utility and industrial systems.

\subsection{ALTERNATE FUEL UTILIZATION}

Tasks currently under way in this subactivity are:

- Coal-oil mixtures

- Alternate fuel combustion

- Coal-bed methane utilization.

The combustion of coal-oil mixtures in combustors traditionally fired with oil offer a near-term opportunity for extending fuel oil resources.

The goal of the Alternate Fuel Combustion task is to provide the fuels technology to assist the timely switching from premium fuel (petroleum and natural gas) to alternatives. This will be accomplished by developing the combustion technology for fuel specification and combustion equipment design and operation. Two groups of fuels are being addressed (1) agricultural and forest residues and industrial wastes (RW) and, (2) principal alternate fuels (PAF) derived from coal and shale. (Municipal and urban wastes utilization are excluded as they are covered by other DOE divisions.)

Methane contained in coal beds is a resource which can significantly augment our supply of pipeline gas. The total resource is estimated to be 800 Quads of which 300 Quads are recoverable. Because of variation in Btu content of the coal-bed gas, variations in well flow rate and local energy requirements, development and demonstration of a mix of recovery/utilization options is required for successful commercialization. The total program involves coordinated tasks in several DOE divisions. This present task addresses the candidate utilization technologies which include on-site power generation, on-site heating for mining operations, LNG and ammonia production.

\subsection{COAL-OIL MIXTURES}

The objectives of this task are to modify or retrofit, operate, and test existing boilers, heaters and furnaces to demonstrate combustion technology and practicability of burning cnal-oil mixtures. Combustion of coal-oil mixtures in existing oil-fired combustors will be investigated to determine the extent to which this retrofit technology can be implemented practically. The goal is to substitute coal for an appreciable fraction of oil in appropriate industrial and utility combustors within the near-term. 


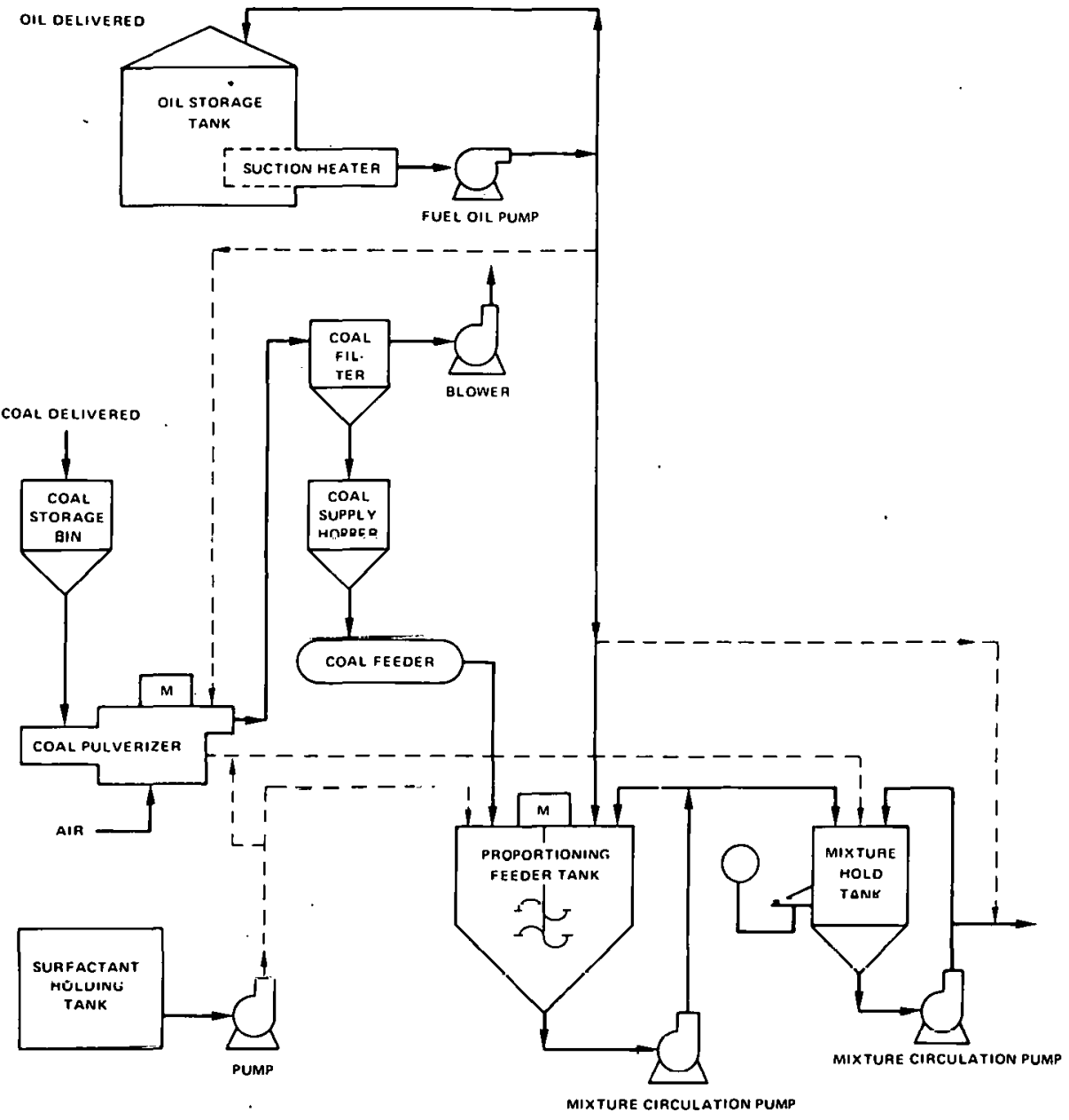

Coal-Oil Mixture Combustion

\section{Project Status}

Three contractors have been selected to apply coal-oil mixture (COM) combustion technology to modified/retrofit existing equipment beginning in early FY 1977. The selected contractors and their project completion datus are:

New England Power Co. Salem, Massachusetts

Acurex Aerotherm Mountainview, California (Site: Danville, Virginia, plant of Lorillard Tobacco Co.)
Coal-Oil Mixture Combustion, Utility Stedm Generator, 80 MW, Originally Designed for Coal and Converted to Oil--Early FY 1980 Completion

Coal-Oil Mixture Combustion, Process Industrial Steam Generator, $80,000 \mathrm{lb} / \mathrm{hr}$ Steam, Originally Designed for Oil/Gas--Early FY 1980 Completion 
Interlake, Inc.

Chicago, Illinois
Coal-Oil Mixture Combustion, Blast Furnace--Early FY 1980 Completion

Also, a 700-hp combustion test facility using coal-oil mixture for combustion is under construction at Pittsburgh Energy Research Center (PERC) and should be completed in early FY 1978. Preliminary COM information has been and is presently being obtained from an existing 100hp firetube test unit at PERC. The objectives of the PERC projects are to develop in-house technical capability in coal-oil mixture technology and to supply direct technical support to the total coal-oil mixture combustion program.

Extensive test programs and detailed analyses will be performed as a portion of each project. In addition, marine application, mechanical emulsifier applications, and beneficiation techniques will be investigated. Finally, market/ economic evaluations of the program will begin in late FY 1977.

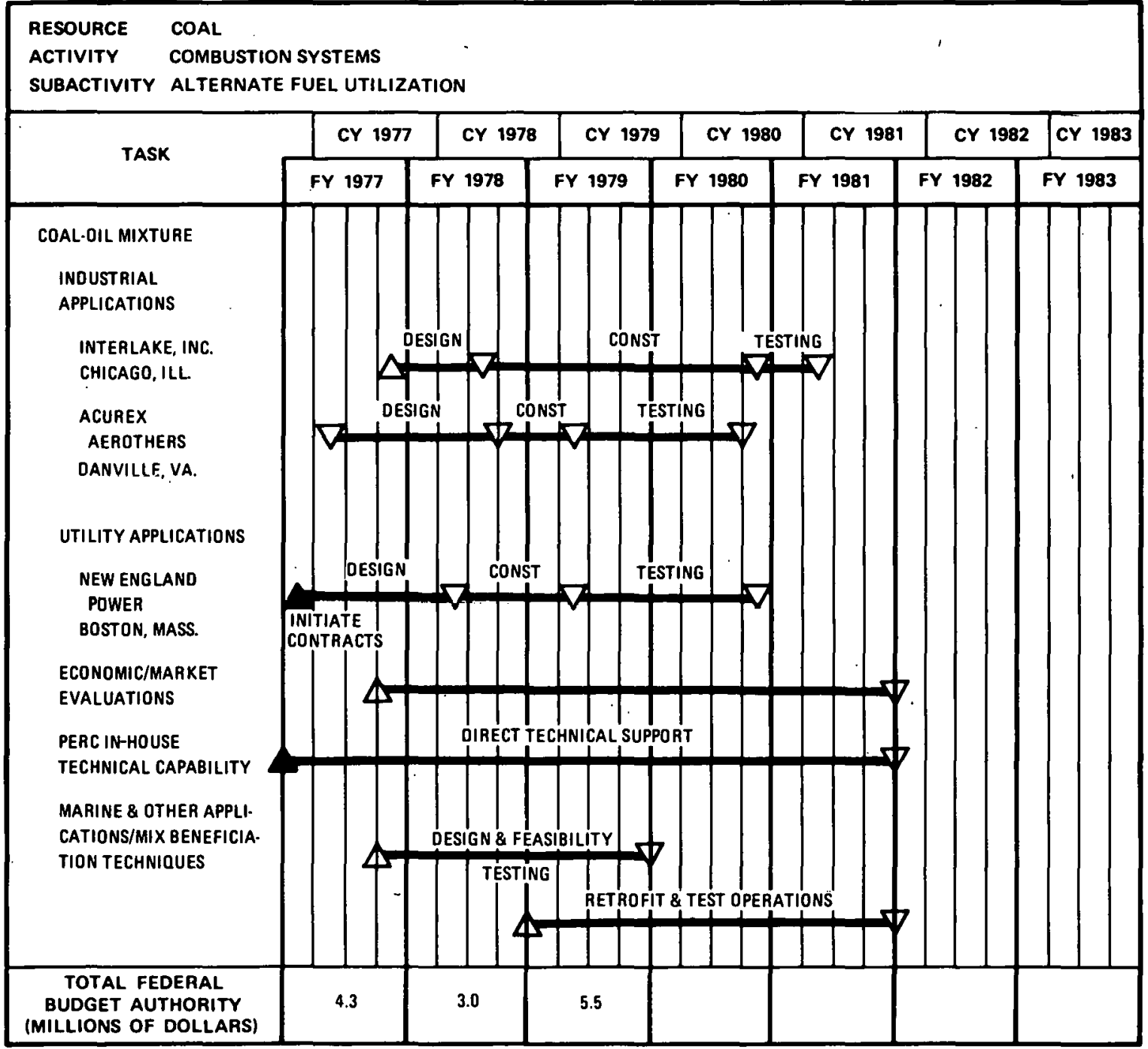

MILESTONE SYMBOLS ARE DEFINFN ON LAST PAGE OF THIS DOCUMENT 


\subsection{ALTERNATE FUEL COMBUSTION}

The objective of this task is the timely substitution of alternate fuels (other than direct coal combustion) for premium fuels. The task is divided into two subtasks: Residue Fuels (RW), including agricultural and forest residues and industrial wastes, and Principal Alternate Fuels (PAF), including coal derived liquids and more plentiful petroleum fractions.

\section{Residue Fuels Subtasks}

The potential fuels addressed by this subtask represent a renewable energy resource of well over 4 Quads/year, with less than 1 Quad/year currently utilized. Fuel transportation economics and site-specific energy requirements indicate attractive possibilities for small scale utilization for residential and industrial heating, oft-grid power generation, and limitcd dulumulive use. 'l'he subject area buids on a data base of current European efforts and, in this country, tec'nology developed mainly prior to 1940. The approach taken under this subtask is an assessment of present utilization opportunities and options, identification of critical technological barriers to expanded utilization, and prosecution of the appropriate RD\&D. Included under this subtask ?re; direct combustion, gasifier/conversion systems, and use of pyrolysis derived products. Major subtask elements are:
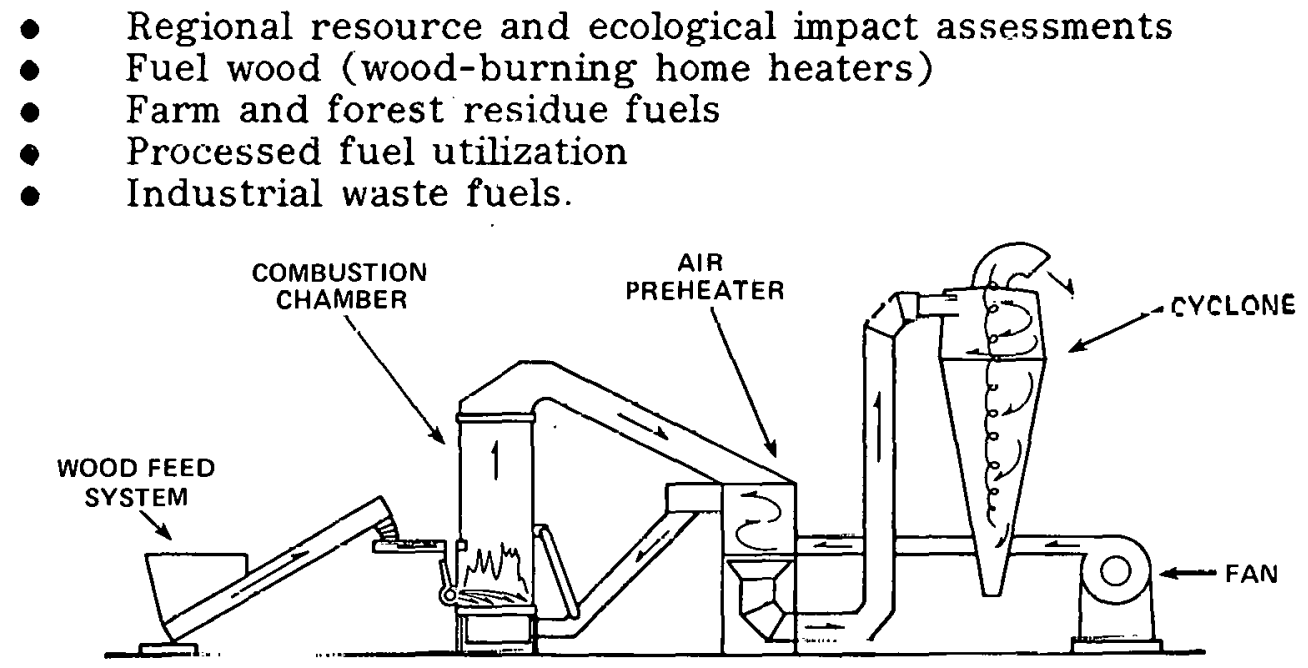

\section{Alternate Fuel Combustion Schematic of Wood-Fired Spreader-Stoker Burner}

\section{Project Status}

- Program plans were formulated and are partially implemented

- A fuel wood project was implemented. Preliminary tests on wood-fired home heaters have confirmed wide variations in performance with potential severe fire safety implications 
- A forest products residue project was implemented. Initial test results have demonstrated the potential for a 5 percent efficiency improvement with emissions reduction in wood residue fired industrial boilers in the Northwest

- Projects in on-site industrial waste combustion and turbine combustion of pyrolytically produced liquid-solid two phase fuels initiated

- Application and technology studies to scope the technology projects and priorities for small-scale agricultural residue gasifier-electrical power systems were completed

- An expanded program plan development was initiated to accelerate the subtask activities.

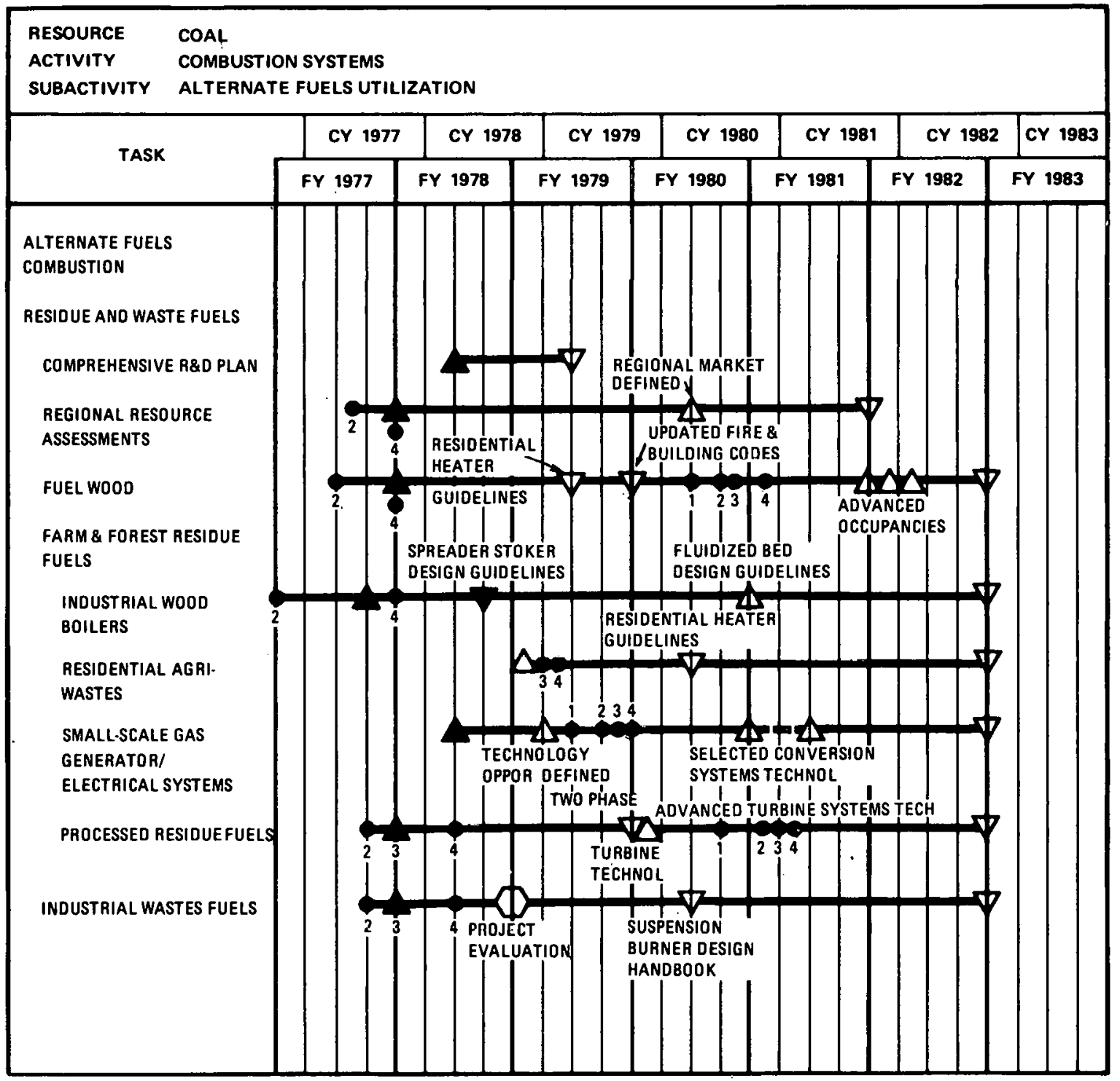

MILESTONE SYMBOLS ARE DEFINED ON LAST PAGE OF THIS DOCUMENT 


\section{Principal Alternate Fuels Subtasks}

The expanded use of minimally processed, heavier petroleum fractions offers an energy efficient strategy to significantly extend oil reserves while coal-derived liquids are leading candidates to furnish the bulk of our liquid fuel requirements after the mid-1990s. The resulting fuel stocks will have notably different characteristics than their petroleum based analogs and require significant energy consumption in processing prior to use in existing combustion equipment. The goal of this subtask is to provide the fuel combustion technology base required for the design of equipment capable of burning these fuels with a minimum of energy intensive processing, and thus allow an energy optimization of the fuel/combustion device system. The overall approach is to determine the relationship between the fundamental fuel composition and those combustion characteristics which are the necessary data for equipment design. The subtask is grouped into the following four elcments:

- Combustion characterization

- Quantification of combustion effects and kinetics

- Development of combustion models

- Emissions and environmental studies.

\section{Project Status}

This subtask was initiated in late FY 1977. Seven projects are currently under way, six in the area of combustion characterization and one in $\mathrm{NO}_{\mathrm{X}}$ emissions control techniques.

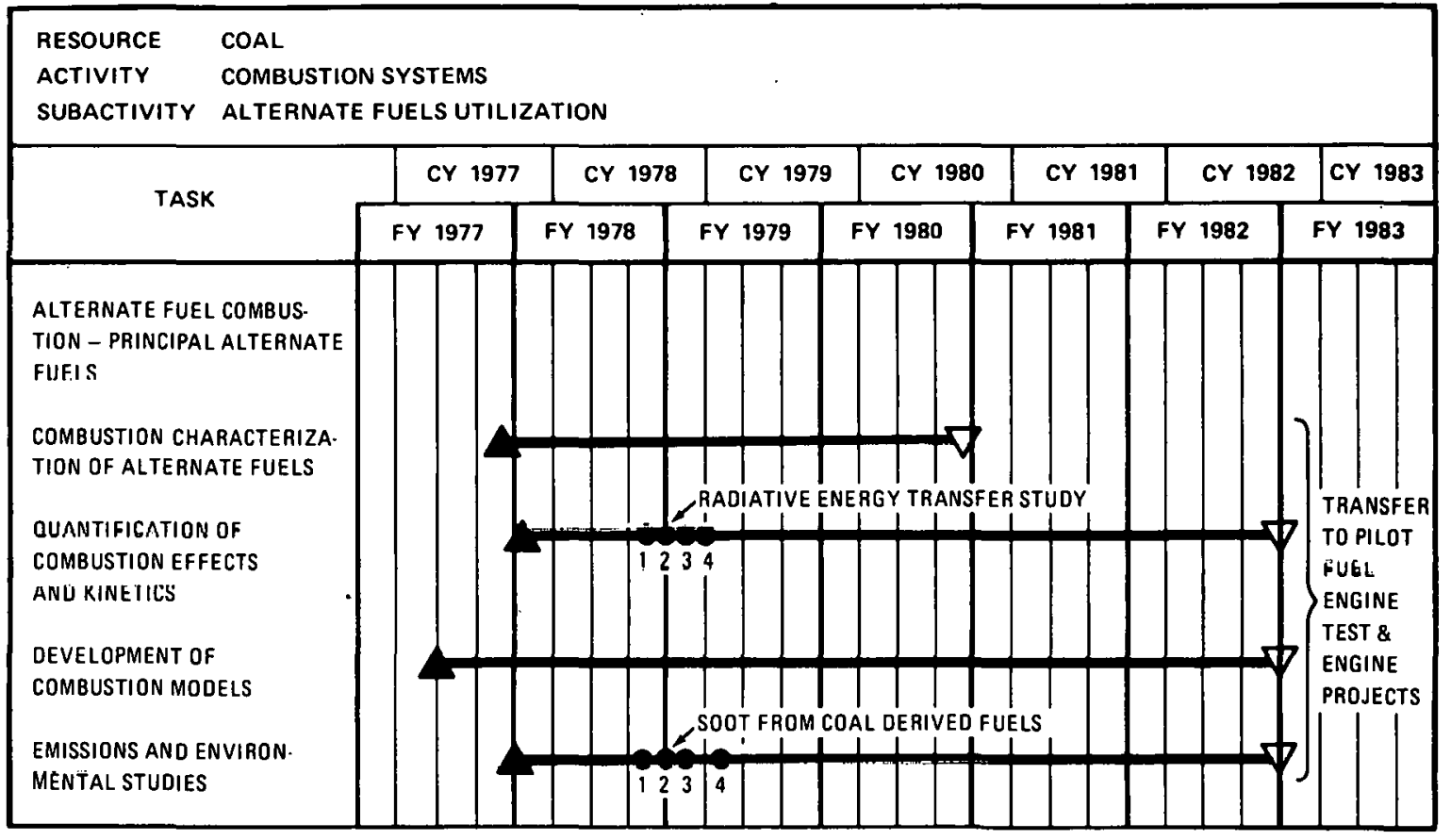

MILESTONE SYMBOLS ARE DEFINED ON LAST PAGE OF THIS DOCUMENT 


\subsection{COAL BED METHANE UTILIZATION}

During the natural process of coal formation, methane (the principal constituent of natural gas) is generated and trapped in the coal seam as well as the adjacent rock strata. All coal deposits contain methane although the concentrations vary from seam to seam and within the seam. The total magnitude of the U.S. coal-associated resource has been estimated at approximately 800 trillion cubic feet ( 800 Quads). Given current and conservatively projected economic and technological factors, the recovery of some 300 trillion cubic feet of this resource appears readily feasible. This is equal to a 10-to-12 year supply based on present consumption.

The shortage of natural gas during the winter of 1976-77 focused attention on the urgent requirement to utilize this energy resource. Safety considerations in active mines have led to much development work by the U.S. Bureau of Mines of techniques for methane removal. These techniques are now practiced by some mine operators with approximately 250 MMcfd of methane being emitted to the atmosphere. This gas is now being irretrievably wasted. The utilization of this valuable resource, including the methane available from "unminable" coal-beds, is the. objective of this task. The research, development, and demonstrations necessary for economical utilization are provided.

Due to the recent natural gas shortage, economics are becoming more favorable for commercial exploitation of this resource. There are, however, still many barriers to extensive recovery and utilization on a commercial basis:

- Although a variety of technologies and techniques give promise of profitable utilization of coal-associated methane, the technical, operational and economic viability of these methods has not yet been sufficiently demonstrated to attract private investment

- The quality of coal-associated gas varies from essentially pure methane for predrained gas, to variable combinations of methane and air for gob gas, to extremely dilute methane-air mixtures in ventilation air

- Gas sources are generally located remotely with respect to demand and individual wells have relatively low production rates compared to conventional gas sources

- Gas prices historically have been insufficient to attract interest to this resource

- Although coal operators have a legal right to release methane in the course of mining, they are wary of the legal implications of gas recovery, since generally, natural gas rights are held by others 
- Since the market value of a ton of coal is on the order of 100 times the value of the methane contained therein, coal mining companies have scant interest in gas-derived revenues relative to their primary objective of coal production. (Recent interest in gas recovery by a few coal companies is due primarily to the prospect of increased coal production. The methane-derived revenues are of secondary importance)

- Low gas prices, low productivity, and the lack of a requirement for additional gas sources in the past have resulted in little or no interest in recovering methane from unminable coal.

The rangcs of quantitative availabllity, gas quality, and geographic location of coal-bed methane snurres make it apparent that no cinglc solution is apprupriale for all cases. Kecent studies cunducted for ERDA (now DOE) and the Bureau of Mincs indicate a high probability of economic gas recovery/ utilization for several approaches, including: direct pipeline injection, LNG production, onsite power generation, and petrochemical production. A variety of specific techniques and technologies have been considered under each of the preceding major hcadings. In some cases, off-the-shelf tcchnology which could be modified for this application is available (e.g., gas turbines, LNG production units and ammonia production units). However, further investigation research, development and demonstration is necessary.

This task provides for:

- Analysis and assessments to define projects, specify subsystems, identify institutional barriers, optimize operations, and transfer the technology to the private sectur. for commercialization

- Near-term demonstration/development projects to verify technical and economic viability using existing technology adapted generally from other uses. The near-term projects are aimed at utilizing coal-bed methane now being wasted even though the equipment is not as efficient as would be possible if developed and designed specifically for coal-bed methane applications

- Technology development of utilization subsystems to improve efficiency, be mure cost effective, and be more attractive for commercial ventures. 


\section{Project Status}

In September, 1977, a contract was awarded to the Westinghouse Electric Corporation to demonstrate power generation by means of a gas turbine generator. The fuel source for the demonstration is the gob gas from the Bethlehem Mines coal mining activity near Ebensburg, Pennsylvania. The power resulting from the demonstration will be mixed with the existing mine power grid.

A contract was awarded to TRW systems in late 1977, to design projects and optimize subsystem applications. In order to satisfy the variety of field conditions necessary for commercialization, projects involving eastern and western coal-beds of differing characteristics as well as different utilization subsystems are currently being planned.

Negotiations are presently being held with the Westinghouse Electric Corporation for the production, collection and utilization of methane from coal beds. The demonstration site is located at Waltz Mill near Pittsburgh, Pennsylvania. Under the proposed contract, Westinghouse will produce and utilize methane from the virgin coal as well as from a gob area. Production technology will center around the use of vertical holes with foam frac. The end-use technologies will include power generation by means of a fuel cell and direct combustion of the coal-bed gas in boilers for steam and to provide for space heating.

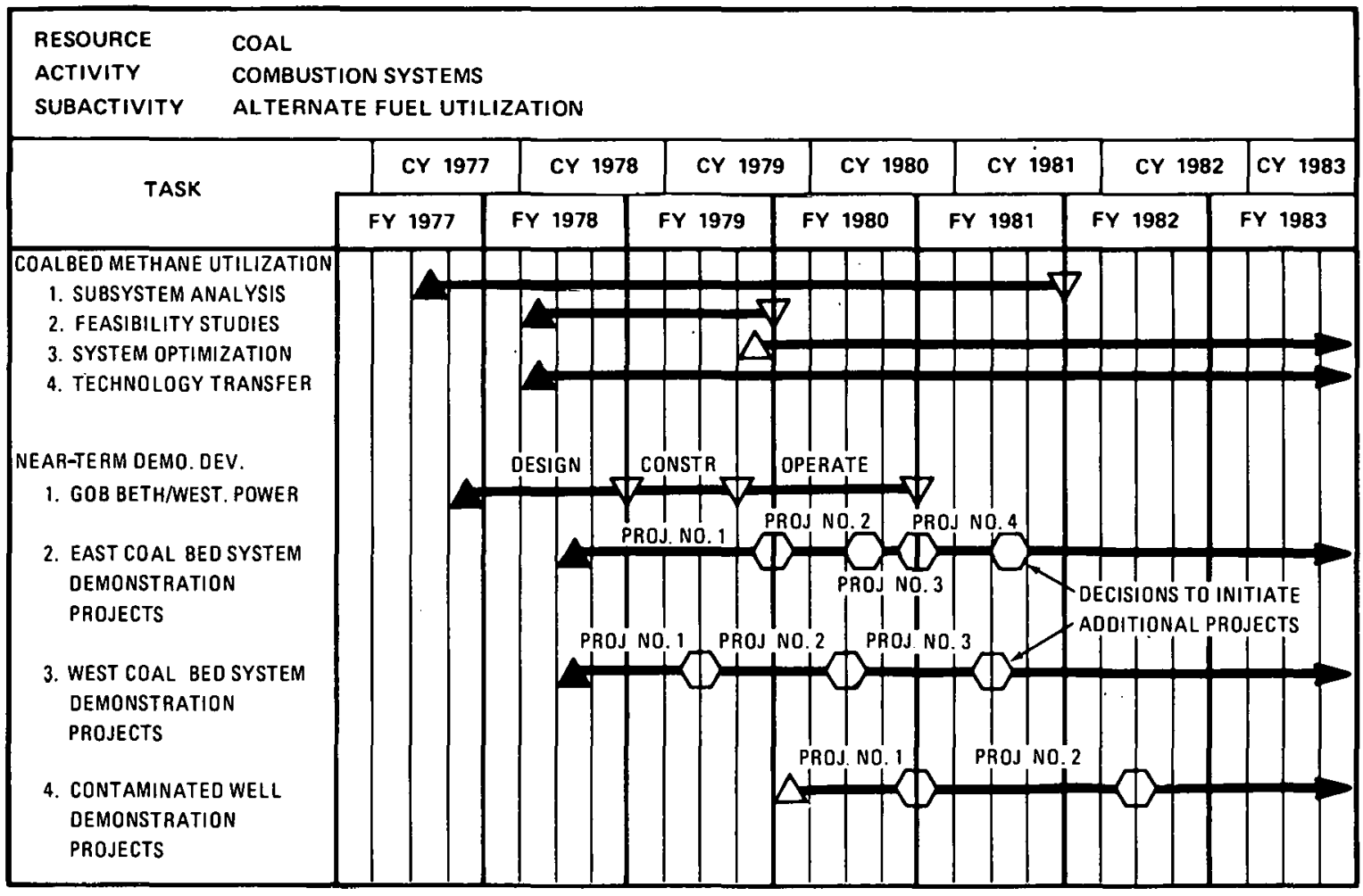

MILESTONE SYMBOLS ARE DEFINED ON LAST PAGE OF THIS DOCUMENT 


\subsection{COMBUSTION DEMONSTRATION PLANT}

Only one demonstration plant in fluidized-bed technology has been initiated to date. A summary of funding for the period FY 1977 to FY 1979 follows.

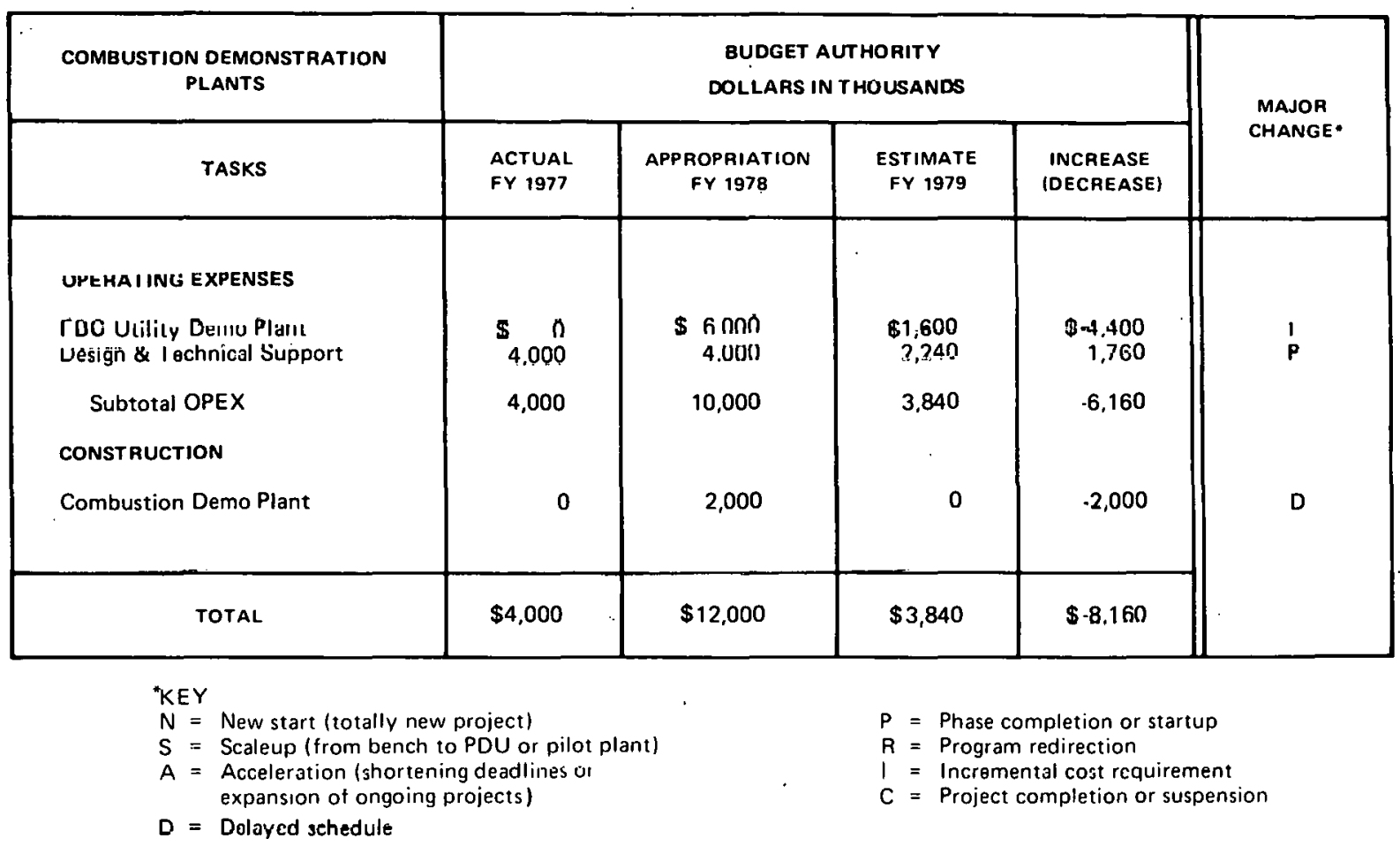

\section{AFB Utility Demonstraton Plant}

The demonstration of a coal-fired fluidized-hed combustion boiler at a near-commercial size will be required to implement commercial adoption by the utilities. Congress authorized a direct combustion demonstration plant in FY 1976. The initial plant is expected to be an atmospheric pressure unit. The pressurized fluidized-bed process is also being considered. The unit is to be a nominal 200-MW size and will provide high-pressure steam for utility power generation.

The planning level power plant conceptual design contracts for complete AFB power plants that were awarded to Stone and Webster and Burns and Roe will be completed in the second qunrter of FY 1978. Plunt Designs used Preliminary Boiler designs funded by DOE. This work is being conducted by three major utility boiler manufacturers and will be completed in the second quarter of FY 1978.

A Program Opportunnity Notice was prepared for release at the starrt of FY 1978. Release of this PON has been deferred pending determination of the effect of the more stringent New Sources Performance Standards resulting from the 1977 Clean Air Act Amendments. 
An activity schedule for the plant is shown in the accompanying milestone chart.

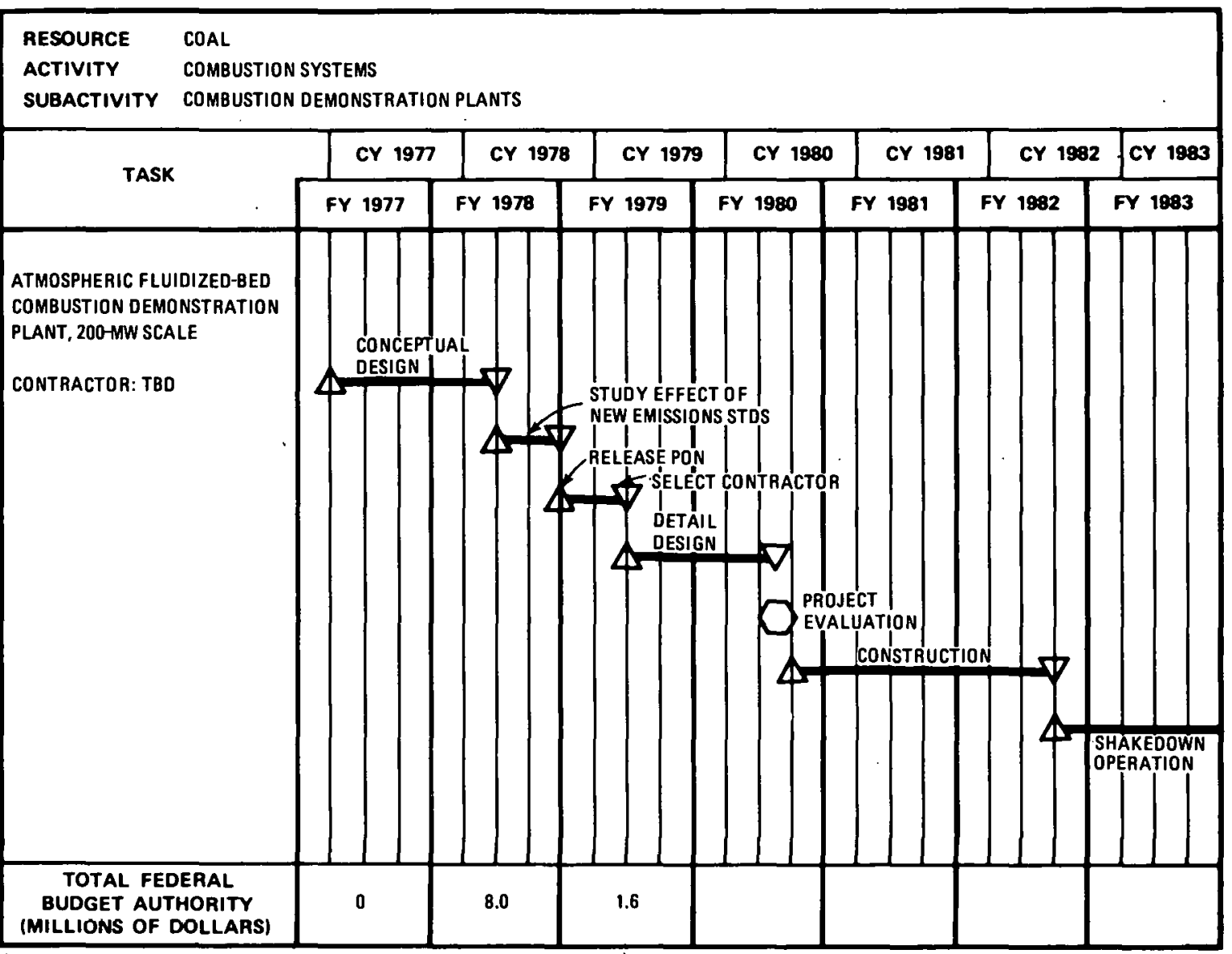

MILESTONE SYMBOLS ARE DEFINED ON LAST PAGE OF THIS DOCUMENT

\subsection{SUMMARY OF PILOT PLANTS, PDUs, AND MAJOR HARDWARE FABRICATION}

The following data summarize funding levels for pilot plants, PDUs, and major hardware fabrication for projects supporting the combustion systems effort. 


\section{Combustion Systems \\ Summary of Pilot Plants, PDUs, and Major Hardware Fabrication \\ (Dollars in Thousands)}

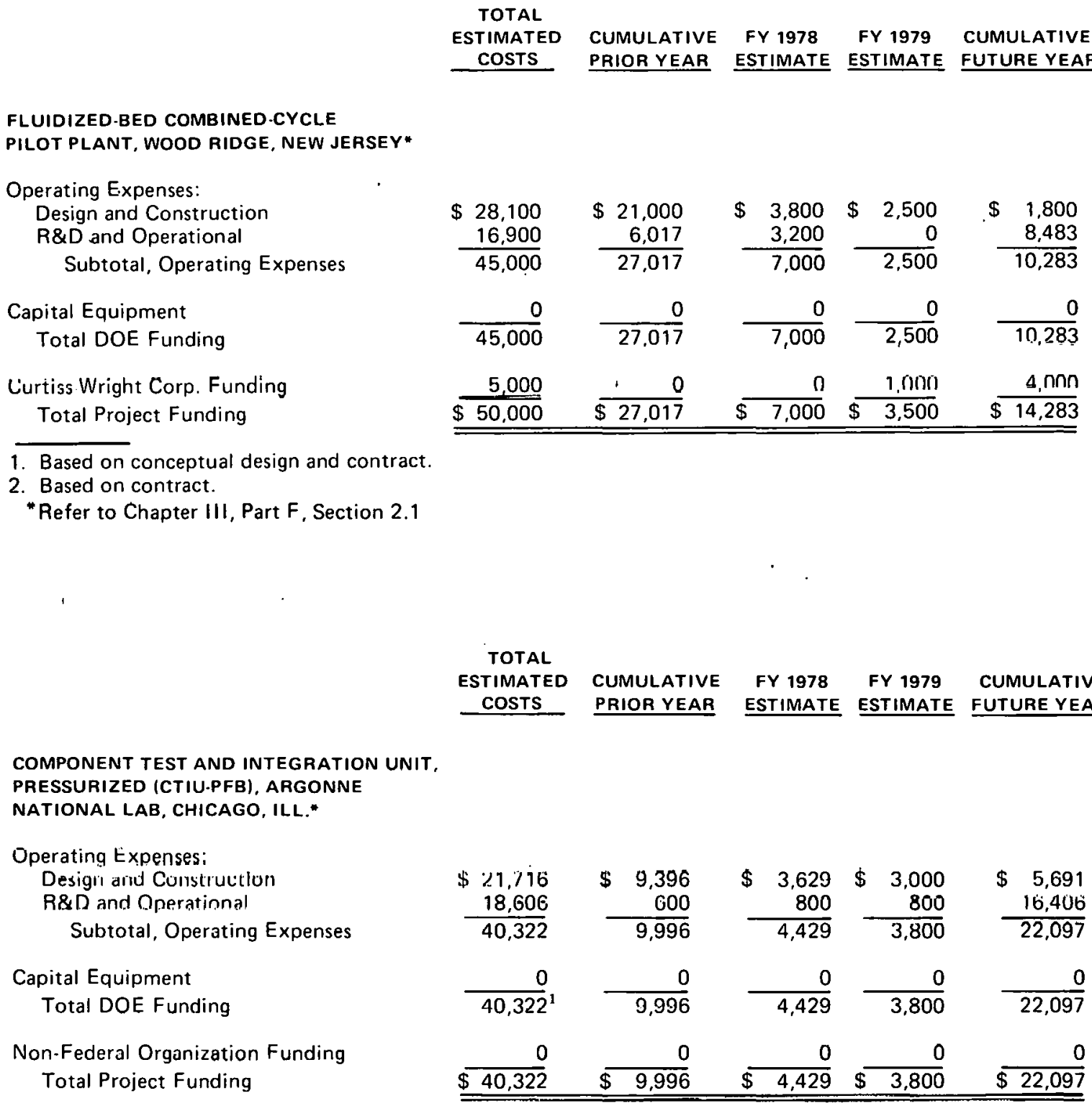

1. Based on A-E studies and estimated operational costs.

${ }^{*}$ Refer to Chapter III, Part F, Section 2.2 
TOTAL ESTIMATED COST CUMULATIVE FY 1978 FY 1979 CUMULATIVE PRIOR YEAR ESTIMATE ESTIMATE FUTURE YEAR

COMPONENT TEST AND INTEGRATION UNIT, ATMOSPHERIC (CTIU.AFB), MERC, MORGANTOWN, W. VA.*

Operating Expenses:

Design and Construction

$R \& D$ and Operational

Subtotal, Operating Expenses

\begin{tabular}{|c|c|c|c|c|c|c|c|}
\hline $\begin{array}{r}34,500 \\
18,435\end{array}$ & $\$$ & $\begin{array}{r}7,002 \\
896\end{array}$ & $\$$ & $\begin{array}{r}12,605 \\
895\end{array}$ & $\begin{array}{r}\$ 10,956 \\
844\end{array}$ & $S$ & $\begin{array}{r}3,937 \\
15,800 \\
\end{array}$ \\
\hline 52,935 & & 7,898 & & 13,500 & 11,800 & & 19,737 \\
\hline 0 & & 0 & & 0 & 0 & & 0 \\
\hline $52.935^{\prime}$ & & 7,898 & & 13,500 & 11,800 & & 19,737 \\
\hline 0 & & 0 & & 0 & 0 & & 0 \\
\hline$\overline{\$ 52,935}$ & $\$$ & 7,898 & $\overline{\$}$ & $\overline{13,500}$ & $\overline{S 11,800}$ & $\bar{s}$ & 19,737 \\
\hline
\end{tabular}

Capital Equipment

Total DOE Funding

Non-Federal Organization Funding

Total Project Funding

1. Based on $A-E$ studies and estimated operational costs.

* Refer to Chapter III, Part F, Section 1.4 


\section{G. FUEL CELLS}

A fuel cell is a device that electrochemically converts fuel energy to electricity in a highly efficient and environmentally acceptable manner. Because of their unique features, fuel cell power plants can be factory built and located close to the point of electricity demand, reducing energy losses associated with transmission and distribution and permitting effective use of waste heat. The modular construction of fuel cell generators provides a size flexibility from kilowatt to megawatt capacities. The essentially nonpolluting, practically noiseless operation permits location in large load centers and even on-site in urban, rural, and residential areas. Measured emissions from an experimental fuel cell power plant were much lower than the Environmental Protection Agency (EPA) ctandarde for modern conventional foseil-fueled central station generators. For the fuel cell system, nitrogen oxides were less than one tenth of the EPA standard, and sulfur oxides and particulates were even less. With current technology (phosphoric acid electrolyte), fuel cell power plants can utilize methane, synthetic natural gas, propane, ethanol, methanol, light distillates, and hydrogen or carbon monoxide rich waste gas streams. Future systems will have the capability to operate on coal-derived liquids and residuals and gasified coal.

A fuel cell power plant is comprised of three sections: the fuel processor, the power section, and the inverter. The fuel processor converts a hydrocarbon fuel into a gaseous mixture of hydrogen and carbon dioxide and/or carbon monoxide. If the product gas is to be used in first-generation phosphoric acid fuel cells, the carbon monoxide is reacted with steam recovered from the power section to generate hydrogen and carbon dioxide. If the product gas (such as gasified coal) is to be used in second-generation molten carbonate fuel cells, the carbon monoxide is used directly as fuel by the power section. The Energy Conversion Alternatives Study (ECAS) indicated that a large central station power plant using molten carbonate fuel cells integrated with a coal gasifier could operate at a projected efficiency of 50 percent from coal to AC electricity.

The fuel cell power section consists of many individual cells in which the processed fuel and oxygen from the air are reacted to produce dc electricity. Because the conversion of fuel to electricity is an electrochemical process, the conversion efficiency is very high and is achieveable for any plant size and at part load. The last subsystem of the fuel cell power plant is a static inverter that converts the DC output to $\mathrm{AC}$. The inverter produces a waveform compatible with conventional electrical supplies generated by rotating machinery. 


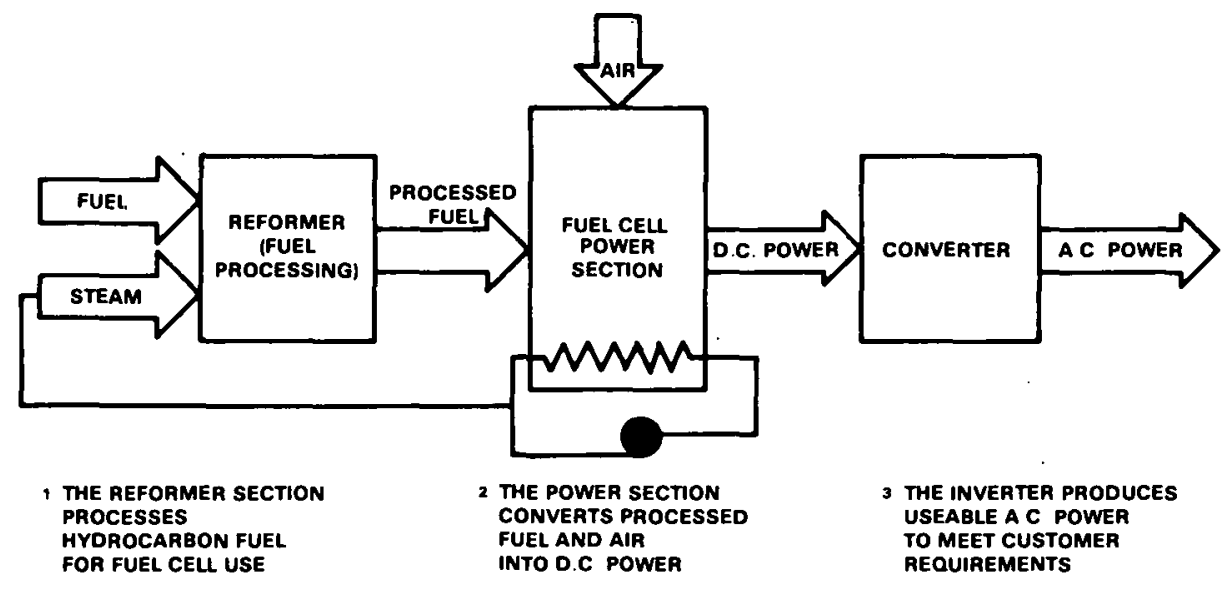

\section{Major Sections of a Fuel Cell Power Plant}

Fuel cell systems evolving within the next five to ten years are strongly viable in the following applications:

- Industrial cogeneration where advantage is taken of the high electrical and thermal efficiencies

- Integrated energy systems for residential and commercial buildings and district heating including operation from waste and coal-derived fuels

- Electric generation including peaking and intermediate cycling loads, spinning reserve, small utilities, replacement of old inefficient units and base load from coal

- Transportation applications including product petroleum pipeline pumping, gas pipeline compression, and electric hybrid vehicles.

In addition to the above energy saving applications, the foreign market potential for phosphoric acid fuel cells is quite large. It fits into four markets:

- Developed countries where environmental considerations are important

- Developing nations because of the small unit size and ability to run without operating personnel

- Oil and gas rich countries where the low capital cost, efficiency, and ability to operate without trained personnel make fuel cells attractive

- Countries that are shifting to an alcohol fuel-based economy. 
The objective of the DOE Fossil Energy Fuel Cell Activity is to establish the commercial feasibility of fuel cell power plants for electric utility applications, industrial cogeneration and building total energy systems in the near-term and to develop advanced, higher efficiency, economically competitive, fuel cell technologies for all end-use applications in the longer term. As a result of the initiatives taken by this fuel cell activity, the nation can experience, over the next three to six years, the development of a fuel cell industry with its significant associated national benefits. Specifically, the fuel cell activity has accomplished the following:

- Initiated a three-way cost-shared program to manufacture and test the first 4.8 MW fuel cell module on a utility grid. After a year's time, this program is on schedule and within projected $\cos \mathrm{t}$

- Initiated a joint effort with a major manufacturing organization and a large segment of our nation's gas industry to develop and test total energy systems for buildings and industry

- Initiated two cost-shared programs with potential competitive manufacturers of phosphoric acid fuel cell systems

- Initiated a cost-shared program with a major electrical equipment manufacturer to develop second-generation, coal-fueled, molten carbonate systems

- $\Lambda$ chievcd a major breakthrough in the manufacturing technology of molten carbonate fuel cells

- Developed a lower-cost phosphoric acid stack technology

- Complctcd a fuel cell design fur use wilh industrial waste hydrogen.

In order to achieve the overall DOE Fossil Energy Fuel Cell objective, the activity is divided into four subactivities. Each of these areas has a specific objective as follows:

- 4.8 MW Electric Utility Power Plant Development: Test, on a urflity grid, the operational feasibility of electric utility fuel cells which are nearing readiness for commercialization.

- Phosphoric Acid Syotcms Devclopment: Develüp füel cell systems for nonelectric utility applications and provide technology to lower cost and increase reliability of phosphoric acid fuel cell systems.

- Molten Carbonate Systems Development: Advance the state-ofthe-art of molten carbonate fuel cells in order to achieve the earliest possible commercialization of coal fueled power plants in electric utility base load and industrial cogeneration applications . 
- $\quad$ Fuel Cell Applied Research: Support emerging systems with a sufficient technology base, examine advanced fuel cell systems and broaden the spectrum of acceptable fuels.

The following table summarizes the funding levels for this Activity for the FY 1977 to FY 1979 period. (Refer to Chapter II.A, Table 5 for budget comparability.)

\begin{tabular}{|c|c|c|c|c|}
\hline FUEL CELLS & \multicolumn{4}{|c|}{$\begin{array}{c}\text { BUDGET AUTHORITY } \\
\text { (OPERATING EXPENSES) } \\
\text { (DOLLARS IN THOUSANDS) }\end{array}$} \\
\hline ACTIVITY & $\begin{array}{c}\text { ACTUAL } \\
\text { FY 1977 }\end{array}$ & $\begin{array}{c}\text { APPROPRIATION } \\
\text { FY 1978 }\end{array}$ & $\begin{array}{c}\text { ESTIMATE } \\
\text { FY 1979 }\end{array}$ & $\begin{array}{c}\text { INCREASE } \\
\text { (DECREASE) }\end{array}$ \\
\hline $\begin{array}{l}\text { Improved Conversion } \\
\text { Efficiency R\&D in Fuel Cells }\end{array}$ & $\$ 19,000$ & $\$ 35,200$ & $\$ 35,500$ & $\$+300$ \\
\hline
\end{tabular}

\subsection{8 MW ELECTRIC UTILITY POWER PLANT TEST AND DEVELOPMENT}

This subactivity consists of design and fabrication of a 4.8 MW fuel cell power plant with subsequent integration of the hardware into a utility grid for testing. The system is being constructed at United Technologies Corporation (UTC). The project is cost-shared by DOE, the Electric Power Research Institute (EPRI) and UTC. Consolidated Edison has been selected as the host utility and the power plant is to be installed and tested in New York City. The overall objective of the project is to establish the operational feasibility of a fuel cell system in the technically and economically competitive market that faces all candidate equipment for the generation of electricity.

The 4.8 MW fuel cell power plant is a modularly constructed, truck transportable, energy conversion device consisting of fuel processor, power section, power conditioner, and ancillary equipment to maintain appropriate process balance. Because of its modularity, as well as its virtual absence of pollutant generation, it has unlimited application for the production of electric power. There is unlimited siting flexibility because of its operating characteristics. It can serve as a component of central station generation, with particular application for intermediate and peaking loads, and as a dispersed generator for utilities, industries, buildings and community systems. In the latter mode, the conservation of energy and dollars is maximized since cogeneration becomes an available option. The 
operating temperature of the system, $375^{\circ} \mathrm{F}$, results in the availability of process steam and low grade heat for environmental conditioning. Thus, the installation of boilers and the consumption of additional energy for these purposes would be eliminated.

The technological feasibility of the phosphoric acid fuel cell for producing electric power has been demonstrated in systems up to $1 \mathrm{MW}$ in size. The 4.8 MW module is the basic building block for a power plant that can satisfy the minimum capacity requirements of a utility.

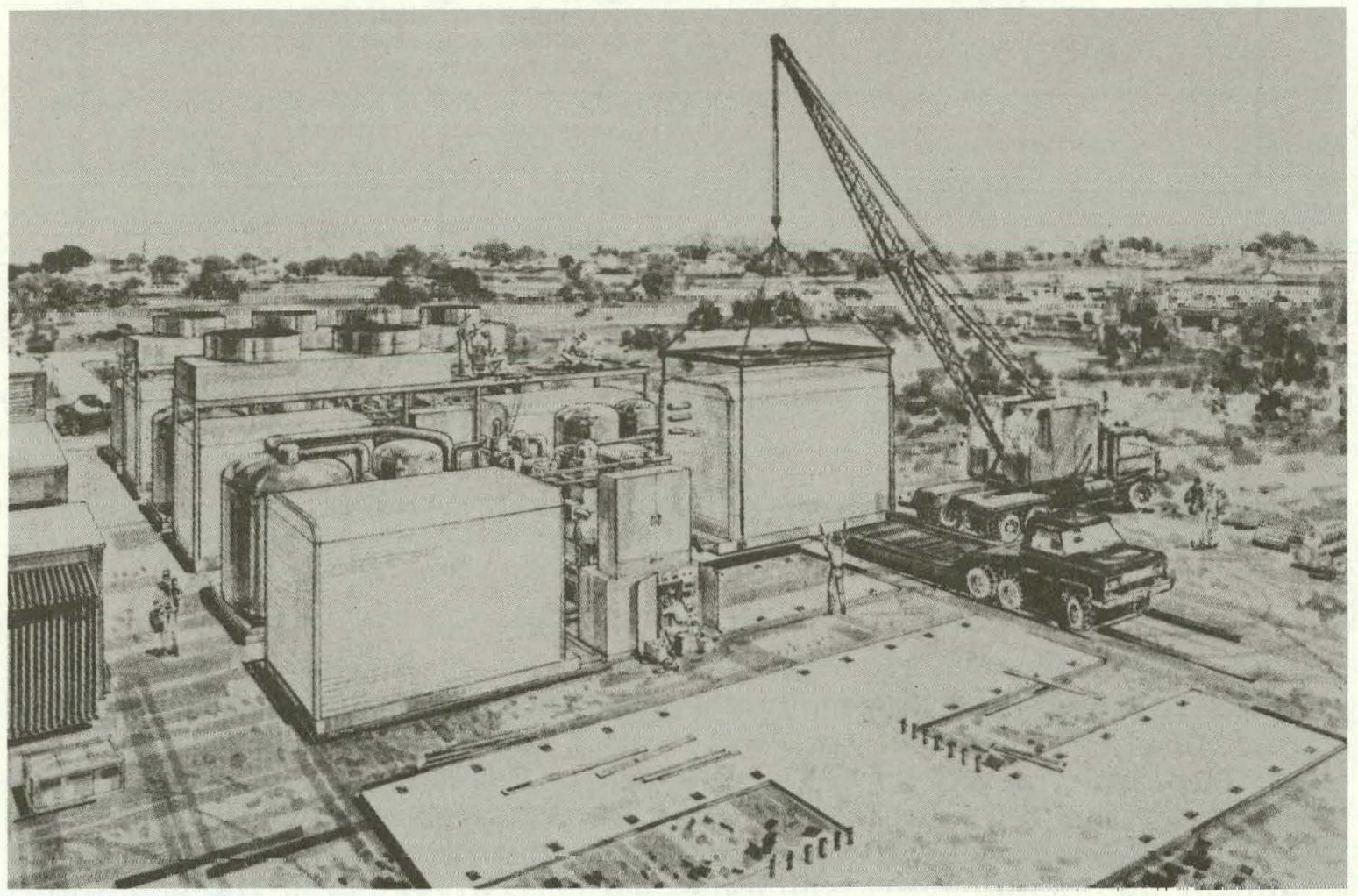

Construction of 4.8 MW Fuel Cell Power Plant

\section{Project Status}

Accomplishments to date include execution of contracts for construction of the 4.8 MW fuel cell power plant and the spare parts required for validation and supplemental testing in a host utility. The design and design confirmation phases of the program have been completed and projected performance, meeting specification goals, has been substantiated through subcomponent testing and modeling. Another contractual action, selection of a host for integration of the power plant in a utility grid, has been completed. Site preparation began in early FY 1978. 
It is expected that the program will closely meet scheduled milestones. This will result in completion of hardware construction during FY 1978 and completion of the utility testing during FY 1979. Implementation of a plan for a commercial feasibility program will be initiated in FY 1979 when projected performance has been achieved through utility demonstration. The commercial feasibility program will involve the improved technology development, the correction of performance deficiencies discovered during the operation test, and the initiation of a manufacturing methods development program.

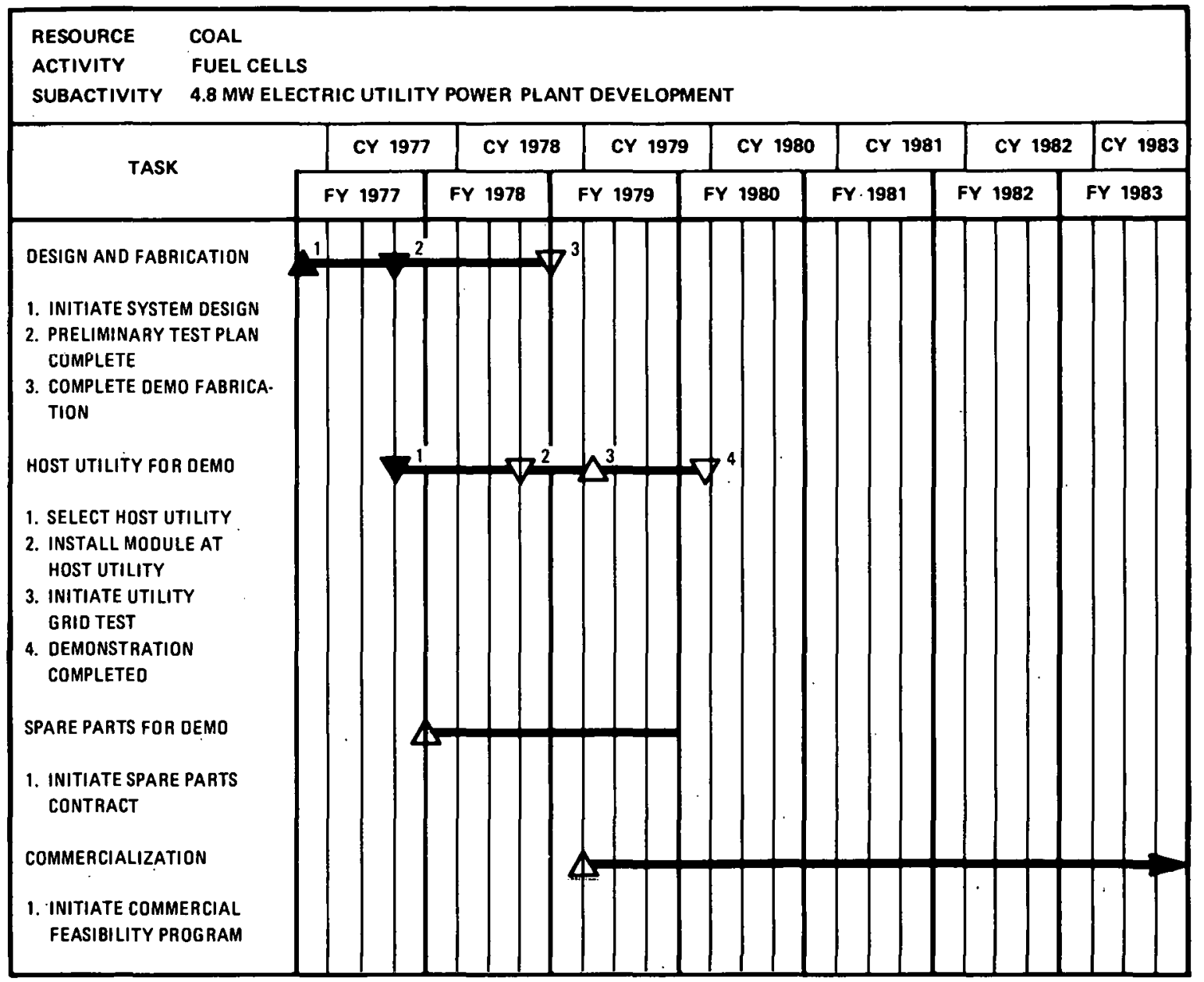

MILESTONE SYMBOLS ARE DEFINED ON LAST PAGE OF THIS DOCUMENT NOTE: BUDGET DETAILS ARE PROVIDED IN SECTION 5.0.

\section{2:0 PHOSPHORIC ACID SYSTEMS DEVELOPMENT}

Phosphoric acid fuel cells are in the transition phase between development in laboratories and the commercial marketplace. These systems require improved performance, longer life and an extension of their range of application. Furthermore, additional industrial suppliers of 
phosphoric acid fuel cells are required in order to provide a competitive environment. Technology demonstrations (such as the $4.8 \mathrm{MW}$ power plant previously described and the $40 \mathrm{kw}$ power plant described below) will be useful but significant improvements will be required. These technology improvements must come in areas of cost reductions, endurance extensions and reliability, and performance improvements.

This subactivity, which includes all nonelectric utility applications of phosphoric acid fuel cells, has the objectives of developing fuel cell systems for specific applications as the last step toward prototype demonstration and providing technology to lower cost and increase reliability of these systems. Potential applications include: 1) fuel cell powered total energy systems for residential and commercial buildings; 2) fuel cell power plants for use in industrial cogeneration, including the utilization of waste stream fuel supplies; and, 3) fuel cell power plants integrated with urban, industrial and agricultural waste conversion systems. In order to meet these objectives, the subactivity is divided into four areas: 1) on-site/integrated energy systems (OS/IES); 2) technology; 3) systems; and 4) transportation applications. A description of each of these areas and the strategy involved follows.

On-site/integrated energy systems, in which the prime mover meets both the electrical and thermal energy demands of the user, have the potential of saving over 20 percent of the present fuel requirements of conventional systems. An integrated energy system using a fuel cell as the prime mover could meet all of the thermal and electrical demands of a residential building complex using no more fuel than is presently used for heating alone. This is made possible because of the availability of waste heat at the application site and the reduction in distribution and transmission losses. The fuel cell power system is a favorable prime mover for the integrated energy system application because of its modularity flexibility and minimum impact to the environment. The integrated energy systems have application in residential and commercial buildings and industrial plants. The power plant performance specifications are different for those applications; however, the improved fuel utilization efficiency is equally applicable. The primary limitations associated with conventional powered total energy systems in the past have been reliability and siting flexibility. Fuel cell systems provide an opportunity for overcoming these limitations. Fuel cell powered total energy systems would replace natural gas and oil burning systems which provide space and process heat. They would also replace conventional grid supplied electrical power. These fuel cell systems could be transitioned to new fuel supplies such as synfuels or coal gasification products. In this area, the power plant capacity requirements are small relative to a utility application and, therefore, potential suppliers are not faced with the prospect of long and costly development and scaleup programs and users would not be subjected to lengthy and costly field construction. Most of the emphasis to date has been on utility applications thereby leaving the field of on-site applications open to competition. This effort has been structured to provide this competition. 
The achievement of significant cost reductions via technology is also receiving major emphasis. Specific efforts involve: 1) improving cell endurance; 2) developing an integral cooler for lower cost and greater durability, 3) developing a design which eliminates the need for nitrogen inert pressurization, 4) improving performance via higher operating temperature and pressure, and 5) developing a new low-cost integral cell stack concept. It is necessary to continually verify that changes which are proposed for purposes of increased performance or reduced cost do not also reduce stack endurance.

The complex process of determining system and technology requirements for OS/IES applications is vital to the success of the effort. Requirements involving electrical efficiency, heat quality, size, operational characteristics, cost and fuel availability and compatibility are some of the items being addressed. The phosphoric acid fuel cell technologies being directed toward potentially competitive OS/IES applications are in the early stage of development. These system studies provide a focus for the technology effort and assess the range of applications that the technology serves.

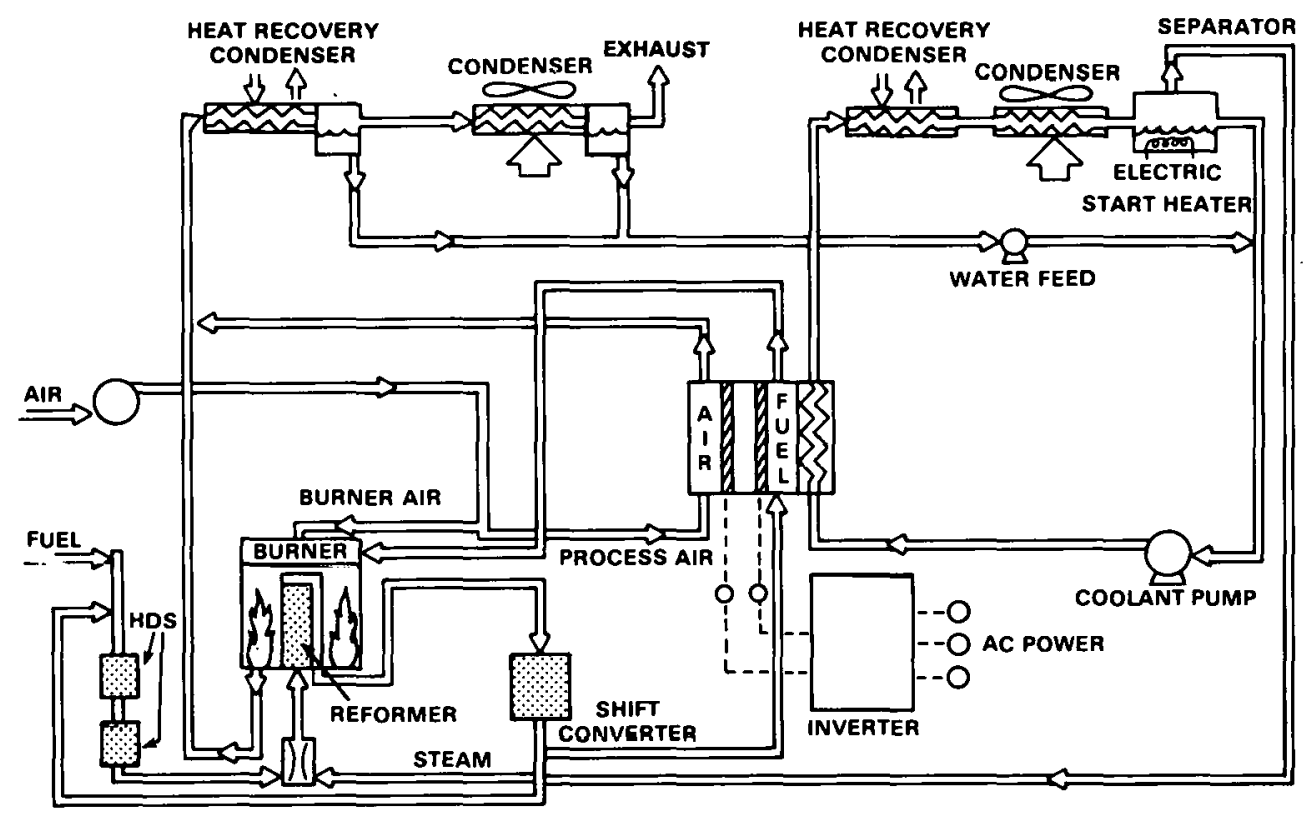

PC 18 System-Air Supply and Inverter

\section{Project Status}

In the OS/IES area, emphasis is on the development of kilowatt size power plants. Of these, the $40 \mathrm{~kW}$ modification and development effort is in the most advanced stage (engineering and development). 
The $40 \mathrm{~kW}$ pilot power plant, pictured schematically above, was originally developed under gas utility and United Technologies Corporation sponsorship and was the starting point for this development effort. This pilot power plant has operated for over 10,000 hours. The current effort, cost-shared with the Gas Research Institute, is directed toward cost, reliability, endurance and performance improvements of the pilot power plant design in order to develop a viable, proper functioning $40 \mathrm{~kW}$ field test power plant.

'Two major cost reduction tasks have been initiated in FY 1978. The first, platinum catalyst activity enhancement, represents an alternative to higher temperature and pressure for increasing performance. This effort will focus primarily on the cathode. The success of this task will have an important impact upon phosphoric acid fuel cells systems being developed for OS/IES applications. The second effort involves the development of a low cost integral cell stack concent. to he incornnrated into the $40 \mathrm{~kW}$ power plants under development for ficld tcoting.

Several systems studies are under way that will be completed during FY 1978 identifying market and regulatory restraints, capital requirements, quantified benefits, and associated costs. In addition, a study of the feasibility of a fuel cell integrated with an urban, industrial or agricultural waste conversion system is under way and will be completed during FY 1978. This study will compare the economics of several fuel cell/waste conversion system configurations with a conventional system and lead to a developmental plan. An industrial cogeneration request for proposals (RFP) utilizing fuel cells will be let resulting in a number of site specific studies from which an initial field demonstration will be selected.

'l'he fuel cell technology development for transportation applications effort was initiated late in FY 1977. Present activities involve refinement of the program plan to emphasize cost reductions, mass fabrication, fuel selection and technology requirements specific to this application. All of these items require significant development work although the benefits appear large, particularly efficiency, environmental pollution, and petroleum dependency reduction. This is the first formalized attempt at developing fuel cells for this application. 


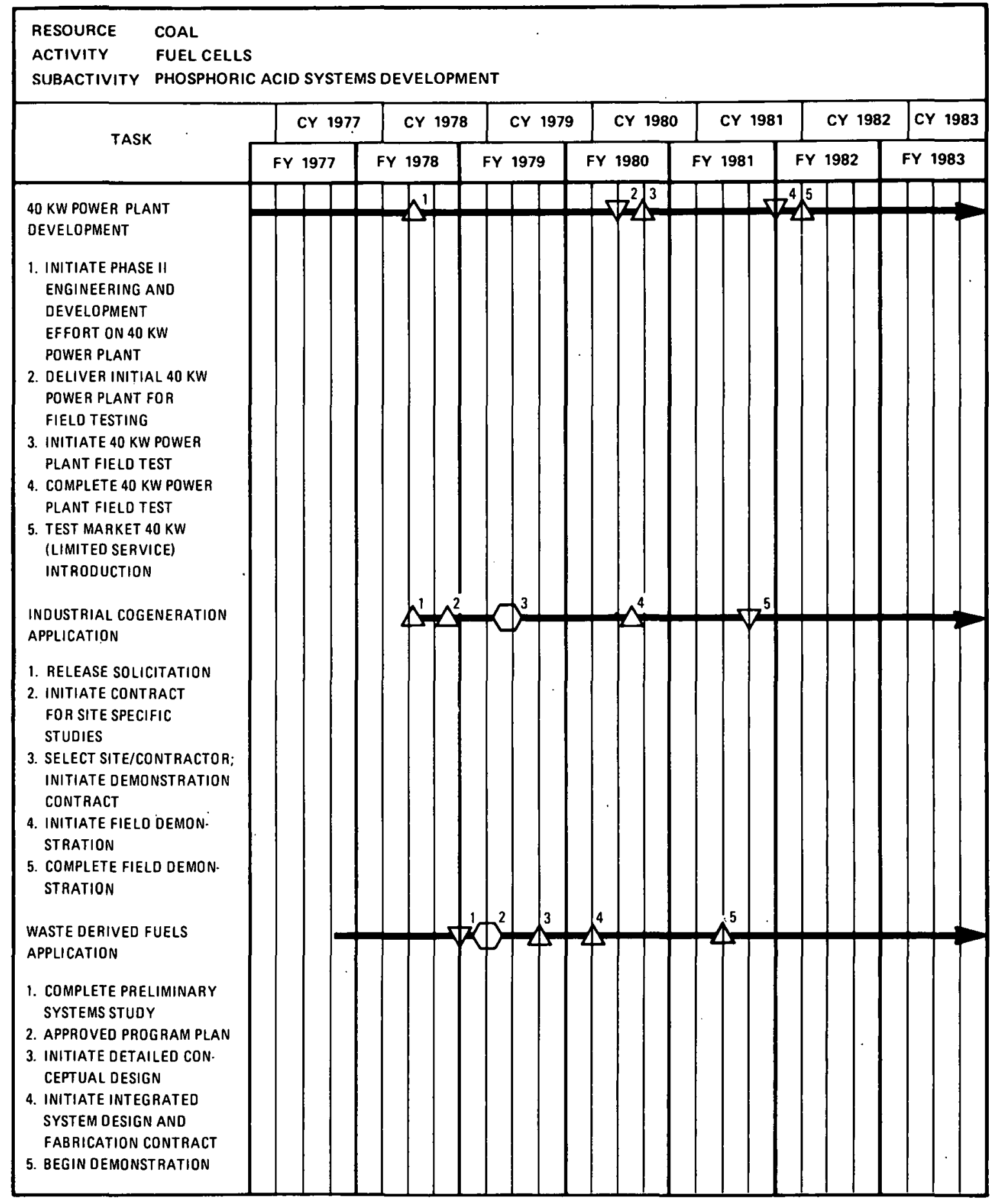

MILESTONE SYMBOLS ARE DEFINED ON LAST PAGE OF THIS DOCUMENT 


\subsection{MOLTEN CARBONATE SYSTEMS DEVELOPMENT}

The objective of the Molten Carbonate Systems Development subactivity is to bring about the earliest feasible commercial use of molten carbonate fuel cell systems, so that the environmental and resource conservation benefits of these clean, efficient, coal-fueled systems can be realized. Replacement of gas and oil with the minimum amount of coal is facilitated by high system efficiency. Sulfur is removed to low levels from the fuel stream, and because the fuel is oxidized electrochemically rather than by combustion, $\mathrm{NO}_{\mathbf{x}}$ emissions are very low. The environmental impact of this type of coal-fueled generator is therefore relatively small.

The primary application of molten carbonate fuel cell generators is for base load electrical generation and the program leading to this product is well-defined, With appropriate liquid fuels, euch as petroleum or coalderived hydrocarbons, it would be possible to meet intermediate and peaking demand as well with similar benefits. The path to this application is also well defined, should liquid fuels become available. The nperating temperature and flexibility of the fuel cell seems well suited to cogeneration of heat and electricity in a variety of commercial and industrial situations; but this application has not yet been studied in detail.

In a molten carbonate fuel cell, which would be thermally integrated with a coal gasifier, coal is gasified with steam and air or oxygen to form a fuel gas stream rich in $\mathrm{CO}$ and $\mathrm{H}_{2}$. The gas stream is purified of particulate and sulfur in the cleanup section, then fed to the fuel cell where it is combined electrochemically with air to form $\mathrm{CO}_{2}$ and $\mathrm{H}_{2} \mathrm{O}$. This process produces DC electric power, which is transformed to AC in the inverter and stepped up to transmission line voltage levels. Sensible heat from the gasifier and the fuel cell outlet gas stream is recovered by raising steam which is used in a steam turbine generator. About two-thirds of the power plant electric output comes from the fuel cells and one-third from the steam turbine. Where plant sizes smaller than about 500 MW are needed, a gas turbine can be used instead of the steam system with about 5 percent less plant efficiency. The sensible heat in this system is also at a high enough temperature to be used directly in many industrial processes to replace gas or oil furnaces. A schematic of this system appears below.

The strategy for implementation is the same for all applications. The approach is to conduct parallel interactive efforts in system definition and component development. The system definition task provides guidance and direction to the development work. Similarly, the recults of the component development work are fed back into the definition effort. For the noxt. fr.w years, the paramount effort will be in cell development since the cells are the least developed part of the system. 


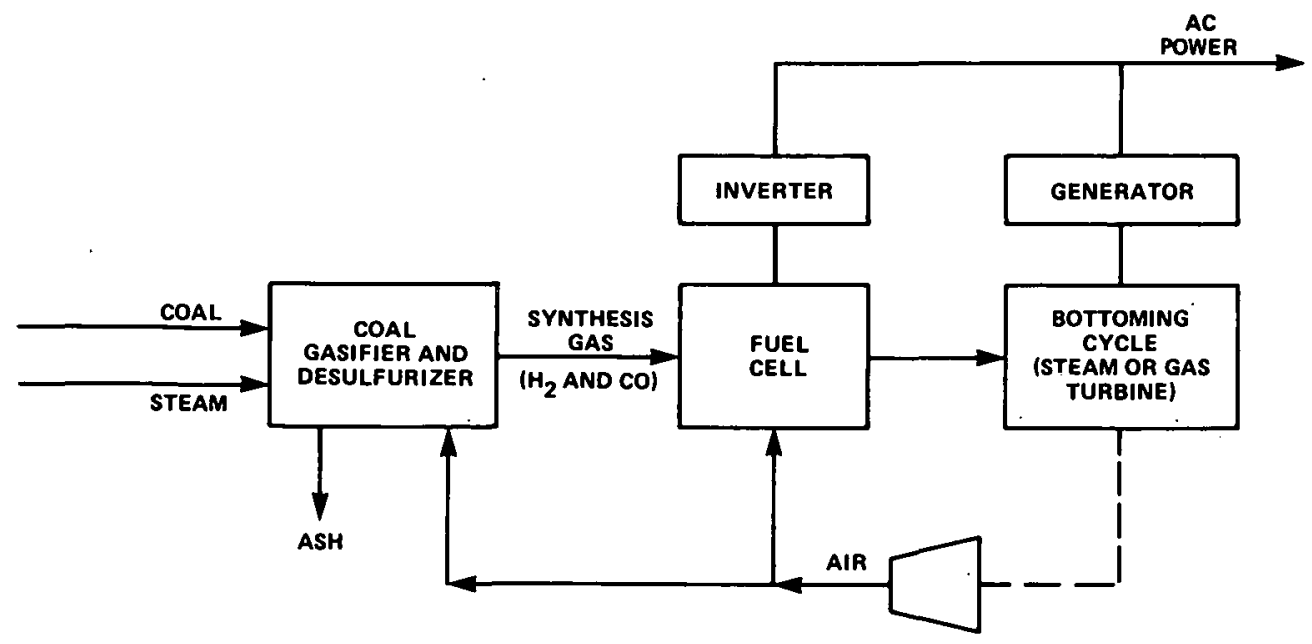

Second Generation Fuel Cell Power Plant

\section{Project Status}

In order to meet the requirements of an electric utility base load system, the following goals were established for the molten carbonate fuel cell stacks:

- Life of 40,000 hours to meet low maintenance requirements

- Current density of $150 \mathrm{~A} / \mathrm{ft}^{2}$ at $0.85 \mathrm{~V}$

- First cost (stack only) of $\$ 60 / \mathrm{kW}$ at the current density and endurance design points.

Successful achievement of these goals will allow for a system design of 50 percent overall conversion efficiency at a competitive capital cost.

Cell performance is rapidly approaching the goal specification, and may well exceed that level before other goals are met. The present current density at $0.85 \mathrm{~V}$ is $100 \mathrm{~mA} / \mathrm{cm}^{2}$. This specification must be met under system operating conditions of temperature $(923 \circ \mathrm{K})$, pressure (10 atm), $\mathrm{CO}_{2}$ recycle (currently by burner) and in-cell fuel utilization (currently 85 percent).

The best cell life to date is 13,500 hours. Obviously, the cell was built with what is now two-year-old technology. Since then, satisfactory solutions to the wet seal corrosion problem (which was the apparent cause of failure) have been devised. The next hurdle appears to be electrolyte management, and scveral approaches to this problem are under study.

Capital cost is of fundamental concern in all aspects of component development. Three manufactured cost-related areas are of special concern. These are scaleup, use of sheet metal cell hardware, and 
electrolyte production methods. Cell scale is currently up to $\mathrm{l} \mathrm{ft}^{2}$ (goal level is 3 to $4 \mathrm{ft}^{2}$ ) and progress has been rapid. The first sheet metal hardware will be operated in February 1978. Major advances in electrolyte production were made during FY 1977, and considerable attention is being given to this area.

The capability of using coal is a systems property. FY 1977 efforts defined acceptable gas compositions and sulfur tolerance with current cell technology, thereby verifying required cleanup system characteristics. Increased impurity tolerance is being sought, and verification of operation on real coal-derived gas is planned for FY 1979.

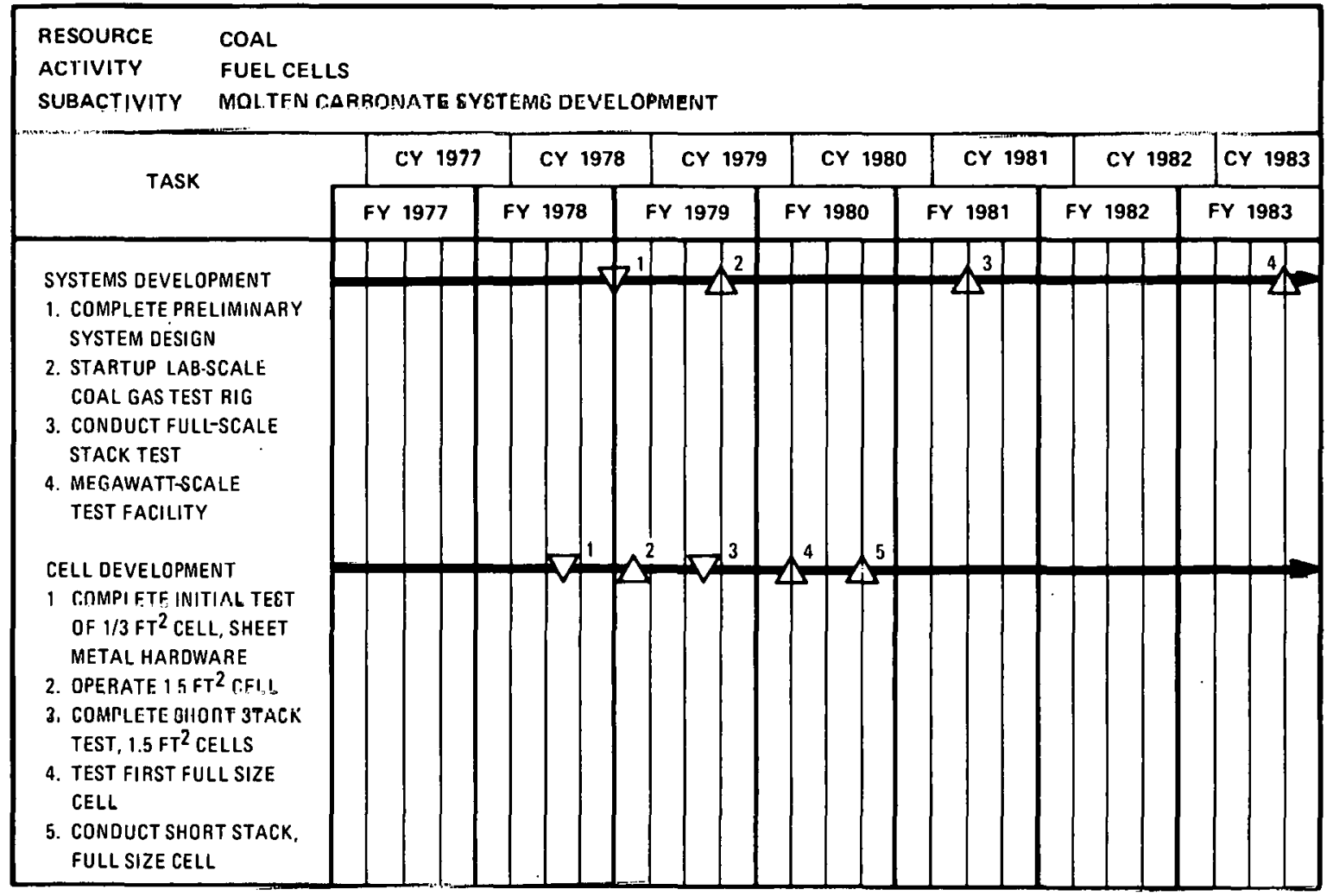

MILESTONE SYMBOLS ARE DEFINED ON LAST PAGE OF THIS DOCUMENT

\subsection{APPLIED RESEARCH}

The Fuel Cell Applied Research subactivity encompasses two efforts: 1) techmoluy advancement and 2) advanced concept investigation. Technology advancement efforts perform phenomenological research in areas where fuel cell development has hown that there are basic problems or technological limitations which adversely affect the cost, efficiency, reliability, and/or lifetime of fuel cells currently under development. In a few cases, the improved knowhow may also accelerate demonstration and commercialization programs by pointing the way to improvements that can 
be incorporated without major engineering changes. Technology advancement deals with fundamental physics and chemistry in depth far beyond that of engineering development. For this reason, the most advanced sources of scientific expertise are utilized in universities and specialized research organizations. Advanced concept investigation efforts consist of exploratory research and development to provide sufficient information to evaluate the development costs, risks, and benefits of new fuel cell concepts. Emphasis is on concepts with the potential for high national benefits but which cannot be evaluated on a sound basis without obtaining additional laboratory, experimental, and/or engineering data.

Advanced concepts explore as many promising concepts as can be accommodated within the budget. After eliminating the less desirable ones, additional research is carried out on the candidate technologies with the greatest likelihood of being attractive to industry. It provides the information necessary to evaluate in greater depth how promising the technology is for commercialization. The same technological data provide a springboard for industrial product development, or in some cases, for government development work outside of the applied research subactivity. The advanced concepts now subject to applied research are shown in the milestone chart.

Government support of these applied research efforts is appropriate not only because the results will be widely used in the national interest but also because it is exceedingly difficult for a single company to earn a satisfactory and timely rate of return on investment in applied research.

\section{Project Status}

Technology development efforts have been initiated to investigate the areas of electrocatalysis, cell materials behavior, electrode polarization, alternate acid electrolytes, and fuel process modeling. Advanced concepts currently being evaluated include solid oxide fuel cells, direct coal fuel cells, direct methanol and methane fuel cells, alkaline fuel cells, and advanced fuels utilization concepts such as partial oxidation, autothermal reforming and advanced steam reforming. 
COAL RESOURCE

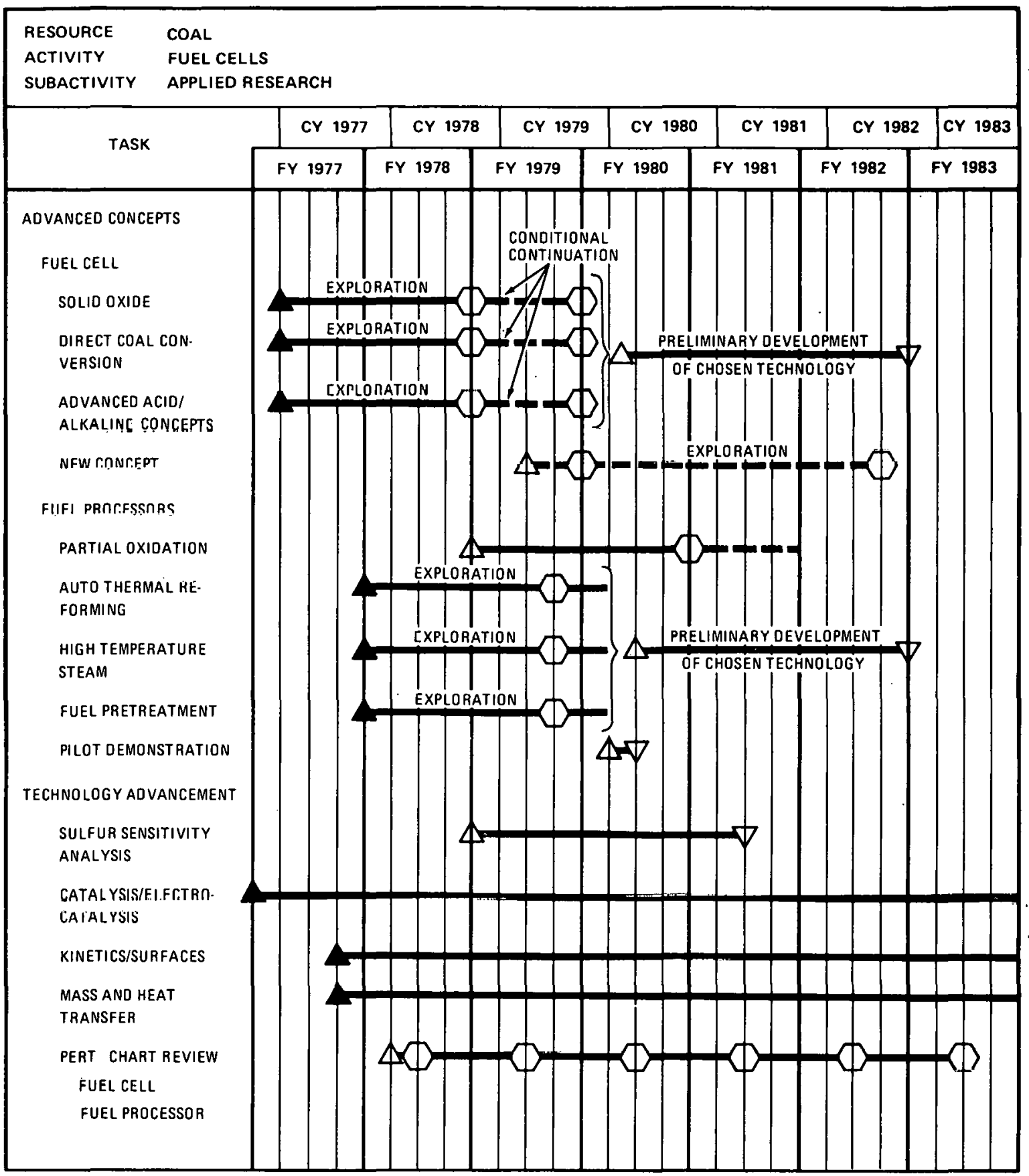

MILESTONE SYMBOLS ARE DEFINED ON LAST PAGE OF THIS DOCUMENT 


\subsection{SUMMARY OF PILOT PLANTS, PDUs, AND MAJOR HARDWARE FABRICATION}

The following data summarize funding levels for the pilot plants, PDUs, and major hardware fabrication for the projects supporting the fuel cells effort.

\section{Fuel Cells \\ Summary of Pilot Plants, PDUs, and Major Hardware Fabrication (Dollars in Thousands)}

\begin{tabular}{clccc}
$\begin{array}{c}\text { TOTAL } \\
\text { ESTIMATED } \\
\text { COSTS }\end{array}$ & $\begin{array}{l}\text { CUMULATIVE } \\
\text { PRIOR YEAR }\end{array}$ & $\begin{array}{c}\text { FY } 1978 \\
\text { ESTIMATE }\end{array}$ & $\begin{array}{c}\text { FY } 1979 \\
\text { ESTIMATE }\end{array}$ & $\begin{array}{c}\text { CUMULATIVE } \\
\text { FUTURE YEAR }\end{array}$ \\
\hline
\end{tabular}

\footnotetext{
4.8MW ELECTRIC UTILITY FUEL CELL DEMONSTRATOR, NEW YORK CITY, NEW YORK ${ }^{3}$

Operating Expenses

a. Design \& Construction

b. R\&D and Operational

Capital Equipment

Total DOE Funding

Host Utility Funding

EPRI Funding*

UTC Funding **

Total Project Funding
}

$$
\begin{array}{r}
10,200 \\
22,800 \\
0 \\
\hline 33,000^{1}
\end{array}
$$$$
900
$$

900
100

$\frac{0}{16,000}$

9,300
7,200

$\frac{0}{16,500}$

$\begin{array}{r}0 \\ 500 \\ 0 \\ \hline 500\end{array}$

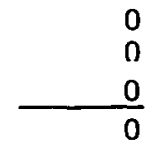

\begin{tabular}{rrrrrr}
1,000 & 1,000 & 0 & 0 & 0 \\
7,500 & 2,700 & 3,600 & 1,200 & 0 \\
$12,000^{2}$ & 6,500 & 5,500 & 0 & 0 \\
\cline { 2 - 5 }$\$ 53,500$ & $\$ 26,200$ & $\$ 25,600$ & $\$ 1,700$ & 0 \\
\hline
\end{tabular}

1. Based on signed contracts to date plus estimates for siting, testing and spares.

2. Contract, Request for Proposal.

3. Refer to Chapter III, Part G, Section 1.0

* Electric Power Research Institute

* United Technologies Corporation 


\section{H. ADVANCED ENVIRONMENTAL CONTROL TECHNOLOGY}

The Advanced Environmental Control Technology Activity is directed toward developing technology which will minimize the environmental impacts of new and existing fossil fuel utilization systems. Beginning in FY 1979, these efforts are being transferred from the Environmental Protection Agency (EPA) to the Assistant Secretary for Energy Technology's Fossil Energy program within DOE. Specific management details of this transfer, e.g., specific projects and overall program management responsibilitites and roles, are currently under negotiation. The goal of this transfer is to integrate all $R \& D$ efforts relating to a single balanced national program for environmentally safe utilization of coal as a primary fuel source. A complete system approach (see figure below) to the fossil fuel utilization/environmental impact problems will be pursued, considering the trade-oft's among environmental control nptinns and the intcractions between control devices and other power systems components.

To achieve this overall goal, several specific objectives have been established:

- Develop advanced technologies for coal cleanup prior to use

- Develop technologies for gas cleanup during the combustion process

- Develop environmental control technologies to clean postcombustion gases including second-generation flue gas Lechnolugies

- Determine cost versus environmental impact trade-offs for envirunintutal $1:$ mil milpower systems combinations.

The EPA program has accomplished the following to date:

- Publication of manuals and data books on coal cleanup including both sulfur and hazardous trace material removal for a variety of coals

- Dcoign, constructioñ, antl onte-year operation of à ivleyers process chemical coal-cleaning test facility

- Development, operation, and initial evaluation/environmental assessment of a $0.63 \mathrm{MW}$ fluidized-bed combustion miniplant

- Construction, operation, and initial data on the chemically active fluid-bed process for converting high-sulfur oil and coal to clean burning low-Btu gas

- Initiation of efforts on second-generation scrubber technologies and high temperature/high pressure particulate control methods. 
In FY 1979, DOE will continue those projects designated for transfer as well as initiate advanced $R \& D$ efforts in environment control technology. A brief and general description of this activity follows:

- Coal Cleanup: Coal cleanup efforts will examine both physical and chemical removal of hazardous trace materials, especially metals, as well as sulfur. Coals will include eastern, midwestern, and western high-sulfur coals. The Meyers process chemical coal-cleaning test facility will be operated collecting additional data on a variety of coals.

- Gas Cleanup: Gas cleanup activities will include efforts on both hot gas cleanup (prior to use in a gas turbine or industrial process) and flue gas cleanup. Experimentation with chemical agents in chemically active fluid-bed combustors will be pursued as a method for generating clean gases. Hot-gas cleanup efforts will be closely coordinated with materials tolerance efforts being conducted in gas turbine efforts. Development of advanced flue gas cleanup technologies will continue with emphasis on both $\mathrm{S} 0 \mathrm{x}$ and $\mathrm{NO}_{\mathbf{X}}$ removal. Aqueous carbonate and ammonia injection systems will be pursued. Emissions from atmospheric and pressurized fluidized-beds will be analyzed, and experiments will continue with the pressurized fluidized-bed miniplant. Advanced technologies in the area of particulate control in high temperature/ high pressure gas streams will also be examined.

Systems Integration: Systems integration efforts will concentrate on defining the trade-offs between various cleanup concepts (precombustion, during combustion, post-combustion) and the interactions between cleanup equipment and other components (turbine, heat exchangers) of power systems. A computer model will be developed which analyzes material flows through power systems, similar to existing models which analyze energy flows. The model will track the formation of pollutants and other waste materials through different configurations of environmental control equipment and power system components. Economic information on each configuration will be established and used to determine cost versus emission level trade-offs. This information will be provided to power systems manufacturers and users and to standard-setting activities in EPA. Additional analysis and integration activities will examine environmental control technologies related to power systems, such as use of alternate or waste fuels in power systems. 


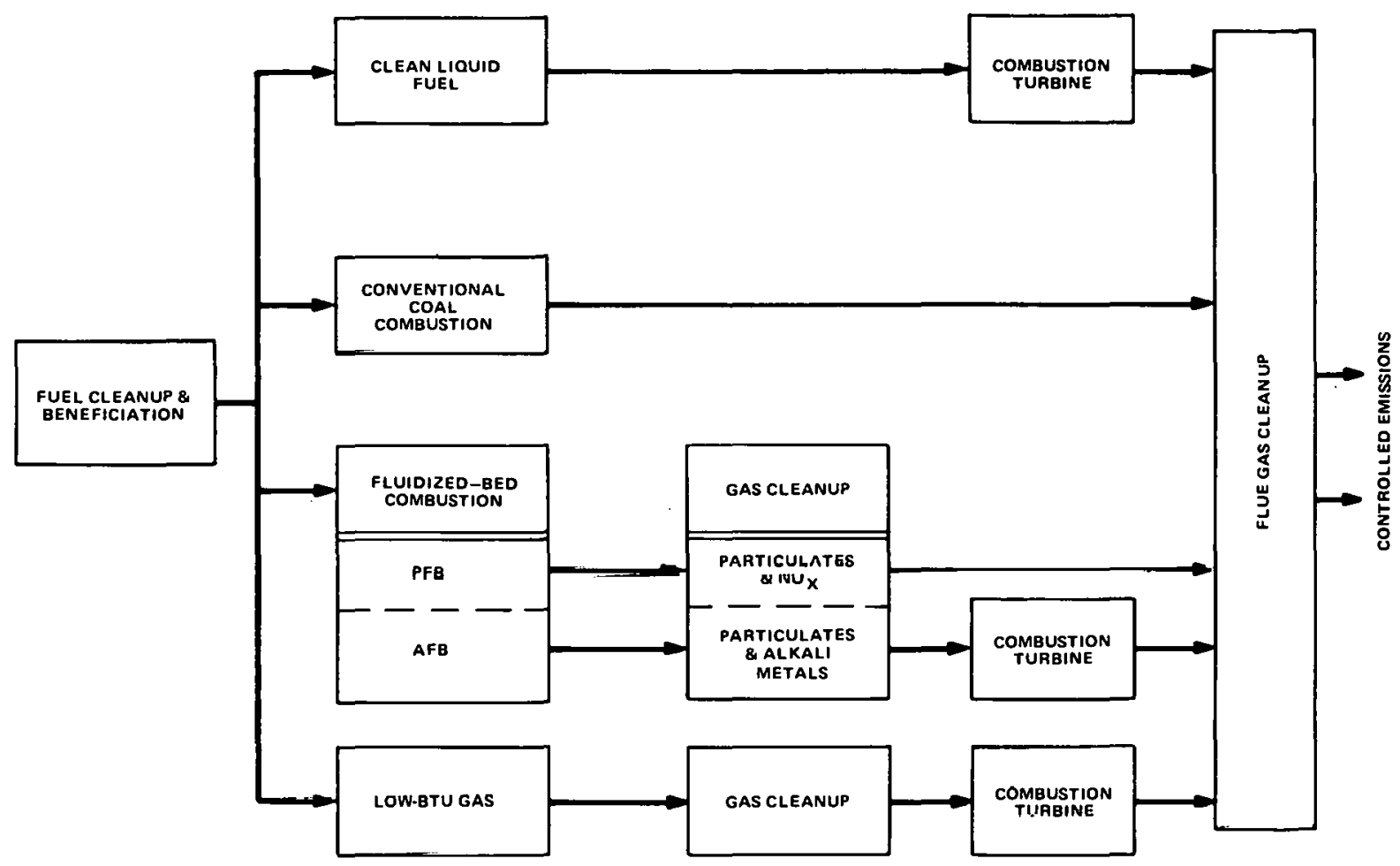

Environmental Control/Power Systems Integration

The table below summarizes the funding level of this Activity for the FY 1977 to FY 1979 period.

\begin{tabular}{|c|c|c|c|c|c|}
\hline \multirow[b]{2}{*}{. } & \multicolumn{4}{|c|}{$\begin{array}{l}\text { BUDGET AUTHORITY } \\
\text { (OPERATING EXPENSES) } \\
\text { (DOLLARS IN THOUSANDS) }\end{array}$} & \multirow{2}{*}{$\begin{array}{l}\text { MAJOR } \\
\text { CHANGE* }\end{array}$} \\
\hline & $\begin{array}{l}\text { ACTUAL } \\
\text { FY } 1977\end{array}$ & $\begin{array}{l}\text { APPROPRIATION } \\
\text { FY } 1978\end{array}$ & \multirow{2}{*}{$\begin{array}{c}\text { ESTIMATE } \\
\text { FY } 1979 \\
\$ 14,000\end{array}$} & $\begin{array}{l}\text { INCREASE } \\
\text { (DECREASE) }\end{array}$ & \\
\hline $\begin{array}{l}\text { Advanced Environmental } \\
\text { Control Technology }\end{array}$ & $\$ 0$ & $\$ 0$ & & $\$+14.0 n n$ & $N^{1}$ \\
\hline \multicolumn{3}{|c|}{$\begin{aligned} & \text { "KEY } \\
& \text { iN }=\text { INew start (totally new project) } \\
& S=\text { Scaleup (from bench to PDU or pilot plant) } \\
& A=\text { Acceleration (shortening deadlines or } \\
& \text { expansion of ongoing projects) }\end{aligned}$} & \multicolumn{3}{|c|}{$\begin{array}{l}P=\text { Phase completion or startup } \\
R=\text { Program redirection } \\
I=\text { Incremental cost requirement } \\
C=\text { Project completion or suspension }\end{array}$} \\
\hline
\end{tabular}




\section{ADVANCED RESEARCH AND SUPPORTING TECHNOLOGY}

The Advanced Research and Supporting Technology (AR\&ST) Activity covers a diverse group of activities ranging from basic and applied research to R\&D supporting activities. These are performed by the various technology program divisions and the Division of Program Control and Support and the Senior Staff of the Program Director for Fossil Energy $(\mathrm{FE})$.

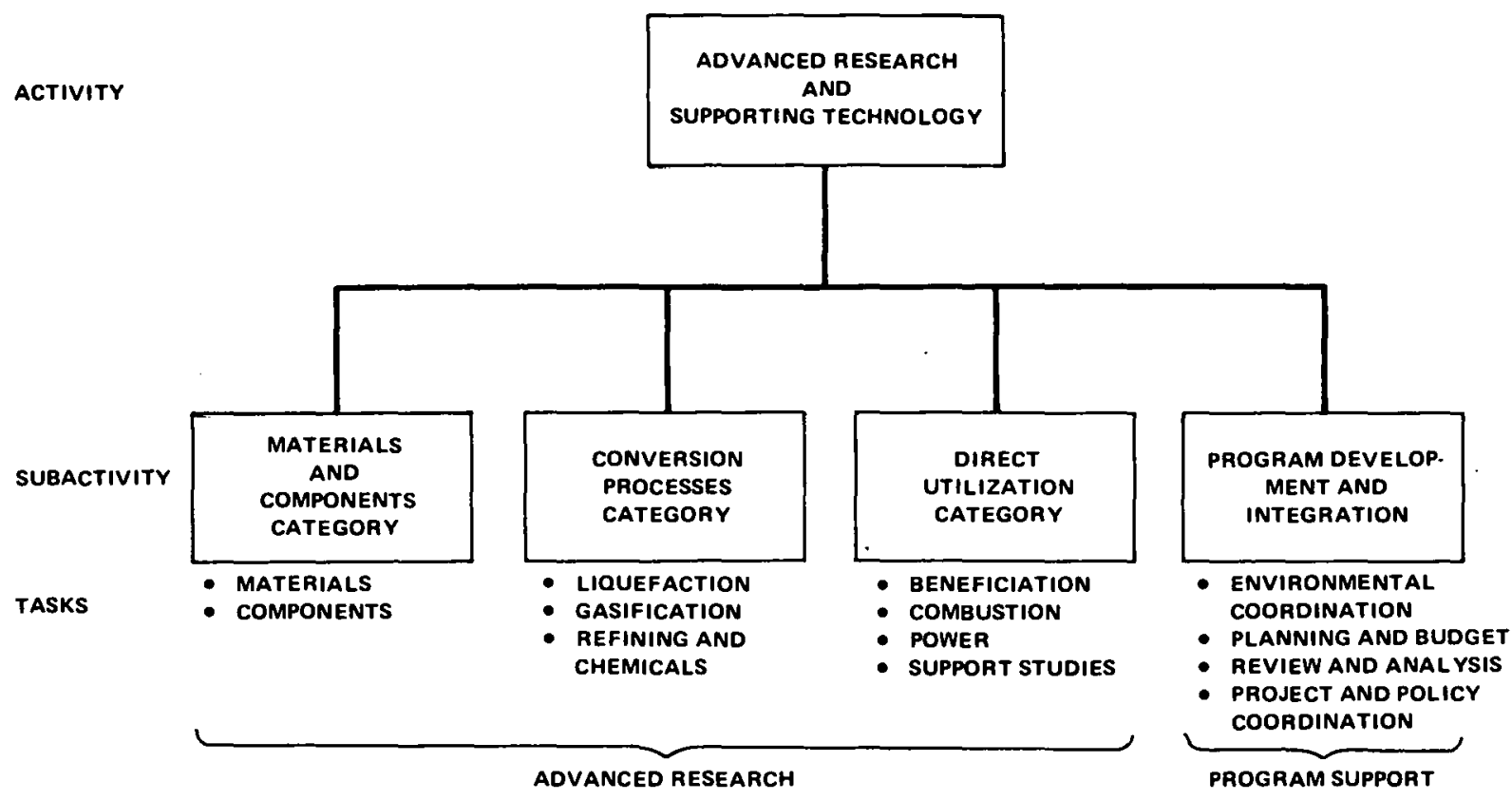

\section{Advanced Research and Supporting Technology Activity Subactivity and Task Support Structure}

Basic and applied research in the subactivities of Materials and Components, Conversion Processes, and Direct Utilization are the responsibility of the respective technology divisions. Materials and Components and Conversion processes are the responsibility of the Division of Coal Conversion. Direct utilization is the responsibility of the Division of Power Systems. In the Program Development and Integration subactivity, the Division of Program Control and Support provides longterm strategy and planning, program review and analysis, financial planning, program integration support, and all aspects of environmental planning and assessment covering all Fossil Energy facilities and programs. The Senior Staff provides advisory and special project support for executive direction of $\mathrm{FE}$ programs.

Major programs of this budget activity are:

- To provide for a central basic and applied research focus for all program areas of Fossil Energy 
- To provide a foundation for innovative technology leading to advanced processes through its programs in the DOE Energy Research Centers (ERC), National Laboratories (NL), other government agencies, private industry, and universities

- To facilitate reliable and efficient operation of synthetic fuel plants through materials and components research

- To investigate and develop through the feasibility stage advanced technology for the direct utilization of coal, including hot gas cleanup and high temperature materials

- To ensure an adequate supply of trained technical personnel from the nation's university system

- To assess the viahility of Fossil Energy processes under development in terms of national needs, economic, social and environmental constraints and benefits.

The current research program explores the following areas discussed in subsequent sections:

- Supporting research on materials and components, waste use and disposal, and basic fossil fuel science and engineering

- Advanced fossil fuel conversion processes, involving coal gasification, liquefaction, and refining of shale and coalderived syncrudes to distillate fuels and chemical feedstocks

- Advanced, environmentally acceptable direct utilization processes for beneficiation and combustion

- Systems studies contributing to development of a logical, integrated strategy and rationale for selection and development of Fossil Energy options. 
The table below summarizes the funding levels by subactivity for the FY 1977 to FY 1979 period.

\begin{tabular}{|c|c|c|c|c|c|}
\hline \multirow{2}{*}{$\begin{array}{l}\text { ADVANCED RESEARCH } \\
\text { \& SUPPORTING TECHNOLOGY } \\
\text { SUBACTIVITIES }\end{array}$} & \multicolumn{4}{|c|}{$\begin{array}{l}\text { BUDGET AUTHORITY } \\
\text { (OPERATING EXPENSES) } \\
\text { (DOLLARS IN THOUSANDS) }\end{array}$} & \multirow{2}{*}{$\begin{array}{l}\text { MAJOR } \\
\text { CHANGE* }\end{array}$} \\
\hline & $\begin{array}{l}\text { ACTUAL } \\
\text { FY } 1977\end{array}$ & $\begin{array}{l}\text { APPROPRIATION } \\
\text { FY } 1978\end{array}$ & $\begin{array}{l}\text { ESTIMATE } \\
\text { FY } 1979\end{array}$ & $\begin{array}{l}\text { INCREASE } \\
\text { (DECREASE) }\end{array}$ & \\
\hline $\begin{array}{l}\text { Materials \& Components } \\
\text { Conversion Processes } \\
\text { Direct Utilization } \\
\text { Program Development \& } \\
\quad \text { Integration }\end{array}$ & $\begin{array}{r}\$ 8,585 \\
15,200 \\
5,535 \\
7,750\end{array}$ & $\begin{array}{r}\$ 9,264 \\
16,401 \\
5,972 \\
\\
8,363\end{array}$ & $\begin{array}{r}\$ 11,090 \\
24,450 \\
9,450 \\
12,836\end{array}$ & $\begin{array}{r}\$+1,826 \\
+8,049 \\
+3,478 \\
\\
+4,473\end{array}$ & \multirow[t]{2}{*}{$\begin{array}{l}\text { A } \\
\text { A } \\
A \\
\text { A. }\end{array}$} \\
\hline TOTAL & $\$ 37,070$ & $\$ 40,000$ & $\$ 57,826$ & $\$+17,826$ & \\
\hline $\begin{array}{l}\text { "KEY } \\
N=\text { New start (totall) } \\
S=\text { Scalcup (from be } \\
A=\text { Acceleration (she } \\
\text { expansion of ong }\end{array}$ & $\begin{array}{l}\text { oject) } \\
\text { DU or pilot } \\
\text { deadlines o } \\
\text { jects) }\end{array}$ & \multicolumn{4}{|c|}{$\begin{array}{l}P=\text { Phase completion or startup } \\
R=\text { Program redirection } \\
I=\text { Incremental cost requirement } \\
C=\text { Project completion or suspension }\end{array}$} \\
\hline
\end{tabular}

AR\&ST projects are carried out approximately 50 percent by industry, 25 percent by ERCs, NLs and other government agencies, and 25 percent by universities. ERC and NL activities are discussed in greater detail in Chapter VI. University programs are discussed in greater detail in Chapter VII.

\subsection{MATERIALS AND COMPONENTS}

The success of coal cnnversion as a source for clean alternate fuels will hinge on both the efficiency and the continuity of operation of the conversion plant. Irrespective of the process selected, continuity will be totally dependent on the reliability of peripheral and support equipment and on the ability to maintain a steady state of operation.

To assure a smooth transition from shakedown to productive plant operation, special emphasis is directed to programs in:

- Materials research and selection

- Development of specialized components and equipment subsystems

- Instrumentation and control 
- Development of operating, maintenance and training manuals

- Development of personnel staffing guides specifically for coal process plants.

Since no large or commercial coal plants have been constructed in the United States, extra emphasis is being directed to the environmental impacts of coal conversion and how these will influence the health and safety aspects of coal plant operations.

The overall program structure is provided in Figure 5.

\subsection{MATERIALS FOR COAL CONVERSION}

Historically, every developing technology has been keyed to the prior development of critical materials. Coal conversion, with its erosive and currosive streams (where effiriency and economy are mucli enlianced at elevated pressures and temperatures) will never develop to successful commercialization without compatible materials of construction. Accordingly, a broad materials program has been undertaken to meet the specific and unique needs of coal-conversion technology. Elements of this program are:

- Conduct failure analysis of materials now in use in pilot plants, PDUs and in coal-handling applications

- Conduct research and development on the mechanisms of erosion, corrosion, abrasion, fatigue and other forms of deterioration as encountered under coal plant operating conditions and environments. Included will be metals, special-purpose alloys, ceramics, and refractories

- Select and develop compatible materials for economy of cost and endurance against wear or deterioration. Included are metals, alloys, ceramics, and refractory linings

- Operate one or more materials test facilities as required to obtain realistic material-test data

- Investigate and identify extra-strong and weldable steels for thick-walled prcoourc vessels

- Provide for the timely dictribution of illaterials information by seminars and newsletters.

A significant portion of these tasks are being investigated at the National Laboratories. Contributing are Ames, Argonne, Oak Ridge, Idaho National Energy Laboratory (INEL), Lawrence Berkeley, and Sandia. 

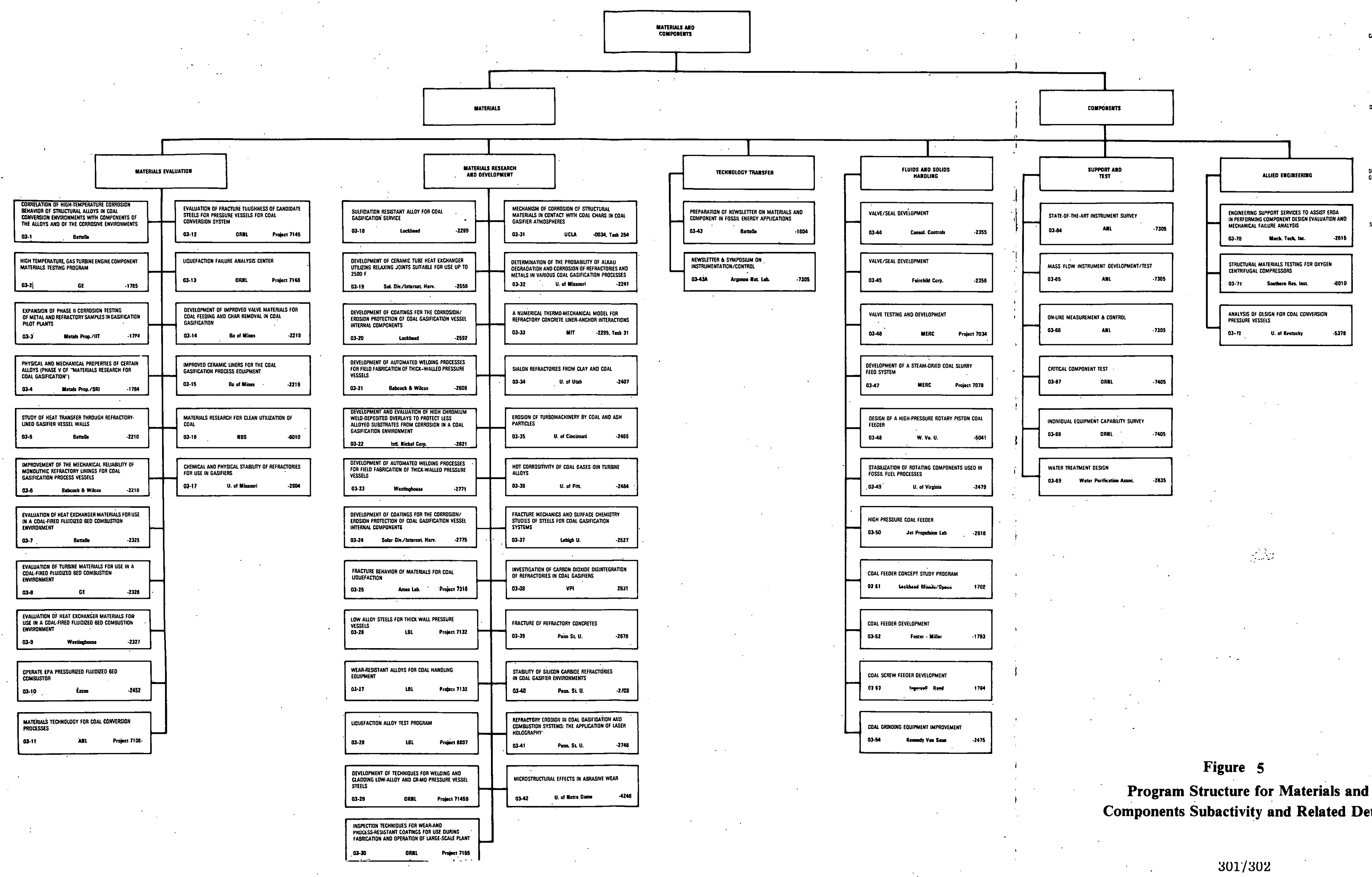

Figure 5

Program Structure for Materials and Components Subactivity and Related Details 
Significant accomplishments reported in FY 1978:

- Sulfidation has been shown the most frequent cause of metal failure in gasification reactors

- High-temperature alloys of $\mathrm{Fe}-\mathrm{Ni}-\mathrm{Cr}$ are not resistant to erosion/corrosion in gasifiers over long periods of exposure

- Alloys of $\mathrm{Fe}-\mathrm{Cr}-\mathrm{Al}$ show marked promise as corrosion-resistant claddings for internal use in gasifiers

- Refractory concretes of 95 percent alumina are degraded in gasifiers containing steam at high pressures; 50 percent $\mathrm{Al}_{2} \mathrm{O}_{3}$ refractories increase in strength under the same environment

- A first evaluation of materials for use in heat exchangers in fluidized-bed combustions (FBCs) and in pressurized fluidizedbed combustions (PFBCs) has been completed.

Anticipated accomplishments in FY 1979:

- Make selections of suitable commercial refractories for dry-ash gasifiers

- Complete the selection and/or development of compatible coatings for the internal surfaces of gasifiers

- Complete a feasibility study to guide development of sulfidationresistant alloys and metals for use in high temperature gasifiers

- Complete a design study of ceramic heat exchangers. 


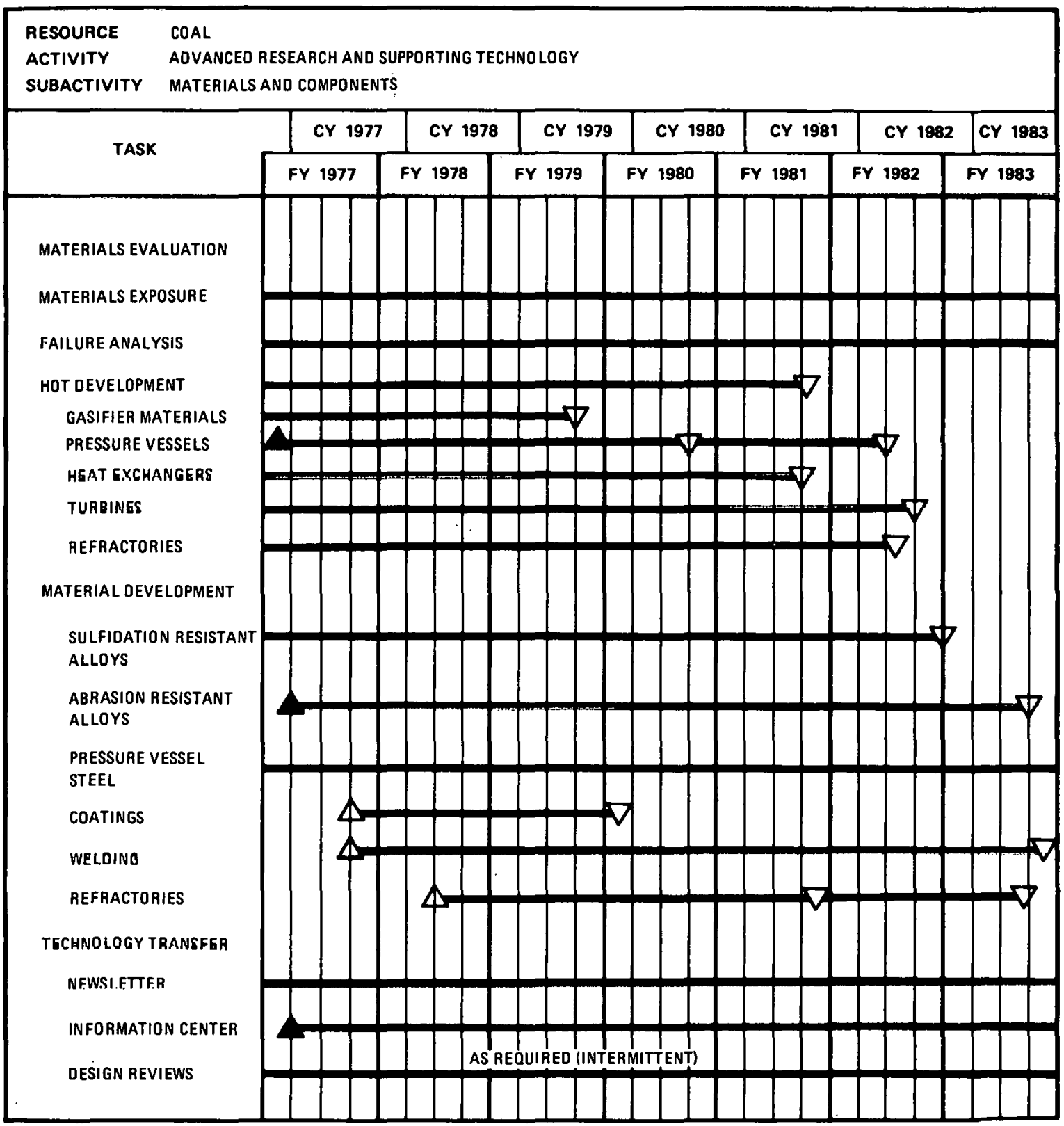

MILESTONE SYMBOLS ARE DEFINED ON LAST PAGE OF THIS DOCUMENT

\subsection{EQUIPMENT SUBSYSTEMS FOR COAL CONVEERSION}

All processes to convert coal to synthetic fuels are essentially similar in the basic chemistry. The difference among processes lie in the operating pressures and temperatures, the residence times, the physical contact between reactants and the composition of in-plant streams. Improvements in conversion processes both in economy and efficiency will result from plant scaleup, higher pressures, higher temperatures, faster reaction rates, and better contact between reactants. 
The coal plant can be no more reliable, however, than its support equipment and peripheral subsystems. Many current operating problems and shutdowns in coal pilot plants are directly attributable to the use of commercial components never intended for the higher temperatures and harsh environments of coal plants and in-plant streams. To provide equipments which will endure these environments over extended periods, a vigorous program has been undertaken to adapt, modify and develop special components, heavy equipment, subsystem and control instrumentation compatible with and scaled up to conversion plant needs with proper emphasis on critical plant geometries.

The following subsystems and components are under active investigation and development:

- Advanced techniques for the continuous feeding of coal to pressurized reactors. Four highly qualified contractors are involved in the solution to this critical problem

- Development and test of lock hopper valves from materials which will perform reliably under adverse and harsh environments

- Selection, adaptation and development of instrumentation and control mechanisms for coal-conversion plants

- Testing, screening and selection of valves in an existing test laboratory at Morgantown Energy Research Center (MERC)

- Selection and development of improved coal-grinding and sizing equipment to match the special plant-feed requirements

- Definition of equipment-test criteria and preparation of layouts and designs of a critical-component test facility or facilities. Prescribe test conditions and protocol which will assure suitable analog tests

- Survey, catalog and document commercial and custom-built coal-handling equipment for availability, compatibility and capacity. Initiate active development programs to provide components and subsystems not available.

Major portions of the above program elements are being implemented by government laboratories. Actively contributing are Oak Ridge, Argonne, Jet Propulsion Laboratory (JPL), and the Morgantown and Pittsburgh Energy Research Centers. 
Major accomplishments for the FY 1978:

- Prepared Critical-Component Test program

- Prepared a Coal-Feeder Development Program and schedule

- Developed competing coal-feeder designs through the pilotplant stage at a feed rate of 5 -tons $/ \mathrm{hr}$

- Successfully fed dry coal continuously into a simulated reactor vessel at a pressure differential of 1,500 psi

- Installed lock hopper valve in laboratory for certification of valve

- Awarded contracts to Fairchild-Stratos and to Consóliualed Controls Corporation on lock hopper valve development

- Completed a survey and documentation of available industrial equipment for use in coal conversion

- Assembled the grinding facility for wet and dry grinding of coal. Processed 400 tons of selected coals through the facility

- Developed an acoustic mass-flow measurement prototype in the area of instrumentation. Fabricated several units for test

- Designed and constructed a test facility for biphasal tests of solids/gas; calibrated same.

Expected accomplishments for FY 1979:

- Complete the coal-grinding contrant. with Kennerdy Van Saun Corporation; publish the Coal-Grinding Handbook

- Initiate high-pressure high-volume centrifugal slurry pump development program

- Develop a hot char discharge system

- Improve significantly the performance of oil/solids filtering systems for liquefaction plants

- Select four coal feeder designs for active development

- Evaluate acoustic and capacitive instruments to measure mass flow in both the HYGAS and Bi-Gas pilot plants

- Complete solids/gas test loop to permit routine active measurements and calibration tests of biphasal instruments.

- Publish an updated state-of-the-art report on instruments and controls for coal-conversion plants. 


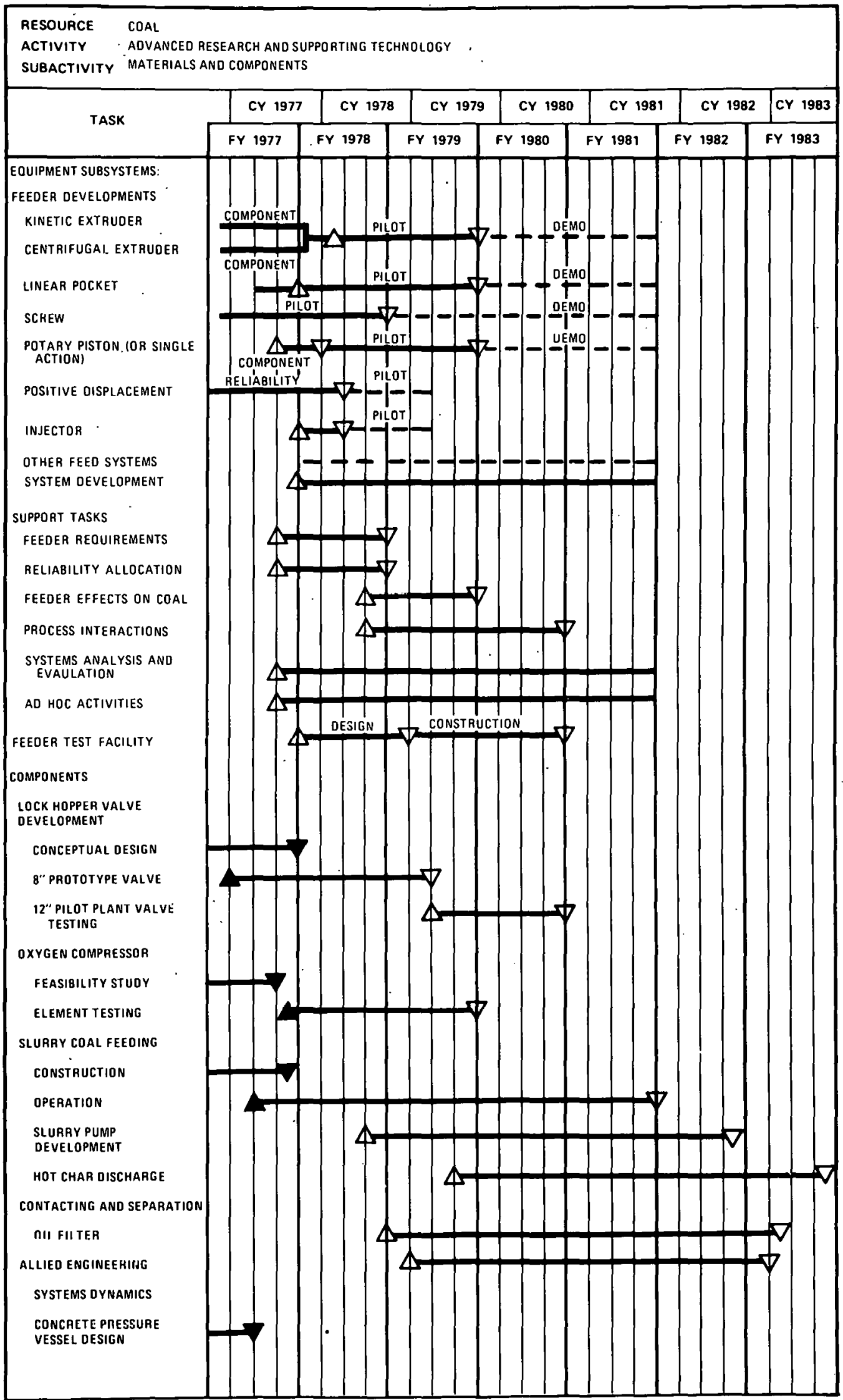

MILESTONE SYMBOLS ARE DEFINED ON LAST PAGE OF THIS DOCUMENT 


\subsection{CONVERSION PROCESSES}

There is considerable risk associated with the scaleup of the latest coal gasification and liquefaction processes under development, even when going from 1 ton/day to 100 tons/day. In addition, their costs will be highly capital intensive, as well as quite sensitive to the cost of the coal (or oil shale) and therefore to the overall thermal efficiency of the process. There is an urgent need for a better scientific and engineering base for ongoing development programs described in an earlier portion of this section, as well as for truly advanced, lower cost, synfuel processes, which have fewer steps and are simpler and permit substantially higher production rates per unit volume of reactor, at reasonably high thermal efficiencies. Finally, there is an ever pressing need for research development to offset the rapidly escalating overall costs of the current, highly capital intensive processes under development, as well as provide major economic improvements for subsequent second- and third-generation commercial plants from 1987 to 1992 . To meet such needs, a comprehensive basic and exploratory process research program is being supported in the arcas of coal gasification, coal liquefaction, and refining of coal-derived syncrudes and shale oil to distillate fuels, including gasoline.

The overall objectives of this process research are as follows:

- To develop basic chemical and engineering knowledge to facilitate the successful development of current and/or modified coal gasification and liquefaction processes and to provide leads to new processes

- To determine the technical feasibility and assess the economic potential of attractive new process concepts through the benchscale under steady-state conditions

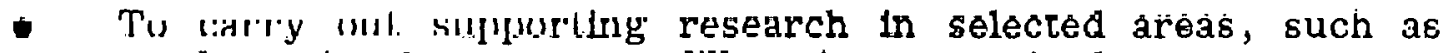
catalyst development, to fill majnr gaps in known processes under development, and/or to provide major improvements in these processes.

\subsection{LIQUEFACTION}

The goal of this researsh is to develnn advanced prosesses through the bench scale which have economic incentive for the direct or indirect liquefaction of coal to low-sulfur liquid boiler fuels, distillate syncrudes, and if possible, to distillate fuels directly. In addition, the goal of this research is to develop efficient processes for production of fuels such as gasoline, diesel fuel, and furnace oil by the upgrading and refining of coal-derived syncrudes. 
The major research categories are as follows:

- Extraction processes

- Hydroextraction/desulfurization process research

- CO-steam process research

- Catalytic hydroliquefaction

- Exploratory evaluation of catalysts

- Slurry catalyst process

- Pyrolysis and indirect liquefaction

- Flash hydrocracking/dilute phase hydrogenation

- Indirect liquefaction from syngas

- Refining and Chemicals

- Exploratory refining process

- Refining of coal derived syncrudes

- $\quad$ Supporting Research

- Basic chemical and engineering studies, e.g., structure of coal, pre-asphaltenes, mechanism of coal hydroliquefaction, coal/solvent/hydrogen mixing studies, catalytic reactor modeling/design studies.

Specific needs include development of a better understanding of the basic chemical and engineering aspects of the preheater stage in direct liquefaction; development of a lower cost reliable process for de-ashing nondistillate fuels; definition of the stages in direct liquefaction and relative rates; definition of the applicability of catalysis in direct liquefaction and of effective catalysts; development of a more cost-effective Lewis acid catalyst than zinc chloride for effecting the hydrocracking of coal to low sulfur, low nitrogen distillate fuels; and determination of the behavior of coal on rapid heat-up in the presence of hydrogen or synthesis gas relevant to the production of distillate fuels.

The overall program structure is provided in Figure 6.

Major accomplishments in FY 1977 and FY 1978:

- Completed exploratory research on entrained flow, flash hydropyrolysis of lignite to a synthetic gasoline blending stock and substitute natural gas

- Established operational reliability of a solvent refined lignite process in a $100 \mathrm{lb} / \mathrm{hr}$ continuous unit

- Demonstrated high conversion and yield of high octane gasoline from coal in a zinc chlorlde hydrocracking process in a benchscale unit

- Demonstrated technical feasibility of converting methanol to high octane gasoline in nearly quantitative yield in a fixed-bed, bench-scale unit 
- Demonstrated on a small scale a novel catalyst system capable of converting syngas to high octane gasoline in one step

- Uncovered new information indicating that coal undergoes irreversible reactions with certain solvents such as pyridine

- Provided experimental evidence that donor solvents such as tetralin, to a certain degree, become bound to coal in addition to transferring hydrogen

- Developed a detailed economic comparison between gasoline via Sasol Fischer-Tropsch technology and via methanol.

An overall milestone chart for the key projects is shown below

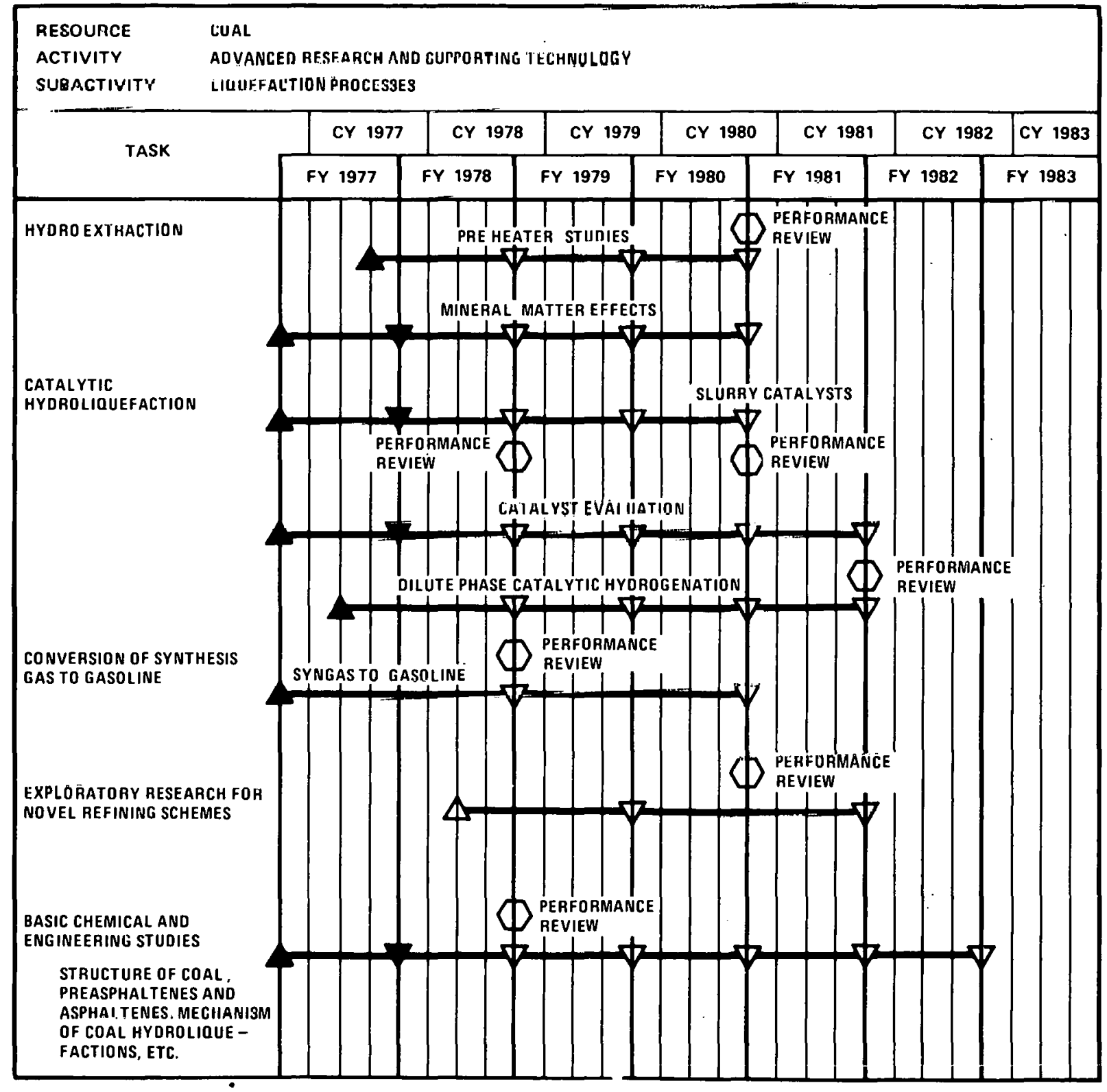

MILESTONE SYMBOLS ARE DEFINED ON LAST PAGE OF THIS DOCUMENT 


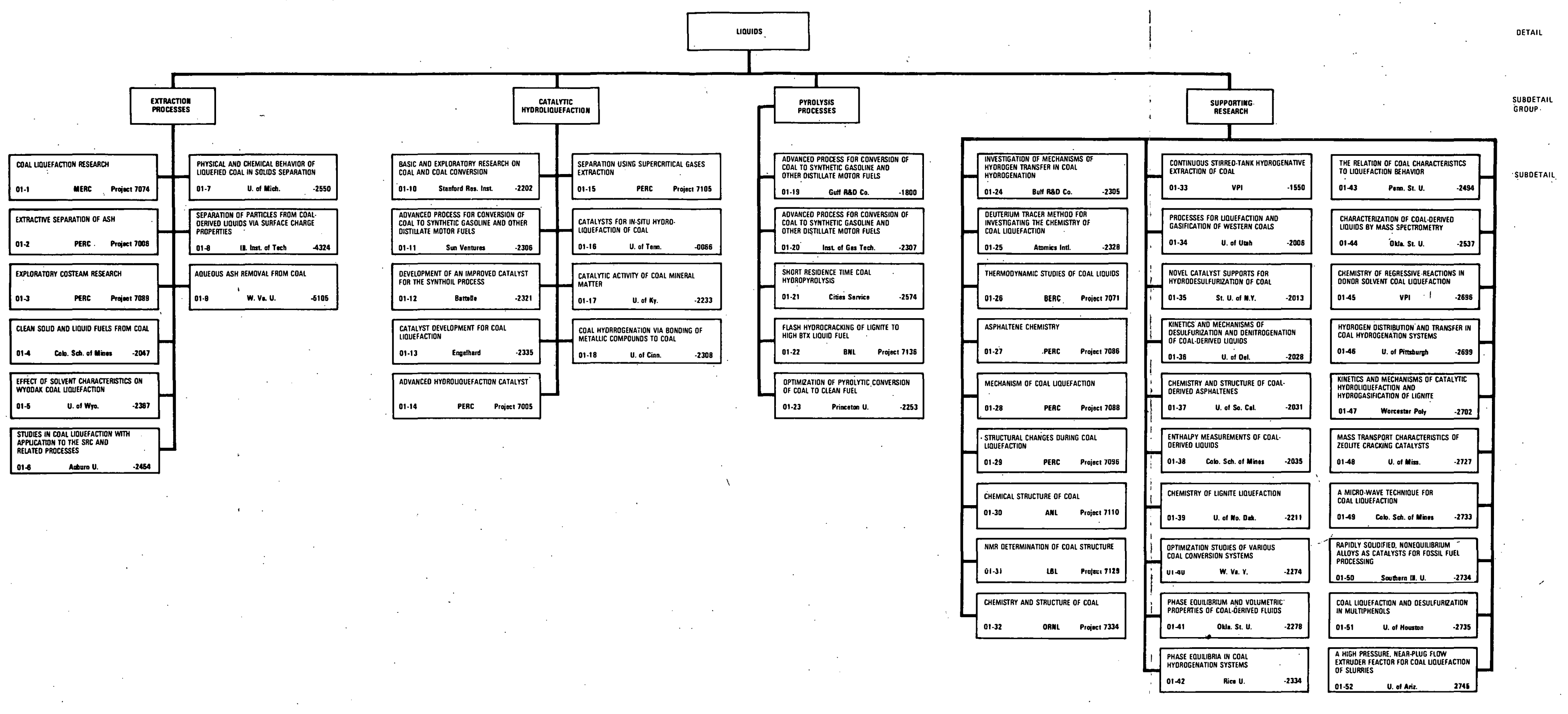

Figure 6

Program Structure for Liquefaction Detail of the Conversion Processes Subactivity 


\subsection{GASIFICATION}

Currently, a number of a second-generation coal gasification processes are being investigated at the pilot plant scale, and some are being considered for evaluation at the larger, demonstration plant level. Economic studies, based upon the available data, indicate that such processes are highly capital intensive and that end product costs are very sensitive to feedstock,' conversion efficiency, and operating conditions. A consideration of the current state-of-the-art indicates that there is need for an improved scientific understanding and a better engineering data base for use in both ongoing development programs and for identifying and evaluating advanced processes which offer technical and economic incentives over present technology. To meet this need, a comprehensive basic and exploratory process research and early development program is in progress.

The overall objectives of this project are:

- To provide an early assessment of the technical and economic potential of new, novel, and advanced gasification processes through small bench-scale and early process development studies

- To develop basic chemical and engineering knowledge to facilitate the successful development of current and future generation coal gasification processes and to suggest new approaches to coal gasification

- To carry out supporting research in selected areas such as catalyst development and gas cleanup to provide major improvements.

Major accomplishments in FY 1977 and FY 1978:

- Evaluated the effectiveness of lime and lime/caustic pretreatments of a caking bituminous coal for fluid-bed gasification with steam or hydrogen at high specific gasification rates and high methane yields

- Demonstrated the technical feasiblity of elements of an advanced, catalytic coal gasification process through benchscale experiments

- Developed technology for rapid rate hydrogasification concepts which produce synthetic natural gas (SNG) or, SNG-light hydrocarbon liquid (BTX) as coproducts by establishing process product yield structures as a function of reactor condition and feed stream composition and characteristics

- Developed improved methods for fabricating Rancy-nickel coated surfaces for use in methanation reactors 
- Expanded the thermodynamic data base for inorganic compounds related to coal conversion processes.

The Advanced Gasification Process Research program contains projects which are directed at conversion of coal to SNG, intermediate-Btu gas, synthesis, and hydrogen. The main program elements are:

- Advanced gasification processes for high-Btu gas

- catalytic gasification

- catalytic methanation

- rapid rate hydrogasification

- Advanced gasification processes for low- and intermediate-Btu gas and hydrogen

- Short residence time (fast pyrolylic) gasification

- catalyote gaeification for hydrngen

- $\quad$ Supporting research

- gas cleanup and separation

- reaction kinetics and thermodynamics

- preliminary engineering and economic assessments

The overall program structure is provided in Figure 7.

Specific current research needs include development of a better understanding of the fundamental controlling factors associated with coal/steam, coal/hydrogen gasification processes; development of an advanced catalytic gasification process; development of an advanced, short residence time hydrogasification process; development of cost effective, efficient hot-gas cleanup systems for removal of sulfur speries, alkali metal species and particulates, and a further expansion of the data base related to process chemistry, kinetics, and thermodynamics.

FY 1979 goals :

- Complete preliminary assessment of technical and economic potential of catalytic coal gasification processes

- Establish process chemistry information for rapid rate hydrogasification of lignites and subbiluminous coals

- Initiate exploratory research on advanced gas cleanup processes for both high- and lnw-Btu gasification

- Develop an improved understanding and dalia base related to the kinetics and thermodynamics of gasification processes.

An overall milestone chart for the key projects is shown below. 

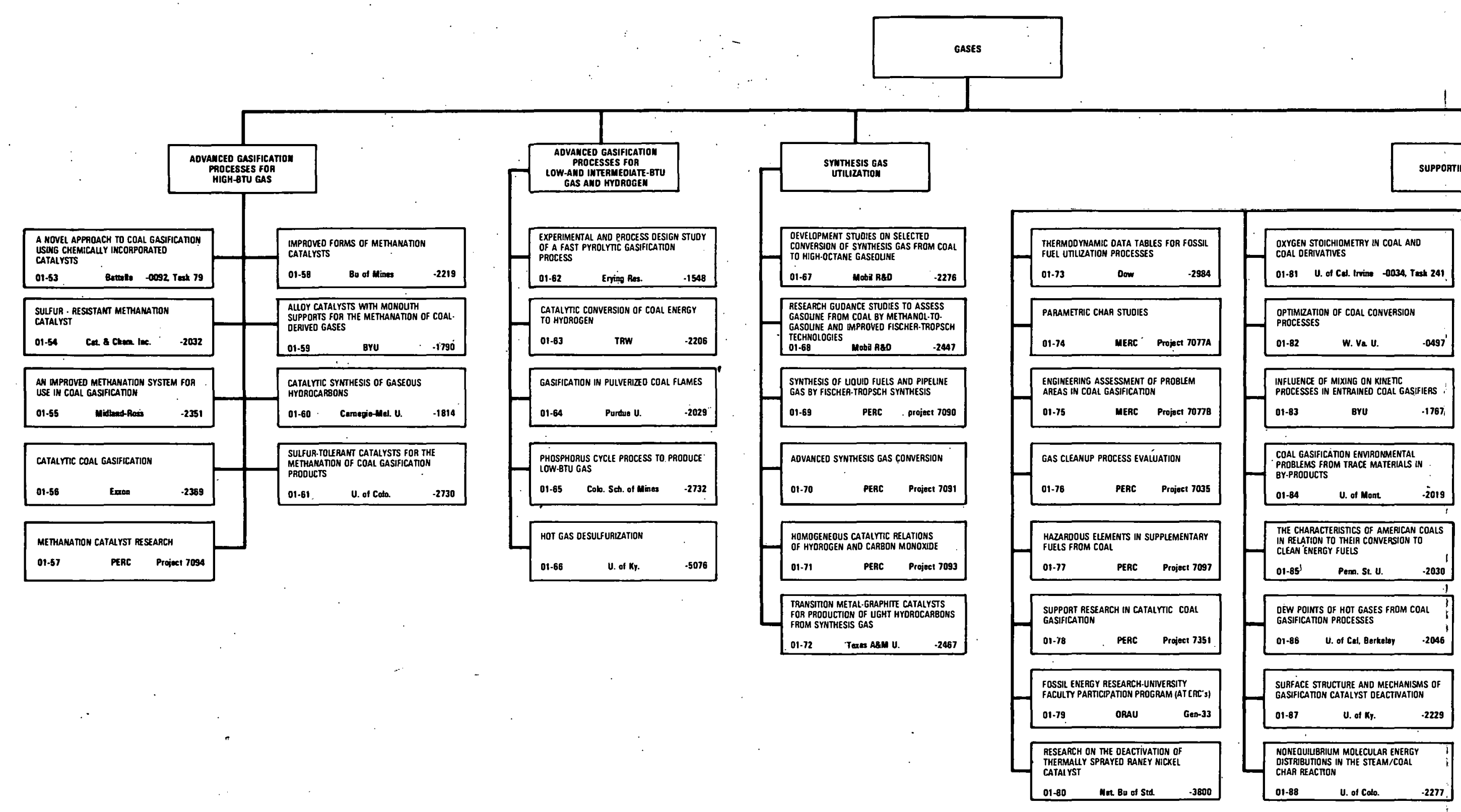

Figure 7

Program Structure for

Gasification Detail of the Conversion Processes Subactivity 


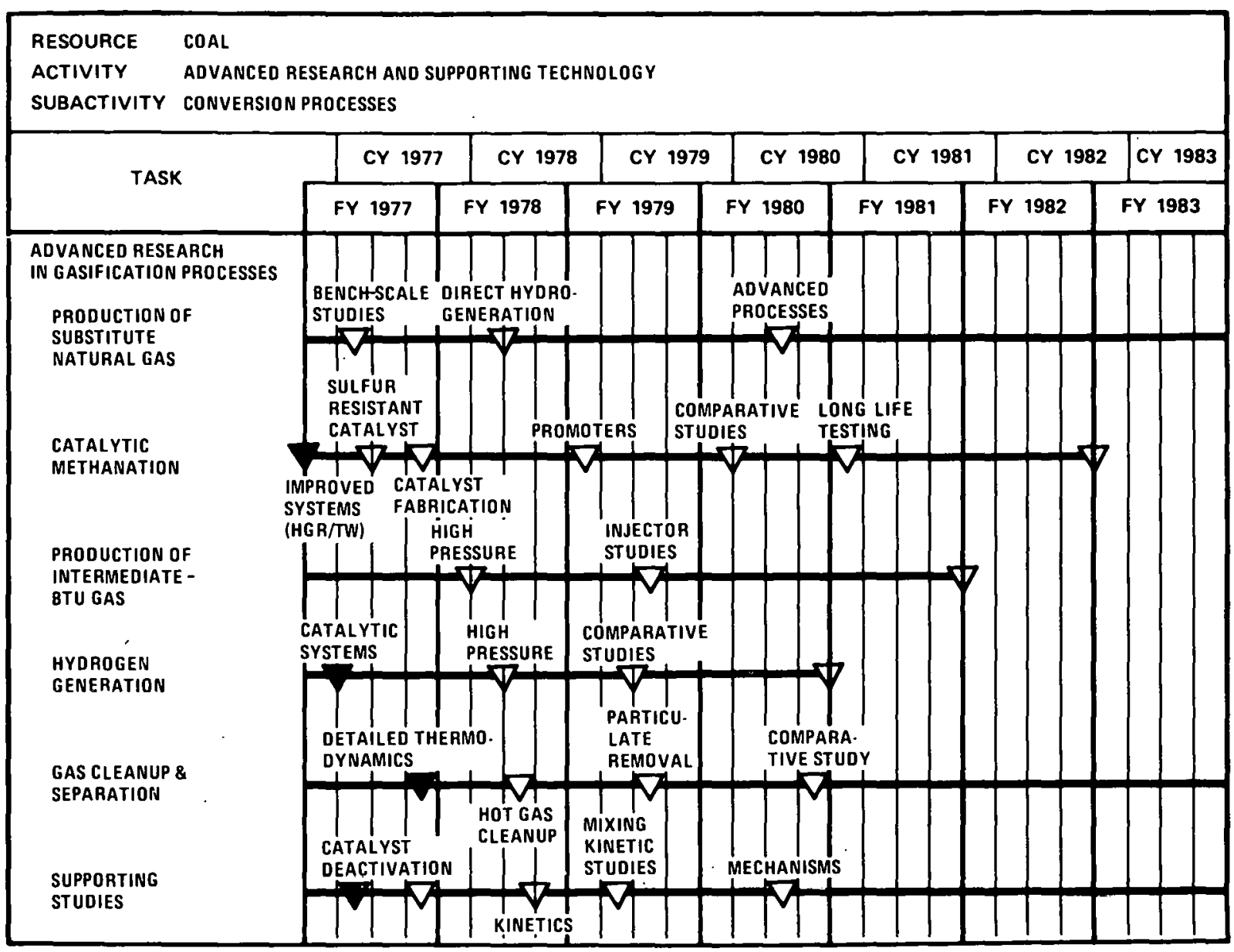

MILESTONE SYMBOLS ARE DEFINED ON LAST PAGE OF THIS DOCUMENT

\subsection{REFINING AND CHEMICALS}

The goal of this research is to develop efficient processes through the bench scale for the production of distillate fuels such as gasoline, diesel, and jet fuels, by the upgrading and refining of coal-derived syncrudes and shale oil, or by the conversion of synthesis gas from coal (i.e., advanced Fischer-Tropsch type processes), and to assess the relative economic potential and trade-offs. Studies to date have shown that there are problems and that a significant economic incentive exists for improved technology and processes.

The major research categories are as follows:

- Refining process research

- Upgrading/refining of solvent-refined-coal

- Technology/economics of refining coal-derived syncrudes

- Catalyst research and development

- Advanced catalytic refining processes

- Exploratory catalyst research

- Synthesis gas utilization - indirect liquefaction

- Conversion of methanol to gasoline

- Advanced Fischer-Tropsch process 
- Engine testing of synthetic fuels

- Characterization of syncrudes

- Chemical feedstocks (as coproduct from above processes)

- Support studies

- Basic chemical and engineering studies, e.g., particulate removal from nondistillate fuels, mechanism of hydrocracking syncrudes

- Engineering and economic assessments

The overall program structure is provided in Figure 8.

Specific needs include definition of the economic trade-offs between indirect and direct liquefaction/refining routes to various distillate fuels; characterization of syncrudes and definition of optimum refining technolngy; refinition of applicability of existing petroleum rel'ining lechnology for coal-derived syncrudes and shale oil, and associated coets; definition of the opportunities for improvements and major advances in the refining of syncrudes; and development of selective catalysts for the efficient hydrogenolysis of coal-derived syncrudes to refined fuels with minimum hydrogen consumption.

An overall milestone chart for the key projects is shown below.

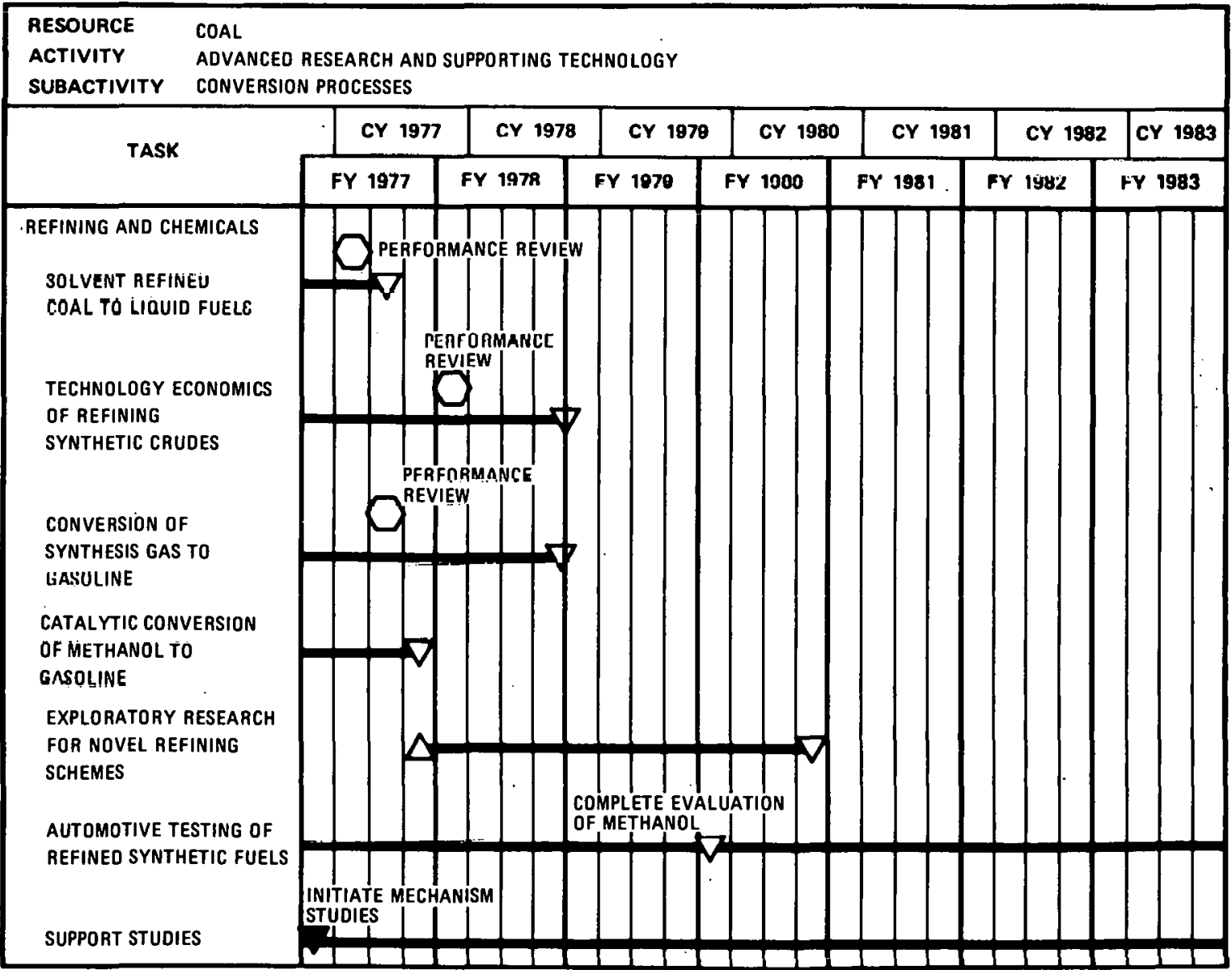

MILESTONE SYMBOLS ARE DEFINED ON LAST PAGE OF THIS DOCUMENT 


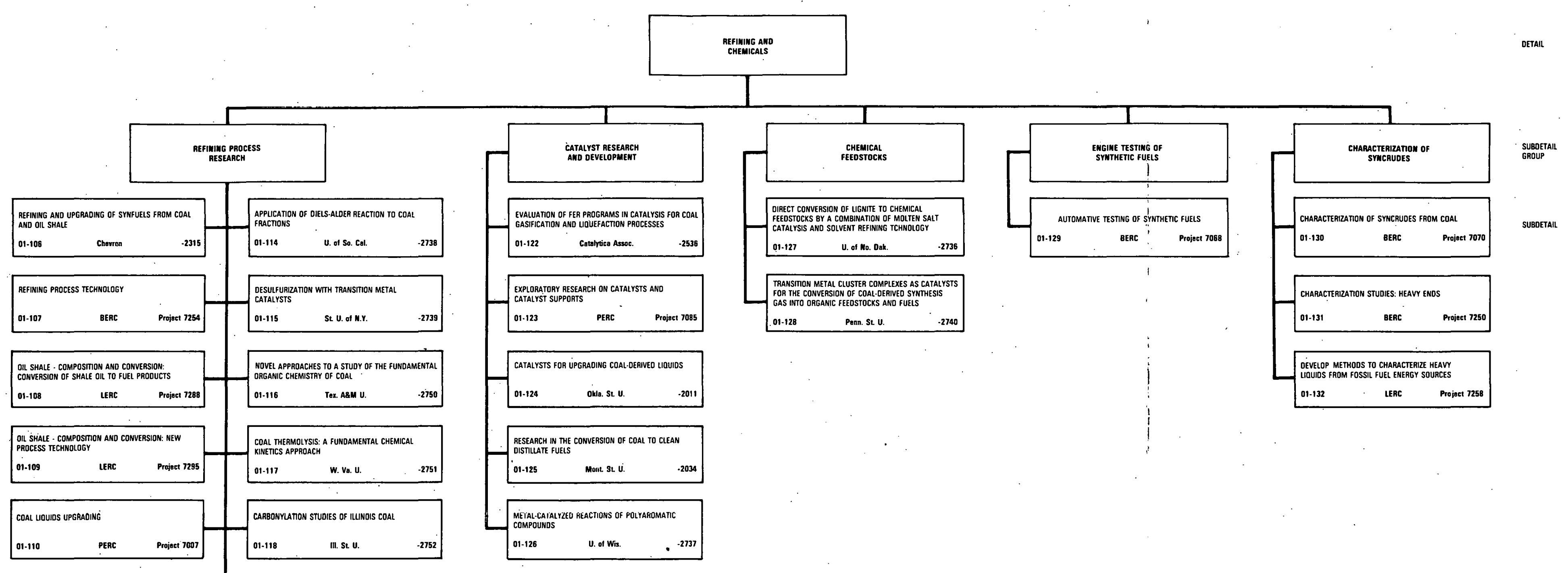

Figure : 8

Program Structure for Refining and Chemicals, Detail of the Conversion Processes Subactivity 


\subsection{DIRECT UTILIZATION TECHNOLOGY}

To accelerate direct utilization of coal by industry, many problems relating to end-product use must be solved. This section indicates which problems will be emphasized to achieve maximum efficiency in direct coal utilization.

This work is intended to improve the competitive position of coal as a commercial fuel for electric power generation and industrial purposes by upgrading raw coal supplies and developing improved methods for environmentally acceptable combustion.

In FY 1976 and 1977, improved sorbent capabilities for $\mathrm{SO}_{2}$ removal and potential for chemical comminution of coal have been demonstrated; quantitative ash-fouling tests have been utilized toward conservative boiler design and the effectiveness of combustion modifications to lower the $\mathrm{NO}_{\mathbf{X}}$ emissions from pulverized-coal combustors has been demonstrated. In FY 1978, the emphasis will be on laboratory and bench-scale development of advanced coal beneficiation processes, alternative preparation methods of coal/oil mixtures, and advanced hot-gas cleanup concepts. The environmental impact of these technologies will be an important aspect of all these studies. Program structure is shown in Figure 9.

\subsection{BENEFICIATION}

The objective of this effort is to improve economic and environmental aspects of coal through precombustion beneficiation. To achieve this objective, chemical, thermal, or physical treatments to reduce sulfur, ash, moisture, and deleterious physical and chemical characteristics currently affecting the cost and environmental acceptability of coal must be developed. 


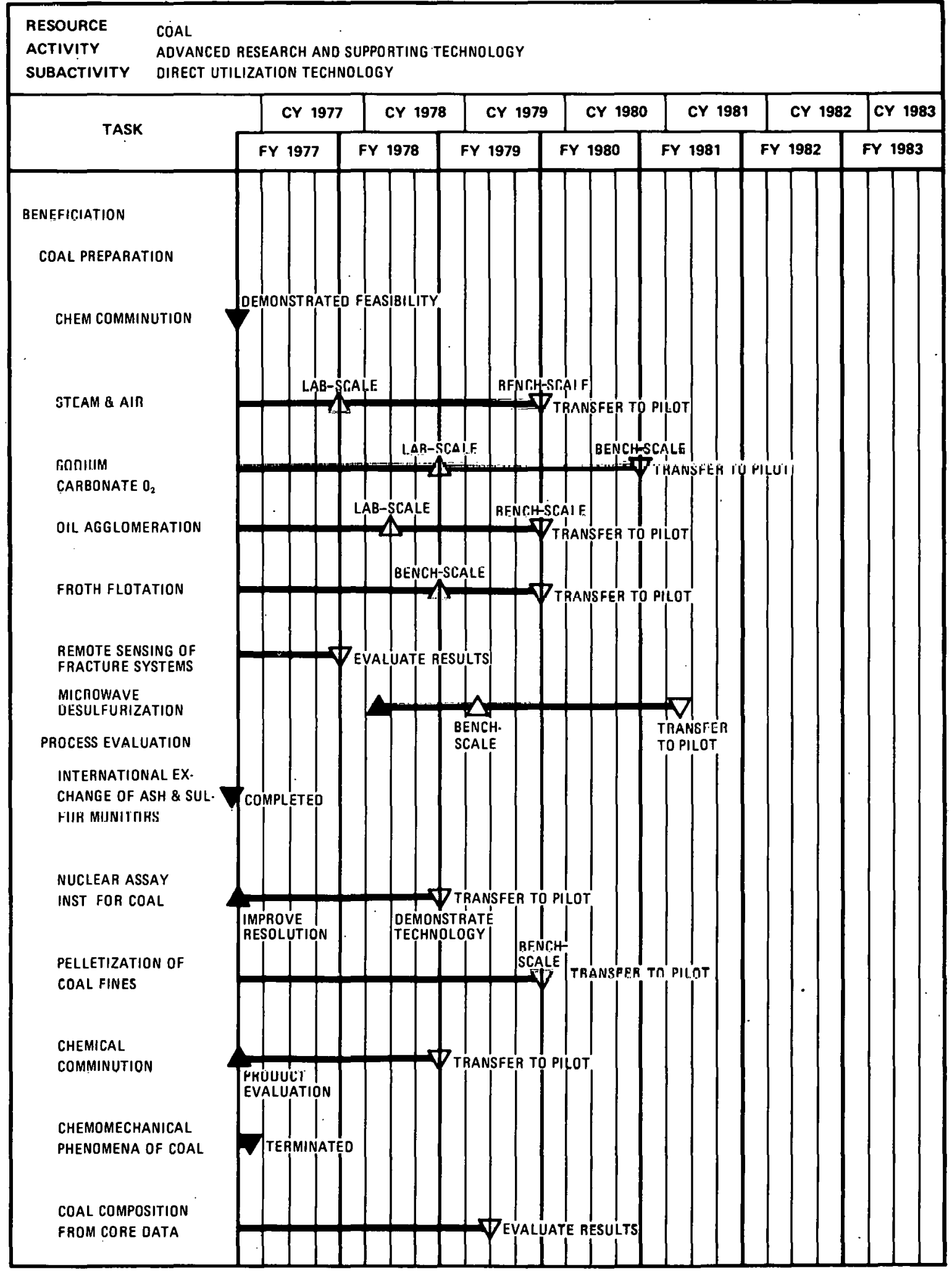

MILESTONE SYMBOLS ARE DEFINED ON LAST PAGE OF THIS DOCUMENT 


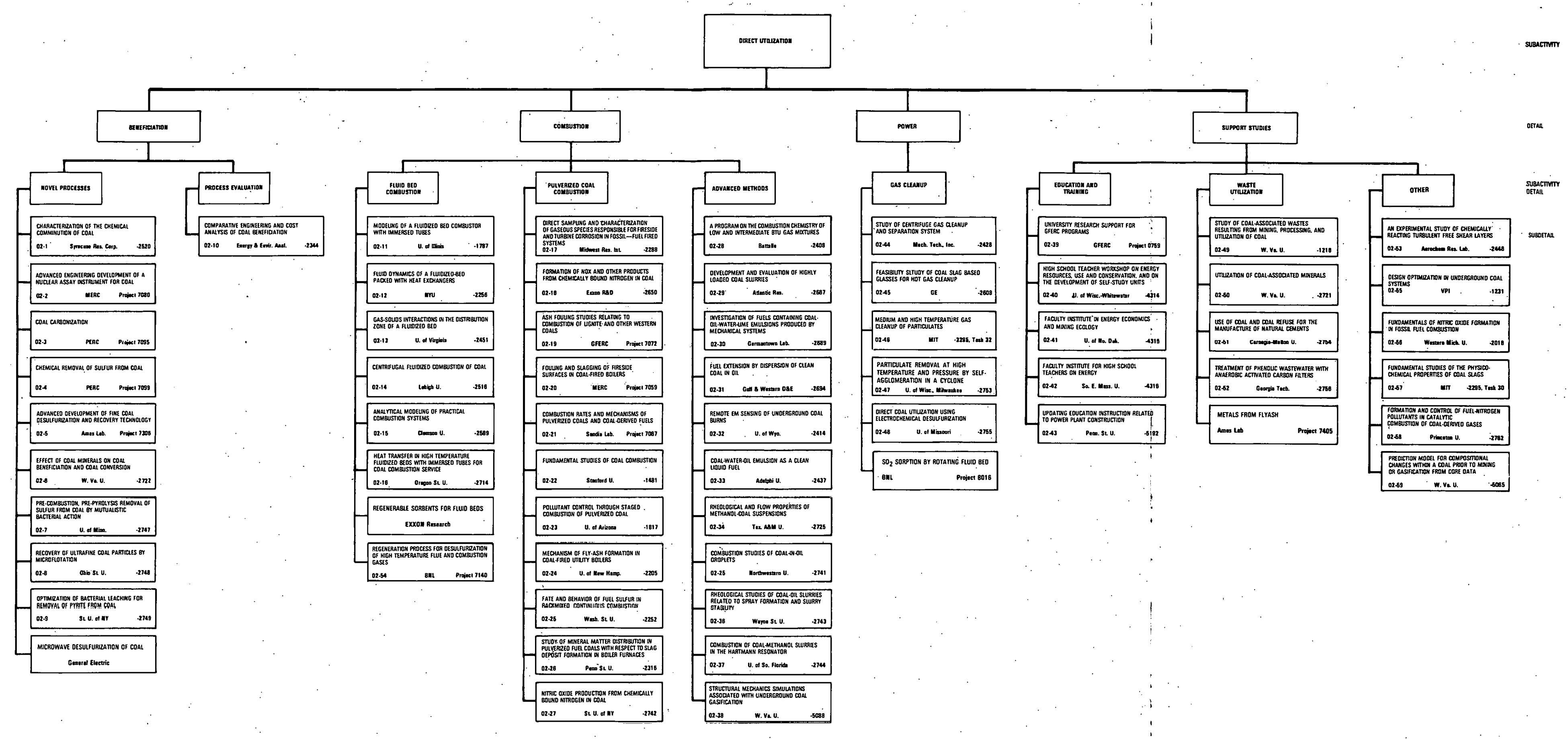

Figure 9

Program Structure for Direct Utilization Subactivity and Related Details 


\subsection{COMBUSTION}

The objective of this effort is to improve the competitive position of coal for power and process heat generation through advanced combustion technology (fluid beds, coal/oil slurries, advanced concepts). New and improved coal combustion processes to reduce environmental impact and cost, and to increase power conversion efficiency of coal-based electric power and process heat production must be developed to achieve the objective of this effort.

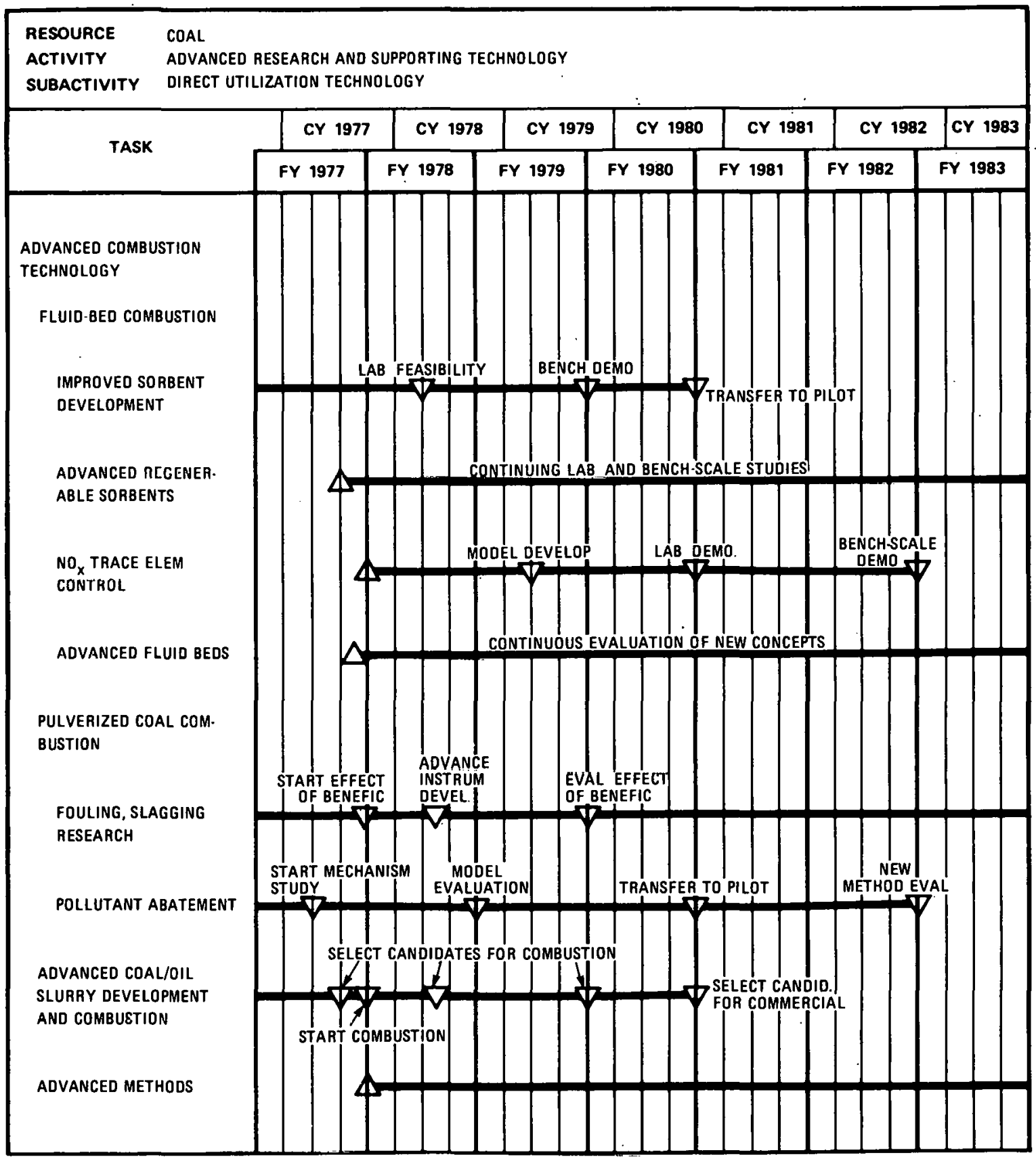

MILESTONE SYMBOLS ARE DEFINED ON LAST PAGE OF THIS DOCUMENT 


\subsection{POWER}

The objective of this technology effort is to extend the use of coal for electric power generation through improved power conversion systems that are economically compatible with coal and coal-derived fuels. Therefore, the technology required to design, construct, and operate advanced power conversion systems of greatest potential commercial benefit on a coal-based fuel economy must be developed.

Cleaning of the hot-gas stream directly as it emerges from a coalconversion or combustion process can make a significant impact on the total cycle efficiency of power generating systems, especially those involving gas turbines. Existing techniques for removing fine particulates resulting from the various coal utilization processes are not fully satisfactory. The objective of this effort is to investigate new or unique concepts to achieve the desired objective of particulate remnval

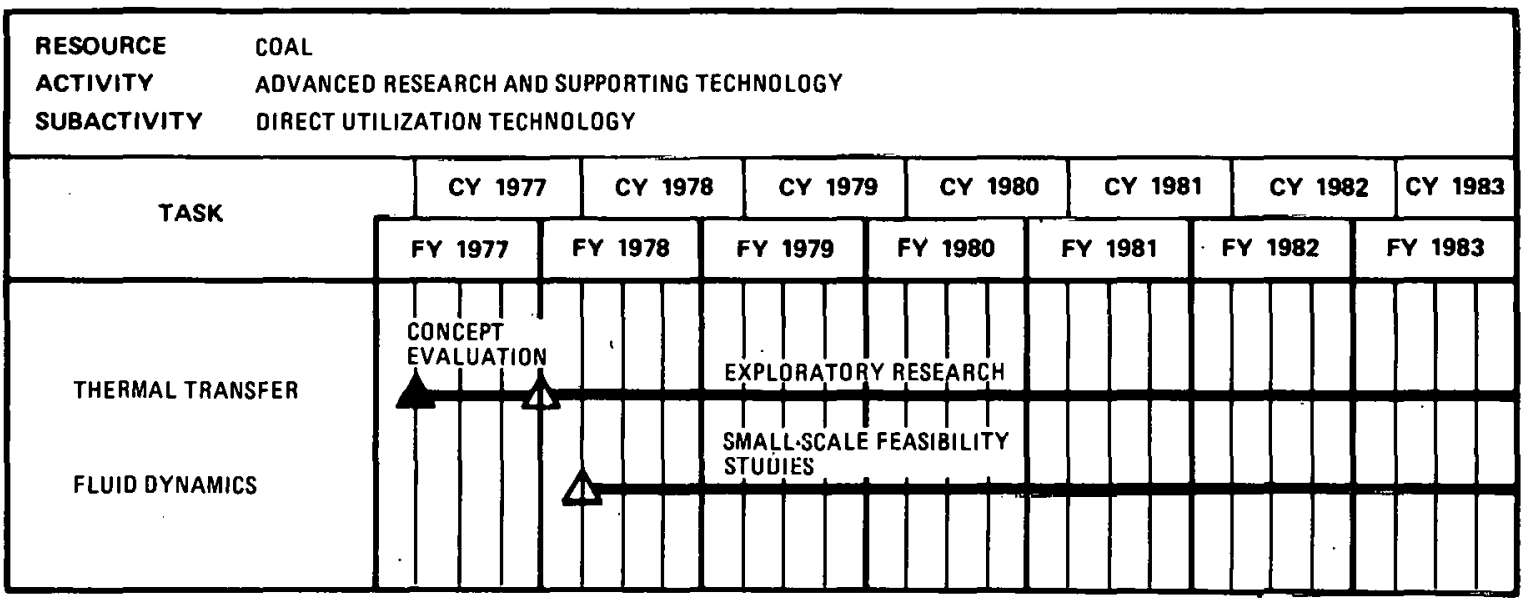

MILESTONE SYMBOLS ARE DEFINED ON LAST PAGE OF THIS DOCLMENT

\subsection{SUPPORT STUDIES}

It is estimated that by 1985 roughly 100 million tons of solid residue (fly-ash, coal-conversion residue, etc), resulting from the utilization of more than 1 billion tons of coal for power and fuels production, will be generated annually. This material, if treated as waste, presents a significant disposal problem to the nation. The objective of the support studies effort is to investigate new methods to improve the economics of extracting resource materials and/or utilization of the waste (e.g., inaterials of construction). 


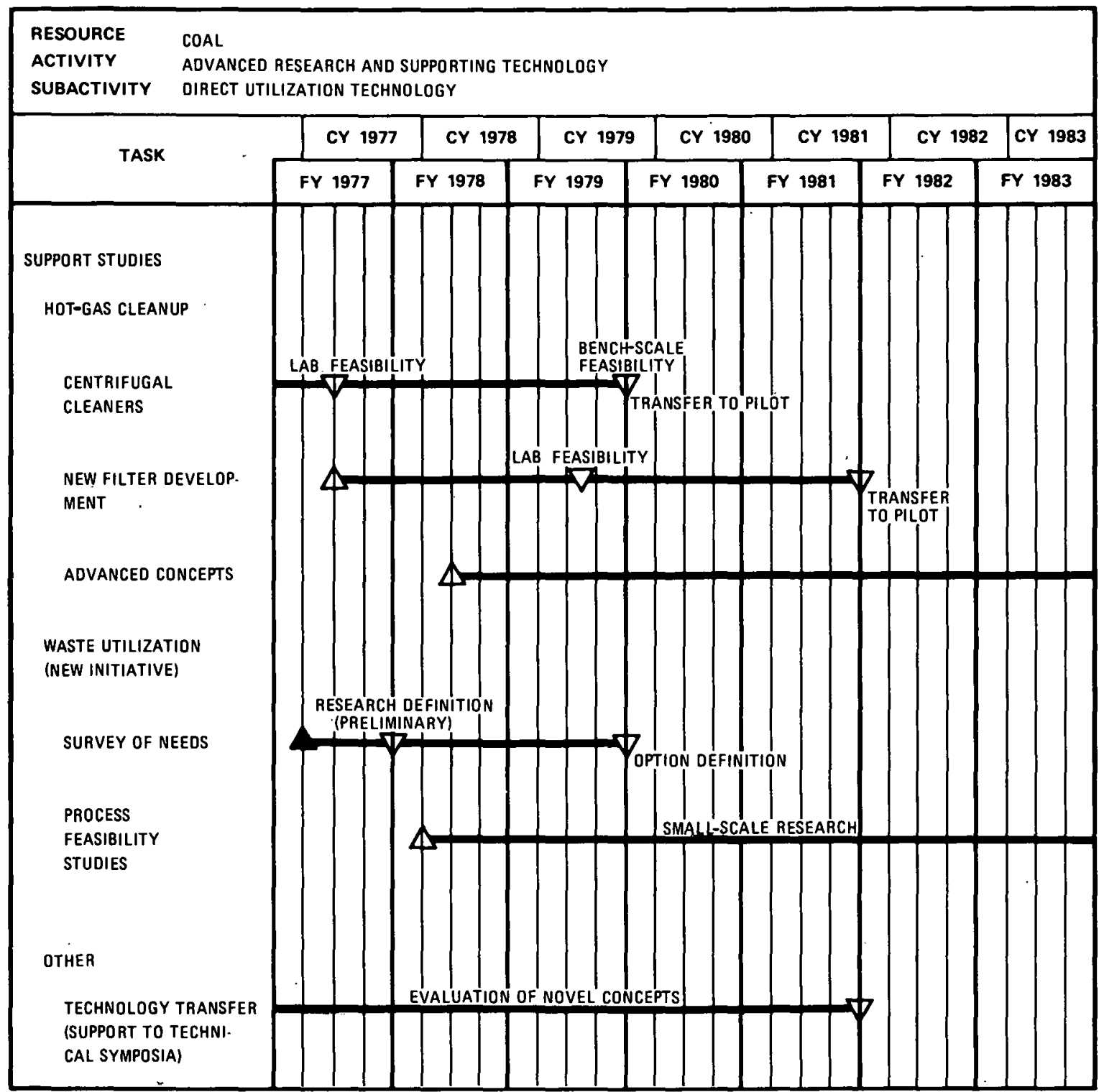

MILESTONE SYMBOLS ARE DEFINED ON LAST PAGE OF THIS DOCUMENT

\subsection{PROGRAM DEVELOPMENT \& INTEGRATION} include:

The four major supporting functions performed under this subactivity

- Environmental Coordination

- Planning and Budget

- Review and Analysis

- Project and Policy Coordination. 


\subsection{ENVIRONMENTAL COORDINATION}

The Office of Environmental Activities with the Division of Program Control Support is responsible for overall environmental and socioeconomic coordination of the Fossil Energy program which includes:

- Identifying needs and program goals for environmental, health, safety and socioeconomic activities associated with fossil technologies

- Preparing the Environmental Development Plans (EDPs) for carrying out fossil-related environmental, health, safety and socioeconomic research in DOE

- Preparing programmatic and site-specific environmental impact statements and providing assistance to the Fossil Fnergy terhnology divisions in oarrying out sitemspecific environmental assessments

- Providing guidance and expertise to the technology divisions in addressing environmental, health, safety, and socioeconomic problems associated with FE programs.

\subsection{PLANNING AND BUDGET}

\section{Planning}

This area will continue development of $\mathrm{FE}$ strategies and rationale to enable a more informed choice of a set of advanced technologies for RD\&D. Continued and planned studies include:

- Policy. Analysis/Mission Analysis: This activity' evaluates new and existing studies and forecasts that relate directly to $\mathrm{FE}$ programs and conducts analyses that provide an appropriate translation and disaggregation of agency forecasts to FE forecasts.

- Technology Program Strategy Development Support: These activities include the strategic analysis and other related activities conducted to support program divisions in the development of new technology program strategies (e.g., EOR, EGR, low-Btu gasification, MHD, etc.). The role of Strategy and Planning in these activities is to plan and execute strategic analyses which will provide an improved analytical basis for the formulation and documentation of a division's strategy for a specific technology program. These analyses are initiated at the request of, and in cooperation with, the program divisions.

- Market Strategy Development Crosscutting: These activities include the market analyses, trade-off analyses, and strategy documentation necessary to develop an analytically supported, coherent FE strategy for each of the principal market sectors (e.g., industrial and electric utility). Strategy and Planning 
has the lead role in these activities which incorporate other staff and divisional participation and integrate the results of analyses from various sources. The further development of these market sector strategies is an essential step in developing FE's ability to relate its program strategies to the markets they are intended to impact.

While the primary focus of these activities is on market sector analysis and strategies, it is also necessary to cut across market sectors and examine the interdependencies and impacts. That is, a rational FE strategy for the industrial market cannot be developed without examining the impact on the other market sector strategies. The activities devoted to examining these interdependencies are grouped under the heading "Analysis of Alternative Strategies."

\section{Budget}

The objective of this program support area is to develop integrated FE program plans and budgets that entail:

- Developing and planning FE resource requirements to carry out R\&D programs. This includes coordinating all FE budget estimates; preparing calls and providing guidance and technical assistance to all program divisions and field offices; coordinating analysis and review of the budget; coordinating the preparation of testimony and supporting justification or information; coordinating reprogramming, amendment, and supplemental budget actions; and coordinating responses to internal, Office of Management and Budget (OMB), and congressional program inquiries.

- Preparing program and planning documents in support of FE R\&D efforts. This includes coordinating the preparation of the annual Fossil Energy Research Program (Gold) Book, Management Review and Control, and Spring Planning Documents and assisting in the preparation of other technical documents.

- Coordinating resource requirements of the Energy Research Centers and National Laboratories. This includes providing the field operations with planning and budget guidance, consolidating and analyzing their resource requests, and providing them with approved operating Financial Plans.

- Ensuring effective utilization of available resources. This includes providing management with up-to-date financial reports; coordinating all contract procurement actions; certifying availability of funds in conjunction with approved procurement and financial plans; maintaining an on-line Data Management System to provide timely data to serve management in resource decision making, and coordinating ERC/NL budget matters with area Operations Offices. 
- Providing a full range of financial management support for FE. This includes all other support in the financial management area which is required to serve FE program and executive management needs such as procurement tracking and financial systems development.

\subsection{REVIEW AND ANALYSIS}

This area will continue independently to review and analyze selected FE projects to assess progress toward outlined objectives and to evaluate and analyze process technology, process design, and process economics as related to FE RD\&D projects. Planned and continuing activities include:

- Intensifying process design and economic analyses of fossil energy recovery and conversion technologies including coal, oil shale, petroleum, natural gas, and lieavy oils; Identffying new fossil energy sources and technologies that warrant process design and economic evaluations

- Reviewing, analyzing, and evaluating selected fossil energy technologies and process designs; comparing competitive processes, and expanding the knowledge base for coal conversion technologies through analysis of foreign technologies

- Developing criteria for analyzing FE program goals and objectives; maintaining continuing review of programs to ensure adequate progress; reviewing specific $F E$ projects to determine their technical progress and performance; and assisting in preparing the overall DOE FE R\&D program plan.

\subsection{PROJECT AND POLICY COORDINATION}

The Performance Assurance System (PAS) is a management technique to help achieve the early, cost-effective and reliable performance of FE plants. It draws upon the principles of reliability and maintainability engineering, life-cycle cost analysis, service life prediction, quality control, data collection and analysis, standardization, and other related performance assurance disciplines which have been developed by both guvernment and industry and incorporates them into a standardized Fossil Energy PAS program.

PAS is designed to ensure or provide for the following:

- Idcntificătion of all reliability critical, maintenance critical, and cost critical items in a plant/project and the recording/documentation of the performance of these critical items throughout the design, construction, and operational phases

- Identification and documentation of failure modes of these critical items 
- Actions to enhance plant operability (i.e., redundancy, improved maintenance, improved quality)

- Life-cycle cost analysis

- Service life estimations of equipment/components

- Standardization through use of common items/material

- Documentation and update of plant configurations, as required

- Development and documentation of operation/maintenance procedures

- Monitoring and documentation of materials suitability

- Collection of complete plant/project operability data.

Also included in this area is special executive directed studies or projects relating to policy and program issues. 


\section{J. MAGNETOHYDRODYNAMICS}

The major objective of the MHD Power System Activity is the development of electrical, utility-sized combined MHD/steam-cycle power generating plants, utilizing coal as a primary fuel in a process that is significantly more efficient and environmentally acceptable than any other known process.

The current MHD Activity is primarily directed toward open-cycle systems and is based on significant supporting science and technology activities, including laboratory-scale testing and preliminary engineering studies. Exploratory work is also proceeding on closed-cycle systems, concentrating on heat exchanger problems. The closed-cycle concept is not as advanced as the open-cycle.technology, and current closed-cycle work is addressing the basic feasibulity issues that must be resolved before the closed-cycle system can be considered a serious alternative to the open-cycle system.

Environmentally, the emissions of $50 \mathrm{x}$ from an MHD facility are less than from conventional coal-fired boilers because of the use of potassium as a seed material which combines with sulfur as an inherent by-product of MHD power generators. These products may be separated out in a downstream process. The overall environmental impacts of MHD will be less than those of conventional combustion because of the high conversion efficiencies associated with the technology. Other environmental concerns under study include:

- $\quad \mathrm{N}_{\mathrm{x}}$ emissions resulting from high operating temperatures

- Development of waste management methods

- Relationship of high-strength magnetic fields to humans.

The table below summarizes the funding levels by task for the FY 1977 to 1979 period.

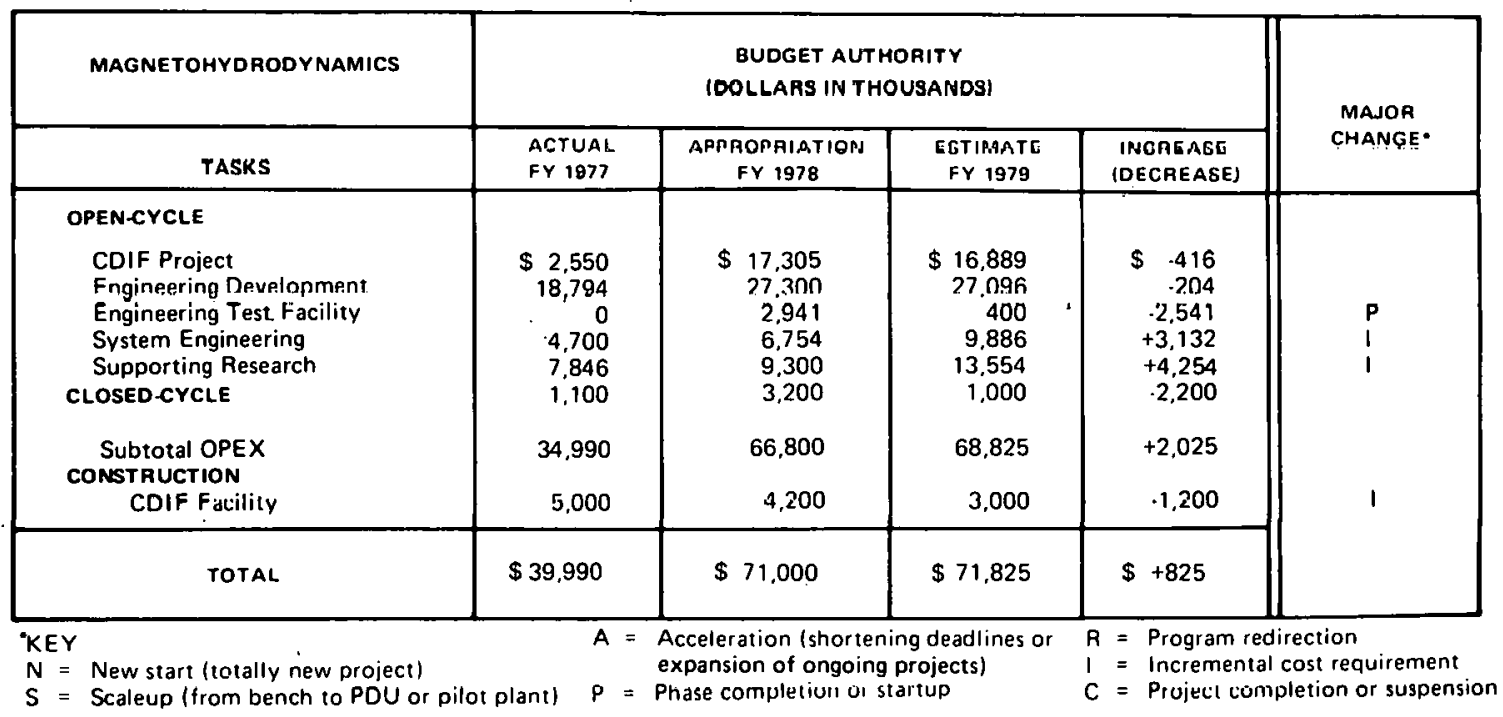




\subsection{OPEN-CYCLE}

The jointly funded ERDA-NSF-NASA Energy Conversion Alternative Study (ECAS) compared the performance and economic merits of many contending advanced electric power conversion system concepts for utility base load applications using coal or coal-derived fuels. The study concluded that the combined open-cycle MHD/steam system offers the greatest potential for significant improvement in overall plant efficiency and cost improvement potential. This system offers efficiencies greater than 50 percent from coal pile to bus bar with a competitive cost of electricity at about 34 mills $/ \mathrm{kWh}$. An additional outstanding feature of the open-cycle MHD generator is that it has an experimentally demonstrated capability of operating with a working fluid produced by the direct combustion of coal without the need for first completely removing the ash and sulphur content. The basic open-cycle process results in plant exhaust emissions that meet the most stringent air quality standards and the MHD plant's higher operating efficiency inherently results in lower thermal pollution levels.

Initial development of MHD began during the late 1950s. Programs exist both in this country and abroad, notably in Japan and the USSR. The basic distinction between the U.S. and foreign programs is the emphasis abroad on "clean" fuels usage; that is, natural gas in the USSR and fuel oils in Japan. In the United States, emphasis is on coal as the primary fuel; with present activities aimed at understanding the basic phenomena, evaluating the performance of small and intermediate size components, and defining the full-scale system requirements. The next critical program objectives are to operate a 5 Tesla superconducting magnet and to initiate critical component developmental testing in DOE-owned test facilities.

MHD power generation is based on the direct conversion of heat to electricity by passing a high temperature, high velocity, electrically conducting fluid through a magnetic field. The principle is similar to a conventional turbine-generator system, the difference being that the rotating conductors of a turbo-generator are replaced by a partially ionized combustion gas which is accelerated to interact with the magnetic field. The interaction of the accelerated conducting fluid with the intense transverse magnetic field induces an electric field within the fluid. If electrodes are present to collect the current, then electric power can be supplied through an inverter to a utility power grid.

Potassium seed typically is injected into the combustor in the form of potassium carbonate to achieve adequate levels of electrical conductivity in the combustion products at the temperature involved. This requirement provides a unique built-in capability for removing sulfur pollutants produced during the combustion of sulfur-bearing coals. The potassium seed reacts preferentially with the sulfur and the products are then removed from the system in the form of potassium sulfate, which is then regenerated to potassium carbonate to recover the seed and separate the sulfur. 
The combustion products leaving the MHD generator are no longer appreciably conductive but still have a temperature in the range of $3000 \%$. The remaining large amounts of usable thermal energy downstream of the MHD generator are used to generate additional power. This is accomplished by the utilization of a bottoming steam-turbine power plant. The concentration of $\mathrm{NO}_{\mathrm{x}}$ products in the exhaust gas are controlled by a combination of two-stage combustion and gas-stream cooling. High temperature combustion can be initially "fuel rich" to minimize N0x formation and can then be completed at lower temperatures to further impede NOx formation. Additionally, by controlling the cooling rate of the gas stream, the N0x products can be allowed to decompose to their equilibrium values.

The program goal is to produce a commercially acceptable coal-fired utility system using a combined MHD/steam power plant. To achieve this goal, two major interim objectives must be achieved: the first, to succesefully test MHD components and subsystems in a Component Development and Integration Facility (CDIF) and then to scale up and integrate them into system tests; the latter to be conducted in the pilotscale Engineering Test Facility (ETF), which is planned for operation in the late 1980s; the second, to develop and operate a commercial-scale demonstration MHD power plant by the 1990s, fueled by coal, in an environmentally acceptable manner. Development of MHD technology will also continue in order to improve the performance, reliability, and benefits of MHD commercialization. These objectives support the current national energy goals.

The strategy of the program is to progress through three overlapping phases, each focused on specific development requirements for commercial demonstration. The purpose of Phase I is to develop and demonstrate MHD components and subsystems of approximately $50 \mathrm{MW}$ thermal and to combine these with other MHD plant components to develop the engineering data and experience needed to build pilot-scale facilities. The goal of Phase II is to provide engineering demonstration by system testing in the ETF of selected complete test trains at approximately 250 MW thermal and up to commercial operating durations $(1,000$ to $2,000 \mathrm{hr})$. Phase III activities will provide the capability of demonstrating commercial feasibility (at approximately 1,000 MWe) and related operating parameters.

The major focus for Phase I will be testing in the Component Development and Integration Facility. The CDIF construction is presently in progress and on schedule with generation of electric current in 1980. MHD components such as combustors, channels, etc., will be tested and integrated with other components of the MHD system for which prepilotscale design data are required. The CDIF, at a 50 MW thermal scale, represents a minimum size for obtaining key component performance results and interaction data between power train components for use in ETF definition. The CDIF information and other data will allow a design to be sclcctcd for the ETF. The conceptual design studies of the ETF are in progress to provide data for both the test program at the CDIF and for the Base Line Commercial Plant Design. 
Significant progress is being made in the meantime from experimental testing both here and abroad. This has provided operational experience and design data for large-size component fabrication. Successful MHD generator operation for 100 hours with moderate slag carryover and improved recovery of seed and slag from the gas stream have been achieved. Promising materials for direct-fired preheater application have been identified, and progress in preheater durability has been demonstrated by a 400-hour test in which temperatures were in excess of $3000^{\circ} \mathrm{F}$. These experimental accomplishments demonstrate tangible progress in generator durability and performance under slagging conditions, prove seed/slag separation and seed recovery techniques, and demonstrate preheater system operation and control.

Additional accomplishments having taken place and anticipated during FY 1978 include:

1. Completion of design and initiation of fabrication of the first group of components for the Component Development and Integration Facility (CDIF) as well as completion of major construction segments of the CDIF and initiation of facility component installation. As of February 1978, the CDIF facility construction is approximately 29 percent complete with costs below estimates. Title II work has been completed.

2. Procurement initiation of the first complete subscale MHD flow train, including procurement of a 5-6 Tesla superconducting magnet. This train will be a subscale prototype for the planned Engineering Test Facility (ETF).

3. Operation of the Soviet U-25B facility to explore operation of sub-sonic channels in high magnetic fields (operating expenses provided by USSR Institute of High Temperatures). Also completion of design and initiation of fabrication of a large ( 8 to 12 MW) MHD generator for duration and loading tests at the Soviet facility. A large U.S. superconducting magnet was delivered to the Soviet facility in October. 1977 and was operational in December 1977.

In the remainder of FY 1978, it is anticipated that ETF conceptual design studies will be completed and final test results will be obtained from a long-duration high-ash generator test in the AVCO MK-VI facility. For closed-cycle, coal-fired heat exchanger tests will be completed in late FY 1978 . 


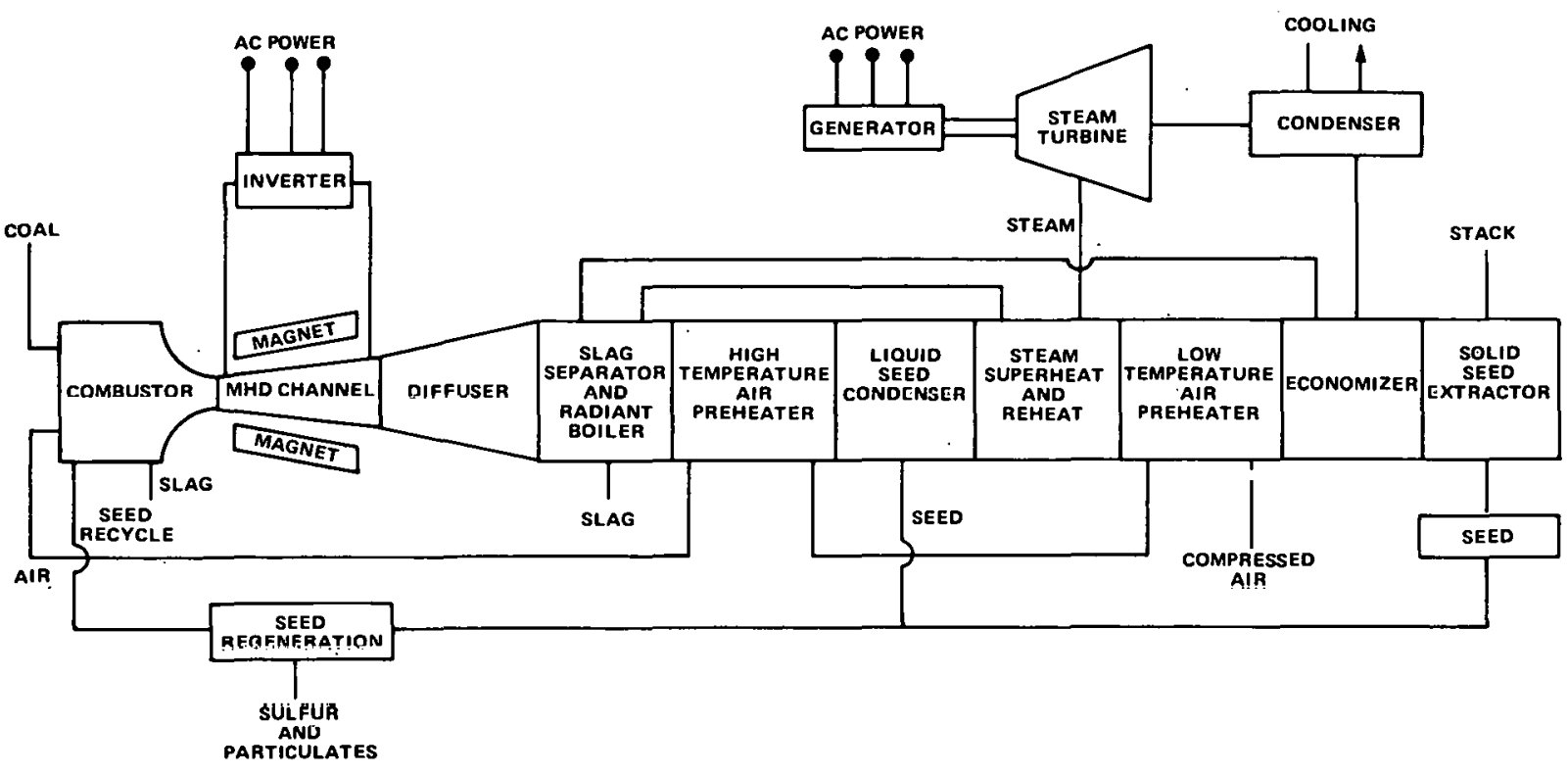

Open-Cycle Coal-Fired MHD System

\subsection{CDIF PROJECT}

The Montana CDIF, located in Butte, is the first key project in the National Open-Cycle MHD Program. The CDIF is critical to achieving national program goals since it will provide advanced capability for testing MHD components and subsystems over a wide range of test conditions using several domestic coals, in particular, the highly reactive western coals. The facility is a major departure from both present small-scale limitedcapability and large size, very short-term facilities, and when in operation will move open-cycle MHD development to the next higher level of engineering realism with respect to program end goals. The CDIF will provide basic data for design of the pilot-scale ETF, the second of the two key projects, by proof and development testing of components and subsystems. The CDIF will also, in its latter phases, provide information concerning complete ETF model test train operation. The CDIF will test open-cycle MHD system components and subsystems of various designs and configurations and will also provide facilities for pretest, on-line, and post-test examinations of the test hardware. The facility will cover approximately 50 acres of a 93-acre site. The experimental aspects of the facility presently being constructed will consist of provisions for two experimental test trains or test bays, each capable of testing components at about the 50-MW thermal size for $20 \mathrm{lb} / \mathrm{sec}$ total mass flow rate. Both trains use a common coal feed and exhaust gas handling system. 


\section{Project Status}

The CDIF major facility construction effort is approximately 29 percent complete and is under estimated cost as of February 1978. Initial generation of electric current is planned for 1980 .

\subsection{CLOSED-CYCLE}

The two MHD closed-cycle processes under investigation involve closed-cycle plasma and closed-cycle liquid metal. The basic conversion process is the same as that for open-cycle, i.e., motional electromagnetic induction. In the closed-loop processes, however, the working fluid receives the heat input from a primary source through a heat exchanger and subsequently recycles the working fluid in a closed loop. The primary heat source can be from the combustion of coal or from a nuclear reactor if a suitable reactor is available. The immediate goal is to continue critical studies which influence basic feasibility of these systems. These involve both generator and heat exchanger studies and material evaluations. Emphasis will be placed on coal or a coal-derived fuel rather than on the clean fuels that have previously been employed. System analysis studies also will be initiated to provide guidance for a program review which will be conducted to establish future program content and directions (assuming program success).

\section{Project Status}

The current effort emphasizes gas system heat exchangers and system engineering studies.

Closed-cycle MHD development is not as advanced as the open-cycle concept, and the current work addresses basic issues that must be resolved before the closed-cycle concept may be considered as a potential alternative to the open-cycle concept. 


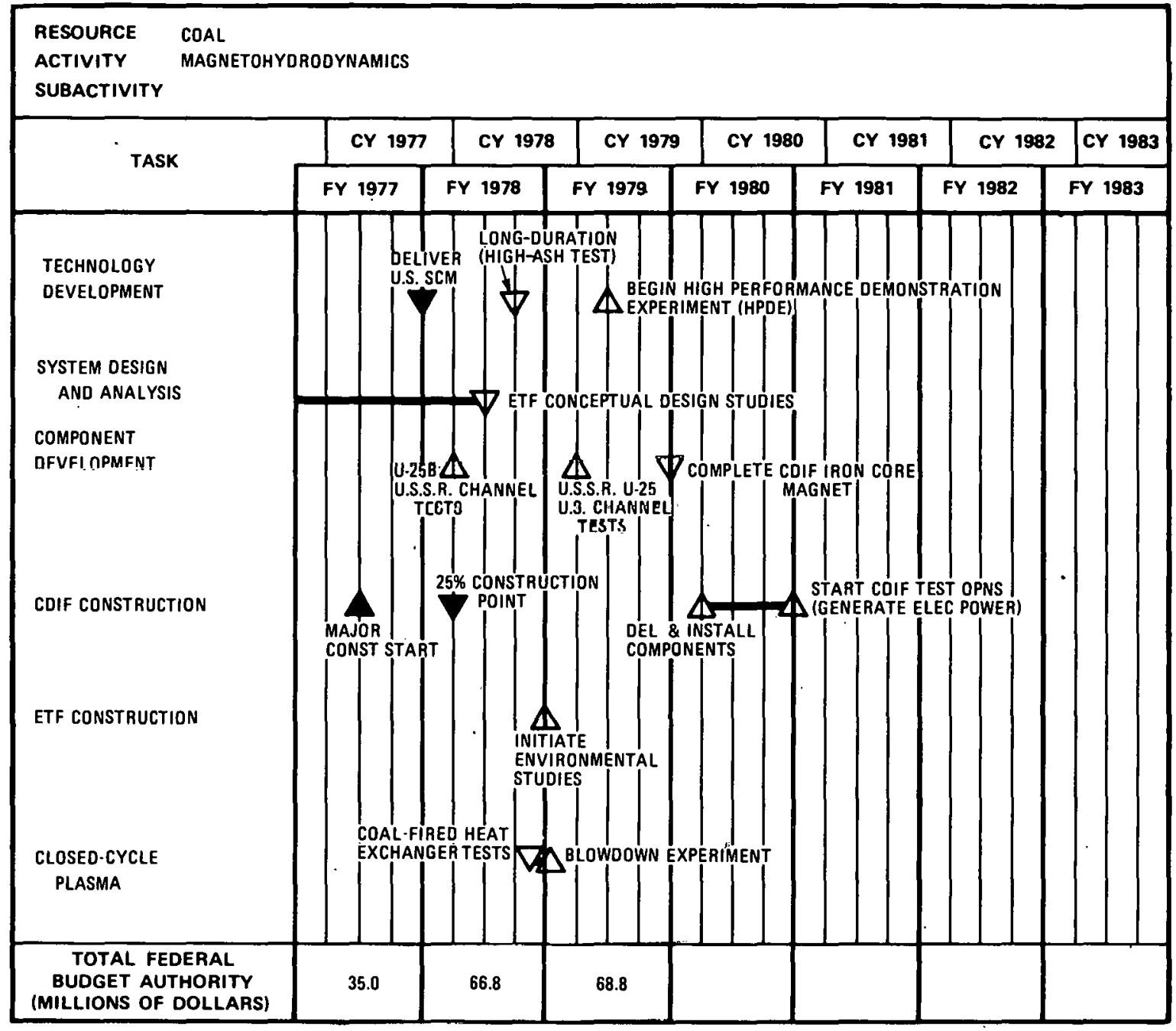

MILESTONE SYMBOLS ARE DEFINED ON LAST PAGE OF THIS DOCUMENT 


\subsection{SUMMARY OF PILOT PLANTS, PDUs, AND MAJOR HARDWARE FABRICATION}

The following data summarize funding levels for the pilot plants, PDUs, and major hardware fabrication for projects supporting the magnetohydrodynamics effort.

\section{Magnetohydrodynamics}

\section{Summary of Pilot Plants, PDUs, and Major Hardware Fabrication}

(Dollars in Thousands)

\begin{tabular}{|c|c|c|c|c|c|c|c|c|c|}
\hline \multirow{2}{*}{$\begin{array}{l}\text { MHD DIRECT COAL-FIRED POWER } \\
\text { GENERATION TEST FACILITY, } \\
\text { TULLAHOMA, TENNESSEE }\end{array}$} & $\begin{array}{c}\text { TOTAL } \\
\text { ESTIMATED } \\
\text { COSTS } \\
\end{array}$ & \multicolumn{2}{|c|}{$\begin{array}{l}\text { CUMULATIVE } \\
\text { PRIOR YEAR } \\
\end{array}$} & \multicolumn{2}{|c|}{$\begin{array}{c}\text { FY } 1978 \\
\text { ESTIMATE }\end{array}$} & \multicolumn{2}{|c|}{$\begin{array}{c}\text { FY } 1979 \\
\text { ESTIMATE }\end{array}$} & \multicolumn{2}{|c|}{$\begin{array}{l}\text { CUMULATIVE } \\
\text { FUTURE YEAR }\end{array}$} \\
\hline & & & & & & & & & \\
\hline $\begin{array}{l}\text { Operating Expenses: } \\
\text { Design and Construction } \\
\text { R\&D and Operational }\end{array}$ & $\begin{array}{r}\$ 12,786 \\
16,141 \\
\end{array}$ & $\$$ & $\begin{array}{l}4,876 \\
2,441 \\
\end{array}$ & $\$$ & $\begin{array}{r}4,710 \\
950 \\
\end{array}$ & $\$$ & $\begin{array}{r}3,200 \\
750 \\
\end{array}$ & $\$$ & $\begin{array}{r}0 \\
12,000 \\
\end{array}$ \\
\hline Subtotal, Operating Expenses & 28,927 & & 7,317 & & 5,660 & & 3,950 & & 12,000 \\
\hline Capital Equipment & $\underline{0}$ & & 0 & & 0 & & 0 & & $\underline{0}$ \\
\hline Total DOE Funding & 28,927 & & 7,317 & & 5,660 & & 3,950 & & 12,000 \\
\hline Non-Federal Organization Funding & $\frac{0}{528927^{1}}$ & $\$$ & $\frac{0}{7317}$ & $\$$ & $\frac{0}{5660}$ & $\$$ & $\frac{0}{3950}$ & $\bar{s}$ & $\frac{0}{12000}$ \\
\hline
\end{tabular}

1. Based on preliminary estimates by Burns \& Roe. 


\section{K. SUMMARY OF CAPITAL ACQUISITION}

The data below summarize plant and capital equipment funding for the Coal Resource.

\subsection{PLANT CONSTRUCTION}

(Dollars in Millions)

Total

Estimated

\begin{tabular}{l} 
Funded \\
to Date \\
\hline
\end{tabular}

Appropriated

Estimated

Future Year

Facility

Cost

FY 1978

FY 1979

Balance

Memonstration Plants

1. Solvent Refined $\$ 425.0$

$\$ 0$

$\$ 0$

$\$ 20.0$

$\$ 405.0$

Coal Demonstration

Plant (site undeter-

mined)

This project provides for design of an SRC demonstration plant capable of processing on the order of 6,000 tons/day coal feed. The proposed demonstration plant would provide essential economic, technical, and environmental data leading to early commercialization of the SRC process.
2. High-Btu
$\$ 246.0$
$\$ 10.0$
$\$ 23.0$
$\$ 40.0$
$\$ 187.0$
Synthetic
Pipeline
Gas Demonstrā-
Lion Plant
(site undeter-
mined

The high-Btu synthetic pipeline gas demonstration plant is specifically directed at stimulating industrial production of pipeline gas from coal, and to demonstrate and transfer to industry technology for converting coal to pipeline gas. The derelopment of altornative sources for pipeline gas is especially needed in view of increasing production shortfalls from natural well-head sources.
3. Low-Btu f'uel
$\$ 150.0$
$\$ 7.3$
$\$ 36.0$
$\$ 14.0$
$\$ 92.7$
Gas Demonstra-
tion Plant (site
undetermined) 
This project is specifically directed to industrial applications: The project includes the conceptual design, construction, and operation of a demonstration facility which would reveal the economic and technical feasibility of converting coal to fuel gas for use by an industrial community, i.e., to serve the needs of a local supplier distributing fuel gas centrally to several large industrial users.

Total

Facility Estimated
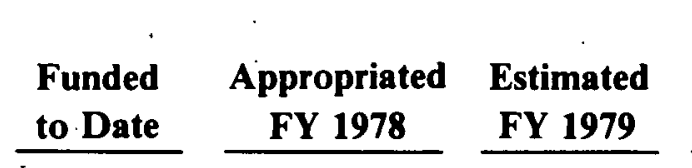

Future Year

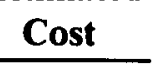

4. Low-Btu Fuel

$\$ 25.0$

$\$ 0$

$\$ 3.0$

Gas Demonstra-

tion Plant Small

Industrial

Balance

This project includes design, construction, and operation of a demonstration plant dedicated to an individual industrial user of energy (i.e., Erie Mining Company). This facility located in Minnesota will consume 500 tons/day of high-sulfur coal using the Woodall-Duckham process and will generate $7.4 \times 10^{6}$ Btu per day. The low-Btu gas produced will heat iron ore pellet shaft furnaces in a taconite plant.

\section{Magnetohydrodynamics (MHD)}

1. $\begin{aligned} & \text { Component } \\ & \text { Development and }\end{aligned}$
Integration
Facility (Butte,
Montana)

Construction of the CDIF began in FY 1976 and will be completed in FY 1980. This facility is intended to pursue open-cycle MHD component development with the purpose of improving the technology and laying the groundwork for a pilot-scale generation plant. The facility consists of two test beds, each capable of testing and evaluating MHD components of about 50 thermal MW size.

$1 \$ 24.8$ funded from Operating Expenses through TQ. Current TEC is $\$ 37.0$. 
Total

\section{Estimated}

Facility

Cost

\section{Funded} to. Date
Appropriated FY 1978
Future Year

Balance

to Complete

\section{Energy Research Centers (ERCs) 1}

1. Modifications \& N/A Additions to ERCs

(various locations)

\subsection{CAPITAL EQUIPMENT}

These include improvements to comply with NIOSH standards, and other items such as elevators, heating systems, air conditioning tunnels, roofs, and other general maintenance and improvement projects at ERCs in Bartlesville, Grand Forks, Laramie, Morgantown, and Pittsburgh.

\begin{tabular}{|c|c|c|c|}
\hline $\begin{array}{l}\text { COAL RESOURCE } \\
\text { CAPITAL EQUIPMENT }\end{array}$ & \multicolumn{3}{|c|}{$\begin{array}{l}\text { BUDGET AUTHORITY } \\
\text { (OPERATING EXPENSES) } \\
\text { (DOLLARS IN THOUSANDS) }\end{array}$} \\
\hline ACTIVITY & $\begin{array}{l}\text { ACTUAL } \\
\text { FY } 1977\end{array}$ & $\begin{array}{c}\text { APPROPRIATION } \\
\text { FY } 1978\end{array}$ & $\begin{array}{l}\text { ESTIMATE } \\
\text { FY } 1979\end{array}$ \\
\hline Mines RD\&D & 0 & 0 & 220 \\
\hline Liquetaction & 0 & 400 & 200 \\
\hline Gasification & 100 & 2400 & 1200 \\
\hline Advanced Power Systems & 0 & 200 & 200 \\
\hline Diroot Combustion & $n$ & $2 n 0$ & 225 \\
\hline Advanced Recearch and & & & \\
\hline Supporting Technology & 0 & 300 & 375 \\
\hline Magnetohydrodynamics & 0 & 500 & 500 \\
\hline Improved Conversion Efficiency & 500 & 500 & 1000 \\
\hline Other & 150 & 0 & 0 \\
\hline TOTAL & 750 & 4500 & 3920 \\
\hline
\end{tabular}

1) Requirements determined on year-to-year basis .

2) For comparative purposes, figures include the Improved Conversion Efficiency and Mines RD\&D Activities which were not part of the FE Program in FY 1977. 


\section{PETROLEUM RESOURCE}

\section{A. PETROLEUM RESOURCE OVERVIEW}

Petroleum will continue to be one of the nation's major energy sources for many years. Recent estimates indicate that production of domestic petroleum will drop rapidly in the late 1970s and 1980s without new sources or the stimulating techniques of enhanced oil recovery.

Present extractive technology is grossly inefficient. Two-thirds of the oil discovered to date remains in the reservoir (about 300 billion barrels), not producible with current recovery practices and economics. The potential for enhanced oil recovery (EOR) is in the area of 60 billion barrels of normal gravity oils and 28 billion barrels of heavy oils and bitumen. This potential constitutes the goal for enhanced oil recovery, which could extend the supply of domestically available oil resources by at least 10 critical years. A near-term goal would be to increase significantly the production of normal gravity oils. The production by present enhanced oil recovery methods is about 240,000 barrels per day. DOEsponsored programs are designed to encourage and accelerate domestic production and are parallel and supplemental rather than competitive to oil industry efforts.

The need for improved oil recovery technology development has been documented in the "Management Plan for Enhanced Oil Recovery." This indepth strategy brought together available information in a logically documented framework of analysis and. included direct surveys with 15 companies (six major, three intermediate, and six independent). Based on current and projected industry efforts, a $600,000 \mathrm{bbl} / \mathrm{d}$ production from EOR has been estimated for 1985 .

For each of the identified technical projects in the Management Plan, there is somc DOE activity with one or more companies. The research efforts are not uniformly distributed, and are constrained by uncertainty and the long payout times. An EOR project is typically four to eight years. Three processes show promise for recovering more oil from existing reservoirs, namely, micellar-polymer, carbon dioxide, and thermal (steam, and in situ combustion). A total of 22 major field tests will be under way in FY 1978, composed of 11 micellar-polymer/improved waterflood projects, five $\mathrm{C}_{2}$ projects, and six thermal projects. In addition, one micellar-polymer pilot, six $\mathrm{CO}_{2}$ minitests, several thermal minitests, and four thermal pilots are planned to start in FY 1978.

A logical progression from the laboratory to develop alternate technologies is to go first to field minitests involving a few wells (up to five); to a small pilot test of 25 to 50 acres, then to a large pilot test involving 200 or more acres. Small pilot tests take four to five years generally and large pilot tests ten or more years. The most significant 
data, however, are usually developed in the first three to five years. All of these technologies require fluid injection through porous media to either release oil and\%or move it to production wells. A definition of required chemicals, equipment, and manpower is part of this job.

An integral part of the EOR program is to establish base line data on all major U.S. reservoirs and to select the best candidates for the different EOR processes. A major emphasis is being placed on this effort in 1978 . This base line reservoir data then becomes part of a broader task of gathering, collating, and analyzing data coming from field tests of all varieties and finally performing inter-field analyses. This is part of the program that leads to technology transfer from DOE to the oil industry. A particular need for this kind of technical assistance is for the small and medium-sized oil producers who do not have ready access to this kind of lechnology.

The nation's abundant oil shale resources comprise annther major source of energy. The technology for conventional mining and surface retorting of oil shale has advanced to a level believed capable of early commercial application to richer grades of oil shale, averaging over 25 gallons per ton, although commercial-scale equipment and operations have not been demonstrated. Present DOE strategy in this area consists of making its Anvil Points facility available for industry-sponsored projects; providing for the technology transfer of results through the DOE observer program; providing general consultation to industry; conducting laboratory-scale supporting research on problems relevant to general oil shale processing, both above ground and in situ; and contracting for development of promising advanced processing methods above the level of bench-scale research but less than commercial-feasibility demonstration scale.

The DOE Oil Shale Activity is focused mainly on developing technology capable of improving total resource recovery and lowering environmental impacts and water requirements. This is accomplished through development of various in situ extraction techniques capable of exploiting the leaner and deeper oil shale deposits as well as offering an alternative to present surface technologies.

In addition to the advantages of in situ methods of relatively lower water, manpower, and shale disposal requirements, the potential application to lower grade shales is important in that two-thirds of the total estimated resource of 1.8 trillion barrels of shale oil in the western Green River formation is in low grade deposits that may never be recovered by techniques that involve conventional mining. Laboratory-scale research on new process technology includes applied research on methods potentially offering similar advantages for above ground processing.

The present Oil Shale Activity includes oil production research involving true in situ methods that require no mining; modified in situ methods that involve enhanced void volume and permeability relative to the true in situ methods generally provided by conventional mining or other methods that remove a portion of the mineral material from the oil shale formation; advanced processing technology with potential for reducing 
environmental impacts and improved energy efficiency of second-generation commercial plants; production research targeted to both eastern and western oil shales; environmental studies related to the in situ processes being developed; and supporting research for oil shale processing that is not tied to any specific technology but rather to oil shale development problems in general.

In situ conversion of oil shale to liquid products offers several potential advantages over conventional mining and surface processing, both economic and environmental, although most methods are presently less developed. However, no single version of in situ technology is applicable to the full range of oil shale deposit types. True in situ techniques rely upon an interconnected system of cracks artificially produced by hydraulic and/or explosive fracturing to provide the required permeability for passage of gases and liquids. No mining or other methods of enhancing void volume by mineral removal are required. Several techniques for creating the required fracture system are under active investigation in both eastern and western oil shale field projects. Although true in situ methods are generally considered limited to oil shales grading less than 30 gallons per ton, in thickness up to approximately 250 . feet, and at depths not greatly exceeding 1,000 feet, these parameters describe about half of the western oil shale resource and are characteristic of much of the eastern organic shales of Devonian and Mississippian age that range from Pennsylvania to Texas in a broad but poorly defined belt. True in situ techniques offer lower environmental impacts than most modified in situ methods (solution mining in the Leached Zone of Colorado's deposits is an exception), but will probably be the most difficult in situ technology to successfully develop. Modified in situ techniques are believed to offer the most promise for early development, and are especially promising for deeper and very thick (more than 300 feet) deposits. Certain modified methods also are potential alternatives for the shales to which true in situ methods would apply. Four major variations of modified in situ are of interest, with choice partially governed by actual thickness of oil shale to be processed. Two of these variations are conceptually similar in that an initially-mined void volume is subsequently redistributed throughout a much larger mass of rubblized shale. Physical dimensions of the completed retort modules have led to the general description of these processes as "vertical" or "horizontal". Two versions of the vertical process are under active development, with one having reached the stage of testing modules of approximately the size required for commercial operations. Both would utilize a downward moving combustion zone to process the shale. Two processing concepts have been proposed for "horizontal" retorts, one using a downward moving combustion zone and the other using a laterally moving combustion zone.

Another modified horizontal technique applicable only to very shallow depths (up to 100 feet of overburden) does not use conventional mining but instead uses proprietary blasting patterns to expand a bed of rubblized shale into space originally occupied by over burden. The raised overburden is sealed to prevent gas leakage before processing commences. This method applies to deposits typical of large areas of Utah oil shale. Field tests to date in PDU-size modules have been very promising. 
A semivertical modified in situ process is under development for processing the Leached Zone in Colorado, that utilizes the void space created by dissolution of water-soluble salts originally distributed throughout this approximately 500-foot thick section of oil shale, that contains an in-place resource equivalent to over $1 \mathrm{MMbbl} /$ acre of shale oil. Because this zone is a salt-water containing aquifer, direct-combustion methods are not considered applicable. The concept of being tested involves passage of super-heated steam through the full thickness of the Leached Zone. Preliminary field tests and calculations of energy balances and economics indicate probable economic success if at least 50 percent of the in-place kerogen is recovered as shale oil.

The mechanism for technology transfer derives from DOE participation in all phases of the technology development. The final phases of development are the pilot field demonstrations, in which DOE costs shares up to 50 percent with industry. This provides maximum flexibility and

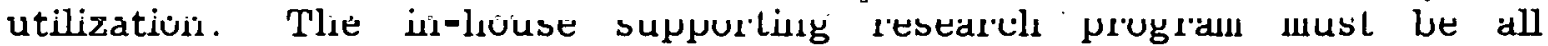
inclusive with respect to developing fundamental data, laboratory and small pilot testing, and technical analysis of results.

A comprehensive Drilling and Offshore Technology Program Strategy Document/ Program Management Plan will be completed in FY 1979. The basic concepts and format for this document will be similar to the Management Plan for Enhanced Oil Recovery.

There are an estimated 100 billion barrels of undiscovered petroleum resources available under the outer continental shelf. The considered opinion of the petroleum industry is that the best change of discovering the most oil, fastest, is in these offshore areas. The hostile environments encountered in these frontier areas strain the state-of-the-art technology and impose the requirement for extensive RD\&D activities. In order to complete the necessary RD\&D with a compressed time schedule, and accelerate the development of this vital resource base, it is important that DOE plan an effective drilling and offshore technology RD\&D program.

As part of its planning and evaluation effort, DOE is appraising the current and projected state-of-the-art in the drilling and offshore technology areas; is defining and co-funding those R\&D efforts required to accelerate needed technology; is identifying those $\mathrm{R} \& \mathrm{D}$ efforts appropriate to its mission; and will plan to determine the priorities of these efforts.

The Petroleum Resource Program contains four Activities: Enhanced Oil Recovery, Oil from Oil Shale, Drilling and Offshore Technology, and Processing and Utilization. 
The table below summarizes the funding levels by Activity for the FY 1977 to 1979 period.

\begin{tabular}{|c|c|c|c|c|}
\hline PETROLEUM & \multicolumn{4}{|c|}{$\begin{array}{l}\text { BUDGET AUTHORITY } \\
\text { (OPERATING EXPENSES) } \\
\text { (DOLLARS IN THOUSANDS) }\end{array}$} \\
\hline ACtIVITIES & $\begin{array}{l}\text { ACTUAL } \\
\text { FY } 1977\end{array}$ & $\begin{array}{c}\text { APPROPRIATION } \\
\text { FY } 1978\end{array}$ & $\begin{array}{l}\text { ESTIMATE } \\
\text { FY } 1979\end{array}$ & $\begin{array}{l}\text { INCREASE } \\
\text { (DECREASE) }\end{array}$ \\
\hline $\begin{array}{l}\text { Enhanced Oil Recovery } \\
\text { Oil from Oil Shale } \\
\text { Drilling and Offshore Technology } \\
\text { Product Characterization } \\
\quad \text { \& Utilization }\end{array}$ & $\begin{array}{r}\$ 23,782 \\
18,678 \\
2,400 \\
1,831\end{array}$ & $\begin{array}{r}\$ 45,940 \\
24,032 \\
1,600 \\
1,400\end{array}$ & $\begin{array}{r}\$ 46,000 \\
29,350 \\
1,600 \\
1,200\end{array}$ & $\begin{array}{r}\$+60 \\
+5,318 \\
0 \\
-200\end{array}$ \\
\hline TOTAL & $\$ 46,691$ & $\$ 72,972$ & $\$ 78,150$ & $\$+5,178$ \\
\hline
\end{tabular}




\section{B. ENHANCED OIL RECOVERY}

The objectives of the Enhanced. Oil Recovery (EOR) Activity are to encourage and support industry participation in developing and demonstrating technologies to enhance the production rate and recovery of original oil-in-place by:

- Initiating field demonstrations that are cost-shared with private industry to accelerate the development and implementation of improved EOR technology

- Pursuing concurrent in-house and contractor research and development to support field testing.

Une of the most promising uppurlunilies for intreasing domcotic energy output in the near-term is EOR. After conventional (primary and secondary) production is depleted, substantial quantities of oil remain in oil fields. This unrecovered oil is estimated to be up to 70 percent of the original oil-in-place. Because of the long lead-time until current DOE EOR projects begin to yield incremental oil, the economic benefits of EOR have not yet been fully demonstrated. Owing to the uncertainty of benefits to be gained, the present oil price structure, government regulations and taxes, the individual members of the industry are reluctant to provide the necessary funds for extensive EOR research and development. A Federal RD\&D program targeted at mitigating the economic and technological uncertainties and reducing the lag between project initiation and commercial production is urgently needed. This is an area of $R \& D$ in which DOE is active.

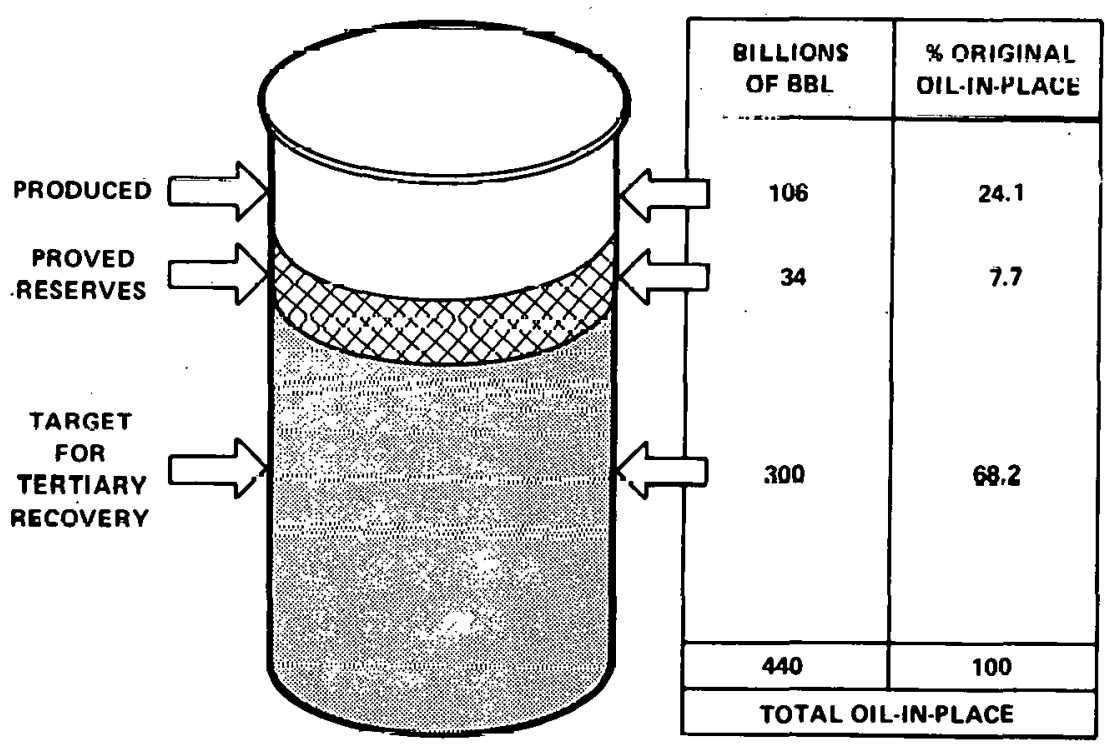

Figure 10 Production, Reserves, and Residual Oil-in-Place - Total United States, Including Offshore and Alaska 
The enhanced recovery area, technology needs, priority efforts, and the DOE role have been. identified. The technical, economic, and environmental feasibilities of the most promising tertiary oil recovery and gas stimulation techniques are being evaluated through cost-shared field tests. Reservoir characteristics vary widely and require a variety of enhanced recovery techniques. Consequently, the DOE program incorporates a sufficient number of tests to develop and prove technologies that are applicable to principal reservoir types.

To date, 21 cost-sharing contracts have been initiated to test the feasibility of EOR technologies in various types of domestic reservoirs. The locations of these projects are shown in the figure below. In addition to the field tests, supplies and demands for chemicals for the micellarpolymer and carbon dioxide injection, technologies are being evaluated through DOE-funded studies.
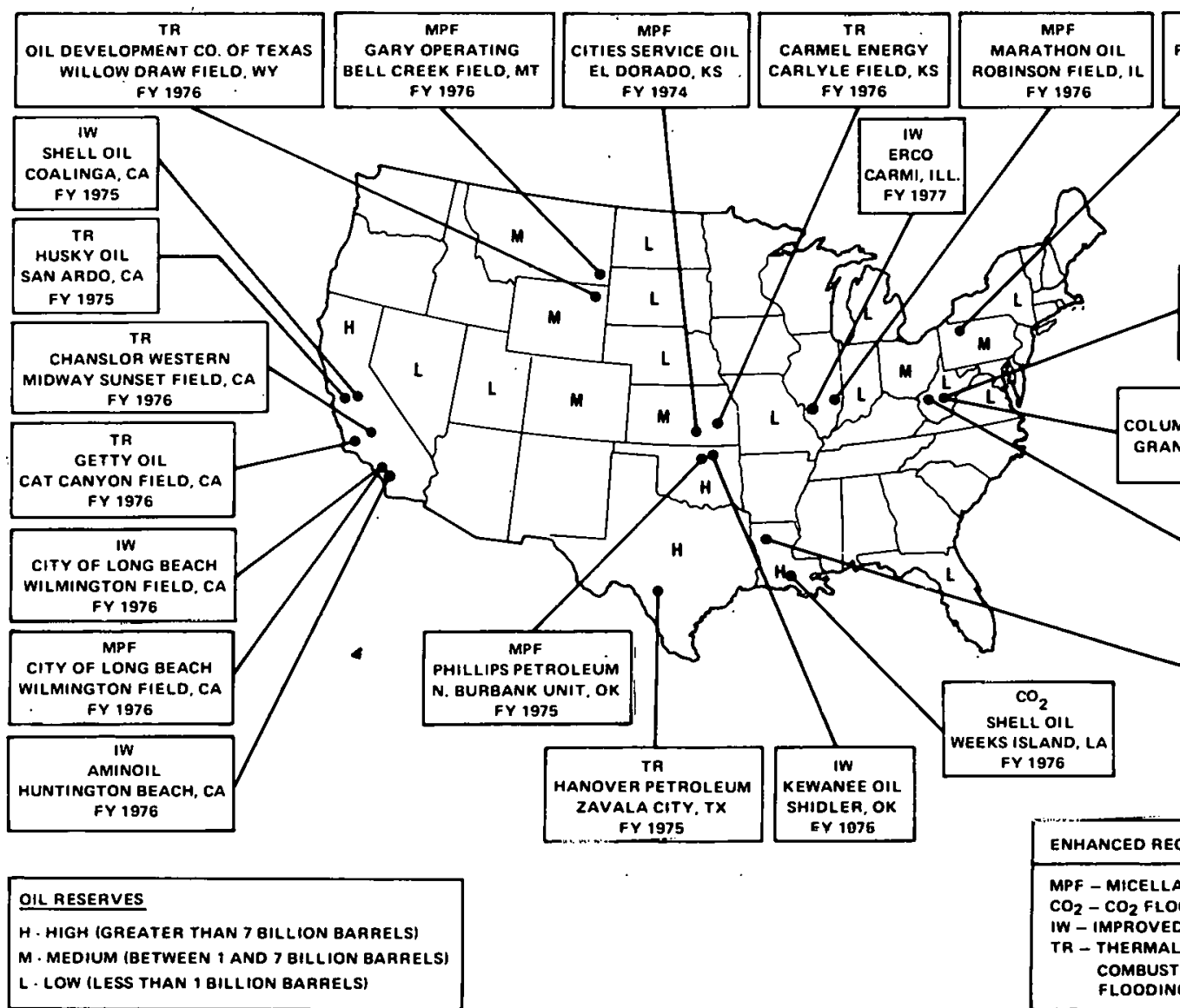
MPF PENN GAADE CRUDE OIL RADFORD FIELO, PA FY 1975 EK FIELO, MT FY 1974 LE FIELO FY 1976

OIL RESERVES

L. LOW (LESS THAN 1 BILLION BARAELS)

\section{Figure 11 Cost-Sharing Contractor Locntions Enlianced Oil Recovery}

The Enhanced Oil Recovery Activity includes university and industry research, both laboratory and field, process development, and demonstration. The objectives of the following three subactivities are to support the development of various processes, assure technology transfer to industry, and assist the private sector in selecting commercially acceptable processes. The milestone charts depict the timetables for the key projects in each of the three main categories. 
The Enhanced Oil Recovery Activity is an R\&D program targeted at producing 10 to 20 percent more of the residual oil and gas that remains after depletion of the primary and secondary production. This task will be accomplished by accelerating the development of an improved scientific, engineering, and economic knowledge base; and by accelerating the transfer of DOE-supported technology to the public.

The Enhanced Oil Recovery RD\&D program is built on the following major components: target orientation, basic definition of the resource base, continuing research, minitests and technical pilot tests, and commercial demonstrations. The ultimate measure of the Enhanced Oil Recovery program's effectiveness will be the incremental oil produced. The goal includes addition of $800,000 \mathrm{bbl} / \mathrm{d}$ of oil by 1985 and ultimate recovery of approximately 15 billion barrels of incremental oil production.

The processes currently being supported by the activity are classified according to the fluid injected ints the reservolr to drive out incremental oil, as discussed in the following subsections.

The table below summarizes the funding levels by subactivity for the FY 1977 to FY 1979 period.

\begin{tabular}{|c|c|c|c|c|c|}
\hline \multirow[t]{2}{*}{ ENHANCED OIL RECOVERY } & \multicolumn{4}{|c|}{$\begin{array}{c}\text { BUDGET' AUTHORITY } \\
\text { (OPERATING EXPENSES) } \\
\text { (DOLLARS IN THOISANDS) }\end{array}$} & \multirow{2}{*}{$\begin{array}{l}\text { MAJOR } \\
\text { CHANGE }\end{array}$} \\
\hline & $\begin{array}{l}\text { ACTUAL } \\
\text { FY } 1977\end{array}$ & $\begin{array}{c}\text { APPROPRIATION } \\
\text { FY } 1978\end{array}$ & $\begin{array}{l}\text { ESTIMATE } \\
\text { FY } 1979\end{array}$ & $\begin{array}{l}\text { INCREASE } \\
\text { (DECREASE) }\end{array}$ & \\
\hline $\begin{array}{l}\text { Micellar-Polymer Fluudirig. } \\
\text { including Improved Waterflooding } \\
\mathrm{CO}_{2} \text { Flooding } \\
\text { Thermal Recovery } \\
\text { Environmental Studies and } \\
\text { Uther Suppuit }\end{array}$ & $\begin{array}{r}\$ 8,500 \\
5,500 \\
4,500 \\
5.282\end{array}$ & $\begin{array}{r}\$ 16,000 \\
6,600 \\
12,000 \\
11,340\end{array}$ & $\begin{array}{r}\$ 10,550 \\
5,220 \\
18,430 \\
11,800\end{array}$ & $\begin{array}{r}+5,450 \\
+1,380 \\
+6,430 \\
+460\end{array}$ & \multirow[t]{2}{*}{$\begin{array}{l}\text { I } \\
\text { A }\end{array}$} \\
\hline TOTAL & $\$ 23,782$ & $\$ 45,940$ & $\$ 46,000$ & $\$+60$ & \\
\hline $\begin{aligned} & { }^{*} K_{1} E Y \\
N= & \text { New start (totally re } \\
S= & \text { Scaleup (from bench } \\
A= & \text { Accelel alivi; (shortor } \\
& \text { expansion of ongoing }\end{aligned}$ & $\begin{array}{l}\text { ioject) } \\
\text { PDU or pilc } \\
\text { rearllines } \\
\text { ojects) }\end{array}$ & & $\begin{array}{l}P=\text { Phas } \\
R=\text { Prog } \\
\mathbf{l}=\text { Incre } \\
\mathcal{L}=\text { Pruj }\end{array}$ & $\begin{array}{l}\text { moletion or sta } \\
\text { redirection } \\
\text { ital cost requir } \\
\text { umpletion or } \mathbf{s}\end{array}$ & \\
\hline
\end{tabular}




\subsection{MICELLAR-POLYMER FLOODING/IMPROVED WATERFLOODING}

Micellar-polymer flooding consists of injecting an appropriate surfactant dissolved in water to displace the residual oil from pores by preferentially wetting the solid matrix. This is followed by a polymer solution that forms a mobility-control bank or buffer in front of the final drive water; the buffer is needed to prevent dilution of the surfactant. Six micellar-polymer flooding projects are under way in the United States, each in a different state. This process may be simplified, with some decrease in effectiveness, by adding chemicals such as the polymers alone or caustic soda to the water of a normal waterflood. The oil recovered may be less than from the micellar-polymer process, but may cost less per barrel. Five improved waterflooding projects are under way; three in California, one in Oklahoma, and one in Illinois.

The Management Plan for EOR identified four projects in the area of micellar-polymer technology, the most important of which is to "extend the application of the micellar-polymer process to other sandstone reservoirs, excluding Illinois, California, and Gulf Coast," or TEMPOS. Some tasks in the TEMPOS project are already under way, and more are scheduled to permit comparisons of chemical stability, displacement efficiency, injectivity, and overall performance of alternative systems. The reservoirs will range from Appalachia to the Rockies and to the mid-continent and the Gulf Coast. The main goal is to determine the technical validity of the micellar system under a variety of reservoir conditions.

The closely related improved waterflooding projects are considered a variation of the Micellar-Polymer process and were originated in FY 1975 and 1976. Emphasis from FY 1977 on will be on the two-step micellar process.

The two-step micellar process consists of using a chemical additive (usually a high molecular weight polymer) in waterflooding to enhance oil recovery. The polymer increases the viscosity of the water, resulting in a thickened material that is less likely to disperse into nonoil bearing zones, and improves mobility control by attempting to achieve a piston-like displacement between injection and production wells. The amount of oil displaced from the reservoir and recovered is thereby increased.

The improved waterflooding projects provide an additional process for increasing the recovery of oil. Only through the use of various injection compounds and procedures applied to different types of reservoirs can the necessary data be collected to determine the best tertiary oil recovery method for each type of formation and reservoir criteria. 
These projects are economically submarginal at today's oil prices, due to the high costs of injection fluids, facilities, and additional drilling. DOE's financial participation with industry is necessary to improve and test the improved waterflooding process.

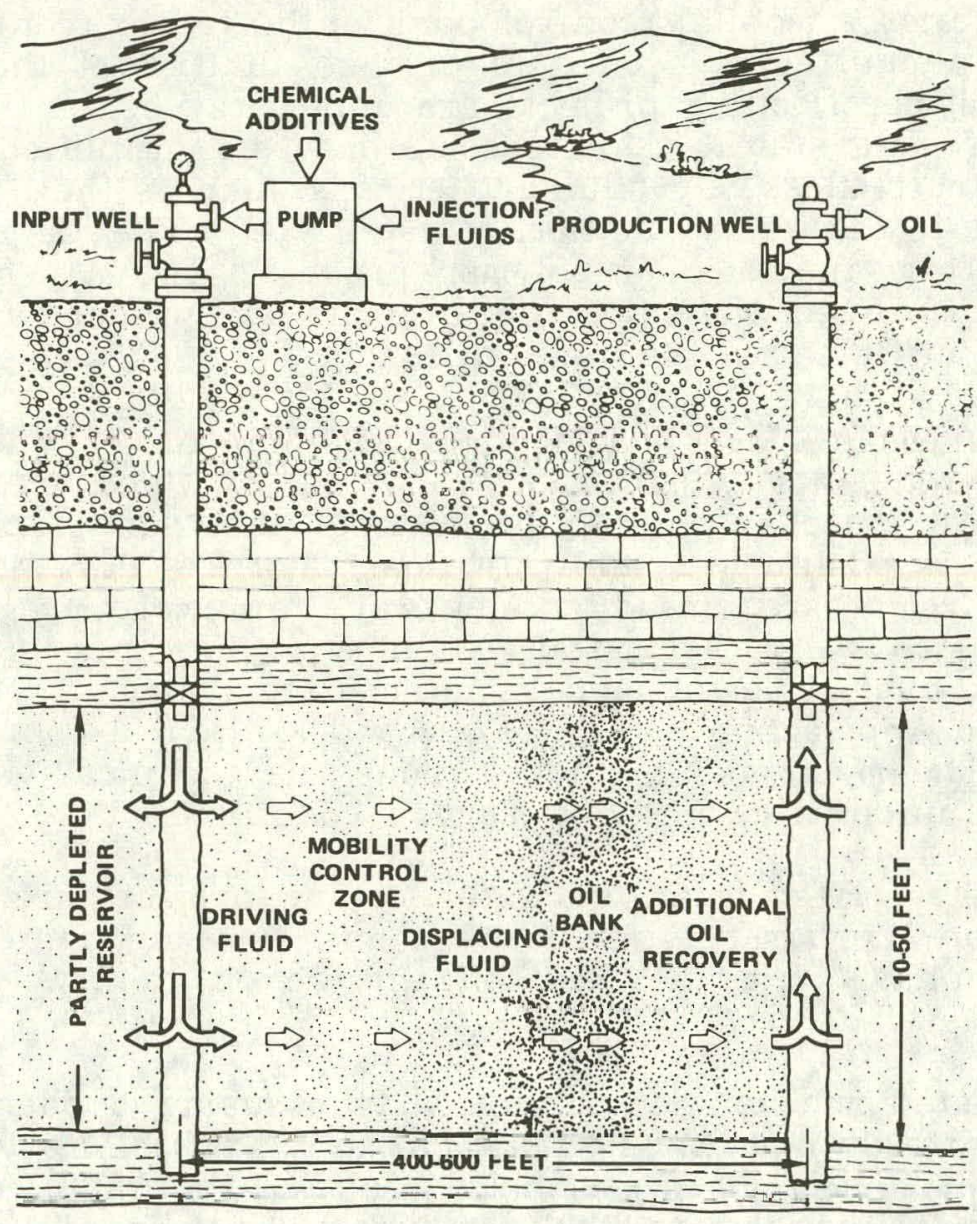

Micellar-Polymer/Improved Waterflooding

\section{Project Status}

The objective of these micellar-polymer and improved waterflooding field tests is to demonstrate the efficiency and economics of recovering tertiary oil from reservoirs already depleted by waterflooding. Laboratory tests and limited field tests conducted by the Bartlesville Energy Research Center (BERC) and other research indicated that, under optimum conditions, a high percentage of residual reservoir oil can be recovered by a micellar flood. To a lesser extent, improvement can be had by adding chemicals. Data were collected on the recovery from cores using various 
micellar and polymer fluids, and injectivity tests were carried out with positive results. This and similar work in industry laboratories led to contracts to evaluate the technique on a larger scale (in parallel with similar private field testing by oil companies).

Gary Operating Company, Bell Creek Field, Montana (Micellar-Polymer)

The objective of this field project test is to demonstrate the technical and economic feasibility of recovering tertiary oil from a successfully depleted waterflood using a micellar-polymer flooding process. The drill sites have been approved and the plan for drilling completed. The pilot demonstration simulation is under way. The project is on schedule. Gary is an independent producer who will use a major oil company technology in the field test.

\section{Cities Service Oil Company, El Dorado Field, Kansas (Micellar-Polymer)}

The objective of this test is to demonstrate the efficiency of recovering tertiary oil from a successfully depleted waterflooded reservoir by using a micellar fluid followed by a mobility-controlled buffer zone to be displaced by water. Preflush injection into the formation is completed, and micellar injection has commenced in two side-by-side field patterns using two competing technologies. The project is running slightly behind the original schedule.

\section{Phillips Petroleum Company, Burbank Field, Oklahoma (Micellar-Polymer)}

The objective of this test is similar to that of the Cities Service project discussed above. The entire surfactant slug has now been injected, and the injection of the polymer is well advanced. The project is on schedule, and encouraging stimulation of oil is appearing.

Penn Grade Crude Oil Association, Bradford Field, Pennsylvania (Micellar-Polymer)

The objective of this test is similar to those above, except that this test will demonstrate the effectiveness of the process in a low-permeability reservoir. Injectivity studies made during Phase I have established the overall feasibility of the project. Seventeen new wells have been drilled and completed so that the tertiary flood on the 25-acre Lawry tract can be accomplished. The micellar solution is currently being injected smoothly . The project is running slightly behind schedule.

\section{City of Long Beach, Wilmington Field, California (Micellar-Polymer)}

The objective of this field demonstration is to design a micellarpolymer system that will displace economic quantities of viscous oil otherwise not recoverable from unconsolidated sands. This project is running slightly behind schedule; however, the subcontractor, Marathon Oil Company, feels that the project will return to schedule within a few months. The process technology has been chosen and injectivity tests are under way. 
Marathon Oil Company, Robinson Field, Illinois (Micellar-Polymer)

The objective of this demonstration is to conduct a commercial-scale test of the micellar-polymer flooding process for improved oil recovery. It is 402 acres in size. The project has progressed smoothly and on schedule. All facilities including injection and production wells have been completed, and the micellar slug is being injected into both the 2.5- and the 5 -acre patterns.

Kewanee Oil Company, Stanley Stringer Field, Oklahoma (Improved Waterflood)

The objective of this field test is to demonstrate the efficiency and economics of recovering tertiary oil from a highly heterogeneous reservoir after waterflooding, by using a polymer slug of tapered concentration to improve the sweep efficiency of the reservoir. This project is un schedule and is sliuwing promising increased production rates. The product may be expanded.

Shell Oil Company, East Coalinga Field, California (Improved Waterflood)

The objective of this field project is to demonstrate the relative merits of polymer flooding and waterflooding in a medium-viscosity oil reservoir which has an unfavorable water-displacement-mobility ratio. Water injection was initiated in June 1976, with an injection rate of $1,350 \mathrm{bbl} / \mathrm{d}$ of water into each of four injection wells. This project is modestly behind schedule but has required additional engineering and control facilities because of the multiple oil sands.

City of Long Beach, Wilmington Field, California (Improved Waterflood)

The objective of this field test is to demonstrate the effect of injccting caustic solution and salt solution to sweep the residual oil from a formation that has been waterflooded. Currently, the nperatnr is redrilling injection wells, including coring, for laboratory analysis and injection studies. The laboratory work has taken more time than expected and is a few months behind schedule. This can be regained.

Aminoil (Improved Waterflood)

This test in the Huntington Beach field in California was started by Aminoil in FY 1976 and joined by DOE in FY 1977. It is a caustic soda flood in a reservnir moderately different than the City of Long Beach, with respect to reservoir charanteristics and oil propertins. The test is well advanced and caustic soda is being injected.

Energy Resources Company, Inc. (Improved Waterflood)

This field test in the Storms Pool Unit at Carmi, Illinois, will use polymer and water to produce light gravity oil from a depleted waterflood. Energy Resources Company (ERCO) is a high technology group that has 
joined an independent oil producer. The project was funded in FY 1976, but delayed until FY 1977 by the need for Small Business Administration funding by the contractor.

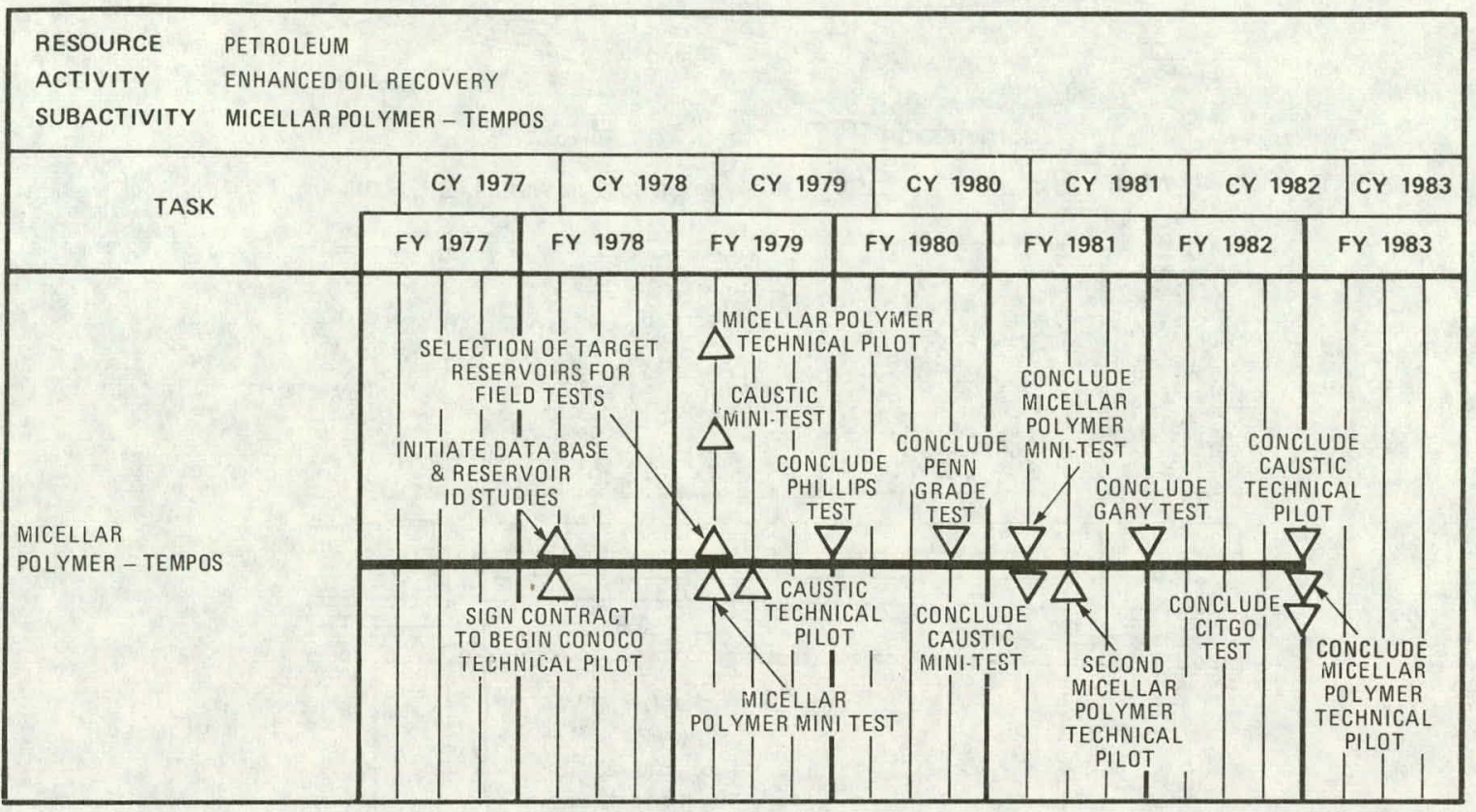

MILESTONE SYMBOLS ARE DEFINED ON LAST PAGE OF THIS DOCUMENT

\section{0 $\mathrm{CO}_{2}$ FLOODING}

There are seven mechanisms in the $\mathrm{CO}_{2}$ displacement process believed to contribute to improved oil recovery, with oil-viscosity reduction and oil swelling (up to 40 percent) being the most important. It is possible to introduce $\mathrm{CO}_{2}$ into the reservoir by several means: pure $\mathrm{CO}_{2}$, carbonated water, acid gas $\left(\mathrm{H}_{2} \mathrm{~S}\right.$ and $\left.\mathrm{CO}_{2}\right)$, separator gas $\left(\mathrm{CO}_{2}\right.$ and hydrocarbon gas), flue gas, or $\mathrm{CO}_{2}$ enriched with intermediate hydrocarbons $\left(\mathrm{C}_{2}-\mathrm{C}_{5}\right)$. The process can be either miscible or immiscible and ancillary materials may be added to improve mobility ratio displacement, and sweep efficiencies.

The Management Plan for EOR identifies four $\mathrm{CO}_{2}$ projects of which the most important one is on the "development and improvement of the $\mathrm{CO}_{2}$ process in carbonate reservoirs having a high residual oil saturation, " $\mathrm{CO}_{2}$ in carbonates. Some of the important goals are to establish the range of physical conditions under which $\mathrm{CO}_{2}$ is miscible with the crude oils in target reservoirs, the nature of additives that might promote miscibility, and, where miscibility is not achieved on first contact, the point in the reservoir at which miscibility can be expected to be achieved. It is possible that miscibility need not be achieved at any point to be effective. 
One of the four $\mathrm{CO}_{2}$ field tests is in a noncarbonate reservoir (Shell Weeks Island, Louisiana). This is a specialized, very promising situation that may draw greater focus as the tests progress.

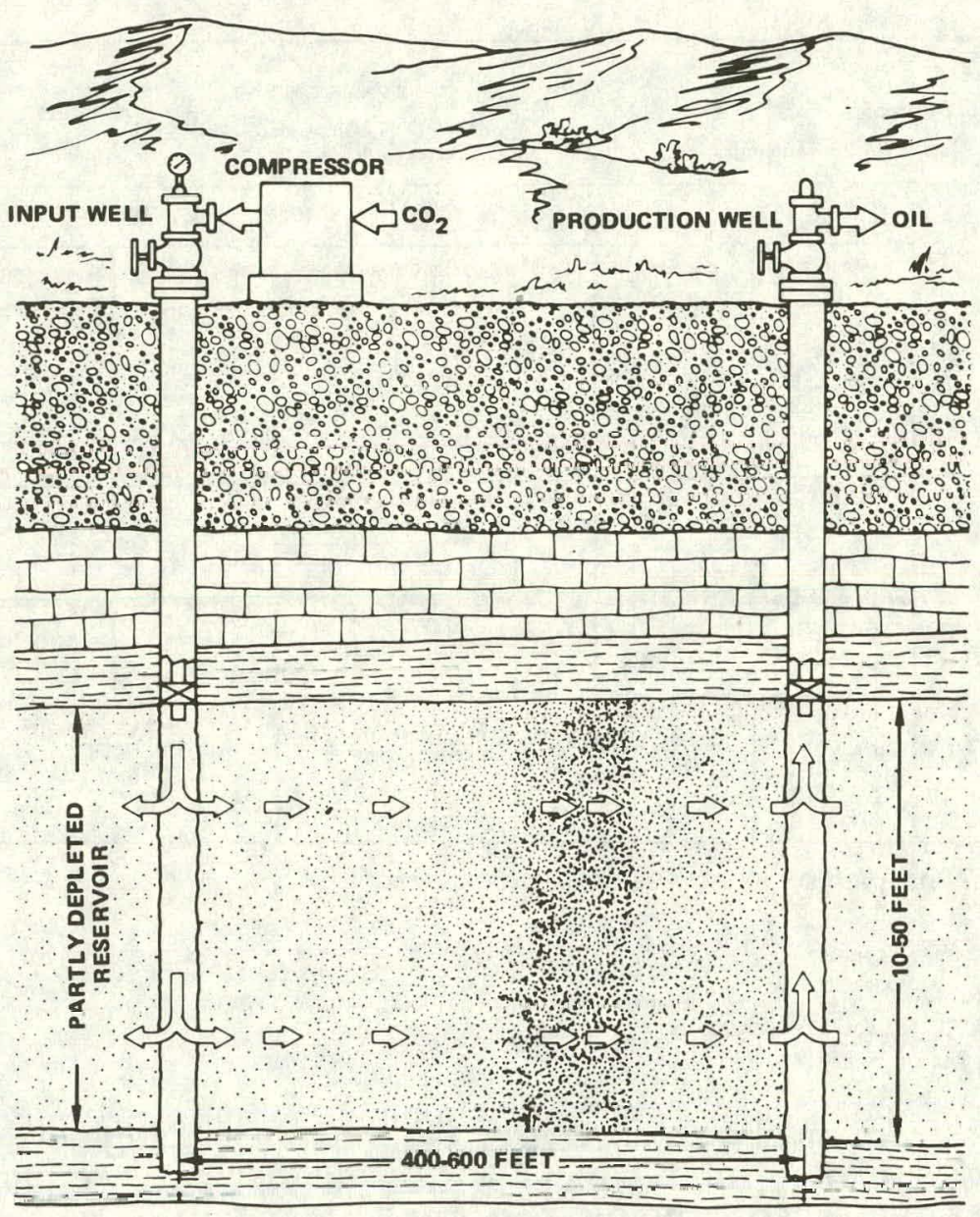

\section{$\mathrm{CO}_{2}$ Injection Process}

\section{Project Status}

\section{Pennzoil Company, Rock Creek Field, West Virginia}

The objective of this projest is to determine the efficiency and economics of recovering oil from a shallow, low-temperature reservoir using carbon dioxide and water to displace oil. Six $\mathrm{CO}_{2}$-injection wells and six of the water-injection wells have been drilled. The injection wells have 
been completed in the producing formation and field pressure is being raised by water injection. $\mathrm{CO}_{2}$ will be injected in mid-1978. The project is on schedule.

Guyan Oil Company, Griffiths Field, West Virginia

The objective of this project is to demonstrate the efficiency and economics of recovering oil from a shallow, low temperature reservoir using carbon dioxide and water to displace the oil. The new wells are drilled and the $\mathrm{CO}_{2}$ storage facility is operable. A delay of several months has resulted from the necessity to perform sizable environmental protective steps such as prevention of silting and erosion, and plugging of old wells . $\mathrm{CO}_{2}$ injection should begin early in 1978. The project is running roughly six months behind its original schedule as of January 1978.

Columbia Gas Transmission, Granny's Creek Field, West Virginia

The objective of this project is to demonstrate the efficiency and economics of recovering oil from a shallow, low temperature, watered-out reservoir using carbon dioxide and water to displace the oil for tertiary recovery. A total of approximately 5,000 tons of $\mathrm{CO}_{2}$ have been injected out of a total of 8,800 tons to be injected. There has been some increase in oil production as a result of this injection. Results are not conclusive, however, and it is necessary for further geological and computer data to be evaluated to improve production efficiency.

\section{Shell Oil Company, Weeks Island Field, Louisiana}

This project was funded late in FY 1976 and is our only EOR project in the deep, high temperature and pressure sands of the Gulf Coast. This project is to use the new technique of employing $\mathrm{CO}_{2}$ (mixed with methane to make it gravity-stable) as a miscible agent to displace residual oil in the "S" Sand. The objective is to determine the feasibility of the $\mathrm{CO}_{2}$ miscible displacement process in the steeply dipping, loosely consolidated highpressure and high-temperature oil zones of the Gulf Coast. The project began in the third quarter of FY 1977. If successful, this test should be a model for many other similar reservoirs on the Gulf Coast. It was delayed roughly seven months by an audit and other contractual details. 


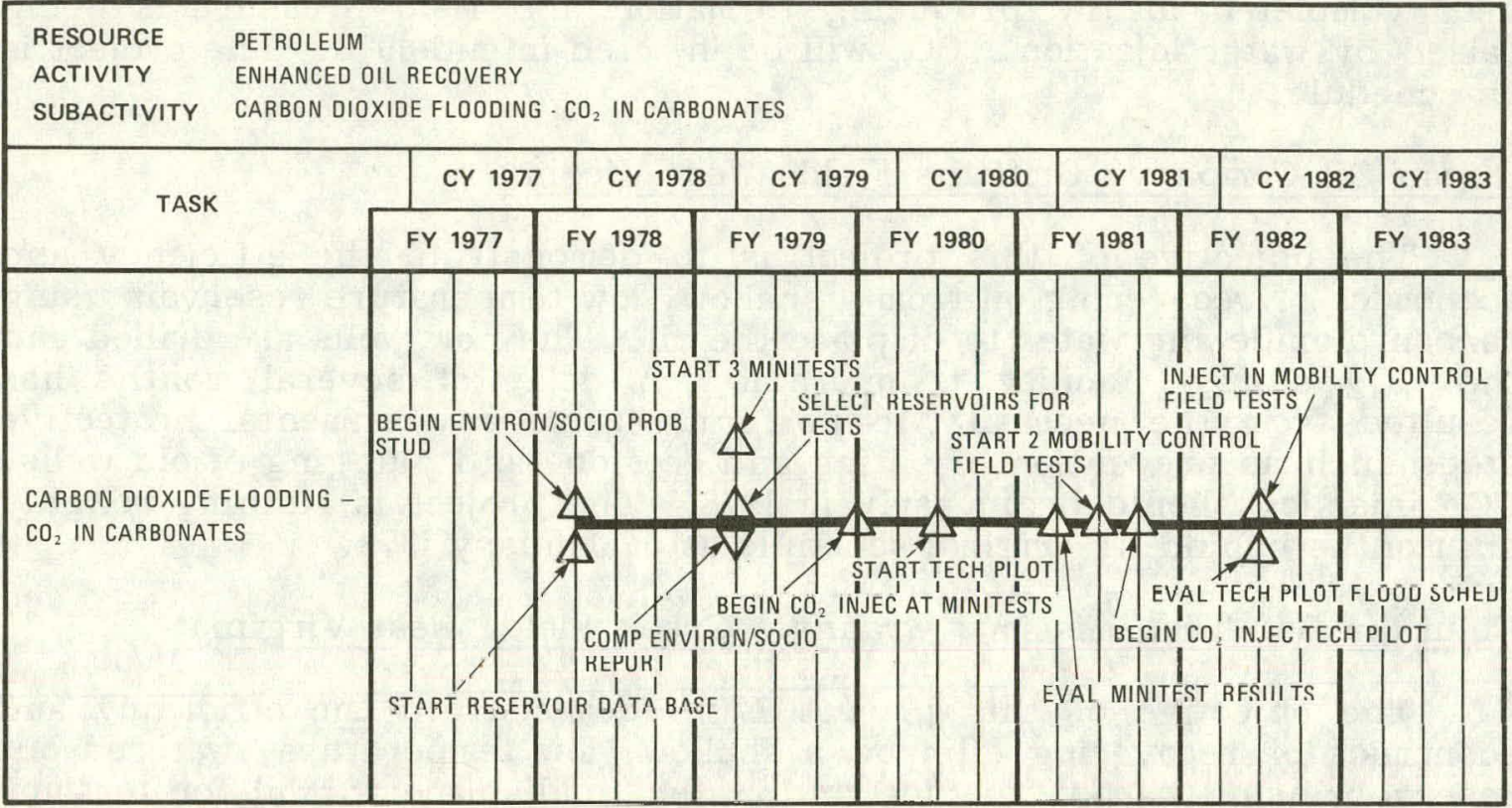

MILESTONE SYMBOLS ARE DEFINED ON LAST PAGE OF THIS DOCUMENT

\subsection{RESOURCES RECOVERY AND SOLVENT (THERMAL)}

Thermal processes use heat to reduce oil viscosity and cause it to flow in the reservoir. Only thermal processes can be used effectively in the recovery of heavy oil and tar sands. Two basic thermal-recovery methods are steam flooding and in-situ combustion.

In steam displacement, steam is injected continuously into a heavy oil bearing formation. As it passes through the formation, it gives up heat, thereby reducing viscnsity of the oil to make it more mobile and displaceable. Steam is effective in relatively shallow, heavy oil reservoirs with high oil content but very low primary recovery. Steam-displacement tests began in FY 1976 and will continue throughout FY 1978.

In situ combustion (forward or reverse, dry or wet) is a process involving high temperature oxidation in the reservoir itself by continuous injection of air or air and water. During the process, part of the oil is converted to coke which is then consumed to produce more heat. The water in the formation is turned to steam that, in turn, distills some of the oil ahead, making it more mobile and causing it to move more readily to the producing wells. Seven thermal recovery projects are currently under way.

The most important project in the thermal recovery area identified in the Management Plan for EOR is to overcome environmental constraints (ENCON) for the production of large amounts of heavy oil found primarily in California (see milestone chart). In the near-term, this project will 
contribute most significantly to our goal of increasing heavy oil recovery, yet environmental regulations limit the amount of emissions that can be introduced into the air. One of our major goals is to develop steam generators and/or ancillary techniques for controlling emissions of steam generators or systems using other fuel that reduce levels of certain combustion products to acceptable levels. Six field thermal projects are now under way.

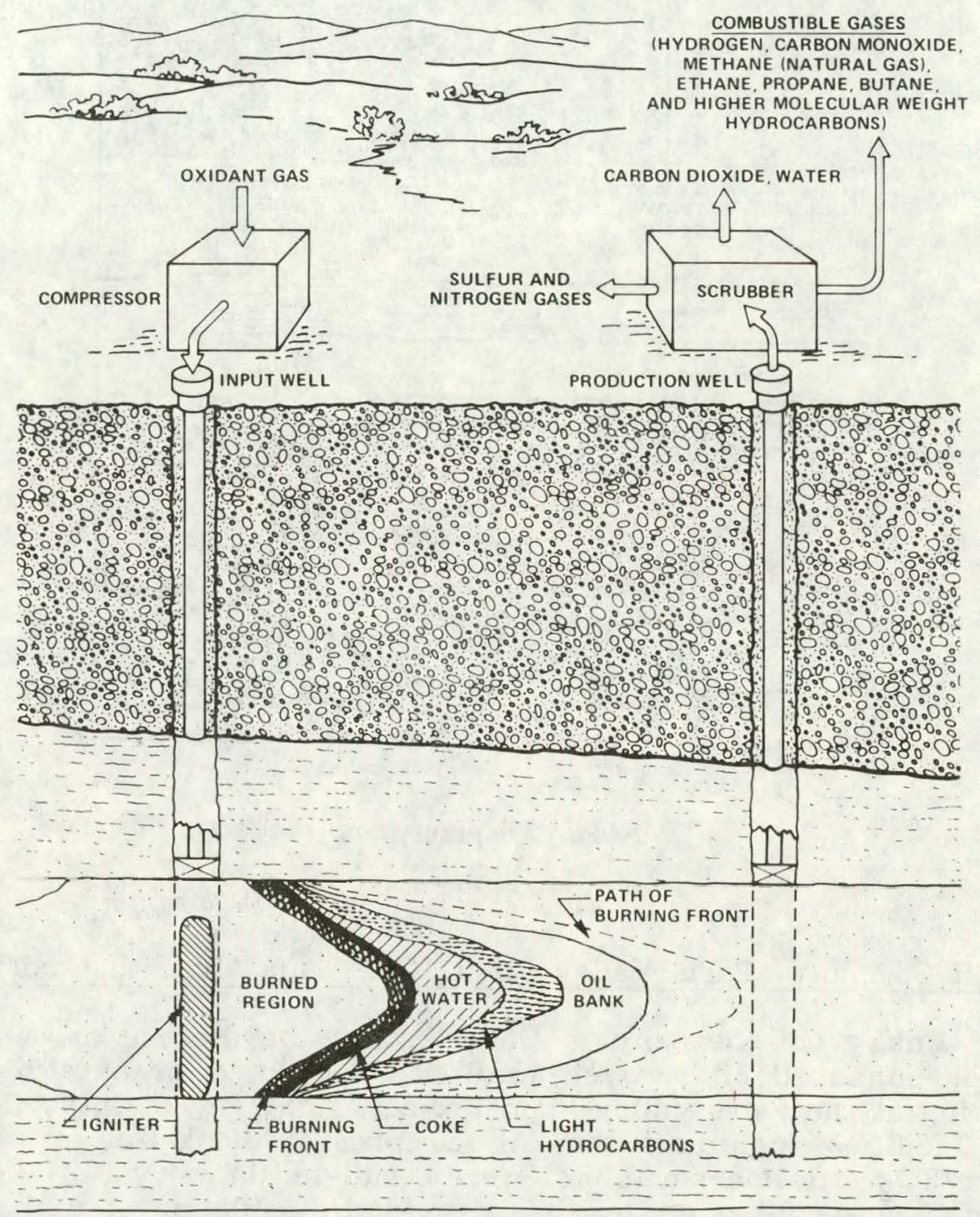

Oil Process In Situ 


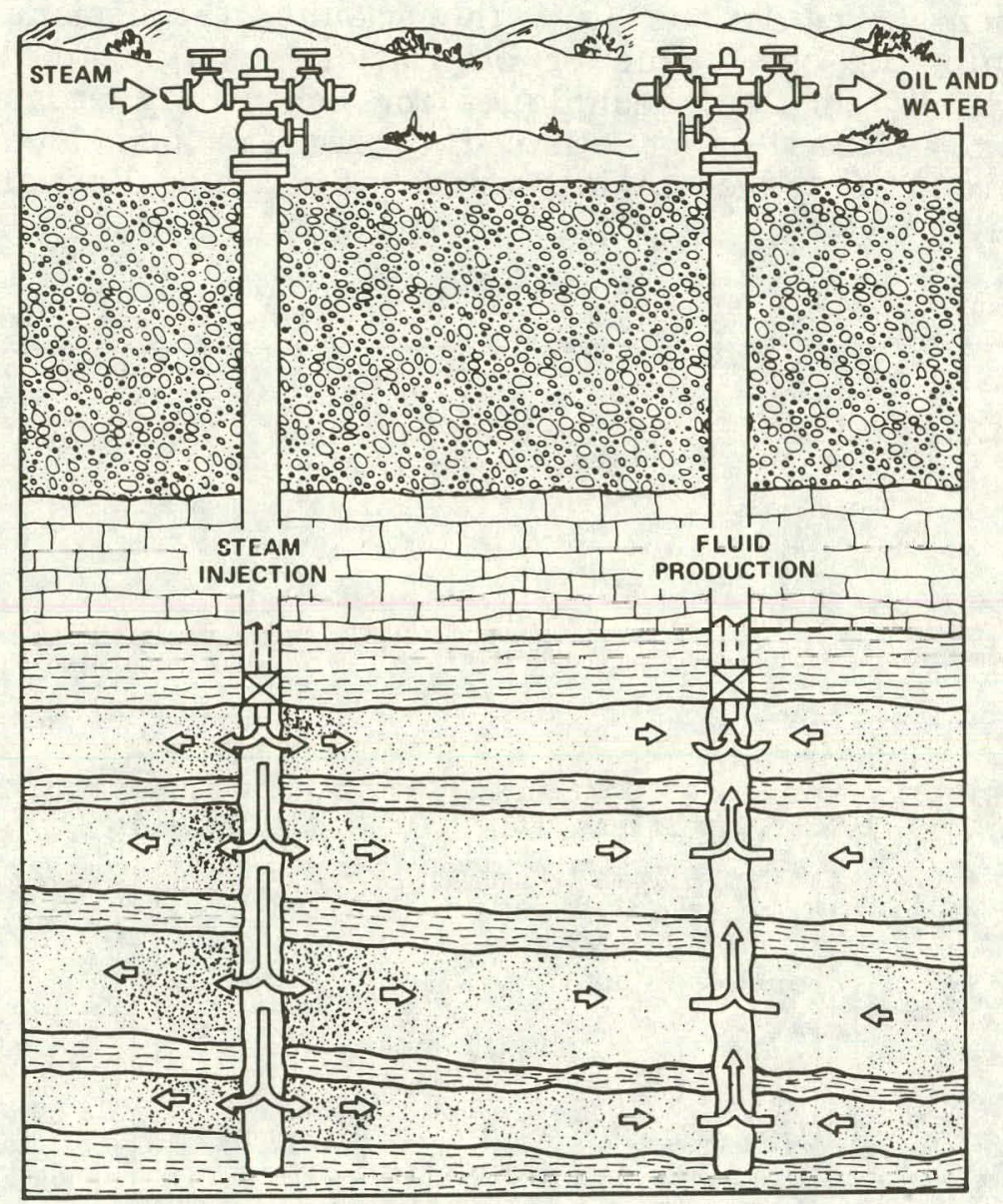

Steam Displacement

Husky Oil Company, Paris Valley Field, California (In Situ Gasification)

The Husky Oil Company is field testing the thermal process in situ method of enhanced oil recovery and has completed preparation for full field testing at the Paris Valley Field Project, Monterey County, California. Surface facilities including the air compressor hook-up, a new steam generator $/ \mathrm{SO}_{2}$ emission scrubber, were completed in early FY 1977. A new generator $/ \mathrm{SO}_{2}$ scrubber system has provided stimulation of higher quality and quantity of steam and exhibited a 93 to 95 percent removal efficiency in tests. Air injection into the test wells is proceeding. Gas analysis from fireflood-producing wells are being conducted weekly. Field testing will continue into 1980 and is now slightly behind schedule because of equipment and facility problems. 
Cities Service Oil Company, Bellevue Field, Louisiana (In Situ Combustion)

The Cities Service Oil Company is field testing improved oil recovery by in situ combustion in the Bellevue Field, Louisiana. All facilities have been completed and were in production as of late FY 1977. In situ combustion has been initiated in several air injection wells, and promising increases in production have been obtained. A combination of air and water are being injected. The product is slightly ahead of schedule as of January 1978.

Getty Oil Company, Cat Canyon Field, California (Steam Flooding)

Getty Oil Company has started a steam drive project in Cat Canyon Field, California. Four inverted five-spot patterns are involved that encompass 20 acres. All producing wells are being cyclically steam stimulated to improve the oil mobility until steam from the injectors breaks through. The estimated recovery from the project is $850,000 \mathrm{bbl}$ of oil, and the project is well under way, although delayed a few months by the approval of an environmental permit for the steam generators.

Chanslor-Western Oil Development Company, Midway Sunset Field, (Steam Flooding) California

Chanslor-Western Oil Development Company has begun a steam drive project in Midway Sunset Field to demonstrate the operational and economic aspects of steam-flooding a typical, low-pressure, flat, heavy-oil reservoir that had unfavorable response to cyclic steam stimulation. Four inverted seven-dot drive patterns are under test; the project is proceeding on schedule. Early breakthrough of steam has been encountered, necessitating additional reservoir data.

\section{Carmel Energy Company, Carlyle Field, Kansas}

Carmel Energy, Inc. is demonstrating the efficiency and economics of recovering heavy oil by using the Vapor-Therm process. The process utilizes a mixture of combustion gases and water vapor to stimulate the production of low-gravity viscous oil. Construction of the commerciallysized Vapor-Therm Unit has been completed, and the injection of the hot vapors has been applied successfully in Kansas. The results have been encouraging, and private expansion in surrounding areas is expected.

Laramie Energy Research Center Tar Sands Project, Vernal, Utah

This process is a combination of reverse and forward combustion. In forward combustion, air travels in the same direction as the combustion front, while in reverse combustion, air passes through the combustion zone in the direction opposite to air flow; oil then flows through rock heated up to about 1000 F.

The first phase of the Laramie in situ combustion test at Asphalt Ridge, Utah, has been completed in FY 1976. The second phase is now being conducted with proper precautions taken against congealing of oil in flow lines, which was one of the main problems during the first phase of 
this program. The second phase of the experiment is on schedule, and the results appear encouraging in view of the great problems that have to be overcome before oil can be produced from tar sands.

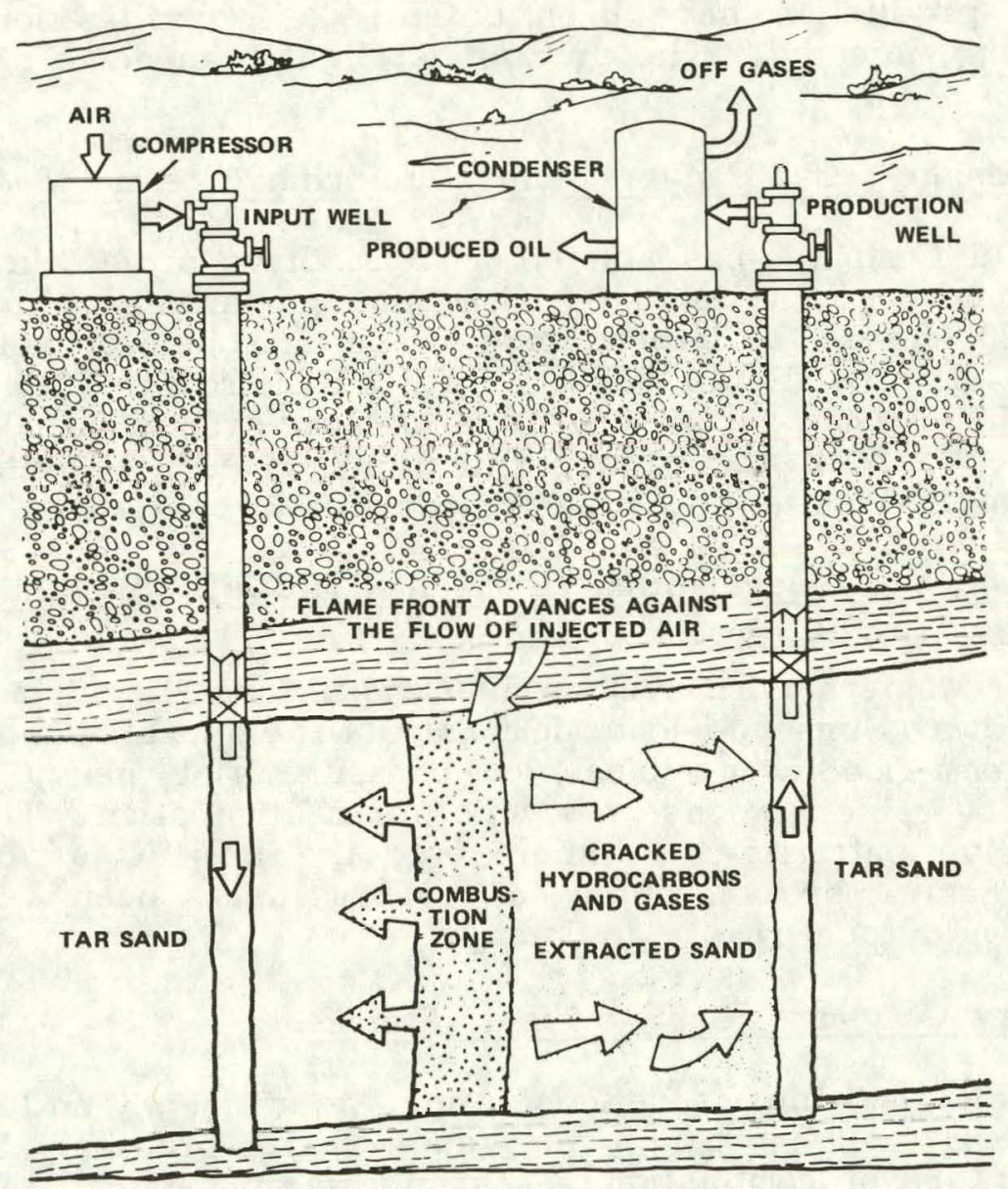

Thermal Methods (Tar Sands) Process 


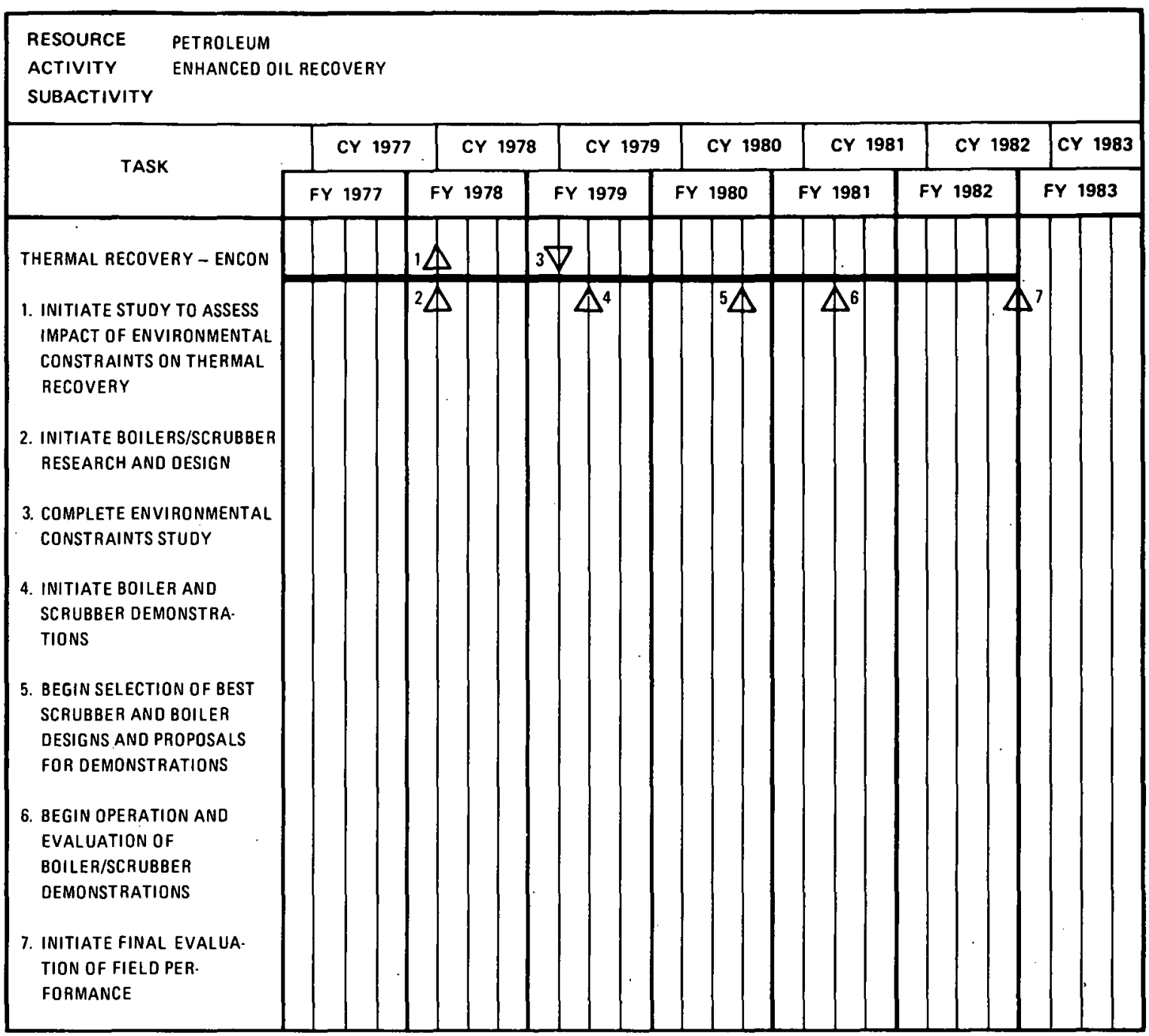

MILESTONE SYMBOLS ARE DEFINED ON LAST PAGE OF THIS DOC.UMENT

\subsection{ENVIRONMENTAL STUDIES AND SUPPORTING RESEARCH}

The Enhanced Oil Recovery Activity includes controls to ensure that every field project will be conducted in accordance with existing and foreseeable environmental, health, and safety (EH\&S) requirements. An EDP is planned to (1) identify and define EH\&S requirements, problems, and milestones; and (2) to plan how these requirements will be fulfilled, how problems will be solved, and how milestones will be completed. The Plan will be conducted in accordance with Federal, state, and local statutes and regulations for EH\&S protection.

Enhanced oil recovery projects are generally undertaken in oil fields that have gone through years of primary and secondary production. Consequently, significant base line environmental information is available for. enhanced oil recovery projects to ensure that adverse environmental effects are not overlooked. Planning for resolving potential environmental problems will be part of this work, and projecte to solve specific environmental problems will be initiated as required. 
The primary objective of supporting research is to provide the appropriate contract and project support to assist the Enhanced Oil Recovery Activity. The strategy is to sponsor basic and applied research at various universities, National Laboratories (NL), Energy Research Centers (ERCs), and industrial organizations. It includes research support and contract monitoring by the ERCs and development and analysis of EOR programs. Other supporting research includes chemicals for EOR, characterization of reservoirs, project Halo, and residual oil determination.

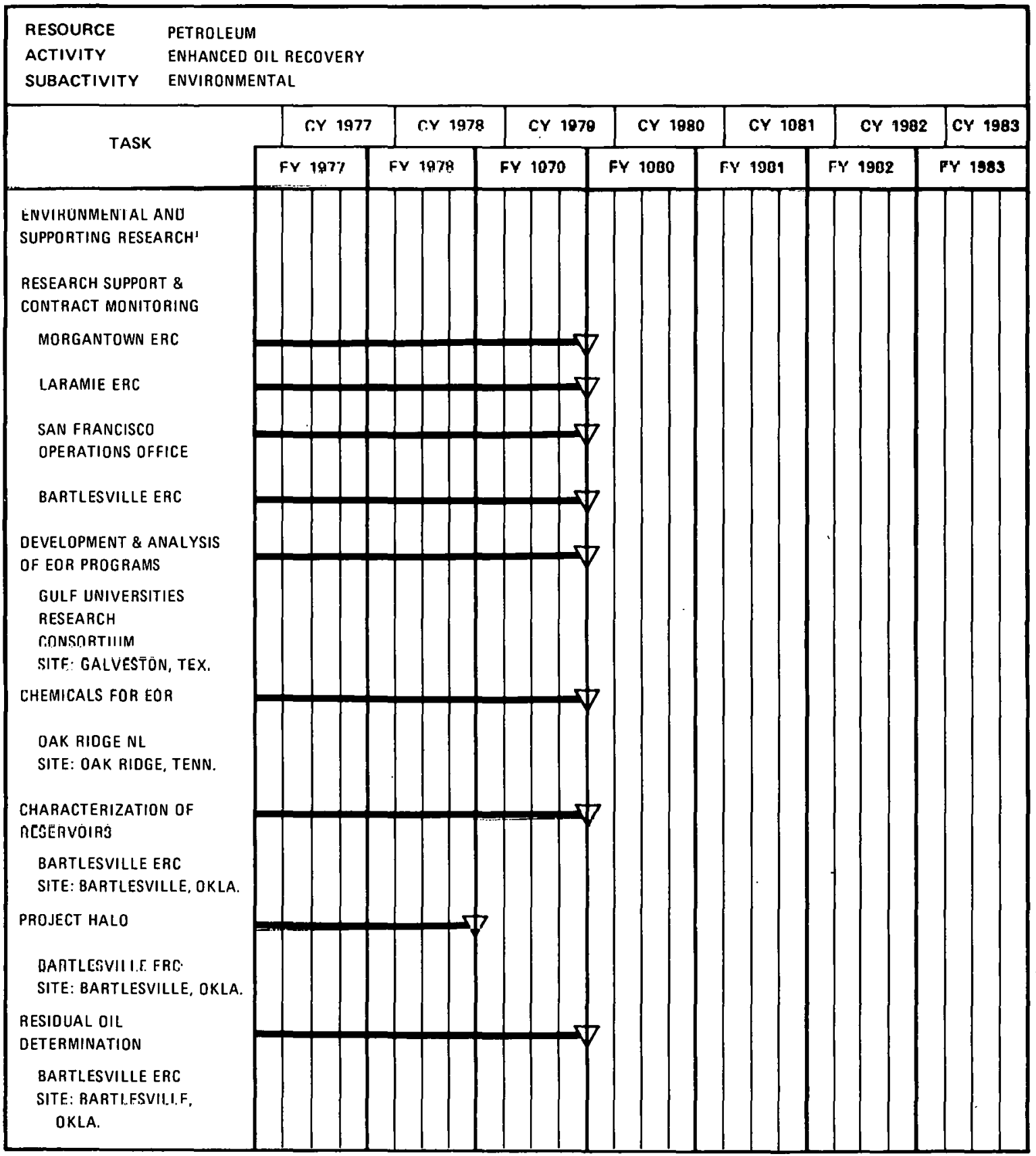

MILESTONE SYMBOLS ARE DEFINED ON LAST PAGE OF THIS DOCUMENT

I RESEARCH PROJECTS AT ERCS AND NLS ARE AUTHORIZED ON AN INCREMENTAL ANNUAL BASIS,

THEREFORE THESE MAY BE EXTENDED BEYDND FY 1979 


\section{OIL FROM OIL SHALE}

\subsection{SHALE OIL PRODUCTION}

- In the past, primary efforts to develop oil shale have employed a combination of mining and surface retorting. An alternative approach is in situ retorting, which if economically attractive could potentially increase the recoverable reserves of oil shale by about 600 billion barrels, reduce water requirements of an oil shale industry, and mitigate the environmental impacts normally associated with mining and surface processing of raw shale.

In situ techniques can be subdivided into two general categories: true in situ and modified in situ. True in situ retorting utilizes methods that require no mining and use only the permeability created in a network of fractures produced by hydraulic and explosive fracturing through boreholes. Very little displacement or reorientation of the broken shale occurs. Such methods are considered applicable principally to western 'shales grading less than 30 gallons per ton, less than 300 feet thick, and at depths less than 1,000 feel. Large deposits of oil shale within these characteristics occur in both the eastern and western United States. The technique is being tested at greater depths in Michigan. Many of these beds are considered unsuited for the better established approach of mining and above ground processing, even though geographic extent and total energy potential are very large. Other types of deposits are equally unsuited for above ground technology and remain largely or entirely undeveloped, but are thought to be suited for in situ techniques that are recognized but different from the true in situ approach. These are generally termed modified techniques because they utilize up to 25 percent of enhanced void volume relative to true in situ methods. The additional void volume is created by removal of shale or other minerals from the space originally occupied in the shale deposit. Such removal may be achieved by conventional mining, solution removal of water soluble minerals, creation of chambers by mechanical and/or explosive breakup and removal of rock at the bottom of boreholes, or substantial uplift of overburden covering shallow deposits and expansion of shale rubble into the volume previously occupied by other rock. Not only are in situ techniques applicable to oil shale deposits that otherwise would be by-passed, but they also offer the potential advantages over above ground methods of decreased environmental hazards as well as decreased water and manpower requirements. The two categories of in situ recovery are described in Section 1.1 and 1.2 .

The following are the direct products expected from in situ retorting operations:

- Shale oil syncrude that can be refined into the various products (refinery fuel-gas, jet fuels, LPG, and coke) needed in the commercial market 
- Low- to medium-Btu gas that can be used on-site in a gasturbine generator to provide electricity for process operation and for sale

- Ammonia and sulfur products that are recovered from a normal shale oil refining scheme.

In production of oil from oil shale, major accomplishments for FY 1978. include the following:

Field tests will be under way in five major in situ contracts in FY 1978, including four projects in western oil shales and one in the Antrim shale of Michigan. Experiments will be in various stages by Geokinetics on 16 PDU horizontal modified in situ retorts in Utah, including preparation of the four largest yet attcmptcd. The two laryesl of these will have dimensions of $160 \times 180 \times 30$ feet thick. Post-burn evaluation will be rnmpleted on five rotorto for which pieliminary calculations of liquid oil yield are as liigh ds 70 percent of Fischer assay. Occidental will complete evaluation of results of the retorting of a vertical-slot design of the vertical modified in situ process in colorado and complete mining and preparation of a horizontal-slot design of the vertical modified process for which retorting is scheduled to begin in late summer of 1978 . Both designs are being tested at approximately the size expected to be used commercially. Equity will complete field preparation of a leached zone retort module in Colorado, approximately one acre in cross-section $x 500$ feet thick, and commence injection of superheated steam in a semi-vertical mode of operation. Talley-Frac will initiate a true in situ PDU module test of one acre in the Green River formation in Wyoming. This test will be the first time that explosive fracturing in pre-created horizontal hydraulic fractures has been applied at depths greater than $100 \mathrm{fcct}$, although the Laramie Energy Research Center (LERC) has previously demonstrated that horizontal hydraulic fractures can be created at depths approaching 1,000 feet. The detailed design of this test will he hased on resulte of the LERC Rock Jprings Sile 12 explosive fracturing test that was successfully completed in early FY 1978 with design and instrumentation by Sandia Laboratories and participation by Talley-Frac as the explosives subcontractor. A number of previous small-scale field tests conducted by LERC to develop this type of explosive fracturing technology have included combustion or retorting tests. However, these previous tests were at about half the depth and did not attempt to fracture the full thickness of a typical Wyoming shale bed as will be done under the Talley-Frac contract (much of the Wyoming oil shale consists of three beds, 40 to 50 feet thick, vertically separated by barren rock). In the Antrim shale of Michigan (a Devonian shale deposit), Dow will perform combustion tests on a previously fractured site with enhanced void volume created by mechanical underreaming of two boreholes; will conduct true in situ fracturing tests using combined hydraulic/explosive techniques; and will attempt solution mining with acid to form a cavity in limestone underlying the Antrim formation prior to explosive rubblization. Two of these techniques are considered modified in situ concepts. 


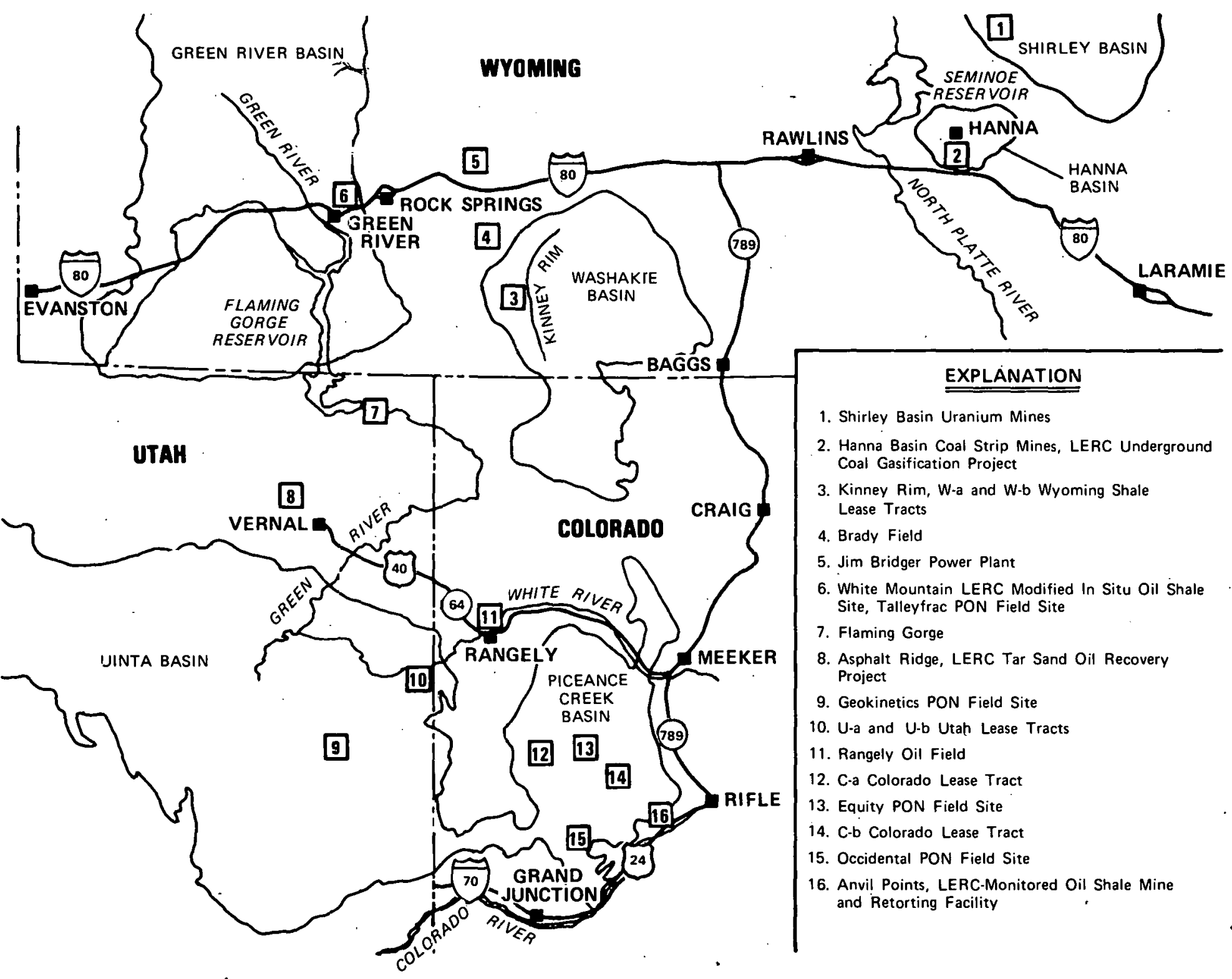

DOE and Industry Energy Projects In Oil Shale Region 
The table below summarizes the funding levels by subactivity for the FY 1977 to FY 1979 period.

\begin{tabular}{|c|c|c|c|c|c|}
\hline \multirow{2}{*}{$\begin{array}{l}\text { OIL FROM OIL SHALE } \\
\text { SUBACTIVITIES }\end{array}$} & \multicolumn{4}{|c|}{$\begin{array}{l}\text { BUDGET AUTHORITY } \\
\text { (OPERATING EXPENSES) } \\
\text { (DOLLARS IN THOUSANDS) }\end{array}$} & \multirow{2}{*}{$\begin{array}{l}\text { MAJOR } \\
\text { CHANGE* }\end{array}$} \\
\hline & $\begin{array}{l}\text { ACTUAL } \\
\text { FY } 1977\end{array}$ & $\begin{array}{l}\text { APPROPRIATION } \\
\text { FY } 1978\end{array}$ & $\begin{array}{l}\text { ESTIMATE } \\
\text { FY } 1979\end{array}$ & $\begin{array}{l}\text { INCREASE } \\
\text { (DECREASE) }\end{array}$ & \\
\hline Shale Oil Production & $\$ 18,678$ & $\$ 24,032$ & $\$ 29,350$ & $\$+5,318$ & 1 \\
\hline \multicolumn{3}{|c|}{ 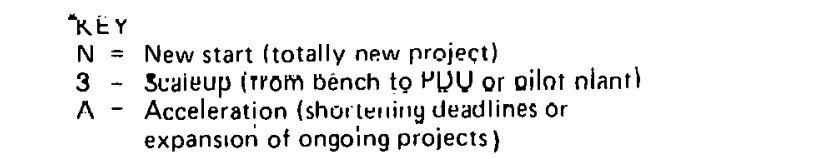 } & \multicolumn{3}{|c|}{$\begin{array}{l}P=\text { Phare complotion or gtartup } \\
\Pi=\text { Pruylari leditetiluil } \\
1 \text { - Inarcmental cüsl reyuiremielli } \\
C=\text { Project completion or suspension }\end{array}$} \\
\hline
\end{tabular}

\subsection{LABORATORY AND FIELD TESTS}

During FY 1978, a number of research projects will be conducted to support the national program. These include projects in modified in situ, true in situ, shale gasification, and environmental aspects. Laboratory and pilot-scale retorting studies are being conducted in above ground equipment by the Laramie Energy Research Center and the Lawrence Livermore Laboratories (LLL). The primary objective of these studies is developing and testing mathematical models that will be sufficiently general for application to large-scale in situ retorts.

A continuing program of field studies of in situ oil shale processing is being conducted by the J.F.R.r. Frasturing the oil shale iu plis:e without mining or removing material by men working underground is a major problem to be solved before true in situ retorting can become technically feasible. The fracturing problem is under investigation with much of the explosive fracturing design and evaluation work being conducted by Sandia Laboratories (SL) and Los Alamos Scientific Laboratories (LASL). SL will, also participate in instrumental evaluation of the Geokinetics, Talley-Frac, and Dow projects in FY. 1978.

In another effort to speed the development of shale technology, working relationships have been estahlished with several major western universities to conduct research on problems related to oil shale development. Training university students in energy technology on major in situ oil shale projects is an important part of technology transfer. 
Information on oil shale technology developed by DOE is readily available through reports and papers published in the open literature and through reports submitted to the Program Administrator for Fossil Energy. To ensure efficient technology transfer from the industrial concerns operating the major in situ oil shale projects described in more detail on the following pages, government employees will be assigned to the projects for monitoring and evaluating the results of the contract research. This approach will provide the Program Administrator for Fossil Energy with the maximum amount of information will ensure that DOE maintains sufficient in-house expertise to conduct an efficient energy development program.

\section{True In Situ Shale Oil Recovery Process}

The true in situ shale oil recovery process is characterized by fracturing techniques that require no mining or removal of major amounts of oil shale. Past experiments conducted by the government used a combination of hydraulic and explosive fracturing to produce permeability in the oil shale bed as well as a particle-size distribution capable of sustaining combustion reactions. In these experiments, sand-propped hydraulic fractures were loaded with liquid or slurried explosives. The explosives were then detonated to further fracture the oil shale. Government and industrial experiments have also used explosive charges emplaced in drilled holes and detonated to fracture the oil shale. Other fracturing techniques have been used with somewhat less success; newer and better methods may develop from the current research.

The fractured oil shale bed can be retorted by two general methods. The shale can be ignited at the bottom of the injection well and combustion sustained by air injection, in which case hot combustion gases retort the shale. In some cases, it is advantageous to supplement the air supply by injecting propane, recycled gas, or some other fuel to enhance combustion. In the second method, energy for retorting the shale can be supplied by injecting heated gases. The gases considered for use in this process are steam, natural gas, nitrogen, and others.

In either method, products of retorting are recovered from the production well. Liquid products collected in the bottom of the well can be pumped to the surface. Liquid cntrained in the exit gas stream can be separated and collected on the surface. Depending on the heating value of the gas stream, it can be used as recycle gas, burned as a source of fuel on the surface, or discarded through a flare to prevent pollution.

True in situ retorting research may be considered a high-risk research effort appropriate for government support. If some of the problems can be solved satisfactorily, the benefits of true in situ processing may be large in terms of resource recovery and environmental acceptability . 
The objective of this activity is to demonstrate the technical and economic feasibility of true in situ retorting techniques. These techniques promise to produce shale oil with minimal environmental impacts.

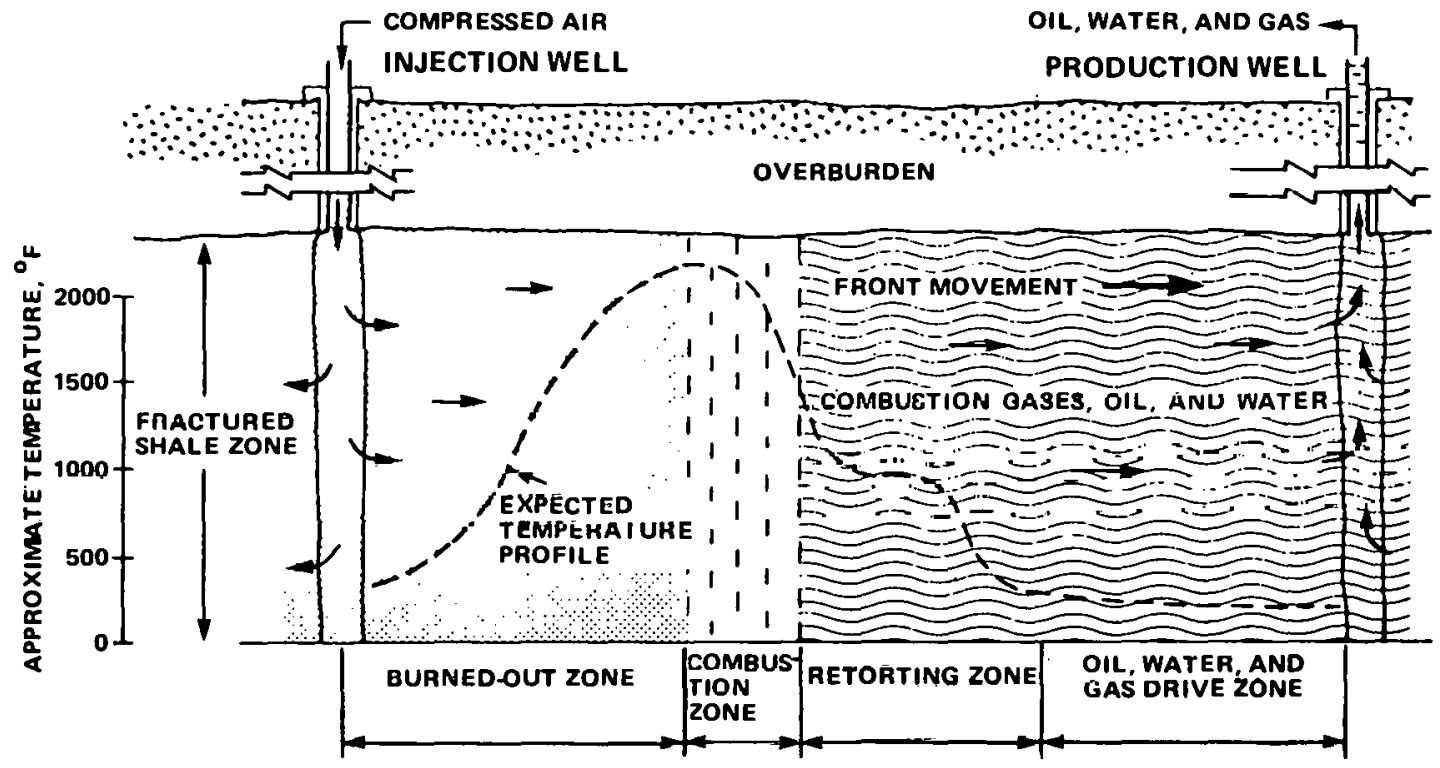

True In Situ Retorting

\section{Project Status}

True in situ processing of oil shale is most likely to be applied to shales deposited in thin beds, possibly interspersed with barren rock. LERC has an experimental in situ project under way on such a shale deposit near Rock Springs, Wyoming. The lelorling phase of one experiment. (Site 9) was completed early in FY 1977, and efforts to rccover additional oll were completed by the end of FY 1977. A second retorting experiment by LERC is planned for FY 1978, at the Site 12 fracturing experiment completed in early FY 1978. These retorting experiments provide realistic field data for input to process control models, and are not designed to produce extensive amounts of shale oil.

Additional projects are under way to continue the invesligation of true in situ technology. As shown on the accompanying milestone chart, both fracturing and retorting experiments are in progress. Courdinated research by LERC, SL, and Los Alamos Scientifir Laboratory (LASI) is aduressing the problem of oil shale fracturing. Retorting experiments are being conducted by LERC in western Wyoming. In addition, projects to develop a model that interrelates fractures with rubble size in oil shale and to determine the effects of oil shale particle-size distribution on pressure drop are being conducted by LLL and LERC. 


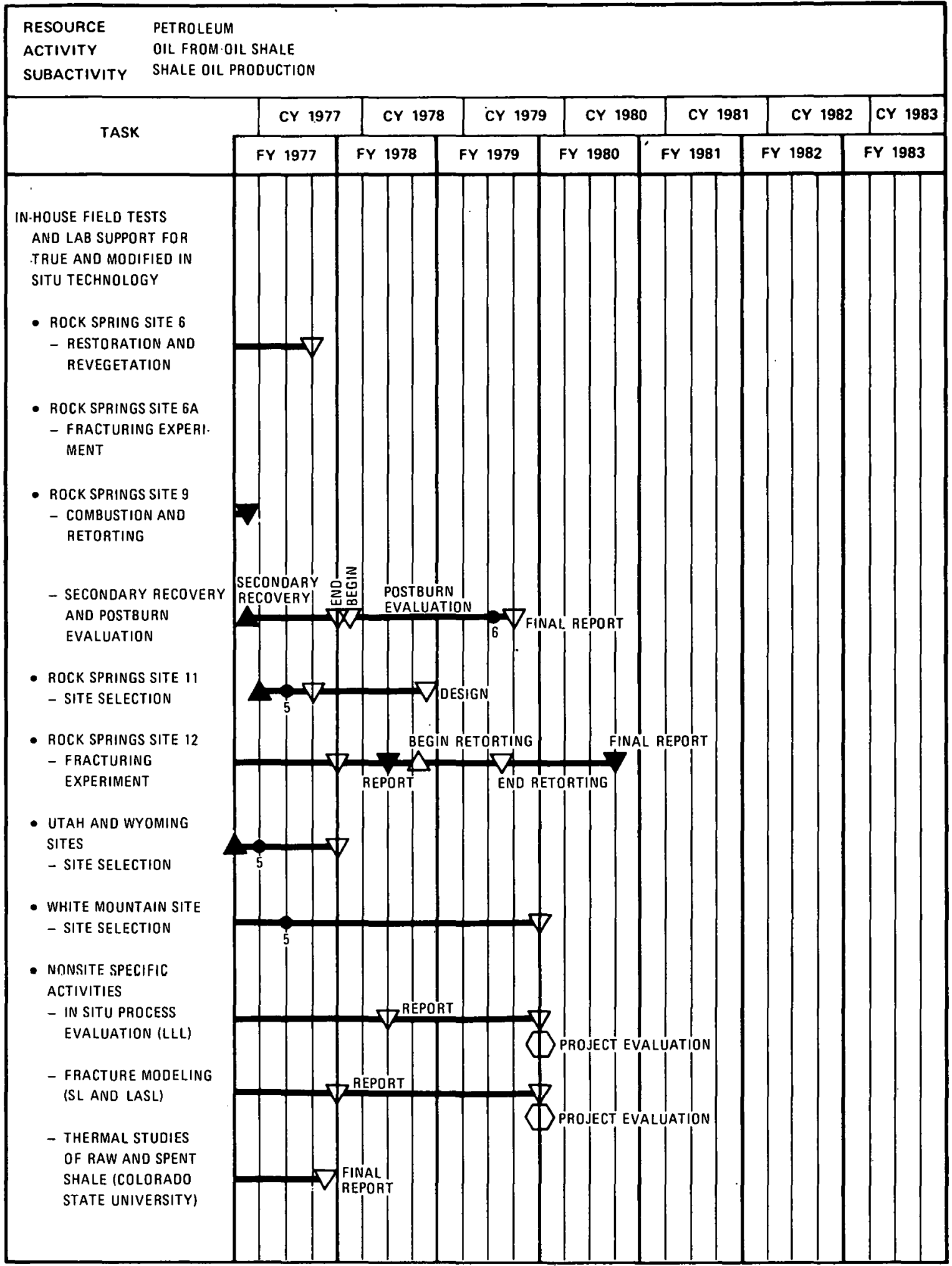

MILESTONE SYMBOLS ARE DEFINED ON LAST PAGE OF THIS DOCUMENT 


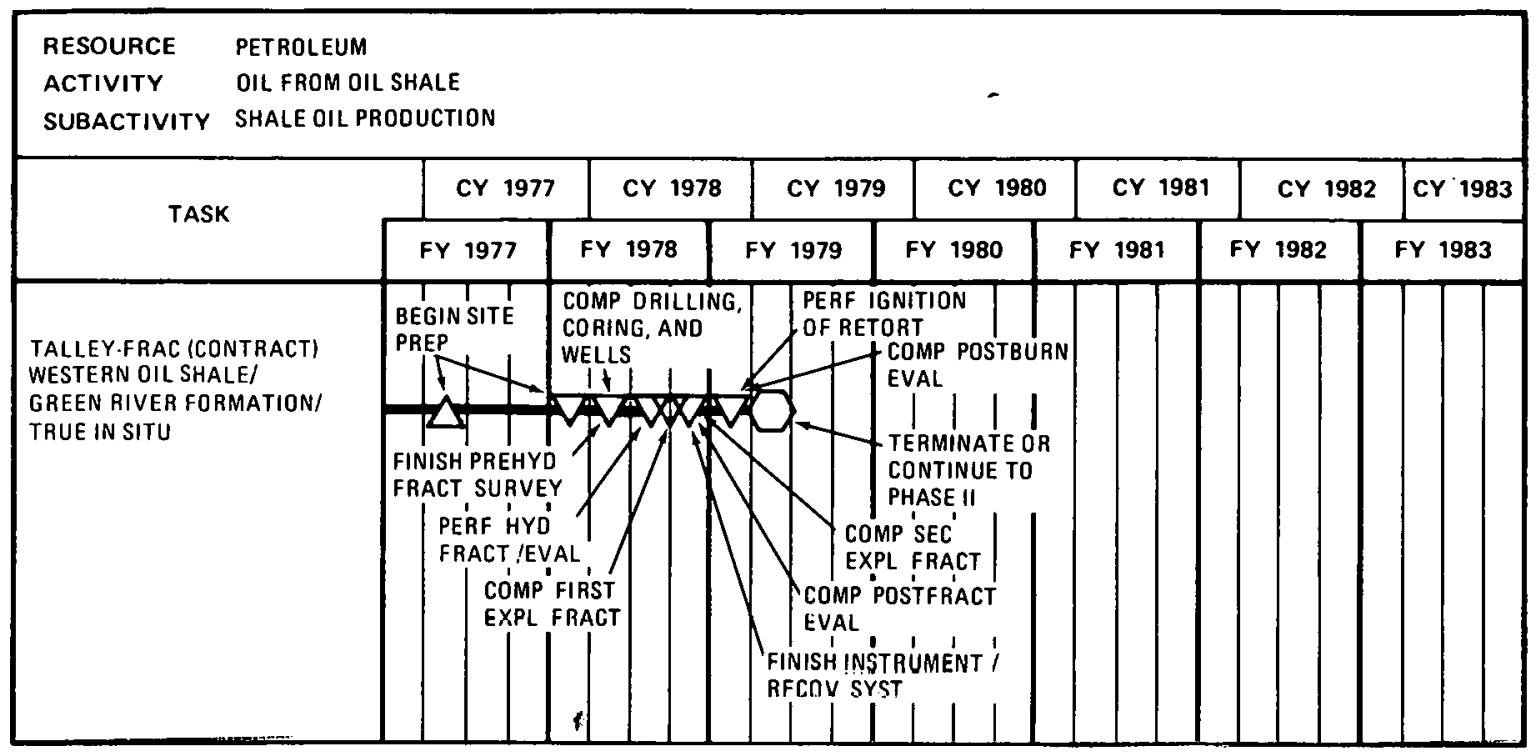

MILESTONE SYMBOLS ARE DEFINED ON LAST PAGE OF THIS DOCUMENT

\section{Modified In Situ Shale Oil Production Process}

The difference between these processes and true in situ retorting methods is that between 15 and 25 percent of the oil shale or other minerals are mined or otherwise rescued from within the retort to provide the void space for enhanced permeability when the remaining shale is rubblized, as previously discussed. If mined shale is oil rich, it will be sent to'surface retorting; but if it is low-grade shale, it will be discarded. This can greatly influence mine designs and detailed development plans. Wells are drilled and prepared prior to fracturing the shale. After the oil shale is fractured through explosive techniques, a porous medium remains and retorting is begun.

Four general concepts of modified in situ techniques can be identified:

- Vertical modified in situ with partial mining in which the relative dimensions of the retort are larger in the vertical direction than in the horizontal, such as a column (Occidental contract.).

- Horizontal modified in situ with partial mining in which thc relative dimensions are larger in the horizontal-direction than in the vertical, such as a bed (in-house project).

- Modified in situ retorting of a zone in which minerals contained in the shale have been removed by naturally occurring ground (leached zone in Colorado) or by solution mining. (Equity Oil Co. contract) 
- Horizontal modified in situ retorting of a rubblized oil shale bed that has been prepared by explosive detonation resulting in noticeable surface uplift. (Geokinetics (GSG) contract)

Modified techniques that require partial mining followed by massive rubblization are believed to offer the most promise for deeper and very thick shale deposits. In these deposits the vertical configuration is most useful. A horizontal technique will be more useful in somewhat thinner deposits or as a secondary recovery method in a previously worked mine.

The objective of modified in situ retorting activities is to develop and test these underground retorting techniques to determine their technical, economic, and environmental feasibilities.

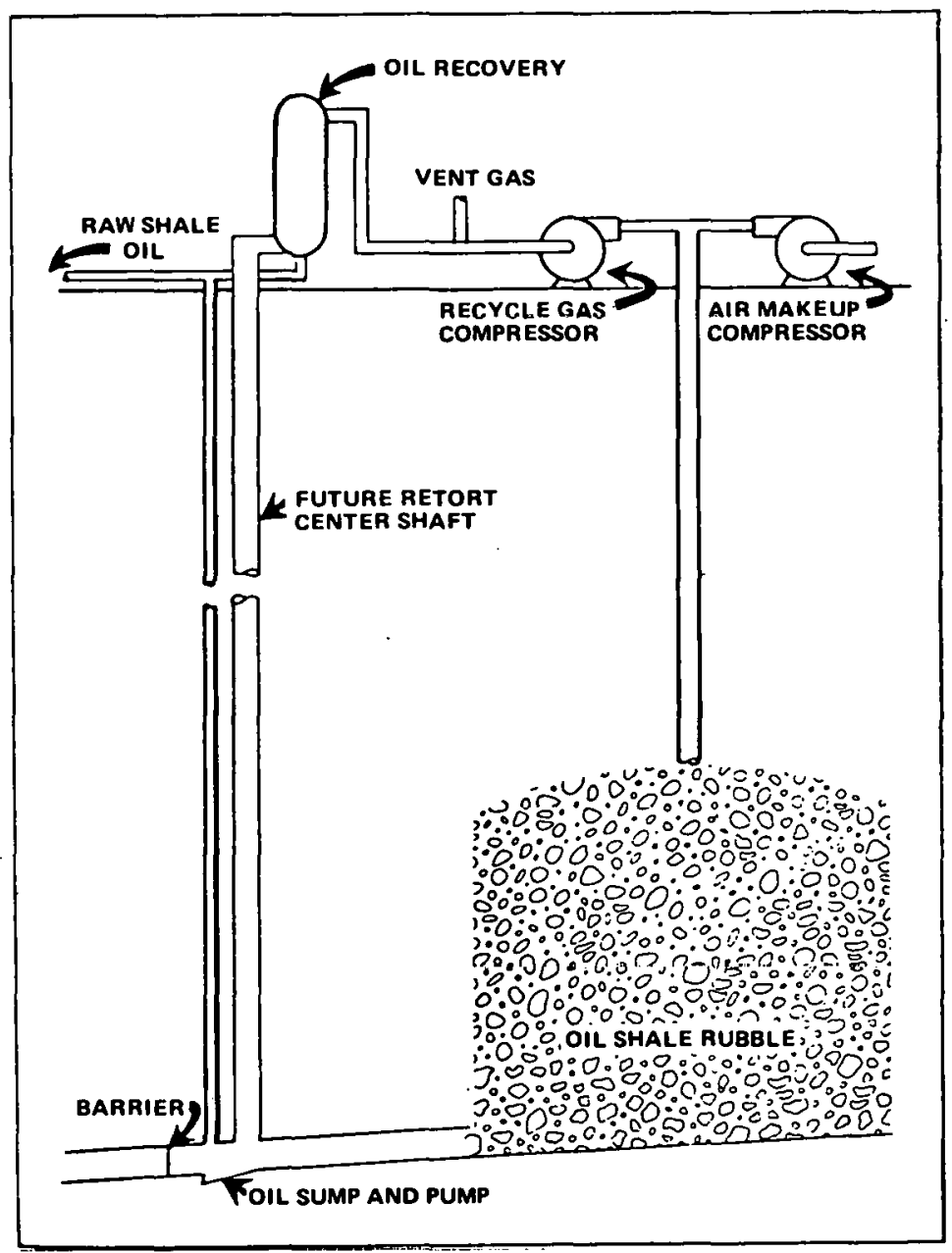

Occidental Oil Shale Process Retort Operation 


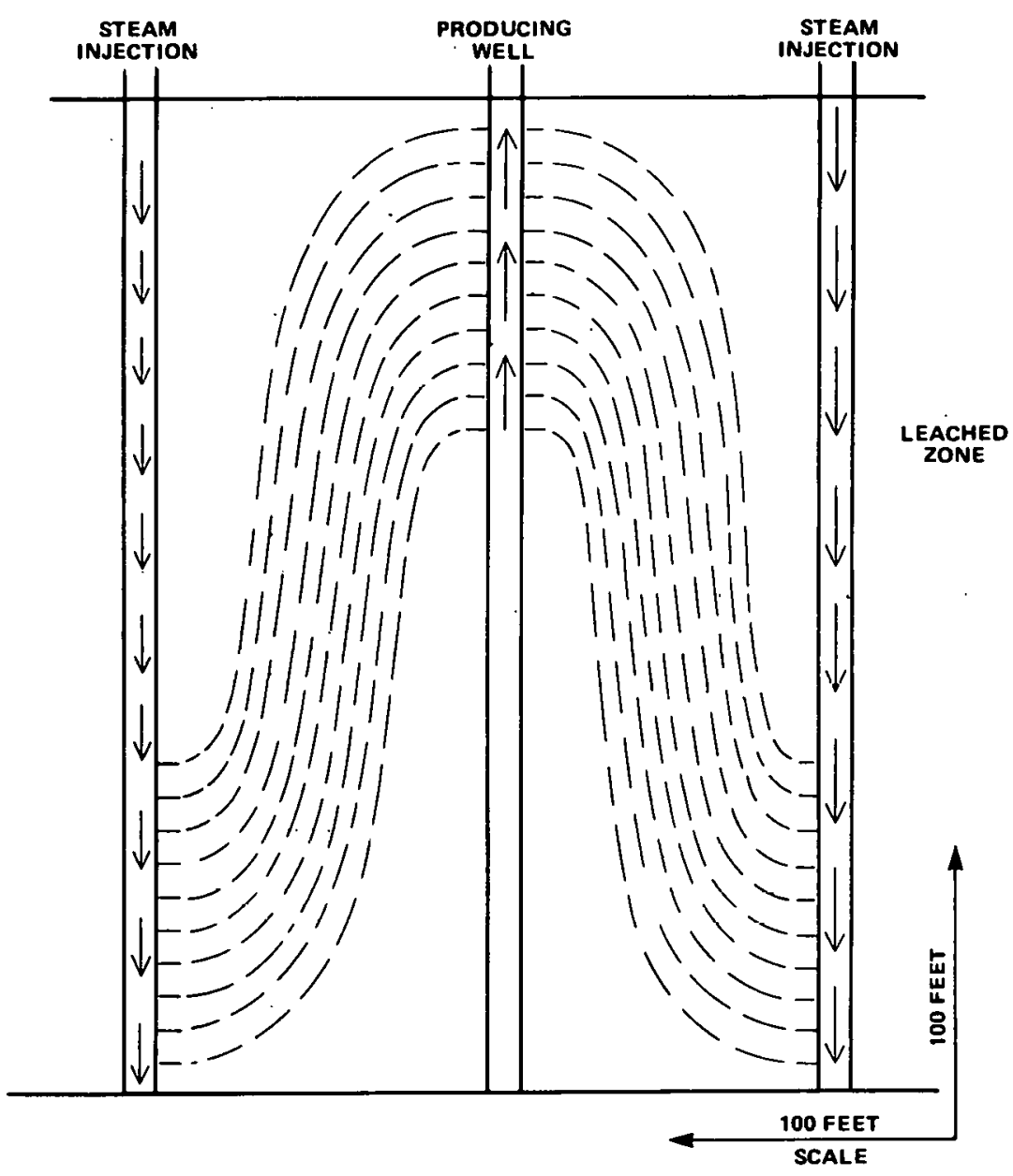

Equity In Situ Project, Idealized Injection/Production

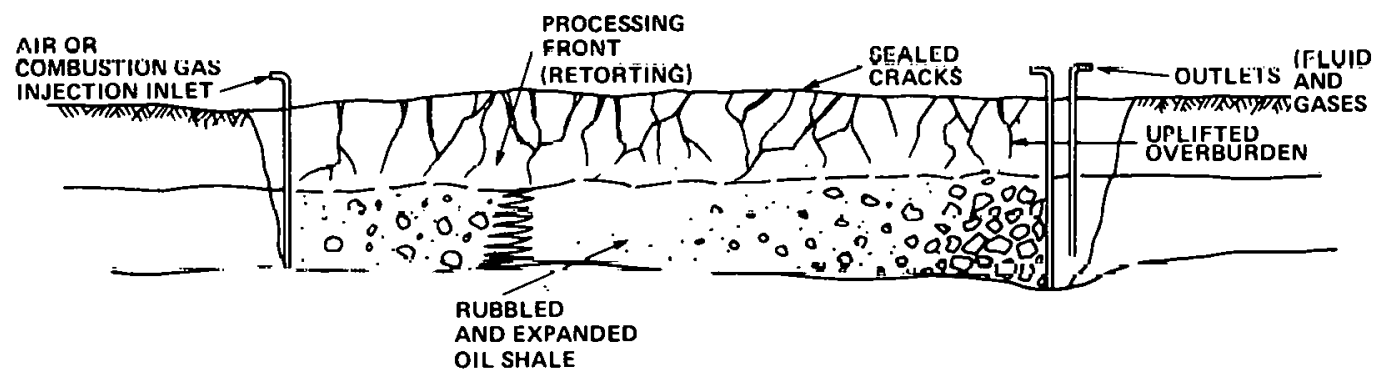

Modified Horizontal In Situ Process-GSG Version 


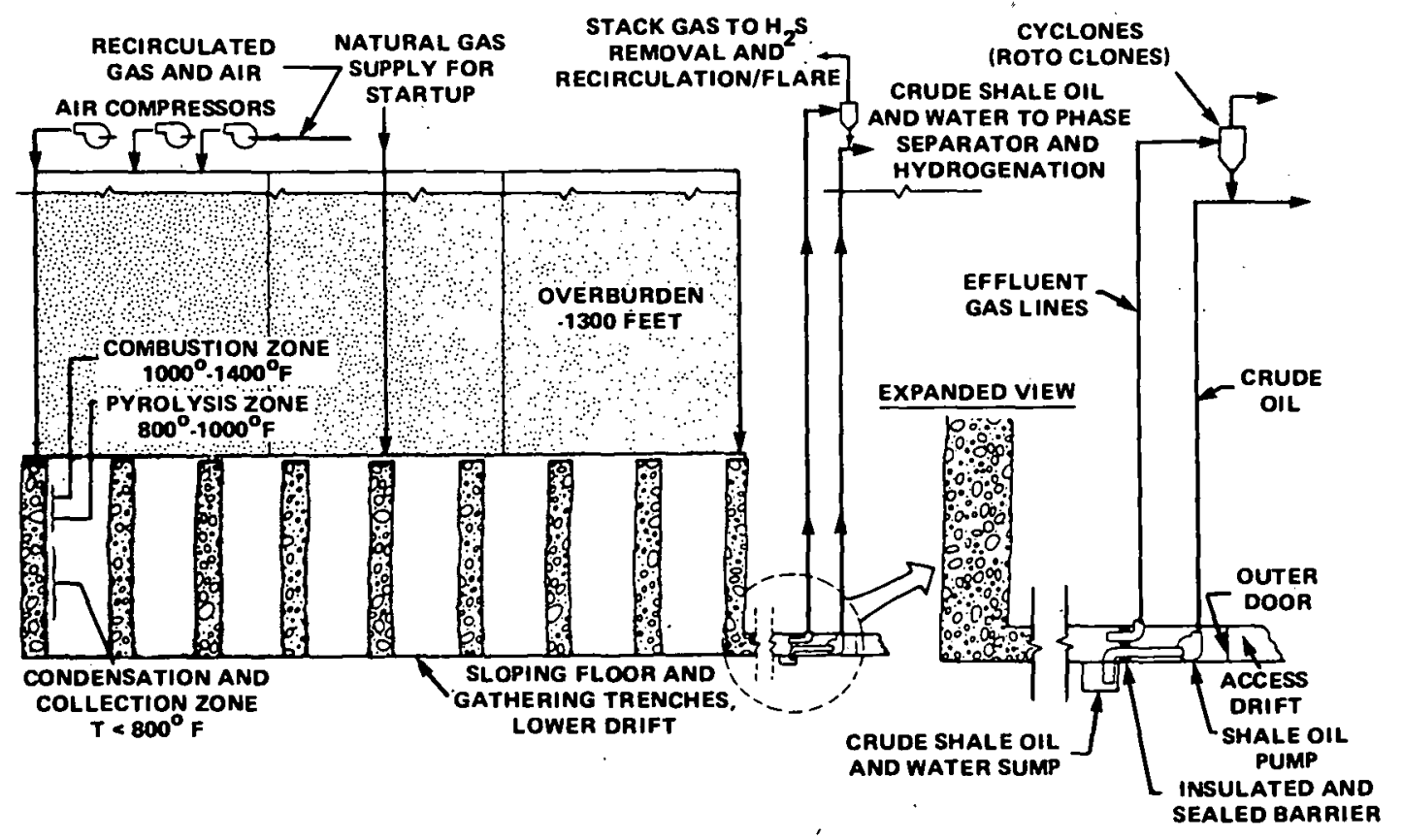

Modified In Situ Shale Oil Production Process

\section{Project Status}

Major areas of research and development of modified in situ retorting include the following parameter investigations:

- Optimum setting of control parameters, such as flow and recycle, to ensure maximum energy. recovery

- Mining and explosive blasting techniques to ensure desired void volume and optimum distribution of rubble permeability to maximize resource recovery

- Optimum underground support, design to minimize surface subsidence

- Range of shale grade that best utilizes the technology

- Retort configuration to maximize resource recovery with minimum pillar dimensions and spacing separating underground retorts

- Control of vertical or horizontal sweep of the retorting gases

- Environmental effects and control technology

- Economic feasibility of the modified horizontal in situ retorting technology in thin-seam oil shale deposits. 


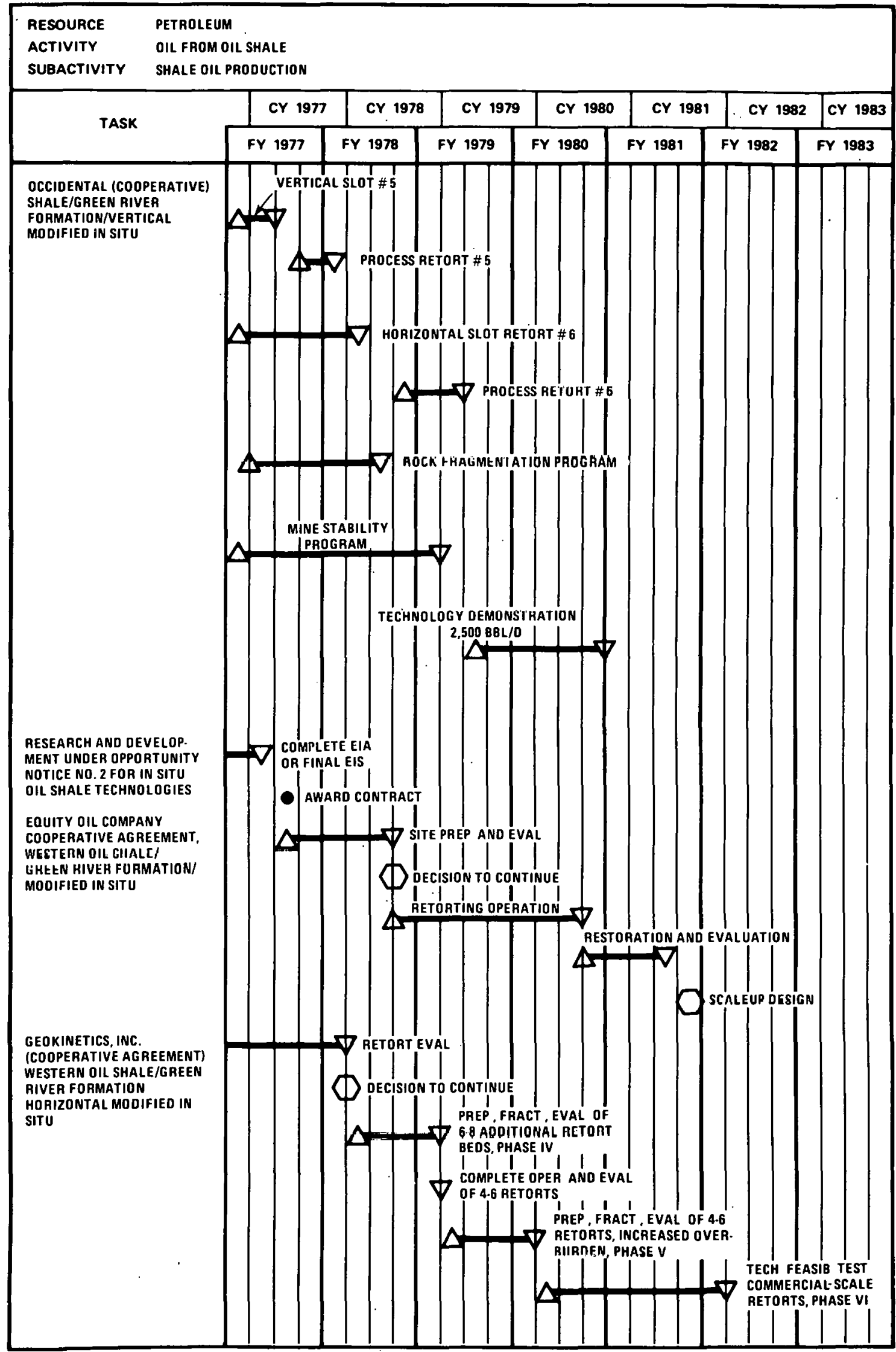

MILESTONE SYMBOLS ARE DEFINED ON LAST PAGE OF THIS DOCUMENT 
- Technology for sensible heat and additional hydrocarbon recovery from spent retort rooms

- Recovery of oil from the pillars

Major problems still to be solved in the modified processes include scaleup to optimum size, some additional fracturing work, and determination of best levels of control variables. Three of the Program Opportunity Notice (PON) No.2* contracts and a contract project in Michigan shale, include research in these areas.

A similar process for underground pyrolysis of oil shale has been the object of research at LLL. Laboratory work to investigate the chemical reactions involved in oil shale retorting as it relates to various-size shale particles, the change in permeability of deep oil shale beds at various temperatures, and how these and other variables contribute to an overall mathematical model of the modified in situ retorting process are currently under development. Results are being incorporated in designs of the Federal lease tract C-a development.

A preliminary research project by LERC on a horizontal configuration retort in western Wyoming will be continued. Environmental base line studies for other possible sites were started in FY 1976 and were completed in FY 1977. Site preparation and additional engineering studies are pending further investigation and other contract results.

\subsection{ENVIRONMENTAL ASPECTS}

There are several environmental concerns relative to oil shale development for both above ground and in situ operations. Major concerns include significant land disturbance, spent shale disposal (including possible surface and ground water contamination), water availability, water usage, and socioeconomic effects. Liquid effluents from oil shale processing such as retort waters and runoff from retorted shale disposal areas will be analyzed. Gaseous and particulate emissions from mining, drilling, surface preparation equipment, fines from shale processing, and off-gas from retorting operations will also be of concern. Underground water contamination from drilling, in situ burns, and underground migration of associated products will be a major environmental attention area. Subsidence from in situ burns also needs to be investigated.

The environmental research being conducted at LERC and at selected universities is designed to address environmental aspects that are peculiar to in situ processing of oil shale. These include disposal of in situ water, migration of fluids during and after in situ processing, surface thermal changes, identification of the materials that can be extracted from in situ processed spent shale, and other environmental research that applies to

*PON was issued in early 1976 regarding a government/industry costshared project for tne development of several in situ technologies. Four contracts were negotiated and awarded hy October 1977. 
site-specific problems of in situ processing. Site-specific environmental research includes geohydrological evaluation, socioeconomic studies, health effects determinations, occupational health studies, ecological effects studies, meteorological and air quality monitoring, compliance monitoring and support research, control system research, and total assessment of the environmental issues associated with the process development.

Environmental activities that address these issues and problems are an integral part of all field work conducted either in-house by DOE or by industry contractors. Preoperational assessments and base line studies are used to analyze the environmental characteristics for in situ and modified in situ oil shale research sites, including DOE's Green River and White Mountain sites. Also, in-house studies of the effects of field operations are being conducted at Rock Springs Sites 9 and 12. Environmental research is a significant aspect of each of the PON contracts. Each contractor has prepared an environmental research plan.

An Environmental Development Plan (EDP) has been formulated for the Oil Shale Activity and was completed in the third quarter of FY 1977. This plan will provide for a comprehensive oil shale environmental strategy and an implementation plan to ensure that all environmental concerns are addressed for the Oil Shale Activity. Environmental Impact Assessments are prepared for all major DOE oil shale field projects. 


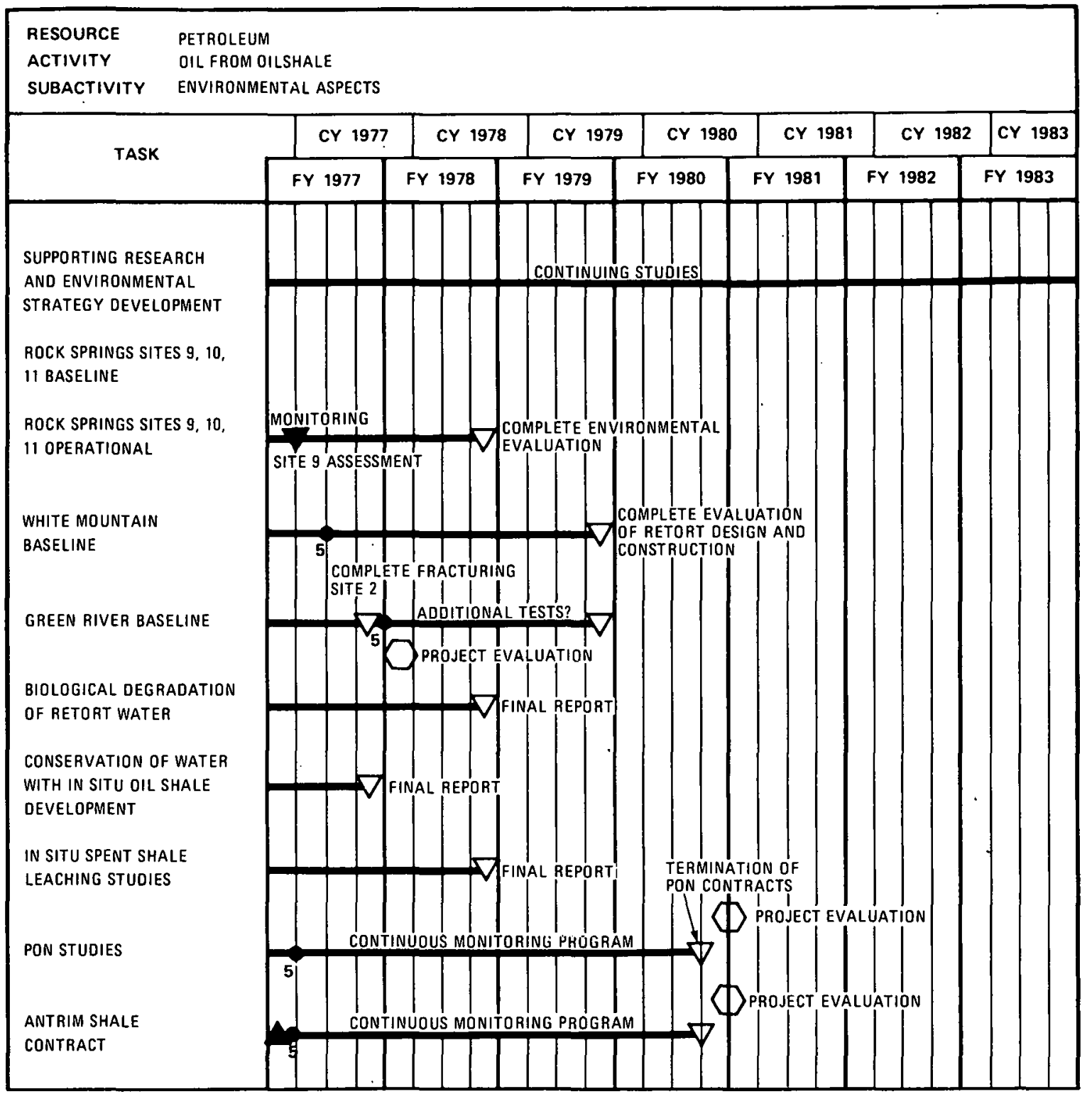

MILESTONE SYMROI.S ARE DEFINED ON LAST PAGE OF THIS DOCUMENT

\subsection{SUPPORTING RESEARCH}

The objectives of studies in this area are as follows:

- To provide reliable information needed to support other parts of the Oil Shale Activity

- To expedite improvements of existing oil shale and shale oil processes 
- To facilitate development of superior new processes

- To develop economic schemes for refining shale oil.

The oil shale supporting research conducted at LERC during FY 1976 and FY 1977 provided broad support for process development. The scope of this work will be similar in FY 1978. It will provide support for all oil shale processing and will not be tied to any specific technology, but rather to oil shale utilization and development problems in general.

In mid-FY 1977 work was begun with Chevron Research Company to investigate bench-scale refining of shale oil and coal liquids using state-ofthe-art technology. As part of the work, Paraho shale oil was refined in laboratory pilot plants using existing petroleum technology. Refinery economics developed from these data indicate that refining shale oil costs $\$ 5$ to $\$ 7 / \mathrm{bbl}$ more than refining conventional crude oil. In FY 1978 research was initiated on advanced shale-oil refining technology with emphasis in reducing the high cost of shale-oil refining.

Laboratory-scale refining studies are being conducted to determine the applicability of modern refining techniques to shale oil. These studies identify required changes in refining process conditions as a function of different retorting processes.

Because of the need to develop a means of converting crude shale oil into specification transportation fuels, the laboratory work in this area will be continued. If results are satisfactory and the oil shale industry becomes an important source of petroleum, then the methods developed in the laboratory will form the basis for commercial processes.

The shale oil characterization research being conducted at LERC is designed to support the development of in situ technology. This is primarily applied research in which the character of the product is related to the retorting parameters. Also, this profect directly supports the production of shale oil by retorting methods other than in situ as well as the production of refined fuels from shale oil.

Research work on the characterization of oil shale is a continuing effort. In the future, LERC will be required to increase the characterization of oil shale cores to provide data for ongoing field projects. This will require that additional wells be drilled. The laboratory investigations will continue to provide for the development of new analytic process technology. A part of the project is to determine the characteristics of oil shales and oil shale deposits to support the energy development efforts. Inder this projccl, a detailed knowledge of the composition and chemical, physical, and thermal properties of oil shale has been accumulated. This is a cumulative process with each year's work adding to the funds of available information. Each year, 20,000 to 25,000 individual oil shale samples are characterized for oil yield and geologic and mineralngic propertics.

Another task is devoted to new oil shale process technologies. It is currently investigating innovative techniques for increasing the solubility of oil shale kerogen and developing the basis for economic and technologic 
assessments of oxidative upgrading of fossil fuels. The research on kerogen solubilization may lead to second-generation technology for aboveground processing that does not require retorting. Oxidative upgrading of shale oil may improve economics by reducing hydrogenation requirements for removing sulfur and nitrogen compounds.

Included under the Supporting Research budget category in FY 1978 is the Anvil Points Observer program. In this task, DOE personnel monitor surface retorting proceedings and tasks at DOE's Anvil Points Facility in Colorado. The activities associated with this project, in which private industry is operating a new above ground retorting process, consist of monitoring and collecting raw data from the project for internal government use and performing mathematical processing and other evaluation of the data for eventual publication. The results, which will be disseminated in accordance with terms of the lease agreement, will be based on independent government analysis of the raw data. Environmental studies are also part of the DOE effort at Anvil Points.

Early in FY 1977, the Navy contracted with the industrial group at Anvil Points to produce a large quantity (60,000 to 100,000 barrels) of shale oil. This quantity of oil was to be used for a refining run designed to produce sufficient quantity of distillate products for specification tests. DOE personnel are continuing to observe this operation. DOE and Navy are planning on a cooperative shale oil refining program pending approval from Congress. It is estimated that oil production will require six months in to 1978 . 


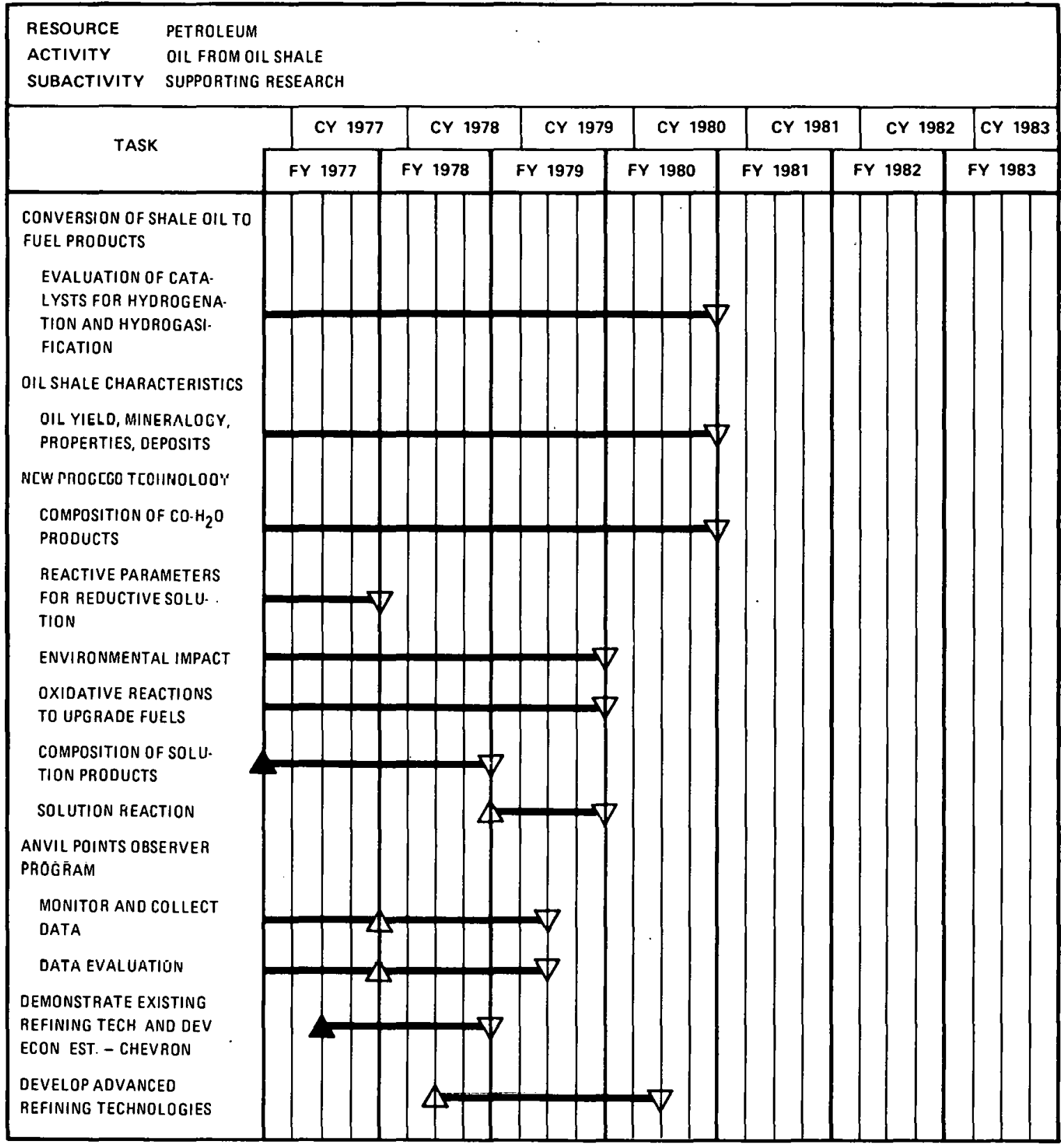

MILESTONE SYMBOLS ARE DEFINED ON LAST PAGE OF THIS DOCUMENT 


\section{DRILLING AND OFFSHORE TECHNOLOGY}

Estimates of potential petroleum and natural gas resources in the 17 U.S. Outer Continental Shelf (OCS) areas' range from 10 to more than, 49 billion barrels of oil, $36 \mathrm{Tcf}$ of proven natural gas reserves, and 42 to 181 Tcf of undiscovered recoverable natural gas resources. DOE drilling and offshore technology activities in the near- and mid-term will be focused on: (1) accelerating and successfully implementing offshore oil and gas technology in OCS areas; (2) mobilizing the nation's technology to supply a sufficient share of the nation's energy needs by 1985; (3) providing viable alternatives and solutions to socioeconomic, environmental, and ecological problems associated with of fshore drilling and production; (4) functioning as a catalyst to resolve societal, jurisdictional, and regulatory conflicts that impede resource development; and (5) cost-share RD\&D programs and projects with Federal agencies, industry, and universities.

This program is heavily impacted by technical, nontechnical, environmental, socioeconomic, and legal constraints which increase as industry moves into deeper water and more hostile frontier areas. The pace at which offshore energy resources are developed is constrained by insufficient data, inadequate technology, lack of long-term investment capital, long lead-time requirements, and wariness of cooperative efforts resulting from the need to protect proprietary interests and maintain a competitive business environment among industry participants.

Studies currently being conducted under drilling and offshore technology include:

- Drilling

- Offshore Technology

- Environment and Support.

The table below summarizes the funding levels by subactivity for the FY 1977 to FY 1979 period.

\begin{tabular}{|c|c|c|c|c|}
\hline $\begin{array}{l}\text { DRILLING AND OFFSHORF } \\
\text { TECHNOLOGY }\end{array}$ & \multicolumn{4}{|c|}{$\begin{array}{l}\text { BUDGET AUTHORITY } \\
\text { (OPERATING EXPENSES) } \\
\text { (OOLLARS IN THOUSANDS) }\end{array}$} \\
\hline SUBACTIVITIES & $\begin{array}{l}\text { ACTUAL } \\
\text { FY } 1977\end{array}$ & $\begin{array}{l}\text { APPROPRIATION } \\
\text { FY } 1978\end{array}$ & $\begin{array}{l}\text { ESTIMATE } \\
\text { FY } 1979\end{array}$ & $\begin{array}{l}\text { INCREASE } \\
\text { (DECREASE) }\end{array}$ \\
\hline $\begin{array}{l}\text { Drilling } \\
\text { Environment \& Advanced } \\
\text { Concepts }\end{array}$ & $\begin{array}{r}\$ 1,800 \\
6 \cap 0\end{array}$ & $\begin{array}{r}\$ 1,000 \\
600\end{array}$ & $\begin{array}{r}\$ 777 \\
823\end{array}$ & $\begin{array}{r}\$-223 \\
+223\end{array}$ \\
\hline TUIAL & $\$ 2,400$ & $\$ 1,600$ & $\$ 1,600$ & $\$ 0$ \\
\hline
\end{tabular}




\subsection{DRILLING}

Projects currently being conducted under this program area include:

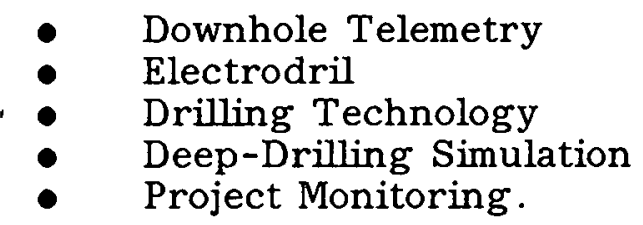

\section{Downhole Telemetry}

The objective of the Downhole Telemetry Project is to accelerate the development and commercial availability of wellbore telemetry. This project addresses the need of the oil and gas industries to develop downhole measuring and telemetering system for parameters (inclination, bil-wear, and weight-nn-hit) whtle drillink is being conduoted. The telemetering of these data contributc to more efficient and economic drulling as well as lu a real-time characterization to the drilling activity as it is being conducted.

This project is being conducted in three distinct phases: Phase I: System Development; Phase II: Systems Manufacture; and Phase III: Field Demonstration. In the system development phase of this project, 25 field tests were successfully completed by the end of 1976. Downhole assemblies were completed and tested, onshore and offshore, during the first quarter of FY 1977. Field tests will continue to be conducted through the last quarter of FY 1978.

The basic design for the downhole telemetry system has been selected and component, subassembly, and assembly drawings have been released for manufacturing. In the manufacturing phase of the project, approximately 50 percent of the machined parts and 75 percent of the standard parts have been ordered. The transmitter housing, sensor housing, and drill collar were orderet anl lested during the second quarler of FY 1977. Field demonstrations of the complete system are scheduled to be conducted in FY 1978.

\section{Electrodril}

The objectives of the Electrodril Project are to (1) verify the reliable, safe, and economical operation of a directional-drilling system consisting of a $60-\mathrm{hp}$ downhole digital instrumentation, conductor system, rig floor, and surface-support equipment; and (2) verify that a conductor system can be successfully integraled witl the dircctional-drilling system under operational condiliuns.

During FY 1977, the deep-drilling system operated successfully with tapered connectors used to drill through an aggregate at Brown Oil Tools. The testing was later discontinued because of connector failure after the first joint of the prewired drill pipc was assembled in the drill string. Initial tests were conducted with a directional-drilling system to determine the system's ability to drill directionally to a predetermined target in a 600-foot hole. This testing was also discontinued as the result of connector failure. Failure data analyses indicated that water seepage was 
the major problem. Testing was later resumed during the end of the first quarter of FY 1977, and all elements of the cable/connector, downhole sensor, and telemetry system operated successfully to 142 feet with some indication of mud leakage.

In addition to the cable/connector problem, motor-system mud/oil seal interface problems have also been identified. This project was scheduled to be completed at the end of the first quarter of FY 1978 but has been extended through the fourth quarter of FY 1978 to conduct further analyses of the failure data and resolve the problems. A no-cost extension of this contract, through April 1978, is anticipated.

\section{Drilling Technology}

The objective of this project is research to enhance the development of drilling technology. Sandia Labs is currently conducting research in the areas of (1) high-performance bit developments, and '(2) high temperature mud-test equipment. In the high-performance bit development area, three activities (stratapax (synthetic diamond) bonding study, bit design, and slim hole coring bit) are currently being conducted. In the stratapax bonding study, the results of two tests of two failed stud assemblies were examined to determine point wear and fatigue. Both assemblies were intentionally caused to fail during very heavy cuts in granite. Multiple fractures were observed in both the diamond and the stud. The failures of both assemblies were similar except that all of the diamond was broken from the stud of one assembly. Bonding experiments were done in the second quarter of FY 1977. A metalization technique for experimental test was transferred to industry in the first quarter of FY 1978.

In the bit design activity, several new studs were made to replace standard-type studs. Four gas-pressure diffusion-bonded stratapax/stud assemblies were evaluated and the data reduction scheduled for completion in February 1977. Hybrid drill bits are to be fabricated, assembled and tested in the third and fourth quarter of FY 1978. In the slim hole coring bit activity, two bits of a new design have been received and are being ground to specification. The grinding was completed in February 1977, and at that time, stratapax will be gas-pressure-diffusion-bonded to bit blanks. In the high temperature mud-test equipment research area, Sandia is considering using a rotating viscometer as an alternative to a telescoping bob viscometer. Tests were conducted during December 1976, and further investigations are scheduled for the remainder of the experiment. Supply and tooling problems were encountered and testing should be completed in the second or third quarter of FY 1978.

\section{Deep-Drilling Simulation}

The objective of this project is to determine the effect of certain drilling variables in a simulated deep-drilling environment. Boone Terra dolomite and Colton sandstone rocks will be utilized in the tests. As of the end of the first quarter of FY 1977, a drilling laboratory was being prepared for high pressure drilling work at 15,000 psi, and three bit types were selected. However, it appears that 6,500 psi may be the highest pressure obtainable. Drilling specimens of Mancos shale were also planned 
to be used, but no specimens were obtainable. A limestone may be substituted. Sample preparation has begun, a high-pressure swivel has been constructed, a high-pressure cuttings-separation vessel has been designed, and materials have been ordered for future testing. The final report was submitted in the last quarter of FY 1977.

\section{Project Monitoring}

Presently, the Bartlesville Energy Research Center (BERC) is monitoring projects which are sponsored in full or cost-shared by DOE. These projects encompass the following research areas: downhole electric drilling motor, and mud-pulse telemetry .

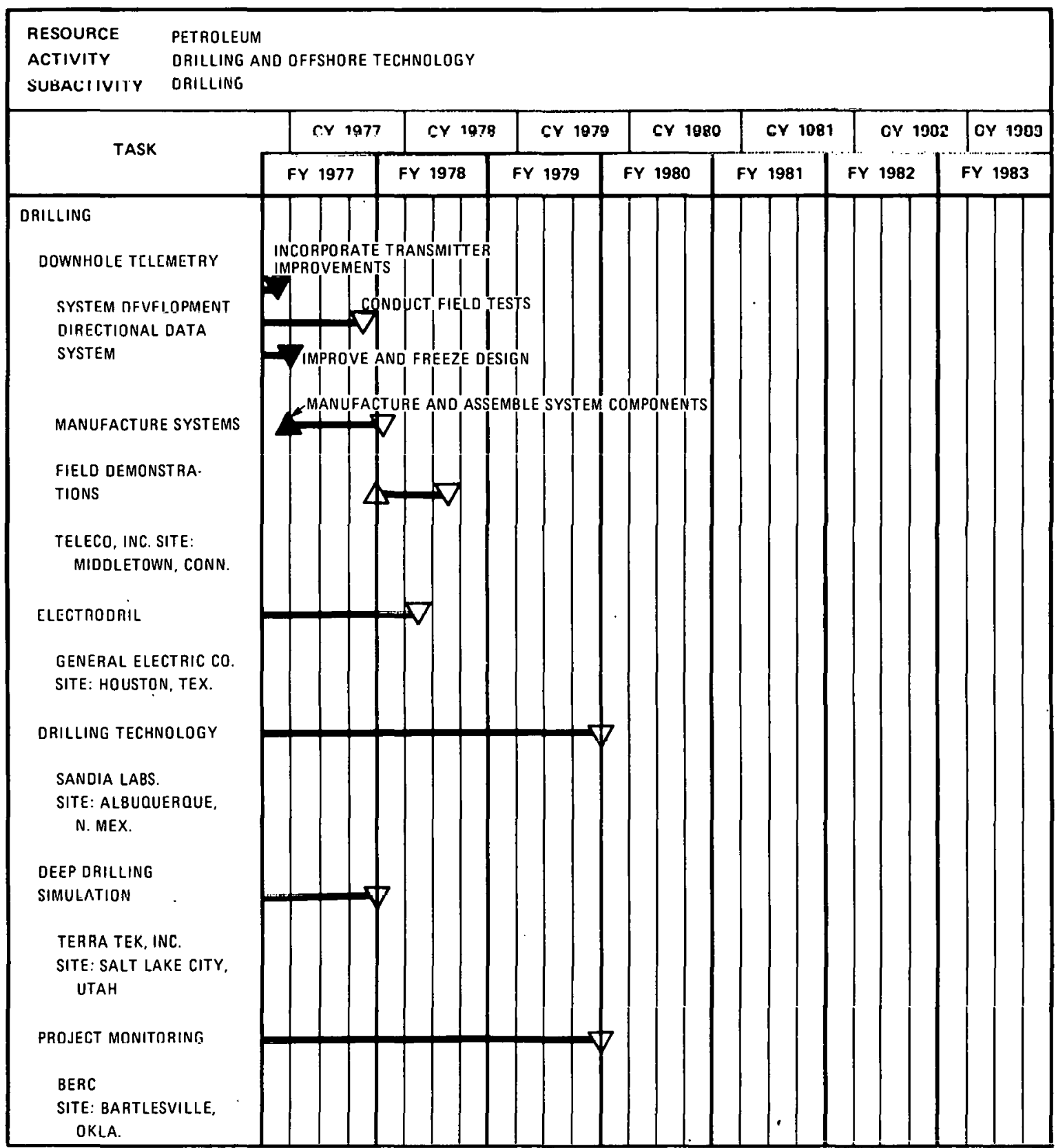

MILESTONE SYMBOLS ARE DEFINED ON LAST PAGE OF THIS DOCUMENT

'SUPPORT PROJECTS AT ERCS ARE SUBJECT TO INCREMENTAL ANNUAL AUTHORIZATION BY DOE (FE), THEREFORE THIS WORK MAY BE EXTENDED BEYOND FY 1979. 


\subsection{OFFSHORE TECHNOLOGY}

Projects currently being conducted under this program area include:

- Sea Floor Instrumentation

- Data Acquisition and Dissemination

- Program Support.

\section{Sea Floor Instrumentation}

The objective of this program is to develop and demonstrate an acoustic data system for undersea measurements of geophysical phenomena. This instrumentation system must be capable of measuring strong motions of the sea-bottom sediments caused by earthquakes to provide inputs to the structural design of offshore platforms. The project was designed to incorporate previous experience with marine sediment penetrators (MSP), seismic instruments implanted in the ocean bottom with a high data-rate telemetry link. The initial project conducted in FY 1976 consisted of assembling and testing the equipment to demonstrate whether the concept was feasible. The results of the initial demonstration were used to identify differences and problems requiring redesign or advanced development. Another result identified the necd for increased flexibility in test parameters. Following an evaluation of the results of the initial testing, additional acoustical equipment was ordered and installed in preparation for the next phase of testing. The equipment and test procedure will allow maximum flexibility in varying the test conditions and signals propagated, direct monitoring of the transmitted wave, and direct comparison of the received signal to the transmitted signal. Such control is expected to optimize the acoustic-link parameters and result in an acoustic-link design to be incorporated in the instrumentation-system prototype scheduled for Gulf of Mexico ocean testing at the end of FY 1977 and the Gulf of Alaska in 1978 .

\section{Data Acquisition, Analysis, and Dissemination}

The objectives of this project are to (1) identify users and their needs for information relevant to offshore oil- and gas-resource development (exploration, development, production, transportation, and onshore impacts); (2) identify data, data sources, and acquisition methods; and (3) assess the completeness of data for satisfying requirements and developing a plan for DOE involvement in assisting users in acquiring timely data in a useful format.

\section{Program Support}

The objective of this activity is to provide management support to the Drilling and Offshore Technology Activity on a continuous basis.

\subsection{ENVIRONMENTAL AND SUPPORTING RESEARCH}

The only project currently active in this area is Analytical Model Development. 


\section{Analytical-Model Development}

The objective of this project is to develop a detailed analytical model which represents the process of offshore oil and gas development from the initial geologic survey to transporting oil ashore. This proposed model will be utilized to identify high priority areas where DOE can institute RD\&D and/or problem solving activities to accelerate development of oil and gas in the OCS. The model will also be used as a tool to identify and assess long-range strategies and the impact of these strategies on the national energy plan.

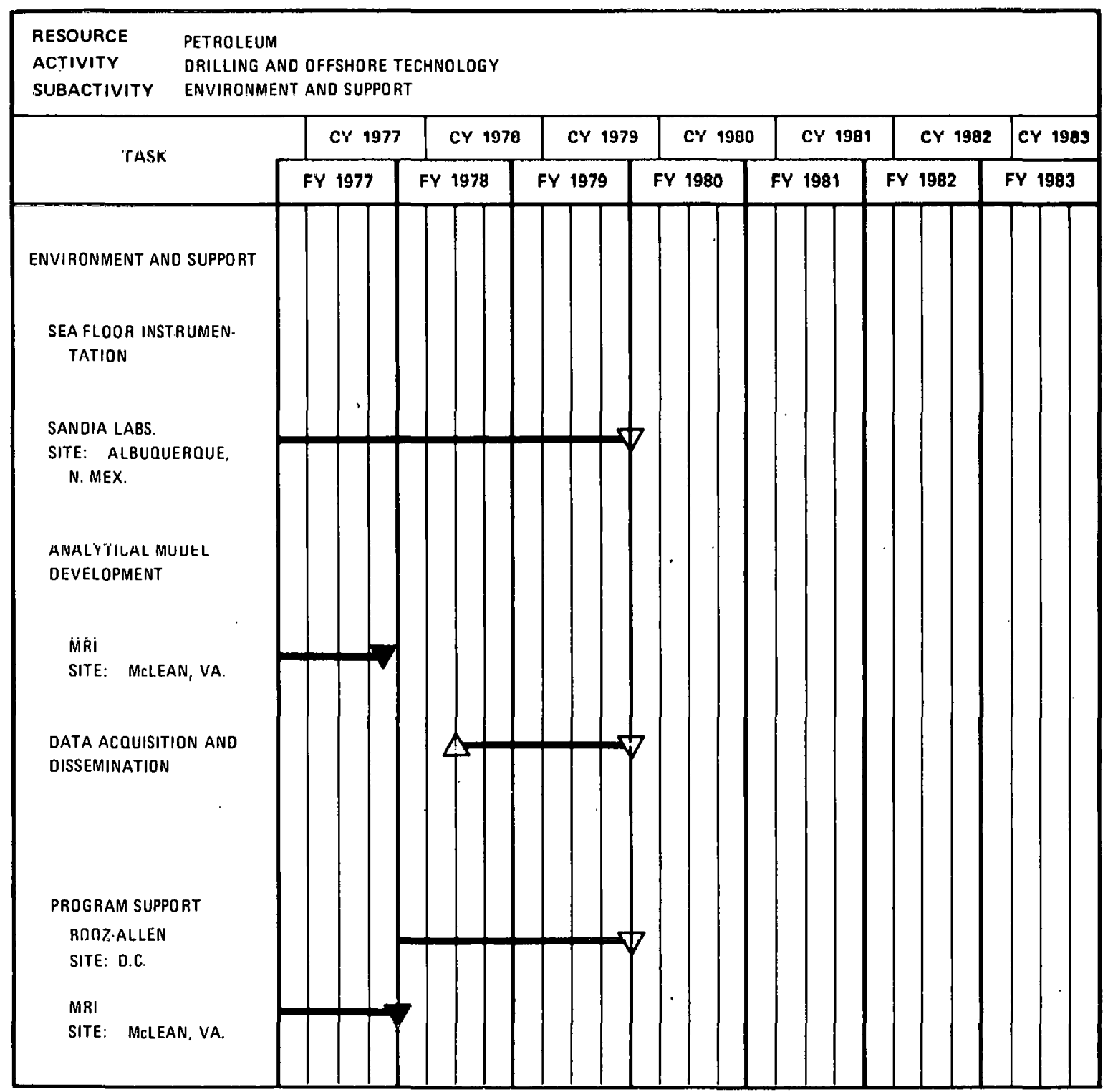

MILESTONE SYMBOLS ARE DEFINED ON LAST PAGE OF THIS DOCUMENT 


\section{E. PRODUCT CHARACTERIZATION AND UTILIZATION}

Product characterization and utilization is aimed at developing more efficient end-uses of oil, gas, and synthetic fuels. Characterization projects involve identifying, compiling, and monitoring the properties and qualities of natural petroleum reserves and imported crude oil; developing methods for identifying oil spill sources; and carrying out broad physicalchemistry studies on heavy petroleum fractions. Utilization projects involve the use of alcohol fuels in automotive engines and improvements in asphalt uses.

The effort in this category is not extensive since the impact on basic energy supplies will be small. All of the current work is being done by the Bartlesville and Laramie Energy Research Centers, although grants to universities and contracts to profit and nonprofit research organizations may be used.

The table below summarizes the funding levels for this Activity for the FY 1977 to FY 1979 period. .

\begin{tabular}{|c|c|c|c|c|}
\hline & \multicolumn{4}{|c|}{$\begin{array}{c}\text { BUDGET AUTHORITY } \\
\text { OPERATING EXENSES) } \\
\text { (DOLLARS IN THOUSANOS) }\end{array}$} \\
\hline & $\begin{array}{c}\text { ACTUAL } \\
\text { FY 1977 }\end{array}$ & $\begin{array}{c}\text { APPROPRIATION } \\
\text { FY 1978 }\end{array}$ & $\begin{array}{c}\text { ESTIMATE } \\
\text { FY 1979 }\end{array}$ & $\begin{array}{c}\text { INCREASE } \\
\text { (DECREASE) }\end{array}$ \\
\hline $\begin{array}{c}\text { Product Characterization } \\
\text { and Utilization }\end{array}$ & $\$ 1,831$ & $\$ 1,400$ & $\$ 1,200$ & $\$-200$ \\
\hline
\end{tabular}

\subsection{CHARACTERIZATION}

Product characterization is a broad area that is concerned with identifying physical and chemical properties of crude oil or refined products. Specific objectives will be discussed with each project.

The oil-identification project identifies and monitors the qualities of domestic petroleum reserves, imported crude oil, and refined petroleum fuels marketed in the United States. Along with this work, tests and 
improved analytical techniques for oil identification are being developed to aid in identifying the source of oil spills.

The objective of the characterization of the heavy-ends and alternate fuels project is to develop and/or apply analytical methods of characterizing the heavy ends of crude oil. This will provide the basis for developing processes to upgrade this low quality petroleum fraction as well as petroleum deposits having properties similar to this fraction; i.e., heavy-oil deposits. Heavy-oil deposits comprise a significant hydrocarbon resource in western United States. Chemical and physical data on heavy ends are essential for development of successful refining process schemes for these materials. Analytical procedures will also be developed for petroleum heavy ends since existing characterization methods cannot be applied to these fractions. Advanced analytical techniques for characterizing all boiling ranges of these materials are being developed and evaluated to provide better capability for dotermining their cumpusilion with respert to usefulncss, performance, refining, and environmental protection.

The project on characterization of heavy liquids adapts and extends the separation/characterization method that was developed for heavy distillable oils to make the method applicable to petroleum residues, bitumens, and syncrudes. The project also develops characterization methods for acids, bases, neutral nitrogen, and polynuclear aromatic compounds and obtains compositional data on these compound types to develop information on the compound-type relationships among the above fossil-energy sources. These techniques will be applied to studying the nature of the asphaltene component of these materials, generally the most difficult component to process. This information will be applied to solving the problems of efficient utilization of the materials as energy sources.

The objective of the refining process technology project is to determine the refining characteristies of synthctic crude oil, the type and quality of finished projects potentially obtainable from alternate raw material sources, and the changes required in refining processes to yield finished fuels. A bench-scale hydrotreating unit will be constructed to develop data on hydrorefining synthetic liquids. Attempts will be made to correlate product quality with coal composition. The physical and chemical properties of the syncrudes and in-process stocks will differ from those of typical petroleum stocks, and correlation of these properties with refinability will be necessary to achieve the most economically feasible commercial production of refined products. 


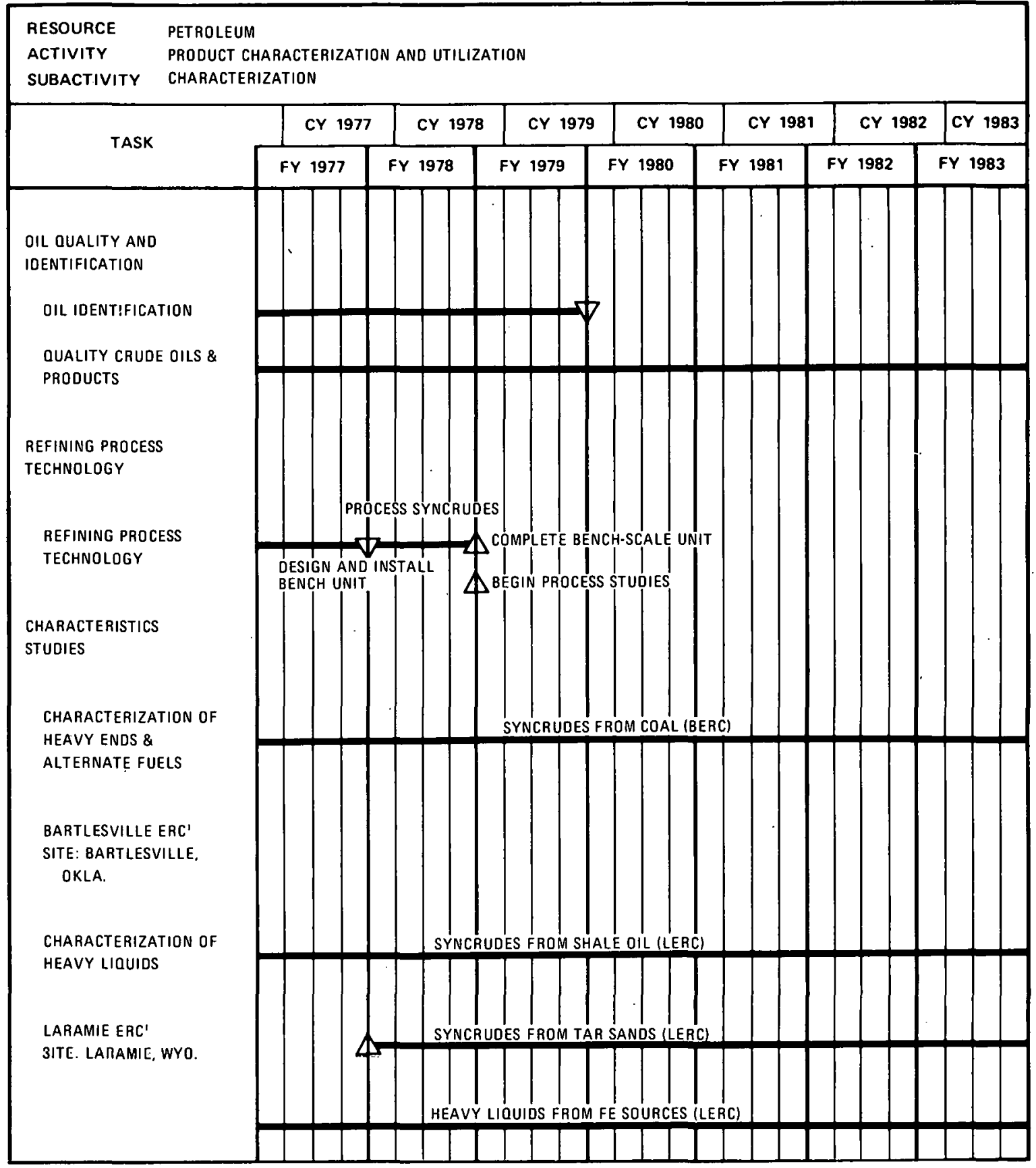

MILESTONE SYMBOLS ARE DEFINED ON LAST PAGE OF THIS DOCUMENT

' PROJECTS ABOVE AT BERC \& LERC ARE SUBJECT TO INCREMENTAL ANNUAL AIJTHORIZATION BY DOE (FE)

\subsection{UTILIZATION}

The objective of the research in the utilization area is to determine the potential and problems of alcohols fuels, specifically methanol, and to increase the road life of asphalt.

The project or utilization of alternate fuels involves the study of methanol as a fuel for internal-combustion engines. Methanol is an 
attractive high-octane automotive fuel which can be made from coal or biomass. The use of methanol, however, has certain operational problems because of differences from conventional gasoline fuels. A different airfuel ratio is required, and methanol is much less volatile than gasoline as well as being corrosive to certain fuel supply parts. This program is aimed at defining the problems of methanol use and developing solutions for them. Optimum carburetion systems are under evaluation as well as the use of high-compression-ratio engines and advanced engine systems (e.g., Stirling engine) to take advantage of methanol's unique properties.

The objective of the asphalt studies is laboratory and field testing of asphalts having chemical properties different from each other and from conventional asphalts to develop longer life for asphalt roads. An unusual opportunity to study the effect of asphalt composition on road performance will be provided. Correlations between chemical properties and field performance for a wide variety of asphalts will provide for scientificallybased specifications rather than empirically-baced oncs. More impurtantly. this technology will yleld new asphalt compositions having much longer road life than conventional materials presently used.

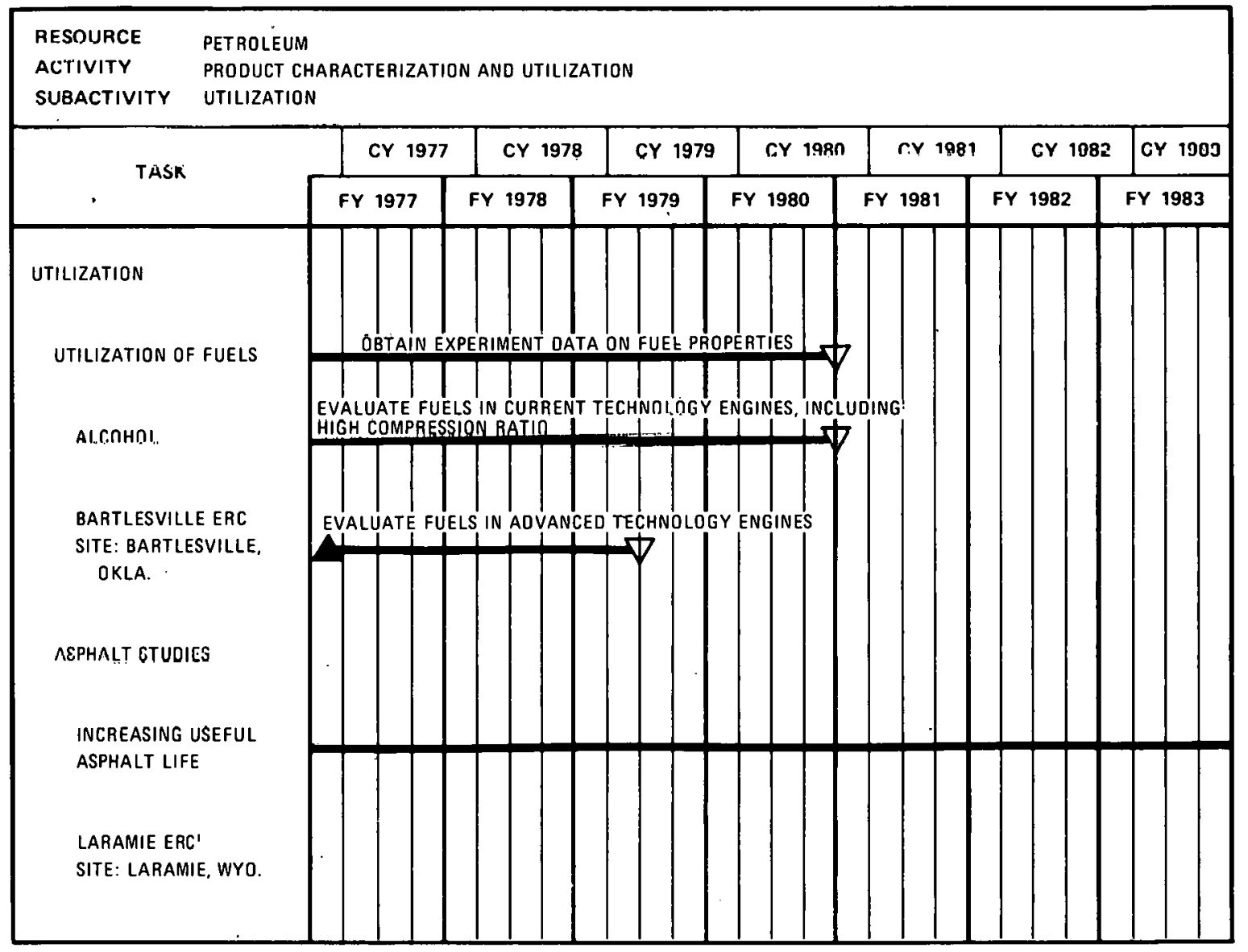

MILESTONE SYMBOLS ARE DEFINED ON LAST PAGE OF THIS DOCUMENT

'PRUJECTIS ABOVE AT ERCS ARE SUBJECT TO INCREMENTAL ANNUAL AUTHORIZATION BY FED. 


\section{F. SUMMARY OF CAPITAL ACQUISITION}

The data below summarize plant and capital equipment funding for the Petroleum Resource.

\subsection{PLANT CONSTRUCTION}

No construction projects are planned through FY 1979.

\subsection{CAPITAL EQUIPMENT}

Petroleum Resource Program support at the various ERCs and field laboratories of ten requires the purchase of capitalized equipment for general laboratory or facility use. The table below summarizes the funding levels for these purchases in the period FY 1977 through FY 1979.

\begin{tabular}{|c|r|r|r|}
\hline \multicolumn{1}{|c|}{$\begin{array}{c}\text { PETROLEUM RESOURCE } \\
\text { CAPITAL EQUIPMENT }\end{array}$} & \multicolumn{3}{|c|}{$\begin{array}{c}\text { BUDGET AUTHORITY } \\
\text { (OPERATING EXPENSES) } \\
\text { (DOLLARS IN THOUSANDS) }\end{array}$} \\
\hline \multicolumn{1}{|c|}{ ACTIVITY } & $\begin{array}{c}\text { ACTUAL } \\
\text { FY 1977 }\end{array}$ & $\begin{array}{c}\text { APPROPRIATION } \\
\text { FY 1978 }\end{array}$ & $\begin{array}{c}\text { ESTIMATE } \\
\text { FY 1979 }\end{array}$ \\
\hline $\begin{array}{l}\text { Enhanced Oil Recovery } \\
\text { Oil from Oil Shale } \\
\text { Other }\end{array}$ & $\begin{array}{r}\$ 100 \\
500\end{array}$ & $\$ 300$ & $\$ 700$ \\
& 0 & 853 & 875 \\
\hline TOTAL & $\$ 600$ & $\$ 1153$ & $\$ 1575$ \\
\hline
\end{tabular}




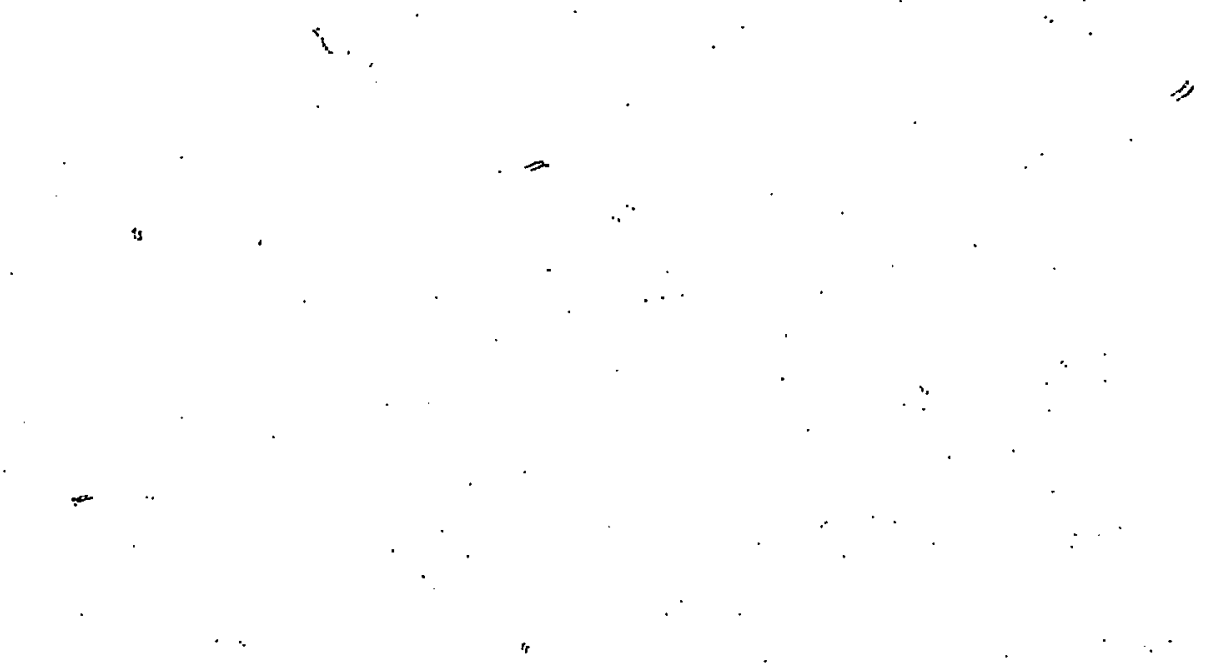

THIS PAGE

WAS INTENTIONALLY

LEFT BLANK 


\section{GAS RESOURCE}

\section{A. GAS RESOURCE OVERVIEW}

Current proved natural gas reserves (216 Tcf) amount to about an $11-$ year supply at the current consumption rate. These proved reserves are found in conventional reserviors (high permeability sandstone and carbonate reservoirs) and can be easily produced and still provide a reasonable profit incentive for the gas producing companies.

Two other. sources of natural gas are available to decrease the difference between supply and demand. Imports are one source; however, this source can be unreliable as was so dramatically demonstrated by the oil embargo in the winter of 1973-1974 and the three-fold increase of import gas prices by Canada. Gas from unconventional geologic sources is the only other domestic source to augment supply. Neither of these sources will completely fill the supply gas. Vulnerability to the adverse effects associated with importing a large percent of our energy supply will be lessened by the development of technology to produce gas from these domestic sources.

A report from the National Research Council, Board of Mineral Resources Commission on the Natural Resources forum held in early 1976, cites four unconventional geologic sources of natural gas. exploited:

These four large unconventional gas resources are not being fully

1. The gas-bearing shalcs of the eastern United States

2. The low permeability (tight) sandstone gas reservoirs of the Rocky Mountain region

3. The free methane present in coal seams

4. The high-pressure, methane-saturated aquifers of the Gulf Coast Region (geopressured aquifers).

Eastern oil shales of Devonian and Mississippian age represent a large potential energy resource although their extent is presently poorly defined. These shales are potentially major producers of synthetic gas and oil although they are considered to be of lower grade than western shales from an oil production standpoint. They are geologically similar to western oil shales, and it is believed that similar technology can be used in exploiting these shales by in situ methods. 
The Department of Energy has initiated a multiyear project directed toward the stimulation of natural gas production in the three major western U.S. petroliferous basins. The objective of the project is to stimulate increased commercial production of natural gas by providing reliable resource data, developing economic extraction alternatives, and demonstrating the commercial feasibility of promising production techniques. The project should provide a significant contribution to the domestic energy base, supply a clean fuel for eastern industrial use, and help alleviate anticipated near-term and long-term shortages of natural gas.

The DOE Eastern Gas Shales project is oriented specifically toward determining the true magnitude of potential gas reserves in the shale, thoroughly characterizing the shalc, and evaluating and improving state-of-the-art gas exploration and extraction technology. Results will be continually evaluated to determine arcas in which new or additional st.udies may be needed and the desiraluillty of planning and conducting a more extensive research, development, and demonstration program. The project will concurrently monitor and protect the environment from possible damage resulting from natural gas development activities.

Emphasis is also being placed on the large resource of natural gas which is not being adequately exploited, i.e., the low-permeability (tight) sandstone gas reservoirs of the Rocky Mountain region (Western Gas Sands project). The domestic industry has made no real effort to develop this resource due to technological problems and attendant uneconomic returns on their investment. Estimates of the gas resource range from 600 to 1200 trillion cubic feet. This resource represents a potential 30 to 60 year supply of natural gas at the current national consumption rate of 20 Tfe/year.

These reserves figures, however, are gross estimates based upon very limited geological and engineering data. The true magnitude of the recoverable reserves and a comprehensive assessment of the physical and chemical properties governing reservior behavior have not been determined. Preliminary data, developed by cost-shared (DOE-industry) field tests of various stimulation and production techniques applied to these tight sandstone reserviors, are encouraging.

A new initiative program (methane from coal and goopressured aquifers) began in FY 1978. Preliminary program planning and contractual studies have been initiated to refine data on the resource bascs and establish beller economic assessments. Close coordination will be maintained with nther projects in DOE and the Department of the Interior.

The Gas Resource Program contains two major Activities, Enhanced Gas Recovery and Gas from Oil Shale. 
The following table summarizes the funding levels by Activity for the FY 1977 to FY 1979 period.

\begin{tabular}{|c|c|c|c|c|}
\hline GAS & \multicolumn{4}{|c|}{$\begin{array}{l}\text { BUDGET AUTHORITY } \\
\text { (OPERATING EXPENSES) } \\
\text { (DOLLARS IN THOUSANDS) }\end{array}$} \\
\hline ACtIVITIES & $\begin{array}{l}\text { ACTUAL } \\
\text { FY } 1977\end{array}$ & $\begin{array}{c}\text { APPROPRIATION } \\
\text { FY } 1978\end{array}$ & $\begin{array}{c}\text { ESTIMATE } \\
\text { FY } 1979\end{array}$ & $\begin{array}{l}\text { INCREASE } \\
\text { (DECREASE) }\end{array}$ \\
\hline $\begin{array}{l}\text { Enhanced Gas Recovery } \\
\text { Gas from Oil Shale }\end{array}$ & $\begin{array}{r}\$ 14,874 \\
3,600\end{array}$ & $\begin{array}{r}\$ 26,785 \\
3,850\end{array}$ & $\begin{array}{r}\$ 21,300 \\
4,350\end{array}$ & $\begin{array}{r}\$ .5 .485 \\
+500\end{array}$ \\
\hline TOTAL & $\$ 18,474$ & $\$ 30,635$ & $\$ 25,650$ & $\$-4,985$ \\
\hline
\end{tabular}




\section{B. ENHANCED GAS RECOVERY}

Natural gas currently supplies approximately 30 percent of the total domestic energy use. Current proved natural gas reserves (216 Tcf) amount to approximately an 11 -year supply at the current consumption rate of $20 \mathrm{Tcf} / \mathrm{year}$. The bulk of these proved reserves are found in conventional reservoirs (high-permeability sandstone and carbonate reservoirs), which are generally located in the Gulf Coast and southwest regions of the United States. These reserves have been developed because they can be easily produced, have high recovery efficiencies (up to 80 percent of the original gas-in-place can be produced), and provide acceptable profit incentives to the gas-producing companies.

There are four large unconventinnal gas rcoources tlial are not being fully exploited. These relate to the FY 1979 Subactivity Budget Structure within the Enhanced Gas Recovery (EGR) Activity and draw upon a variety of recovery technologies such as Advanced Hydraulic Fracturing, Chemical Explosive Fracturing, Deviated Wells and Earth Fracture Systems, all of which are discussed in a later section.

- The gas-bearing Devonian shales of the eastern United States (Eastern Gas Shale)

- The low-permeability (tight) gas sandstones of the Rocky Mountain region (Western Gas Sands)

- The free methane (natural gas) present within coal seams (Methane from Coal)

- The high-pressure, methane-saturated saltwater aquifers of the Gulf Coast règion (Cicopressured Aquifers).

The second Market Oriented Program Planning Study (MOPPS) arrived at the following estimates of potentially recoverable gas; eastern Devonian shales 10 to $520 \mathrm{Tcf}$, western tight gas sands 50 to $320 \mathrm{Tcf}$, Methane from coal beds 16 to 500 Tcf, and Geopressured Aquifers 150 to 2000 Tcf.

Specific near-term objectives of the EGR Artivity are;

- Improvement of techniques necessary for prompt, orderly dcvelopment of the nation's gas resources

- $\quad$ Addition of $10 \mathrm{Tcf}$ of producible reserves by 1985

- Increase of gas production by an incremental 3 Bcf/d by 1985 .

Specific Project Plan Ducuments (PPIs) have been prepared for each of the major projects, the Eastern Gas Shales Project and the Western Gas Sands Project. These PPDs establish project goals, guidelines, deliverables, and general project activities for the current fiscal year. 
The PPD for the Eastern Gas Shales Project was published in October 1976. The PPD for the Western Gas Sands Project was published in August 1977. PPDs are updated annually.

A comprehensive EGR Activity Strategy Document, which will coordinate planning and implementation of all DOE activities and projects in EGR, will be completed this year. The basic concepts and format for this strategy document will be similar to the Management Plan for Enhanced Oil Recovery (December 1976).

The table below summarizes the funding levels by subactivity for the FY 1977 to FY 1979 period.

\begin{tabular}{|c|c|c|c|c|c|}
\hline \multirow{2}{*}{$\begin{array}{l}\text { ENHANCED GAS RECOVERY } \\
\text { SUBACTIVITIES }\end{array}$} & \multicolumn{4}{|c|}{$\begin{array}{c}\text { BUDGET AUTHORITY } \\
\text { (OPERATING EXPENSES) } \\
\text { (DOLLARS IN THOUSANDS) }\end{array}$} & \multirow{2}{*}{$\begin{array}{l}\text { MAJOR } \\
\text { CHANGE }\end{array}$} \\
\hline & $\begin{array}{l}\text { ACTUAL } \\
\text { FY } 1977\end{array}$ & $\begin{array}{c}\text { APPROPRIATION } \\
\text { FY } 1978\end{array}$ & $\begin{array}{l}\text { ESTIMATE } \\
\text { FY } 1979\end{array}$ & $\begin{array}{l}\text { INCREASE } \\
\text { (DECREASE) }\end{array}$ & \\
\hline $\begin{array}{l}\text { Eastern Gas Shale } \\
\text { Western Gas Sands } \\
\text { Methane from Coal } \\
\text { Geopressured Aquifers } \\
\text { Environment and Support }\end{array}$ & $\begin{array}{r}\$ 9,500 \\
4,474 \\
0 \\
0 \\
900\end{array}$ & $\begin{array}{r}\$ 14,000 \\
4,300 \\
2,000 \\
1,500 \\
4,985\end{array}$ & $\begin{array}{r}\$ 12,000 \\
5,500 \\
0 \\
0 \\
3,800\end{array}$ & $\begin{array}{r}\$-2,000 \\
+1,200 \\
-2,000 \\
-1,500 \\
-1,185\end{array}$ & \multirow[t]{2}{*}{$\begin{array}{l}\mathrm{C} \\
\mathrm{C}\end{array}$} \\
\hline TOTAL & $\$ 14,874$ & $\$ 26,785$ & $\$ 21,300$ & $\$-5,485$ & \\
\hline \multicolumn{3}{|c|}{$\begin{array}{l}\text { "KEY } \\
N=\text { New start (totally new project) } \\
S=\text { Scaleup (from bench to POU or pilot plant) } \\
A=\text { Acceleration (shortening deadlines or } \\
\text { expansion of ongoing projects) }\end{array}$} & \multicolumn{3}{|c|}{$\begin{array}{l}P=\text { Phase completion or startup } \\
R=\text { Program redirection } \\
I=\text { Incremental cost requirement } \\
C=\text { Pruject completion or suspension }\end{array}$} \\
\hline
\end{tabular}

\section{Project Descriptions}

\subsection{EASTERN GAS SHALES PROJECT}

The DOE has initiated a multiyear project directed toward the stimulation of natural gas production in the three major eastern U.S. petroliferous basins. The objective of the project is to stimulate increased commercial production of natural gas by providing reliable resource data, developing economic extraction alternatives, and demonstrating the commercial feasibility of promising production techniques. The project should provide a significant contribution to the domestic energy base, supply a clean fuel for eastern industrial use, and help to alleviate anticipated near-term and long-term shortages of natural gas.

The DOE Eastern Gas Shales Project will be oriented specifically toward determining the true magnitude of potential gas reserves in the shale, thoroughly characterizing the shale, and evaluating and improving 
state-of-the-art gas exploration and extraction technology. Results will be continually evaluated to determine areas in which new or additional studies may be needed and the desirability of planning and conducting a more extensive research, development, and demonstrațion (RD\&D) program. The project will concurrently monitor and protect the environment from possible damage resulting from natural-gas development activities.

The resource evaluation portion of the project includes surface and subsurface mapping, structural studies, geochemical studies, clay mineralogy studies, borehole-gravity surveys, and data acquisition and processing for an appraisal of potential gas reservoirs in eastern shales. Many of the needed data and analyses will be obtained by universities and state geological surveys in the study area. Laboratory work will consist of chemical, physical, elemental, and mineralogical studies; fractureorientation determination from cores; statistical analyses of fracturing data; and cost-effectiveness studies of fracturine techniques. Technology Uevelupment and demonstration will be accumplished by field projerts propoeed and cost-sliared by private industry. Some projects will be initiated by issuing requests for proposals for testing techniques such as massive hydraulic fracturing, chemical-explosive fracturing, foam hydraulic fracturing, gas hydraulic fracturing, and drilling of directionally-deviated wells.

Shales in the eastern and southwestern United States are a vast, essentially unexploited source of gas. These shales are estimated to contain up to 1,300 cubic feet/ton of gas and the wells that are productive yield gas at relatively constant rates for extended periods of time. However, the amount of gas contained in the shales and the characteristics of the shales in areas which have not been adequately tested remains a question. Reserve estimates need to be firmly established and a concerted effort should be directed toward developing technology to stimulate production of larger amounts of this gas.

Columbia Gas Transmission Corporation, from laboratory studies and production histories, estimates the natural-gas resource for the Devonian shales in Appalachia contains 460 quadrillion cubic feet of gas $(4.6 \times 105$ Quads of energy) ${ }^{2}$, of which an estimated $285 \mathrm{Tcf}$ (285 Quads of energy) could be extracted using present technology if the economics were more favorable.

The U.S. Geological Survey (USGS), operating under an interagency agreement with DOE, is providing technical expertise in the areas of stratigraphic, structural, geochemical, and remote-sensing analyses for lhe Eastern Gas Shales Project. The USGS will also serve as the technical rnordinatio for the numeruus support contractors engaged in resource characterization work connected with the Eastern Gas Shales Project.

Very limited reliable quantitative data are available on the size and production characteristics of the Devonian shale. Mnst of the geological expertise resides in the state geological surveys and universities located in the Appalachian region and midwestern states. These institutions actively engage in research and basic data collection relative to petroleum and 
mineral production within their regions. Moreover, these institutions have large existing data files and technical libraries from which information can be drawn.

The Eastern Gas Shales Project involves specialized studies of the physical and chemical properties and distribution of the Devonian shales. Most of the work will be performed by universities and state geological surveys located within the study area. Certain highly specialized analytical $\mathrm{lab}$ and field techniques have been contracted with the national and nonprofit research laboratories. Contracts are currently under way with 16 institutions.

Alfred University (Alfred, New York)
Battelle Labs (Columbus, Ohio)
University of Cincinnati (Cincinnati, Ohio)
Juniata College (Huntingdon, Pennsylvania)
Indiana Geological Survey (Bloomington, Indiana)
Illinois Geological Survey (Urbana, Illinois)
Kentucky Research Group (Lexington, Kentucky)
Los Alamos Scientific Laboratory (Los Alamos, New Mexico)
Mound Laboratory (Miamisburg, Ohio)
University of North Carolina (Chapel Hill, North Carolina)
New York Geological Survey (Albany, New York)
Ohio Geological Survey (Columbus, Ohio)
Pennsylvania Geological Survey (Pittsburgh, Pennsylvania)
Tennessee Geological Survey (Nashville, Tennessee)
West Virginia University (Morgantown, West Virginia)
West Virginia Geological Survey (Morgantown, West Virginia)

In DOE, the Eastern Gas Shales Project is being expanded in FY 1978 toward determining the true magnitude of potential gas reserves in the shale, thoroughly characterizing the shale, and evaluating and improving state-of-the-art gas exploration and extraction technology. Results will be continually evaluated to determine areas in which new or additional studies may be needed and the desirability of planning and conducting a more extensive RD\&D program. The project will concurrently monitor and protect the environment from possible damage resulting from natural-gasdevelopment activities.

Preliminary projects suggest that as much as 0.7 Quad of gas could be obtained from Devonian (eastern) shales (and associated sandstones) by 1985. The Devonian shales can be reached with relatively low-cost shallow wells and are close to large markets. Development of this resource depends upon success in applying and extending the technology for fracturing these formations to increase rates of gas flow.

This effort will provide a sound technical demonstration of state-ofthe-art stimulation, production, and utilization techniques. The proximity of these eastern shales to industrial areas that are subject to curtailment from existing supplies, and the fast response time from drilling to production (weeks vs. years), makes it important that these resources be developed in the shortest time possible. 
Local utilization schemes such as portable liquefied natural gas (LNG) conversion units or direct pipelines to schools and industry would be evaluated. Local consumption could allow more efficient gas production at lower wellhead pressures, as opposed to higher pressures required for existing pipelines. This program could provide for concentrated well development in selected areas, thus providing sufficient production to warrant associated gas transmission costs.

The demonstration wells would be located in New York, Pennsylvania, Ohio, West Virginia, Kentucky, Michigan, Indiana, Illinois, and Tennessee. The development of these resources will contribute significantly towards supplementing existing supplies of gas to eastern markets.

Some of the specific work being done is briefly described below.

Solimbia Gas System Bervice Corporation, Ohin, West Virginia, Virginia, Kentucky

The Columbia Gas Sandstone and Shale Project is a multiphase experiment in advanced hydraulic fracturing (AHF) involving site selection, planning, drilling, and stimulating 13 new and existing gas wells, nine sandstone and four Devonian shale wells, in five eastern states. To date, seven wells have been fractured with dendritic, cryogenic and gelled water treatments. Of these, six showed improved production and one was abandoned due to salt water production. Three wells are drilled and waiting treatment. Three remain to be treated. This project is due to be completed in FY 1978.

Columbia Gas System Service Corporation, Lincoln County, West Virginia

The Columbia Gas System Service Corporation (Columbus, Ohio) Shale Project is a three-well experimont aimed al: increasing gas reserves and production from the Devonian shales by advanced hydraulic fraclure treatuents. The experiment is being conducted in Lincoln County, West Virginia. The three wells have been drilled, cored, logged, and two have had a four-stage AHF treatment. The treatment of the third well will depend on the test results of the first two wells. The work is schedulcd to be complete this fiscal year.

DOE is sponsoring an ongoing projcct with industry to research the feasibility of directional drilling for natural gas in Devonian shale. Other DOE research at Energy Research Centcrs (ERCs) and National Laboratories (NLs) has developed a technique of analyring stress ficlds and induced fractures.

Consolidated Gas Supply Corporation, Jackson County, West Virginia

The Consolidated Gas Supply Corporation, Clarksburg, West Virginia, is cost-sharing a directionally-drilled well test in the Devonian shale formation of Jackson County, West Virginia. The well will be drilled, hydraulically fractured, and production tested. Geologic analyses for site 
selection and preliminary well design plans are currently under way. Selection of the final drill site and commencement of drilling activities will be in 1978 .

\section{Los Alamos Scientific Laboratory, Los Alamos, New Mexico}

Los Alamos Scientific Laboratory (LASL), Los Alamos, New Mexico, will experiment with shaped-charge explosives as a technique for fracturing Devonian shales as a means of increasing permeability or providing conduits for emplacing liquid explosives for fracturing.

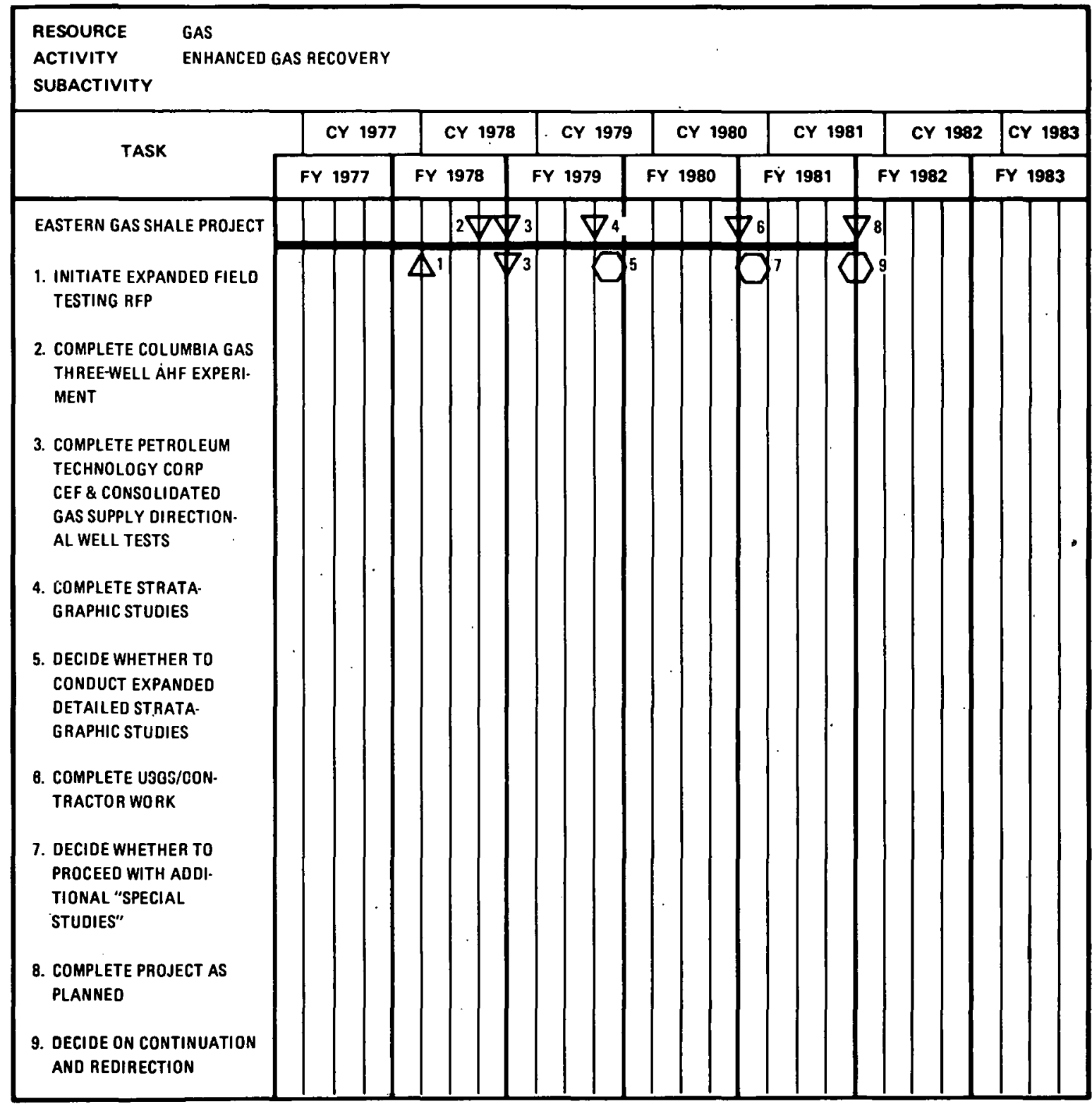

MILESTONE SYMBOLS ARE DEFINED ON LAST PAGE OF THIS DOCUMENT 


\subsection{WESTERN GAS SANDS PROJECT}

Geologic studies by both industry and government have indicated that an immense resource of natural gas exists in the western states. This resource will not be commercially developed until it has been demonstrated that a significant fraction of estimated gas-in-place can be produced profitably. Most of this potential resource lies within low-permeability reservoirs in a number of geologic basins scattered throughout the western states. Low-permeability or "tight" reservoirs will not readily flow gas into the wellbore. An additional difficulty arises from the depositional characteristics of these sands. Gas-bearing sands are interspersed with shales throughout intervals that are thousands of feet in gross thickness. Potentially productive reservoirs within such intervals might number a hundred or more. These sand reservoirs may range in thickness from a few feet to 100 feet or more and may be either blanket-type with large areal extent or lenticular of unknown size.

A Federal Power Commission study in 1973 identified three areas in the western states as having large areal extent, containing a large fraction of the low-permeability reservoirs, and having a sizable existing data base. A fourth such area was identified by the United States Geological Survey (USGS). These areas are estimated to contain $730 \mathrm{Tcf}$ of gas-in-place. If methods can be found to recover half of the resources in these basins, they would provide a volume of gas equivalent to a 16-year supply (at current consumption rates).

The following is a brief review of ongoing work in the WGSP area.

Gas Producing Enterprises Inc., Uintah County, Utah

Gas Producing Enterprises, Inc. (GPE), Denver, Colorado, is currently conducting a seven-well AHF experiment in the tight Mesaverde sandstone reservnirs of the Uintah Basin, Utah. Exlensive evaluation of the producing formation, detailed geophysical log analysis, rock-mechanics studies, and prefracture production tests will be made to optimize the final AHF program design. The distinguishing feature of the GPE experiments is the large interval over which the well is fractured, often many hundreds of feet. The engineering and economic feasibility of this technique merits thorough study.

Five wells have heen treated. Four worc considered to be successes with production increased from an initial production of 30 to $50 \mathrm{Mcf} / \mathrm{d}$ before treating to 300 to $1200 \mathrm{Mcf} / \mathrm{d}$ after treating.

Two additional wells are being tested and treated during FY 1978.

Mobil Corporation, Rio Blanco County, Colorado

Mobil Oil Corporation, New York, New. York, is cost-sharing a onewell project in Piceance Creek, Colorado. Mobil will employ a fracturing technique that uses a relatively low-viscosity fluid, high pumping rate, and limited entry over a thick vertical sequence. This technique has been successful in low-permeability reservoirs in other areas. Mobil has 
developed extensive expertise during years of intensive research, development, and field testing of improved hydraulic fracturing theory and techniques.

During FY 1977 the well was drilled, cored, and extensively tested and two AHF treatments were staged. Initial indications.are that this work will be successful. During the winter months of FY 1978 these two zones will be produced to the pipeline. Next spring the well will be tested to determine additional zones for stimulation. This experiment will be completed in FY 1978.

Petroleum Technology Corporation, Kentucky, West Virginia, Texas

The Petroleum Technology Corporation (PTC, Redmond, Washington) has three working chemical explosive fracturing (CEF) field tests. Each project will involve three separate experiments utilizing three different wells. Two of the projects are being conducted in cooperation with the Kentucky-West Virginia Gas Company (Kentucky) and the Columbia Gas System Service Corporation (West Virginia), and will involve testing in the Devonian shales of the Appalachian région. The third project is being conducted in cooperation with the Union Oil Company (Texas) and will test the technique in the tight gas sandstones of south Texas. The PTC technique involves mixing a chemical-explosive slurry in the borehole, pumping the slurry into existing fractures, and detonating the explosive.

\section{U.S. Geological Survey, Menlo Park, California}

The USGS is providing resource inventory and characterization studies relating to the low-permeability gas sandstones of the Rocky Mountain region. USGS is the sole source of characterization work for WGSP. The project will be funded in two phases. The first phase was a one-year survey to see what data are available and what data need to be developed. The second phase will be a multiyear resource inventory and characterization program aimed at thoroughly quantifying this gas resource. Inftial work on the first phase of the project began in early 1977.

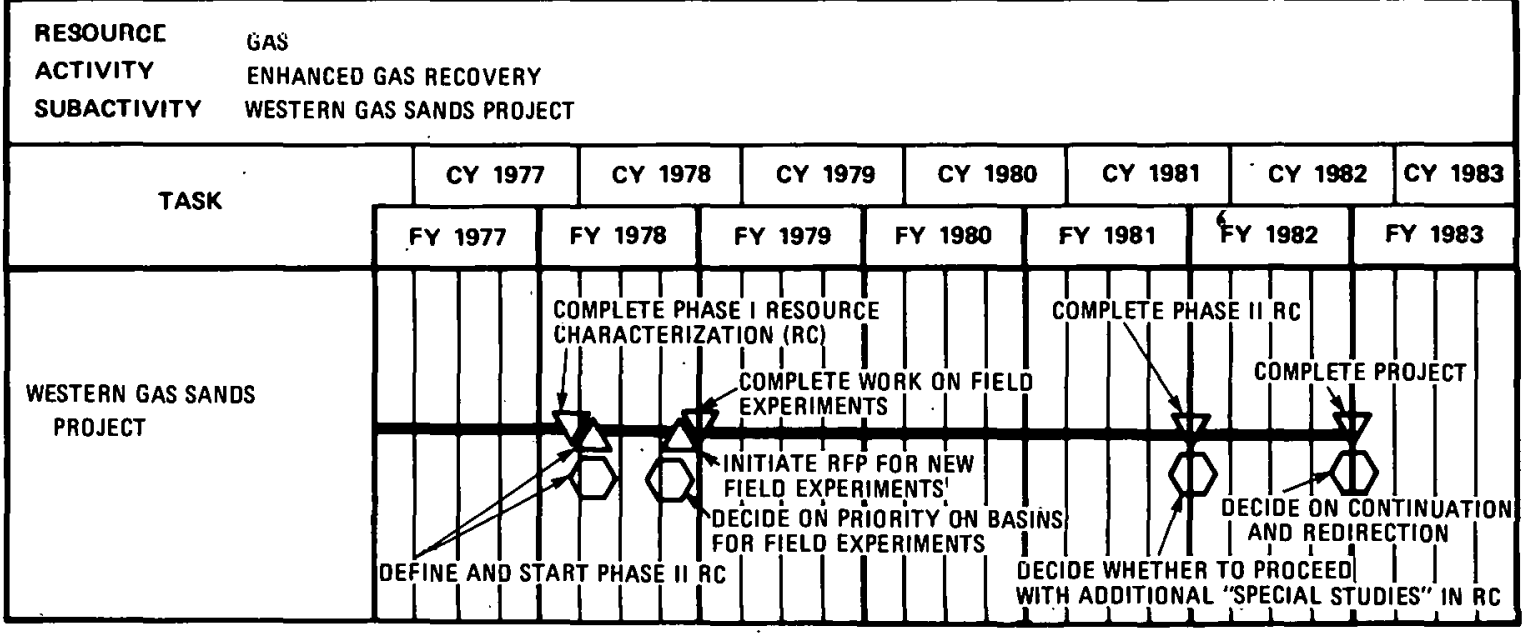

MILESTONE SYMBOLS ARE DEFINED ON LAST PAGE OF THIS DOCUMENT 


\subsection{METHANE FROM COAL AND GEOPRESSURED AQUIFERS}

In FY 1978, DOE undertook a preliminary investigation of two additional unconventional gas resources, MFC and GPA. Both resources could contain large potential reserves. Unfortunately, reliable estimates of the size of both resources are not available because of very limited geologic and engineering data. A concerted, coordinated effort to determine the true magnitude of the recoverable reserves and assess the physical and chemical properties governing gas production is needed. The unattractive economic picture associated with these two resources provides no real incentive for the oil and gas industry to develop a reliable data base. The DOE program will initiate work on this data base and provide the necessary impetus for future industry participation.

Anticipated work in the areas of Methane from Coal and Geopressured Aquifers will be carried out through in-house recourch at Murgantown Fnergy Kesearch Ccnter (MERC) and by contractual arrangement with outside enyineer'ing and geological consultants. Work on methane from coal seams will be closely coordinated with other Fossil Energy divisions and the Bureau of Mines (BOM). The Bureau's work involves removal of methane from currently mined areas and is related to mine safety.

Work on methane from geopressured aquifers will be coordinated with DOE, Division of Geothermal Energy (DGE), and the U.S. Geological Survey. DGE is currently investigating the geopressured aquifers as a source of thermal and kinetic energy with methane production as a byproduct. The USGS is performing limited studies of the potential gas reserves in these geopressured aquifers.

\subsection{PROJECT SUPPORT ACTIVITIES}

In addition to conducting field experiments, DOF, the National Laboraturirs, and the U.S. Geologic Survey are providing technology support for various $\mathrm{AHF}$ experiments.

Sandia Laboratories, Nevada Test Site

Sandia Laboratories (SL), Albuquerque, New Mexico, is developing a technique for mapping the length and direction of AHF-induced fractures using an electropotential resistivity technique. SL is also conducting field experiments aimed at relating actual AHF fracture geometry to theoretical rock mechanics' predictions. The fractures are delineated by physirally mining back intu the fractured rock and mapping the fractures. These tests are being carried out at the Ncvada Test Sile. The ultimate goal of these experiments is to enable engineers to correctly predict the direction and extent of hydraulically induced fractures prior to actually performing the AHF job.

Lawrence Livermore Laboratory, Livermore, California

Lawrence Livermore Laboratory (LLL), Livermore, California, has developed one- and two-dimension computer codes to model fracture behavior and is in the process of developing three dimensional codes. LLL 
is also experimenting with geophysical logging techniques to aid in both understanding fracture propagation during $\mathrm{AHF}$ and predicting resultant reservoir performance.

\section{U.S. Geological Survey, Menlo Park, California}

The USGS, Menlo Park, California, is conducting research in the use of tiltmeters (extremely sensitive level-indicating devices) to map fractures induced during AHF. The method is analytically very complex, but experiments have determined that the technique will work. This work is performed in parallel with the SL efforts mentioned above.

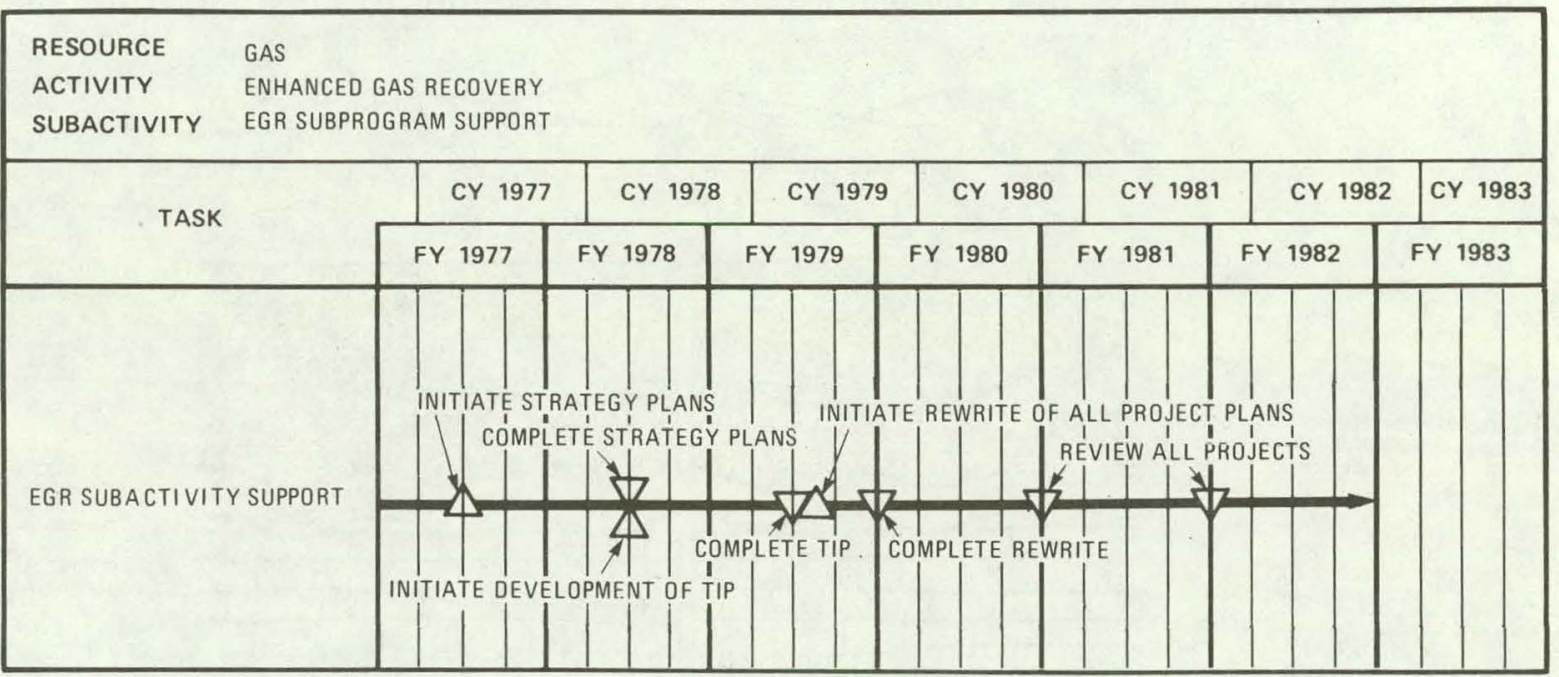

MILESTONE SYMBOLS ARE DEFINED ON LAST PAGE OF THIS DOCUMENT

\section{Technology Descriptions}

Under Enhanced Gas Recovery, processes and efforts currently being developed and tested to recovery the unconventional gas resources previously outlined include:

- $\quad$ Advanced Hydraulic Fracturing Process

- Chemical Explosive Fracturing Process

- Deviated Wells and Earth Fracture Systems Process

- Resources Characterization

- Environmental and Supporting Research.

\subsection{ADVANCED HYDRAULIC FRACTURING PROCESS}

Hydraulic fracturing is a mechanical process for creating an extensive fracture in a reservoir formation. In the single-well technique illustrated below, fluid is injected through the wellbore to overcome natural stresses within the reservoir rock, thus causing a fracture to develop. Coarse sand is carried along with the fluid and acts as a propping material to hold the fracture open after fluid injection is stopped and the attendant pressure is released. These fractures increase formation permeability by permitting faster migration of gas into the wellbore, thus increasing gas production. 
The first commercial hydraulic fracturing job was performed in 1947. This first small-scale project involving the injection of 2,000 to 3,000 gallons of fluid has gradually evolved to the point where fracturing jobs requiring 500,000 gallons of fluid, 1 million pounds of sand, and injection pressures in excess of 15,000 psi are not exceptional. Primary advances in AHF technology have been in equipment development (large-volume, highpressure portable pumping units) and refinements in the science of fracture mechanics and reservoir engineering.

Although many of the AHF techniques being investigated by DOE are not totally unique to the gas industry, the techniques still need further refinement and have not been extensively employed to develop the gas

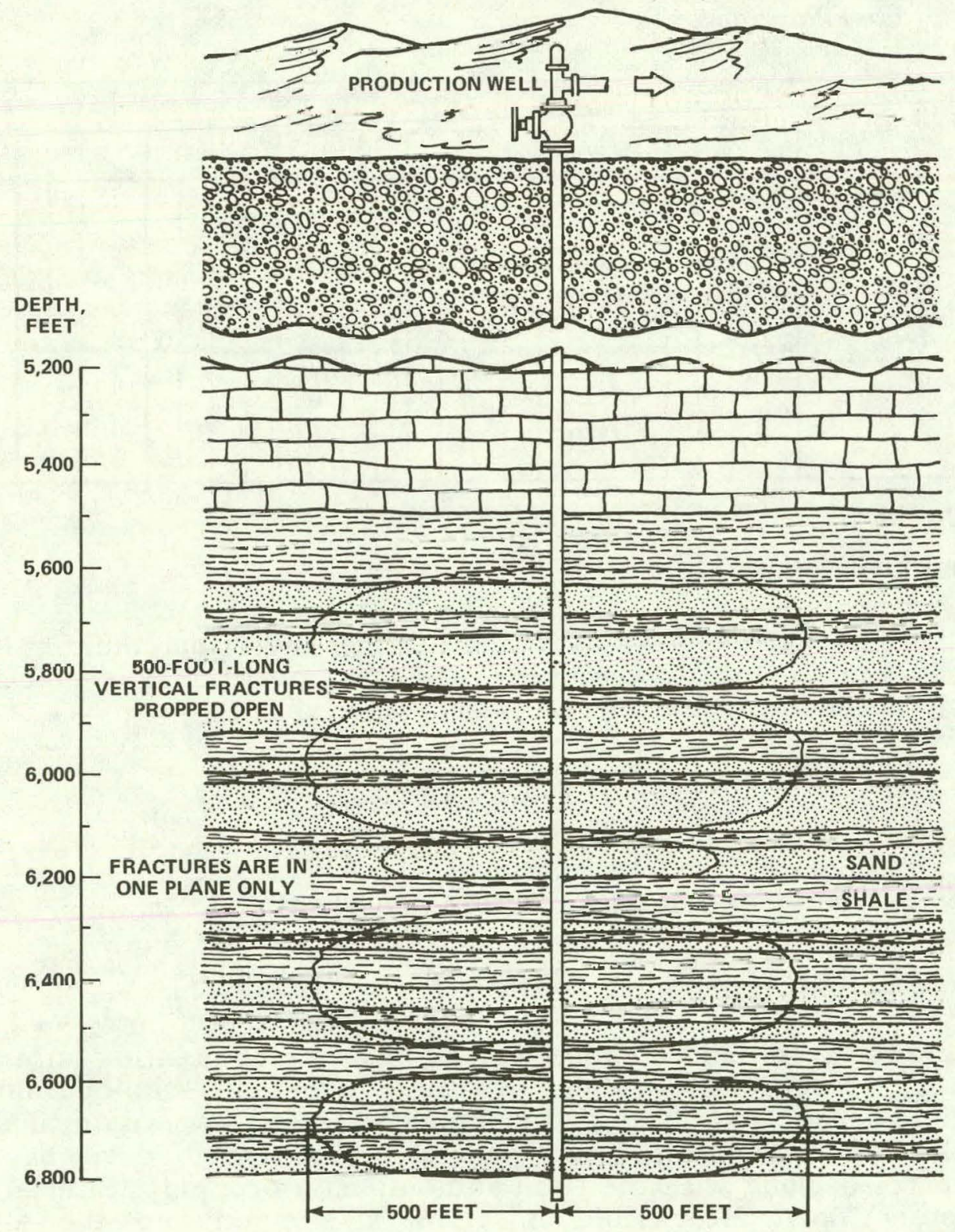

Massive Hydraulic Fracturing Process 
resources under consideration. DOE is taking an active part in developing AHF stimulation technology with the ultimate goal of transferring successful techniques to the oil and gas industry.

DOE is funding contracts in AHF to test new techniques and fracturing concepts in several different geologic formations. The projects were selected on the basis of their demonstrated technical merit. In addition, all the contractors are actively engaged in drilling and exploration within the geographic areas in which DOE's program activities are concentrated (the Devonian shales of the eastern United States and the tight gas sands of the Rocky Mountain region).

\subsection{CHEMICAL EXPLOSIVE FRACTURING PROCESS}

There are two basic approaches to the chemical explosive fracturing of gas wells. Borehole shooting, which consists of fracturing a portion of the open hole with nitroglycerin or a shaped-charge explosive, has been employed in some areas for many years. A newer concept in CEF involves pumping a chemical explosive slurry into a formation and then detonating the mixture. In some cases the injection pressure is sufficient for the explosive slurry to actually induce hydraulic fracturing of the reservoir. The explosive slurry can also be pumped into existing natural fractures or existing hydraulic fractures. Current fracture mechanics theory predicts that the explosive shock wave resulting from detonation extends the existing fractures, thus increasing permeability and gas production.

Borehole shots using nitroglycerin have been used routinely for more than 60 years. Development of more sophisticated explosive compounds and shaped-charge propellants began in the mid-1940s. The results of crude borehole shooting with nitroglycerin are generally unpredictable and not particularly cost-effective, in terms of incremental gas production, over the long-term well life. Many of the newer techniques have evolved from R\&D activities in missile and military explosives technology. The DOE program in CEF encourages the development of more sophisticated explosives (rocket propellants and other tuned explosives) and design concepts based upon modern rock mechanics studies. The goal of the DOE-sponsored research is to achieve better (in terms of production), more cost-effective, and predictable final results. The DOE program fills a technological void that industry is not actively pursuing.

The DOE projects funded for CEF research and development were selected because the proposed techniques are unique when compared with current commercial CEF techniques. 


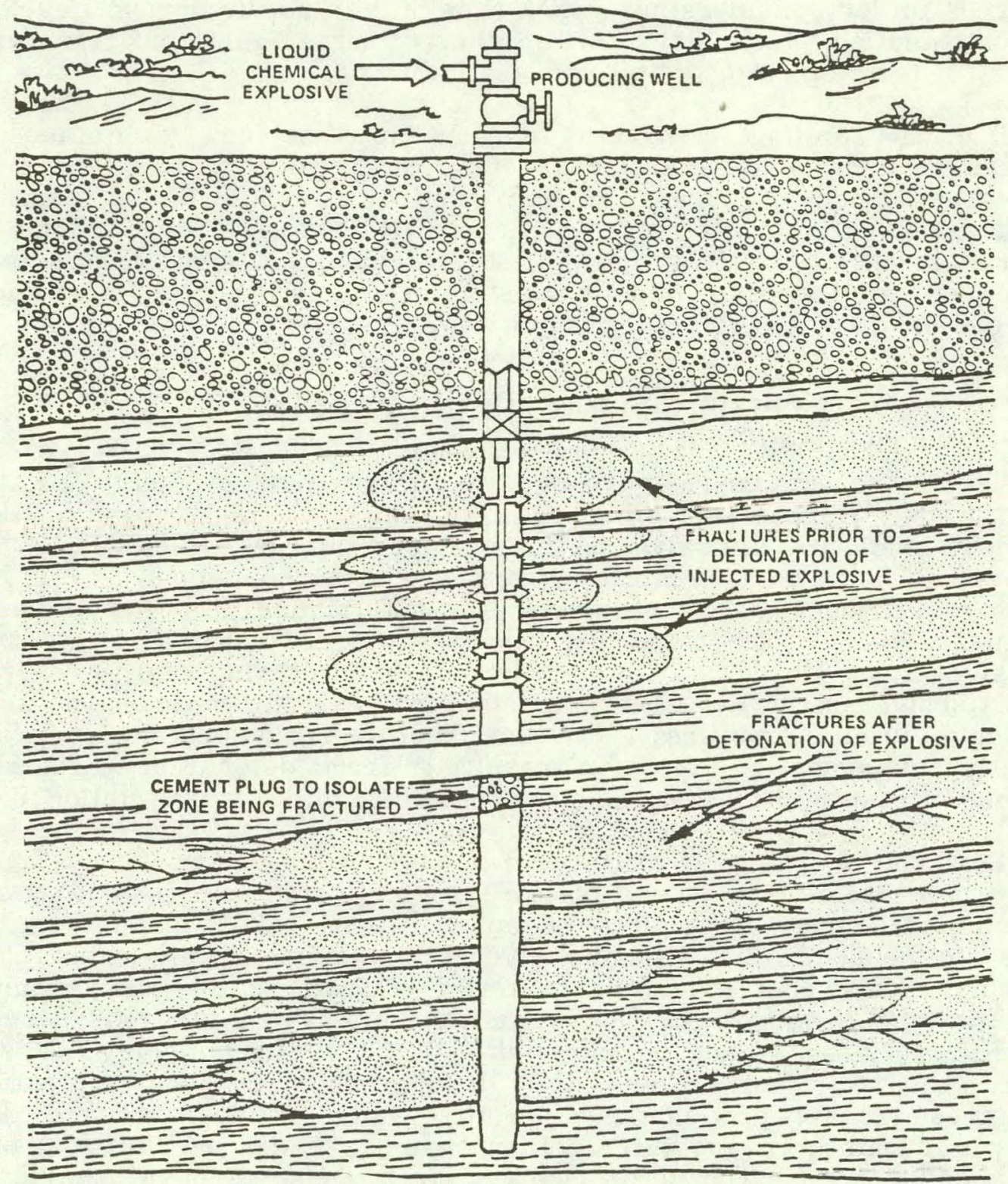

\section{Cliemical Explosive Fracturing Process}

$\mathrm{DOE}$ is funding four experiments in CEF to evaluate the concept under actual field conditions. Additional tests and expansions are planned for the future as shown in the milestone chart. Several requests for proposals (RFPs) will be issued in the upcoming years. 


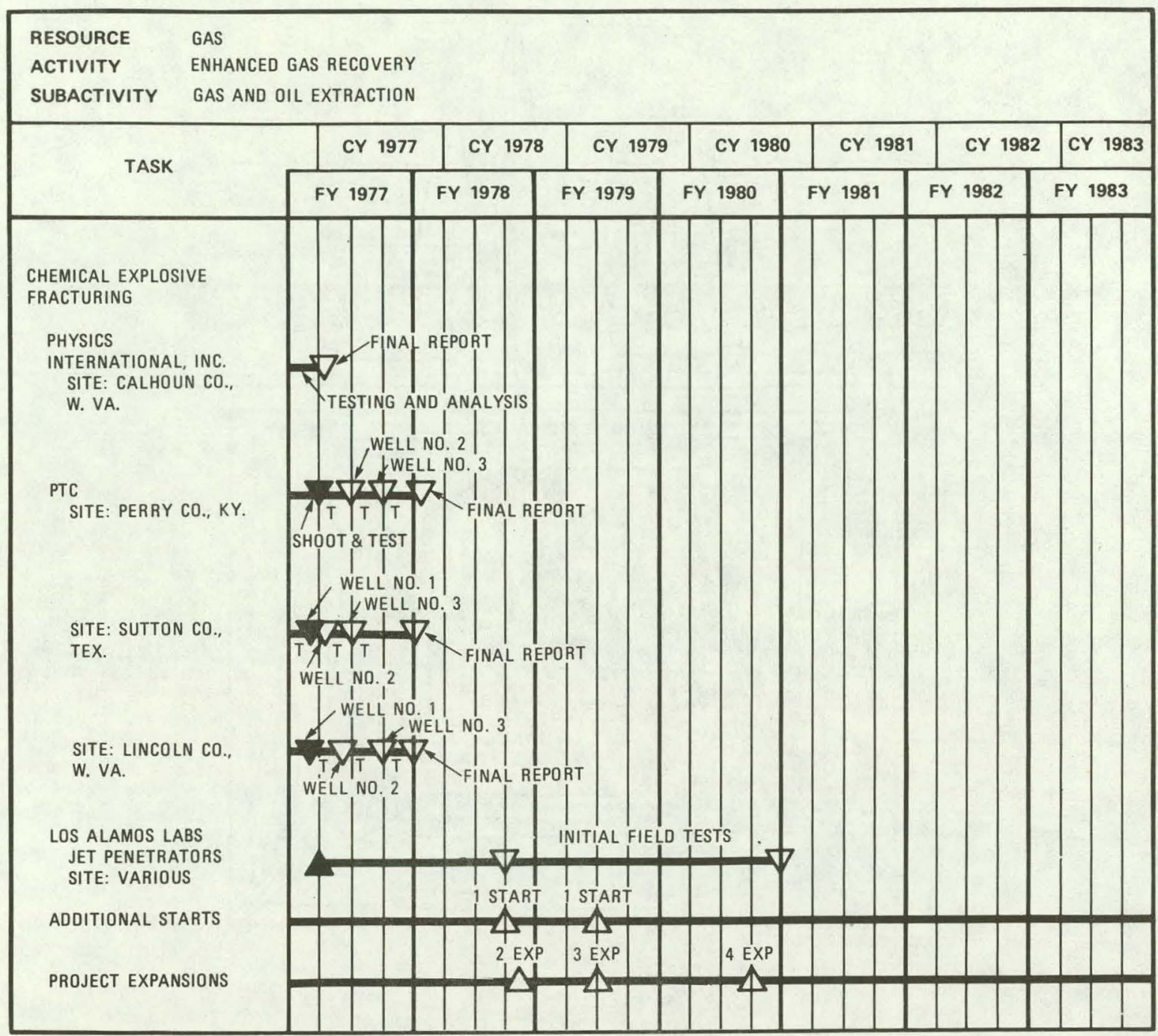

MILESTONE SYMBOLS ARE DEFINED ON LAST PAGE OF THIS DOCUMENT

${ }^{1} \mathrm{~T}$ = WELL TEST

\subsection{DEVIATED WELLS AND EARTH FRACTURE SYSTEMS PROCESS}

Directionally drilled (deviated) wells attempt to utilize existing natural fracture systems to increase gas production. The natural fracture system is thoroughly studied and mapped prior to drilling. Once the orientation of local fracture systems is determined, an optimum drill site is selected and a well is directionally drilled to maximize the probability of intersecting the fracture system. Each fracture cut by the wellbore represents a path of higher permeability for gas migration; the greater the number of fractures, the larger the gas flow. In addition, the fracture system will provide conduits for hydraulic or explosive fracturing fluids for subsequent $\mathrm{AHF}$ or $\mathrm{CEF}$ stimulations. The ultimate effect is an extension of existing fractures, an increase in reservoir permeability, and improved production of gas above the production rate expected by drilling conventional vertical wells. The Devonian shales of the eastern United States should be excellent candidates for directional-drilling techniques, since the shales are intensely fractured in several areas. 


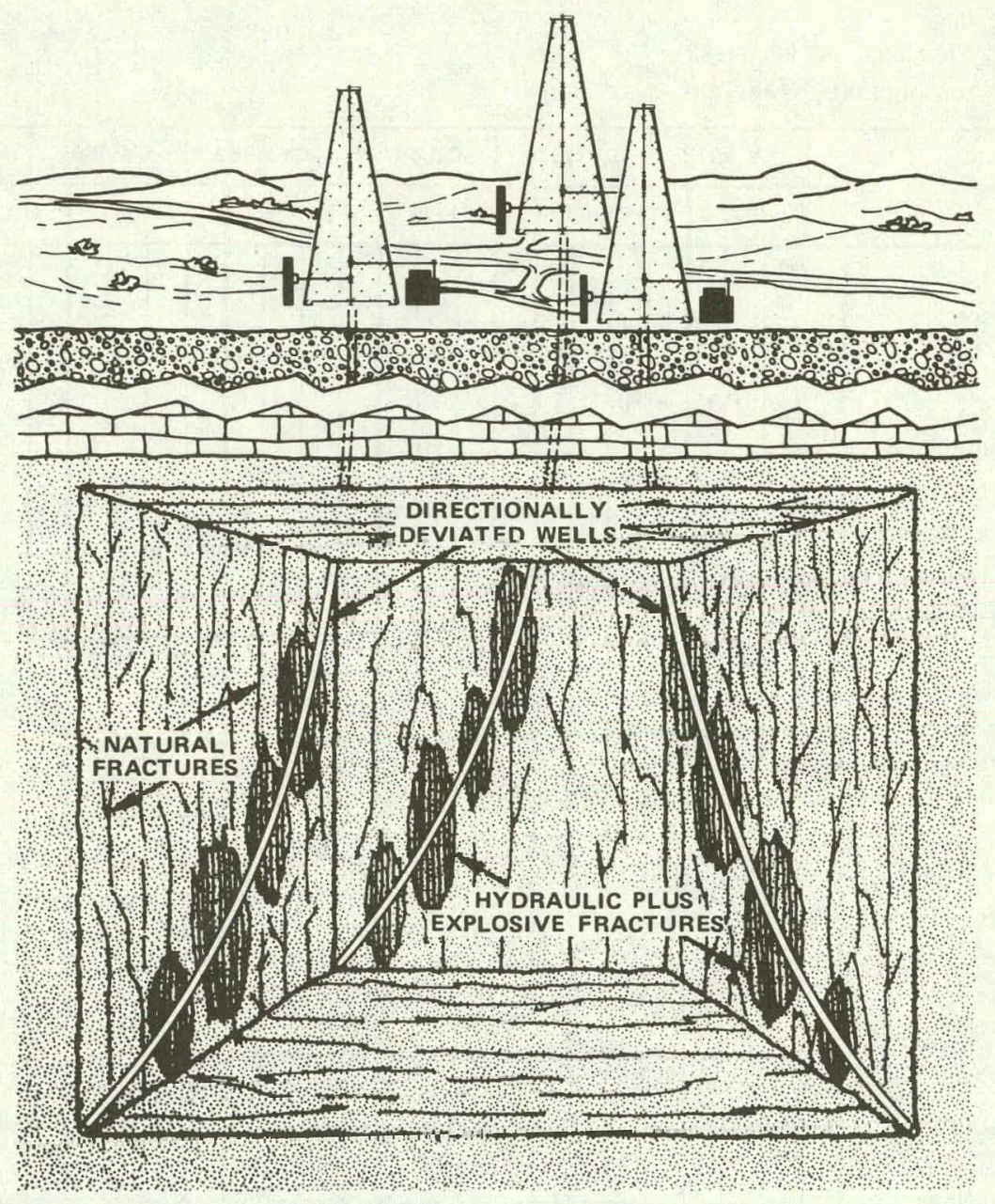

\section{Deviated Wells and Earth Fracture Systems Process}

Directional drilling of multiple wells from a single platform is a standard technique for producing oil and gas reserves in the offshore areas. Directional drilling of wells in the gas fields located onshore is rarely done except as a means of avoiding some surface nhstacle or as a safety relief well for a blowout or a well on fire. The gas-producing formations onshore are also much harder-to-drill rocks. Generally speaking, there have been f'ew incentives and, subsequently, little expertise devrloped by the vil and gas industry with regard to directional drilling in the Appalachian or Rocky Mountain regions where DOE is conducting its program activities. DOE believes it should actively sponsor $R \& D$ efforts in this area, especially as the technique can be applied to development of the Devonian shales. 


\subsection{RESOURCE CHARACTERIZATION}

Résource characterization work involves an evaluation of the magnitude and distribution of the resources plus characterization studies, to determine the physical and chemical properties affecting reservoir behavior. These support programs involve comprehensive surface and subsurface geological mapping, structural and rock mechanics studies, geochemical studies, mineralogy studies, geophysical logging and interpretation techniques, reservoir engineering studies, and computer data analyses.

Due to present uneconomic aspects of the gas resources under investigation, the natural gas industry is not putting any effort into defining either the size of the resources or their producing characteristics. DOE must provide the initiative by developing a reliable data base of technical information. The development of this data base will provide incentives for future field tests of the various stimulation technologies.

\subsection{ENVIRONMENTAL AND SUPPORTING RESEARCH}

The EGR Activity includes controls to ensure that all field projects will be conducted in accordance with existing and foreseeable environmental, health, and safety (EH\&S) requirements. A thorough understanding of the environmental implications of the new drilling and fracturing techniques is important to the success of the EGR Activity. Environmental assessments will be made of all planned field activities to ensure proper consideration of all potential problems and to minimize adverse environmental impacts. Data compiled and analyzed during the program should provide a sound basis for predicting the environmental impact of commercial operations utilizing similar technologies.

Additional support work, such as economic analyses to assess cost effectiveness of various techniques, will provide the basis for defining and refining the overall EGR Activity. Management support from professional systems analysts and engineering consultants will be used extensively to develop a courdinated coherent management plan for EGR. 


\section{GAS FROM OIL SHALE}

The table below summarizes the funding levels for this Activity for the FY 1977 to FY 1979 period.

\begin{tabular}{|c|c|c|c|c|}
\hline GAS FROM OIL SHALE & \multicolumn{4}{|c|}{$\begin{array}{c}\text { BUDGET AUTHORITY } \\
\text { (OPERATING EXPENSES) } \\
\text { (DOLLARS IN THOUSANDS) }\end{array}$} \\
\hline SUBACTIVITY & $\begin{array}{c}\text { ACTUAL } \\
\text { FY } 1977\end{array}$ & $\begin{array}{c}\text { APPROPRIATION } \\
\text { FY } 1978\end{array}$ & $\begin{array}{c}\text { ESTIMATE } \\
\text { FY 1979 }\end{array}$ & $\begin{array}{c}\text { INCREASE } \\
\text { (DECREASE) }\end{array}$ \\
\hline Shiale Gas Production & $\$ 3,600$ & $\$ 3,850$ & $\$ 4,350$ & $\$+500$ \\
\hline
\end{tabular}

\subsection{SHALE GAS PRODUCTION} follows :

The major goals of the In Situ Shale Gas Production subactivity are as

- To study means of producing large quantities of low-Btu (100 to $300 \mathrm{Btu} / \mathrm{scf}$ ) gas from oil shale by an economically feasible in situ process

- To study the feasibility of producing medium-Btu (300 to 500 Btu/scf) gas from oil shale for upgrading to pipeline gas and of developing production methods

- To define the operating parameters necessary to ensure maximum utilization of the resource

- To determine the yield and composition of liquid and gaseous products from oil shale retorting and their relationship to process variables.

An underground operation to produce gas from oil shale can be identical to one designed to produce shale oil. Changes in the levels of sperating variables, resulting in higher shale bed temperatures, tend to favor gas production nver liquid production. The heating value of the gas can be changed by changing the composition of the injected gas. 


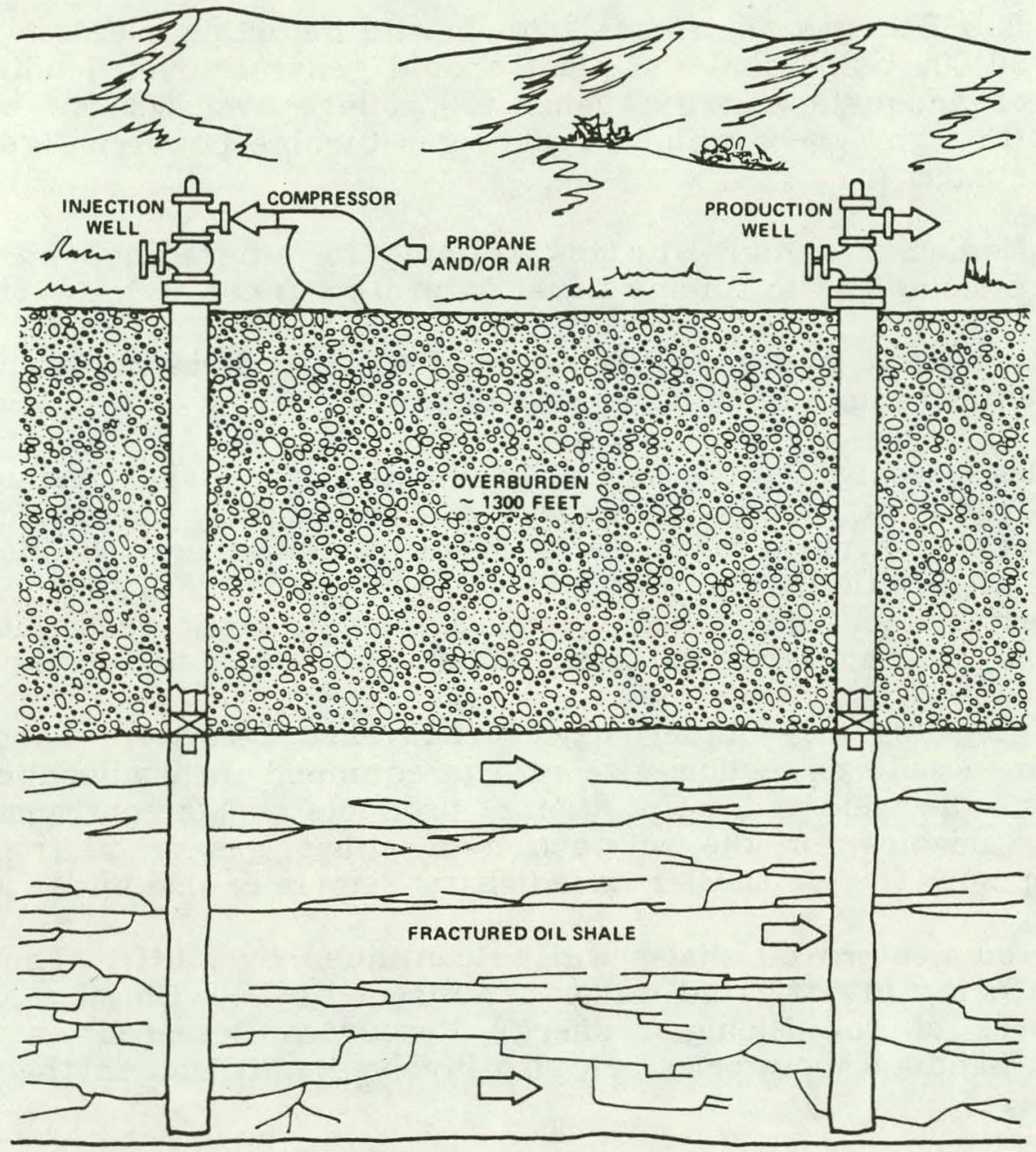

Shale Gas Production

\section{Project Status}

Past research at Laramie Energy Research Center (LERC) has demonstrated that low- to medium-Btu gas may be obtained from oil shale at low pressure by proper selection of control parameters (e.g., gas flow rates and oxygen concentration). Work on gasification of eastern and western oil shale varies in nature because of the differences in the potential oil content of the shale and the desired products. Low-grade eastern oil shale exists in great abundance in close proximity to highly populated areas. For this reason, the preferred products are low-Btu gas suitable for gas-turbine generators and/or medium-Btu gas for upgrading for home heating purposes. Some current work at LERC has demonstrated that proper control of process variables allows usable gas to be produced concurrently with high quality shale oil. Bench-scale retort work to develop statistical models to relate operating parameters to products has been under way for more than two years at LERC. An intermediate-scale (0.5-ton batch) gasification retort will be in operation during FY 1978 to verify the models. Products expected from the gasification of western oil shale, concurrent with shale oil production, are: 
- Low-Btu gas as off-gas from in situ retorting plants. A single $50,000 \mathrm{bbl} / \mathrm{d}$ shale oil plant should generate over 1 billion scf $/ \mathrm{d}$ of adequate calorific value to produce over 500 MW when put through a combined-cycle gas-turbine-powered generating system

- Medium- to high-Btu gas suitable for upgrading and used as pipeline gas to fill any usual natural gas need.

A side benefit is greater utilization of the energy in the resource (up to 20 percent) through oil and gas production.

Problems facing the commercial gasification of oil shale include those common to retorting, that is, the creation of sufficiently permeable surface area through the shale to allow efficient retorting and gasification to proceed. In addition, the proper level of field controllable parameters must be established and a full technical and economic feasibility study completed to determine the best methods of utilization of the resource.

Work is currently under way at Lawrence Livermore Laboratories (LLL) using small- to medium-size retorts equipped with adiabatic shields to determine the yield and composition of products and the optimum level of operating variables for the production of either gas or oil from shale. Supporting work in five smaller nonadiabatic retorts is also under way.

Work on western oil shales will be continued by LERC. The eastern shales are being investigated under a contract by Dow Chemical Company and members of the Michigan Energy Resources Research Association. LERC and Sandia Laboratories are also involved with Dow in the work on eastern shales. 


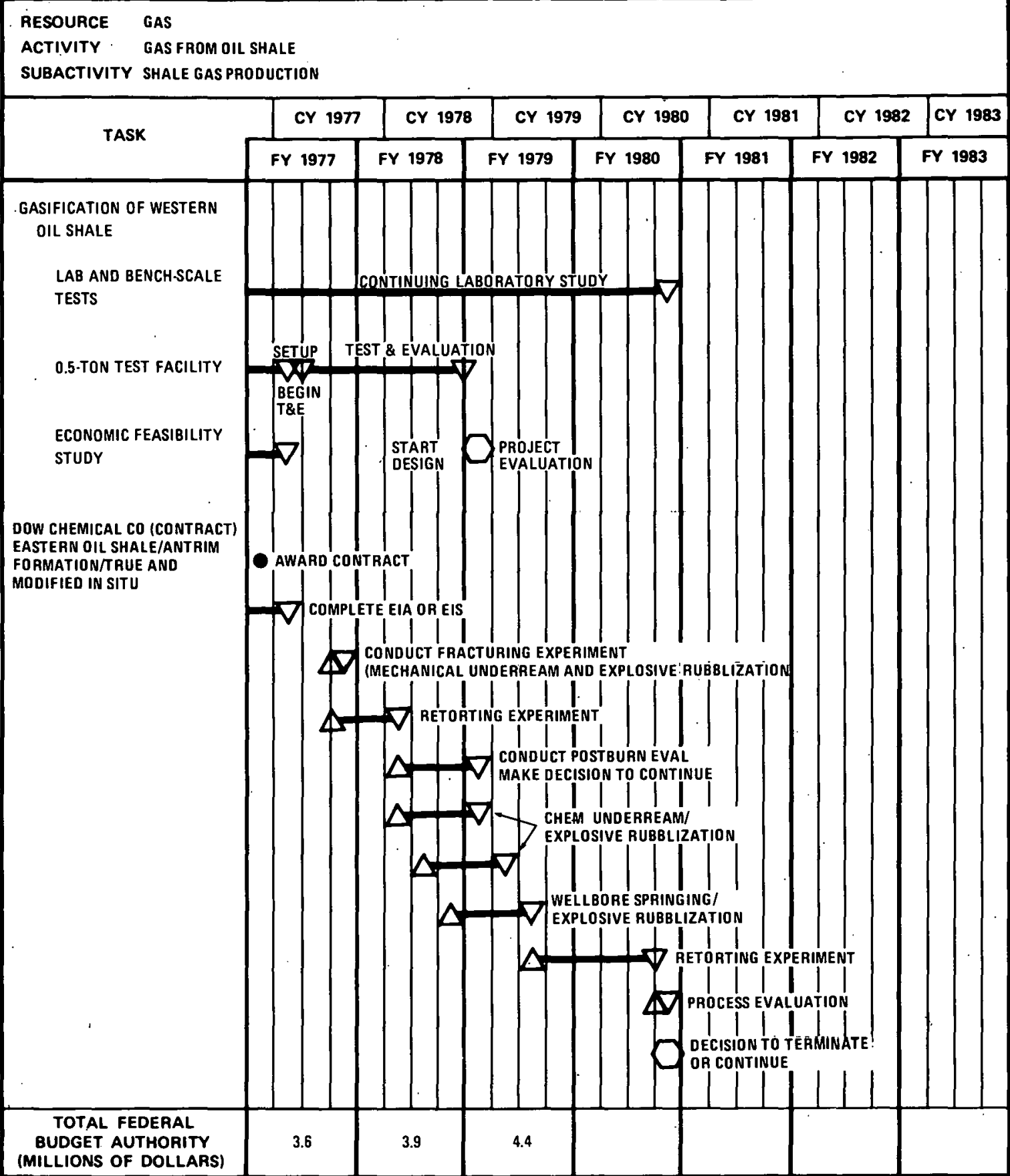

MILESTONE SYMBOLS ARE DEFINED ON LAST PAGE OF THIS DOCUMENT 


\section{SUMMARY OF CAPITAL ACQUISITION}

The data below summarize plant and capital equipment funding for the Gas Resource.

\subsection{PLANT CONSTRUCTION}

No construction projects are planned through FY 1979.

\subsection{CAPITAL EQUIPMENT}

Gas Resource program support at the various energy research centers and field laboratories of ten requires the purchase of capitalized equipment for general laboratory or facility use. The table below summarizes the levels of funding by Activity for the FY 1977 to FY 1979 period.

\begin{tabular}{|c|c|c|c|}
\hline $\begin{array}{c}\text { GAS RESOURCE } \\
\text { CAPPITALEQUIPMENT }\end{array}$ & & $\begin{array}{l}\text { 3UDGET AUTHORI } \\
\text { PERATING EXPENS } \\
\text { LLARS IN THOUSA }\end{array}$ & \\
\hline ACTIVITY & $\begin{array}{l}\text { ACTUAL } \\
\text { FY } 1977\end{array}$ & $\begin{array}{c}\text { APPROPRIATION } \\
\text { FY } 1978\end{array}$ & $\begin{array}{l}\text { ESTIMATE } \\
\text {. FY } 1979\end{array}$ \\
\hline $\begin{array}{l}\text { Enhanced Gas Recovery } \\
\text { Gas from Oil Shale } \\
\text { Uther }\end{array}$ & $\begin{array}{r}\$ 0 \\
0 \\
1 \overline{7} 0\end{array}$ & $\begin{array}{r}\$ 300 \\
47 \\
0\end{array}$ & $\begin{array}{r}\$ 200 \\
25 \\
0\end{array}$ \\
\hline 'IUTAL & $\$ 170$ & $\$ 347$ & $\$ 226$ \\
\hline
\end{tabular}




\section{ENERGY RESEARCH CENTERS, MINING OPERATIONS CENTERS, AND NATIONAL LABORATORIES}

The significant research center and national laboratory support of DOE's Fossil Energy activity elements are discussed in this chapter. Table 8 summarizes these activities.

\section{A. ENERGY RESEARCH CENTERS (ERCs)}

The ERCs play an important role in achieving DOE goals in Fossil Energy technology. They have demonstrated the ability to achieve solutions: to specific R\&D problems affecting the timetable of major Fossil Energy systems development. In addition to the in-house research efforts at each center, their technical personnel have functioned in a supervisory and liaison capacity in the management of contract research work with universities and laboratories in every major area of the Fossil Energy development program. Although relatively small, the ERCs are staffed by highly skilled scientists, engineers, and technicians with a long history of accomplishments in RD\&D in the production and utilization of fossil fuels. They have produced new ideas, new data, and new processes for better utilization of Fossil Energy resources.

Although the ERCs are a part of Fossil Energy, a few projects are conducted for other DOE efforts, primarily in the Conservation, Environment and Safety, and Physical Research Program areas.

A summary table of resource levels devoted to each program at the ERCs is provided in Table 7.

\subsection{BARTLESVILLE ERC (BERC)}

Research at BERC is focused primarily on the production of petroleum. and natural gàs with in-house efforts on processing and utilization of petroleum. A lesser effort is devoted to the characterization and use of liquid fuels manufactured from nonpetroleum sources. The center plays a major role in providing in-house support and research and technical cognizance for DOE's field demonstration projects in enhanced recovery of oil. In FY 1979, an increasing emphasis will be placed on the enhanced recovery of petroleum and natural gas from presently known U.S. reserves and especially those with near-term potential. 
- Petroleum and Natural Gas. Research and development activities in the area of oil and gas extraction in projects costshared with industry are centered on developing improved secondary and tertiary methods for the recovery of oil and gas. Field operations are being conducted in micellar polymer flooding, caustic flooding, and thermal recovery. The effectiveness of massive hydraulic fracturing and the use of chemical explosives to increase recovery of natural gas from tight formations are being investigated. Research studies will continue on the characterization of crude oil and its products and on improved process methods.

- Coal. Characterization studies of the properties of syncrudes from coal were initiated in FY 1976 to provide the bases for processes to upgrade syncrudes to refinery feedstocks and finished fuels. In FY 1979, research will continue on the properties, combustion, and engine performance characteristics of liquid fuels derived from coal which are developed throughout the Coal Resource program.

\subsection{GRAND FORKS ERC (GFERC)}

GFERC is concerned primarily with near- and mid-term technologies for the utilization of western coals, including lignite and subbituminous coals, in an environmentally sound manner to alleviate urgent energy supply problems in the western and midwestern United States.

- Coal. Research and development activities are continuing in the special problem areas of coal liquefaction, gasification and combustion and in the control of pollution arising from utilization of the relatively abundant lower Btu-value coals. The effect of mineral matter in lignite on liquefaction will be studied in the $\mathrm{CO}$-steam project. Since the fixed-bed slagging gasifier is a major project, detailed investigation of liquid effluents is being initiated. Development of these data affects the design of scaleup systems and is important for environmental considerations.

\subsection{LARAMIE ERC (LERC)}

LERC serves as the focal point for R\&D on the production and utilization of vast oil-shale resources. Additionally, research is conducted on production, processing, and utilization of petroleum and in the in situ gasification of coal.

- Oil Shale and In Situ Technology. In Oil Shale, current emphasis is being placed on the development of in situ retorting processes for recovering oil from oil shale deposits. Process support and field studies focus on developing fracturing techniques and methods for recovering oil from the fractured shale, and on refining the shale oil. Modified in situ processes 
involving industry contracts and monitoring of above ground retorting studies also are receiving major emphasis. A major effort is under way to develop underground coal gasification processes. A field test site is located near Hanna, Wyoming, in a seam of subbituminous coal 30 feet thick at a depth of about 400 feet. In FY 1979, the main program thrust will be development and demonstration of the modular concept for expanding underground coal gasification technology to a commercial scale. Environment and safety research activities will also be part of the in situ coal gasification and $6 \mathrm{il}$ shale efforts. in FY 1979. Projects jointly managed with Fossil Energy activities are designed to identify environmental control needs for effluents from in situ operations. Data will be obtained from an in situ environmental burn at the Hanna site and other field studies and an analysis of environmental control needs will be made.

- Petroleum and Natural Gas. In FY 1979, principal petroleum and gas research will be aimed at the development of processes for recovering oil from tar sand deposits, characterization of heavy liquids derived from fossil fuels, and methods for improving the performance and utilization of asphalts.

\subsection{MORGANTOWN ERC (MERC)}

Research and development on coal and enhanced gas and oil recovery are major activities at MERC. A diverse program is carried out to develop technology for direct combustion and low-Btu gasification. of coal. Enhanced recovery of oil and gas is also being investigated as is in situ gasification of coal."

- Coal. Current studies involve operation of a fixed-bed coal gasifier and an accelerated hot gas cleanup effort at the pilot plant scale. Construction of the atmospheric fluidized-bed component test and integration unit, which was begun in FY 1977, will continue. Operation is scheduled to begin in FY 1980. In the direct combustion program, fouling and corrosion of fireside surfaces are being studied.

- Petroleum and Natural Gas. In FY 1979, characterization and resource inventory of U.S. natural gas reserves will continue with areas in Illinois, Michigan, and the Appalachian region being emphasized. Results of FY 1978 studies will be analyzed for major impacts on needed recovery technology. Additionally, the center provides technical oversight for DOE field demonstration projects on cnhanced oil and gas recovery. These activities will be continued in FY 1979. Environmental considerations will be emphasized, and efforts in the utilization of methane recovered from coal beds will continue. 
- In Situ Technology. Program objectives are to demonstrate new technology, including directionally deviated wells that can be combined to degasify, devolatilize, carbonize, and gasify relatively thin, deep eastern coal seams. In FY 1979, laboratory studies will be continued, longwall generator flow testing and techniques for reverse burn and forward burn will be completed.

\subsection{PITTSBURGH ERC (PERC)}

PERC is the largest Federal laboratory devoted solely to R\&D on coal. The center carries out a diversified program on coal including: basic research to obtain new knowledge of the chemical and physical properties and reactions of coal; conversion of coal to electricity and to clean-burning liquid and gaseous fuels; direct combustion of solids and coal-oil slurries; and environmental impacts arising from coal úsage.

- Coal. Major efforts are under way in the development of processes to liquify and gasify coal. Back-up research and technical direction are provided for the 75 tons/day Synthane coal gasification pilot plant. A 10 tons/day Synthoil process development unit is being operated to study the conversion of coal to low-sulfur fuel oil. In FY 1979, PERC will demonstrate continued process reliability, develop improved components, and obtain process design data for the scaleup of the Synthoil process. In the coal hydroliquefaction process using disposable catalysts, improved catalyst blends will be developed and tested. Additional research is being conducted on combustion of coal-oil mixtures, coal combustion in adiabatic diesel engines, development of a coal-fired two-stage gasifier-combustor to supply a high-temperature plasma for an MHD power plant, and on chemical coal desulfurization. Research is done on analytical techniques to sharaoterize cual and coal products. Other major products will be in the R\&D of technology in the Synthane process and in other advanced research and supporting technology. Environmental control technology, conservation, and safety of coal conversion processes will be studied intensively. 


\section{B. MINING OPERATIONS CENTERS (MOCs)}

The two Mining Operations Centers (MOCs) formerly under the Bureau of Mines Mining RD\&D program are recent additions to Fossil Energy in accordance with the Department of Energy Organization Act of 1977 - PL 95-91. These centers are currently being integrated into Fossil Energy in support of the Mines RD\&D Activity. A summary table of resource levels devoted to each MOC is provided in Table 7.

\subsection{CARBONDALE MOC}

Research at CMOC involves both surface and underground mining particularly with application to the mid-continent area. Emphasis is on the more effective use of standard equipment and improvement of present mining systems. In addition, novel developments for improved performance will be integrated into the mining work.

CMOC also provides technical assistance and support to Fossil Energy headquarters management in planning and implementing the Mines Research, Development, and Demonstration (MRD\&D) contract effort.

\subsection{PITTSBURGH MOC}

Research at PMOC emphasizes underground coal mining centered around mine development, room and pillar mining, panel mining, and haulage and advanced systems, however, surface mining R\&D work is also done to a lesser degree. PMOC has just completed a comprehensive, modern test facility for underground mining.

PMOC also provides technical assistance and support to Fossil Energy, headquarters management, in planning, implementing and monitoring the MRD\&D contract effort. In-house research efforts are also conducted on coal preparation and beneficiation research investigations aimed at improving the quality of coal prior to combustion or conversion. These investigations include the development of new techniques to: 1) reduce sulfur, ash and trace elements in runoff mine coals to acceptable levels prior to combustion and prior to conversion of coal to liquid or gas; 2) lower water content in washed coal; 3) recover fine coal in washery effluents; 4) remove organic sulfur by chemical dissolution; 5) improve properties of lignite by reducing moisture content and pelletizing; and 6) reduce the volume and change the character of plant wastes to minimize environmental degradation. 


\section{Table 7 Energy Research Center and Mining Operation Center Funding and Employment Levels}

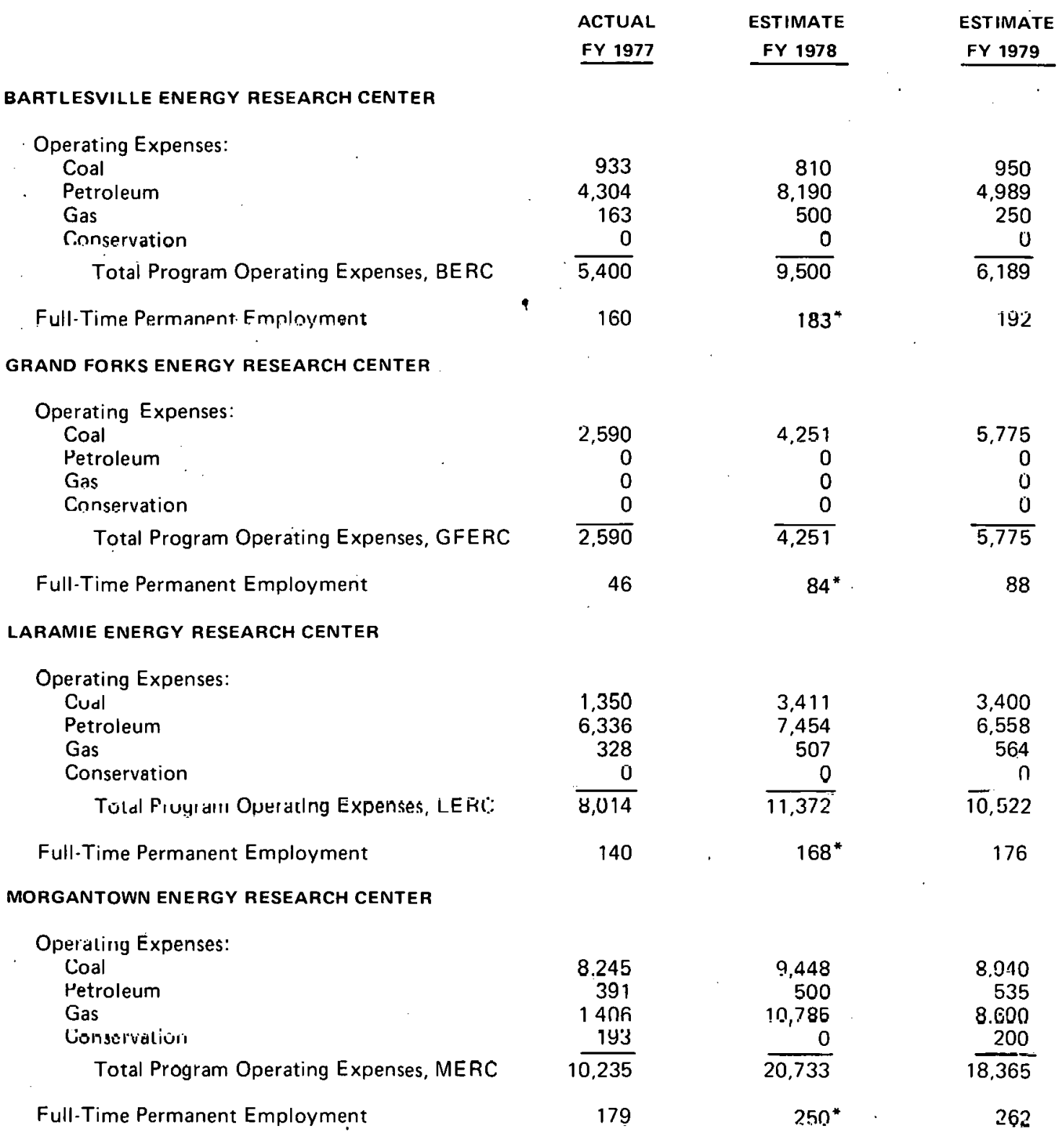




\section{Table 7 (Continued)}

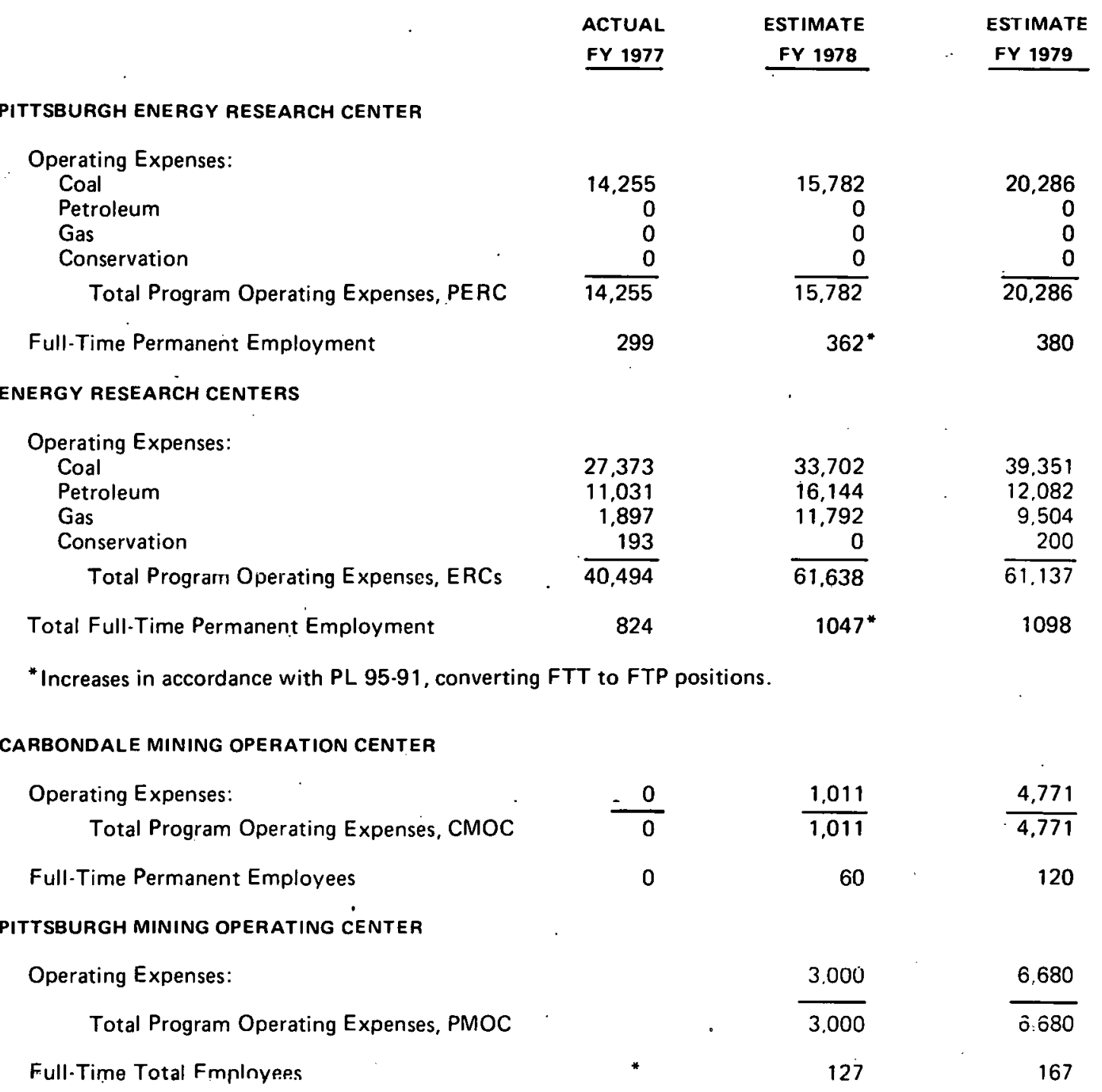

*PMOC was part of a larger center under the Bureau of Mines and was not considered separately. 


\section{NATIONAL LABORATORIES}

In addition to the significant contributions made by the Energy Research Centers and Mining Operations Centers to the overall Fossil Energy R\&D program, 11 National Laboratories provide supportive contributions. These DOE laboratories possess unique facilities and inhouse expertise which can contribute significantly in providing specialized task support to projects managed by Fossil Energy. These laboratories, like the ERCs, submit proposals for R\&D work relating to Fossil Energy development in their respective areas of expertise. Many of these proposals are accepted and provide significant benefits to the various Fossil Energy R\&D programs.

A brief summary of planned FY 1979 artivity in support of Fossil Energy programs is providen in the following 11 subsecliuns.

\subsection{AMES LABORATORY (AL)}

Ames Laboratory support concentrates on two basic research tasks: coal beneficiation alloy evaluation and development of fossil fuel plants.

\subsection{ARGONNE NATIONAL LABORATORY (ANL)}

Argonne's work focuses on the Coal Resource including a major effort on construction of the pressurized fluidized-bed (PFB) component test and integration unit (CTIU) as well as other sturies in fluidised"bed combustion in support of Combustion Systems Activity technology, and work on high temperature/pressure samplers (High-Btu Gásification). Argonne provides engineering support to the demonstration plant efforto, and has a second major effort in the MHD Component Development and Integration Facility as well as to other areas of open- and closed-cycle MHD technology and is involved in the US-USSR effort in MHD. Materials research for coal conversion processes is also included in ANL's task for Fossil Energy. Argonne also provides R\&D support for the Heat Engines and Heat Recovery and the Fuel Cell Activities.

\subsection{BROOKHAVEN NATIONAL LABORATORY (BNL)}

Brookhaven National Laboratory provides limiled basic research support in the coal R\&D area, specifically relating to flash liydropyrolysis of cual and regenerative processes for desulfurization of high-temperature combustion and fuel gases. Additional efforts in principal alternate fuel combustion and fuel cells are being conducted.

\subsection{IDAHO NATIONAL ENERGY LABORATORY (INEL)}

The Idaho National Energy Laboratory provides research support in the area of high-temperature materials. 


\subsection{LAWRENCE BERKELEY LABORATORY (LBL)}

LBL provides support for two task areas: research in hightemperature erosion/corrosion resistance materials development and tertiary recovery with mobility control and surface active agents for enhanced oil recovery

\subsection{LAWRENCE LIVERMORE LABORATORY (LLL)}

LLL is involved with supporting tasks in the massive hydraulic fracturing process for stimulating natural gas recovery. Supporting work in modified in situ oil shale recovery techniques and development of the packed-bed process for the In Situ Coal Gasification subactivity are also being accomplished at LLL. In addition, efforts in direct injected stratified charge engine combustion are being conducted.

\subsection{LOS ALAMOS SCIENTIFIC LABORATORY (LASL)}

LASL has two tasks planned for FY 1979 in the Oil Shale and In Situ Technology subactivities. Specifically, these efforts are explosively produced fracture of oil shale and in situ coal gasification of southwest coals with minimal water requirements. LASL also is investigating the explosive stimulation of natural gas and laser pyrolysis for characterization of Devonian shale, ceramic heat pipes and fuel cell transportation applications.

\subsection{MOUND LABORATORY (ML)}

The Mound Laboratory is providing technical support for the fuel gas demonstration plant project and has a project for characterization of Devonian shale.

\subsection{OAK RIDGE NATIONAL LABORATORY (ORNL)}

Oak Ridge is performing many support tasks in the areas of demonstration plants by providing technical assistance. Sevcral research support tasks primarily in materials and component development are also planned, along with coal liquefaction research support. In the Gas and the Petroleum Resources Activities, ORNL is providing support in the enhanced oil recovery and processing and utilization areas. ORNL is supporting In Situ Coal Gasification technology by pyrolysis of large coal blocks, the Heat Engines and Heat Recovery Activity, and molten carbonate fuel cell efforts.

\subsection{PACIFIC NORTHWEST LABORATORY (PNL)}

PNL has two tasks planned for FY 1979 involving hot gas cleanup with molten salt and an electrode/insulation program for MHD technology development. 


\subsection{SANDIA LABORATORY (SL)}

Sandia provides major support work for the Gas and Petroleum Resources Activities and In Situ Gasification subactivity. Other minor task support is being provided in the MHD and advanced power systems technology areas. Major efforts include work in the massive hydraulic fracturing technology for enhanced gas recovery and instrumentation; diagnostic, bed preparation work for in situ oil shale recovery and coal gasification; and offshore drilling technology development. In addition, studies on direct injected stratified charge engine combustion are being conducted.

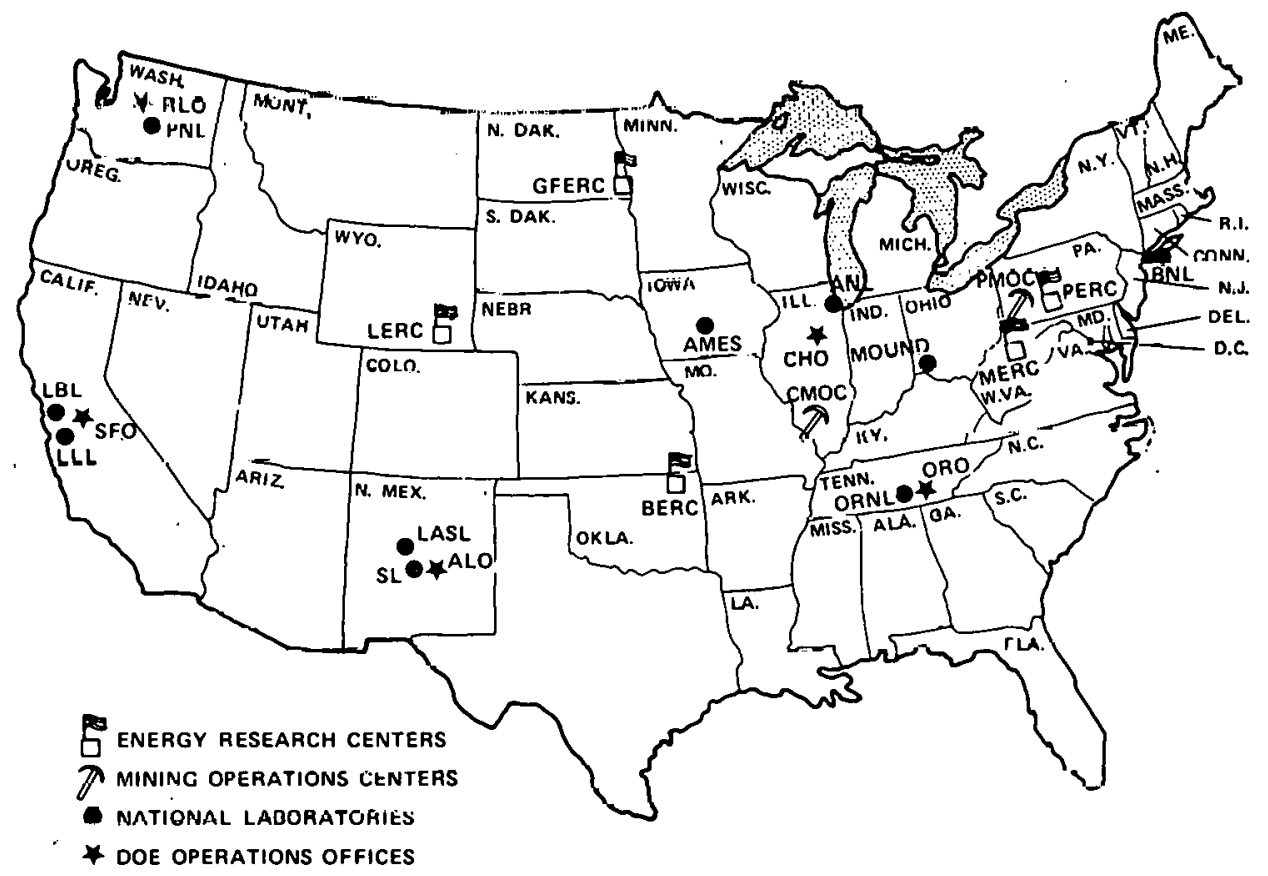

Figure 12 Location of DOE Fossil Energy Research Centers, Mining Operations Centers and National Laboratories 
Table 8

Fossil Energy Development

Energy Research Centers/Mining Operations Centers/ National Laboratories Support Activities

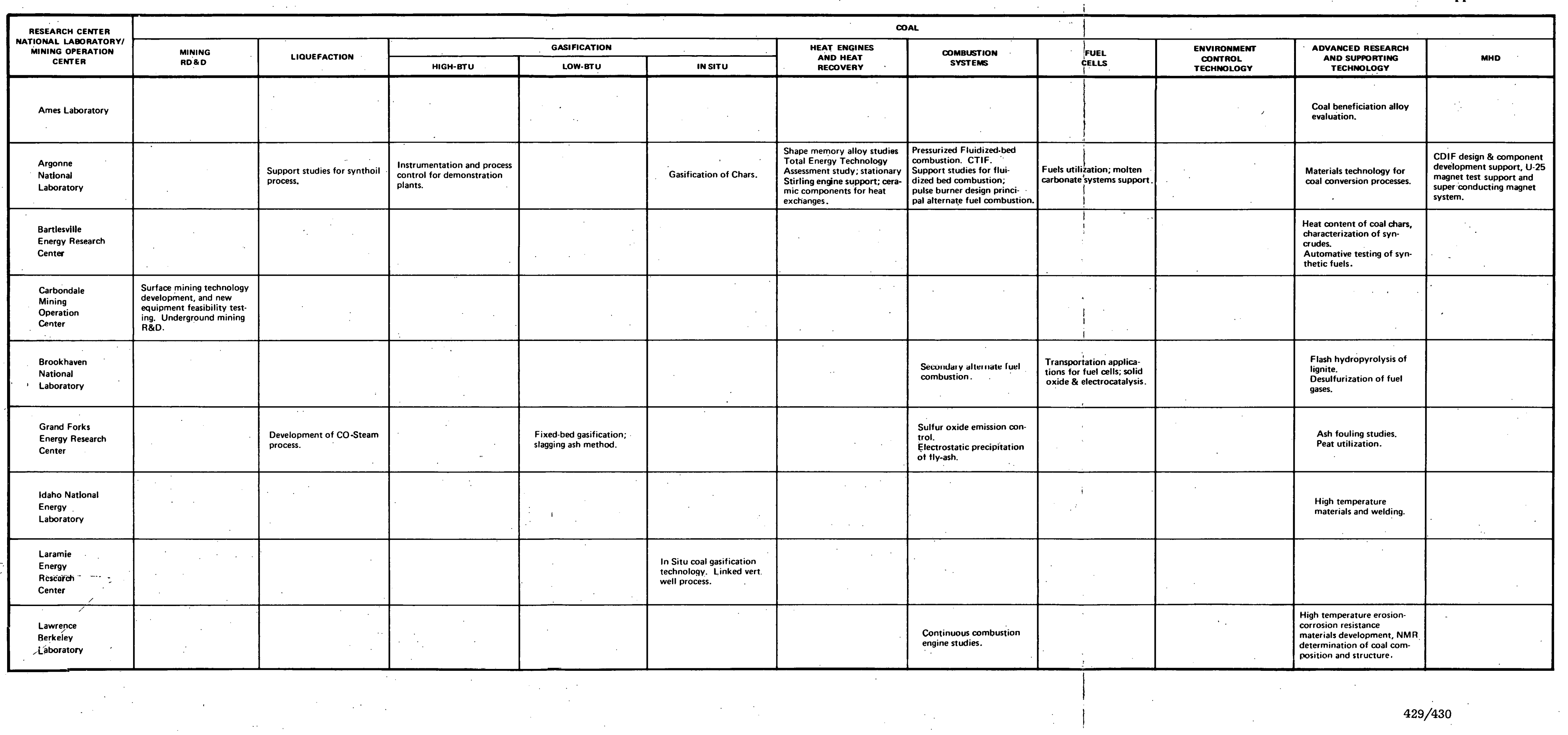




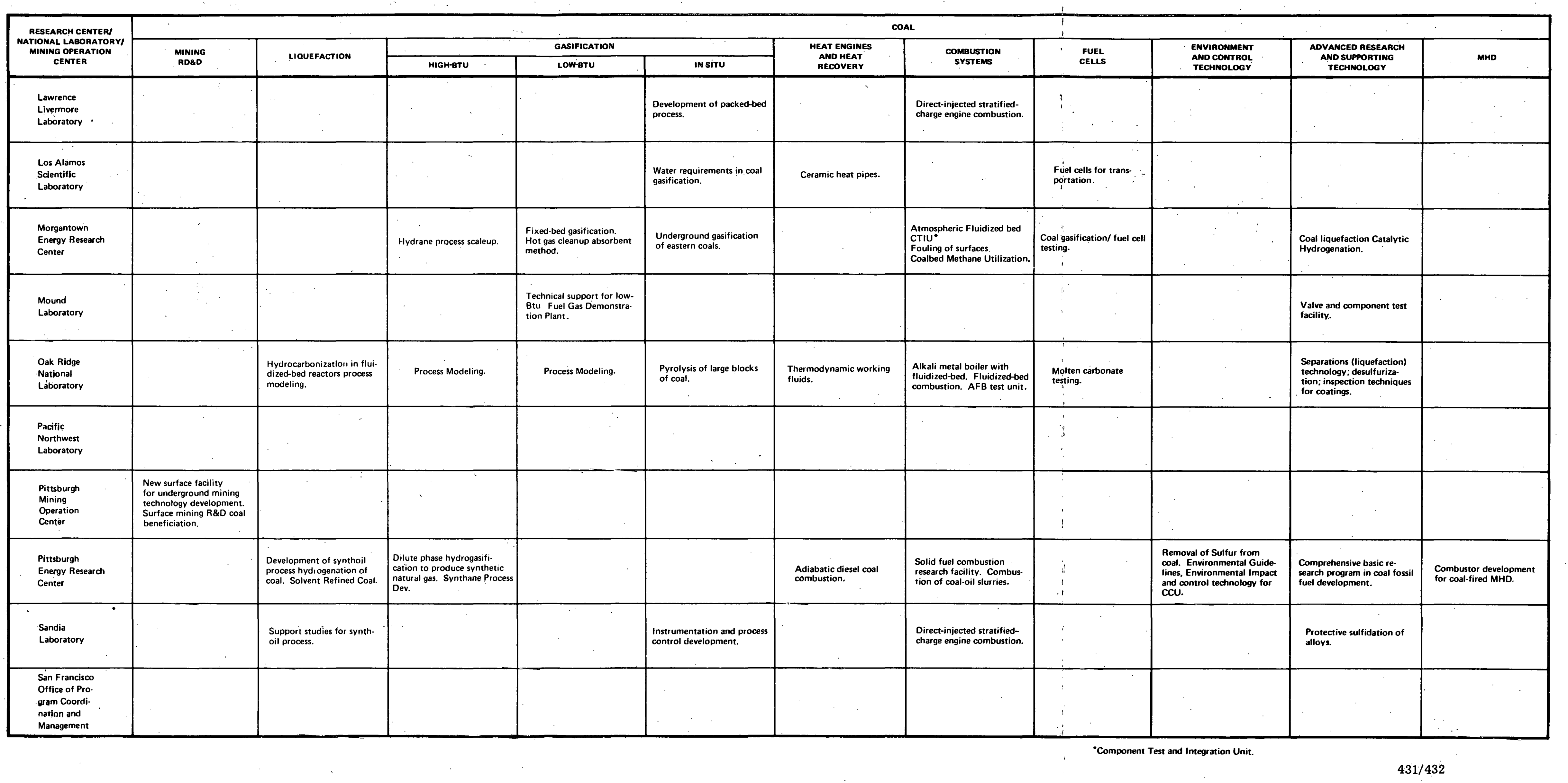




\begin{tabular}{|c|c|c|c|c|c|c|}
\hline \multirow{2}{*}{ 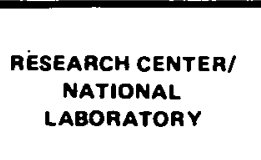 } & \multicolumn{4}{|c|}{ Petraoleum } & \multicolumn{2}{|c|}{ gas } \\
\hline & 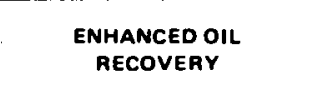 & 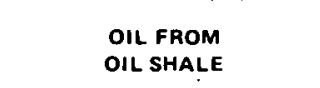 & 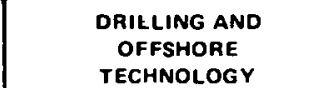 & 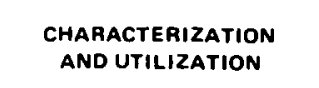 & 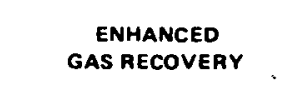 & 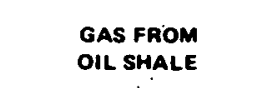 \\
\hline 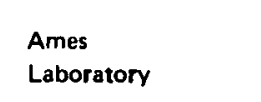 & & & & & & \\
\hline 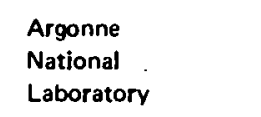 & & & & & & \\
\hline 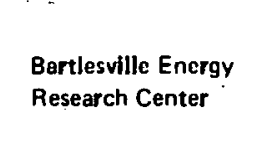 & 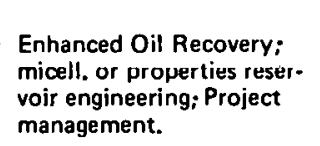 & & 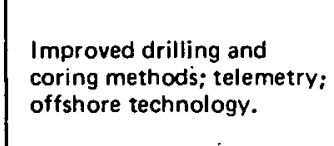 & 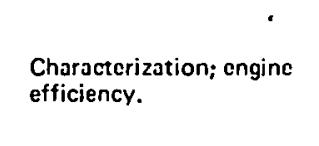 & 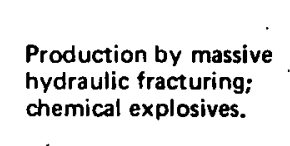 & \\
\hline 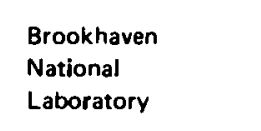 & & & & & & \\
\hline 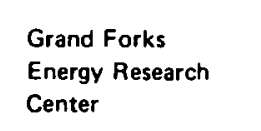 & & & & & & \\
\hline 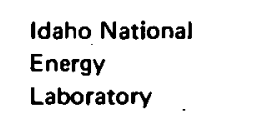 & & & & & & \\
\hline 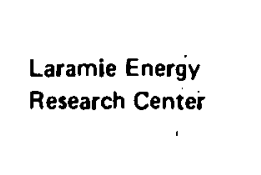 & 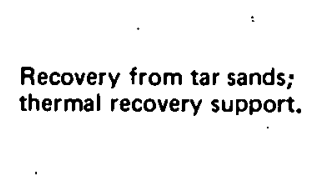 & 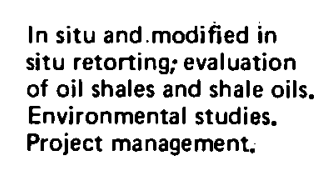 & & 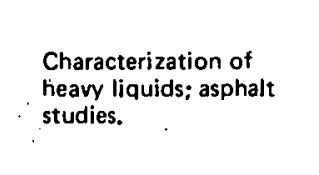 & & 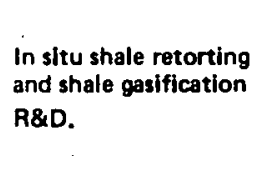 \\
\hline $\begin{array}{l}\text { Lawrence Beretery } \\
\text { Laboratery. }\end{array}$ & 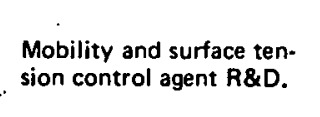 & 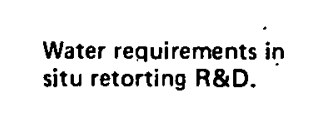 & & & & \\
\hline 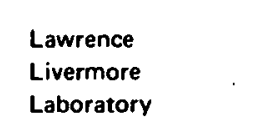 & & 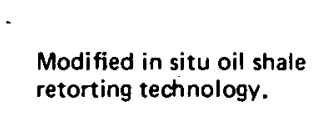 & & & 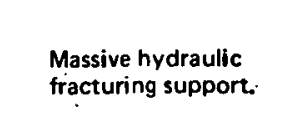 & \\
\hline
\end{tabular}

\begin{tabular}{|c|c|c|c|c|c|c|}
\hline \multirow{2}{*}{ 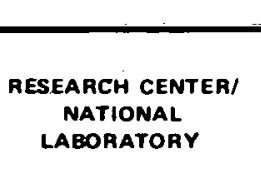 } & \multicolumn{4}{|c|}{ efraolecum } & \multicolumn{2}{|c|}{ cas } \\
\hline & 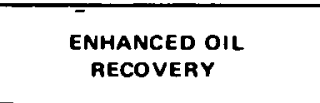 & $\begin{array}{l}\text { Oill from } \\
\text { Ool state }\end{array}$ & 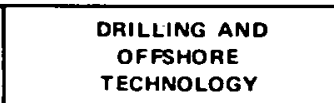 & 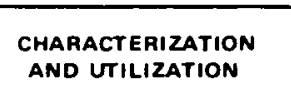 & 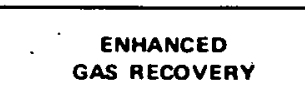 & 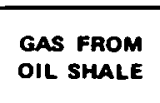 \\
\hline 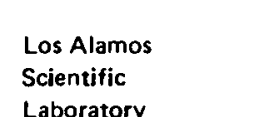 & & $\begin{array}{l}\text { Exololivit tracturing } \\
\text { ReD }\end{array}$ & & & 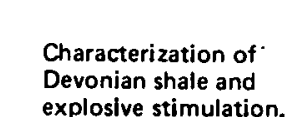 & \\
\hline 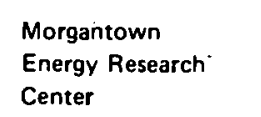 & 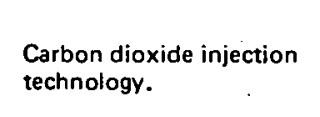 & & & & 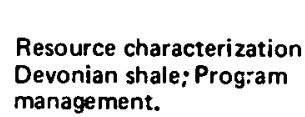 & \\
\hline Mound Laboratory & 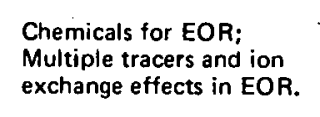 & & & & 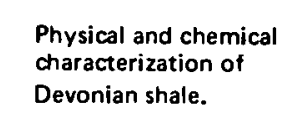 & \\
\hline 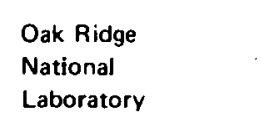 & & 1 & & & & \\
\hline 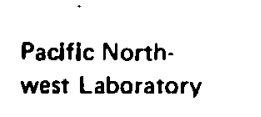 & & & & & & \\
\hline 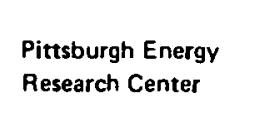 & & & & & & \\
\hline $\begin{array}{l}\text { Sandia } \\
\text { sacosartor }\end{array}$ & & 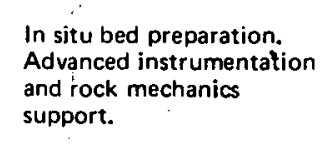 & 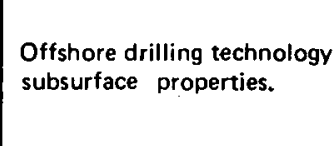 & & 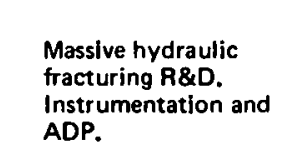 & \\
\hline 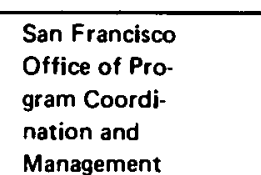 & 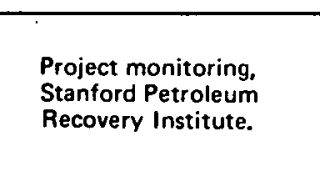 & & & & & \\
\hline
\end{tabular}




\title{
VII. UNIVERSITY ACTIVITIES
}

\author{
A. OVERVIEW
}

Fossil Energy's University Activities program has two principal objectives :

1. To ensure the foundation for innovative technology through the use of the capabilities and talents in our academic institutions

2. To provide an effective, two-way channel of communication between the Department of Energy and the academic community to ensure trained technical manpower is developed to carry out basic and applied research in support of DOE's mission.

The nation's current energy situation requires that the academic community play a critical role in both energy-related research and in training our young people for future manpower demands. Universities and colleges, both large and small, have been called into play through:

- Sponsorship of meritorious projects through our unsolicited proposal system: provides engineering, scientific, and base line data that can be useful in explaining and developing processes related to Fossil Energy goals and objectives.

- Sponsorship of faculty and student participation programs through the country: provides summer salary support for college professors, as well as students, to perform research of mutual interest at an Energy Center.

- Starter Grants Program: provides investigations related to longer-ranged objectives. They are used to explore potentially useful, but higher risk technical processes.

- Teacher Workshops and Summer Institutes: provides educators with up-to-date information on the nation's energy problems and assists them with the development of educational materials for classroom use.

- University Rotator Program: acquaints university faculty with the administrative operations and management objectives of the Fossil Energy Program. 
There has been a constant interchange of information. New areas of research have been identified. New and improved technologies have been developed; all as a direct result of the close association developed between the academic community and the Federal government. Examples of accomplishments produced by this interchange with colleges and universities are:

- Improved data and models obtained for flash hydrogeneration of coal (City College of New York and Massachusetts Institute of Technology)

- Expanded Coal Sample Bank and Data Bank to 900 samples for use of all Fossil Energy contractors (Pennsylvania State University)

- Coal-uil-water mixtures found to have improved combustion properties due to mini-explosions of water droplets (Adelphi University)

- Improved techniques found for analysis of coal-derived liquids by mass spectrometry and nuclear magnetic resonance (Oklahoma State University and Virginia Polytechnic Institute)

- A waste material (gasifier bottom ash) found to be effective and easily regenerated sorbent for removal of sulfur from low-Btu gases (University of Kentucky)

- Honeycomb catalyst supports shown to be promising for treatment of coal-derived liquids (Oklahoma State University and State University of New York at Buffalo)

- 'l'eshniques developed for reduction of nitrogen uxides frum combustion of coàl (University of Arizona)

- More selective catalysts found for the production of LNG hydrocarbons from carbon monoxide and hydrogen (University of Utah). 
A map indicating the relative geographical location of university work supporting the Fossil Energy activities is provided below.

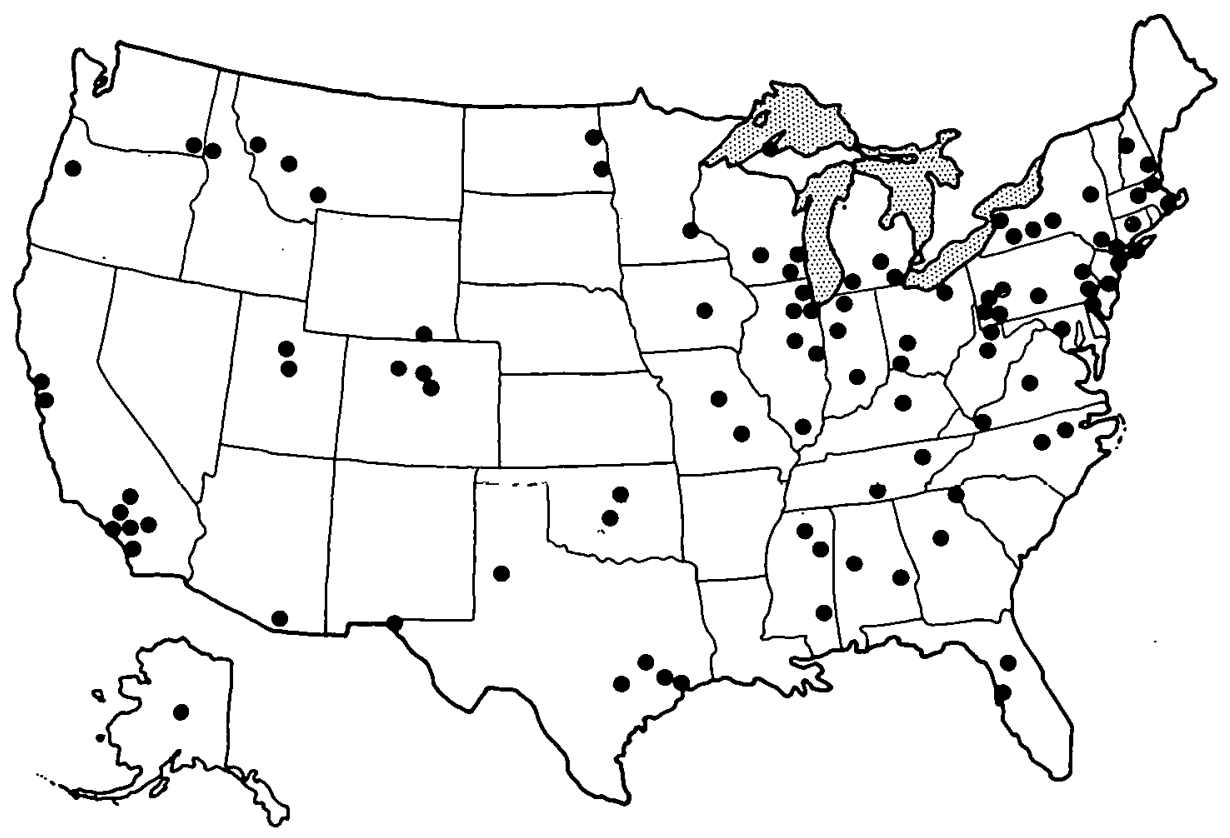

\section{University Activities}

The University Activities program is administered by the Office of University Activities (OUA). The OUA functions primarily in direct administrative support of the research objectives of the major Fossil Energy technology divisions through joint management of major university research and development programs totalling over $\$ 30$ million. An FY 1978 University program profile is provided in the figure below.

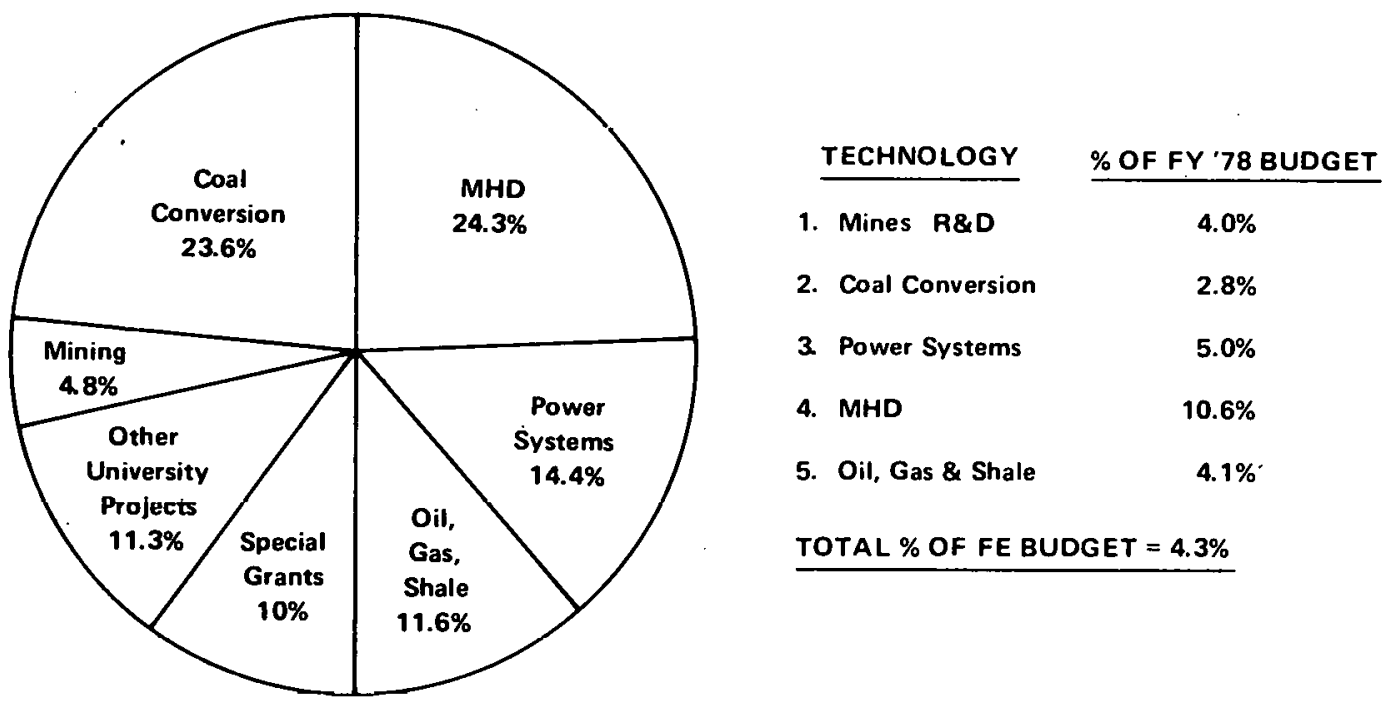

Fussil Energy University Activitles Program 


\section{B. COAL LABORATORIES (PL 95-87)}

The enactment of the Surface Mining Control and Reclamation Act of 1977 (Public Law 95-87) authorizes $\$ 30$ million in FY 1979 for the establishment of ten coal research laboratories in universities. The Office of University Activities has the responsibility for administration of all matters concerned with the selection and operation of these laboratories. In the initial stages, this includes the establishment of an ad hoc task force in the Fossil Energy Program to develop, in consultation with the National Academy of Engineering, adequate criteria for selection of the universities to run the laboratories.

These laboratories at universities will allow the application of interdisciplinary approaches toward the complex problems anticipated in the expanded use of coal; will train the skilled manpower necessary to develop fossil energy resources; and will serve to demonstrate the magnitude of the commitment of the Federal government toward developing domestic energy supplies. 


\section{ENVIRONMENTAL AND SOCIOECONOMIC IMPLICATIONS}

Energy technology seeks to advance the availability of environmentally and socially acceptable energy resources. The strategy to achieve this goal incorporates independent activities conducted within each ET program and close cooperation among ET and its industrial partners, the office of the Assistant Secretary of Environment, Federal, state and local regulatory agencies and the public.

The Fossil Energy (FE) strategy recognizes the need to develop, on an urgent basis, a broad range of environmentally sound technology options for utilizing domestic fossil energy resources. This means that the technology should have acceptable impacts on the physical and biological environment, protect the health and safety of workers and the public, enhance the socioeconomic values, especially for the communities most affected and should contribute to the high efficiency of energy production and use. Consequently, environmental, health and safety, and socioeconomic issues associated with the operation of fossil energy processes are identified as early as possible, and research projects are developed to resolve these issues.

FE conducts four basic types of environmental activities: policy analysis, planning, National Environmental Policy Act (NEPA) compliance and operations. Generally, these environmental activities are directed toward areas which develop new knowledge in FE chemistry, materials, technology, processing, engineering, analysis, sampling, worker management and protection, and property management and protection. In this context, the term "environmental" refers to health and safety, socioeconomic, and energy process conservation issues as well as the physical impact of processes on the environment.

The results of the environmental policy analysis activities serve as input to the technology goals. FE sponsors studies which consider how current and emerging laws, standards and regulations impact its programs and technologies and the potential for commercialization. The technical performance, resource requirement, and economic information resulting from such studies is used to review new regulations and is exchanged with regulatory agencies:

NEPA requires that an environmental impact statement (EIS) be prepared for each major Federal action which could have an adverse effect on the human environment. FE prepares environmental impact assessments for all field projects; EISs are prepared for all demonstration projects and other projects which could have major environmental impact or are considered controversial. In addition, $\mathrm{FE}$ must consider the cumulative impacts of the programs and the ultimate commercialization of the technologies; these topics are addressed in programmatic environmental impact statements. Finally, FE reviews NEPA documents prepared by other DOE offices and other agencies. 
Planning activities are carried out at both the programmatic and project level to assure that environmental problems are addressed at the earliest possible point. Programmatic considerations are addressed in the Environmental Development Plans (EDPs) prepared for each activity. FE planning activities address the ability of FE projects to meet current environmental requirements, the development of technical resource, and economic performance information about $\mathrm{FE}$ technologies for input into future regulatory decisions.

During the project planning, procurement and design phases, the environmental impacts of the proposed plant, including plans for the disposal of wastes resulting from the operation of the plant, are analyzed and considered in evaluating the proposed project's potential.

Since environmental performance is considered an integral criterion of technology performance, monitoring is initiated prior to construction and continued through the operational phase to verify the true impacts on the environment. Sampling and monitoring activities encompasses both compliance oriented data collection and special projects to determine whether new pollutants are introduced into the environment. Projects are carried out under representative environmental conditions so that an adequate assessment of their consequences can be made. Processing conditions are varied to obtain adequate environmental, safety and health, and resource efficiency data. Environmental and safety control technology is developed when adequate technology does not exist.

Implementing the environmental strategy requires coordination between FE and its industrial partner. To facilitate this coordination, selected responsibilities are assigned to each of the co-sponsors. FE establishes the criteria necessary to carry out these activities, reviews and approves the environmental protection plan prepared by the industrial partners, monitors the effort and undertakes supporting and complementary research to assure the completeness and validity of the information being gathered.

Within FE, the technology divisions and the Office of Environmental Activities (EA) conduct complementary projects. The technology divisions are primarily responsible for site specific activities. The office of Environmental Activities supplements and coordinates the activities of the technology divisions.

The primary goal of the Office of Environmental Activities is to help ensure the environmental acceptability of FE technologies by working to attain these specific objectives:

- Incorporation of environmental activities, including health, safety, and socioeconomics, into FE funding proposals

- Full consideration of environmental values when projects are selected from among competing alternatives for FE funding

- Compliance by FE program projects with applicable Federal and state environmental laws 
- Collection and interpretation of environmental data to provide a basis for future environmental regulatory decisions.

Increased efforts to analyze major environmental policies will be needed if FE is to be successful in projects with early pay-off potentials. The desire to rapidly commercialize such technologies frequently is thwarted by unanticipated constraints due to environmental regulations or standards. In particular, increased utilization of coal, as proposed in the National Energy Plan, requires increased attention to the environmental and health implications. New legislation also requires increased analysis. For example, work to understand the implication of new standards of performance and offset policies, as prescribed by the Clean Air Act Amendments of 1977, is already well under way, additional resources, however, will be needed to understand the implications of policies such as the prevention of significant deterioration. Preliminary analyses of provisions of the Toxic Substances Control Act, the Resource Recovery and Reclamation Act, the Water Pollution Control Act, and others are also under way, but these efforts will need to be intensified as the performance of $\mathrm{FE}$ processes becomes better understood or new regulations are proposed.

Preparation of the EDPs and assisting the technology programs in planning the environmental portions of their budgets will continue to be high priority projects for EA in FY 1979. EDPs are the principal planning mechanism for coordination of planning activities at the activity level. EDPs examine the environmental impacts of the energy system, define the uncertainties and assess the current knowledge about those impacts, and identify areas for further research. The information developed in the EDP process is used to structure alternative projects for addressing the environmental problems associated with a given process and then assist the project managers in selecting methods of resolving these problems.

Current NEPA compliance activities emphasize completion of the Final Coal RD\&D, EIS, and the initiation of draft programmatic EISs for the Eastern Gas Shales Project, the Enhanced Gas Recovery Activity, the Enhanced Oil Recovery Activity, and the Oil Shale Project. The site specific EISs for 10 Enhanced Oil Recovery projects will also be completed this year. During FY 1979, the major thrust of the NEPA compliance activities will be completing the final EISs for the four programmatic statements initiated in FY 1978.

Activities for support to the FE Technology Divisions include participation on project teams for FE demonstration plants at all stages of project development as well as reviewing all environmental, health, and safety activities. Potential sites for fossil demonstration plants are analyzed to evaluate the environmental and socioeconomic impacts. 
Programs to develop an integrated approach to potential occupational health problems associated with FE development have been initiated. Several projects are under way to develop environmental guidelines and review criteria for site evaluations for pilot, demonstration, and commercial-scale projects. As program development and project support activities proceed, additional issues for study are identified. Such studies may relate to the development of environmental control technology, the resource requirements of $\mathrm{FE}$ projects, the need for additional monitoring activities and characterization studies; and the impact of FE technologies on health, the environment, and the socioeconomic structure of the communities involved. A high priority effort for FY 1979 will be the initiation of worker protection and worker health data collection programs at key sites. 


\section{INTERNATIONAL PROGRAMS}

Increasing world-wide competition for finite energy supplies has extended traditional concepts of resource development to include international cooperation in the search for energy sources. It has been acknowledged that a rate of growth of energy supply lower than energy demand will tend to produce competition among the countries of Western Europe, Japan and North America. This competition could well be intensified if, as some estimates indicate, the U.S.S.R. and those East European countries who rely on Soviet energy resources also enter the international energy market.

Recognizing the urgency of this situation, the United States is seeking to expand world energy production while simultaneously planning to cultivate its own self-sufficiency. Initial expansion of world energy supplies requires U.S. involvement in overseas exploration and sales of technology, such as the North Sea ventures currently under way. For the long run, government and industry are cooperating in those international R\&D activities that hold promise for expanding world energy supplies and for utilizing them more efficiently. In support of these missions, DOE/FE seeks to establish international agreements for cooperation in R\&D efforts. Such agreements will enhance domestic and foreign efforts by:

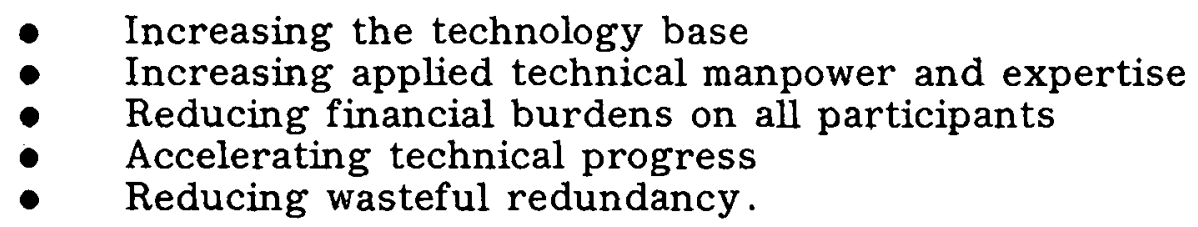

Cooperation may be bilateral, multilateral, or government/industry, and may take the form of information or personnel exchange; equipment loan or exchange; sharing of work at existing experimental facilities; joint construction and operation of facilities or experiments; activities involving a coordinated program but conducted by national teams in their own country; or a combination of one or more of the above.

Increased efforts are also under way in coordinating the planning of broad areas of various national R\&D programs to assure maximum complementarity between them while not sacrificing any special strengths or the pertinence of a nation's efforts to its own needs.

A complete listing of ongoing DOE/FE formal multilateral and bilateral activities and a summary of cooperative programs are given below. In addition to these ongoing activities, $\mathrm{DOE} / \mathrm{FE}$ is exploring possibilities of cooperation with the Less Developed Countries (LDC), and expanding our international cooperative activities in the fields of oil, gas and other fossil resources production and utilization technologies. 


\begin{tabular}{|c|c|}
\hline \multicolumn{2}{|c|}{ DOE/FE INTERNATIONAL ACTIVITIES } \\
\hline PARTICIPANTS & ACTIVITIES \\
\hline US-IEA & $\begin{array}{l}\text { 1. Pressurized Fluid-Bed Combustion Project* } \\
\text { 2. Mining Technology Clearing House } \\
\text { 3. Economic Assessment Service } \\
\text { 4. Technical Information Service } \\
\text { 5. National Planning Coordination in Coal } \\
\text { Hydrogenation Technology } \\
\text { 6. Cooperation in Coal Technology Development } \\
\text { 7. Energy Conservation/Combustion Project } \\
\text { 8. Energy Conservation/Heat Transfer Project }\end{array}$ \\
\hline US-UK & $\begin{array}{l}\text { 1. Coal Utilization } \\
\text { 2. Coal Mining }\end{array}$ \\
\hline US-Bergbau Forschung & 1. Coal Mining \\
\hline US-USSR & $\begin{array}{l}\text { 1. MHD* } \\
\text { 2. Oil } \\
\text { 3. Natural Gas } \\
\text { 4. Coal }\end{array}$ \\
\hline US-Poland & $\begin{array}{l}\text { 1. MHO } \\
\text { 2. Coal Liquefaction } \\
\text { 3. Combustion of Synthetic Fuels } \\
\text { 4. Coal Mining and Preparation }\end{array}$ \\
\hline
\end{tabular}

*

Largest Activities 


\section{A. UNITED STATES-INTERNATIONAL ENERGY AGENCY (IEA)}

The International Energy Agency, established at U.S. initiative in 1974 to promote the development of secure energy supplies, has undertaken an extensive program in the development of energy technologies for the utilization of a wide range of resources. The Department of Energy/Fossil Energy has been actively participating in development and implementation of cooperative IEA programs in the area of Coal Technology .

In 1975, five multilateral agreements in this area were signed by the interested IEA member countries; as the United States representative, $\mathrm{DOE} / \mathrm{FE}$ participates in the following four:

- Pressurized Fluidized-Bed Combustion

- Economic Assessment Service for Coal

- Technical Information Service

- Mining Technology Clearing House.

In October 1977, two bilateral commitments were concluded under IEA auspices between the United States and the Federal Republic of Germany:

- Memorandum of Understanding for National Planning Coordination in the Field of Coal Hydrogenation Technology

- Letter of Intent for Cooperation in Coal Technology .

Seven multilateral agreements in Energy Conservation have been established and DOE/FE participates as United States representative in two:

- Combustion

- Heat Transfer.

Responsibility for the development of Coal Technology cooperative programs has been delegated to the IEA Working Party on Coal Technology (WPCT) by the IEA Committee on Energy Research and Development. The WPCT is currently developing additional cooperative programs, and $\mathrm{DOE} / \mathrm{FE}$ is actively participating in this planning activity.

The multilateral IEA Coal Technology programs are implemented by a specially created (formal) organization, the U.K. National Coal Board (NCB), IEA Services, Ltd. Although this organization is legally a subsidiary of the $\mathrm{NCB}$, it is funded entirely by the IEA members participating in various (coal). projects. The United Kingdom is the lead country for these coal programs. The policy and program of work for each project are controlled by an Executive Committee (EC) consisting of one member from each participating country. The EC meets biannually to approve work programs and budgets and to review progress. Technical committees, with members appointed by each EC member, provide support to the ECs. 
Implementation procedures for the U.S.-Federal Republic of Germany (FRG) bilateral commitments are in the developmental stages.

The United States is the lead country for the Combustion project, and the United Kingdom is the lead country for the Heat Transfer project.

\subsection{FLUIDIZED-BED COMBUSTION}

(Participating Countries: United States, United Kingdom, and Federal Republic of Germany.)

The major objective of this program is to design, build, and operate a flexible experimental facility (at Grimethorpe, Yorkshire, U.K.) for investigating combustion, heat transfer, corrosion, and energy recovery in pressurized fluidized-bed systems, which require more advanced technologies than systems operating at atmospheric pressure. The facility also provides for the later addition of an $85 \mathrm{MW}$ gas turbine. Results from these experiments will be used in the design of commercial-scale pressurized fluidized-bed combustion plants.

The duration of the project is 8 years (1975-83), with start of plant construction in late 1977, operation by early 1980 , and with construction and operating costs to be shared equally by the United States (DOE/FE), the United Kingdom, and the Federal Republic of Germany. The experimental program will make use of coals from the U.S., the FRG, and the U.K., in a test program now being decided upon by the participating nations. A a full participant of the IEA project, DOE/FE will have complete access to the plant's design and performance data through drawings, reports, operating logs, as well as through direct participation in all aspects of the program.

The accomplishments as of the end of 1977 are:

- Basic plant design completed

- Detailed design of plant in progress

- Long lead major components ordered.

Argonne National Laboratory will participate in the design of probes, instrumentation and control systems.

- Initial site work clearance done (hole in the ground, chimney let)

- Initial coals to be tested have been chosen

- Details of experimental program are being developed

- Commissioning tests are scheduled to start February 1979. The facility will be ready for experiments two to three months later. 


\subsection{ECONOMIC ASSESSMENT SERVICE FOR COAL}

(Participating Countries: United States, Canada, Federal Republic of Germany, Italy, Netherlands, Spain, Sweden, and United Kingdom.)

The aim of the Economic Assessment Service (EAS) is to evaluate world-wide potential uses of coal, both to assess the likely impact of current and projected conversion and utilization technologies and to facilitate formulation of new R\&D projects by member countries.

The future use of coal in international commerce depends greatly on its availability by type to the various countries seeking to utilize it, and on the pollution control regulations they have in effect or are likely to establish. Given this context, the job of EAS is to analyze the many economic/technical studies completed by many competent organizations in various countries, to understand the results free of the particular context in which they were performed. The results can then be applied to the particular economic circumstances of other member countries.

By March 1979, a series of reports will be issued to member countries and as a result, EAS will have:

1. Reviewed the status and performance of coal conversion technology and pointed out the strength, doubts, and areas of concern in process operation. (Report: Parts II-IV already issued.)

2. Reviewed economic and financing conventions in different countries and indicated a central view for comparison of different processes. (Report: Part I already issued.)

3. Calculated for the circumstances of different countries' relative costs of different forms of secondary energy from coal (study in progress.)

4. Reviewed the likely world-wide availability and broad costs of coal up to the year 2000, taking in to account not only the declared intentions of major nations, but also the likelihood of these intentions being realized. (Study in progress, first report already issued.)

5. Studied future trends in transport costs, and the possible constraints of transport costs on coal trade. (Study in progress.)

6. Presented a view on the demand for coal in various uses, taking account of the likely costs of coal-based energy in relation to other primary energy. (Study to be carried out.)

7. Presented a view of some of the pollution problems associated with coal use. (Report on sulfur-oxides produced, the rest of the study is in progress.) 
The expenditure incurred in the operation of the Economic Assessment Service is borne by the contracting IEA countries in the following proportions: Canada $(3.2 \%)$, Germany $(18.0 \%)$, Italy $(3.2 \%)$, Netherlands $(2.8 \%)$, Spain $(4.0 \%)$, Sweden $(2.6 \%)$, U.K. (17.2\%), and U.S. DOE $(49.0 \%)$. The duration of this agreement is three years (1975-1978) subject to renewal. The renewal option will be considered in the spring of 1978 .

\subsection{TECHNICAL INFORMATION SERVICES}

(Participating Countries: United States, Austria, Belgium, Canada, Federal Republic of Germany, Italy, Japan, Netherlands; Spain, Sweden, and United Kingdom.)

The objective of the Technical Information Service ('TIS) is to report on developments in coal technology world-wide and to facilitate exchange of information between participating countries. The essential basis for the Tis is a central information storage and retrieval system. This is being established in the form of a computerized data base, with input of abstracts from member countries covering appropriate areas of interest, either in the form of computer tape, already indexed for retrieval, or in printed form, which in some cases will require translating and/or indexing. Once the TIS data base is established, a monthly Abstract Journal will be produced automatically using a computerized printing technique.

Upon the establishment of the data base and Abstract Journal, the service to be supplied by TIS will fall into two broad categories; answering inquiries for information on any particular aspect of coal technology from members; and the preparation of critical surveys in areas of particular interest. The latter will be initiated by members and by TIS. Additional project activities will be to report on existing information services relating to coal science and technology in member countries, to produce and maintain an active register of ongoing rescarch in coal science and technology, and to publish a regular news bulletin.

Progress in developing the data base (central storage and retrieval system) from selected international journals and other sources is proceeding well. Development of the monthly current awareness Abstract Journal is on schedule.

The expenditure incurred in the operation of the Technical Information Service for the first three years shall be borne by the contracting countries in the following proportions: Austria (2.0\%), Belgium (2.9\%), Canada $(3.6 \%)$, Germany $(13.9 \%)$, Italy $(2.3 \%)$, Japan (6.1\%), Netherlands (2.0\%), Spain (2.9\%), Sweden (1.9\%), U. K. (13.4\%), U.S. $(49.0 \%)$. The duration of this agreement is three years (1975-1978) subject to renewal. 


\subsection{MINING TECHNOLOGY CLEARING HOUSE}

(Participating Countries: United States, Belgium, Canada, Germany, Italy, Spain, and the United Kingdom.)

Under the 1977 Energy Reorganization Act, this cooperative activity has been transferred to DOE/FE from the Bureau of Mines. The basic aim of the Mining Technology Clearing House (MTCH) Service is to collect, collate, and disseminate information on research and development in all aspects of coal mining (both surface and underground) and coal preparation technologies, including the improvement of operational efficiency and safety and health; research in the physics and chemistry of coal; and demonstration of new methods and equipment. As it develops, the Service will cover all relevant $R \& D$, arrange contacts between experts in particular disciplines, and assist in the formation of new cooperative projects.

Initially, the Mining Technology Clearing House program is aimed at establishing a series of Project Registers of ongoing . work and at investigating the situation of certain technical subjects in member countries.

The Registers currently being compiled are of four technical fields:

1. Mechanized drivage of roads, slopes, and shafts

2. Coal seam exploitation techniques

3. Monitoring and control of mining systems and machines

4. Reliability of equipment.

Technical investigations cover an equally wide range:

1. Underground transport of solids

2. Optimization of cutting techniques

3. Transport (trackless) of men and materials

4. Mining methods to improve in-seam recovery

5. Certification of equipment for underground use.

\subsection{NATIONAL PLANNING COORDINATION IN THE FIELD OF COAL HYDOGENATION TECHNOLOGY AND 6.0 COOPERATION IN COAL TECHNOLOGY}

(Participating Countries: United States and Federal Republic of Germany.)

Detailed implementation guidelines are being developed for these new cooperative R\&D activities between the U.S. and the Federal Republic of Germany. The objective of the National Planning Coordination effort is to eliminate duplication of $R \& D$ efforts in the field of coal hydrogenation technology. Cooperation in Coal Technology will involve our participation in German experiments in coal conversion facilities, and German participation in our planned coal conversion pilot plant. 


\subsection{COMBUSTION}

(Participating Countries: United States, United Kingdom, and Sweden)

In 1976, energy conservation in combustion was established as a separate project area with the objective of improving. the energy-efficiency of combustion technologies and developing the fuel-switching capability of combustion equipment. Cooperative research and development efforts and information exchange among participating parties are currently under way.

In March 1977, an implementing agreement and an annex entitled Energy Conservation in Combustion were signed. The contracting parties will investigate methods for improving the information, instrumentation, and calculating procedures used in the design, manufacture, and operation of combustion equipment.

Within the agreement, three specific areas for investigation have been identified: (1) combustion systcm modcling; (2) inctrumentation and studies of fundamental processes in combustion; (3) and resource exchange. In accordance with the provisions of the implementing agreement, US/DOE and UKAEA have accepted responsibility for the first task, all members of the executive committee are undertaking aspects of task 2 , and US/DOE and UKAEA will assume responsibility for task 3.

Research in combustion-system modeling is directed toward developing combustion technology for engines and furnaces. In the work related to fundamental processes in combustion, participants will develop instruments and experimental techniques for measuring fundamental parameters and properties of combustion systems, and investigate the basic physical phenomena relevant to the combustion process. The purpose of the third area, resource exchange, is to provide for information exchange among the contracting parties on such subjects as the objectives and results of past programs, numerical analysis methods, laboratory analysis, and experimental test facilities.

\subsection{HEAT TRANSFER}

(Participating Countries: United States, United Kingdom, Sweden, alld Bwil.rerliald.)

The participants in the heat transfer project are seeking, through cooperative R\&D and information exchange, to improve the design and operation of heat-transfer systems, particularly heat exchangers, as a means of conserving fuel. The specific objectives of the project are to: (1) increase the efficiency of thermal-energy conservation through the development of more effective heat-transfer systems; (2) reduce free energy loesee in procesees by facilitating the operation of heat-exchange systems at reduced temperature differences without unacceptable capitalcost requirements; and (3) investigate mechanical and other design constraints to the achievement of higher thermal efficiencies. 
An implementing agreement and annexes to cover research in each of three project areas (i.e., extended-surface heat transfer, optimal design of heat-exchanger networks, and heat-exchange tube vibration) were signed in June 1977 . The executive committee recently decided to organize additional research in the three designated project areas.

\section{B. UNITED STATES-UNITED KINGDOM}

On January 24, 1974, an International Agreement covering both coal mining and utilization technologies was executed by the Department of Interior with the National Coal Board of Hobart House, England. The Agreement was written for a three-year period, with an automatic extension for future periods of two years each and a provision for discretionary termination by either country.

Under the Energy Reorganization Act of 1974, the coal utilization program was transferred to the Department of Energy/Fossil Energy. The mining technology program is in the process of being transferred to DOE/FE under the Energy Reorganization Act of 1977.

\subsection{COAL UTILIZATION}

The coal utilization program activity includes exchange of personnel, equipment, research material, and basic information on all aspects of utilization of coal from resource identification to end-use. Both countries have nominated correspondents to cover specific fields in R\&D coal utilization and problems associated with disposal and use of by-product materials. Joint activities have been established in several areas (for example, in the development of monitoring instruments).

\subsection{COAL MINING}

The mining technology program activity includes the exchange of information in the field of coal mining. During 1976, seven detailed joint projects were formalized in this area. Exchanges of specialists occur approximately on a six-month basis.

\section{UNITED STATES-BERGBAU FORSCHUNG (FEDERAL REPUBLIC OF GERMANY)}

\subsection{COAL MINING}

A cooperative agreement in the areas of mining engineering and safety was signed in March 1977, by the United States Department of Interior (DOI) Bureau of Mines (BOM), and Bergbau Forschung, a West German corporation. Since much of the work of mutual interest was tied to programs that were transferred from DOI/BOM to DOE/FE, transfer of applicable portions of the Agreement is being negotiated. 
The details of specific cooperation projects are being developed. Initial exchange of personnel occurred in October 1977, with a visit by three U.S. specialists (correspondents) to Germany .

\section{UNITED STATES-UNION OF SOVIET SOCIALIST REPUBLICS (U.S.S.R.)}

On June 28, 1974, a broad Agreement on Cooperation in the Field of Energy was signed by representatives of the United States and the Soviet Union. Cooperative activities include the development and implementation of programs that would accelerate $R \& D$ efforts in both existing and alternative sources of energy. To implement the Agreement, a joint U.S./U.S.S.R. Committee on Cooperation on the Field of Energy was established. The Committee's functions include approval of specific joint projects and establishment of working groups to perform specifir. assignments. The cooperative MHD program was officially transferred to this Agreement in June 1974; programs in the areas of coal, oil, and gas were officially established in December 1976. The Agreement was signed for a five-year period (1974-1979); an automatic extension for an additional five-year period was included.

\subsection{MAGNETOHYDRODYNAMICS}

The international cooperative program on MHD power generation is based on the complementary nature of MHD development in the two countries. In the U.S., emphasis in MHD has been in gaining a scientific understanding of the process and through this, learning how to predict the behavior of the key components, especially the MHD generator channel itself. In the Soviet Union, emphasis has been on the modeling and construction of plants of increacing size and complexity. $A$ further balancing factor is the Soviet Union's concentration on natural gas as a fuel for MHD, while U.S. emphasis has moved increasingly to the utilization of coal as the primary fuel. The objectives of the cooperative program are to obtain jointly as much engineering experience as possible, utilizing both U.S. and Soviet facilities, where practical, for testing components and materials, and to share the techniques developed for analysis of key MHD components. Two significant installations developed in the Soviet Union are the U-02 MHD systems test facility and the U-25 MHD pilot plant, both located in Moscow. In addition, there is a small plant located in Kiev in the Ukrainian Republic.

The cooperative effort has focused on joint work contributing to the development and operation of the MHD channel, the major component of a commercial MHD power plant. By exchanging experience and information in this way, MHD development can be pursued more quickly, more economically, and with less risk of technical failure than would be possible 
if the two countries pursued the work separately. A determined effort has been made to avoid the program becoming merely an exchange of information, and work is being focused on a few specific tasks to assist in the technical development of MHD in both countries. During the past year, work progressed smoothly in all areas. Efforts are proceeding on schedule in the design and fabrication of a large-scale MHD channel which will be tested in the Soviet U-25 pilot plant. This channel is due for delivery to Moscow in December 1978. The 5T superconducting magnet was delivered and installed in the U-25B facility in June 1977. The joint status report was completed in 1977 and will be published in 1978. The major progress, however, was in establishing the U-25B facility for channel development and studies of high-field MHD phenomena. Phase III of the joint U-02 electrode/insulator subsystem tests is in progress as a follow-up of Phases II and I.

The Soviets have been extremely cooperative in providing information on their current work and future plans in developing commercial MHD power systems. A number of Soviet reports containing valuable information have been translated and published by DOE. In conjunction with the writing of the status report, the Institute of High Temperatures (IHT) provided the U.S. with its most recent results in all areas of commercial MHD development. IHT representatives also briefed U.S. specialists on their most recent achievement of attaining 250 hours of continuous operation at power levels between 2 and $10 \mathrm{MW}$ in their U-25 pilot plant. The Soviets are continuing with the preliminary design of a 500 to $600 \mathrm{MWe}$ commercial demonstration plant and indicated a willingness to share the results of this work with their U.S. colleagues.

\subsection{OIL}

In December 1976, the U.S.-U.S.S.R. Joint Committee on Energy established a Joint Working Group of oil experts and charged it with the responsibility of identifying specific $R \& D$ activities of interest to both countries in the field of exploration and production of oil. The first meeting of the Group was held in the U.S. in the fall of 1977. The Group agreed on five cooperative activities and on the methods for their implementation. Proposed activities were submitted to the Joint Committee and were approved on Lecember 7, 1977. Project groups are being established to implement approved cooperative activities.

\subsection{GAS}

Although a Joint Working Group of Gas Experts was formally established by the U.S.-U.S.S.R. Joint Committee on Energy in December 1976 , a number of discussions on subjects of mutual interest took place earlier in both countries. These preliminary meetings resulted in identification of a number of topics of mutual interest, which were spelled out in the February 1976 protocol. Since no protocol has been concluded by the formal Joint Working Group of gas experts, the 1976 document currently serves as the guideline document for renewed efforts in this area. 
On December 7, 1977, the Joint Committee affirmed mutual interest in the development of cooperation in a number of suggested areas (e.g. increasing gas and gas condensate recovery from productive formations) and made a number of recommendations to the Working Group. It is hoped that a formal working agreement will be reached during the next meeting of the Joint Working Group. The meeting is scheduled for the spring of 1978 and will probably he held in the U.S.S.R.

\subsection{COAL}

Though preliminary discussions have taken place between the representatives of both countries, the specifics of cooperation in the area of coal mining and utilization have not been agreed upon. A Working Group of coal experts will be officially established by the Joint Committee in 1978. The Group will then proceed with the identification of specified R\&D activities of interest to both countries.

\section{E. UNITED STATES-POLAND}

In accordance with the agreement between the government of the People's Republic of Poland and the United States, signed on October 8, 1974, the Marie Sklodowska-Curie Fund was established to finance joint scientific and technological research projects, including joint activities in the area of coal mining and utilization technologies and MHD systems. Joint activities utilize PL 480 special foreign currency funds. Specific projects agreed upon (by the end of 1977) are:

\subsection{MAGNETOHYDRODYNAMICS}

The main thrust of the Polish MHD program is to use the exhanst gases from an MHD generator for coal gasification. This is an idea that originated at AVOC Everett Research Labs in Massachusetts but was never fully explored. Cooperation with Poland will allow the U.S. to investigate this concept without having to initiate and fund such a research effort in the United States. The Agreement for mutual cooperation in these areas has been signed in June 1977. Two or three joint experiments per year are expected to be performed in Poland. The first meeting to plan detailed joint experiments was held in the U.S. in January 1978.

\subsection{COAL LIQUEFACTION}

The agreement for mutual cooperation in six coal liquefaction projects was signed in June 1977. The projects are:

- Catalysts of Hydrogenation Processes

- Coal Extraction and Ash Removal From Coal Liquefaction Processes

- Carbonization of Solid Residues from Coal Liquefaction Processes 
- Effects of Hydrogen Donor Solvent in Extraction Process

- Noncatalytic Coal Liquefaction in the Presence of Hydrogen

- Test on the Suitability of Pumps for High-Pressure Operation.

Details of cooperative activities are being developed.

\subsection{COMBUSTION OF SYNTHETIC FUELS FOR POWER GENERATION}

This project was included in the June 1977 document (2.0 above). The first meeting to plan joint experiments was held in the U.S. in January 1978.

\subsection{COAL MINING AND PREPARATION}

Programs for projects in the area of coal mining and preparation technologies were developed and finalized b.y the U.S. Department of Interior and Poland in October 1976. Four of these projects will be transferred to DOE/FE. The projects are:

- Removal and recovery of fine-size coal from coal preparation plant waters

- Classification of roofs in U.S. mines for the selection of suitable mechanized support for longwalls

- Modern underground mining technologies for pitching coal bed extraction

- Subsidence prediction and control.

Detailed implementation procedures are being developed. 


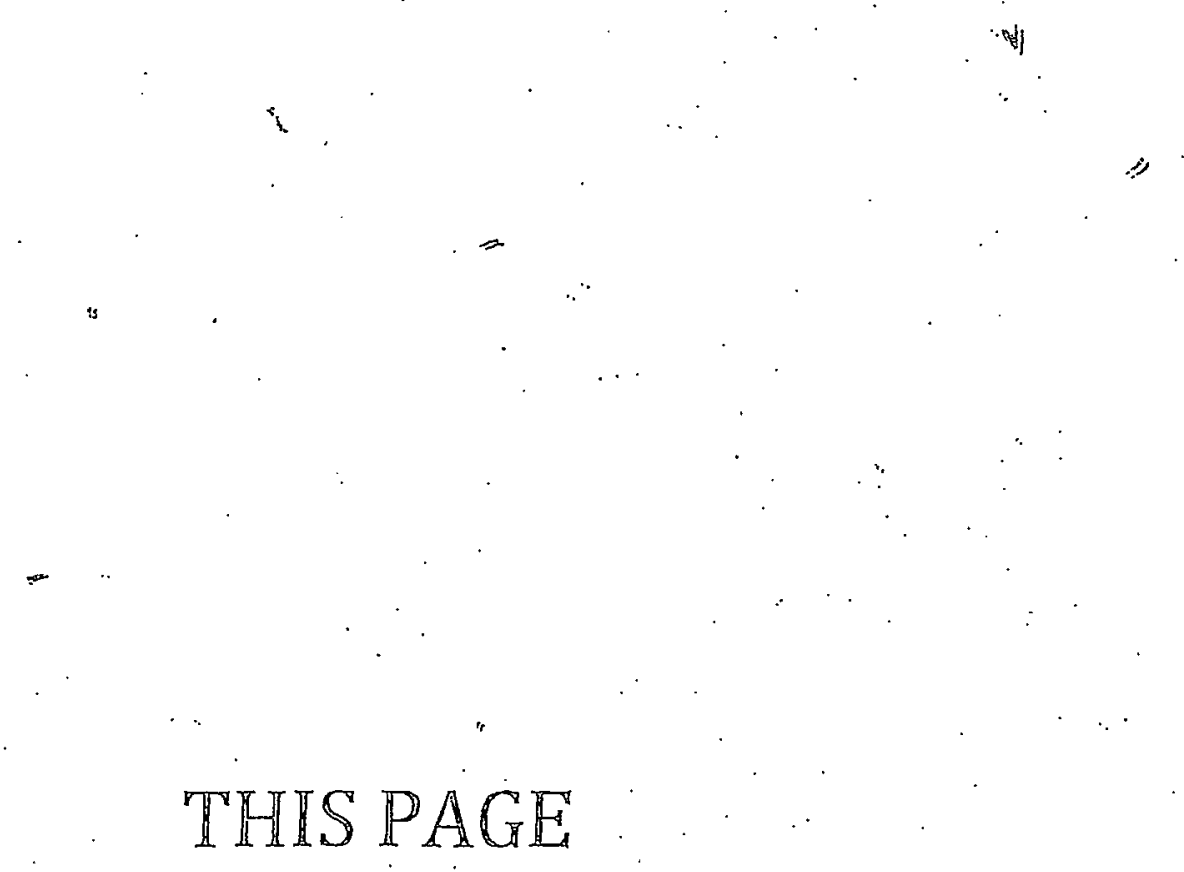

\section{WAS INTENTIONALLY \\ LEFT BLANK}




\section{DEFINITIONS}

\section{A. RD\&D SCALEUP PHASES}

This section provides definitions of the various research, development, and demonstration scaleup phases as they pertain to the

Fossil Energy Coal Resource. Included are the distinguishing features of :

- Process Development Units (PDU)

- Pilot Plants

- Demonstration Plants

- Commercial Demonstration Plants.

The key to the definition is not so much size, as the purpose--the kind of information the activity is designed to yield. In this context the relative scales can be differentiated as follows:

\section{Process Development Unit (PDU)}

The purpose of a PDU is to establish the basic technical feasibility of the process; acquire basic physical, chemical, and engineering data needed to evaluate the process; and develop the design data necessary to allow further scaleup to a larger stage if feasible.

Other distinguishing features of the PDU are as follows:

- PDU்s follow laboratory "bench" experimental work.

- PDUs incorporate results of bench-scale work on key process steps to form an integrated small-scale process to test key variables on performance. (Technology development phase of $\mathrm{R} \& \mathrm{D})$

- PDUs generally operate continuously and process the minimum amount of raw material necessary to test the process feasibility .

- PDUs are never facilities in themselves, but are a component of, or contained in an existing facility, (e.g., laboratory or plant), and can undergo considerable modification to enhance the process.

\section{Pilot Plant}

The purpose of a pilot plant is to establish the integrated process feasibility by combining commercial type (not commercial size) components into a small model plant to test and evaluate the critical parameters of scaleup, and to acquire engineering data needed to assess economic feasibility and design a läger near-commercial-size plant. 
Other distinguishing features of a pilot plant are as follows:

- Pilot plants are the first scaleup facility to produce enough endproduct to permit product testing and refinement.

- Pilots, as experimental facilities, are subject to continuing and significant modifications to help identify candidate process and components that could be used for further scaleup to larger plant sizes (engineering phase of RD\&D).

- Pilot plants are limited to three years or less of operating life and in most instances are dismantled after fact finding is complete unless they can be modified to cost-effectively test new processes.

- Dotermining the projectcd cconomico and cost of a prospective commercial-sized plant is' a significant. R\&D objestive of pilnt. plants.

- Large pilot.plants for some technical development may provide sufficient data about operations before pseudo-commercial conditions to allow the development to proceed directly to commercial demonstration.

\section{Demonstration Plants}

The purpose of demonstration plants is to demonstrate and validate economic, environmental, and productive capacity of a near-commercial-size plant by integrating and operating a single modular unit using commercialsized components.

Other distinguishing features of a demonstration plant are as follows:

- These are still developmental in the sense that technological scaleup problems may occur and require engineering modification; however, the risk is much lower since the plant production process was developed and tested at the pilot stage.

- These facilities that have a long life and are planned to be expanded to become part of the commercial plant, after their successful demonstration period, by the industrial cost sharing partner. In this case the industrial partner will purchase the facilities at a fair market value.

These are used only to demonstrate and verify secondgeneration technologies (those not currently used commercially) and will demonstrate only the most feasible process surviving competition of alternatives regardless of whether previous pilot plant work was done in private industry or government. 
- These facilities are neither formal systems acquisitions nor fullscale development but are the final stage in the R\&D process aimed at accelerating and reducing the risks of industrial process implementation.

\section{Commercial Demonstration Plants *}

The purpose of commercial demonstration plants is to resolve commercial investment uncertainties by establishing the actual economic factors, environmental feasibility, socioeconomic impact, capital and resource requirements, constraints and product markets for currently available as well as newly introduced synthetic fuel products and encourage creation of a viable industry using these technologies.

Other distinguishing features of commercial demonstration plants are as follows :

- These plants demonstrate viability of a facility and/or process to produce a commercial-grade product at a rate of production considered to be commercially significant using commercial-scale equipment under commercial conditions.

- The government's role is to provide financial incentives to stimulate industry construction and commercial production and marketing of synthetic fuel products by loan guarantees or other incentives.

- Commercial plants do not constitute R\&D work. Most technical problems have been solved. Their demonstration value is limited to setting industry standards and precedent for a viable synthetic fuels industry.

- Commercial demonstration plants represent a scale of three to five times the productive capacity of demonstration plants by combining modular production units of the type singularly demonstrated in a demonstration plant to achieve full-scale commercial production of a product.

*Commercial Demonstration Projects are the responsibility of the Assistant Secretary for Resource Applications in the DOE. 


\section{B. ABBREVIATIONS AND ACRONYMS}

A

A

AAG

$\mathrm{AC}$

ACS

$\mathrm{A} / \mathrm{E}$

AES

AFB

$\mathrm{AFBC}$

AGA

AHF

AL

ANL

API

APS

AR\&ST

ARS

atm

$\mathrm{bbl}$

$\mathrm{bbl} / \mathrm{d}$

Bcf

BCR

BCURA

BERC

BNI.

BOM

BSB

Btu

BTX

$\mathrm{CBC}$

$\mathrm{CC}$

$\mathrm{CCDC}$

CCU

CDIF

CDTF

CEF

CEQ

CFCC

CFFC

CFPD

CMOC

$\mathrm{CO}$
Ampere

Agglomerating Ash Gasifier

Alternating Current

Advanced Cogeneration Systems

Architect and Engineer

Automated Extraction System

Atmospheric Fluidized-Bed

Atmospheric Fluidized-Bed Combustion

American Gas Association

Advanced Hydraulic Fracturing

Aures Laluoralury

Argonne National Laboratory

American Petroleum Institute

Advanced Power Systems

Advanced Research and Supporting Technology

Agricultural Research Service

Atmosphere (of pressure)

B

Barrel

Barrels per Day

, Billion Cubic Feet

Bituminous Coal Research, Inc.

British Coal Utilization Research Association

Bartlesville Energy Research Center

Brookhaven National Laboratory

Bureau of Mines

Blind Shaft Borer

British Thermal Unit

Benzene, Toulene and Xylene

C

Carbon Burn-up Cell

Coal Conversion

Conoco Coal Develnpment Company.

Coal Conversion and Utilization

Component Development and Integration Facility

Component Development Test Facility

Chemical Explosive Fracturing

Council on Environmental Quality

Coal-Fired Combined Cycle.

Clean Fuel from Coke

Cubic Feet per Day

Carbondale Mining Operations Center

Carbon Monoxide 


$\mathrm{CO}-\mathrm{H}_{2} \mathrm{O}$
$\mathrm{CO}_{2}$
COE
COED
COM
CPCS
CPU
CSF
CTAS
CTF
CTIF
CTIU
CW
CY

DC $\mathrm{DCCU}$ DGE DISC DOC DOD DOE DOI DPS

EA EACC EAC EC ECAS ECP EDP EEI EGR EH\&S EIA EIS ENCON EOR EPA EPRI ER\&E ERCO ERC ERDA ETF.
Carbon monoxide-Water

Carbon Dioxide

Crude Oil Equivalent

Coal Oil Energy Development - Liquefaction Process

Coal-Oil Mixture

Cross-pit Conveying Systems

Continuous Process Unit

Consolidation Synthetic Fuel

Cogeneration Technology Alternative Study

Cresap Test Facility

Component Test and Integration Facility

Component Test and Integration Unit

Curtiss-Wright

Calendar Year

D

Direct Current

Division of Coal Conversion and Utilization

Division of Geothermal Energy

Direct Injected Stratified Charge

Department of Commerce

Department of Defense

Department of Energy

Department of Interior

Division of Power Systems

E

Office of Environmental Activities

Eastern Associated Coal Corporation

Economic Assessment Service

Executive Committee

Energy Conversion Alternative Study

Engineering Change Proposal

Environmental Development Plan

Edison Electric Institute

Enhanced Gas Recovery

Environmental Health \& Safety

Environmental Impact Assessmen.t

Environmental Impact Statement

Environmental Constraints

Enhanced Oil Recovery

Environmental Protection Agency

Electric Power Research Institute

Exxon Research and Engineering Company

Energy Resources Company

Energy Research Center

Energy Research and Development Administration Engineering Test Facility 
FBC

FE

FEARP

FGD

FRG

$\mathrm{ft}^{3}$

FTP

FTT

FY

GBP

GE

GFERC

GR\&DC

GOCO

GPA

GPE

$\mathrm{gr}$

GURC

$\mathrm{H} 2 \mathrm{~S}$

H-Coal

HEW

HGMS

HFR.

hI

HPDE

HRI

HUD

Hydrogenation

Fluidized-Bed Combustion

Fossil Energy

Fossil Energy Authorization and Review Board

Flue Gas Desulfurization

Federal Republic of Germany

Cubic feet

Full-Time Permanent

Full-Time Total

Fiscal Year

G

Granular-Bed Filter

General Electric Company

Grand Forks Energy Research Center

Gulf Research and Development Company

Government Owned, Contractor Operated

Geopressured Aquifer

Gas Producing Enterprises, Inc.

Gram

Gulf Universities Research Consortium

$\mathrm{H}$

Hydrogen Sulfide

Hydrogen-Fed Coal

Department of Health, Education and Welfare

High-gradient Magnetic Separation

Hot-Gas Recyclc

Horsepower

High Performance Demonstration Equipment

Hydrocarbon Research, Incorporated

Department of Housing and Urban Development

The process of combining or treating with hydrogen

I

IC

ICGG

IEA

IGT

IHT

INEL

In situ

IW

JPL

Internal Combustion

Illinois Coal Gasification Group

Internalional Energy Agency

Institute of Gas Teehnology

Institute of High Temperatures

Idaho National Energy Laboratory

In its original position or in place

Improved Waterflooding

$\mathrm{J}$

Jet Propulsion Laboratory 
$\mathrm{KC}$-oil kerogen $\mathrm{kWh}$

Koppers Creosote Oil Organic material from which shale oil is extracted Kilowatt Hour

L

Los Alamos Scientific Laboratory

Pound per hour

Lawrence Berkeley Laboratory

Less Developed Countries

Laramie Energy Research Center

Longwall Generator

The process of being liquefied

Lawrence Livermore Laboratory

Liquefied Natural Gas

Liquefied Petroleum Gas

Linked Vertical Well

M

M
MA
MAF
Mcf
MERC
MFB
MFC
MFCD
MHD
MIT
MIUS
ML
MLGW
MM
MMbbl/d
MMscf
MOC
MOPPS
MPF
MRD\&D
mSec
MSP
MSR
MTCH
MVMA
MW
MWe
MY

Thousand

Milliampere

Moisture- and Ash-Free

Thousand cubic feet

Morgantown Energy Research Center

Multicell Fluidized-Bed Boiler

Methane from Coal

Multiple Face, Continuous Drivage

Magnetohydrodynamics

Massachusetts Institute of Technology

Modular Integrated Utility Systems

Mound Laboratory

Memphis Light, Gas, and Water

Million

Millions of Barrcls per Day

Millions of Standard Cubic Feet

Mining Operation Center

Market Oriented Program Planning Study

Micellar-Polymer Flooding

Mines Research, Development, and Demonstration Millisecond

Marine Sediment Penetrators

Management Status Reviews

Mining Technology Clearing House

Motor Vehicles Manufacturing Association

Megawatt

Megawatt Electrical.

Man-year 
$\mathrm{N} / \mathrm{A}$

$\mathrm{NaCl}$

NASA

NBS

NCB

NEP

NEPA

NIOSH

NL

NOx

NSF

NTIS

OCGT

OCR

OCS

OGSIST

OGST

OMB

ONR

OPEC

OPPA

ORBCS

ORC

ORNL

OS/IES

OSHA

OUA

P\&M

PAD

PAF

PB

PBP

PDS

PDU

PERC

I'TB

PFBC

PL

PMOC

PNG

PNL

PON

psi

psig

PTC
Not applicable

Sodium Chloride

National Aeronautics and Space Administration

National Bureau of Standards

National Coal Board

National Energy Plan

National Environmental Policy Act

National Institute of Occupational Safety and Health

National Laboratory

Nitrogen Oxides

National Science Foundation

National Technical Information Service

$\mathrm{O}$

Open-Cycle Gas Turbine

Office of Coal Research

Outer Continental Shelf

Oil, Gas, Shale and In Situ Technology

Oil, Gas, and Shale Technology

Office of Management and Budget, Executive Office of the President

Office of Naval Research

Oil Producing and Exporting Countries

Office of Program Planning and Analysis

Organic Rankine Bottoming Cycle System

Occidental Research Corporation

Oak Ridge National Laboratory

On-Site Integrated Energy. Systems

Occupational Safety and Health Administration

Office of University Activities

$\mathbf{P}$

Pittsburg \& Midway Coal Mining Company

Program Approval Document

Principal Alternate Fuels

Packed-Bed

Packed-Bed Process

PAS Library and Uatá System

Process Development Unit

Pittsburgh Energy Research Center

Pressurized Fluidized-Ded

Pressurized Fluidized-Bed Combustion

Public Law

Pittsburgh Mining Operations Center

Petroleum and Natural Gas

Pacific Northwest Laboratory

Program Opportunity Notice

Pounds per Square Inch

Pounds per Square Inch, Gauges

Petroleum Technology Corporation 
Q

$Q_{e}$
$Q_{f}$
$Q_{r}$
Quad

$\mathrm{RC}$

$R \& D$

RD\&D

retort

RFP

RON

RW

$\operatorname{scf}$

$\operatorname{scf} / d$

$\mathrm{scf} / \mathrm{h}$

$\mathrm{SCM}$

SCPE

SDB

SFME

SFMP

SIC

SL

SNG

$\mathrm{SO}_{2}$

$\mathrm{S} 0 \mathrm{x}$

SRC

SRL

SSO

Syngas

TBD

TBM

TBS

Tcf

$t / d$

TEC

TETAS

TG

$\mathrm{t} / \mathrm{h}$

TIS

TMSP

TR

TTU
Quads of Electrical Energy

Quads of Fossil Fuel Consumption

Quads of Heat Rejection

1015 (Quadrillion) Btus

\section{$\mathrm{R}$}

Resource Characterization

Research and Development

Research, Development, and Demonstration

Distill or decompose by heat

Request for Proposal

Research Octane Number

Residue Fuels

$\mathrm{S}$

Standard Cubic Feet

Standard Cubic Feet per Day

Standard Cubic Feet per Hour

Super Conducting Magnet

Sublevel Caving with Pillar Extraction

Steeply Dipping Bed

Single Face, Multiple Entry.

Solid Fuel Mining and Preparation

Standard Industrial Code

Sandia Laboratory

Substitute Natural Gas

Sulfur Dioxide

Oxides of Sulfur

Solvent Refined Coal

Solvent Refined Lignite

Source Selection Official

Synthetic Natural Gas

$\mathrm{T}$

To Be Determined

Tunnel Boring Machine

To Be Supplied

Trillion Cubic Feet

Tons per Day

Total Estimated Cost

Total Energy Technology Assessment

Transport Gas

Tons per Hour

Technical Information Service

Thick, Multiple, and Steeply Pitching Seams

Thermal Recovery

Technology Test Unit 
U

UCG

UCL

U.K.

UOP

USGS

USS

U.S.S.R

UTC

V

WEST

WGSP

WPCT

WRC

$\mathrm{ZnCl}_{2}$
Underground Coal Gasification

Underground Coal Liquefaction

United Kingdom

Universal Oil Products

United States Geological Survey

United States Steel

Union of Soviet Socialist Republics

United Technologies Corporation

V

Volts

W

Westinghouse Electric Company

Western Gas Sands Project

Working Party on Coal Technology

Water Resources Council

Z

Zinc ' Chloride 


\section{INDEX}

Page

Number

Abbreviations and Acronyms $\quad 460$

Advanced Cogeneration Systems $\quad 208$

Advanced Combustion Technology 254

Advanced Concepts and Supporting Research

$\begin{array}{ll}\text { (In Situ Gasification) } & 173 \\ & 294\end{array}$

$\begin{array}{ll}\text { Advanced Environmental Control Technology } & 294 \\ \text { Advanced Hydraulic Fracturing Process } & 407\end{array}$

$\begin{array}{ll}\text { Advanced Mining Systems } & 47\end{array}$

Advanced Power Systems 197

Advanced Research and Supporting Technology 297

Alternate Fuel Combustion $\quad 268$

Alternate Fuel Utilization (Combustion Systems) 265

Ames Laboratory $\quad 426$

Analytical Model Development (Drilling and Offshore Technology) 388

Anthracite Applications $\quad 246$

Applied Research (Fuel Cells) $\quad$ i 290

Area Mining $\quad 51$

Argonne National Laboratory $\quad 426$

$\begin{array}{ll}\text { Ash Agglomeration } & 141\end{array}$

Atmospheric Fluidized-Beds (AFB) 236

Atmospheric Fluidized-Bed Anthracite Applications $\quad 246$

Atmospheric Fluidized-Bed Closed-Cycle Gas

Turbine Technology Test Unit 242

Atmospheric Fluidized-Bed Component Test and Integration
Unit

Atmospheric Fluidized-Bed Industrial Applications 240

Atmospheric Fluidized-Bed $30 \mathrm{MWe}$ Boiler $\quad 238$

Atmospheric Fluidized-Bed Utility Demonstration Plant 274

Automated Rail Haulage 48

$\begin{array}{ll}\text { Bartlesville ERC } & 419\end{array}$

Beneficiation (AR\&ST) 321

Bergbau Forschung - International Programs (FRG) 451

Bi-Gas Pilot Plant $\quad 109$

Blind Shaft Borer $\quad 34$

Brookhaven National Laboratory $\quad 426$

Capital Equipment - Coal Resource $\quad 342$

Capital Equipment - Gas Resource 418

Capital Equipment - Petroleum Resource 393

Carbondale MOC $\quad 423$ 
Catalyst Development (Synthane Support) 156

Catalytic Gasification Pilot Plant 118

Catalytic Methanation (Synthane Support) 155

CDIF Project (MHD) . 336

Characterization (Petroleum Resource) $\quad 389$

Chemical Explosive Fracturing Process $\quad 409$

Closed-Cycle Processes (MHD) 337

Closed-Power Systems $\quad$. 202

CO-Steam Process $\quad 79$

$\mathrm{CO}_{2}$ Flooding $\quad 355$

Coal Red Methane Utilization $\quad 271$

Coal Combustion Support and Engineering Evaluations 258

Coal rastflcalion - Iligh * Btu 105

Coal Gasification - In Situ 158

Coal Gasification - Low-Btu 121

Coal Laboratories $\quad 438$

Coal Liquefaction $\quad 60$

Coal Liquefaction - International Programs 454

Coal Liquids Refining $\quad 95$

Coal Mine Shaft Development 33

Coal Mining - International Programs 451

Coal Mining and Preparation - International Programs 455

Coal-Oil Mixtures (Combustion Systems) 265

Coal Preparation Research $\quad 57$

Coal Preparation Technology $\quad 57$

Coal Resource $\quad 27$

Coal Resource Overview 27

Coal Resource Strategy 21

Coal Utilization - International Programs 451

Cual - Intcrnational Progralls 454

COGAS Process 177

Combined-Cycle Test Facility 135

Combustion (AR\&ST) $\quad 325$

Combustion Demonstration Plant 274

Combustion of Synthetic Fuels for Power Generation -

\begin{tabular}{ll} 
Combustion Systems & 233 \\
\hline & 450
\end{tabular}

Combustion - Internaliuial Programe $\quad 450$

Combustion Systems - Engineering Support Studies 259

Combustion Systems - Environmental Studies and Support Projents 260

Combustion Systems - Nonfluidized-Bed Combustion $\quad \mathbf{2 6 0}$

Combustion Systems - Regeneration 260

Commercial Demonstration Plants - Definition 459

Component Development and Integration Facility 335

Continuous Face Haulage $\quad 42$

Continuous Roof Supports $\quad 39$

Contour Mining 53

Conventional Mining Equipment Improvements 53 
Conversion Processes (AR\&ST) 308

Conveyor Systems $\quad 54$

Cooperation in Coal Technology - International Programs 449

Cresap Liquefaction Test Facility $\quad 92$

Crossridge Demonstrations $\quad 55$

Decrease Longwall System Costs 44

Deep-Drilling Simulation $\quad$. 385

Definitions $\quad 457$

Demonstration Plants - Definition 458

Design and Technical Support 190

Design and Technical Support (Liquefaction) 102

Deviated Wells and Earth Fracture Systems Process 411

Direct Hydrogenation $\quad 62$

Direct Utilization Technology (AR\&ST) 321

Directional Drilling $\quad 38$

Directly-Fired Heat Cycles $\quad 212$

Disposable Catalytic Hydrogenation $\quad 69$

Donor Solvent Process $r$

Downhole Telemetry (Petroleum) 384

Drilling (Petroleum) $\quad 384$

Drilling and Offshore Technology 383

Drilling Technology (Petroleum) 385

Eastern Coal Technology (Longwall Generator) 167

Eastern Gas Shales Project $\quad 399$

Ebullated-Bed (H-Coal) Pilot Plant 62

Economic Assessment Service for Coal - International Programs 447

Electrodril (Petroleum) $\quad 384$

Energy Research Centers 419

Energy Research Centers, Mining Operations Centers, and
National Laboratories

Engine Combustion Technology - $\quad 255$

Engineering Evaluations (Gasification) 153

Engineering Evaluations (Liquefaction) . 96

Enhanced Gas Recovery $\quad 398$

Enhanced Oil Recovery 348

Entrained-Bed Gasification, Atmospheric Process 133

Entrained Pyrolysis Process $\quad 85$

Environmental and Socioeconomic Implications 439

Environmental Aspects (Oil from Oil Shale) 377

Environmental Coordination (AR\&ST) 328

Environmental Studies (Gasification) 156

Environmental Studies (Mines RD\&D) 48

Environmental Studies and Supporting Projects (Liquefaction) 96

Environmental and Supporting Research (Drilling and Offshore Technology)

387

Environmental and Supporting Research (Enhanced Gas Recovery) 
Environmental Studies and Supporting Research (Enhanced Oil Recovery)

363

172

154

304

218

Face Haulage Vehicles

Fast Fluid-Bed Process

Fixed-Bed Gasification, Stirred Process . 123

\begin{tabular}{lr} 
Fixed-Bed Gasifier, Slagging Process & 125 \\
\hline
\end{tabular}

Fixed-Bed Hydrogenation (Synthoil) PDU 65

$\begin{array}{ll}\text { Flash Tinuefartion Prnress } & 87\end{array}$

Fluid Coke Process 89

Fluidized-Bed Combustion - International Programs 446

Fluidized-Bed Gasification, Tri-Gas Pressurized 129

Fluidized-Bed Gasification, Two-Stage Pressurized 127

Fort Lewis Pilot Plant (Liquefaction)

Fossil Energy Resource Strategies $\quad 21$

Fossil Energy Research: Fiscal Year 1979 Overview 5

4.8 MW Electric Utility Power Plant Test and Development 281

Fuel Cells $\quad$. 278

Fuel Gas, Industrial - Conceptual Designs A \& B 182

Fuel Gas, Small Industrial Plant $\quad 187$

Fuel Gas, Utility Plant 186

Gas - International Program 453

Gas From Oil Shale $\quad 414$

Gas Resource 395

Gas Resource Overview 395

Gas Resource Strategy 23

Gasification (AR\&ST) 313

Gasification Demonstration Projects 174

Gasification (High-Btu) 105

Gasification (In Situ) 158

Gasification (Low-Btu) 121

Gasification (Synthane Support) 155

Gasification - Environmental Studies 156

Gasification - Equipment, Materials, and Process Developmènt 154

Gasification - Summary of Pilot Plants, PDUs, and Major Ilardware Fabrication)

Gasification - Systems Engineering/Planning 156

Gasifiers in Industry $\quad 144$

Geopressured Aquifers (EGR) 406

Grand Forks ERC $\quad 420$

H-Coal Process $r$

Heat Engines and Heat Recovery 194

$\begin{array}{ll}\text { Heat Exchanger Technology } & 229\end{array}$

6

20

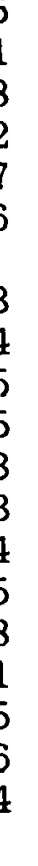


Page

Number

Heat Recovery Component Technology 222

Heat Transfer - International Programs 450

High-Btu Pipeline Gas Demonstration Project 174

High-Btu Gasification 105

High-Btu Gasification Processes, Novel 155

High Grade Heat Recovery 226

Highwall Mining Systems 55

Horizontal Drilling 39

Hot-Gas Cleanup 253

Hot-Gas Cleanup, Iron Oxide Process 151

Hot-Gas Cleanup, Molten Salt Process 149

Hydrogasification

Hydrogen-From-Coal Facility .

HYGAS Demonstration Plant 179

HYGAS Pilot Plant 107

Idaho National Energy Laboratory 426

Improved Oil and Gas Burners 258

Improving Longwall System Performance 43

Industrial Applications (AFB) 240

In-Mine Development 34

In-Seam System $\quad 37$

In Situ Coal Gasification 158

In Situ Gasification - Advanced Conceptual Supporting 173

Integrated Coal Conversion Utilization Systems 197

International Energy Agency 445

International Programs 443

Laboratory and Field Tests (Oil from Oil Shale) 368

Laramie ERC $\quad 420$

Lawrence Berkeley Laboratory 427

Lawrence Livermore Laboratory 427

Linked Vertical Wells 161

Liquefaction (AR\&ST) 308

Liquefaction Demonstration Projects 98

Liquefaction Residue Materials Gasification $\quad 98$

Liquefaction - International Programs 454

Lock Hopper Valve Development 154

Longwall Generator 167

Longwall Multilift Method 45

Longwall in Steeply Pitching Seam 45

Longwall in Sublevel Caving 46

Los Alamos Scientific Laboratory 427

Low-Btu Fuel Gas Demonstration Plants 181

Low-Btu Gasification 121

Low-Grade Heat Recovery $\quad 223$

MHD Technology 332

Magnetohydrodynamics 332

Magnetohydrodynamics - International Programs (Poland) 454 


\begin{tabular}{|c|c|}
\hline & $\begin{array}{l}\text { Page } \\
\text { Numbe }\end{array}$ \\
\hline Magnetohydrodynamics - International Programs (U.S.S.R.) & 452 \\
\hline Materials and Components (AR\&ST) & 299 \\
\hline Materials and Metallurgical Development (Gasification) & 155 \\
\hline Materials Development (Gasification) & 155 \\
\hline Materials for Coal Conversion (AR\&ST) & 300 \\
\hline Methane Drainage & 37 \\
\hline Methane from Coal and Geopressured Aquifers (EGR) & 406 \\
\hline Micellar-Polymer Flooding/Improved Waterflooding & 351 \\
\hline Mine Design and Planning & 51 \\
\hline Mines Research, Development, and Demonstration & 31 \\
\hline Mining Operations Center & 423 \\
\hline Mining Technology Clearing House & 449 \\
\hline Mixed Face System & 36 \\
\hline Modifiod In Situ Shalc Oil Production Prucess & 372 \\
\hline Molten Carbonate Systems Development & 288 \\
\hline Molten Salt Pressurized Process & 137 \\
\hline Morgantown ERC & 421 \\
\hline Mound Laboratory & 427 \\
\hline Multiple Seam Mining & 52 \\
\hline Multistage Liquefaction Process & 71 \\
\hline National Energy Plan and Fossil Energy Technology & \\
\hline National Laboratories & 426 \\
\hline National Planning Coordination in the Field of Coal & \\
\hline Hydrogenation Technology & 449 \\
\hline Nonfluidized-Bed Combustion & 260 \\
\hline Novel High-Btu Gasification Processes & 155 \\
\hline Novel Systems (Production Mining) & 44 \\
\hline Oak Ridge National Laboratory & 427 \\
\hline Offshure Technology & 387 \\
\hline Oil From Oil Shale & 365 \\
\hline Oil - International Programs & 453 \\
\hline Open-Cycle Process (MHD) & 333 \\
\hline Open-Cycle Gas Turbine Systems & 199 \\
\hline Other Support and Special Projects (Gasification) & 156 \\
\hline Overview (University Activities) & 435 \\
\hline Packed-Bed Process & 164 \\
\hline Pacific Northwest Laboratory & 42.7 \\
\hline Panel (Production Mining) & 43 \\
\hline Partial Liquefaction by Direct Hydrogenation Process & 87 \\
\hline Peat Gasification & 155 \\
\hline Petroleum Resource & 343 \\
\hline Petroleum Resource Overview & 343 \\
\hline Petroleum Resource Strategy & 22 \\
\hline Phosphoric Acid Systems Development & 283 \\
\hline Pilot Plant - Definition & 457 \\
\hline Pittsburgh ERC & 422 \\
\hline Pittsburgh MOC & 423 \\
\hline Planning and Budget (AR\&ST) & 328 \\
\hline
\end{tabular}


Plant Construction - Coal Resource

Plant Construction - Gas Resource

Plant Construction - Petroleum Resource 393

Poland - International Programs 454

Power (AR\&ST) 326

Pressurized Fluidized-Beds

Pressurized Fluidized-Bed Combined-Cycle Pilot

Plant, 13 MWe

247

Pressurized Fluidized-Bed Component Test and Integration Unit

248

Principal Alternate Fuels Subtasks (Combustion Systems) 270

Process Development Unit - Definition -

Process Test Facility (Mines RD\&D)

457

57

Product Characterization and Utilization (Petroleum) 389

Program Development \& Integration (AR\&ST)

327

Program Management

Program Structure and 1979 Program Budget Request

Project and Policy Coordination (AR\&ST)

Project Support Activities (EGR)

Prototype Systems Assessment (Heat Engines and Heat Recovery)

Pyrolysis Projects

RD\&D Scaleup Phases

Refining and Chemicals (AR\&ST)

Remote Controlled Continuous Miner

Residue Fuels Subtasks (Combustion System)

268

Resource Characterization (EGR)

413

Resources Recovery and Solvent - Thermal (EOR) 358

Review and Analysis (AR\&ST)

Room and Pillar (Production Mining)

Rotary Drilling System

Sandia Laboratory

Sea Floor Instrumentation

Shale Gas Production

Shale Oil Production

Slagging Lurgi Process

Small Industrial Scale Plant (Gasification)

Solids/Liquids Separation

Solvent Extraction Projects

Solvent Refined Coal Demonstration Plant 99

Solvent Refined Coal Pilot Plant $\quad 75$

Solvent Refined Coal Utilization $\quad 79$

Special Projects and Support Studies (Gasification) 149

Steam Iron Pilot Plant 114

Steeply Dipping Beds

Sublevel Caving with Pillar Extraction (TMSP)

Summary of Capital Acquisition - Coal Resource

340

Summary of Capital Acquisition - Gas Resource

418 


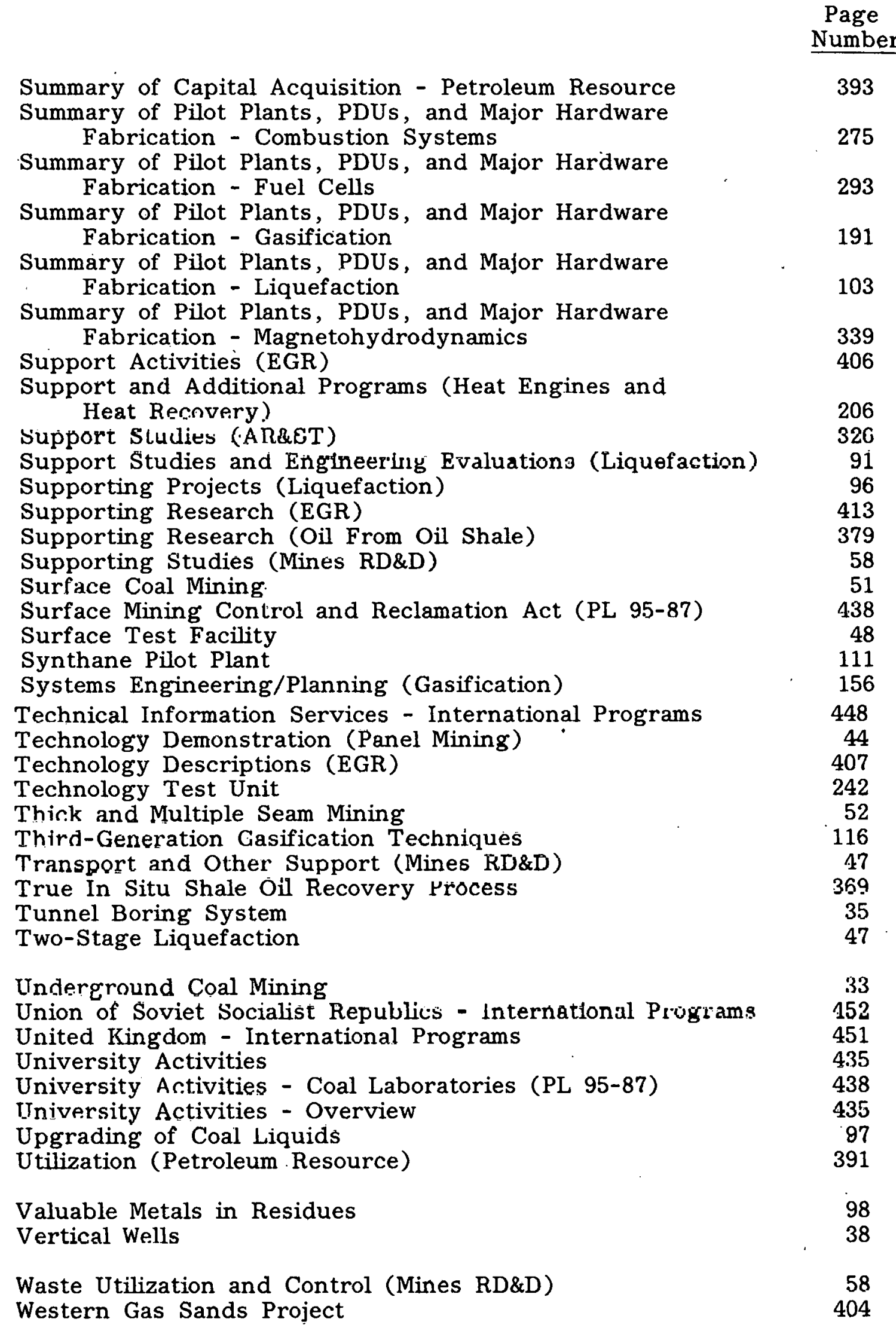


Western Low-Btu Gas (Linked Vertical Wells)

Wèstern Medium-Btu Gas (Packed-Bed)

U. S. GOVERNMENT PRINTING OFFICE : 1978 O -257-308 


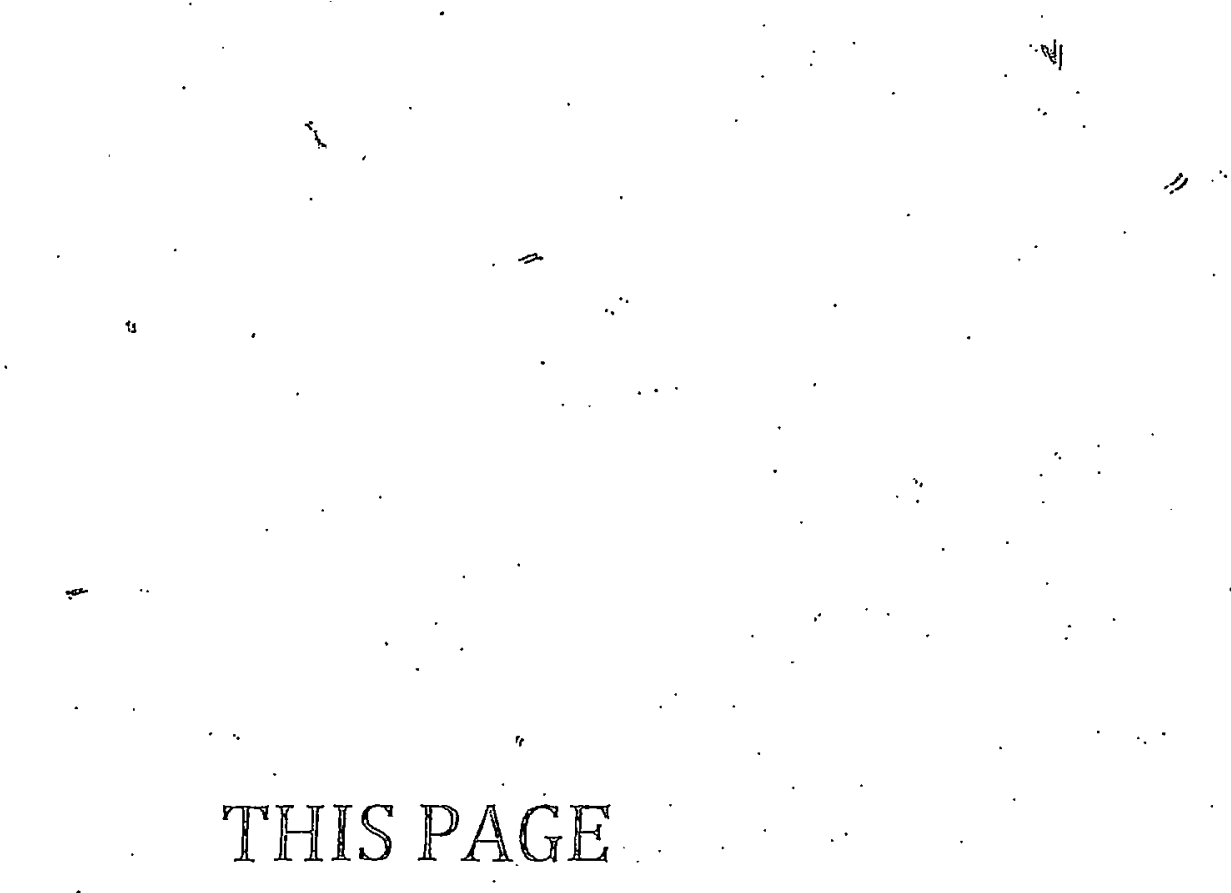

\section{WAS INTENTIONALLY \\ LEFT BLANK}


SYMBOL

\section{TASKS}

Acceptance Test

Bid Package Review

Construction Status Review

Critical Design Review

Performance Review

Pilot Plant Construction

$\bigcirc$ Process Concept Review

Process Development Unit
Construction

$\bigcirc$ Project Evaluation

Technology Assessment
Review performance demonstration test data and other supporting data, including analyses, Iower level test dag, and vendor lest ata. control records, test logs and pertinent compliance to the statement of work and

Review construction bid packages.

Review (pcriodically) of construction against critical path methods for construction or equivalent control mechanisms.

Review detail design drawings and specifications, analytical and expecimental list bid package plan siting and environmental impacts, final test and evaluation plan, configuration and change

Establish degree of compliance with planned testing and evaluation program. Evaluate progress towards determination

Review procurement plans, adequacy of construction go-ahead actions, construction actin

Evaluate feasibility of proposed proces concepts using the best available empirica

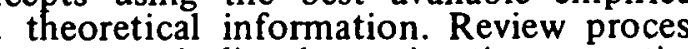
systems practicality by estim

Review procurement plans, adequacy of construction go-ahead actions, construction

Review project progress and accomplishments, compare achieved results with established objectives. Review outcome Evaluate feasibility of the proposed technology concepts, using the best available the technology's practicality by estimating operating conditions and general economics.

\section{SYMBOL DEFINITIONS}

$\triangle$ Begin Milestone

$\nabla$ End Milestone

Decision Milestone

$\triangle$ Begin Milestone (Task Completed)

$\nabla$ End Milestone (Task Completed)

Decision Milestone (Decision Made)

- Release Request for Proposals

1 or Program Opportunity Notice

2 Proposals Received

3 Contractor Selected

4 Contract Award

5 Order Long-Lead Items

6 Final Environmental Impact Statement

TInformation Transfer 